\title{
TÓPICOS EM GESTÃO DA PRODUCC̄̃̃ VOLUME 3
}

\section{Marcelo Ruy}

(Organizador)

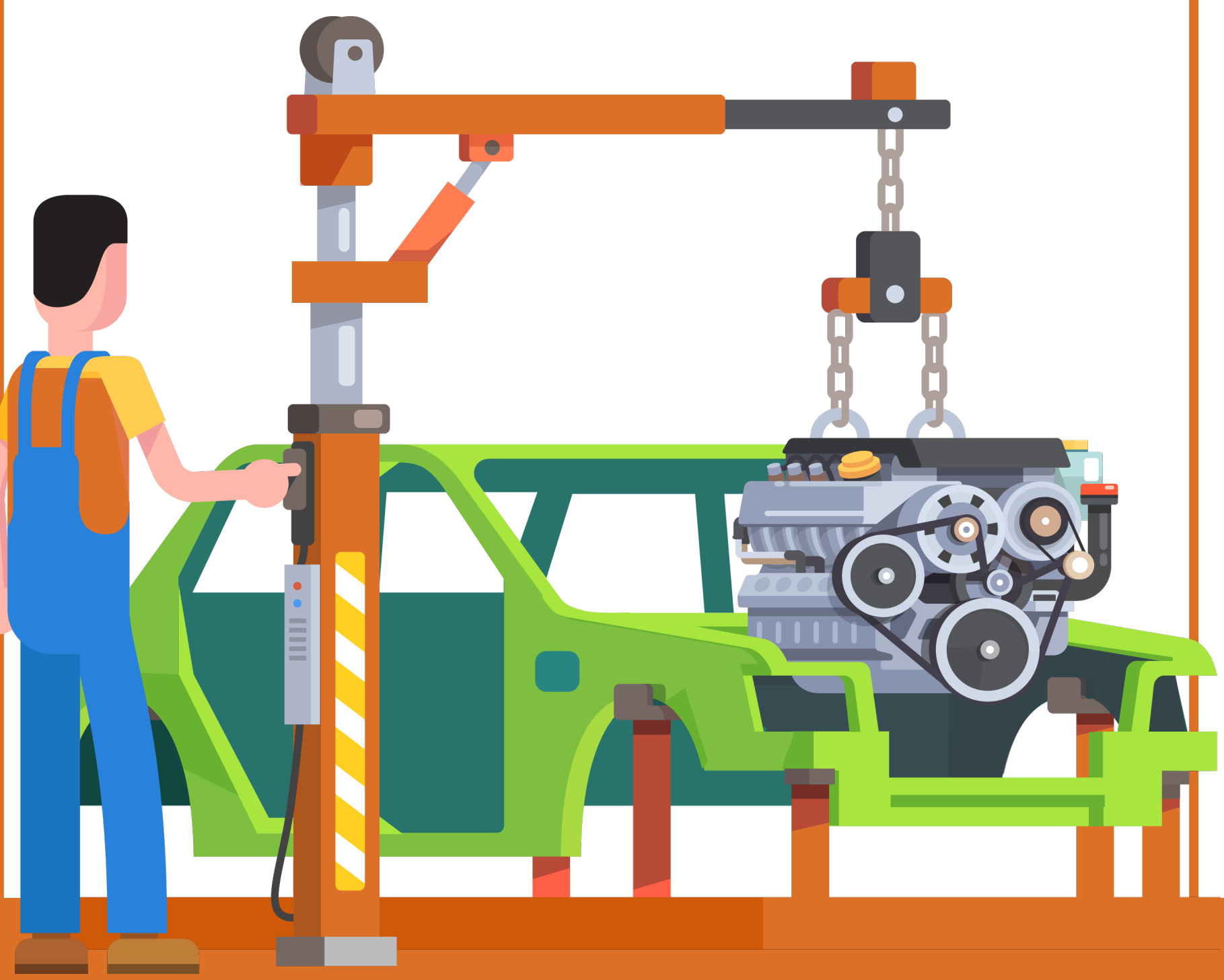

Editora Poisson 
Marcelo Ruy

(organizador)

\section{Tópicos em Gestão da Produção Volume 3}

1a Edição

Belo Horizonte

Poisson

2017 


\section{Conselho Editorial}

Dr. Antônio Artur de Souza - Universidade Federal de Minas Gerais

Dra. Cacilda Nacur Lorentz - Universidade do Estado de Minas Gerais

Dr. José Eduardo Ferreira Lopes - Universidade Federal de Uberlândia

Dr. Otaviano Francisco Neves - Pontifícia Universidade Católica de Minas Gerais

Dr. Luiz Cláudio de Lima - Universidade FUMEC

Dr. Nelson Ferreira Filho - Faculdades Kennedy

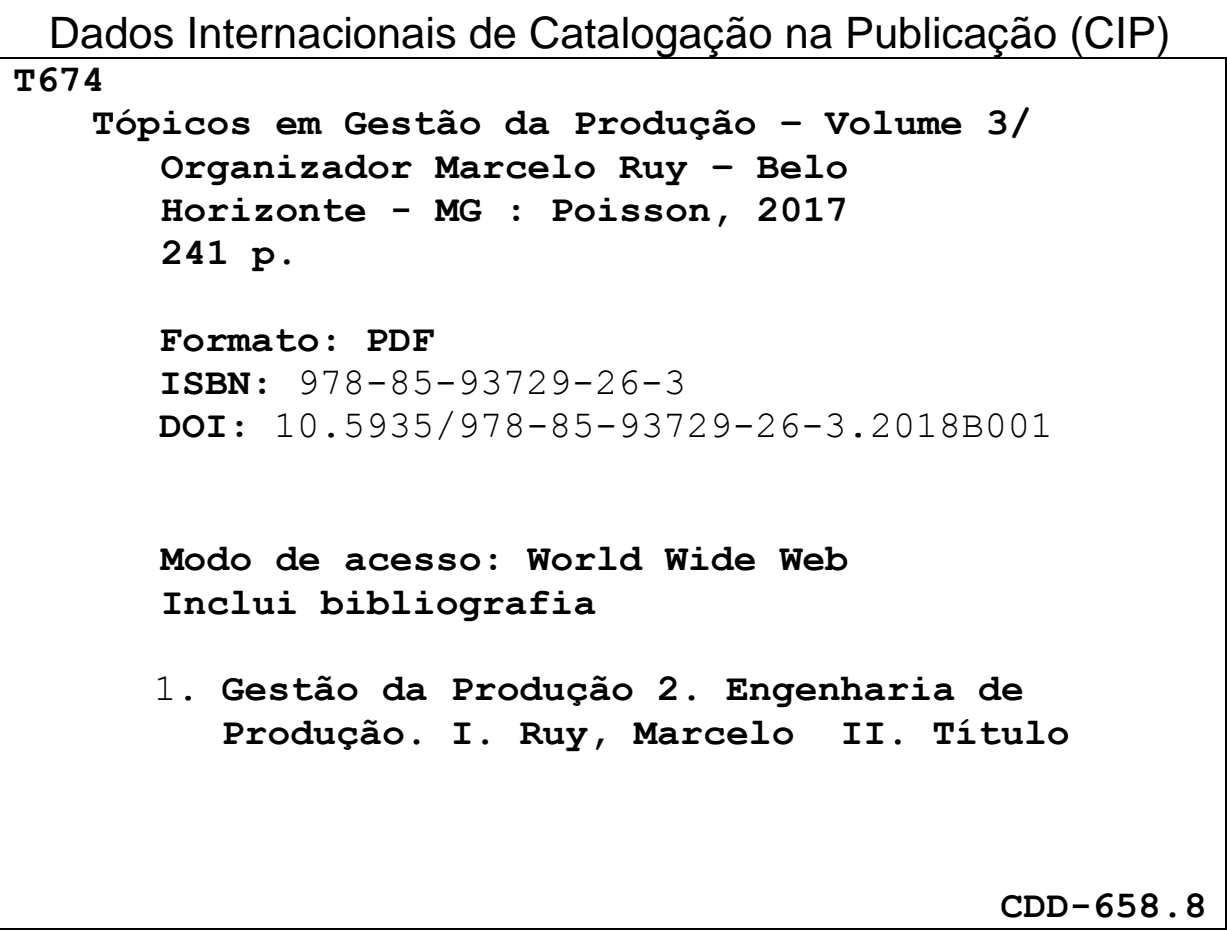

O conteúdo dos artigos e seus dados em sua forma, correção e confiabilidade são de responsabilidade exclusiva dos seus respectivos autores.

www.poisson.com.br

contato@poisson.com.br 


\section{Apresentação}

A Administração da Produção é responsável por gerenciar os recursos que criam e entregam produtos e serviços aos clientes, sendo, por consequência, de importância central a qualquer organização. Ela engloba o projeto, a operação e o controle dos sistemas responsáveis pelo uso de matérias primas, informações, recursos humanos, equipamentos e instalações. Tal definição evidencia de maneira inequívoca a variedade e amplitude de temas abordados pela Administração da Produção.

Dessa forma, a coletânea de artigos constante neste volume apresenta uma série de estudos que cobre uma gama de áreas da Administração da Produção, incluindo, Planejamento e Controle da Produção, Gestão Econômica e Gerenciamento de Processos de Negócios. A Pesquisa Operacional está representada por dois estudos em decisão multicriterial e modelagem de séries temporais. No tema Sustentabilidade, há artigos em economia solidária, logística reversa e reciclagem, auditoria ambiental e sustentabilidade em pequenas e médias empresas. Na Engenharia Organizacional, os temas tratados são gestão do conhecimento, inovação, pesquisa \& desenvolvimento e sistemas de informação gerencial. Por fim, a Logística se faz presente por meio dos tópicos gestão da cadeia de suprimentos, transporte e movimentação de materiais.

Com abordagem objetiva, o livro se mostra relevante para estudantes de graduação, pós-graduação, profissionais atuantes no mercado e professores, por apresentar temáticas e metodologias diversas, bem como situações brasileiras reais.

Aos autores, agradecemos pela confiança e cordial parceria. E uma ótima leitura a todos!

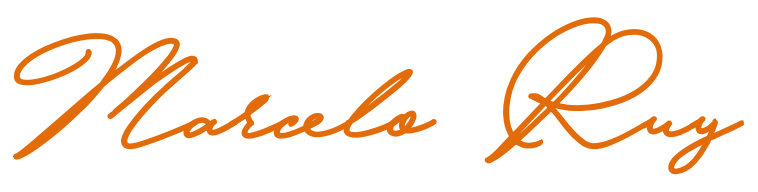




\section{SUMÁRIO}

Capítulo 1 - Gerenciamento de estoques: O caso de uma loja de conveniência (Flaviani Souto Bolzan Medeiros, Bruna Ferreira Lederes, Juliana Andréia Rüdell Boligon,

Flaubiane Figueredo Machado, Ana Rita Schneider Dias)

Capítulo 2 - O mercado financeiro na perspectiva de estudantes de engenharia de produção: Entre o interesse pessoal e o profissisonal

(Elizabeth Liang, Ruth Margareth Hofmann)

Capítulo 3 - As compras públicas em prol do desenvolvimento econômico sustentável: Um estudo da participação de micros e pequenas empresas nos pregões eletrônicos da Universidade Federal do Paraná

(Andréa Roseli Moreira Cruz Jankoski, Vanessa Ishikawa Rasoto)

Capítulo 4 -Modelo de simulação dos processos de uma lavanderia (Ernane Rosa Martins)

Capítulo 5 - Economia solidária - A economia real do desenvolvimento sustentável nas colonias lapó e Santa Clara no município de Castro - PR.

(Alcione Lino de Araújo, Bethânia Ávila Rodrigues, Juliana Vitória Messias Bittencourt,

Maria Helene Giovanetti Canteri)

Capítulo 6 - Mapeamento de processos de logística reversa de resíduos

eletroeletrônicos para reciclagem

(Emmily Caroline Cabral da Fonseca, Eriton Carlos Martins Barreiros, Nathalia Almeida Castro Rodrigues

André Cristiano Silva Melo, Denilson Ricardo de Lucena Nunes)

Capítulo 7 - Investimentos em P\&D (Pesquisa \& Desenvolvimento) e potenciais reflexos nos custos de produção

(Andreia Maria Berto, Claudelino Martins Dias Junior)

Capítulo 8 - Minério de ferro e Vale S.A.: Uma história de sucesso

(Suheir Kamal Genena, Aguinaldo Eduardo de Souza, Francielly Galdino, Marília Patrão Viveiros)

Capítulo 9 - Previsão do consumo italiano de gás natural utilizando modelos arima

(Jair Paulino de Sales, Francisco de Assis Vilar Sobreira Júnior, João Marcos Pereira Silva

Andersson Alves da Silva)

Capítulo 10 - Métodos de decisão multicritério aplicados no desenvolvimento de novos produtos: Uma abordagem teórica (Ana Caroline Dzulinski, Aldo Braghini Junior)

Capítulo 11 - Descrição da utilização do sistema de informação gerencial para resolução de problemas em empresas do PIM 
Capítulo 12 - Gestão do conhecimento e inovação: Estudo de caso em uma empresa de dispositivos eletroeletrônicos

(Rony Peterson da Rocha, Andressa Carina Waideman Pedrezini, Thays J. Perassoli Boiko

Márcia de Fátima Morais, Fabrício Wesley da Rocha)

Capítulo 13 - Lean service: Aplicado a um processo de abastecimento

(Tassiara de Almeida de Silva, Jeancarlos Araldi, Edson Pacheco Paladini)

Capítulo 14 - Os papéis de agentes em rede para a promoção da inovação em pequenas empresas tradicionais

(Geralda Cristina de Freitas Ramalheiro, Ricardo Augusto Bonotto Barboza, Sergio Azevedo Fonseca)

Capítulo 15 - Proposta de melhoria de processo de planejamento da contratação de TI na Gestão Pública

(Dyego Alves da Silva, Edgard Costa Oliveira, Edna Dias Canedo, Simone Borges Simão Monteiro)

Capítulo 16 - Análise da acuracidade de estoques: Um estudo da aplicação do método do inventário rotativo na empresa Alfa

(Izadora Pereira, André Luís Almeida Bastos)

Capítulo 17 - Cadeia do frio: Revisão da literatura e estudo de caso em uma sorveteria. (Flavia Haweroth, Vanina Macowski Durski Silva, Silvia Lopes de Sena Taglialenha)

Capítulo 18 - Estudo de alternativas para exportação da soja brasileira através do Porto de Itaqui

(Priscila Santos Clemente da Silva, Marcos Vinicius H. da Silveira, Tathiana Apollo dos S. da C. Camargo)

Capítulo 19 - Fluxo Logístico a partir do diagrama de Causa-efeito de Ishikawa: Um estudo em um comércio de materiais de construção

(Christian Monteiro Schutts, Michele Schneider, Julio César Zilli, Adriana Carvalho Pinto Vieira, Ricardo Pieri)

Capítulo 20 - Redução de custos operacionais e condições inseguras em um almoxarifado após automatização de rotas internas

(Pedro Ferrelli, Raphael Ribeiro Machado, Wesley de Araujo Moreira, Ruy Gomes da Silva)

Capítulo 21 - Uso de ferramentas tecnológicas e práticas logísticas na gestão da cadeia de suprimentos da construção civil

(Christiane Wagner Mainardes Krainer, Jefferson Augusto Krainer, Cezar Augusto Romano

Bernardo Pasquini Cavassin, Ryan Ramos Scheidt) 


\section{CAPÍTULO 1}

\section{GERENCIAMENTO DE ESTOQUES: O CASO DE UMA LOJA DE CONVENIÊNCIA}

\section{Flaviani Souto Bolzan Medeiros}

\section{Bruna Ferreira Lederes}

\section{Juliana Andréia Rüdell Boligon}

Flaubiane Figueredo Machado

Ana Rita Schneider Dias

Resumo: A constante mudança no mercado faz com que antigas práticas sejam revisadas pela gestão e novas sejam adotadas para enfrentar melhor a crescente competição existente. Deste modo, na busca de um diferencial junto ao cliente, à logística tornou-se uma das áreas mais desafiadoras e sua utilização é indispensável para qualquer empresa principalmente na gestão de estoques. Devido a sua grande importância a procura por melhores ferramentas tornou-se contínua seja na aquisição, na movimentação e/ou na armazenagem dos produtos. Considerando esta realidade, o presente estudo tem como objetivo propor ferramentas que aperfeiçoem o controle de estoque de uma loja de conveniência. Para isso, foi realizada uma pesquisa descritiva, de cunho qualitativo, por meio de estudo de caso. A coleta dos dados ocorreu na forma de entrevistas estruturadas com os responsáveis das áreas analisadas, como também, obteve-se acesso ao relatório com a posição do estoque (software usado para o controle). Além disso, contou ainda com observações in loco na referida loja de conveniência aqui objeto de investigação. Entre os resultados obtidos constatou-se através do estoque de segurança que a empresa deve gerenciar melhor o estoque de determinados produtos e corrigir as falhas no controle logístico atualmente utilizado.

Palavras Chave: Logística; Gerenciamento de estoques; Varejo. 


\section{INTRODUÇÃO}

O atual ambiente empresarial tem feito com que as empresas observem com mais atenção o seu macroambiente na tentativa de visualizar outras oportunidades e, assim, agir buscando obter vantagens competitivas nas suas transações. Essa constante mudança no mercado faz com que antigas práticas sejam revisadas pela gestão e novas sejam adotadas para enfrentar melhor a competição existente. Para isso, é inevitável estar sempre se atualizando, procurando tecnologias que possam contribuir para aproveitar mais cedo o surgimento de possíveis oportunidades junto ao cliente.

Sob essa perspectiva, a logística tornou-se uma das áreas mais desafiadoras e sua utilização é indispensável para qualquer empresa, principalmente na gestão de estoques. Devido a sua grande importância, a procura por melhores ferramentas é contínua, seja na aquisição, movimentação e/ou armazenagem dos produtos.

Cada empreendimento possui uma padronização de processos e fluxos, mas quando se trata dos objetivos da logística todos buscam por: eficiência, redução dos custos, competitividade e agilidade. Deste modo, por uma questão estratégica, as empresas estão adotando ferramentas específicas para o gerenciamento de estoques, investindo cada vez mais no gerenciamento logístico com a utilização de Sistemas de Informação e obtendo como resultado um ambiente organizacional mais ágil, dinâmico e integrado.

Para Fleury et al. (2000), estas ferramentas como o estoque de segurança entre outras, têm potencial para auxiliar a organização a obter tanto vantagem em custo ou produtividade, como a vantagem em valor. Os Sistemas de Informação atuam como elos que ligam as atividades logísticas em um processo integrado, através da disponibilização de informações atualizadas gerando gráficos e planilhas que permitam acompanhar a real situação da empresa.

Em relação à gestão de estoques no varejo, Bowersoxe Closs (2001) salientam que os estoques das empresas comerciais varejistas são constituídos basicamente de mercadorias para revenda, sendo assim, o gerenciamento de estoques é fundamentalmente uma questão de compra e venda. O risco associado ao elevado investimento em estoques é minimizado pela diversidade das mercadorias.

Nesse contexto, o presente artigo tem como objetivo propor ferramentas que aperfeiçoem o controle de estoque em uma loja de conveniência. Oestudo justificase pelo fato de que a logística precisa responder com precisão as novas demandas exigidas diariamente das empresas além da devida atenção que precisa ser dada ao estoque e a sua adequada gestão e controle. No caso da logística no varejo, seu diferencial está nos pequenos ganhos, como na redução dos custos operacionais que, muitas vezes, representam uma grande diferença para a sobrevivência nesse contexto tão concorrido.

Acerca da estrutura, imediatamente após esta breve contextualização inicial, este trabalho segue com o embasamento teórico adotado - no caso tópicos sobre a logística, a questão do gerenciamento de estoques, bem como o estoque de segurança, e ainda, a relação dos sistemas de informações gerenciais e a logística empresarial - em seguida, apresenta-se a metodologia seguida visando o alcance do objetivo proposto no estudo. Na sequência, encontra-se a análise e discussão dos resultados e encerrando vislumbram-se as considerações finais a partir da pesquisa realizada.

\section{LOGÍSTICA}

No início de 1991, a logística e a estratégia competitiva, demonstraram sua importância. Como preparação para a Guerra do Golfo, os Estados Unidos e seus aliados tiveram que deslocar grandes quantidades de materiais a grandes distâncias. Equipamentos foram transportados por mar em questão de meses, usando os recursos da logística. Apenas num passado recente é que as organizações empresariais reconheceram o impacto vital que o gerenciamento logístico pode ter na obtenção da vantagem competitiva. Entretanto, a logística não se refere apenas à distribuição física e sim, a gestão de estoques, armazenagem, distribuição, gestão de compras e transporte, além das atividades de apoio. Ao longo do tempo, a logística vem evoluindo, passando de ações isoladas para ações sinérgicas, ou seja, à logística integrada e, atualmente, supply chain management (AVOZANI; SANTOS, 2010). 
A logística é uma das atividades econômicas mais antigas e ao mesmo tempo um dos conceitos gerenciais mais modernos. Os procedimentos de estocagem, armazenagem e transporte, considerados como as três funções logísticas de maior importância, surgiram mediante ao processo de troca da produção excedente entre os produtores (CHRISTOPHER, 2005).

Ballou (1993) define que a missão da logística é dispor mercadoria ou serviço, no lugar correto, no tempo certo e nas condições desejadas, ao mesmo tempo em que fornece a maior contribuição à empresa. Com relação à logística interna, Porter (1989, p. 36) define que "[...] são atividades associadas ao recebimento, armazenamento e distribuição de insumos do produto, como manuseio de material, armazenagem, controle de estoque, programação de frotas, veículos e devolução para fornecedores".

Sob essa perspectiva, Gasnier (2005) complementa que sem essas atividades, não haveria o fluxo e, portanto, as transformações que agregam valor aos produtos, sendo que onde a logística interna está comprometida, os custos podem até inviabilizar processos produtivos, deteriorando uma vantagem competitiva conquistada nos demais processos. O autor ressalta que sem a distribuição física, os produtos não seriam encaminhados para onde está a demanda, e assim a comercialização não seria concretizada.

\subsection{GERENCIAMENTO DE ESTOQUES}

Viana (1999) define estoque como sendo os materiais, mercadorias ou produtos acumulados para utilização posterior, de modo a permitir o atendimento regular das necessidades dos usuários para continuidade da atividade da empresa, sendo o estoque gerado, consequentemente, pela impossibilidade de prever-se a demanda com exatidão.

Para Oliveira (1999 apud IVAN, 2007), o estoque representa o custo das mercadorias possuídas por uma empresa numa data específica. É uma conta que registra os bens adquiridos para serem revendidos ou transformados. O autor destaca ainda que o tipo de estoque que uma empresa possui, depende do seu objetivo social: se for uma empresa que comercializa produtos, que é neste caso, ela compra e vende os mesmos produtos e seu estoque é constituído de mercadorias.

O controle de estoques é parte vital do composto logístico, pois o estoque de uma empresa pode absorver de $25 \%$ a $40 \%$ dos custos totais da empresa. Assim, o controle de estoques exerce influência muito grande na rentabilidade da empresa, pois eles absorvem uma parcela do capital que poderia estar sendo investido de outras maneiras. Portanto, aumentar a rotatividade do estoque auxilia a liberar ativo e economiza o custo de manutenção de inventário (BALLOU, 1993). Nesse sentido, conforme Bowersox e Closs (2001), a gerência de estoque tem como objetivo básico, obter a máxima rotatividade dos produtos satisfazendo, ao mesmo tempo, os compromissos com o cliente.

\subsubsection{ESTOQUE DE SEGURANÇA}

Um problema importante é a determinação do nível de estoque mais econômico para a empresa. Sabendo que os custos de estoques são influenciados por diversos fatores, tais como: volume disponibilidade, movimentação, mão-de-obra e o próprio recurso financeiro. Cada variável possui um determinado peso em relação a uma razão específica (POZO, 2007).

Segundo Francischini (2004), as falhas mais críticas no procedimento de reposição de estoque ocorrem em três pontos principais:

a) Aumento repentino de demanda: aumentos nãoprevistos da demanda do item em estoque podem ocorrer por várias causas, como, por exemplo: a chegada de um grande pedido do produto final para determinado cliente, o aumento da produção para estocagem do produto final, promoções etc.;

b) Demora no processo do Pedido de Compra: falhas no Sistema de Informação do Almoxarifado ou da área de Compras podem incorrer em demoras excessivas na expedição do pedido; e

c) Atrasos de entrega pelo fornecedor: o fornecedor nem sempre tem condições de cumprir seus prazos de entrega em virtude de problemas no seu sistema de produção, transporte ou dependência 
de liberação alfandegária.

Assim, a maneira mais comum de tratar esse problema é dimensionar um estoque de segurança que fique à disposição dos usuários quando algo sair fora do planejado. De acordo com Pozo (2007), o estoque mínimo ou estoque reserva é uma quantidade mínima de peças que tem que existir no estoque com a função de cobrir as possíveis variações do sistema, que podem ser: eventuais atrasos no tempo de fornecimento pelo fornecedor, rejeição do lote de compra ou aumento na demanda do produto, onde sua finalidade é não afetar o processo produtivo e, principalmente, não acarretar transtornos aos clientes por falta de material e, consequentemente, atrasar a entrega do produto.

Para definir o nível de estoque de segurança, existem alguns modelos matemáticos, mas neste estudo será usado o Método com Grau de Atendimento Definido, no qual visa determinar um estoque de segurança baseado em um consumo médio do produto durante certo período e um atendimento da demanda não em sua totalidade, mas em determinado grau de atendimento. Conforme Pozo (2007), calcula-se o estoque de segurança da seguinte forma:

1) Calcular o Consumo Médio Diário (Cmd):

$$
C m d=\frac{\sum C}{n}
$$

2º) Calcular o Desvio Padrão ( )

$$
\delta=\frac{\sqrt{(C-C m d)^{2}}}{n-1}
$$

3o) Calcular o estoque de segurança (ES):

$$
E S=\delta x k
$$

Onde:

Cmd = Consumo Médio Diário

$\mathrm{C}=$ Consumo Mensal

$\mathrm{n}=$ Número de Períodos

= Desvio Padrão

$\mathrm{k}=$ Coeficiente de risco/nível de serviço.
Sendo que nível de serviço ou coeficiente de risco refere-se ao risco dado em porcentagem, no qual é definido pelo administrador em função da sua sensibilidade de mercado e as informações que colhe junto a vendas e a suprimentos (POZO, 2007).

\subsection{OS SISTEMAS DE INFORMAÇÕES GERENCIAIS E A LOGÍSTICA EMPRESARIAL}

A informação possui papel crucial para a eficácia do desempenho da logística porque é o alicerce sólido para que os gestores estruturem seus planejamentos e decisões. A logística hoje depende das ferramentas que a tecnologia da informação disponibiliza, pois está evoluindo em ritmo acelerado, em velocidade e capacidade de armazenamento das informações, gerando simultaneamente reduções significativas de custos e otimizando processos (NOGUEIRA, 2009).

Os sistemas de informações chegam para minimizar possíveis erros ou falhas que ocorrem na logística empresarial, como a difícil tarefa de controlar estoques. Muitas vezes o estoque é considerado arriscado pela grande maioria dos administradores, pois este exige um alto investimento inicialmente e uma manutenção onerosa. Os sistemas de informações permitem um maior processamento de dados, disponibilidade de relatórios da situação atual do estoque, ou de um produto específico, correção imediata se houver necessidade, sistema interligado na entrada e saída de produtos entre outras tantas vantagens. Tachizawa (2004, p. 332) cita que a:

[...] tecnologia da informação, processos e sistemas de informação devem ser concebidos para dar suporte à cadeia produtiva nas organizações, assim como tais recursos sistêmicos devemse subordinar às decisões e estratégias de negócios implementados por seus empresários e executivos.

Batista (2004) conceitua os sistemas de informações gerenciais como sendo um conjunto de tecnologias que disponibilizam os meios necessários à operação do processamento dos dados disponíveis. Este está voltado a um sistema de coleta, armazenagem, 
recuperação e processamento de informações usadas ou desejadas por um ou mais executivos no desempenho de suas atividades. O processo de transformação de dados em informações proporciona a sustentação administrativa para otimizar os resultados esperados.

Nesse contexto, nota-se a importância dos sistemas de informações para a logística, especificamente no controle de estoques, estes dão suporte as atividades de aquisição, movimentação e armazenagem dos produtos. Lee e Whang (2002 apud BEZERRA, 2002) ressaltam essa importância dizendo que o segredo está em utilizar as informações obtidas e alavancar os recursos disponíveis para coordenar ações, priorizando os fluxos de informações. A palavra chave passa a ser a integração empresarial para obtenção de vantagem competitiva.

\section{METODOLOGIA}

Para Jung (2004), a metodologia é definida como um conjunto de técnicas e procedimentos que tem por finalidade viabilizar a execução da pesquisa, obtendose como resultado um novo produto, processo ou conhecimento. Sendo assim, neste estudo, adotouse uma pesquisa qualitativa quanto à natureza, do tipo descritiva em relação aos objetivos, sendo desenvolvida por meio de um estudo de caso no que se refere aos procedimentos de coleta.

Dessa forma, acerca da pesquisa qualitativa, segundo Clemente (2011), esta visa à construção da realidade, mas que se preocupa com as ciências sociais em um nível de realidade que não pode ser quantificado, trabalhando com o universo de crenças, valores, significados e outros construtos profundos das relações que não podem ser reduzidos à operacionalização de variáveis.

No que tange à pesquisa descritiva, Bacha (1998) explica que esta possui objetivos bem definidos e formulados, obedecendo a procedimentos formais e estruturados para a solução de problemas ou avaliação de alternativas de cursos de ação. Em relação ao estudo de caso, de acordo com Furasté (2010), é um estudo feito exaustivamente de algum caso em particular, de pessoa ou de instituição, para analisar as circunstancias específicas que o envolvem.

Quanto ao plano de coleta dos dados realizaramse entrevistas estruturadas com os responsáveis encarregados das áreas analisadas na empresa, bem como uma análise documental no relatório com a posição do estoque (software utilizado) no período estudado, e ainda, observação in loco na loja. Neste caso, o propósito foi verificar e conhecer como era feito o gerenciamento do estoque, possibilitando assim, coletar o máximo de informações para a identificação das possíveis falhas no método existente de controle.

Vale ressaltar que a pesquisa documental tem sua coleta de dados restrita a documentos escritos, ou não, constituindo o que se denomina de fontes primárias (MARCONI; LAKATOS, 2001). Na sequência, após a coleta das informações, foi realizada a verificação de como era o controle de estoque na loja de conveniência.

Assim, o método utilizado pela empresa foi aperfeiçoado a partir da utilização do software pelo Sistema de Informação (S.I.) que já disponibilizavam, mas com a adição do estoque de segurança. Os dados obtidos foram calculados com base na venda média diária e as fórmulas para a realização dos cálculos estão devidamente mencionadas no referencial teórico abordado.

\section{ANÁLISE E DISCUSSÃO DOS RESULTADOS}

O fluxograma exposto na Figura 1, a seguir, mostra o processo de chegada do produto na empresa até a emissão do relatório para ser efetuada uma nova compra. 
Figura 1 - Controle logístico da empresa analisada

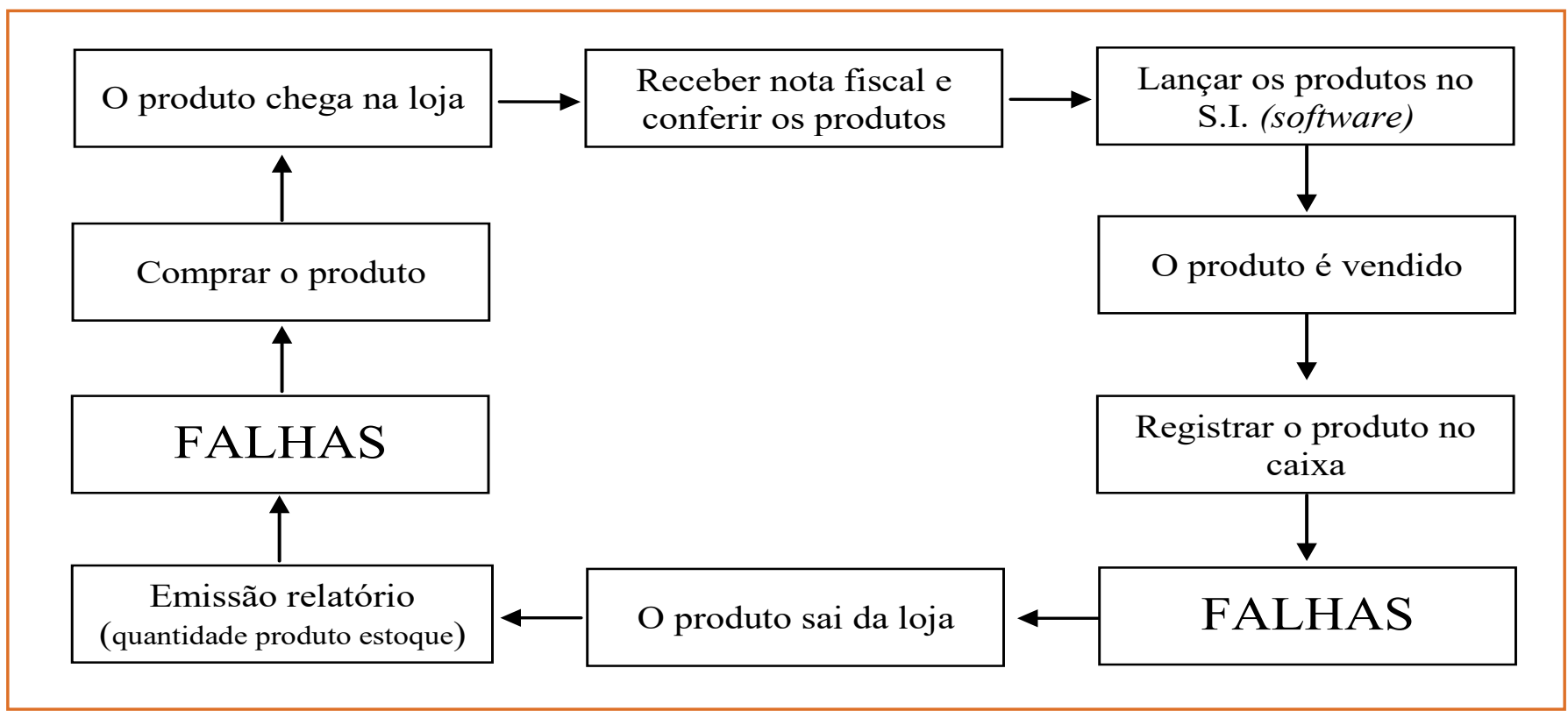

Observa-se na Figura 1 que inicialmente o produto chega à empresa através dos fornecedores, logo após a gerente da loja de conveniência recebe a nota fiscal e confere os produtos. Nesta conferência, se por acaso o produto apresentar algum dano, estrago ou quebra, este é devolvido ao fornecedor para que na próxima compra a empresa seja ressarcida com um novo produto. Posteriormente, a conferência uma unidade de cada produto é levada para pessoa encarregada de registrar e cadastrar esses produtos no software (S.I.) que a empresa utiliza para fazer todo o controle de estoque.

Após este cadastro, os produtos já estão no estoque à disposição para serem colocados à venda. Conforme a necessidade de reposição, estes vão sendo agrupados nas suas devidas prateleiras. Quando vendidos, estes produtos são registrados no caixa e estarão automaticamente sendo subtraídos do registro que consta no software (os programas são interligados). Nesse momento ocorrem às falhas, que segundo a gerente da Loja, alguns produtos não são registrados devido a um fluxo maior de pessoas em certos horários, as atendentes não conseguem atender a demanda. Ela ainda relata que esta falha está diretamente ligada a sobras de caixa, pois estas sobras são produtos que não foram registrados.

O produto sai da Loja e o dinheiro é debitado no caixa.
Por fim, no dia 28 de cada mês emite-se um relatório com a quantidade dos produtos em estoque para posteriormente ser efetuada a compra dos mesmos. Novamente o fluxo se repete e as falhas vão se acumulando mês a mês.

É importante ressaltar que como alguns produtos não são registrados, o relatório que é emitido no final do mês não corresponde com a quantidade de produtos disponíveis na loja, em consequência disto, a falta de alguns produtos é constante, como no caso da cerveja e refrigerante do tipo coca-cola. A pessoa encarregada da tarefa de realizar as compras estará comprando os produtos com base em um relatório "fictício" que não apresenta a situação real da quantidade de produtos que a empresa dispõe em estoque.

Outro questionamento teve como objetivo saber se a empresa tinha conhecimento de uma margem de roubo, erro ou falha do próprio software. A gerente então relata que a empresa não tem conhecimento de quantas unidades estariam sendo prejudicadas ou de quanto isso estaria prejudicando o Ativo da empresa. Além disso, outra questão abordada relaciona-se com os procedimentos de contagem dos produtos, ou seja, como é feito o controle do que foi vendido " $x$ " unidades em estoque. Observou-se que a contagem é feita mensalmente, mais precisamente no dia 28 de cada mês, em que a gerente da loja e mais uma atendente 
são encarregadas desta tarefa. A contagem começa pelo estoque e depois para os produtos que estão disponíveis nas prateleiras.

Segundo a gerente, quando a quantidade em estoque não confere com a quantidade emitida no relatório, esta segunda quantidade é ignorada colocando a quantidade que está disponível neste mesmo relatório para que posteriormente seja feita a correção no software. Após esse relato percebe-se que a gestão com relação ao estoque deve ser reavaliada rapidamente, pois não é realizada de forma adequada. Também teve-se acesso a uma lista da atual posição do estoque da empresa com todos os produtos que esta comercializa, separados por grupo e discriminados conforme: quantidade em estoque, custo médio, valor custo médio, preço de venda, venda média diária e dias de estoque (quantos dias um produto permanece no estoque). Na Tabela 1 estão os principais grupos de produtos da empresa que servirão de base para o cálculo do estoque de segurança visando minimizar e controlar as falhas existentes no setor.

Tabela 1 - Principais grupos de produtos comercializados

\begin{tabular}{|c|c|}
\hline \multicolumn{1}{|c|}{ Grupos } & Tipos de produtos \\
\hline Bebidas alcoólicas & 35 \\
\hline Bebidas não alcoólicas & 92 \\
\hline Refrigerados & 10 \\
\hline Congelados & 55 \\
\hline Mercearia & 25 \\
\hline Biscoito/Snake & 80 \\
\hline Fast Food & 29 \\
\hline Bombonier & 228 \\
\hline Tabacaria & 66 \\
\hline Não alimentícios & 23 \\
\hline Publicações (revistas) & 30 \\
\hline Produtos locais & 3 \\
\hline Produtos promocionais & 2 \\
\hline Padaria & 16 \\
\hline Higiene e beleza & 38 \\
\hline Automotivos & 1 \\
\hline Total & 734 \\
\hline
\end{tabular}

Fonte: Elaborado pelos autores com base nos dados da pesquisa
Ressalta-se os produtos selecionados para a realização do cálculo do estoque de segurança foram discriminados com base na sua demanda mensal e também levou-se em consideração o preço dos produtos.

\subsection{CÁLCULO DO ESTOQUE DE SEGURANÇA}

Para complementar os cálculos do estoque de segurança e facilitar a interpretação, apresenta-se na Tabela 2, os níveis de serviços para os respectivos grupos de produtos comercializados.

Tabela 2 - Nível de serviço dos produtos comercializados

\begin{tabular}{|c|c|}
\hline \multicolumn{1}{|c|}{ Grupos } & Nivel de serviço (k) \\
\hline Bebidas alcoólicas & $95 \%$ \\
\hline Refrigerados & $98 \%$ \\
\hline Mercearia & $99,90 \%$ \\
\hline Fast Food & $95 \%$ \\
\hline Tabacaria & $99,90 \%$ \\
\hline Publicações & $97,50 \%$ \\
\hline Padaria & $99,90 \%$ \\
\hline Automotivos & $99,90 \%$ \\
\hline Bebidas não alcoólicas & $99 \%$ \\
\hline Congelados & $98 \%$ \\
\hline Biscoito/Snake & $99,90 \%$ \\
\hline Bombonier & $97,50 \%$ \\
\hline Não alimentícios & $99,90 \%$ \\
\hline Produtos locais & $95 \%$ \\
\hline Higiene e beleza & $99,90 \%$ \\
\hline
\end{tabular}

Fonte: Elaborado pelos autores com base nos dados da pesquisa

Os números do nível de serviço (k) foram disponibilizados pela empresa, sendo que para se chegar a estes números, esta levou em consideração o grau atendimento prestado aos seus clientes, ou seja, com o maior valor $(99,90 \%)$ a empresa atendeu aproximadamente a totalidade dos serviços exigidos pelos clientes em relação aos produtos solicitados. Com relação à porcentagem de 95\%, a menor encontrada na Tabela 2, esta se aplica aos grupos em que as necessidades não foram atendidas por completo, faltando algum produto mais de uma vez no período.

Na Tabela 3 são apresentados os produtos selecionados para calcular o estoque de segurança. 
Para o grupo de bebidas alcoólicas selecionou-se os produtos: CERV NORTENA 960ML, CERV SKOL BIG
NECK 500ML e CERV POLAR 350ML LT e, assim, sucessivamente os produtos para os demais grupos.

Tabela 3 - Estoque de segurança

\begin{tabular}{|c|c|c|c|c|c|c|}
\hline Grupo & Produto & $\begin{array}{l}\text { Consumo } \\
\text { Médio } \\
\text { Mensal }\end{array}$ & $\begin{array}{l}\text { Consumo } \\
\text { Médio Diário }\end{array}$ & $\begin{array}{c}\text { Resposta } \\
\text { Desvio } \\
\text { Padrão }\end{array}$ & $\begin{array}{l}\text { k (Nível de } \\
\text { serviço) }\end{array}$ & $\begin{array}{c}\text { ES } \\
\text { (unidades) }\end{array}$ \\
\hline \multirow{4}{*}{$\begin{array}{c}\text { BEBIDAS } \\
\text { ALCOÓLICAS }\end{array}$} & CERV NORTENA 960ML & 57,90 & 1,93 & 10,39 & 1,645 & 17 \\
\hline & CERV SKOL BIG NECK 500ML & 352,10 & 45,07 & 57,01 & 1,645 & 94 \\
\hline & CERV POLAR 350ML LT & 272,10 & 9,07 & 48,84 & 1,645 & 80 \\
\hline & ENER RED BULL 250ML & 70,80 & 2,36 & 12,71 & 2,326 & 30 \\
\hline \multirow{6}{*}{$\begin{array}{c}\text { BEBIDAS } \\
\text { NÃO } \\
\text { ALCOÓLICAS }\end{array}$} & REFR COCA COLA 600ML & 417,90 & 13,93 & 75,01 & 2,326 & 174 \\
\hline & REFR COCA COLA 250ML & 782,10 & 26,07 & 140,39 & 2,326 & 327 \\
\hline & BEB LAC NEST 300ML GAR & 21,30 & 0,71 & 3,82 & 2,082 & 8 \\
\hline & BEB.LAC.NINHO MAC.BA.180G & 8,70 & 0,29 & 1,56 & 2,082 & 3 \\
\hline & BEB LAC NEST PESS 180ML & 12,9 & 0,43 & 2,31 & 2,082 & 5 \\
\hline & SORV CORNETTO BRIG 79G & 64,20 & 2,14 & 11,89 & 2,082 & 25 \\
\hline \multirow[t]{3}{*}{ CONGELADOS } & PIC KIBON TABLITO 65G & 105 & 3,50 & 18,85 & 2,082 & 39 \\
\hline & PIC CHICABON 65G & 158,70 & 5,29 & 28,49 & 2,082 & 59 \\
\hline & PIPOCA AMPM MICR NAT UM & 8,70 & 0,29 & 1,56 & 2,326 & 4 \\
\hline \multirow[t]{3}{*}{ MERCEARIA } & MAC NISSIM LAMEN CARN 80G & 6,30 & 0,14 & 1,14 & 2,326 & 3 \\
\hline & REFR PO TANG LAR 45G & 4,20 & 0,14 & 0,75 & 2,326 & 2 \\
\hline & BISC DACOLO AMAN GOI 350G & 49,20 & 1,64 & 8,83 & 2,326 & 21 \\
\hline \multirow{3}{*}{$\begin{array}{l}\text { BISCOITOI } \\
\text { SNAKE }\end{array}$} & UN BAT FRI AMPM & 94,20 & 3,14 & 16,91 & 2,326 & 39 \\
\hline & BISC CLUB SOC ORIG 26G & 72,90 & 2,43 & 13,08 & 2,326 & 30 \\
\hline & SALGADOS & $1.750,80$ & 58,36 & 314,27 & 1,645 & 517 \\
\hline \multirow[t]{3}{*}{ FAST FOOD } & BEB PRON CAFÉ & $3.407,10$ & 113,57 & 661,59 & 1,645 & 1.006 \\
\hline & PAO QUE AMPM GRANDE UM & $1.272,90$ & 42,43 & 228,49 & 1,645 & 376 \\
\hline & CHIC TRIDENT REG MEN 8,5G & 117,90 & 3,93 & 21,16 & 1,960 & 41 \\
\hline \multirow[t]{3}{*}{ BOMBONIER } & BOMB SEREN AMOR 20G & 287,10 & 9,57 & 51,53 & 1,960 & 101 \\
\hline & BALAS & $1.729,20$ & 57,64 & 310,40 & 1,960 & 608 \\
\hline & CIG DUN CAR RED BOX & 662,10 & 22,07 & 118,85 & 2,326 & 367 \\
\hline \multirow[t]{3}{*}{ TABACARIA } & CIG LM BLU RSP FC & 182,10 & 6,07 & 32,69 & 2,326 & 101 \\
\hline & CIG SHELTON ORI SOF & 287,10 & 9,57 & 51,54 & 2,326 & 159 \\
\hline & BON BARBIE PRINCESA & 2,10 & 0,07 & 0,38 & 2,326 & 1 \\
\hline \multirow{2}{*}{$\begin{array}{c}\text { NÃO } \\
\text { ALIMENTÍ́cIOS }\end{array}$} & CAN BIC 1 UN & 4,20 & 0,14 & 0,75 & 2,326 & 2 \\
\hline & FOSF PARANA 10UN & 36,30 & 1,21 & 6,52 & 2,326 & 20 \\
\hline
\end{tabular}




\begin{tabular}{|c|c|c|c|c|c|c|}
\hline Grupo & Produto & $\begin{array}{l}\text { Consumo } \\
\text { Médio } \\
\text { Mensal }\end{array}$ & $\begin{array}{c}\text { Consumo } \\
\text { Médio Diário }\end{array}$ & $\begin{array}{c}\text { Resposta } \\
\text { Desvio } \\
\text { Padrão }\end{array}$ & $\begin{array}{l}\text { k (Nivel de } \\
\text { serviço) }\end{array}$ & $\begin{array}{c}\text { ES } \\
\text { (unidades) }\end{array}$ \\
\hline \multirow{3}{*}{ PUBLICAÇÕES } & REV.PLAYBOY & 25,80 & 0,86 & 4,63 & 1,960 & 9 \\
\hline & JORN ZERO HORA SEM 1UN & 128,70 & 4,29 & 23,10 & 1,960 & 45 \\
\hline & JORN CORREIO DO POVO DIAR & 47,10 & 1,57 & 8,45 & 1,960 & 17 \\
\hline \multirow{4}{*}{$\begin{array}{l}\text { PRODUTOS } \\
\text { LOCAIS }\end{array}$} & ERV MATE TAURA 1KG & 42,90 & 1,43 & 7,70 & 1,645 & 13 \\
\hline & ERV MATE TAURA 500G & 139,20 & 4,64 & 24,99 & 1,645 & 41 \\
\hline & BISC. ROSCA CHOC RADCAU & 10,80 & 0,36 & 1,94 & 1,645 & 3 \\
\hline & DONUTS DOCE LEITE PAD UN & 90,00 & 3,00 & 16,15 & 2,326 & 50 \\
\hline \multirow[t]{2}{*}{ PADARIA } & CROISSANT FORNO & 218,70 & 7,29 & 39,26 & 2,326 & 121 \\
\hline & COXINHA PADAR KG & 387,90 & 12,93 & 69,63 & 2,326 & 215 \\
\hline \multirow{3}{*}{$\begin{array}{c}\text { HIGIENE } \\
\text { E } \\
\text { BELEZA }\end{array}$} & PRESRV JONT SENS GUN & 10,80 & 0,36 & 1,94 & 2,326 & 6 \\
\hline & ABSO SEMPRE LIVRE ESP 8UN & 6,30 & 0,21 & 1,13 & 2,326 & 3 \\
\hline & CUR BAND AID 4OUN & 4,20 & 0,14 & 0,75 & 2,326 & 2 \\
\hline AUTOMOTIVOS & TOA MAGIC AZ 10UN & 12,90 & 0,43 & 2,31 & 2,326 & 7 \\
\hline
\end{tabular}

Fonte: Elaborado pelos autores com base nos dados da pesquisa

Na Tabela 3, inicialmente, para calcular o Desvio Padrão levou-se em conta o consumo mensal, o consumo médio diário, bem como o número de períodos que neste caso foram trinta dias. Em relação a variável "k" que representa o nível de serviço, utilizou-se os valores correspondentes com estimativas fornecidas pela empresa de acordo com Pozo (2007).

No que se refere ao estoque de segurança, este foi calculado através da aplicação da fórmula (3) que está mencionada no referencial teórico. Como resultados pode-se constatar que para o produto CERV POLAR 350ML LT, o estoque de segurança é de 80 unidades. Isso representa que, considerando o nível de serviço da empresa com este produto e, o desvio padrão que faz a relação entre o Consumo mensal e o Consumo médio diário, a empresa deve manter em cada mês 80 unidades do produto no seu estoque para conseguir atender sua demanda.

Ressalta-se que este estoque de segurança pode oscilar de acordo com o nível de serviço prestado, ou seja, se este aumentar e passar de 95\% para $98 \%$ o estoque de segurança tende a diminuir. Como também o estoque de segurança será influenciado pela variação do Consumo total e médio dos produtos, na proporção de que se aumentar a demanda e o nível de serviço permanecer constante, o estoque de segurança tenderá a aumentar. Evidencia-se também, que no caso do produto CERV POLAR 350ML LT, o qual possui uma demanda considerável no mês, em consequência disso obteve-se um valor alto de produtos para o estoque de segurança. Logo, se a empresa não mantiver esta quantidade em estoque correrá o risco de não disponibilizar o produto quando solicitado pelos clientes.

\section{CONSIDERAÇÕES FINAIS}

O diferencial da logística no varejo está nos pequenos ganhos, como na redução dos custos operacionais, que muitas vezes, representam uma grande diferença para a sobrevivência nesse mercado concorrencial. Os custos operacionais estão relacionados às atividades de aquisição, movimentação e armazenagem dos produtos e os ganhos estão relacionados com a determinação da quantidade exata a ser comprada, bem como um estoque de segurança com a obtenção de informações concisas para menores custos no processamento de pedidos possibilitando a compra de maiores quantidades, com informações confiáveis de vendas passadas e o conhecimento dos níveis de controle de estoques etc. Quando se trata de varejo, a falta de mercadoria à disposição do consumidor acarretará em perdas de vendas e consequentemente perda de lucros.

Através do estudo realizado, foi possível identificar 
falhas no gerenciamento de estoques adotado pela loja de conveniência, bem como encontrar os resultados que esta desconhecia como o estoque de segurança. Os resultados obtidos poderão contribuir para que a organização não cause transtornos aos seus clientes por falta de produtos, isso porque agora a empresa possui informações necessárias para gerenciar seu estoque e, portanto, não deixar faltar produtos para os seus clientes.

Recomenda-se, em relação ao estoque, que seja realizado diariamente um controle dos produtos, como no caso segunda-feira a contagem de cigarros, terçafeira a contagem das bebidas, e assim sucessivamente para os demais itens. Sem esse controle a empresa não consegue ter informações precisas sobre a disponibilidade dos produtos, a real necessidade de estar realizando um novo pedido ao fornecedor.

Como sugestão de pesquisa futura, fica a proposta de realização na própria empresa objeto desse estudo a acurácia de estoque de alguns produtos, considerando que a relação da quantidade física existente no depósito, muitas vezes, não confere com os dados do relatório emitido (quantidade teórica) como relatado pela gerência da organização.

\section{REFERÊNCIAS}

[1] AVOZANI, C.; SANTOS, A. R. Logística descomplicada: logística empresarial - conceitos e definições, fev. 2010. Disponível em: <http://www.logisticadescomplicada.com/ tag/definicao-logistica/>. Acesso em: 18 set. 2011.

[2] BACHA, M. de L. Introdução à pesquisa de marketing. São Paulo: CenaUn, 1998.

[3] BALLOU, R. H. Logística empresarial: transporte, administração de materiais e distribuição física. São Paulo: Atlas, 1993.

[4] BATISTA, E. de O. Sistema de informação: o uso consciente da tecnologia para o gerenciamento. São Paulo: Saraiva, 2004

[5] BEZERRA, A. C. Modelagem de um sistema de informações logísticas genérico através da unified modeling languag. In: ENCONTRO NACIONAL DE ENGENHARIA DE PRODUÇÃO, 22., Curitiba, 2002. Anais... ENEGEP: Curitiba, 2002.
[6] BOWERSOX, D. J.; CLOSS, D. J. Logística empresarial: o processo de integração da cadeia de suprimento. São Paulo. Atlas, 2001

[7] CHRISTOPHER, M. Logística e gerenciamento da cadeia de suprimentos: criando redes que agregam valor. 2 . ed. São Paulo: Thomson, 2005.

[8] CLEMENTE, F. Pesquisa qualitativa, exploratória e fenomenológica: alguns conceitos básicos. 2011. Disponível em: <http://www.administradores.com.br/informe-se/artigos/ pesquisa-qualitativa-exploratoria-e-fenomenologica-algunsconceitos-basicos/14316/>. Acesso em: 20 out. 2011.

[9] FLEURY, P. F.; WANKE, P. F.; FIGUEIREDO, K. F. (Org.). Logística empresarial: a perspectiva brasileira. São Paulo: Atlas, 2000.

[10] FRANCISCHINI, P. G.; GURGEL, F. do A. Administração de materiais e do patrimônio. São Paulo: Pioneira Thompson Learning, 2004.

[11] FURASTÉ, P. A. Normas técnicas para o trabalho científico: com explicitação das normas da ABNT. 15. ed. Porto Alegre: Brasul, 2010.

[12] GASNIER, D. G. Logística não é só transporte. ASLOG - Associação Brasileira de Logística, São Paulo, fev. 2005. Disponível em: <http://www.aslog.org.br/novo/ noticias_interna.php?q=eccbc87e4b5ce2fe28308fd9f2a7b af3\&idn $=6 c 4 b 761 a 28 b 734 f e 93831$ e3fb400ce87>. Acesso em: 12 mai. 2011

[13] IVAN, G. dos S. Importância do controle de estoque de mercadorias para as empresas comerciais. Portal do Administrador, 2007. Disponível em: <http://www. administradores.com. br/informe-se/artigos/importancia-docontrole-de-estoque-de-mercadorias-para-as-empresascomerciais/13788/>. Acesso em: 24 jun. 2011.

[14] JUNG, C. F. Metodologia para pesquisa e desenvolvimento: aplicada a novas tecnologias, produtos e processos. Rio de Janeiro: Axcel Books, 2004.

[15] MARCONI, M. de A.; LAKATOS, E. M. Metodologia do trabalho científico: procedimentos básicos, pesquisa bibliográfica, projeto e relatório, publicações e trabalhos científicos. 5. ed. São Paulo: Atlas, 2001.

[16] NOGUEIRA, A. A importância da TI nos processos logísticos. Revista Mundo Logística, 2009. Disponível em: $<$ http://amarildonogueira.com.br/site/a-importancia-da-tinos-processos-logisticos/>. Acesso em: 25 ago. 2011.

[17] PORTER, M. Vantagem competitiva: criando e sustentando um desempenho superior. Rio de Janeiro, Campus, 1989

[18] POZO, H. Administração de recursos materiais e patrimoniais: uma abordagem logística. 4. ed. São Paulo: Atlas, 2007 
[19] TACHIZAWA, T. Gestão ambiental e responsabilidade social corporativa: estratégias de negócios focadas na realidade brasileira. São Paulo: Atlas, 2004.
[20] VIANA, J. J. Administração de materiais: um enfoque prático. São Paulo: Atlas, 1999. 


\section{CAPÍTULO2}

\section{O MERCADO FINANCEIRO NA PERSPECTIVA DE ESTUDANTES DE ENGENHARIA DE PRODUÇÃO: ENTRE O INTERESSE PESSOAL E O PROFISSIONAL}

\section{Elizabeth Liang}

\section{Ruth Margareth Hofmann}

Resumo: Ao longo de sua formação acadêmica, a depender de seu perfil e de suas preferências, os estudantes de graduação em engenharia de produção podem manifestar maior afinidade com determinadas áreas de conhecimento. De acordo com a Associação Brasileira de Engenharia de Produção (ABEPRO) a formação de um engenheiro de produção contempla dez subáreas do conhecimento, dentre as quais, a subárea denominada "engenharia econômica", que inclui a gestão econômica, a gestão de custos, a gestão de investimentos e a gestão de riscos. O objetivo do presente trabalho é identificar como os estudantes de engenharia de produção de uma universidade brasileira veem o mercado financeiro ao longo de sua formação durante a graduação. Considerando que dentre as competências desenvolvidas por graduandos em engenharia estão as de caráter financeiro, os estudantes cursam disciplinas obrigatórias e optativas que os põem em contato ou os instigam a compreender o mercado financeiro, o que depende das intenções pessoais e profissionais dos estudantes. Para tanto, foram aplicados questionários estruturados com questões acerca da motivação, do interesse e dos conhecimentos financeiros dos graduandos a partir de seus contatos com disciplinas optativas e obrigatórias ofertadas no curso de Engenharia de Produção. As análises foram norteadas pela bibliografia referente à formação em engenharia de produção, bem como pela literatura em finanças comportamentais. Dentre os resultados, foi possível identificar o perfil dos estudantes em termos de seu comportamento financeiro, incluindo aspectos como aversão a risco, além da importância de fatores pessoais e profissionais que motivam seus interesses por finanças.

Palavras Chave: Vantagem Competitiva, Logística de Transporte, Centro de Distribuição, PRODEPE. 


\section{INTRODUÇÃO}

A Engenharia de Produção é área ampla e abrange, de acordo com a Associação Brasileira de Engenharia de Produção (ABEPRO), dez subáreas do conhecimento tais como: engenharia de operações e processo de produção, logística, engenharia de qualidade, pesquisa operacional, engenharia do produto, engenharia econômica, engenharia da sustentabilidade, engenharia organizacional, engenharia do trabalho e educação em engenharia de produção. E é devido a essa amplitude que o curso possui que o presente estudo possui como objetivo analisar a visão dos graduandos com relação à área financeira de atuação do engenheiro de produção formado nas universidades brasileiras, que abrange gestão econômica, custos, investimentos e riscos.

$\mathrm{Na}$ estrutura curricular do curso, as disciplinas obrigatórias relacionadas a essa área do conhecimento são: economia, engenharia econômica e contabilidade custos industriais.

A partir do referencial teórico a respeito da formação acadêmica do engenheiro e finanças comportamentais, a análise dos dados obtidos por meio de questionários aplicados no período de 2014 a 2015, é possível identificar a propensão do interesse financeiro dos estudantes possuírem caráter pessoal ou profissional.

A pesquisa é uma forma de avaliar o quanto o conhecimento adquirido ao longo da graduação está influenciando no papel do engenheiro de produção.

\section{REVISÃO DA LITERATURA}

O mercado financeiro se trata das principais atividades financeiras feitas por instituições financeiras e é algo que está em constantes mudanças principalmente quando se aborda sobre o cenário brasileiro, entretanto conhecer os conceitos básicos teóricos a respeito de seu funcionamento auxilia a conseguir acompanhar suas alterações. O sistema financeiro basicamente é formado por instituições e operações de recursos monetários entre agentes econômicos, além disso, ele pode ser visto como um mercado de empréstimos. (MELLAGI FILHO, 1995; MELLAGI FILHO e ISHIKAWA, 2003).

\subsection{FORMAÇÃO ACADÊMICA DO ENGENHEIRO DE PRODUÇÃO}

As constantes mudanças socioeconômicas, assim como os avanços tecnológicos que são introduzidos à produção, obrigam que cada vez mais os engenheiros possuam domínio de conhecimentos amplos, ou seja, a multidisciplinaridade se torne ainda mais presente no dia-a-dia desse profissional. Além disso, é possível identificar o sucessivo aumento de atividades em áreas de gestão e administrativas por parte dos engenheiros. (OLIVEIRA e PINTO, 2006).

O curso de Engenharia de Produção da Universidade Federal do Paraná (UFPR) contém em sua grade curricular as disciplinas (relacionadas a finanças) semestrais de: Economia; Engenharia Econômica; e Contabilidade e Custos Industriais; todas de natureza obrigatória e com carga horária de 60 horas. (ENGENHARIA DE PRODUÇÃO - UFPR, 2015).

Com relação às ementas, a disciplina de Economia aborda: conceitos de economia e econometria, microeconomia e macroeconomia. Já em Engenharia Econômica são previstos assuntos tais como: juros, fatores de equivalência, amortização de dívidas, depreciação, análise de investimentos, substituição de equipamentos, análise de custo-volume-lucro, apuração do lucro, e gestão de riscos. E em Contabilidade e Custos Industriais a abordagem é em torno de: contabilidade legal e gerencial, demonstrativos contábeis e suas finalidades, estrutura contábil, análise por meio de indicadores, verticais e horizontais, estudos dos métodos e importância dos custos industriais, método ABC, RKW, UEP e aplicabilidade da TOC. (ENGENHARIA DE PRODUÇÃO - UFPR, 2015).

\subsection{FINANÇAS COMPORTAMENTAIS}

Um aspecto importante a se analisar quando se trata de investimentos é a análise de finanças comportamentais.

\subsubsection{RISCOS}

A Teoria de Perspectiva de Kahneman e Tversky (1979) aborda a influência do fator psicológico na 
tomada de decisões envolvendo riscos, a partir, do que os autores denominam: efeito certeza, efeito reflexão, e efeito isolamento. O efeito certeza trata da tendência de se considerar em grau as possibilidades que possuem probabilidades maiores de acontecer; efeito reflexão ocorre quando há perdas envolvidas nas possibilidades, nesse caso, a escolha por opções que fornecem uma chance maior de ganho certo mesmo sendo valores menores é escolhida, entretanto, quando se trata de perdas, a situação se inverte para a escolha da opção que há perdas maiores com probabilidades menores de ocorrência; e por fim há o efeito isolamento, em que a escolha entre duas alternativas é feita pelos componentes que as distinguem, que demonstram diferentes perspectivas quando se analisa as alternativas de forma separada.

\subsubsection{COMPORTAMENTO DO INVESTIDOR}

Tratando-se de mercado de ações, a tendência é que grupos de investidores busquem comprar ações que estejam valorizando e vendam as que estejam desvalorizando a partir de seus históricos de rendimentos, assim como, baseando-se em suas reações pouco ou muito exageradas a respeito de informações recebidas sobre ativos. (GRINBLATT e KELOHARJU, 2000).

Ainda nesse âmbito do mercado financeiro, podese comentar a respeito da excessiva confiança demonstrada por parte dos investidores, ignorando informações contrárias aos seus pensamentos, de uma maneira geral quando estão em situações de otimismo ou pessimismo exagerados. (MILANEZ, 2003).

Além disso, ainda existe a influência das mídias que afetam as decisões dos investidores de duas formas: primeiramente com as justificativas dos preços baseadas em notícias divulgadas (reforçando a confiança dos investidores), e por segundo, a força que essas notícias possuem ao causar euforia (otimismo exacerbado) e pânico (excessos de pessimismos), devido ao fato que as pessoas acreditam que a partir disso é possível antecipar os resultados dos eventos que estão por vir, gerando assim um excesso de confiança. (MILANEZ, 2003).

\section{METODOLOGIA}

O presente estudo de caso utiliza como base análises comportamentais descritas em diversas literaturas e a comparação das mesmas com resultados obtidos por meio de questionários realizados com estudantes de engenharia de produção.

Os questionários utilizados possuem o objetivo de identificar o comportamento financeiro, analisar perfis de aversão a risco, e o interesse pessoal e profissional. Sendo o primeiro abordado de forma quantitativa e qualitativa, e o segundo e o terceiro de forma quantitativa. A aplicação das perguntas foi realizada no período de 2014 a 2015.

Com relação à pesquisa sobre aversão à risco foram apresentados 13 problemas de múltipla escolha, sendo que alguns desses problemas são os mesmos elaborados por Kahneman e Tversky (1979), para identificar se os estudantes apresentavam maior ou menor grau de aversão a perda, como por exemplo, o problema que se refere a optar por uma das duas opções:

(A): $33 \%$ de probabilidade de ganhar $2.500 ; 66 \%$ de probabilidade de ganhar 2.400; $1 \%$ de probabilidade de ganhar 0 (zero); ou (B): Ganho certo de 2.400 .

Outro exemplo de problema proposto no mesmo formato do anterior, porém, ao invés de dar opções de ganho, trata da probabilidade de perda:

(A): $25 \%$ de chance de perder 6.000 ; ou (B): $25 \%$ de perder 4.000 e $25 \%$ de perder 2.000 .

O questionário de comportamento de financeiro pode-se destacar algumas que serão o objeto de estudo da presente pesquisa, entre elas as que estão apresentadas no quadro 1 : 
Quadro 1 - Exemplos de perguntas do questionário de comportamento de financeiro

\begin{tabular}{|c|c|}
\hline Pergunta & Tipo de resposta \\
\hline Possui poupança ou alguma forma de investimento para a aposentadoria? & Aberta \\
\hline Mantém algum tipo de investimento financeiro? & $\begin{array}{l}\text { Múltipla escolha com alternativas de "sim" e } \\
\text { "não" }\end{array}$ \\
\hline $\begin{array}{l}\text { Você registra por escrito seus objetivos financeiros, definindo o montante de dinheiros } \\
\text { necessário para alcança-los, e a data para realização do objetivo (Por exemplo: comprar } \\
\text { um carro, } \mathrm{R} \$ 30.000,00 \text { em 2014)? }\end{array}$ & \multirow{4}{*}{$\begin{array}{l}\text { Múltipla escolha com as seguintes } 4 \\
\text { alternativas: "sempre", "frequentemente", } \\
\text { "raramente" e "nunca". }\end{array}$} \\
\hline $\begin{array}{l}\text { Você poupa regularmente para objetivos de longo prazo, como por exemplo, para comprar } \\
\text { uma casa? }\end{array}$ & \\
\hline $\begin{array}{l}\text { Você mantém dinheiro suficiente para arcar com no mínimo três meses de gastos que tem } \\
\text { regularmente? }\end{array}$ & \\
\hline Você aumenta sua poupança quando sua renda (mesada, bolsa, salário, etc.) aumenta? & \\
\hline
\end{tabular}

\section{Fonte: Elaboração própria}

No questionário sobre o interesse pessoal e profissional dos estudantes de engenharia de produção da Universidade Federal do Paraná foram realizadas 13 questões. Sendo aplicado via formulário online, divulgado por meio de e-mails e redes sociais. A se considerar as questões que indicam a motivação para o estudo de finanças, sendo ele de caráter pessoal e/ ou profissional, tais como apresentados no quadro 2:

Quadro 2 - Exemplos de perguntas do questionário sobre o interesse pessoal e profissional dos estudantes de engenharia de produção.

\section{Pergunta}

Quantas disciplinas optativas na área de finanças já cursou?

Interesse em assuntos financeiros

Intenção de trabalhar com finanças

Interesse em estudar finanças

Interesse pessoal em aprender mais sobre: ações, opções, Flls, Tesouro Direto, Poupança, CDB e CDI, VGBL e PGBL, outros.

Interesse profissional em aprender mais sobre: ações, opções, Flls, Tesouro Direto,

Poupança, CDB e CDI, VGBL e PGBL, outros.

Interesse em buscar informações por conta própria sobre assuntos financeiros

Em termos gerais, seu interesse em finanças

\section{Tipo de resposta}

Múltipla escolha, com escala de 0 a 3 ou mais;

Múltipla escolha, com escala de 0 a 4 sendo 0 nenhum interesse e 4 como muito interessado.

Fonte: Elaboração própria

\section{RESULTADOS}

Foram obtidas 115 respostas para a pesquisa de aversão à risco, 111 no questionário acerca de comportamento financeiro, e 45 no de interesse em finanças.

\subsection{AVERSÃO A RISCOS}

Os resultados dos principais problemas propostos por meio das pesquisas de aversão a risco, seguindo o padrão dos questionários aplicados nos estudos de Kahneman e Tversky, são: 
Figura 1 - Gráfico dos problemas 1 (esquerda) e 2 (direita).
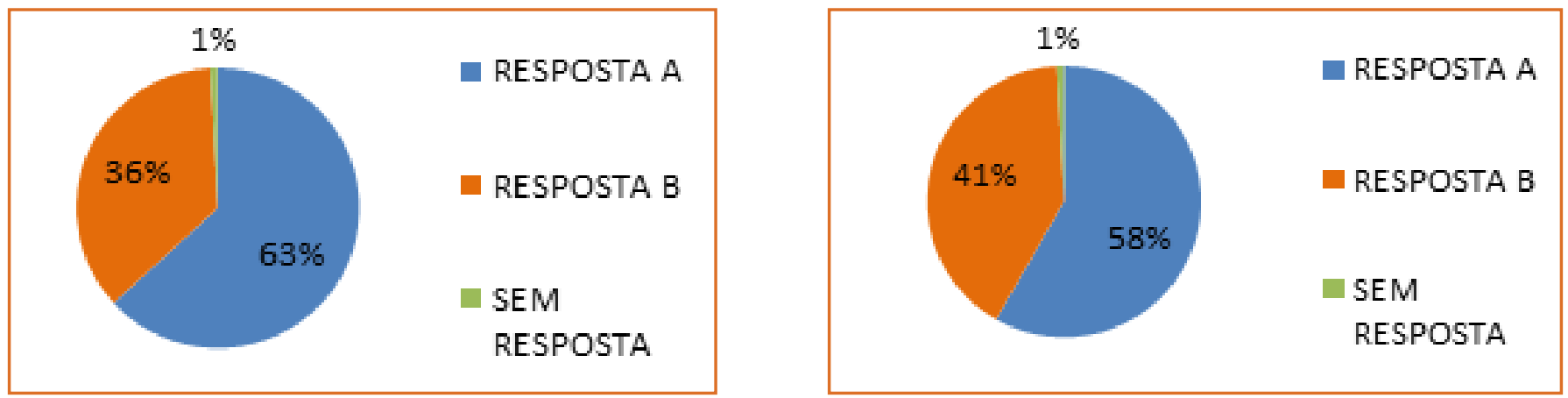

Fonte: Elaboração própria.

A Figura 1 apresenta os gráficos com as respostas referentes ao problema 1 e 2 , no caso do primeiro, a resposta " $A$ " com 63\%, representa o que os autores propõem como efeito certeza, em que levando-se em conta a alta probabilidade de se obter o mesmo ganho ou mais corresponde a um valor muito superior quando se comparado ao risco de se ter ganho 0 a uma taxa de 1\% de possibilidade de ocorrência. E no 2, 58\% das respostas condizem com a opção que tem a menor chance de não possuir ganho zero.

Figura 2 - Gráfico dos problemas 3(esquerda) e 4 (direita).
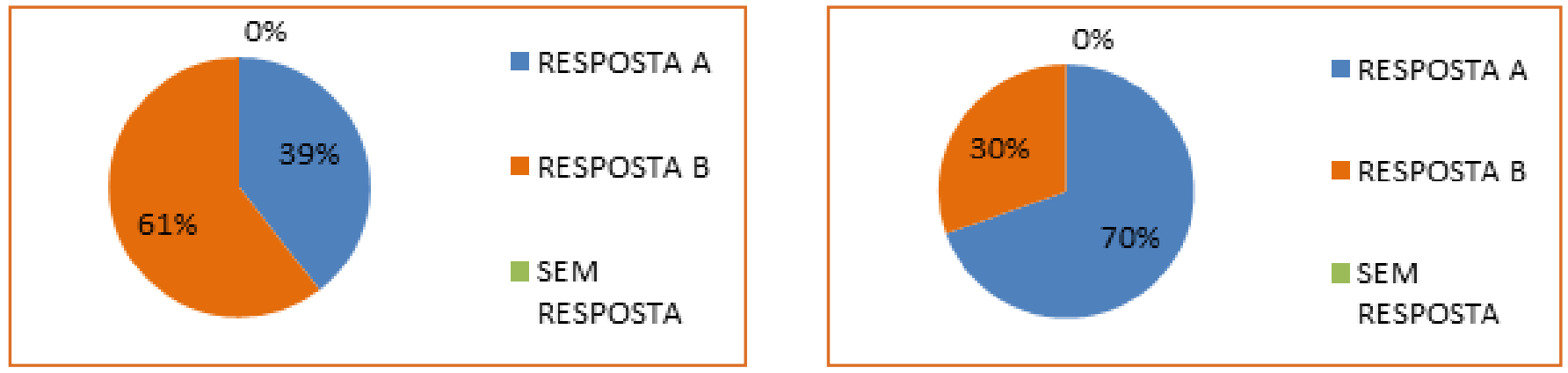

Fonte: Elaboração própria.

A Figura 2 apresenta os resultados dos problemas 3 e 4 , em que mostra o que fora classificado anteriormente como efeito reflexão, em que as alternativas são escolhidas devido as suas maiores chances de obter ganho, no caso, o ganho certo apesar de ser um valor inferior, ao contrário problema 1, as chances obter um ganho 0 nesse problema apresentam-se em uma taxa muito maior, que corresponde a $20 \%$. No segundo gráfico pode-se verificar a escolha pela alternativa $A$, em que o ganho é maior, porém a diferença percentual de probabilidade de ocorrência é de apenas 5\%.

Figura 3 - Gráfico dos problemas 5 (esquerda) e 6 (direita).
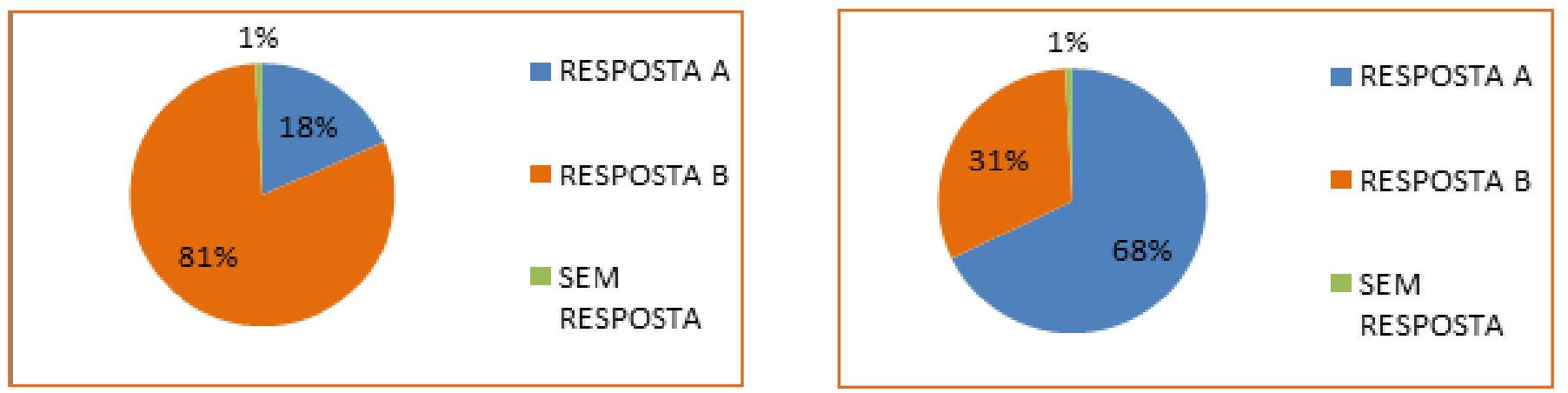

Fonte: Elaboração própria. 
A Figura 3, apresenta os problemas 5 e 6 , o problema 5 demonstra que $81 \%$ das pessoas preferem a alternativa com $100 \%$ de chance de uma viagem a Inglaterra ocorrer ao invés de $50 \%$ de chance de três viagens ocorrerem. Já o problema 6 apresenta as mesmas alternativas do anterior, porém com as porcentagens alteradas, 68\% das pessoas optaram por preferir a alternativa com $5 \%$ de probabilidade de acontecer, mas com as três viagens, no lugar de optar pela alterativa com $10 \%$ de probabilidade para uma viagem.

Figura 4 - Gráfico dos problemas 7 (esquerda) e 8 (direita).
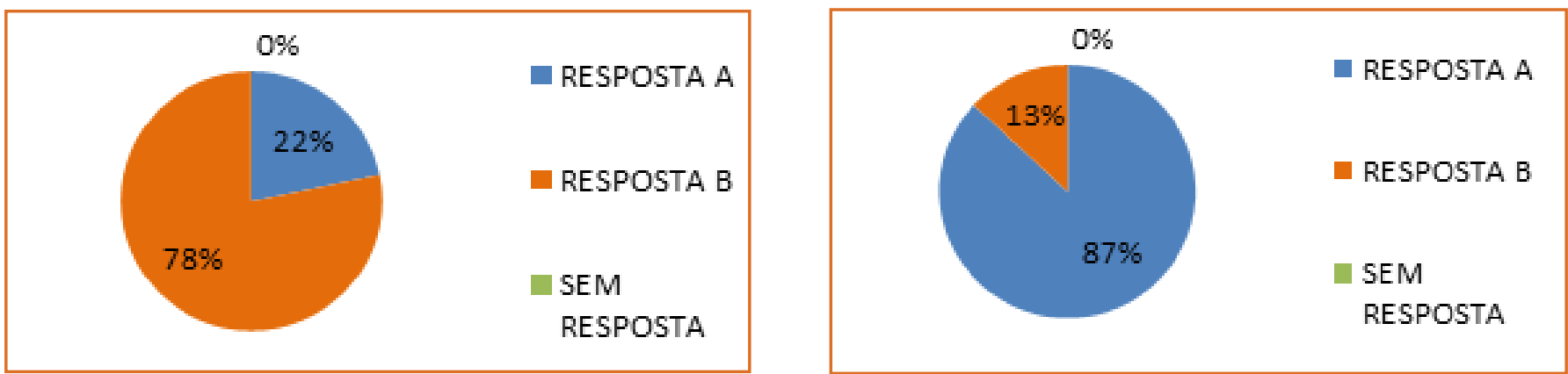

Fonte: Elaboração própria.

A Figura 4, trata dos problemas 7 e 8 . Dos resultados obtidos, $78 \%$ preferem uma posição mais conservadora ao optar pela alternativa com maiores probabilidades, porém ganhos menores, tratando-se uma diferença de $45 \%$ entre as probabilidades no problema 7 . No problema 8, ocorre o contrário do visto no gráfico anterior, $87 \%$ dos graduandos optou por uma menor chance de ganho com um retorno maior, sendo desta vez a diferença de 0,1\% de ocorrência.

Figura 5 - Gráfico dos problemas 9 (esquerda) e 10 (direita).
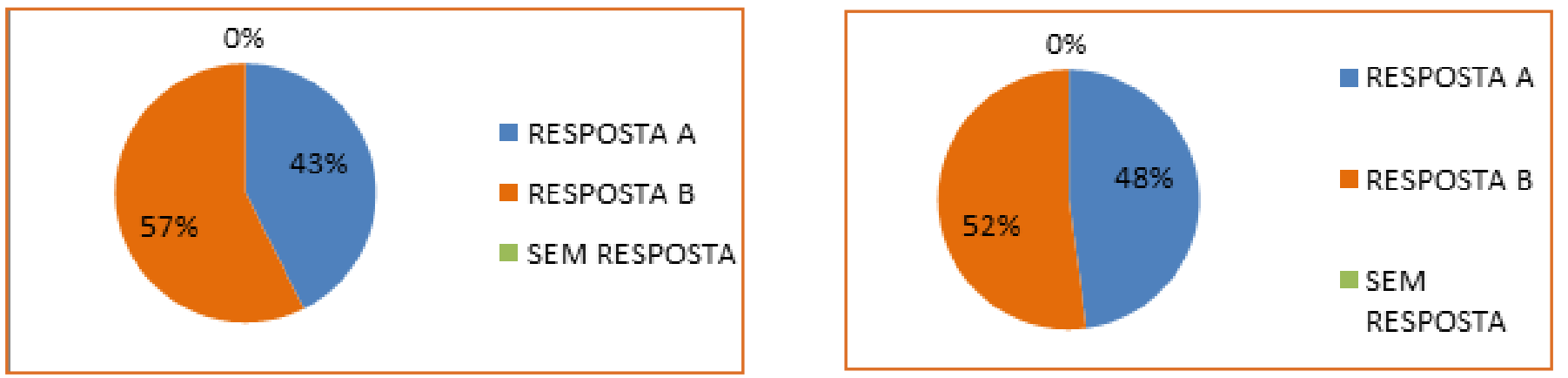

Fonte: Elaboração própria.

E por fim, os problemas 9 e 10 estão representado na figura 5, ambos apresentam alternativas semelhantes, com o mesmo valor para as probabilidades e os valores de retorno, entretanto, no problema 9 é a respeito de ganhos, e no problema 10 trata-se de perda. Com o resultado pode-se verificar que as respostas das alternativas "B" foram as predominantes, que são as alternativas que apresentavam mais possibilidades ganhos e perdas. 


\subsection{COMPORTAMENTO FINANCEIRO}

Figura 6 - Gráfico de respostas do questionário de comportamento financeiro.
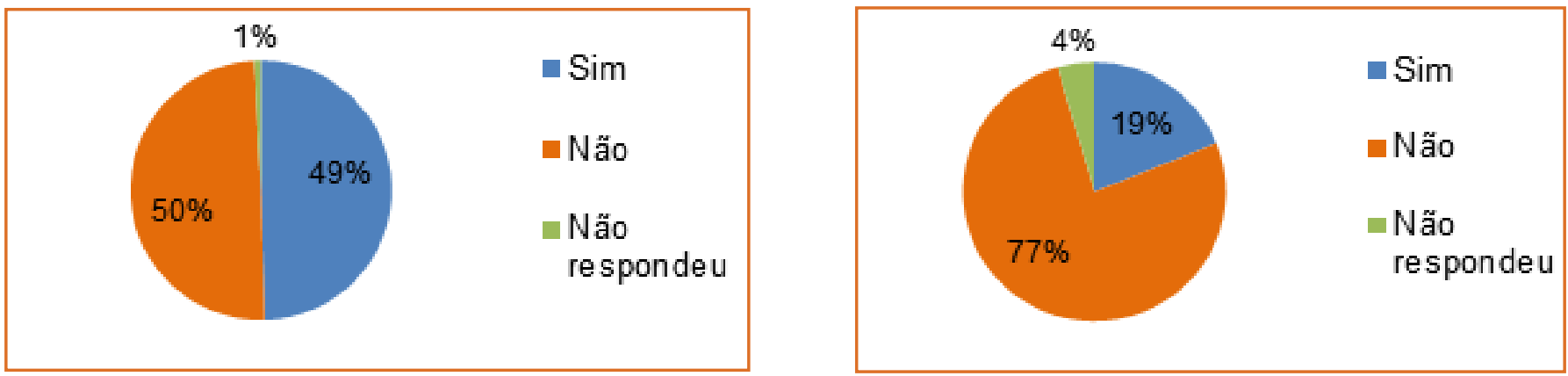

Fonte: Elaboração própria.

$\mathrm{Na}$ figura 6, são apresentadas respectivamente as questões: "Possui poupança ou alguma forma de investimentos para a aposentadoria?" e "Mantém algum tipo de investimento financeiro?". Na primeira questão pode-se verificar através do gráfico que quase a metade dos estudantes de engenharia de produção possuem uma iniciativa de investimento a longo prazo, visando a aposentadoria, entretanto em se tratar de investimentos que não visando a aposentadoria (a se considerar investimentos tanto de curto como de longo prazo), boa parte dos estudantes (77\%), não possuem nenhum investimento, sendo as principais justificativas para esse resultado: a falta de renda; falta de conhecimento para tal; e falta de planejamento.

Figura 7 - Gráfico de respostas do questionário de comportamento financeiro.
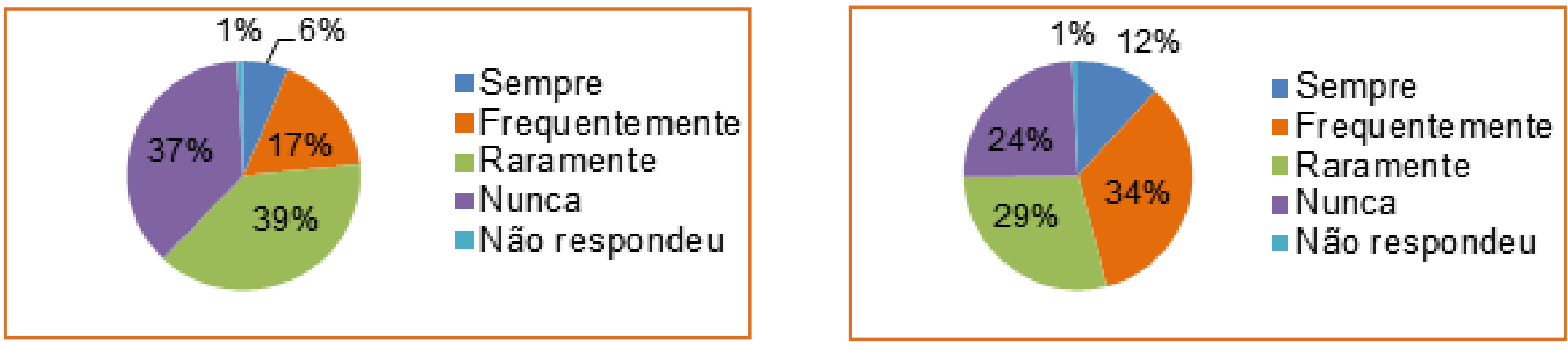

Fonte: Elaboração própria.

Na figura 7, são apresentadas as questões: "Você registra por escrito seus objetivos financeiros, definindo o montante de dinheiro necessário para alcançá-los, e a data para realização do objetivo (Por exemplo: comprar um carro, R\$30.000,00 em 2014)?" (esquerda) e "Você poupa regularmente para objetivos de longo prazo, como por exemplo, para comprar uma casa?" (direita), Apesar da maioria dos estudantes dizer que raramente faz um registro financeiro sobre um objetivo, poupar com grande frequência a fim de se alcançar objetivos de longo prazo ainda é uma prática de grande parte deles. 
Figura 8 - Gráfico de respostas do questionário de comportamento financeiro
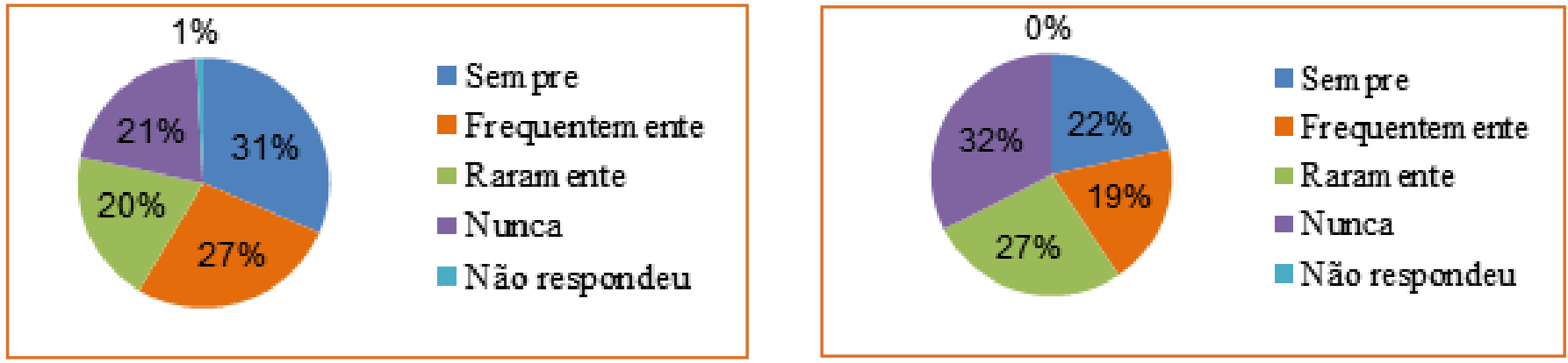

Fonte: Elaboração própria.

A figura 8 apresenta as questões: "Você aumenta sua poupança quando sua renda (mesada, bolsa, salário etc.) aumenta?" e "Você mantém dinheiro suficiente para arcar com no mínimo três meses de gastos que tem regularmente?". Já levando em consideração o que foi apresentado na Figura 7, o fato de grande parte dos graduandos possuírem o hábito poupar quando necessário, mesmo que não registrando, denota um conhecimento sobre a necessidade de se poupar para atingir um objetivo maior que é refletido no primeiro gráfico da Figura 8, uma vez que a grande maioria com o aumentar de sua fonte de renda aumenta consequentemente sua poupança. Entretanto, quando se trata de um prazo mais curto, como no caso do gráfico a direita da Figura 8 que se trata de 3 meses, os estudantes acabam por não tendo essas reservas para esse período, o que pode ser explicado pela mesma justificativa da Figura 6, em que devido a falta de uma renda fixa influencia no fato de não se manter o suficiente para os gastos regulares de 3 meses.

\subsection{INTERESSE EM FINANÇAS}

Os resultados obtidos em relação ao questionário de interesses em finanças aplicado aos estudantes de engenharia de produção são apresentados a seguir:

Figura 9 - Gráfico de respostas do questionário de comportamento financeiro.
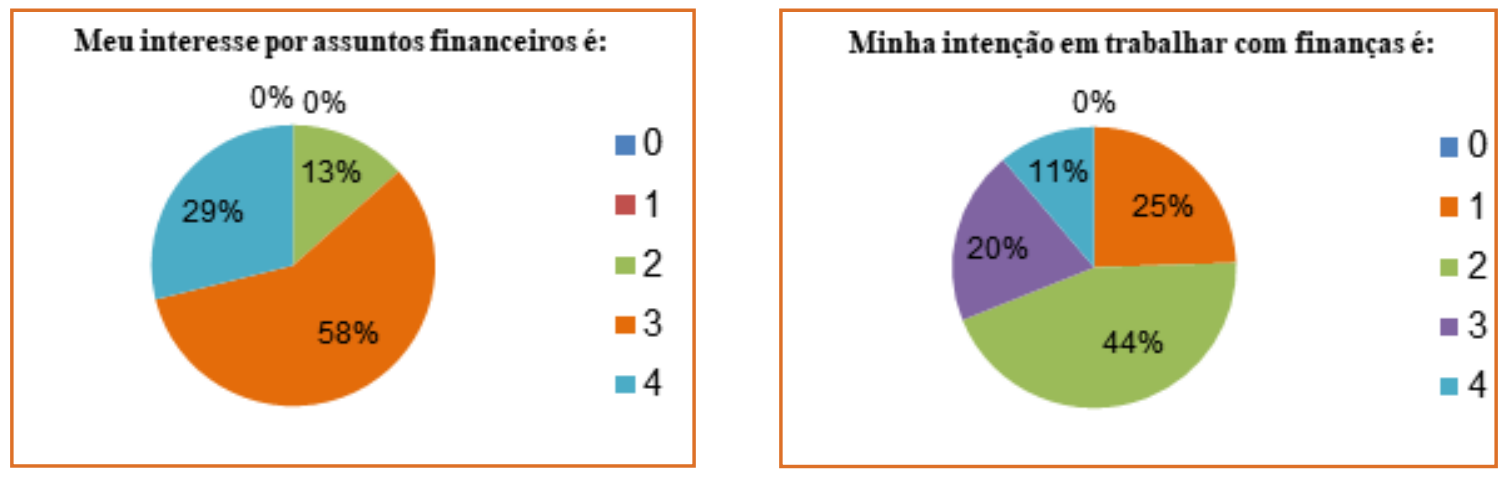

Fonte: Elaboração própria

No primeiro gráfico da Figura 9, são apresentadas as respostas que correspondem os interesses dos estudantes por assuntos financeiros de modo geral, seja pessoal ou profissional, tendo uma aceitação boa, uma vez que, 58\% das pessoas responderam que possuem um grau 3 de interesse por essa área do conhecimento. Como a engenharia de produção por si só é um curso versátil, apesar da relevância das finanças na formação do engenheiro, grande parte das respostas a respeito da intenção em trabalhar com esse assunto (como apresentado do lado direito na figura 9) estão na média, ou seja, 44\% das respostas marcadas com nota 2 . 
As figuras a seguir representam as respostas sobre o interesse pessoal e profissional em obter aprendizado sobre determinados temas relacionados a investimentos:

Figura 10 - Gráfico dos interesses em aprender sobre Ações.
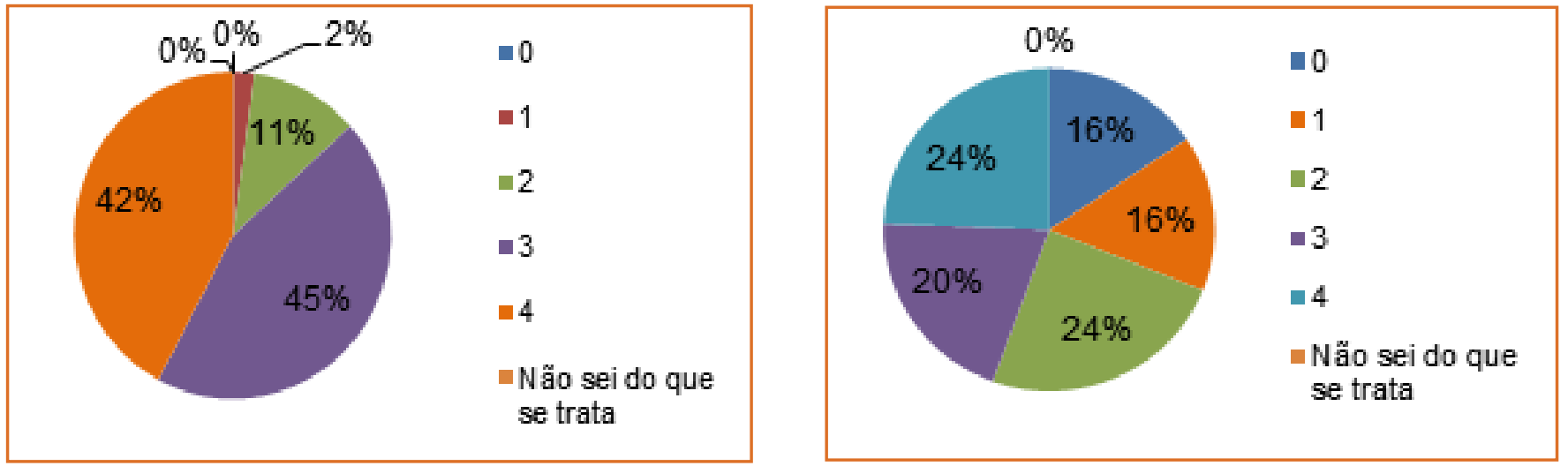

Fonte: Elaboração própria.

A Figura 10 apresenta uma comparação entre o interesse pessoal (gráfico da esquerda) e profissional (gráfico da direita) quando se trata de investimentos em ações, nesse caso pode-se verificar que em se tratando de mercado de ações, a motivação para aprender sobre é predominantemente pessoal, que possui parcelas grandes das respostas em graus de interesse 3 e 4, ao contrário da distribuição de respostas do gráfico de interesse profissional que estão distribuídas de forma mais uniforme.

Figura 11 - Gráfico dos interesses em aprender sobre Flls.
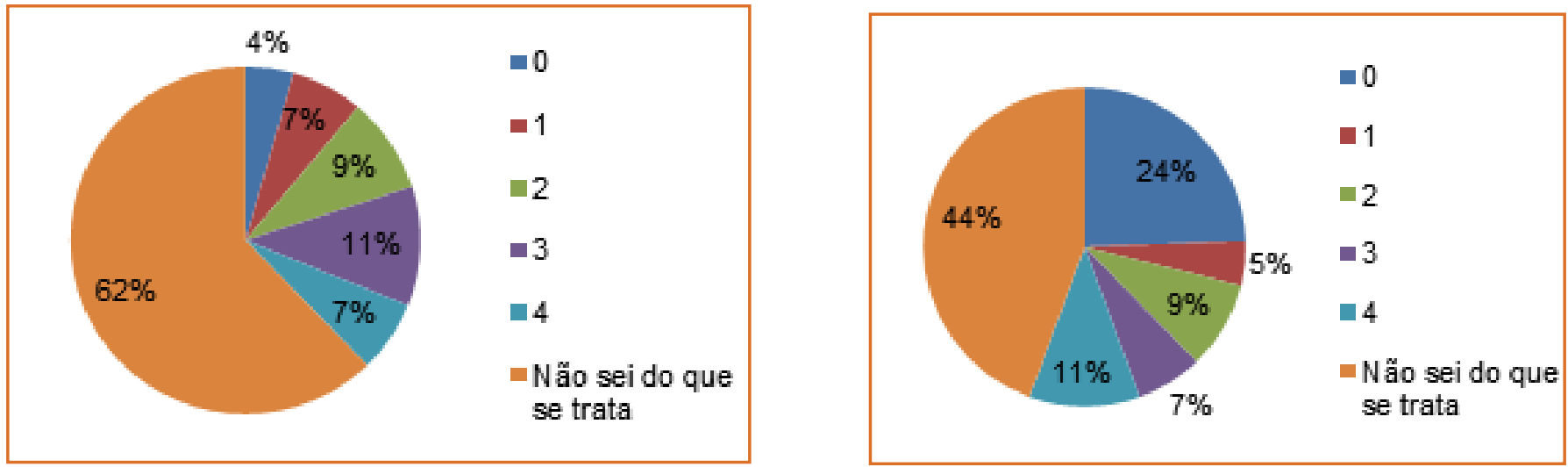

Fonte: Elaboração própria.

Na Figura 11, estão representadas as respostas que correspondem ao interesse em aprender sobre os Fundos de Investimentos Imobiliários (FIls), sendo que do lado esquerdo estão representados o interesse pessoal e no direito o profissional. Para ambos os tipos de interesses a maioria das respostas foi de a de não saber do que se trata ou como funciona esse tipo de investimento. 
Figura 12 - Gráfico dos interesses em aprender sobre Poupança.
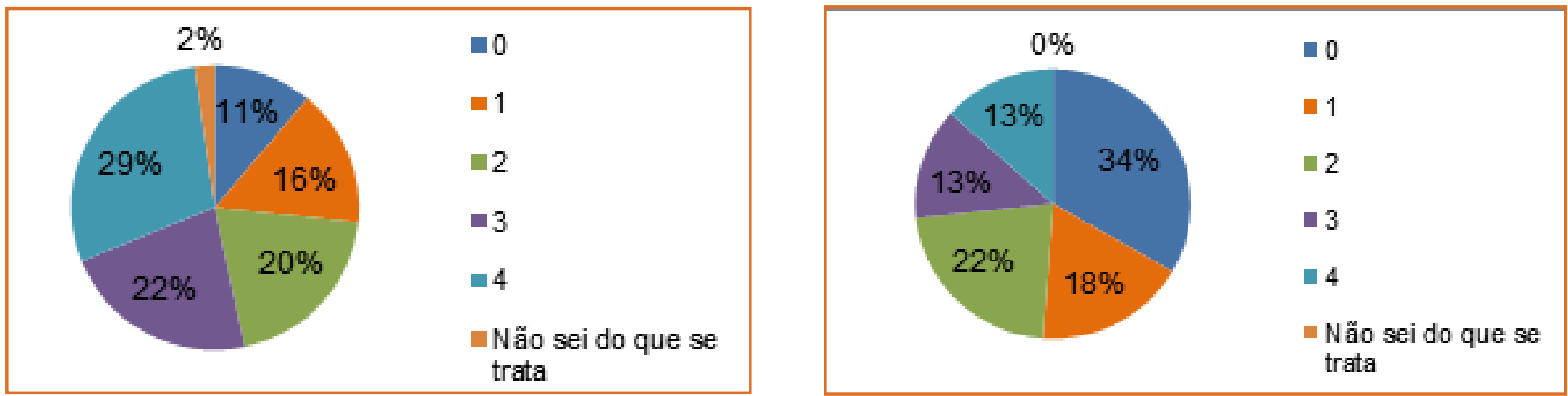

Fonte: Elaboração própria.

A Figura 12 apresenta o interesse dos estudantes em aprender mais sobre Poupança, no caso, mostra que é um investimento mais atrativo pensando no âmbito pessoal (gráfico a esquerda) do que profissional.

Figura 13 - Gráfico dos interesses em aprender sobre VGBL e PGBL.
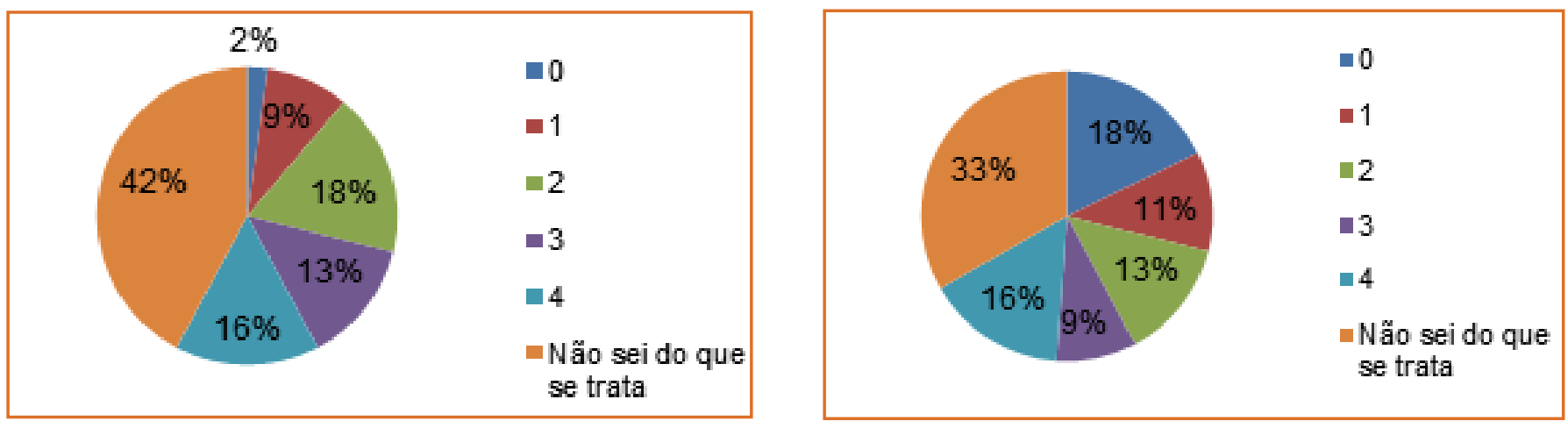

Fonte: Elaboração própria.

Com relação a investimentos de VGBL e PGBL, que são investimentos de previdência privada, assim como no caso dos Flls, a maioria dos estudantes desconhece do que se tratam esses investimentos, porém dos que sabem e possuem algum interesse demonstraram preferir aprender sobre o mesmo com intenção de lidar com esse investimento de maneira pessoal.

Figura 14 - Gráfico dos interesses em aprender sobre Opções.
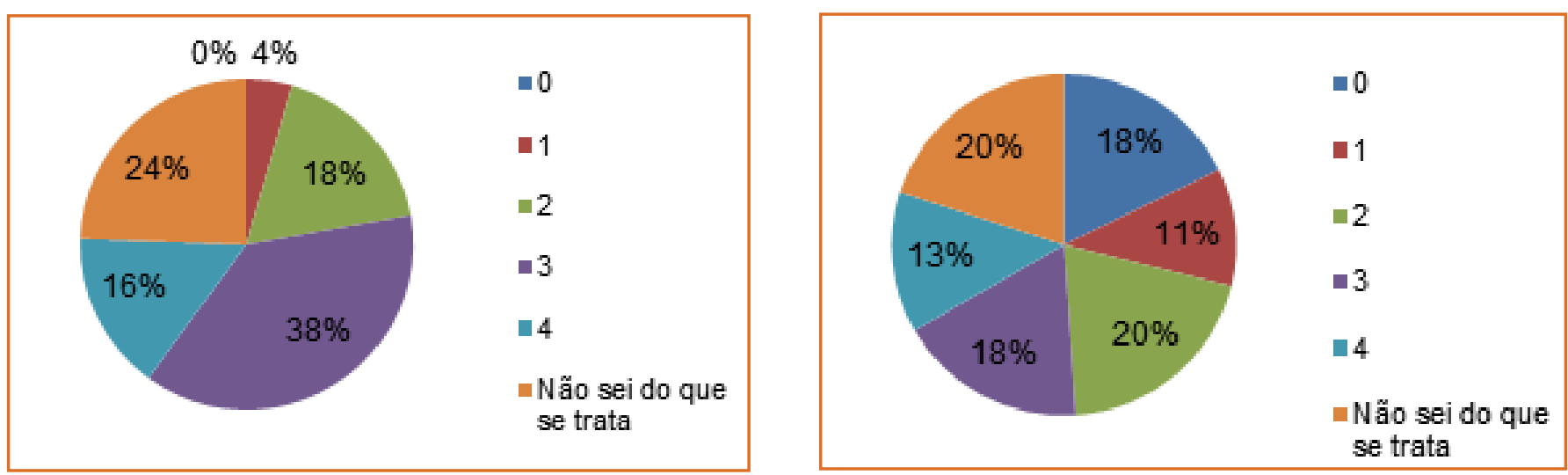

Fonte: Elaboração própria. 
A respeito de Opções, a Figura 14, mostra que para o interesse para aprendizado pessoal é mais expressivo que para o aprendizado profissional, apesar de possuir uma porcentagem relevante de $24 \%$ e $20 \%$ de respostas que indicam não saber do que se trata, com relação ao interesse pessoal e profissional respectivamente.

Figura 15 - Gráfico dos interesses em aprender sobre Tesouro Direto.
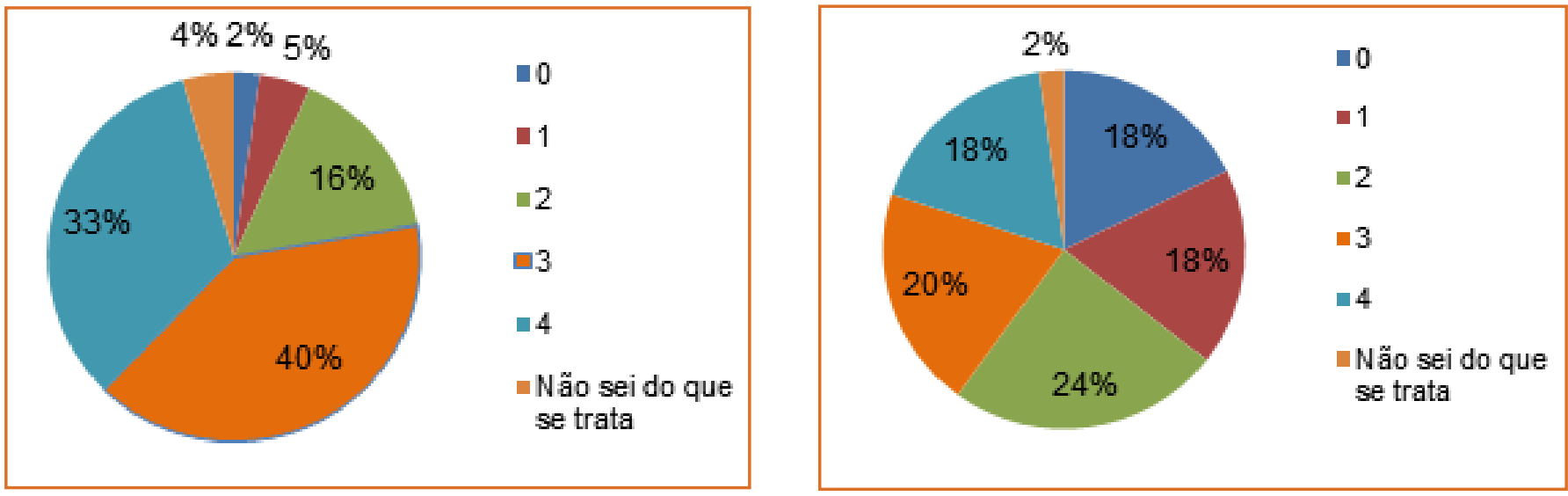

Fonte: Elaboração própria.

Com relação ao investimento em Tesouro Direto, o interesse maior foi pessoal (gráfico da esquerda), representado com níveis de interesse de 3 e 4, com
$33 \%$ e $40 \%$ respectivamente, e novamente para o interesse profissional (gráfico da direita), a distribuição do grau de interesse ficou entre $18 \%$ a $24 \%$.

Figura 16 - Gráfico dos interesses em aprender sobre CDB e CDI (direita)
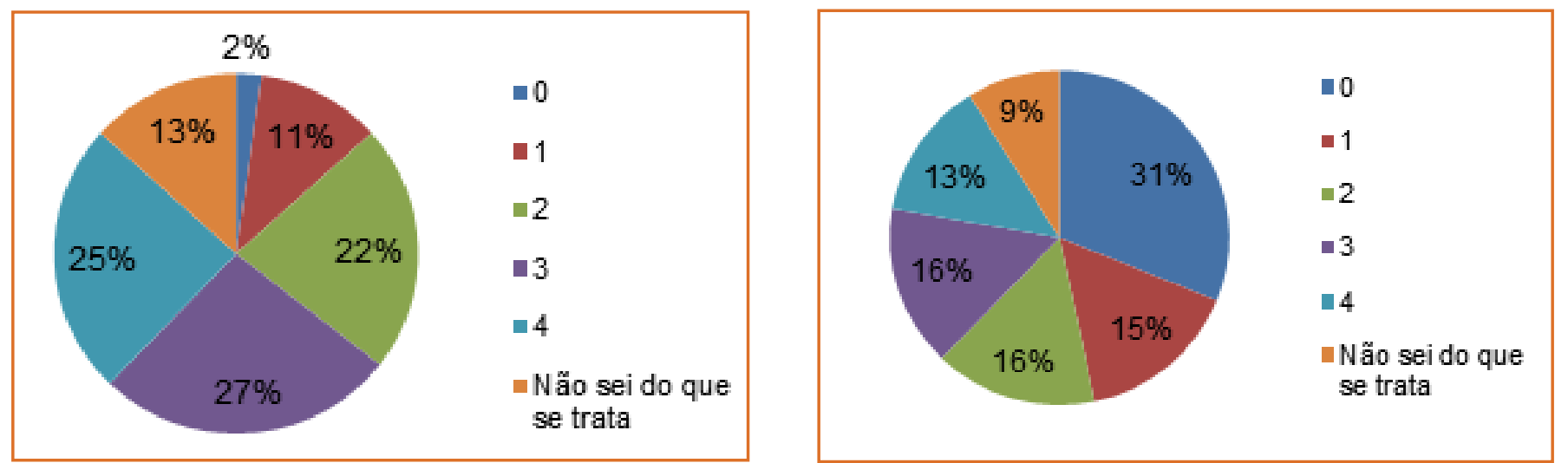

Fonte: Elaboração própria.

A Figura 16 apresenta os níveis de interesse em CDB e CDI, que tratam de Certificado de Depósito Bancário e Certificado de Depósito Interbancário respectivamente, apresenta maior interesse pessoal (gráfico da esquerda), visto que para o gráfico de interesse profissional (gráfico da direita) há um número significativo de $31 \%$ de desinteresse. 
Figura 17 - Gráfico dos interesses em aprender sobre e Outros.
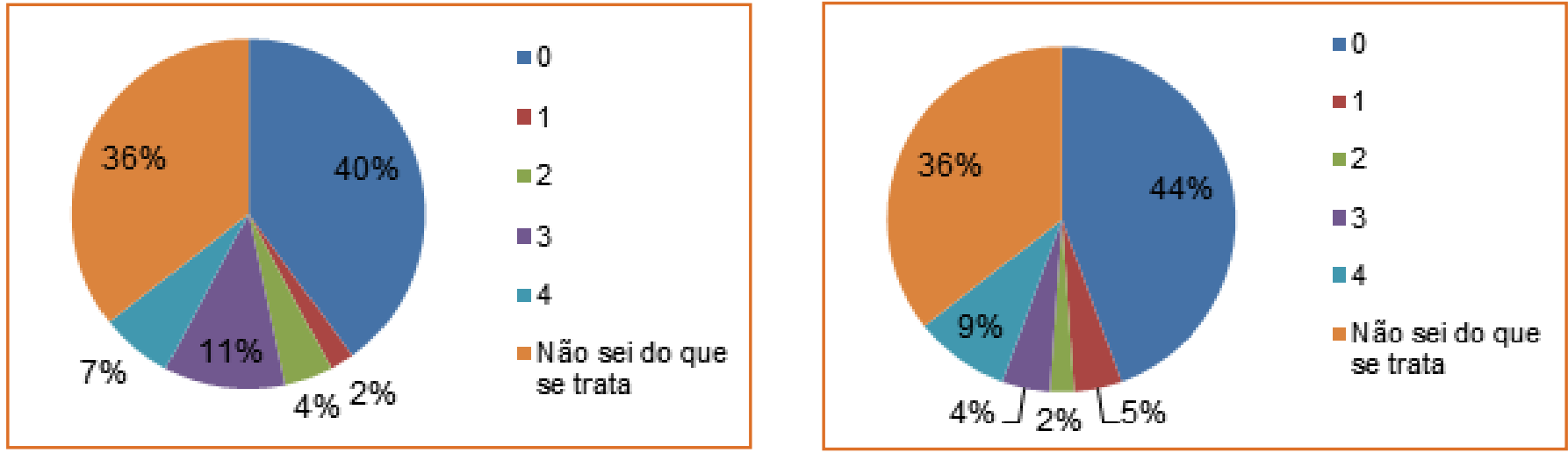

Fonte: Elaboração própria.

E por fim, com relação a outros tipos de investimentos, tanto pessoal como profissionalmente, a maioria dos estudantes não se demonstrou interessado em aprender sobre outros tipos além dos supracitados.

Figura 18 - Gráfico de respostas do questionário de interesse em finanças.
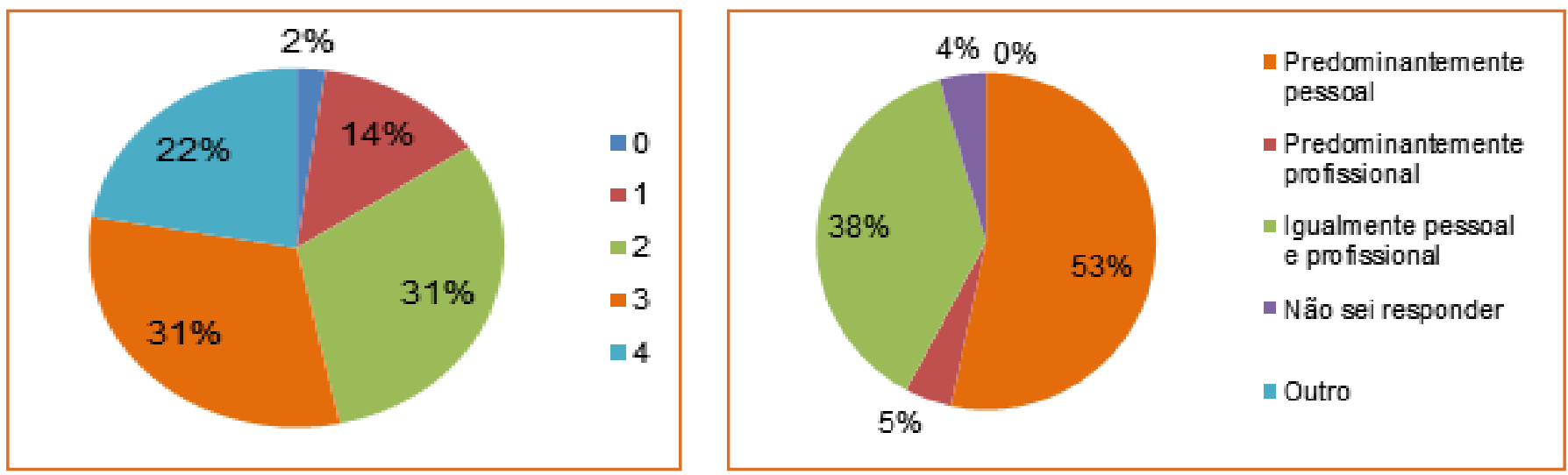

Fonte: Elaboração própria.

A Figura 18, apresenta do lado esquerdo o interesse próprio dos estudantes em buscar mais informações sobre finanças que não por meio de disciplinas ofertadas no curso de graduação, apresentando valores expressivos para um maior interesse sendo $53 \%$ (equivalente as respostas de grau 3 e 4 ) das respostas favoráveis a busca. Já do lado direito da Figura 18 está representado de uma forma geral a qual a natureza do interesse pelo mercado financeiro, sendo que mais da metade das respostas é predominantemente pessoal, apesar da predominância do uso desse conhecimento ao longo da formação ser utilizado para a vida pessoal, não obstante ele também é expresso de modo significativo como igualmente pessoal e profissional (38\%), confirmando boa parte dos resultados anteriores que demonstraram ser principalmente com motivação pessoal.

\section{CONCLUSÃO}

Com relação a aversão ao risco, pode-se verificar que o perfil dos estudantes procura analisar principalmente a diferença percentual como forma de optar por uma alternativa que incorre riscos, além disso, se a diferença de valores a se ter como retorno possui alta discrepância, os graduandos tendem a se arriscar mais para obter um ganho maior dado que a opção mais conservadora não trará um resultado tão bom quanto a outra alternativa. $\mathrm{Na}$ análise proposta a respeito do nível de interesse pessoal e profissional na formação do engenheiro de produção pode-se concluir que a grande maioria dos estudantes possui 
um interesse muito mais pessoal do que profissional, embora devido a característica do curso de engenharia de produção poder atuar em diversas áreas dentro de uma organização, muitos dos estudantes veem as finanças de forma vantajosa tanto pessoal como profissionalmente.

Além disso, ao verificar os três questionários analisados no presente estudo também se verificam que a atuação no mercado financeiro é para se obter um ganho extra, visto que na maioria dos casos, essa aplicação do dinheiro não ocorre devido a falta de renda, ou seja, os investimentos não seriam a principal fonte de renda.

Com relação a metodologia do presente estudo, as limitações que a pesquisa está sujeita são principalmente com relação a falta de justificativas de determinadas escolhas aplicadas nos questionários.

Por fim, outras vertentes da análise financeira poderiam ser realizadas a respeito dos estudantes em engenharia de produção, visto que o mercado de trabalho busca profissionais dessa área para ocupar cargos relacionados finanças, devido a formação abrangente e visão ampla que o estudante vai adquirindo ao longo de sua formação.

\section{REFERÊNCIAS}

[1] ABEPRO - Associação Brasileira de Engenharia de Produção. Áreas e Sub-áreas da Engenharia de Produção. Disponível em: <http://www.abepro.org.br/interna. $a s p ? p=399 \& m=424 \& s=1 \& c=362>$. Acesso em 10/02/2015.
[2] ENGENHARIA DE PRODUÇÃO - UFPR. Estrutura Curricular. Disponível em: <http://www.engprod.ufpr.br/ estrutura.pdf>. Acesso em 10/02/2015.

[3] ENGENHARIA DE PRODUÇÃO - UFPR. Ementas (Arquivo 1). Disponível em: <http://www.engprod.ufpr.br/ ementas_1.pdf>. Acesso em 10/06/2015.

[4] ENGENHARIA DE PRODUÇÃO - UFPR. Ementas (Arquivo 2). Disponível em: <http://www.engprod.ufpr.br/ ementas_2.pdf>. Acesso em 10/06/2015.

[5] GRINBLATT, M., KELOHARJU, M. The investment behavior and performance of various investor types: a study of Finland's unique data set. Journal of Financial Economics, p. $43-67,2000$.

[6] MELLAGI FILHO, A. Mercado financeiro e de capitais: uma introdução. 2. ed. São Paulo: Atlas, 1995.

[7] MELLAGI FILHO, A., ISHIKAWA, S. Mercado financeiro e de capitais. 2. ed, São Paulo, Atlas, 2003.

[8] MILANEZ, D.Y. Finanças comportamentais no Brasil. 53f. Dissertação (Mestrado em Economia das Instituições e do Desenvolvimento) - Faculdade de Economia, Administração e Contabilidade da Universidade de São Paulo, São Paulo, São Paulo, Brasil, 2003.

[9] WALTER, S. A., FREGA, J. R., da SILVA, W. V. Análise do comportamento e da percepção do investidor em relação ao risco sob a ótica da teoria de finanças comportamentais. R.Adm., São Paulo, v.45, n.2, p.172-187, abr./maio/jun. 2010.

[10] KAHNEMAN, D., TVERSKY, A. Prospect theory: an analysis of decision under risk. Econometrica (pre-1986), ABI/INFORM Global, v. 47, n.2, p. 263-291, March, 1979.

[11] OLIVEIRA, V. F. de, PINTO, D. P. Educação em engenharia como área do conhecimento. Anais do XXXIV COBENGE. Passo Fundo: Ed. Universidade de Passo Fundo, p. 12.62, setembro, 2006. 


\section{CAPÍTULO3}

\section{AS COMPRAS PÚBLICAS EM PROL DO DESENVOLVIMENTO ECONÔMICO SUSTENTÁVEL: UM ESTUDO DA PARTICIPAÇÃO DE MICROS E PEQUENAS EMPRESAS NOS PREGÕES ELETRÔNICOS DA UNIVERSIDADE FEDERAL DO PARANÁ}

Andréa Roseli Moreira Cruz Jankoski

Vanessa Ishikawa Rasoto

Resumo: O artigo teve como objetivo analisar a participação de micros e pequenas empresas nas compras públicas na modalidade pregão eletrônico a partir do estudo na Universidade Federal do Paraná-UFPR. Para compor o trabalho, foi realizada uma pesquisa bibliográfica e documental e os dados dos pregões eletrônicos foram coletados no Portal de Compras do Governo Federal. Os resultados foram interpretados através da participação das microempresas e empresas de pequeno porte no certame licitatório. Constatou-se que os pregões eletrônicos estudados geraram uma economia na ordem de $25 \%$ no volume total contratado para os cofres da UFPR. Mostrou também que houve uma crescente participação das MPEs nos pregões eletrônicos realizados pela UFPR nos últimos cinco anos. Conclui-se que os incentivos que o Governo Federal tem proporcionado para as MEs e EPPs participarem dos processos de pregão eletrônico tem gerado um grande potencial para estimular e promover o desenvolvimento econômico sustentável.

Palavras Chave: Compras públicas; desenvolvimento sustentável; pregão eletrônico. 


\section{INTRODUÇÃO}

O Governo Federal tem como estratégia para apoiar o crescimento econômico o uso do seu poder de compras para alavancar o desenvolvimento de micro e pequenas empresas (MPEs). A política de fornecimento de bens e serviços por Micro e Pequenas Empresas e aquisição de itens sustentáveis são exemplos de como o governo direciona recursos para áreas estratégicas para o desenvolvimento do país. Entre elas, está a obrigatoriedade de contratação de MPEs para compras públicas de até $\mathrm{R} \$ 80$ mil. (MINISTÉRIO DO PLANEJAMENTO, 2013)

Ressalta-se que, ao analisar os gastos públicos segundo o porte, em 2014 as MPES forneceram bens e serviços da ordem de $R \$ 16,7$ bilhões, ou seja, $27 \%$ do total dessas contratações.

Além disso, em 2014, o pregão eletrônico respondeu por $59,7 \%$ das compras governamentais, com um gasto de $R \$ 37,08$ bilhões, sendo empregado em 33,8 mil processos (17,1\%). Se comparado apenas às modalidades licitatórias, essa forma de contratação foi responsável por 91,1\% dos gastos em aquisições, resultando numa economia para os cofres públicos da ordem de $R \$ 7,9$ bilhões (18\%).

Ainda segundo o Portal de Compras Governamentais, entre as modalidades licitatórias merece destaque o pregão eletrônico, tendo em vista que do total de $\mathrm{R} \$ 37,08$ bilhões licitados por essa modalidade, as MPE responderam por R $\$ 14,2$ bilhões (38,51\%). Comparando-se os doze meses de 2014 com o mesmo período de 2013, o crescimento das MPE nas compras por pregão eletrônico foi da ordem de 5\%. A economia nas aquisições públicas pelo uso dessa modalidade, junto às MPE, foi de $R \$ 3,4$ bilhões (19\%).

Vale lembrar, que as micros e pequenas empresas são as que mais geram emprego no país, em 2012, responderam por $71,5 \%$ das vagas formais, notícia divulgada pelo sítio do SEBRAE Paraná. Dados mais recentes divulgados pelo SEBRAE informam que em "fevereiro de 2014, os pequenos negócios registraram saldo líquido de 148.152 novos empregos celetistas, respondendo por 56,8\% dos empregos formais gerados no país" (SEBRAE, 2014).
Partindo do pressuposto que as compras públicas realizadas por meio do pregão eletrônico podem alavancar o crescimento das micros e pequenas empresas, pretende-se analisar a participação dessas empresas nos pregões eletrônicos no período de 2010 a 2014 e ainda, avaliar os resultados econômicos desses pregões eletrônicos realizados com exclusividade para as microempresas e empresas de pequeno porte, por meio do valor de estimado e do valor global contratado, referentes à compra de itens de subsistência realizados no âmbito da Universidade Federal do Paraná no ano de 2013.

O artigo será desenvolvido utilizando pesquisa bibliográfica e documental, através leis, documentos oficiais, bem como, artigos científicos relevantes publicados em revistas eletrônicas. A coleta de dados se dará através do Portal de Compras do Governo Federal, sendo, portanto, do tipo quantitativa. Quanto aos objetivos a pesquisa é descritiva.

A seção 2 aborda o referencial teórico, incluindo leis, decretos, fala da Lei de Licitações, do Pregão Eletrônico e da Lei Complementar 123/2006 referente a participação diferenciada da micro e pequena empresa nas compras públicas.

A seção 3 menciona a análise e discussão dos resultados. Em seguida, têm-se as considerações finais e as referências utilizadas na fundamentação teórica.

\section{REFERENCIAL TEÓRICO}

Nessa seção, será abordado resumidamente o conceito de desenvolvimento sustentável, bem como definirá a Lei das Licitações, o Pregão Eletrônico e a Lei Complementar n 123/ 2006 que trata do Estatuto Nacional da Microempresa e da Empresa de Pequeno Porte.

\subsection{DESENVOLVIMENTO SUSTENTÁVEL}

O entendimento de sustentabilidade está intimamente relacionada à preservação do meio ambiente. Em 1981 foi publicada a Lei no 6.938 que dispõe sobre a 
Política Nacional de Meio Ambiente, cujos objetivos, expressos no seu artigo $2^{\circ}$, são preservar, melhorar e recuperar a qualidade ambiental almejando assegurar o desenvolvimento socioeconômico, os interesses da segurança nacional e a proteção da dignidade da vida humana no nosso país (BRASIL, 1981).

E de acordo com a Lei no. 6.938/81 traz no seu artigo $4^{\circ}$, inciso $1^{\circ}$, como conceito de desenvolvimento sustentável a "compatibilização do desenvolvimento econômico-social com a preservação da qualidade do meio ambiente e do equilíbrio ecológico". (BRASIL, 1981, p.1).

A sustentabilidade é um processo contínuo e deve ser um instrumento norteador da tomada de decisões dos gestores públicos que precisam aliar fatores econômicos aos ambientais nas suas ações. Após a Conferência das Nações Unidas sobre o Meio Ambiente, a Rio-92, o conceito de sustentabilidade foi definido como a necessidade de garantir os recursos disponíveis mediante uma gestão de proteção ambiental, justiça social e desenvolvimento econômico equilibrado (SANTOS et al., 2010).

Segundo Sachs (1993), a noção de sustentabilidade baseia-se, em garantir a disponibilidade dos recursos para as gerações futuras, promover a igualdade social e a redução da pobreza para que os setores produtivos, as cidades e as nações se desenvolvam de maneira sustentável.

Cumpre assinalar, que de acordo com a Earth Summit $2002(\mathrm{RIO}+10)$ o temo desenvolvimento sustentável define o desenvolvimento "que atende as necessidades das gerações atuais sem comprometer a capacidade de as futuras gerações terem suas próprias necessidades atendidas". Convém, por oportuno ressaltar, o conceito já consolidado pela Comissão Mundial sobre o Meio Ambiente e Desenvolvimento, no ano de 1987, foi idealizado como o "desenvolvimento sustentável que satisfaz as necessidades presentes, sem comprometer a capacidade das gerações futuras de suprir suas próprias necessidades". dispositivos para dinamizar a economia local, pois o setor público está entre os grandes consumidores do mercado de bens, serviços e obras, gastando cerca de 10 a 15\% do PIB (IPEA, 2011)

\subsection{O PROCESSO LICITATÓRIO}

A Constituição Federal de 1988 em seu artigo 37, inciso XXI, trouxe a obrigatoriedade da realização de licitação para contratação de obras, serviços (inclusive de publicidade), compras e alienações e locações no âmbito dos poderes da União, dos Estados, do Distrito Federal e dos Municípios. A regulamentação de tal artigo adveio com o estatuto jurídico das licitações e contratos, chamada de Lei das Licitações: Lei no 8.666 , de 21 de junho de 1993. De acordo como Art. 1esta "Lei estabelece normas gerais sobre licitações e contratos administrativos pertinentes a obras, serviços, inclusive de publicidade, compras, alienações e locações no âmbito dos Poderes da União, dos Estados, do Distrito Federal e dos Municípios".

O artigo terceiro, diz que a licitação, além de observar o princípio constitucional da isonomia e a seleção da proposta mais vantajosa para a administração, deve também promover o desenvolvimento sustentável nacional (BRASIL, 1993).

\subsection{PREGÃO ELETRÔNICO: ASPECTOS CONCEITUAIS}

O Pregão surge no contexto de necessidade de eficiência das compras públicas, juntamente ao aperfeiçoamento das modalidades licitatórias. Foi introduzida, no ordenamento jurídico, pela Medida Provisória nํ⒉026, de 04 de maio de 2000, e é regida pela Lei no 10.520, de 17 de julho de 2002; e quando se trata da modalidade pregão eletrônico, pelo Decreto nº 5.450, de 31 de maio de 2005.

O pregão eletrônico é definido por Justen Filho (2009) da seguinte forma: 
O pregão, na forma eletrônica, consiste na modalidade de licitação pública, de tipo menor preço, destinada à seleção da proposta mais vantajosa para a contratação de bens ou serviços comum, por meio de propostas seguidas de lances, em que os atos jurídicos da Administração Pública e dos interessados desenvolvem-se com a utilização dos recursos da Tecnologia da Informação, valendo-se especialmente da rede mundial de computadores (Internet).

Conforme o Tribunal de Contas da União (2010, p. 62), "bens e serviços comuns são produtos cuja escolha pode ser feita tão somente com base nos preços ofertados, haja vista serem comparáveis entre si e não necessitarem de avaliação minuciosa". São encontráveis facilmente no mercado.

São exemplos de bens comuns: canetas, lápis, borrachas, papéis, mesas cadeiras, veículos, aparelhos de ar refrigerado etc. e de execução de serviços: confecção de chaves, manutenção de veículos, colocação de piso, troca de azulejos, pintura de paredes, etc.

Desse modo, o pregão pode ser empregado em aquisições de qualquer valor e tem as seguintes peculiaridades:

- Procedimento, com duas características principais: (1) inversão das fases de habilitação e julgamento e (2) possibilidade de renovação de lances por todos ou alguns dos licitantes, até se chegar à proposta mais vantajosa;

- Embora as propostas possam ser por escrito, o desenvolvimento do método envolve a formulação de novas proposições (lances) sob a forma verbal, ou mesmo sob a forma eletrônica;

Em linhas gerais, o pregão eletrônico é uma sessão virtual pública utilizada para a disputa do menor preço, entre os licitantes, previamente cadastrada no Sistema Integrado de Cadastro de Fornecedores (SICAF). Por ser acessível via internet, facilita a participação de licitantes que se situam fisicamente distantes do órgão ou entidade pregoeiro. Isso aumenta o número de licitantes e a concorrência entre estes, o que reduz o preço ofertado ao Estado.

É constituído por três fases: preparatória, externa e competitiva. Na fase preparatória, a autoridade competente justifica a necessidade da contratação, define prazos para fornecimento e designa o pregoeiro e a equipe de apoio. Na fase externa, os interessados são convocados para definição do dia e horário do pregão. E na fase competitiva, ocorre o pregão.

Todos os lances e acontecimentos de um pregão são registrados em atas eletrônicas no Portal de Compras do Governo Federal, cujo acesso pode ser feito por qualquer interessado. Assim como a sociedade, as micros e pequenas empresas também se beneficiaram com a implantação do pregão eletrônico.

O sistema utilizado pelo pregão eletrônico, qualquer que seja, tende a automatizar muitas etapas, acelerando o processo, o que economiza tempo e dinheiro. Além disso, o pregão, em qualquer espécie, inverte as fases de um processo licitatório tradicional previsto na Lei 8.666, de 1993. Numa licitação tradicional, conferese a habilitação de todos os participantes (se forem muitos, esta fase pode levar meses) e depois se passa para a fase de propostas de preço. No pregão, as propostas de preço ocorrem em primeiro lugar e, depois, se confere a habilitação do melhor colocado. Tal inversão contribuiu para a celeridade do certame, tendo em vista que só os documentos habilitatórios do licitante da melhor proposta de preço serão objeto de apreciação.

\subsection{ESTATUTO NACIONAL DA MICROEMPRESA E DA EMPRESA DE PEQUENO PORTE}

O Estado usa seu poder de compra para promover o desenvolvimento e reduzir as desigualdades regionais, entre outras práticas, no fomento de políticas públicas para tratamento diferenciado de micro e pequenas empresas. 
Por reconhecer este poder de compra do Estado é que a Lei 12.349/2010 incluiu uma terceira finalidade legal à licitação, qual seja, a promoção do desenvolvimento nacional sustentável, alteração promovida no art. 3o da Lei 8.666/93, em perfeita consonância à Constituição Federal que, em seu art. 3o, alçou o desenvolvimento nacional a objetivo fundamental da República Federativa do Brasil, ao lado da construção de uma sociedade livre, justa e solidária; da erradicação da pobreza e da marginalização, assim como da redução das desigualdades sociais e regionais; da promoção do bem de todos, sem preconceitos de origem, raça, sexo, cor, idade e quaisquer outras formas de discriminação. (MACHADO, et al)

Ainda que, a alteração legislativa é relativamente recente, outras normas já viam a licitação como instrumento de políticas públicas, a exemplo da Lei Complementar 123/06, que estabeleceu um tratamento diferenciado na licitação às microempresas e empresas de pequeno porte, em atendimento ao disposto nos arts. 170, IX, e 179, da Constituição Federal. No seu artigo $1^{\circ}$ declara:

Art. 1 Esta Lei Complementar estabelece normas gerais relativas ao tratamento diferenciado e favorecido a ser dispensado às microempresas $e$ empresas de pequeno porte no âmbito dos Poderes da União, dos Estados, do Distrito Federal e dos Municípios (...)

Atualmente, o mesmo tratamento foi enfatizado no capítulo do Sistema Tributário Nacional com - arcabouço constitucional dando origem ao Supersimples e ao Empreendedor Individual, no bojo da Lei Geral da Micro e Pequena Empresa. (SPÍNOLA, 2012)

Art. 3o para os efeitos desta Lei Complementar consideram-se microempresas ou empresas de pequeno porte a sociedade empresária, a sociedade simples, a empresa individual de responsabilidade limitada e o empresário a que se refere o art. 966 da Lei $\mathrm{n} \cong 10.406$, de 10 de janeiro de 2002 (Código Civil), devidamente registrados no Registro de Empresas
Mercantis ou no Registro Civil de Pessoas Jurídicas, conforme o caso, desde que:

- I - no caso da microempresa, aufira, em cada ano-calendário, receita bruta igual ou inferior a $R \$$ 360.000,00 (trezentos e sessenta mil reais); e

- Il - no caso da empresa de pequeno porte, aufira, em cada ano-calendário, receita bruta superior a $\mathrm{R} \$ 360.000,00$ (trezentos e sessenta mil reais) e igual ou inferior a $\mathrm{R} \$ 3.600 .000,00$ (três milhões e seiscentos mil reais).

A lei define como Pequeno Empresário, assim, (i) a sociedade empresária, a sociedade simples, a empresa individual de responsabilidade limitada ou empresário individual; (ii) regulares, ou seja, devidamente registrados no Registro de Empresas Mercantis ou no Registro Civil de Pessoas Jurídicas, conforme o caso; (iii) que aufiram, em cada ano-calendário, receita bruta igual ou inferior a $\mathrm{R} \$ 360.000,00$ (trezentos e sessenta mil reais) - Microempresário; ou receita bruta superior a $\mathrm{R} \$ 360.000,00$ (trezentos e sessenta mil reais) e igual ou inferior a $\mathrm{R} \$ 3.600 .000,00$ (três milhões e seiscentos mil reais) - Empresário de Pequeno Porte.

Consubstanciando a importância da participação das MPEs nas compras públicas, SPINOLA (2012, p.5), declara:

Temos nas micro e pequenas empresas um segmento dos mais importantes, sustentáculo da livre iniciativa e da democracia, responsável pela esmagadora maioria dos postos de trabalho e do total de empresas de qualquer país. No Brasil não é diferente. Esse segmento teve, e tem, importante papel como maior fonte de empregos, absorvendo a maior parte da mão de obra oriunda das demissões em massa de grandes empresas, assoladas pelo alto índice de desestatização, abertura econômica (globalização) e políticas governamentais recessivas. 
Ressalta-se, conforme Lima (2008, p. 19) que o tratamento diferenciado concedido às ME e EPP, "objetiva a promoção do desenvolvimento econômico e social no âmbito municipal e regional, ampliação da eficiência das políticas públicas e o incentivo à inovação tecnológica".

O Capítulo V da Lei Geral dispõe do Acesso aos Mercados, mais especificamente das Aquisições Públicas ou compras governamentais sujeitos a processos licitatórios na aquisição de produtos e serviços.

Para tanto, foram criados os seguintes mecanismos que atentem o princípio da igualdade e favorecem as MPEs:

a. A regularização tardia dos documentos de regularidade fiscal de habilitação, caso apresentem alguma pendência;

b. Cria o empate ficto, caso a MPE apresente proposta superior a 10\% superior a de outra média ou grande empresa. Este intervalo é de 5\%, em caso de pregão.

Além desses, tem-se ainda mais três procedimentos especiais que depende de regulamentação por parte do ente licitante. Assim, a fim de promover o desenvolvimento econômico e social das MPEs, a administração pública poderá realizar processo licitatório:

I - destinado exclusivamente à participação de MPE nas contratações de até $R \$ 80.000,00$;

II - exigindo dos licitantes (médias ou grandes empresas) a subcontratação de MPEs para fornecimento de até $30 \%$ do total do objeto licitado;

III - estabelecendo cota de até $25 \%$ do objeto para a contratação de MPEs para a aquisição de bens e serviços de natureza divisível, ou seja, quando a compra pode ser dividida em várias partes.
Evidencia-se que o tratamento distinto, simplificado e beneficiado procura nada mais que uma igualdade entre os pequenos negócios e as grandes corporações, uma vez que estas têm mais facilidade de acesso ao crédito, as informações, produção e comercialização em larga escala, o que, consequentemente, leva a uma compra de insumos e matérias primas também em larga escala, com uma forte redução de custos e preços, dentre uma série de outros fatores que agravam a desigualdade de competição entre a pequena e a grande empresa.

Por outro lado, os pequenos negócios são responsáveis pela maioria dos empregos, de forma descentralizada e com isso promovendo a democratização de oportunidades em nosso País.

Dados divulgados pelo Ministério do Planejamento, Orçamento e Gestão e Ministério do Trabalho confirma que o acesso das pequenas empresas às contratações realizadas pelo Estado aumentou consideravelmente. De 2006 para 2007 houve um crescimento de 8\% para 28\%; de 2007 para 2008 chegou a 32\%. Em 2011 esse acesso cresceu $43,36 \%$, em face da aplicação do tratamento diferenciado assinalado na Lei Complementar. (MINISTÉRIO DO PLANEJAMENTO, 2011)

Em relação ao governo federal, de 2002 a 2011, a contratação de pequenas empresas teve um crescimento de $\mathrm{R} \$ 2,56$ bilhões para 15,29 bilhões, comprovando que o poder de compra do Estado pode fomentar o desenvolvimento nacional, de forma sustentável. (MACHADO et al)

Em resumo, o poder de compra do Estado pode ser uma estratégia de políticas voltadas ao desenvolvimento econômico sustentável, para a geração de emprego e renda e para a erradicação da pobreza e das desigualdades sociais, concretizando, enfim, as promessas da Constituição Federal. E o fomento às pequenas empresas é uma das vias já previstas em nosso ordenamento jurídico para a consecução desse objetivo. (lbid) 


\section{ANÁLISE E DISCUSSÃO DOS RESULTADOS}

Nessa seção traremos a discussão e a análise os dados estudados referentes aos pregões eletrônicos realizados na Universidade Federal do Paraná (UFPR) em 2013. Como amostra, foram escolhidos os pregões referentes às compras de itens de subsistência, que são produtos alimentícios. Para o tratamento dos dados foi utilizado um programa de planilha eletrônica para resolver cálculos simples como percentagem, médias e somatórios.

A escolha por esses pregões se deu pelo fato que os produtos alimentícios abastecem os restaurantes universitários que fornecem desde café da manhã, almoço e jantar aos estudantes e servidores da UFPR. Em média, são oferecidos 4750 almoços diários e 1200 refeições a noite.

No âmbito da UFPR foram realizados 216 pregões eletrônicos no ano de 2013, sendo que, da totalidade, dois pregões foram suspensos, três anulados e quatro revogados, equivalendo a $4 \%$ ao todo. O orçamento global foi de $R \$ 1.054 .512 .273,30$ previstos para execução orçamentária. Os gastos com material de consumo foram de $\mathrm{R} \$ 14.063 .602,51$.

Do total dos pregões, 92 (43\%) foram materiais de consumo, 60 (28\%) materiais permanentes e 55 (25\%) serviços. Os pregões que foram anulados, revogados ou suspensos foram pelos motivos de inexistência de propostas, ou porque os valores ofertados estavam acima dos valores estimados pela instituição, conforme Gráfico 1.

Gráfico 1 - Percentual de pregões realizados na UFPR em 2013

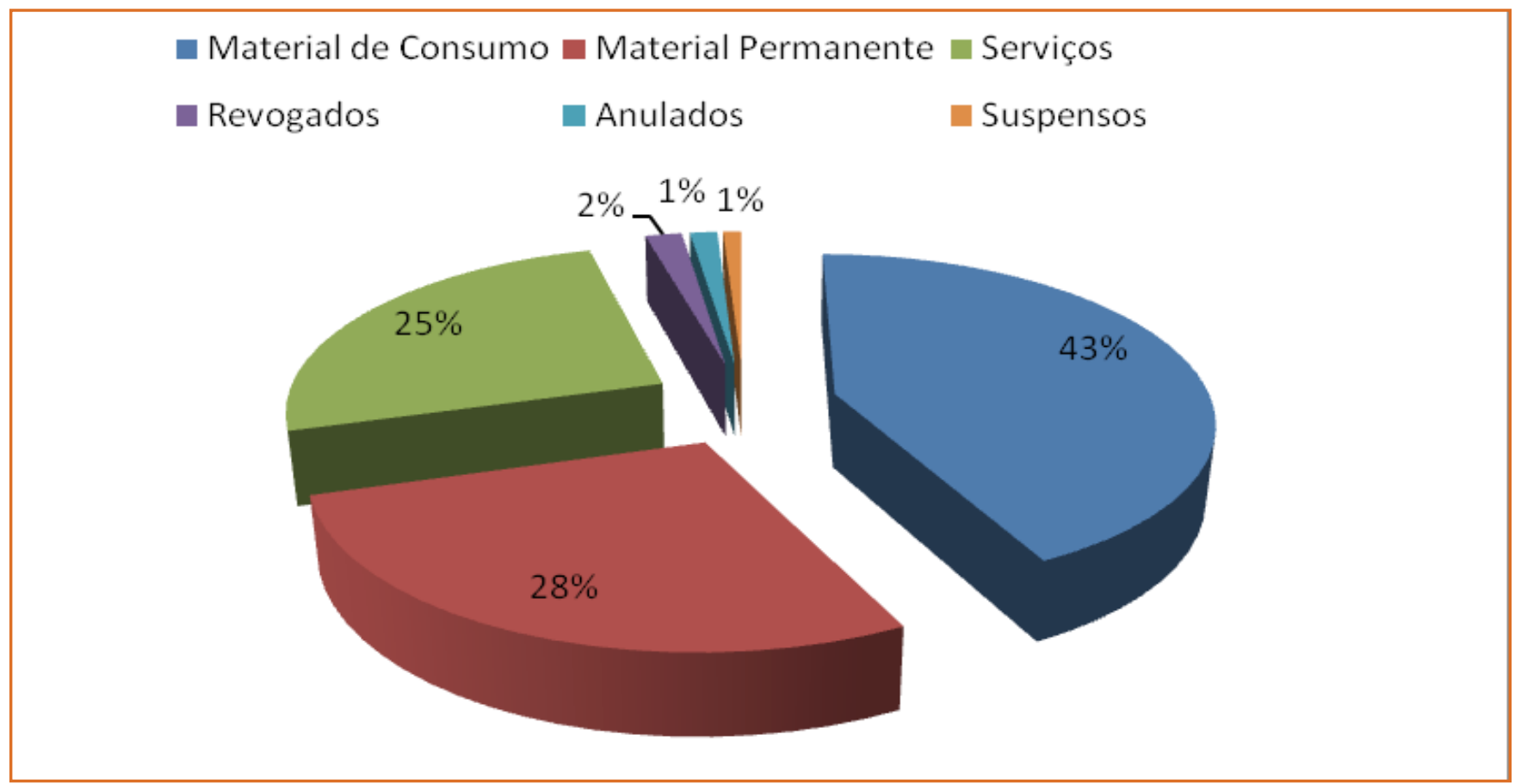

Fonte: Elaboração própria

Dos 216 pregões realizados na UFPR no ano de 2013, analisou-se apenas doze pregões referentes a compras de produtos de subsistência, ou seja, produtos alimentícios perecíveis e semiperecíveis, incluindo água mineral, biscoitos, carnes, massas, hortifrutigranjeiros, chás, cafés entre outros.
Em relação às MEs (microempresas) e EPPs (empresas de pequeno porte), essas possuem benefícios nas licitações (o que inclui o pregão eletrônico), por conta do disposto nos arts. 42 a 49 da Lei Complementar 123/2006, como forma de fomentar seu crescimento e sua participação nesse mercado público consumidor. 
Dos doze pregões estudados, verificou a participação das MPEs em todos eles, o que representa o montante de $100 \%$, o qual pode ser considerado significativo. A média de participações ficou em torno de dezenove MPEs por pregão.

Averiguou-se ainda, nos pregões estudados, em 83\% constava na ata a participação exclusiva das micro e pequenas empresas, com tratamento diferenciado do tipo 1, o que quer dizer que os pregões foram destinados exclusivamente à participação das MPEs nas contratações cujo valor seja de até $\mathrm{R} \$ 80.000,00$ (oitenta mil reais), conforme disposto no art. 48 inciso I e em cumprimento ao art. 47 da mesma lei:

Nas contratações públicas da União, dos Estados e dos Municípios, poderá ser concedido tratamento diferenciado e simplificado para as microempresas e empresas de pequeno porte objetivando a promoção do desenvolvimento econômico e social no âmbito municipal e regional, a ampliação da eficiência das políticas públicas e o incentivo à inovação tecnológica, desde que previsto e regulamentado na legislação do respectivo ente". (grifo nosso)

Além disso, constatou-se que o montante global licitado foi de $R \$ 11.304 .633,55$, esse valor representa $80 \%$ do que foi gasto em material de consumo.

Um fato que chamou a atenção foi que uma única empresa foi vencedora de cinco certames licitatórios no referido ano e valor global licitado foi de $R \$$ $6.350 .246,85$, correspondendo a $56 \%$ do valor total, outra empresa venceu quatro pregões com o montante de $\mathrm{R} \$ 271.409,25$ (2\%) e uma terceira empresa venceu três vezes e o valor total licitado foi de $R \$ 637.919,00$ (6\%). As três empresas juntas correspondem a $64 \%$ do montante global licitado.

A nosso ver, os dados acima refletem no interesse das MPEs participarem dos certames licitatórios e na importância dessa participação, pois podem produzir resultados significativos em relação ao aumento da renda e de emprego e com isso promover o crescimento dessas empresas.

Em atendimento ao objetivo quanto a economia gerada nos Pregões Eletrônicos estudados, foi realizada uma busca minuciosa no Portal de Compras do Governo Federal que tem o acesso aberto a todos os interessados. Ao todo foram analisados 266 itens para obter o valor estimado e o valor contratado.

O pregão eletrônico está sustentado pelo valor de referência, ou seja, o que decide se um pregão atingiu um índice de economicidade bom ou ruim é o valor de referência ou valor estimado.

Para obter o valor estimado, a unidade solicitante deve realizar pesquisa de mercado com no mínimo três orçamentos, desde que estes apresentem diferenças de valores aceitáveis (aproximadamente 30\% entre si) e depois se calcula o preço médio.

Esta medida é imprescindível, pois o preço de referência para a contratação é informação fundamental para orientação do Pregoeiro quando da análise e julgamento das propostas. Uma variação extrema dos preços não representaria a realidade dos valores praticados no mercado, prejudicando a efetividade desta avaliação.

Ressalta-se que o valor estimado correspondente à média dos valores praticados no mercado é a referência de valor máximo para contratação que o Pregoeiro deve adotar quando da realização da sessão do Pregão, constituindo parâmetro para analisar a aceitabilidade das propostas.

Para se chegar ao volume global contratado e estimado, multiplicou-se o valor unitário de cada item pela quantidade ofertada, referente a cada pregão consultado.

Levando-se em consideração o valor estimado e o valor contratado dos pregões, em termos gerais, no ano de 2013 verificou-se que a UFPR atingiu um índice de $25 \%$ de economia no volume de compras efetuadas de produtos alimentícios e em valores monetários a $\mathrm{R} \$ 3.770 .180,82$, conforme Tabela 1. 
Tabela 1 - Pregões eletrônicos referentes a aquisição de produtos alimentícios realizados na UFPR, 2013

\begin{tabular}{|c|c|c|c|c|c|}
\hline \multirow{2}{*}{ PREGÃO No } & \multicolumn{2}{c}{ OBJETO } & $\begin{array}{c}\text { VALOR ESTIMADO } \\
\text { (R\$) }\end{array}$ & $\begin{array}{c}\text { VONTRATADO (R\$) } \\
\text { CONIFERENGA }\end{array}$ ECONOMIA \\
\hline GERADA
\end{tabular}

Fonte: Elaboração própria

Os pregões que mais geraram economia foram: $n^{\circ}$ 146/2013 - Aquisição de hortifrutigranjeiros (52\%) e $n^{\circ}$ 93/2013 - Aquisição de café (49\%). E os que menos geraram economia foram os pregões $n^{\circ}$ 29/2013 referente à aquisição de carnes e n 172/2013 referente à aquisição de carnes, derivados e massa fresca em torno de $1 \%$ e $14 \%$, respectivamente.

Em relação a participação das MPE's nos pregões eletrônicos a tabela a seguir mostra o percentual de participação nos anos de 2010 a 2014.

Tabela 2 - Percentual de participação das MPEs nos pregões eletrônicos na UFPR, no período de 2010 a 2014

\begin{tabular}{|c|c|c|}
\hline \multicolumn{1}{|c|}{ ANO } & No DE PREGÕES & PERCENTUAL DE PARTICIPAÇÃO DAS MPES \\
\hline 2010 & 255 & $89,02 \%$ \\
2011 & 238 & $83,19 \%$ \\
2012 & 154 & $83,77 \%$ \\
2013 & 193 & $95,85 \%$ \\
2014 & 191 & $94,24 \%$ \\
\hline
\end{tabular}

Fonte: Portal de Compras do Governo Federal

Verifica-se que é expressivo a participação das microempresas e empresas de pequeno porte nos pregões eletrônicos realizados pela UFPR, obtendo a média de $89,21 \%$ no período de cinco anos. Nos anos de 2013 e 2014 a participação cresceu consideravelmente, sendo $95,85 \%$ e $94,24 \%$, respectivamente.

A Tabela 3 mostra o volume global gastos em compras públicas e valor total adquirido em material e serviço nos pregões eletrônicos realizados pela UFPR nos últimos cinco anos. 
Tabela 3 - Volume global gastos em compras públicas pela UFPR, no período de 2010 a 2014

\begin{tabular}{c|c|c|c|}
$\begin{array}{c}\text { ANO } \\
\text { VALOR TOTAL CONTRATADO EM COMPRAS } \\
\text { PÚBLICAS }\end{array}$ & $\begin{array}{c}\text { VALOR TOTAL CONTRATADO EM } \\
\text { PREGÖES ELETRONICOS }\end{array}$ \\
\hline 2010 & $\mathrm{R} \$ 266.504 .330,12$ & $\mathrm{R} \$ 147.153 .847,24$ & $55,22 \%$ \\
\hline 2011 & $\mathrm{R} \$ 328.193 .515,18$ & $\mathrm{R} \$ 135.812 .159,77$ & $41,38 \%$ \\
\hline 2012 & $\mathrm{R} \$ 178.787 .209,92$ & $\mathrm{R} \$ 71.267 .786,13$ & $39,86 \%$ \\
\hline 2013 & $\mathrm{R} \$ 106.602 .279,15$ & $\mathrm{R} \$ 74.525 .407,13$ & $69,91 \%$ \\
\hline 2014 & $\mathrm{R} \$ 150.744 .724,41$ & $\mathrm{R} \$ 87.971 .616,33$ & $58,36 \%$ \\
\hline
\end{tabular}

Fonte: Portal de Compras do Governo Federal

Constata-se que o volume total adquirido em material e serviço nas compras públicas nos últimos cinco anos foi de um trilhão de reais, sendo que a modalidade pregão eletrônico correspondeu em 52,95\% em média do volume total gastos em compras públicas. Isso representa que as MPEs responderam por 460 milhões de reais $(44,72 \%)$ considerando tudo que foi adquirido através dos pregões eletrônicos.

Em vista dos resultados obtidos, nota-se a crescente participação das MPEs nos pregões eletrônicos realizados pela UFPR nos últimos cinco anos.

\section{CONSIDERAÇÕES FINAIS}

O artigo procurou analisar a participação das micros e pequenas empresas nos pregões eletrônicos referentes à compra de itens de subsistência realizados no âmbito da Universidade Federal do Paraná no ano de 2013. Também, mostrou a participação das microempresas e empresas de pequeno porte nos pregões eletrônicos realizados no período entre 2010 a 2014. O pregão eletrônico, instituído pela Lei n.10.520/02 e regulamentado pelo Decreto n.5.450/05 pretende democratizar a participação nas compras governamentais com transparência e modernidade, e a exclusividade para micro e pequenas empresas foi instituída pela Lei Complementar n.123/2006.

Considerando que o Governo Federal têm promovido consideráveis mudanças em relação a diversas leis que abordam as compras públicas, principalmente a Lei Complementar 213/2006 que propõe tratamento diferenciado a micro e pequenas empresas tem gerado impacto positivo. Os resultados mostraram que a Lei Complementar trouxe benefícios para as microempresas e empresas de pequeno porte, inovando, modernizando e facilitando o acesso às compras públicas.

Tratando especificamente dos resultados percebidos a partir da análise dos dados, a crescente participação das MPEs nos pregões estudados nesse artigo, trazem importantes resultados, principalmente porque uma única empresa foi vencedora em cinco vezes dos pregões eletrônicos ao longo do ano de 2013.

Em relação ao Pregão Eletrônico pode-se dizer que as vantagens do processo licitatório na forma de pregão eletrônico implicam em uma maior transparência nas ações governamentais, menos procedimentos burocráticos e celeridade nas decisões. Desta forma, o pregão em sua forma eletrônica, comprovou-se como um instrumento indispensável à eficiência e à modernização da gestão pública.

Sendo assim, os incentivos que o Governo Federal tem proporcionado para as MEs e EPPs participarem dos processos de pregão eletrônico tem gerado um grande potencial para estimular e promover o desenvolvimento econômico sustentável. 


\section{REFERÊNCIAS}

[1] BRASIL. Decreto n. 5.450, de 31 de maio de 2005. Regulamenta o pregão, na forma eletrônica para aquisição de bens e serviços comuns e dá outras providências. Disponível

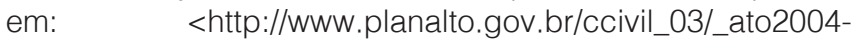
2006/2005/decreto/d5450.htm >. Acesso em: 07/05/2015.

[2] L_Lei n. 10.520, de 17 de julho de 2002. Institui, no âmbito da União, Estados, Distrito Federal e Municípios, nos termos do art. 37, inciso XXI, da Constituição Federal, modalidade de licitação denominada pregão, para aquisição de bens e serviços comuns, e dá outras providências. Diário Oficial [da] República Federativa do Brasil, Brasília, DF, 17 jul. 2002. Disponível em: < http://www.planalto.gov.br/ ccivil_03/leis/2002/L10520.htm>. Acesso em: 07/05/2015.

[3] _. Lei n. 8.666, de 21 de junho de 1993. Regulamenta o art. 37, inciso XXI, da Constituição Federal, institui normas para licitações e contratos da Administração Pública e dá outras providências. Brasília, DF, 1993.

[4] L_Lei n.123/06, de 14 de dezembro de 2006. Disponível em <http://www.planalto.gov.br/ccivil_03/Leis/ LCP/Lcp123.htm> Acesso em: 08/05/2015.

[5] _L Lei no 6.938, de 31 de agosto de 1981. Dispõe sobre a Política Nacional do Meio Ambiente, seus fins e mecanismos de formulação e aplicação, e dá outras providências. Brasília, 1981. Disponível em: <http://www. planalto.gov.br/ccivil_03/leis//6938.htm>. Acesso em: 26 set. 2015.

[6] IPEA. Sustentabilidade ambiental no Brasil: biodiversidade, economia e bem-estar humano. O uso do poder de compra para a melhoria do meio ambiente. Série eixos do desenvolvimento brasileiro. n. 82. Comunicados do Ipea, 2011. Disponível em: <www.ipea.gov.br/>. Acesso em: 27/04/2015.
[7] JUSTEN FILHO, Marçal. Pregão: comentários à legislação do pregão comum e eletrônico. 5 ed. São Paulo: Dialética, 2009.

[8] LIMA, Jonas. Lei complementar 123/2006: Aplicações. Curitiba: Negócios Públicos, 2008.

[9] MACHADO, Ana Carolina et al. A promoção do desenvolvimento nacional sustentável. Disponível em: <http://www.jmleventos.com.br/arquivos/news/newsletter_ adm_publica/arquivos/ANEXO_1_14_01.pdf>. Acesso em: 24/09/2015.

[10] MINISTÉRIO DO PLANEJAMENTO. Informações gerenciais de contratações e compras públicas: janeiro a dezembro de 2013. Disponível em: <www.comprasnet.gov. br.> Acesso em: 10/05/2015.

[11] SPÍNOLA, André Silva. O tratamento diferenciado, simplificado e favorecido concedido à microempresa e à empresa de pequeno porte e os princípios constitucionais da igualdade e da capacidade contributiva. Revista do Administrador Público: Governet. Acesso em: 19/05/2015.

[12] SANTOS, Rogerio Santanna dos, et al.. Guia de compras públicas sustentáveis para a administração federal. 2010. Disponível em: <http://cpsustentaveis.planejamento.gov. br/wp-ontent/uploads/2010/06/Cartilha.pdf>. Acesso em: 05/09/ 2015.

[13] TRIBUNAL DE CONTAS DA UNIÃO. Licitações e contratos: orientações e jurisprudência do TCU. 4. ed. rev., atual. e ampl. Brasília: TCU, 2010 


\section{CAPÍTULO4}

MODELO DE SIMULAÇÃo DOS PROCESSOS DE

UMA LAVANDERIA

Ernane Rosa Martins

Resumo: A melhoria permanente dos processos produtivos é uma das principais preocupações das organizações na busca por mais competitividade no mercado. Tendo em conta essa necessidade, este trabalho teve como objetivo analisar, através de técnicas de simulação computacional, os processos de uma lavanderia localizada em AnápolisGO, que não está conseguindo suprir a demanda, buscando expandi-la, dentro das disponibilidades de investimento. A metodologia utilizada é a de modelagem através de simulação computacional, de caráter teórico/bibliográfico, pela necessidade de aprofundar o conhecimento sobre simulação, prático/estudo de caso, por ser uma pesquisa empírica que investiga um fenômeno contemporâneo dentro de seu contexto de vida real e de natureza exploratória qualitativa, pois objetiva aprofundar e aperfeiçoar as ideias. Um modelo foi implementado no software de simulação Arena. A partir deste modelo foram realizadas variações para estudar novas configurações de máquinas e secadoras. Os resultados obtidos na simulação demonstraram que, com a utilização de mais máquinas, todos os clientes que chegavam para lavar a roupa conseguiam encontrar uma máquina de lavar a disposição, assim como, com a utilização de mais secadoras, todos os clientes que chegam para utilizar à secadora, sempre encontravam pelo menos uma livre para poder ser utilizada. 


\section{INTRODUÇÃO}

Este artigo tem como objetivo analisar, através de técnicas de simulação computacional, os processos de uma lavanderia automática localizada em AnápolisGO.

A metodologia usada na pesquisa foi de caráter teórico/bibliográfico, pela necessidade de aprofundar o conhecimento sobre simulação, prático/estudo de caso, por ser uma pesquisa empírica que investiga um fenômeno contemporâneo dentro de seu contexto de vida real e de natureza exploratória qualitativa, pois objetiva aprofundar e aperfeiçoar as ideias.

Esta pesquisa se justifica, pois nenhum trabalho desse tipo havia sido realizado na empresa estudada. Durante a realização desse projeto, várias alternativas puderam ser estudadas a fim de se obter o correto direcionamento das atividades, e é nesse contexto que a modelagem e simulação de sistemas produtivos surgem como uma poderosa metodologia para as empresas, pois através dela é possível prever o comportamento de um determinado sistema. Dessa forma, o correto dimensionamento e direcionamento de recursos podem ser realizados para a redução de custos e detecção de melhorias.

A simulação permite criar, em computadores, ambientes virtuais que imitam o comportamento de quase todos os tipos de sistema, não necessitando de nenhuma modificação física das estruturas. Tendo como objetivos melhorar a eficiência de um sistema produtivo e redução de custos, além de possibilitar propor melhorias e detecção de erros que permitem aos gestores um maior respaldo na tomada de decisão.

Para Freitas Filho (2008), o crescimento da utilização dessa ferramenta deve-se, à atual facilidade de uso e sofisticação dos ambientes de desenvolvimento de modelos computacionais, aliadas ao crescente poder de processamento das estações de trabalho.

Este artigo está estruturado nas seguintes seções. Além desta presente seção com a introdução. A seção 2 traz uma revisão de literatura, com a formação de uma base conceitual e teórica, que fornece subsídios para a compreensão dos principais conceitos abordados. A seção 3 descreve a metodologia, com os procedimentos de investigação, utilizados pelo pesquisador. Na seção 4 são apresentados os resultados da pesquisa. Por fim, a seção 5 reúne as considerações finais.

\section{REFERENCIAL TEÓRICO}

\subsection{O PROCESSO DE SIMULAÇÃO}

É possível definir simulação como sendo uma técnica de estudar o comportamento e reações de determinados sistemas através de modelos, ou seja, a realização de experimentos amostrais em um modelo de um sistema. Assim, os testes são realizados no modelo, ao invés de ser no sistema real, por ser mais fácil e com um menor custo (HILLIER, 1988).

Segundo Carson (2004), a representação de um sistema ou processo pode ser considerada um modelo. A modelagem de um sistema ou processo com a inserção do tempo e as mudanças apresentadas é considerada um modelo de simulação.

As etapas para se chegar ao consenso a respeito de simulação é observada por Chase (1989) da seguinte forma: em um primeiro momento, definir um modelo do que se deseja simular e em um segundo momento, movimentá-lo ao longo de um determinado tempo.

Por fim, os modelos de simulação conseguem baratear e agilizar as estimativas do desempenho de configurações de um sistema e/ou alternativas de procedimentos operacionais (BARTON, 2004).

\subsection{VANTAGENS DA SIMULAÇÃO}

Uma das vantagens claras na utilização da simulação é conseguir alterar determinados parâmetros do sistema e observar o resultado, servindo, ao final, como auxílio na tomada de decisão sobre futuras alterações no sistema real.

Do ponto de vista de Law e Kelton (2000), as vantagens da simulação são as seguintes:

- Sistemas complexos que contenham elementos estocásticos que não conseguem ser tratados 
- adequadamente por técnicas analíticas podem ser, na maioria das vezes, estudados por simulação;

- Fornece um controle melhor sobre as condições experimentais do que seria possível na experimentação no sistema real;

- Autores como Chung (2004) destacam outras vantagens na utilização do modelo por simulação:

- A experimentação pode ocorrer em um curto período de tempo, em virtude do apoio computacional;

- Menor necessidade de análise, uma vez que os pacotes de softwares disponíveis no mercado facilitam a análise dos dados;

- Facilidade da demonstração dos modelos, em virtude da alta capacidade gráfica dos pacotes de softwares disponíveis no mercado para a simulação.

\subsection{DESVANTAGENS DA SIMULAÇÃO}

Durante o processo de simulação do sistema, devese ter uma atenção redobrada para que o modelo seja o mais fiel possível. Caso isso não aconteça, os resultados encontrados não serão confiáveis. Robinson (2004) descreve outras desvantagens:

- Custo elevado, uma vez que o software tem um alto custo de aquisição;

- Contratação de consultores para a construção do modelo, o custo pode ser ainda mais alto;

- Consome muito tempo e os benefícios podem não ser imediatos;

- A maioria dos modelos para simulação requer uma quantidade significativa de dados.

Além destas desvantagens, Law e Kelton (2000) descreve alguns pontos que devem ser observados, pois são considerados como armadilhas na modelagem de um sistema:

- Falha na definição de um conjunto claro de objetivos;

- Nível inapropriado de detalhes no modelo;

- Falha por falta de interação com a gerência regularmente;

- Conhecimento insuficiente de simulação e estatística por parte do analista;

- Software inapropriado;
Desta forma, é possível verificar que o desenvolvimento do modelo do sistema real é um processo bastante meticuloso e deve ser realizado com paciência e prudência, haja vista que, qualquer erro pode resultar em alterações significativas nos resultados da simulação.

\section{METODOLOGIA}

A metodologia adotada é de caráter teórico/ bibliográfico, pela necessidade de aprofundar o conhecimento sobre simulação, prático/estudo de caso, por ser uma pesquisa empírica que investiga um fenômeno contemporâneo dentro de seu contexto de vida real e de natureza exploratória qualitativa, pois objetiva aprofundar e aperfeiçoar as ideias.

Yin (2005) diz que o estudo de caso é um tipo de pesquisa empírica que investiga um fenômeno contemporâneo dentro de seu contexto de vida real, especialmente quando os limites entre o fenômeno e o contexto não estão claramente evidentes. Em geral o estudo de caso é a estratégia preferida quando questões do tipo "como" e "por que" são colocadas, quando o investigador tem pouco controle sobre os eventos e quando o foco é um fenômeno contemporâneo entre algum contexto da vida real (YIN, 2005).

De acordo com Santos (2005, p. 173) a pesquisa exploratória qualitativa "se caracteriza pela existência de poucos dados disponíveis, objetiva aprofundar e aperfeiçoar as ideias".

A realização desta pesquisa consta de três fases distintas. A primeira fase consiste na fundamentação bibliográfica, ressaltando o processo de simulação e as vantagens e desvantagens da simulação. A segunda fase diz respeito ao estudo de caso, com a coleta de informações, junto à empresa, relativos ao processo produtivo a ser analisado, bem como outras informações relevantes. A terceira fase consiste na construção do modelo computacional e análises de outros cenários. Para a construção dos cenários em modelos computacionais, foi utilizado o software Arena. 
De acordo com Chwif e Medina (2007), o desenvolvimento de um modelo de simulação compõese de três grandes etapas:

\section{a) Concepção ou formulação do modelo}

Nesta etapa tem-se o entendimento do sistema a ser simulado. É necessário discussões do problema com os especialistas do setor e então ocorre a definição do escopo. Neste momento são também coletados os dados de entrada, certificando-se da importância que a qualidade destes tem em todo o modelo. Faz-se então a representação do Modelo Abstrato (que está na mente do analista) utilizando técnicas adequadas. Esta representação trará um Modelo Conceitual;

b) Implementação do modelo:

Neste momento, através do Modelo Conceitual é desenvolvido o Modelo Computacional utilizando um software de simulação comercial. O modelo computacional deve então ser comparado frente ao modelo conceitual para sua avaliação, ou seja, se o modelo está condizente com o sistema real. Durante este procedimento são feitas as validações (relativo ao modelo) e as verificações (relativo ao comportamento do modelo no computador);

c) Análise dos resultados do modelo:

Nesta etapa o modelo computacional está pronto para realização dos experimentos. Temos então o Modelo Experimental. A partir desse momento, são realizadas várias "rodadas" no simulador e analisados os resultados. Caso seja necessário, fazem-se alguns ajustes no modelo computacional e reinicia as "rodadas". Após as análises dos resultados, conclusões e recomendações sobre o sistema poderão ser registradas.

\section{RESULTADOS OBTIDOS}

\subsection{O MODELO}

Os clientes chegam a lavanderia de uma forma aleatória, segundo uma exponencial, com um intervalo médio entre chegadas de 15 minutos. Eles se posicionam em uma fila a espera de uma entre sete máquinas de lavar existentes na lavanderia. Cada máquina leva exatamente 25 minutos para lavar qualquer quantidade de roupa suja trazida pelo cliente (não há problema de capacidade!). No final da lavagem o cliente se serve de um cesto (de um total de 12 existentes), se houver um disponível, para transportar as roupas até uma secadora (de um total de 2 existentes). Descarregar a máquina de lavar tem uma duração uniformemente distribuída num intervalo de 1 a 4 minutos. Transportar a roupa entre a lavadora e a secadora também tem duração uniformemente distribuída no intervalo de 1 a 4 minutos. O tempo de secagem é distribuído segundo uma normal de média 6 e variância 1. Colocar a roupa na secadora leva 2 minutos.

\subsection{O DIAGRAMA DE CICLOS DE ATIVIDADES DO PROBLEMA}

Através do modelo citado no item 4.1, foi elaborado o DCA do problema, que é mostrado na Figura 1.

Figura 1 - DCA do problema Lavanderia Automática.

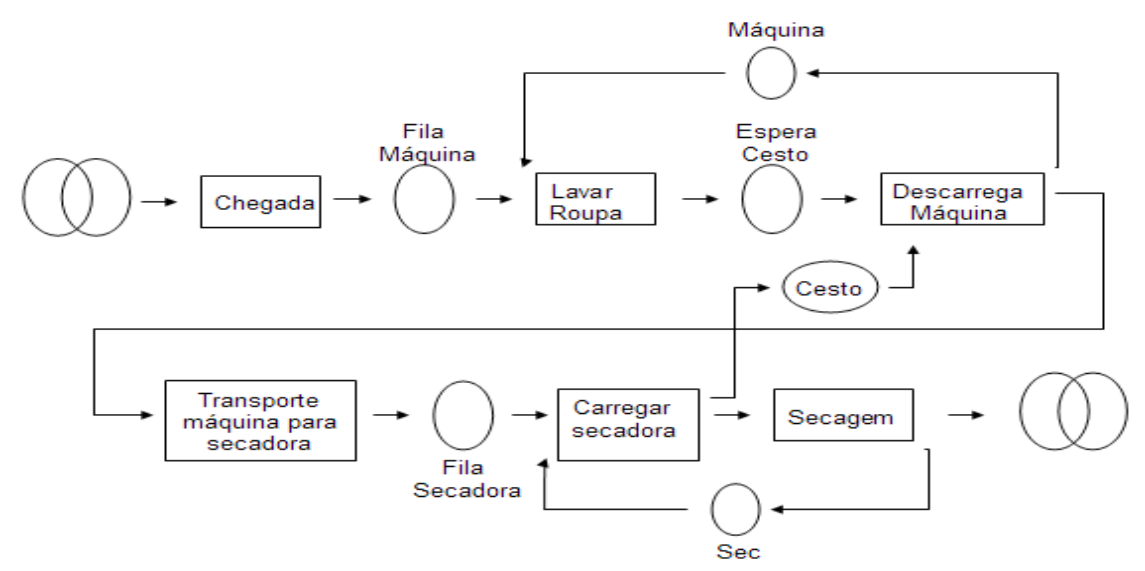

Fonte: Elaborado pelo autor. 
O DCA modela uma lavanderia automática, onde temos os processos de lavar roupa, descarregar as roupas da máquina de lavar, transportar as roupas da máquina de lavar para a secadora, carregá-las na secadora e realizar a secagem.

Para cada um destes processos, temos recursos que irão ser utilizados para que os processos possam ser realizados. Temos, portanto, a chegada dos clientes nesta lavanderia com o intuito de lavar as suas roupas na máquina de lavar. Este cliente irá aguardar em uma fila, uma máquina de lavar ficar desocupada. Assim que a máquina ficar desocupada, o cliente poderá lavar usufruir do recurso máquina de lavar.

Quando terminar de lavar a roupa, o cliente deverá aguardar em outra fila a desocupação do cesto para então poder descarregar sua roupa da máquina de lavar. Com o cesto em mãos, o cliente irá descarregar a máquina de lavar (liberando a máquina para que outro cliente possa utilizá-la) e irá transportar as suas roupas para uma secadora desocupada. Caso não encontre nenhuma secadora desocupada, o cliente irá aguardar em uma nova fila até que consiga uma secadora.

Assim que for liberada uma secadora, iremos carregála (libera o recurso cesto para que outro cliente possa utilizá-lo) e aguardar que as roupas fiquem secas. Somente após este processo que o cliente irá liberar a secadora para outro. Após este ultimo processo, o cliente irá deixar a lavanderia.

\subsection{O MODELO PROGRAMADO}

De posse do DCA do problema e utilizando-se o software ARENA, construiu-se o modelo programado do problema, que pode ser visto na Figura 2.

Figura 2 - Modelo programado do problema Lavanderia Automática.

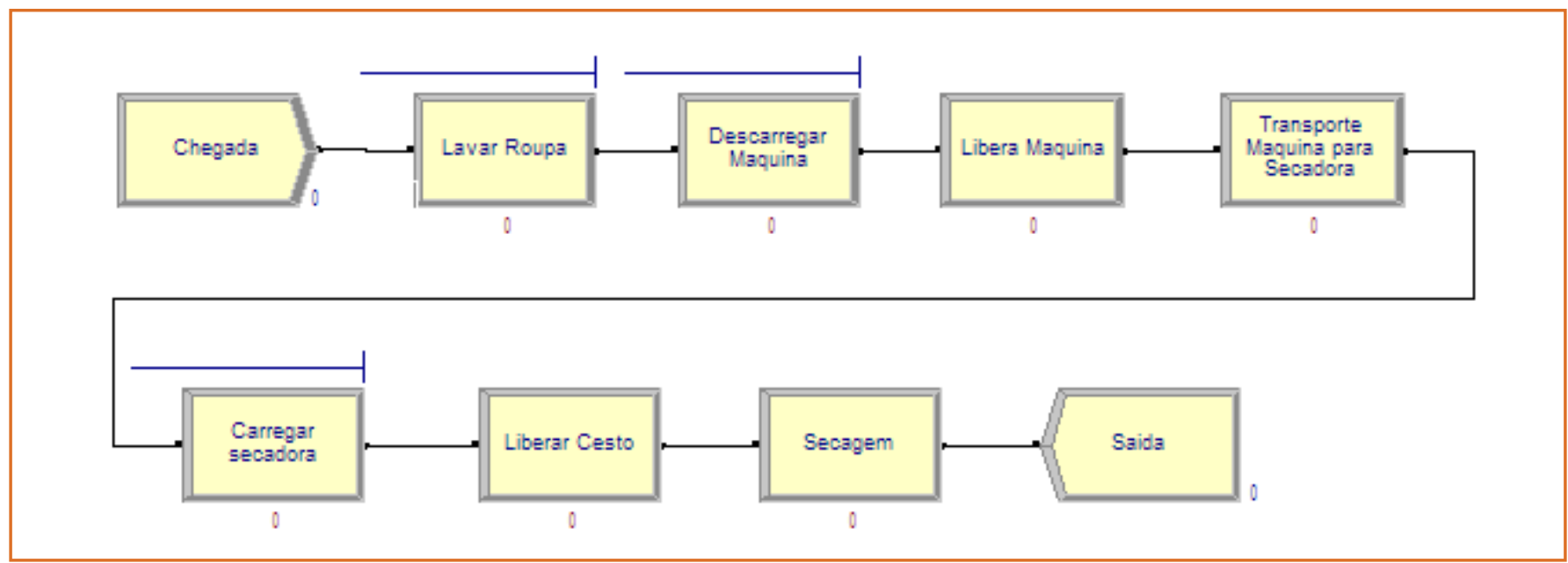

Fonte: Elaborado pelo autor.

\subsection{RESULTADO DA EXECUÇÃO DO MODELO PROGRAMADO}

O software ARENA gera um relatório quando o modelo é executado. Este relatório possui informações importantes sobre o comportamento do sistema.
Os principais parâmetros do sistema que foram analisados são apresentados na Tabela 1. Serão mostrados os parâmetros referentes à média aritmética dos valores encontrados nas 10 rodadas. 
Tabela1 - Principais parâmetros do modelo Lavanderia Automática.

\begin{tabular}{|c|c|c|}
\hline & Parâmetro & Valor Obtido \\
\hline 1 & Replication ended at time & 5880.0 Minutes \\
\hline 2 & Clientes.Numberln & 429.3 \\
\hline 3 & Clientes.NumberOut & 428.1 \\
\hline 4 & Clientes.WIP & 2.7992 \\
\hline 5 & Maquina.Utilization & .28656 \\
\hline 6 & Secadora.Utilization & .29309 \\
\hline 7 & Cesto.Utilization & .04455 \\
\hline 8 & Carregar Secadora.Queue.NumberInQueue & .02651 \\
\hline 9 & Descarregar Maquina.Queue.NumberInQueue & .00000 \\
\hline 10 & Lavar Roupa.Queue.NumberInQueue & 9.2562E-05 \\
\hline 11 & Carregar secadora.Queue.WaitingTime & .36423 \\
\hline 12 & Descarregar Maquina.Queue.WaitingTime & .00000 \\
\hline 13 & Lavar Roupa.Queue.WaitingTime & .00127 \\
\hline
\end{tabular}

Fonte: Elaborado pelo autor.

\subsection{INTERPRETAÇÃO DOS RESULTADOS}

No 1․ Parâmetro tem-se o tempo do sistema que foi simulado em cada rodada. Como cada replicação executada era de 7 dias com 14 horas/dia, tem-se: 7 *14 * $60=5880$ minutos. O valor 60 da expressão foi utilizado para mudar o valor resultante em horas para minutos.

Pelos parâmetros de número 2 e 3 mencionados na Tabela 1, entraram 429,3 no sistema e saíram 428,1. O motivo dos números serem diferentes é pelo fato da simulação executar até um tempo pré-determinado (5880 minutos), sendo finalizado após esse tempo ter decorrido. Nesse caso quando a simulação finalizou, em média 1,2 clientes ainda estavam no sistema.

Outras particularidades do sistema podem ser verificadas:

O parâmetro 4 da tabela 1 indica a média do número de pacientes que estão em processo no sistema (Clientes. WIP). De acordo com a Tabela 1, a média de pacientes em processo no sistema é de 2.7992 pacientes.

Os parâmetros de 5 a 7 informam a respeito da média de utilização de cada recurso presente no sistema. Os valores podem variar de um valor zero (não há utilização do recurso) até o valor um (utilização do recurso durante $100 \%$ do tempo):
- Maquina.Utilization: .28656

- Média de utilização do recurso máquina.

- Secadora.Utilization: .29309

- Média de utilização do recurso secadora no sistema Lavanderia Automática.

- Cesto.Utilization: .04455

- Média de utilização do recurso cesto no sistema.

- Os parâmetros de 8 a 10 procuram relacionar o número de clientes presentes em cada fila existente no sistema. Segue abaixo a explicação de cada uma das filas:

- Carregar Secadora.Queue.NumberInQueue: .02651

- Número médio de clientes presentes na fila para utilização do recurso secadora.

- Descarregar Maquina.Queue.NumberInQueue: .00000

- Número médio de clientes presentes na fila para descarregar máquina (utilização do recurso cesto). No caso todos os clientes conseguem um cesto, não havendo assim pessoas na fila de espera por um cesto.

- Lavar Roupa.Queue.NumberInQueue: 9.2562E-05

- Numero médio de pessoas presentes na fila para lavar roupa (necessita do recurso máquina de lavar).

Os parâmetros de 11 a 13 informam a respeito do tempo médio que cada cliente permanece nas filas 
existentes no sistema Lavanderia Automática. Vejamos abaixo:

- Carregar secadora.Queue.WaitingTime: .36423

- Tempo médio que cada cliente espera na fila para utilizar a secadora.

- Descarregar Maquina.Queue.WaitingTime: .00000

- Tempo médio que cada cliente aguarda na fila para utilizar o cesto e descarregar a máquina de lavar roupa.

- Lavar Roupa.Queue.WaitingTime: .00127

- Tempo médio que cada cliente aguarda na fila para utilizar a máquina de lavar roupa (necessário o recurso máquina de lavar).

Para responder à pergunta do problema e determinar o tempo médio que um cliente permanece no interior da lavanderia devem ser realizados os seguintes cálculos:

1) Descobrir quanto tempo o cliente gasta em cada simulação e em seguida calcular a média aritmética desses valores:
Cada relatório possui uma variável (Clientes.TotalTime) que informa o tempo total gasto por cada cliente na lavanderia. Este tempo total inclui o tempo gasto nas filas e nos processos existentes no sistema.

Devemos então encontrar a soma de todas estas variáveis e em seguida realizar a média aritmética desses valores, encontrando assim a média que cada cliente gasta na lavanderia. Os valores encontrados para as 10 simulações encontram-se na Tabela 2.

Tabela 2 - Parâmetro tempo total gasto na Lavanderia em cada simulação.

\begin{tabular}{|c|c|}
\hline \multicolumn{2}{|c|}{ Clientes.TotalTime } \\
\hline 1으 Sim & 38,53 \\
\hline $2^{\text {a }} \operatorname{Sim}$ & 38,462 \\
\hline 3 $\operatorname{Sim}$ & 38,269 \\
\hline $4^{\mathrm{a}} \mathrm{Sim}$ & 38,057 \\
\hline $5^{\text {a }} \mathrm{Sim}$ & 38,209 \\
\hline 6은 $\operatorname{Sim}$ & 38,099 \\
\hline 7a $\mathrm{Sim}$ & 38,25 \\
\hline $8^{\mathrm{a}} \mathrm{Sim}$ & 38,32 \\
\hline 9a $\mathrm{Sim}$ & 38,208 \\
\hline $10^{\mathrm{a}} \mathrm{Sim}$ & 38,387 \\
\hline TOTAL & 382,791 \\
\hline
\end{tabular}

Fonte: Elaborado pelo autor.

$$
\frac{38,53+38,462+38,269+38,057+38,209+38,099+38,25+38,32+38,208+38,387}{10}=38,27
$$

O tempo médio gasto por cada cliente na lavanderia é de 38,27 .

\subsection{SIMULAÇÃO COM NOVOS PARÂMETROS PARA O PROBLEMA}

Após ter sido verificado os parâmetros do sistema para os recursos (quantidade de máquinas de lavar roupa, cestos e secadoras) e processos que são encontrados no sistema real, pode-se alterar as variáveis do sistema para verificar se podem ser feitas melhorias com o intuito de minimizar o custo (diminuir a quantidade de máquinas de lavar roupa, cestos e secadoras) ou melhorar o atendimento (aumentar a quantidade de máquinas de lavar roupa, cestos e secadoras). De acordo com os resultados obtidos pode-se verificar se as mudanças são ou não são compensatórias.
1) Alterando o número de máquinas de lavar do sistema.

Iremos realizar a alteração do número de máquinas do sistema de 7 para 14 máquinas e verificar os parâmetros que sofreram variações. Os novos dados são apresentados na Tabela 3.

Tabela 3 - Parâmetros após alteração do recurso máquina de lavar roupa.

\begin{tabular}{|c|c|c|}
\hline & Parâmetro & Valor Obtido \\
\hline 1 & Maquina.Utilization & .1432 \\
\hline 2 & $\begin{array}{l}\text { Lavar Roupa.Queue. } \\
\text { NumberInQueue }\end{array}$ & .0000 \\
\hline 3 & Lavar Roupa.Queue.WaitingTime & .0000 \\
\hline
\end{tabular}

Fonte: Elaborado pelo autor. 
De acordo com os novos parâmetros, tivemos uma diminuição no tempo de utilização do recurso máquina, pois antes tínhamos $28,65 \%$ de máquina sendo utilizada no sistema e agora temos apenas $14,32 \%$.

Esta alteração do recurso máquina influenciou diretamente outros 2 parâmetros no sistema que são o tempo que cada cliente aguarda para lavar a roupa (Lavar Roupa.Queue.WaitingTime) e o número de clientes presentes na fila (Lavar Roupa.Queue. NumberlnQueue) aguardando para utilizar uma máquina de lavar roupa.

Ambos os parâmetros chegaram ao valor 0 , concluindo assim que todos os clientes que chegavam para lavar a roupa conseguiam encontrar uma maquina de lavar à disposição.

\section{2) Alterando o número de secadoras}

Iremos realizar uma nova alteração no sistema, agora aumentaremos o número de secadoras para verificarmos quais parâmetros serão influenciados para em seguida conseguirmos concluir se a mudança irá trazer ou não benefícios para o sistema. Os novos dados são apresentados na Tabela 4.

Tabela 4 - Parâmetros após alteração do recurso secadora.

\begin{tabular}{|c|l|l|}
\hline \multicolumn{2}{|l|}{ Parâmetro } & \multicolumn{1}{c|}{ Valor Obtido } \\
\hline 2 & Secadora.Utilization & .1415 \\
\hline \multirow{2}{*}{$\begin{array}{l}\text { Carregar Secadora.Queue. } \\
\text { NumberInQueue }\end{array}$} & .0000 \\
\cline { 2 - 3 } $\begin{array}{l}\text { Carregar secadora.Queue. } \\
\text { WaitingTime }\end{array}$ & .0000 \\
\hline
\end{tabular}

Fonte: Elaborado pelo autor.

Com a alteração do recurso secadora, observamos que o tempo de utilização da mesma no sistema diminuiu, passando de $29,30 \%$ de utilização para 14,15\%.

A alteração do recurso secadora influenciou diretamente outros 2 parâmetros no sistema que são o tempo que cada cliente aguarda para secar a roupa (Carregar secadora.Queue.WaitingTime) e o número de clientes presentes na fila (Carregar Secadora.
Queue.NumberlnQueue) aguardando para utilizar uma secadora.

Os parâmetros estão com o valor igual a 0, concluindo assim que todos os clientes que chegavam para utilizar a secadora sempre encontram pelo menos uma livre para poder ser utilizada.

\section{CONSIDERAÇÕES FINAIS}

Este artigo teve como objetivo analisar, através de técnicas de simulação computacional, os processos de uma lavanderia automática localizada em AnápolisGO. Este permitiu obter um maior conhecimento sobre modelagem e simulação de problemas encontrados no mundo real e analisar o desempenho atual do sistema modelado quanto para a idéia de tomada de decisão sobre se é ou não viável promover alterações no sistema. Com a simulação, foi possível alterar os parâmetros do sistema e verificar o resultado dessa alteração sem alterar na realidade, verificando se o sistema atual pode ser melhorado ou não.

Para a realização desse trabalho, utilizaram-se os recursos básicos do ambiente de programação ARENA. Este ambiente se mostrou muito versátil e de fácil utilização para problemas de modelagem e simulação de processos, além de gerar um relatório detalhado, que possibilita uma melhor análise e compreensão do modelo estudado.

Os resultados obtidos demonstraram que na utilização, com mais máquinas, todos os clientes que chegavam para lavar a roupa conseguiam encontrar uma maquina de lavar a disposição, assim como, com mais secadoras, todos os clientes que chegavam para utilizar a secadora sempre encontram pelo menos uma livre para poder ser utilizada.

\section{REFERÊNCIAS}

[1] BARTON, R. R. Designing Simulation Experiments. Proceedings of the Winter Simulation Conference, USA, 2004.

[2] CARSON, J. S. Introduction to Modeling And Simulation. Proceedings of the Winter Simulation Conference, U.S.A, 2004. 
[3] CHASE,R.B; AQUILANO,N.J. Production and Operations Management. 5th ed. IRWIN. 1989.

[4] CHUNG, A. A. Modeling Handbook: A practical approach. Boca Raton: CRC Press, 2004.

[5] CHWIF, L; MEDINA, A. C. Modelagem e simulação de eventos discretos, teoria \& aplicações. Segunda edição. São Paulo, 2007.

[6] FREITAS FILHO, P. J. Introdução à modelagem e simulação de sistemas: com Aplicações em Arena. 2. ed. São Paulo, SP: Editora Visual. 2008.

[7] HILLIER, F. S., LIEBERMAN G. J. Introdução à pesquisa operacional. 3. Ed. Rio de Janeiro: Campus / São Paulo: Universidade de São Paulo, 1988.
[8] LAW, A. M.; KELTON, W. D. Simulation modeling and analysis. 3. Ed. McGraw-Hill Higher Education, 2000.

[9] ROBINSON, S. Simulation: the practice of model development and use. Chichester: John Wiley \& Sons, 2004.

[10] SANTOS, I. E. Manual de métodos e técnicas de pesquisa cientifica - 5 ed. rev. atual. e ampl. Niterói, RJ: Impetus, 2005.

[11] YIN, R. K. Estudo de Caso: Planejamento e métodos. Porto Alegre: Bookman, 2005. 


\section{CAPÍTULO5}

ECONOMIA SOLIDÁRIA - A ECONOMIA REAL DO

DESENVOLVIMENTO SUSTENTÁVEL NAS COLONIAS IAPÓ E

SANTA CLARA NO MUNICÍPIO DE CASTRO - PR

\section{Alcione Lino de Araújo \\ Bethânia Ávila Rodrigues \\ Juliana Vitória Messias Bittencourt \\ Maria Helene Giovanetti Canteri}

Resumo: Com o intuito de descobrir as relações existentes entre a economia solidária, agricultura familiar, e principalmente no âmbito dos princípios de desenvolvimento sustentável, esta pesquisa foi realizada com o objetivo de identificar o desenvolvimento sustentável na economia solidária nas colônias IAPÓ e Santa Clara a partir da produção agrícola familiar no ano de 2014. O surgimento da economia solidária teve impulso após o surgimento excedente de mão de obra, resultado do êxodo rural, e um movimento de militantes sociais que lutavam por formas diferentes de organização laboral. Quanto à metodologia da pesquisa, optou-se por um estudo de natureza aplicada, caracterizado como quantitativo e qualitativo na Associação de Agricultores Familiares nas Colônias IAPÓ e Santa Clara, localizada na cidade de Castro - Paraná. Desse modo, foi possível perceber não apenas a presença das dimensões analisadas, mas também as suas relações e efeitos proporcionados pela economia solidária e o desenvolvimento sustentável para agricultura familiar.

Palavras Chave: Agricultura Familiar, Economia Solidária, Desenvolvimento Sustentável. 


\section{INTRODUÇÃO}

A Economia Solidária surgiu no cenário econômico e social no final do século XIX, como uma alternativa aos modelos organizacionais capitalistas. Esse novo modelo de economia teve lugar em diversos países. Não é por acaso que esse modelo de economia carrega o adjetivo de "solidária", pois justamente "a novidade, a força e o diferencial da economia solidária gravita em torno da ideia de solidariedade" (LISBOA, 2005, p.110). Ao experimentar uma relação de trabalho digna, afetiva, solidária, com equidade de direitos, o trabalhador associado motiva-se ao trabalho cooperado, tendo em vista que seu emprego dá-se por um acordo mutuo, além de dispor de maior capacidade de trabalho.

A atividade agrícola familiar é um sistema de produção simples, comumente adotado por pequenas propriedades rurais, onde o sustento e a sobrevivência da família dependem do manejo da terra. Esse tipo de atividade não é recente no país, porém vêm ganhando mais destaque, devido a sua expansão. Nesse sentido, Winck et al. (2014, p.32) afirma que "a agricultura familiar não é uma categoria social recente, ou seja, a utilização que Ihe tem sido atribuída nos últimos anos assume uma postura diferenciada".

Os empreendimentos solidários são produtores de diversos insumos, incluindo alimentos, artesanatos e matérias prima. Uma forma de comercialização e troca de seus produtos são as redes de economia solidária, que ganham maior visibilidade devido a sua extensão e alcance. De acordo com Filho (2008, p.224), as redes "representam a expressão concreta de uma via sustentável-solidária na promoção do desenvolvimento local"; compreender as redes de economia solidária, "significa uma associação ou articulação de vários empreendimentos e/ou iniciativas de economia solidária com vistas a construção de um circuito próprio de relações econômicas e intercâmbio de experiências e saberes formativos".

A prática da economia solidária indica uma experiência bem sucedida e sustentável, principalmente por atuar em diversas dimensões como: econômica, social, ambiental, cultural e territorial. A economia solidária contribui significativamente para o desenvolvimento local ampliando as oportunidades de emprego e renda, pois, de acordo com Domingues (2009, p.2), "é uma fonte de experiências que se cruzam e se enriquecem mutuamente e se fortalecem em redes de cooperação econômica, criando uma alternativa forte e sustentável".

O desenvolvimento local pode ser considerado como o conjunto de atividades culturais, econômicas, políticas e sociais vistas sob óticas inter-setoriais e transescalar que participam de um projeto de transformação consciente da realidade local. Na transformação social, há significativo grau de interdependência entre os diversos segmentos que compõem a sociedade (âmbitos político, legal, educacional, econômico, ambiental, tecnológico e cultural) e os agentes presentes em diferentes escalas econômicas e políticas (do local ao global).

Para Fischer (2002), o desenvolvimento local remete à combinação entre estabilidade e transformação, inovação e permanência, competição e solidariedade, sentidos esses, contraditórios, que são manejados simultaneamente por interesses coletivos representados por gestores de processos em diversas escalas. Partindo-se da premissa da valorização dos atores locais, a complexidade na definição do termo desenvolvimento é ampliada quando se insere no contexto local o desenvolvimento sustentável com o intuito de acrescentar as dimensões econômicas, sociais, culturais e ambientais.

A busca pelo desenvolvimento sustentável solidário deve iniciar-se pelo rearranjo das economias locais, tarefa difícil, uma vez que envolvem atores e interesses diversos e "implica a superação de alguns desafios fundamentais" (FILHO, 2008, p. 228).

Com o intuito de explorar as relações existentes entre os sistemas de agricultura familiar e os empreendimentos de economia solidária, principalmente no âmbito dos princípios de desenvolvimento sustentável, esta pesquisa foi realizada com o objetivo de identificar a desenvolvimento sustentável na economia solidária nas colônias IAPÓ e Santa Clara a partir da produção agrícola familiar no ano de 2014. 


\section{ECONOMIA SOLIDÁRIA}

A Economia Solidária surgiu no cenário econômico e social no final do século XIX, como uma alternativa aos modelos organizacionais capitalistas. Esse novo modelo de economia teve lugar em diversos países, porém enfrentou dificuldades quanto à diferenciação do sistema capitalista, fazendo com que algumas dessas iniciativas se submetessem ao capitalismo, o que as fez perder suas características solidárias (SANTOS et al., 2012).

De acordo com Santos et al. (2012), o surgimento da economia solidária teve impulso após o surgimento excedente de mão de obra, resultado do êxodo rural, e um movimento de militantes sociais que lutavam por formas diferentes de organização laboral. Ao constituírem um empreendimento solidário, todos os atores envolvidos estão interessados em seu desenvolvimento e sucesso, e devido a isso, os empreendimentostornam-se, aolongo dotempo, viáveis e sustentáveis. O trabalho cooperado, organizado e solidário representa uma forma significativa de promover o desenvolvimento econômico e social para sociedades carentes de renda e de políticas públicas pertinentes (TAUILE; RODRIGUES, 2004).

Para Gaiger (2003, p.191), "o fenômeno da economia solidária guarda semelhanças com a economia camponesa", principalmente por haver diferenças entre o modo social de produção solidária e o modo de produção assalariado, e pela distinção de princípios e finalidades do que excede da produção. No entanto, as iniciativas de Economia Solidária assumem diversas experiências, incluindo agricultura familiar, empresas recuperadas através de autogestão, cooperativas, associações, economias indígenas e quilombos (LISBOA, 2005).

Empreendimentos solidários "surgem em grande número, sejam de produção, trabalho, consumo ou crédito, dentro de um movimento cada vez mais combinado entre a sociedade civil e as políticas públicas progressivas" (TAUILE; RODRIGUES, 2004, p.36). Porém, a prática da economia solidária prevê uma unidade entre a posse dos meios de produção e o uso desses no processo produtivo. Além disso, o poder de decisão, controle, e a gestão do empreendimento pertencem à sociedade de trabalhadores, onde todos participam, com direitos iguais (GAIGER, 2003).

Não é por acaso que esse modelo de economia carrega o adjetivo de "solidária", pois justamente "a novidade, a força e o diferencial da economia solidária gravita em torno da ideia de solidariedade" (LISBOA, 2005, p.110). Ao experimentar uma relação de trabalho digna, afetiva, solidária, com equidade de direitos, o trabalhador associado motiva-se ao trabalho cooperado, tendo em vista que seu emprego dá-se por um acordo mutuo, além de dispor de maior capacidade de trabalho. De acordo com Gaiger (2003, p.193), essas características "provocam uma reversão do processo ocorrido nos primórdios do capitalismo, quando o trabalhador foi separado dos objetos por ele produzidos e converteu-se em propriedade de outrem, em mercadoria adquirida e destinada ao uso capital".

Embora alternativo ao capitalismo, este não se trata de um setor não lucrativo ou que não pratica o comércio. Empreendimentos solidários não buscam pelo lucro máximo, o que não significa que não almejam qualquer lucratividade. É o lucro, também renomeado de excedente, resultado ou sobras de suas atividades mercantis, que possibilita investimentos, inovação, expansão e a sustentabilidade dessa atividade econômica (LISBOA, 2005). Nesse sentido, "quando um empreendimento econômico abre mão da possibilidade de maximizar o lucro em função duma perspectiva social e ecológica, então essa empresa tem uma postura solidária dentro da troca mercantil" (LISBOA, 2005, p.109).

\subsection{AGRICULTURA FAMILIAR}

A atividade agrícola familiar é um sistema de produção simples, comumente adotado por pequenas propriedades rurais, onde o sustento e a sobrevivência da família dependem do manejo da terra. Esse tipo de atividade não é recente no país, porém vêm ganhando mais destaque, devido a sua expansão. Nesse sentido, Winck et al. (2014, p.32) afirma que "a agricultura familiar não é uma categoria social recente, ou seja, a utilização que lhe tem sido atribuída nos últimos anos assume uma postura diferenciada". 
Buscando definir agricultura familiar, Abramovay (1998, p.146) diz que "é aquela em que a gestão, a propriedade e a maior parte do trabalho vêm de indivíduos que mantém entre si laços de sangue ou de casamento". Ou seja, a gestão dos processos produtivos é planejada pelo próprio núcleo familiar.

Durante muito tempo, a atividade agrícola familiar não era valorizada e incentivada pelos governos, resultando no alto índice de migração das famílias campesinas para os centros urbanos, em busca de sobrevivência (EID; EID, 2003). No entanto, esse cenário de fuga do campo e êxodo rural, passou a mudar, com o reconhecimento da importância dessa atividade e a sanção da lei nacional da "Agricultura familiar", no 11.326 em julho de 2006, que passou a estabelecer princípios e conceitos para essa atividade (BRASIL, 2006).

No sentido de incentivar e fomentar a produção da agricultura familiar, foram desenvolvidos programas governamentais federais, com a obrigatoriedade de adquirir o alimentos oriundos da produção agrícola familiar. Conforme Amistá (2013), o programa social mais antigo e duradouro é o Programa Nacional e Alimentação Escolar (PNAE), que vem evoluindo desde a década de 40 e tem, no mínimo, 30\% dos recursos repassados pelo Fundo Nacional de Alimentação Escolar (FNDE) destinados à aquisição de merenda escolar produzidas por agricultores familiares (BRASIL, 2013).

Outro programa desenvolvido pelo governo federal é o Programa de Aquisição de Alimentos (PAA), regulamentado pelo art. 19 da lei $n^{0} 10.696$ de 2003 (BRASIL, 2003), alterado pela lei $n=12.512$, de outubro de 2011, que adquire produtos da agricultura familiar, para destiná-los, gratuitamente, para populações em situação de fragilidade alimentar (BRASIL, 2013). O PAA tem como primeiro objetivo "incentivar a agricultura familiar, promovendo sua inclusão econômica e social, com fomento à produção com sustentabilidade, ao processamento de alimentos e industrialização e à geração de renda" (BRASIL, 2011).

Com os incentivos governamentais, reconhecendo a sua capacidade de produção e importância a atividade agrícola familiar, para o desenvolvimento da região, muitas famílias produzem visando a comercialização para esses programas.

\subsection{DESENVOLVIMENTO SUSTENTÁVEL EM EMPREENDIMENTOS DE ECONOMIA SOLIDÁRIA}

Não raramente surgem ações e políticas públicas estimulandoacriaçãodeempreendimentos deeconomia solidária. Tais iniciativas oferecem apoios institucionais e motivacionais para os empreendimentos, porém os serviços são ineficientes quanto ao desenvolvimento e manuseio de ferramentas comuns de gestão e aos pressupostos de técnicas administrativas e econômicas da autogestão, resultando em uma lacuna que poderá comprometer o desenvolvimento sustentável desses empreendimentos, dificultando atividades básicas, como comercialização e acesso a novas técnicas e conhecimentos (RUTKOWSKI, 2007).

O desenvolvimento sustentável pressupõe uma "interação equilibrada e sustentável das três dimensões essenciais: econômica, social e ambiental" (DOMINGUES, 2009, p.6). A dimensão econômica compreende a necessidade de crescimento e desenvolvimento econômico, porém, atentando à sustentabilidade do ambiente. Na dimensão social, há uma preocupação quanto às necessidades sociais dos indivíduos e da sociedade em que está inserido. E por fim, a dimensão ambiental corresponde à preservação e valorização dos recursos naturais e do ambiente como um todo (DOMINGUES, 2009).

A busca pelo desenvolvimento sustentável solidário deve iniciar-se pelo rearranjo das economias locais, tarefa difícil, uma vez que envolvem atores e interesses diversos e "implica a superação de alguns desafios fundamentais" (FILHO, 2008, p. 228).

\subsection{DESENVOLVIMENTO LOCAL E REGIONAL}

A criação de empreendimentos solidários proporciona muitas oportunidades de trabalho e renda para a sua comunidade. Tais iniciativas possuem uma "perspectiva alternativa de sustentabilidade no longo prazo, além de ajudarem o país a crescer, contribuem com a elevação do bem-estar da população e, consequentemente, com 
seu desenvolvimento econômico e social" (TAUILE; RODRIGUES, 2004, p.43).

Os empreendimentos solidários são produtores de diversos insumos, incluindo alimentos, artesanatos e matérias-prima. Uma forma de comercialização e troca de seus produtos são as redes de economia solidária, que ganham maior visibilidade devido a sua extensão e alcance. De acordo com Filho (2008, p.224), as redes "representam a expressão concreta de uma via sustentável-solidária na promoção do desenvolvimento local"; compreender as redes de economia solidária, "significa uma associação ou articulação de vários empreendimentos e/ou iniciativas de economia solidária com vistas a construção de um circuito próprio de relações econômicas e intercâmbio de experiências e saberes formativos".

A prática da economia solidária indica uma experiência bem sucedida e sustentável, principalmente por atuar em diversas dimensões como: econômica, social, ambiental, cultural e territorial. A economia solidária contribui significativamente para o desenvolvimento local ampliando as oportunidades de emprego e renda, pois, de acordo com Domingues (2009, p.2), "é uma fonte de experiências que se cruzam e se enriquecem mutuamente e se fortalecem em redes de cooperação econômica, criando uma alternativa forte e sustentável".

\section{MATERIAL E MÉTODO}

A presente pesquisa é classificada do ponto de vista de sua natureza como aplicada, com o objetivo de gerar conhecimentos para aplicação prática e dirigida à solução de problemas específicos. Pode ser também caracterizada como quantitativa e qualitativa, visto que traduz em números as opiniões e informações para sua classificação e análise, mas, também porque os dados obtidos foram analisados indutivamente (SILVA e MENEZES, 2005).

No que diz respeito aos objetivos, pode ser classificada como explicativa. Visa identificar os fatores que determinam ou contribuem para a ocorrência dos fenômenos. Quanto aos procedimentos técnicos, tratase de uma pesquisa experimental, pois foi determinado um objeto de estudo e as variáveis capazes de influencia-lo foram selecionadas, bem como as formas de controle e de observação dos efeitos que a variável produz no objeto foram definidas (GIL, 2002).

O método científico utilizado foi o indutivo, pois parte de dados particulares para obtenção de uma verdade geral não contida nas partes examinadas (MARCONI e LAKATOS, 2001).

A pesquisa foi composta pela população de 40 (quarenta) escolas municipais; sendo 26 (vinte e seis) na Zona Urbana e 14 (quatorze) na Zona Rural, com um total de 8.615 (oito mil seiscentos e quinze) alunos matriculados, no município de Castro no estado do Paraná. A Secretaria Municipal de Educação no ano de 2014 adquiriu semanalmente 47 (quarenta e sete) produtos da Associação de Agricultores Familiares das Colônias IAPÓ e Santa Clara divididos por classes: frutas, produtos processados (panificação) e olerículas, que foram repassados as escolas com a finalidade do preparo da merenda escolar para os alunos.

\section{APRESENTAÇÃO E DISCUSSÃO DOS RESULTADOS}

As Colônias IAPÓ e Santa Clara foram colonizadas por povos eslavos (poloneses, ucranianos, thecos e albaneses), fugidos da invasão russa em seus países de origem, formaram o núcleo colonial IAPÓ e Santa Clara no ano de 1920, essencialmente lavradores. Como todos, os imigrantes sofreram muito no processo de adaptação aos padrões culturais e climáticos do Brasil e ao descaso das autoridades brasileiras com a implantação das colônias. Para garantir a sobrevivência uniram-se para abrir os lotes de 10 alqueires destinados a cada família e formaram um núcleo comum onde construíram o centro comunitário, a igreja e a escola.

No ano de 2014, a Associação de Agricultores Familiares das Colônias IAPÓ e Santa Clara através da contribuição dos programas do Governo Federal PAA e PNAE forneceu os produtos solicitados pela Secretaria de Educação para ser produzida a merenda escolar nas escolas da zona urbana e rural 
do municipio de Castro - PR. Nesse fornecimento os produtos foram dividos por classes como: frutas, produtos processados (panificação) e olerícolas.

No gráfico e tabela 1, apresenta-se o consumo das frutas no ano de 2014 em relação a quantidade de alunos matriculados. O cardápio da merenda escolar prioriza sempre que possível uma fruta em cada refeição servida ao aluno. Assim as frutas que tiveram o maior consumo foram: banana com 211.203 mil unidades; laranja com 200.582 mil unidades e maçã 199.953 mil unidades; as demais são: morango com 60.745 mil unidades, caqui com 36.800 mil unidades, kiwi 16.780 mil unidades, Iaranja pêra com 13.618 mil unidades, ponkan 9.725 mil unidades, e laranja lima / rosa 4.390 mil unidades.
Tabela 1 - Consumo de cada aluno versus fruta no ano de 2014

\begin{tabular}{|ccc|}
\hline FRUTA & Total de fruta & $\begin{array}{c}\text { Quantidade de fruta } \\
\text { consumida por aluno em } \\
\text { UND }\end{array}$ \\
\hline Banana & 211.203 & 24,51 \\
Laranja & 200.582 & 23,28 \\
Maça & 199.953 & 23,2 \\
Morango & 60.745 & 7,05 \\
Caqui & 36.800 & 4,27 \\
Kiwi & 16.780 & 1,94 \\
Laranja pêra & 13.618 & 1,58 \\
Ponkan & 9.725 & 1,12 \\
Laranja lima / rosa & 4.390 & 0,5 \\
\hline
\end{tabular}

Gráfico 1 - Frutas

\section{FRUTAS}

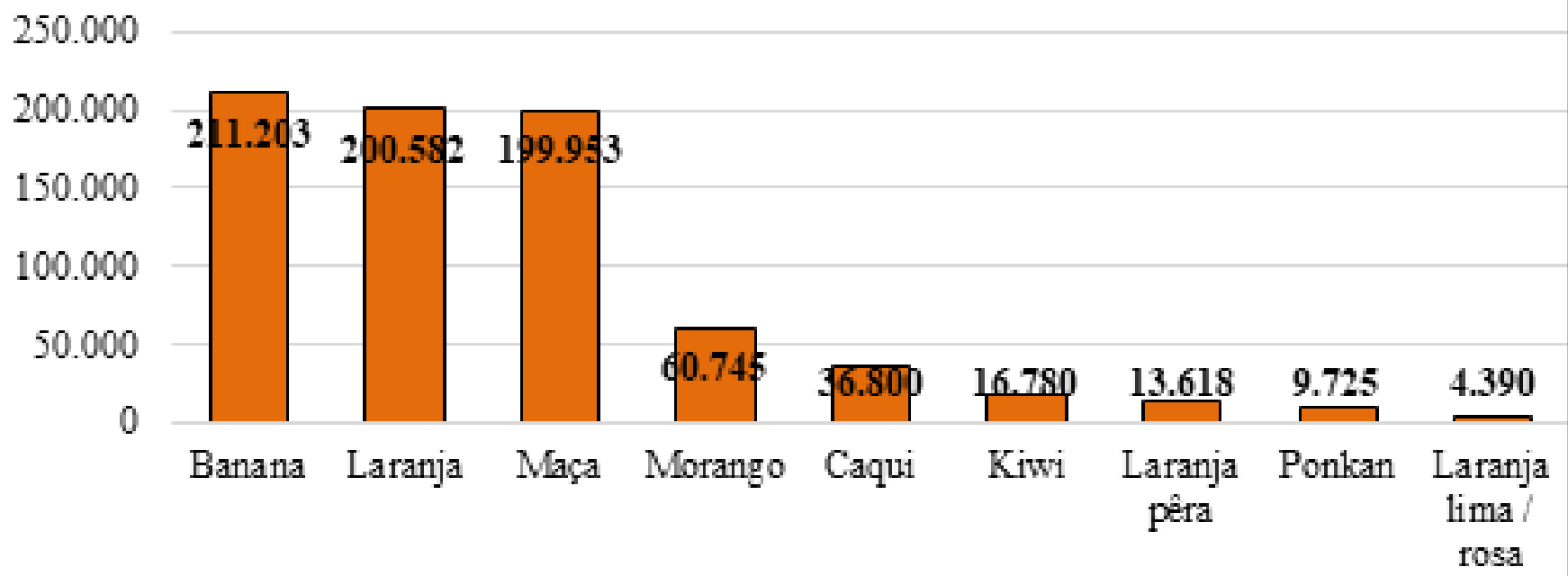

O gráfico 2 apresenta as frutas que mais se destacaram na merenda escolar: banana, laranja e maçã. As demais apresentam uma significativa participção, mas acredita-se que esse destaque se dê por elas serem mais populares e por terem uma maior aceitação por parte das crianças. 
Gráfico 2 - Frutas mais consumidas pelos alunos no ano 2014

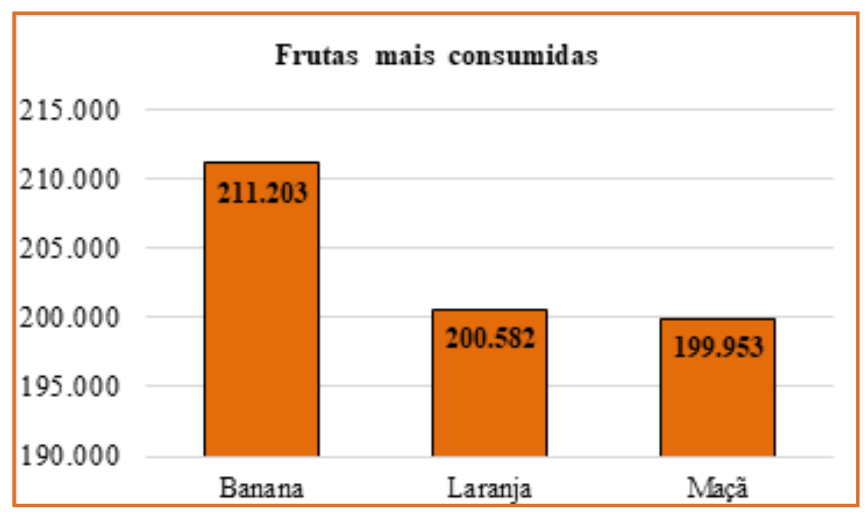

O gráfico 3 e a tabela 2 apresenta os produtos processados. Esses produtos são gênero de panificação fabricados pelas mulheres da Associação de Agricultores Familiares das Colônias IAPÓ e Santa Clara, nas cozinhas comunitárias, onde as mulheres têm sua renda com a venda desses produtos. Dos produtos relacionados no gráfico todos são produzidos em quilo, porém existe o Pão de Mel que é produzido em unidades, e por isso não foi incorporado ao gráfico por ter unidade diferente dos demais. No ano de 2014 a quantidade de Pão de Mel foi de 76.636 mil unidades. Isso significa que cada criança consumiu 8,89 unidades de Pão de Mel durante o ano de 2014.

Na Tabela 2 observa-se a quantidade de produtos que foram processados e consumidos por cada criança.

Tabela 2 - Consumo de cada aluno versus produtos processados - gênero de panificação - no ano de 2014

\begin{tabular}{|ccc|}
$\begin{array}{c}\text { Produtos } \\
\text { Processados }\end{array}$ & $\begin{array}{c}\text { Total de } \\
\text { produtos } \\
\text { processados }\end{array}$ & $\begin{array}{c}\text { Quantidade de } \\
\text { produtos processados } \\
\text { consumido por aluno } \\
\text { em KG }\end{array}$ \\
Biscoito & $13.430,00$ & 1,55 \\
Pão caseiro & $4.527,00$ & 0,52 \\
Pão integral & $4.424,50$ & 0,51 \\
Cuca & $2.750,00$ & 0,31 \\
Pão enriquecido & $2.379,40$ & 0,27 \\
Broa de centeio & $1.744,20$ & 0,2 \\
Pão de leite & $1.129,00$ & 0,13 \\
Pão de sementes & $1.006,20$ & 0,11 \\
Pão de milho & 478,00 & 0,05 \\
\hline
\end{tabular}

Gráfico 3 - Produtos Processados

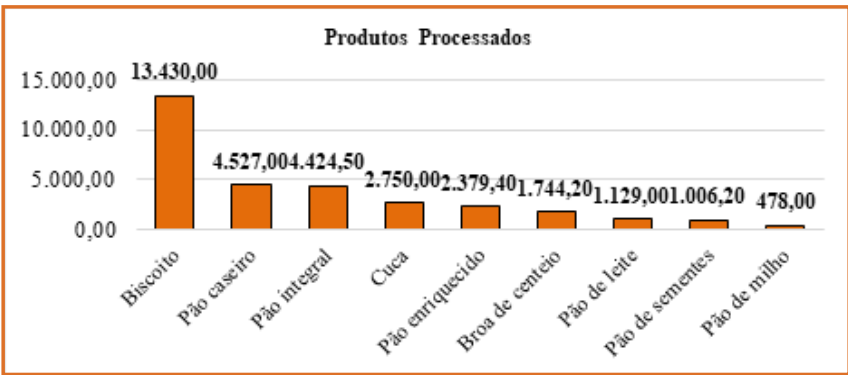

O gráfico 4 apresenta os produtos processados do gênero de panificação com maior aceitação pelas crianças nas escolas como: biscoito, pão caseiro, pão enriquecido, pão integral, e cuca.

Gráfico 4 - Produtos Processados - Gênero de Panificação mais consumidos

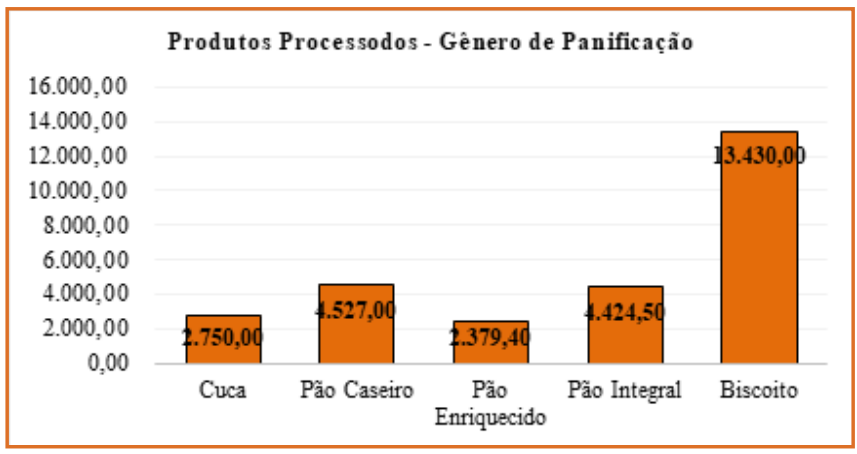

No gráfico 5 são exibidos os produtos da classe olerícola, ou seja: legumes, verduras, tubérculos, frutas, etc. Além desses produtos encontra-se ovos, alimento de origem animal, distribuídos em unidades, num total de 62.712; isso significa que cada criança consumiu 7,27 ovos/ano. Esse produto não foi apresentado no gráfico por não estar na mesma unidade de medida dos demais que se encontram na tabela 3. Nessa tabela observa-se a quantidade de produtos da classe olerícola e consumidos por cada criança.

Tabela 3 - Consumo de cada aluno versus produtos In Natura no ano de 2014

\begin{tabular}{|ccc|} 
Produtos & $\begin{array}{c}\text { Total de } \\
\text { produtos In } \\
\text { Natura }\end{array}$ & $\begin{array}{c}\text { Quantidade de produtos } \\
\text { In Natura consumido por } \\
\text { aluno em KG }\end{array}$ \\
\hline Melancia & $17.420,00$ & 2,02 \\
Mamão & $16.653,00$ & 1,93 \\
Tomate & $4.938,90$ & 0,57 \\
Cenoura & $4.096,60$ & 0,47 \\
Pepino & $3.471,50$ & 0,4 \\
Batata & $3.410,00$ & 0,39 \\
\hline
\end{tabular}




\begin{tabular}{|c|c|c|}
\hline Produtos & $\begin{array}{l}\text { Total de } \\
\text { produtos In } \\
\text { Natura }\end{array}$ & $\begin{array}{l}\text { Quantidade de produtos } \\
\text { In Natura consumido por } \\
\text { aluno em KG }\end{array}$ \\
\hline Beterraba & $2.733,60$ & 0,31 \\
\hline Chuchu & $2.122,00$ & 0,24 \\
\hline Repolho & $2.097,50$ & 0,24 \\
\hline Vagem & $1.984,60$ & 0,23 \\
\hline Abobrinha & $1.871,50$ & 0,21 \\
\hline Brócolis & $1.565,00$ & 0,18 \\
\hline Acelga & $1.240,00$ & 0,14 \\
\hline Alface & 881,10 & 0,1 \\
\hline $\begin{array}{l}\text { Couve } \\
\text { Manteiga }\end{array}$ & 742,00 & 0,08 \\
\hline Couve-Flor & 607,50 & 0,07 \\
\hline
\end{tabular}

\begin{tabular}{|lll|} 
Produtos & $\begin{array}{l}\text { Total de } \\
\text { produtos In } \\
\text { Natura }\end{array}$ & $\begin{array}{l}\text { Quantidade de produtos } \\
\text { In Natura consumido por } \\
\text { aluno em KG }\end{array}$ \\
\hline $\begin{array}{l}\text { Mandioca/ } \\
\text { Aipim }\end{array}$ & 590,00 & 0,06 \\
$\begin{array}{l}\text { Alface } \\
\text { Americana }\end{array}$ & 462,80 & 0,05 \\
$\begin{array}{l}\text { Morango } \\
\text { Batata Inglesa }\end{array}$ & 430,00 & 0,04 \\
Batata Comum & 222,50 & 0,04 \\
Batata Doce & 193,50 & 0,02 \\
Abóbora & 157,30 & 0,02 \\
\hline
\end{tabular}

Gráfico 5 - Produtos In Natura

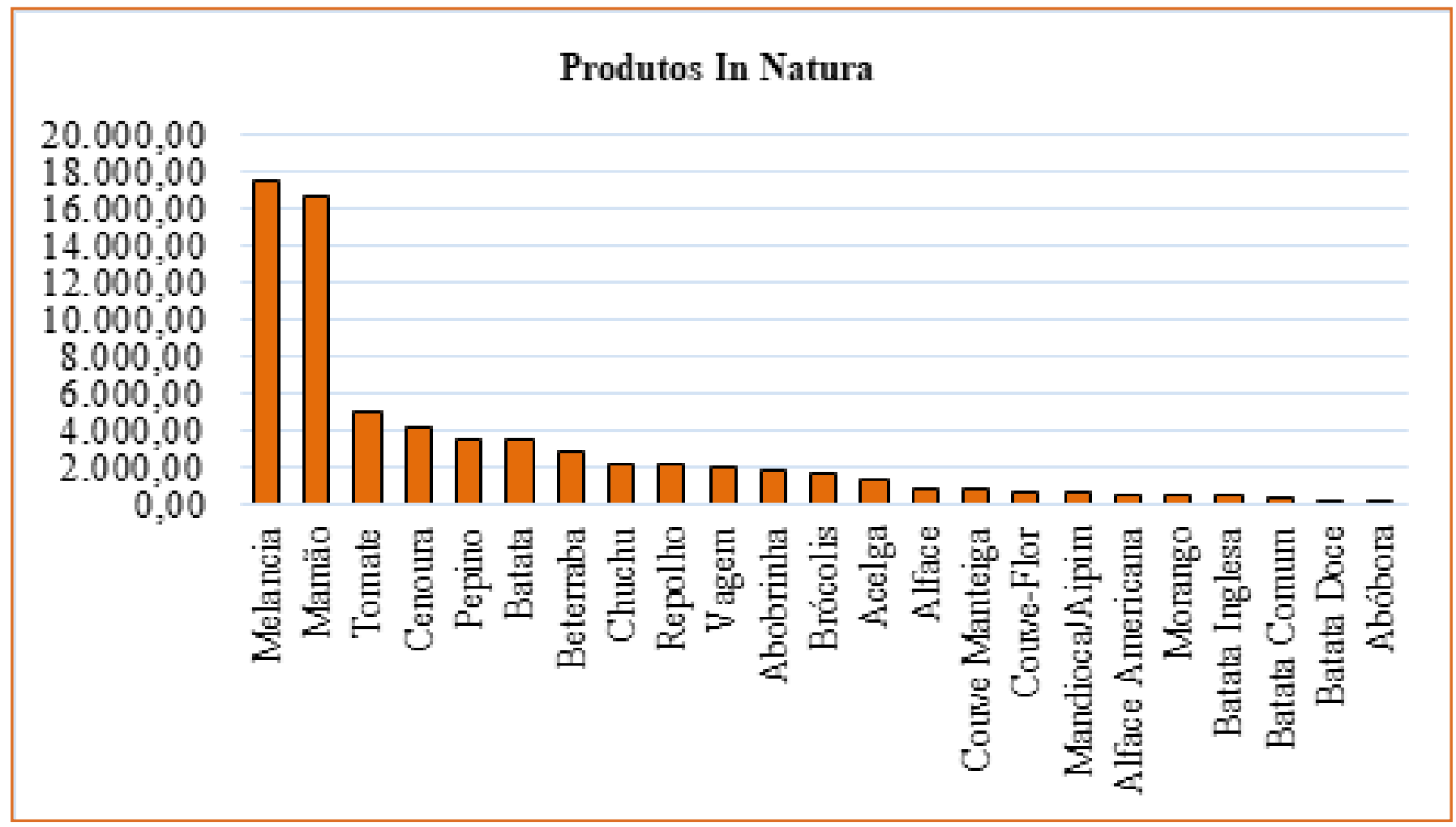

O gráfico 6 proporciona uma leitura dos produtos da classe olerícola que foram mais solicitados pela Secretaria de Educação, e que apesar da maioria ser legumes, verduras, tubérculos, tem-se duas frutas mamão e melancia que não são distribuídas por unidade, são distribuídas por quilo e que fizeram parte da classe olerícola; portanto, elas se destacam nesse gráfico. Mas, ao ler e interpretar o gráfico sem a informação das frutas observa-se que quem obteve maior destaque foram: tomate, cenoura, pepino, batata, beterraba, chuchu, repolho, vagem, abobrinha, brócolis e acelga. 
Gráfico 6 - Produtos In Natura mais consumidos nas escolas no ano de 2014

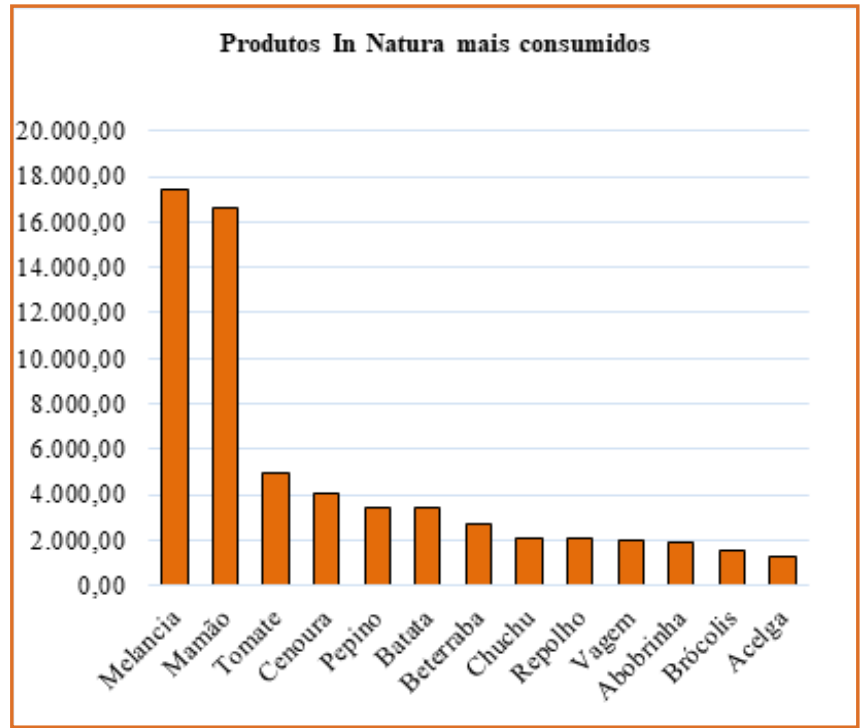

\section{CONCLUSÃO}

Um dos pontos principais para Associação de Agricultores Familiares das Colônias IAPÓ e Santa Clara na cidade de Castro - PR foi a integração entre a comunidade e os vários segmentos governamentais e sociais. Quando há um trabalho conjunto, em que os interesses são negociados e a Prefeitura tem visão e vontade política, acreditando que tais ações visam à desconcentração de renda e ao fortalecimento da economia local, é possível realizar projetos com resultados positivos e ver que a economia real do desenvolvimento sustatével é viável.

A contribuição que a economia solidária oferece para a Associação refere-se ao fortalecimento da economia local e/ou desenvolvimento local pela retenção do capital gasto pela Prefeitura no PNAE ( Programa Nacional de Alimentação Escolar) dentro da própria região; aumento e diversificação da produção; fortalecimento institucional; redução do êxodo rural pelo ânimo renovado dos pequenos produtores, principalmente no caso do PAA (Programa de Aquisição de Alimentos), abertura de novos mercados após o início das vendas para a Prefeitura, investimento na atividade produtiva, garantia de renda tanto para os homens quanto para as mulheres daquela associação, ampliação da qualidade de vida, e aumento da formalização dos agricultores familiares por meio do cadastramento em Programas Governamentais e até mesmo participar de Cooperativas e/ou Associações.

Tais resultados derivaram de uma série de ações e programas implementados ou apoiados pela Prefeitura Municipal de Castro, através do Governo Federal, de outras entidades locais ou regionais - a partir da demanda da merenda escolar e do atendimento à sua legislação.

\section{REFERÊNCIAS}

[1] ABRAMOVAY, R. Agricultura familiar e serviço público: novos desafios para a extensão rural. Cadernos de Ciência \& Tecnologia. Brasília, v.15, p.137-157, 1ํo sem. 1998.

[2] AMISTÁ, M. J. de M. Programa de alimentação escolar: perfil dos beneficiários, qualidade e atuação de gestores da comunidade de Guariba. 2013, 174f. Dissertação (Mestrado) - Escola Superior de Agricultura "Luiz de Queiroz", Universidade de São Paulo - SP, Piracicaba, 2013.

[3] BRASIL. Lei no 11.326, de 24 de julho de 2006. Brasília, 2006. Disponível em: <http://www.planalto.gov.br/ccivil_03/_ ato2004-2006/2006/lei//11326.htm>.

[4] Lei no 10.696 de 02 de julho de 2003. Brasília, 2003. Disponível em: <http://www. planalto.gov.br/ ccivil_03/leis/2003/l10.696.htm>.

[5] Lei $n$ ㅇ 12.512 de 14 de outubro de 2011. Brasília, 2011. Disponível em: <http://www.planalto.gov.br/ ccivil_03/_Ato2011-2014/2011/Lei/L12512.htm\#art33>

[6] Ministério do Desenvolvimento Social. Programa de Aquisição de Alimentos - PAA. Disponível em: <http://www.mds.gov.br/falemds/perguntas-frequentes/ seguranca-alimentar-e-nutricional/aquisicao-de-alimentos/ distribuicao-de-alimentos-a-grupos-especificos/distribuicaode-alimentos-a-grupos-especifico>.

[7] Portal Brasil. Merenda escolar utiliza cada vez mais produtos da agricultura familiar. Brasília, 2013. Disponível em: <http://www.brasil.gov.br/governo/2013/07/ merenda-escolar-utiliza-cada-vez-mais-produtos-daagricultura-familiar $>$.

[8] DOMINGUES, M. P. T. S. Economia solidária: a economia real do desenvolvimento sustentável. Artigo apresentado no $\checkmark$ Colóquio Ibérico De Cooperativismo E Economia Social. Santarém, 2009. Disponível em: < http://pt.solecopedia.org /images/archive/d/d5/20110111184816!Artigo_-_Economia_ Solid\%C3\%A1ria.pdf>.

[9] EID, F.; EID, R. M. C. O. Marketing e agricultura familiar: estudo em uma cooperativa de reforma agrária. In: XXIII Encontro Nacional de Engenharia de Produção - ENEGEP, Ouro Preto, 2003. Anais. 
[10] FILHO, G. C. de F. A via sustentável-solidária no desenvolvimento local. Organizações \& Sociedade, [S. I.], v. 15, n-45, abr./jun. 2008.

[11] FISCHER, T. Gestão do desenvolvimento e poderes locais: marcos teóricos e avaliação. Salvador: Casa da Qualidade, 2002.

[12] GAIGER, L. I. G. A economia solidária diante do modo de produção capitalista. Caderno $\mathrm{CRH}$, Salvador, nำ39, p.182-211, jul./dez. 2003.

[13] GIL, A. C, (2002). Como elaborar projetos de pesquisa. 4 ed. São Paulo: Atlas.

[14] LISBOA, A. de M. Economia Solidária e autogestão: imprecisões e limites. Pensata, [S.I.], no3, p.109-115, jul./set. 2005.

[15] MARCONI, M. de A.; LAKATOS, E. M, (2001). Fundamentos de metodologia científica. 4 ed. São Paulo: Atlas.
[16] RUTKOWSKI, J. Sustentabilidade em empreendimentos econômicos solidários: outro mundo, outra economia, outra engenharia. In: V Encontro Internacional de Economia Solidária. São Paulo, 2007. Anais.

[17] SANTOS, et al. Empreendimentos de Economia Solidária na cidade de Londrina/PR e suas estratégias de ação. In: XV Seminários de Administração - SEMEAD, [S.I.], 2012. Anais.

[18] SILVA, E. L. da; MENEZES, E. M. Metodologia da pesquisa e elaboração de dissertação. 4ed. Ver. Atual Florianópolis: UFSC, 2005.

[19] TAUILE, J. R.; RODRIGUES, H. Economia Solidária e Autogestão: a criação e recriação de trabalho e renda. IPEA - Mercado de Trabalho, [S.I.], no 24, p.35-43, º sem. 2004.

[20] WINCK, C. A. et al. Agricultura familiar e rendas alternativas na região da Quarta Colônia/RS. Revista Brasileira de Gestão e Desenvolvimento Regional. São Paulo, v. 10, p.28-51, 1ํㅗ sem. 2014. 


\section{CAPÍTULO 6}

\section{MAPEAMENTO DE PROCESSOS DE LOGÍSTICA REVERSA DE RESÍDUOS ELETROELETRÔNICOS PARA RECICLAGEM}

Emmily Caroline Cabral da Fonseca

Eriton Carlos Martins Barreiros

Nathalia Almeida Castro Rodrigues

André Cristiano Silva Melo

Denilson Ricardo de Lucena Nunes

Resumo: Ao levar em consideração que o desenvolvimento tecnológico vem avançando e que a quantidade de resíduos eletroeletrônicos também tem acompanhado tal crescimento, o presente estudo propôs um mapa de processos de coleta e pré-processamento para reciclagem de resíduos eletroeletrônicos, contemplando as proposições da Política Nacional de Resíduos Sólidos, voltadas à implantação da Logística Reversa para a atividade de reciclagem destes resíduos, de tal forma que o fluxograma proposto possa auxiliar decisões de cooperativas de catadores de materiais recicláveis na organização e gestão de suas operações. Nesta conjuntura, a pesquisa foi considerada um estudo de caso, uma vez que envolveu o estudo profundo de objetos de maneira que se permita o seu amplo e detalhado entendimento, utilizando-se do conhecimento adquirido em periódicos, sites e documentos oficiais do governo. Ademais, o resultado desta pesquisa pode contribuir para a divulgação de informações mais detalhadas sobre essas operações uma vez que, especialmente em grandes centros de consumo, existe a necessidade crescente de destinar adequadamente tais resíduos.

Palavras Chave: Mapeamento de Processos, Resíduos Eletroeletrônicos, Logística Reversa, Política Nacional de Resíduos Sólidos. 


\section{INTRODUÇÃO}

De acordo com a Agência Brasileira de Desenvolvimento Industrial (ABDI, 2013), os Equipamentos Eletroeletrônicos (EEE) são todos aqueles produtos cujo funcionamento depende do uso de corrente elétrica ou de campos eletromagnéticos. Segundo a Associação Brasileira da Indústria Elétrica e Eletrônica (ABINEE, 2014), o faturamento geral do setor de eletroeletrônicos, em 2013, no Brasil, atingiu $\mathrm{R} \$ 156,7$ bilhões, um crescimento nominal de $8 \%$ sobre 2012, motivado por smartphones e tablets.

A existência de grande variedade de EEE aumenta a complexidade da atividade de reciclagem, pois muitos desses equipamentos possuem substâncias perigosas, o que gera, também, uma preocupação relativa ao ambiente ocupacional. Frequentemente, há a necessidade de um pré-tratamento dos resíduos, para que esses possam ser processados em recicladoras, sem causar danos à saúde dos funcionários (ARAÚJO, 2013).

Em virtude da complexidade existente na etapa de reciclagem dos resíduos de EEE, ora pela variedade ora pela necessidade de tratamento específico para cada tipo de resíduo, surge a necessidade de visualização detalhada dessa etapa, tendo em vista os diversos componentes existentes em cada EEE. Uma das formas de obter essa visão geral é fazer um mapeamento dos processos referente à fase de processamento de Resíduos Eletroeletrônicos (REE). Para tanto, esta pesquisa teve como base conceitos de Logística Reversa, paralelamente a observação do que está disposto na Política Nacional de Resíduos Sólidos e no documento "Logística Reversa de Equipamentos Eletrônicos - ABDI”. Para então, com o auxílio do software Bizagi Modeler, para assim responder à questão norteadora do estudo: qual é o mapa de processos de pré-processamento de REE? Além da pesquisa básica relacionada, foram pesquisadas referências em periódicos, sites e documentos oficiais do governo, com o intuito de prover um mapa de processos aderente à realidade.

O texto deste artigo foi organizado da seguinte forma: na Seção 2 estão reunidos os principais conceitos da metodologia científica em que o estudo se enquadra; na Seção 3 estão os conceitos que serviram de suporte para a o mapeamento proposto; Os resultados obtidos são apresentados e discutidos na Seção 4; por fim, as considerações finais estão reunidas na Seção 5.

\section{METODOLOGIA}

Esta pesquisa, de acordo com a sua natureza, foi considerada básica, por objetivar gerar conhecimentos novos e úteis para a ciência, além de que, não possui aplicação prática prevista (SILVA E MENEZES, 2005). Já no que diz respeito à abordagem do problema, Silva e Menezes (2005) sustentam que esta é caracterizada como qualitativa, uma vez que sua base foi a interpretação dos fenômenos e a atribuição de significados, de forma que não requeriu o uso de técnicas estatísticas.

Do ponto de vista de seus objetivos, a pesquisa foi definida como exploratória, por possuir a finalidade de proporcionar mais informações sobre o assunto, possibilitando sua definição e seu delineamento, isto é, facilitar a delimitação do tema da pesquisa (PRODANOV E FREITAS, 2013).

Nesse contexto, do ponto de vista dos procedimentos técnicos, foi considerada estudo de caso, uma vez que Gil (2010), afirma que este consiste no estudo profundo e exaustivo de um ou mais objetos, de maneira que permita seu amplo e detalhado conhecimento. Assim, a essência do estudo de caso é tentar esclarecer uma decisão, ou um conjunto de decisões, seus motivos, implementações e resultados (SCHRAMM, 2000 apud YIN, 2001).

\subsection{MÉTODO DE PESQUISA}

A pesquisa biblioráfica para o estudo foi realizada em acervos bibliográficos, como periódicos, anais de eventos, livros, páginas eletrônicas que tratam do tema, jornais, dentre outros. Ressalta-se que o Documento Base para o estudo foi "Logística Reversa de Equipamentos Eletrônicos - ABDI". Dessa forma, buscou-se propor pontos capazes de auxiliar na resposta da questão norteadora do estudo.

Após o levantamento das informações disponíveis atual 
literatura, buscou-se organizar os dados de forma que um mapa de processos fosse proposto, englobando os contextos atuais do país e a forma com que o mercado de resíduos sólidos está inserido em tais contextos. Tal mapa foi proposto para cooperativas de catadores de materiais recicláveis, no sentido de promover maior e melhor entendimento dos processos, por parte de seus cooperados, bem como sua adoção como base para melhorias.

Por conseguinte, o mapa de processos de préprocessamento envolvidos na logística reversa de REE foi desenhado com o auxilio do software Bizagi Modeler, e considerações acerca deste desenho foram realizadas.

\section{REFERENCIAL TEÓRICO}

\subsection{POLÍTICA NACIONAL DE RESÍDUOS SÓLIDOS}

Em 3 de agosto de 2010, entrou em vigor a Lei da Política Nacional de Resíduos Sólidos (PNRS), 12.305, que estipulou um prazo até agosto de 2012 para que os municípios brasileiros apresentassem seus planos de gestão integrada de resíduos sólidos, conforme o artigo 55, ao mesmo tempo em que determinou o fechamento dos lixões a céu aberto, artigo 54 (BRASIL, 2010 apud CANTO, 2014). Segundo Redação EcoD (2010), após tramitar pelo Congresso Nacional por 21 anos, a sansão dessa Lei distinguiu os resíduos e os rejeitos como lixo que pode ser aproveitado ou reciclado e lixo que não pode ser reaproveitado, respectivamente. Além de ter como um dos principais objetivos, a não-geração, redução, reutilização e tratamento de resíduos sólidos.

Isso evidencia como a destinação adequada ao lixo ainda é uma problemática brasileira. Em 2013, foram geradas $4,1 \%$ a mais de lixo em relação a 2012, o que equivale a 76 milhões de toneladas de resíduos sólidos, onde apenas $58,3 \%$ dos resíduos coletados recebem destinação adequada, sendo a porcentagem complementar equivalente a 28,8 milhões de toneladas (PORTAL DO PURUS, 2014).

Uma parte destes resíduos constitui risco ao meio ambiente, pois pode ser composto por metais tóxicos cujo manuseio gera impactos à saúde, pela exposição humana. Alguns destes metais, como mercúrio, cádmio, berílio e chumbo, em contato com o solo, contaminam o lençol freático e, se incinerados, poluem o ar, causando outros danos (DUAN et al., 2013).

A dificuldade na formulação de modelos eficientes é muito maior, tendo em vista a natureza descentralizada do consumo e, portanto, do descarte dos resíduos gerados. São situações especialmente difíceis, pois a PNRS determina, aos produtores e importadores, a responsabilidade compartilhada, assim como a necessidade de organização da Logística Reversa (LR) como um instrumento que tem um caráter de gestão. Além disso, existe uma dificuldade adicional, pois nem sempre os equipamentos necessários à reciclagem adequada desses produtos existem (ABRAMOVAY; SPERANZA; PETITGAND, 2013).

\subsection{LOGÍSTICA REVERSA}

A Logística surgiu como parte do Supply Chain Management como uma abordagem de gestão que inclui o planejamento, gerenciamento de transporte, frota, armazenagem, manuseio,

atendimento de pedidos, gerenciamento de estoques e abastecimento, gestão de serviços de terceiros e prestadores de serviços logísticos. Assim, está envolvida em todos os níveis de planejamento e execução, estratégico, operacional e tático, além de possuir função integradora, de coordenação e otimização de todas as atividades logísticas, bem como a integração dessas atividades com as outras áreas da organização (CSCMP, 2015).

Já Para Alméri et al. (2014), a logística é imprescindível para as organizações, pois objetiva otimizar e controlar os fluxos, onde a eficácia do processo é de extrema importância ao alcance dos resultados almejados. É indicado, então, que práticas gerenciadas de logística sejam implementadas junto às atividades reversas para que, assim, bons índices de desempenho sejam, também, alcançados.

No que diz respeito aos seus fluxos, podem ser subdivididos em diretos e reversos. Os fluxos diretos 
constituem os materiais e componentes, transacionados com fornecedores, e produtos, peças de reposição e materiais de propaganda, transacionados com clientes. Já os fluxos reversos envolvem o retorno de embalagens e produtos para reparos, eliminação e reciclagem, e o retorno de excessos de estoques (DORNIER et al., 2000).

No âmbito dos fluxos reversos, a constante procura por redução de custos e diferenciação de serviços, aliada às crescentes pressões ambientais, têm elevado a atenção das organizações às atividades de reciclagem e reaproveitamento de bens e embalagens. Tais atividades exigem planejamento específico, visando a gerenciar o fluxo inverso de materiais, que vai do ponto de consumo ao ponto de origem. (GRUNDEMANN \& RAMOS, 2014).

Segundo Leite (2014), a LR, área da logística empresarial responsável por finalizar o ciclo dos fluxos logísticos tradicionais da logística direta, ocupando-se com os diversos fluxos de retorno de mercadorias, sob a forma de produtos de pós-venda ou de pós-consumo, tem ganhado grande notoriedade. Claramente, a LR constitui uma considerável ferramenta na busca por soluções para alguns dos problemas da gestão de Resíduos Sólidos Urbanos (RSU).

Ao considerar a era tecnológica atual, onde o ciclo de vida do EEE é extremamente curto e cada produto é superado por outro tecnologicamente superior em questões de meses, percebe- se que o maior gargalo de REE está na LR, que não é muito bem delineada. A função dos atores não é muito clara, tão pouco as oportunidades são bem evidenciadas, o que gera problemas logísticos na cadeia reversa (PESSOA et al., 2014).

Logo, a implementação de programas de LR aos REE também passa pelo aspecto econômico, que está intimamente ligado ao fator operacional de análise custo/benefício. Ou seja, para viabilizá-la, é necessário realizar estudos acerca dos ganhos dessa iniciativa, tanto aos produtores quanto aos recicladores (BERGAMO E STEFANELLO, 2014).

\subsection{PROCESSOS ENVOLVIDOS NA RECICLAGEM DOS RESÍDUOS ELETROELETRÔNICOS}

Resíduo eletroeletrônico (REE) constitui o lixo gerado pelo descarte de produtos e equipamentos eletrônicos, que necessita de destinação adequada devido aos componentes tóxicos existentes e que são prejudiciais ao meio ambiente e à saúde humana (PREFEITURA SÃO MIGUEL PAULISTA, 2013). Os produtos eletrônicos (EEE) podem ser divididos em quatro categorias amplas:

a. Linha Branca: refrigeradores e congeladores, fogões, lavadoras de roupa e louça, secadoras, condicionadores de ar;

b. Linha Marrom: monitores e televisores de tubo, plasma, LCD e LED, aparelhos de DVD e VHS, equipamentos de áudio, filmadoras;

c. Linha Azul: batedeiras, liquidificadores, ferros elétricos, furadeiras, secadores de cabelo, espremedores de frutas, aspiradores de pó, cafeteiras;

d. Linha Verde: computadores desktp e laptops, acessórios de informática, tablets e telefones celulares.

Uma vez utilizados, o EEE geram os REE, que no caso de descarte inadequado, os componentes existentes nestes podem gerar danos ao meio ambiente e à saúde humana. O Quadro 1 associa os componentes existentes em REE aos EEE e aos possíveis riscos de danos à saúde humana. 
Tabela 1 - Componentes de REE, EEE e possíveis riscos de danos à saúde humana

\begin{tabular}{|c|c|c|}
\hline $\begin{array}{l}\text { Componentes } \\
\text { de REE }\end{array}$ & EEE & $\begin{array}{l}\text { Riscos de danos à } \\
\text { saúde }\end{array}$ \\
\hline Arsênio & Celulares & $\begin{array}{l}\text { Doenças de pele, } \\
\text { câncer de pulmão } \\
\text { e prejuízos ao } \\
\text { sistema nervoso }\end{array}$ \\
\hline Berílio & $\begin{array}{l}\text { Computadores e } \\
\text { celulares }\end{array}$ & Câncer no pulmão \\
\hline Cádmio & $\begin{array}{l}\text { computadores, em } \\
\text { monitores de tubos } \\
\text { antigos, baterias e } \\
\text { laptops }\end{array}$ & $\begin{array}{l}\text { Envenenamento, } \\
\text { danos aos ossos, } \\
\text { rins e pulmões }\end{array}$ \\
\hline Chumbo & $\begin{array}{l}\text { Computadores, } \\
\text { televisões e celulares }\end{array}$ & $\begin{array}{l}\text { Sistemas nervoso e } \\
\text { sanguíneo }\end{array}$ \\
\hline Mercúrio & $\begin{array}{l}\text { Computadores, monitores } \\
\text { e em televisores de tela } \\
\text { plana }\end{array}$ & $\begin{array}{l}\text { Riscos ao cérebro } \\
\text { e ao fígado }\end{array}$ \\
\hline $\begin{array}{l}\text { Retardantes de } \\
\text { chamas - BRT }\end{array}$ & $\begin{array}{l}\text { Componentes } \\
\text { eletrônicos, para prevenir } \\
\text { incêndio }\end{array}$ & $\begin{array}{l}\text { Alterações } \\
\text { hormonais, } \\
\text { reprodutivas e } \\
\text { nervosas }\end{array}$ \\
\hline PVC & $\begin{array}{l}\text { Fios elétricos, como } \\
\text { isolante elétrico }\end{array}$ & $\begin{array}{l}\text { Problemas } \\
\text { respiratórios, ao ser } \\
\text { queimado e inalado }\end{array}$ \\
\hline
\end{tabular}

Fonte: No Olhar (2015)

Uma das formas de reduzir os REE seria prover vida extra aos bens, consequentemente, para dado período, haverá menos produção, menos resíduos e, quando os resíduos de pós-consumo forem perigosos, caso dos REE, haverá menos substâncias perigosas geradas. Ao planeta, o reuso reduz o consumo de matérias-primas, e energia e a poluição nas três fases do ciclo de vida da maioria dos produtos que são: extração de matérias-primas, fabricação e descarte/ reciclagem (MIGUEZ, 2010, p.24).

Outra maneira de enfrentar o problema dos REE é recorrer a reciclagem, que é definida como o processo de transformação dos resíduos sólidos que envolve a alteração de suas propriedades físicas, físico-químicas ou biológicas, com vistas à transformação em insumos ou novos produtos (ABDI, 2013). Além disso, é um processo diferenciado, devido às características que exigem reengenharia na separação, trituração e limpeza, para prover a reinserção da matéria-prima com qualidade na fabricação de novos produtos (CEMPRE, 2014), e pode seguir algumas etapas, a saber:

a. Eliminação dos dados que, no caso de equipamentos de informática e telecomunicações, é indispensável, definitiva e irreversível, sendo feita através da desmagnetização dos discos rígidos, fitas, placas de circuitos, CDs, DVDs e outros dispositivos de armazenamento (ECO DEBATE, 2012).

b. Pesagem, processo que se inicia a partir da avaliação do produto, pesando e comparando o valor obtido na pesagem com o valor discriminado nas documentações ou informações adquiridas do produto, para que assim, estes resíduos possam ser posteriormente descaracterizados e separados de acordo com suas composições (plásticos, eletrônicos, metais, cabos) (SPOLAVORI, 2012).

c. Desmontagem que, de acordo com Spolavori (2012), ocorre devido à grande variedade de materiais e formatos de equipamentos recebidos para descaracterização. Esse processo pode ser manual, constituindo oportunidade de geração de postos de trabalho e de renda. Ressalta- se ainda que todo o processo de segregação de todo e qualquer resíduo é realizado com os devidos equipamentos de proteção individual, através da utilização de luvas, sapatos, óculos de proteção, entre outros.

d. Separação por tipo de materiais - ferrosos, não ferrosos e plásticos que, de acordo com Ecosucatas (2015), nessa etapa, é realizada a separação dos materiais ferrosos (aço, ferro fundido e ferro laminado), não ferrosos (metais, com exceção do ferro, como: cobre; estanho; zinco; chumbo; platina; alumínio; magnésio; titânio) e plásticos (materiais orgânicos poliméricos sintéticos como, por exemplo, tereftalato de polietileno, Poliestireno, Cloreto de polivinila, politetrafluoroetileno, polipropileno).

e. Compactação dos materiais com características similares que consiste um sistema onde, depois de descarregados, os resíduos são compactados por uma prensa. Assim, ocorre a otimização da quantidade de resíduos transportados e a minimização de poeiras e odores, além da diminuição do seu volume e aumento da densidade (LEVY, 2006). 
f. Processamento mecânico, para recuperação de materiais de valor, utilizado em etapas de tratamento e beneficiamento de minérios na metalurgia primária. Consiste na combinação de um ou mais processos operacionais para o reaproveitamento do material descartado. Atualmente, diversos estudos de processamento mecânico vêm sendo realizados com materiais heterogêneos, como a sucata eletrônica (JUCHNESKI \& VEIT, 2013). Este processo é composto pelos estágios destacados a seguir. Para Veit (2001), a Trituração tem por finalidade a redução do tamanho de um sólido e os mecanismos a serem usados podem ser pressão, impacto, abrasão ou corte. Já a Moagem libera materiais presentes em minérios, resíduos e sucatas através da ação mecânica. Fonseca (2011) comenta que a Desintoxicação consiste no aumento da temperatura em uma câmara selada a $1200 \mathrm{C}^{\circ}$ e resfriamento em 4 segundos para $700 \mathrm{C}^{\circ}$, facilitando a filtragem de dioxinas, liquidificação, separação por densidade, separação por eletrólise, decantação, refino e solidificação em barras.

g. Processamento químico, para recuperação de materiais de valor, que inclui todas as transformações químicas, espontâneas ou resultantes da ação de catalisadores (processos catalíticos) ou microrganismos (processos biotecnológicos). No caso dos REE, um dos métodos mais utilizados é a hidrometalurgia, ou seja, a extração dos metais com a lixiviação, usando água-régia (75\% de ácido clorídrico e 25\% de ácido nítrico) ou ácido-sulfúrico, obtendo-se frações pesadas (metais) e frações leves (plásticos e cerâmicos) (ECYCLE, 2015).

h. Refino de recursos no lixo eletroeletrônico, atualmente possível e respaldado por soluções técnicas capazes de voltar matérias-primas, com impacto ambiental mínimo. Um exemplo é o processo de eletrometalurgia, feito em metais através da eletrólise, na qual os metais impuros sofrem eletrodeposição, e metais, como cobre, zinco, cádmio, alumínio, metais preciosos, entre outros, podem ser recuperados com um elevado grau de pureza (GERBASE \& OLIVEIRA, 2012).

i. Tratamento e disposição de resíduos perigosos que, de acordo com a PNRS, são aqueles que, em razão de suas características de inflamabilidade, corrosividade, reatividade, toxicidade, patogenicidade, carcinogenicidade, teratogenicidade e mutagenicidade, apresentam significativo risco à saúde pública ou à qualidade ambiental, de acordo com lei, regulamento ou norma técnica de determinada região (BRASIL, 2010).

Cada atividade possui risco ambiental proveniente da substância nociva processada. Por meio da reciclagem, os resíduos passam a ser insumo que pode ser reinserido no processo produtivo, desta forma viabilizando a função de suprimento e reduzindo a demanda por extração de nova matéria-prima. Os insumos gerados pela reciclagem dos resíduos não precisam ser necessariamente obtidos por meio da LR de ciclo fechado (resíduo utilizado na produção do mesmo produto), e podem ser destinados à fabricação de materiais distintos dos originais (logística reversa de ciclo aberto) (ABDI, 2013).

\section{ANÁLISE DE DADOS E RESULTADOS OBTIDOS}

A partir do documento "Logística Reversa de Equipamentos Eletroeletrônicos: Análise de viabilidade técnica e econômica", juntamente com a revisão de literatura e Fonseca et.al (2015), foi possível dividir o processo estudado em três etapas: Eliminação dos dados contidos nos equipamentos; Pesagem; Desmontagem. Os processos mapeados são ações características da etapa de processamento de REE para reciclagem. Porém, ressalta-se que os REE necessitam de uma série de cuidados, devido à sua grande complexidade intrínseca, além da elevada quantidade de substâncias que oferecem risco à saúde do ser humano.

Os processos internos à LR de REE voltados à reciclagem ocorrem após os processos externos de LR (coleta, consolidação, carregamento, transporte e descarregamento), e têm início com a Eliminação dos dados contidos nos equipamentos, uma vez que muitos aparelhos eletrônicos podem conter informações pessoais do usuário, senhas e códigos salvos, o que poderia gerar algum tipo de exposição e constrangimento. Em seguida, os REE 
são direcionados ao setor de Pesagem, atividade que facilita o inventário e a cobrança de preços por grama ou quilo de determinada classe de resíduos.

Por fim, os resíduos devem ser desmontados (Desmontagem) para facilitar o seu manuseio, seguindo para a fase de Separação por tipos (ferrosos/não ferrosos e plásticos), etapa importante, pois os resíduos ferrosos necessitam de cuidados relativamente distintos dos não ferrosos, além de que, os plásticos, muitas vezes resultantes da parte externa do material, devem ser encaminhados para empresas especializadas, dando, assim, a Destinação adequada. O mapa proposto do processo interno de $L R$ voltado à reciclagem de REE encontra-se na Figura 1.

Os materiais ferrosos ou não ferrosos podem, ou não, passar pela etapa de compactação, uma vez que esta serve para diminuir o volume do resíduo. Em seguida, estes podem, ou não, passar pela etapa de trituração, fato que depende de suas características, pois resíduos extremamente pequenos, podem, por exemplo, ser isentos dessa atividade, partindo do princípio que esta tem a finalidade de redução do tamanho.
A Desintoxicação é importante principalmente para o seguro manuseio dos resíduos, uma vez que estes possuem diversos componentes prejudiciais à saúde dos que o manuseiam, além dos danos que podem ser causados ao meio ambiente, como contaminação dos lençóis freáticos por chumbo e mercúrio, por exemplo. Esta fase pode retirar componentes que não são compatíveis com a fase seguinte.

A Filtragem é considerada uma fase complementar à desintoxicação, uma vez que ela pode separar os resíduos que, por ventura, não foram excluídos na desintoxicação. Os resíduos são encaminhados, posteriormente, ao processamento químico, onde as toxinas são separadas de forma mais eficiente, uma vez que este já utiliza componentes mais abrasivos ao resíduo.

O Refino é encarregado de confirmar se todos os processos ocorreram de forma correta e se o produto está em conformidade com as especificações definidas para o tipo de resíduo. Logo, o refino atua como uma etapa de confirmação. Além de direcionar, se o resíduo é ou não reaproveitável, dependendo de seu estado, como se pode observar na Figura 1. 
Figura 1 - Proposta de mapeamento da etapa de processamento dos REE

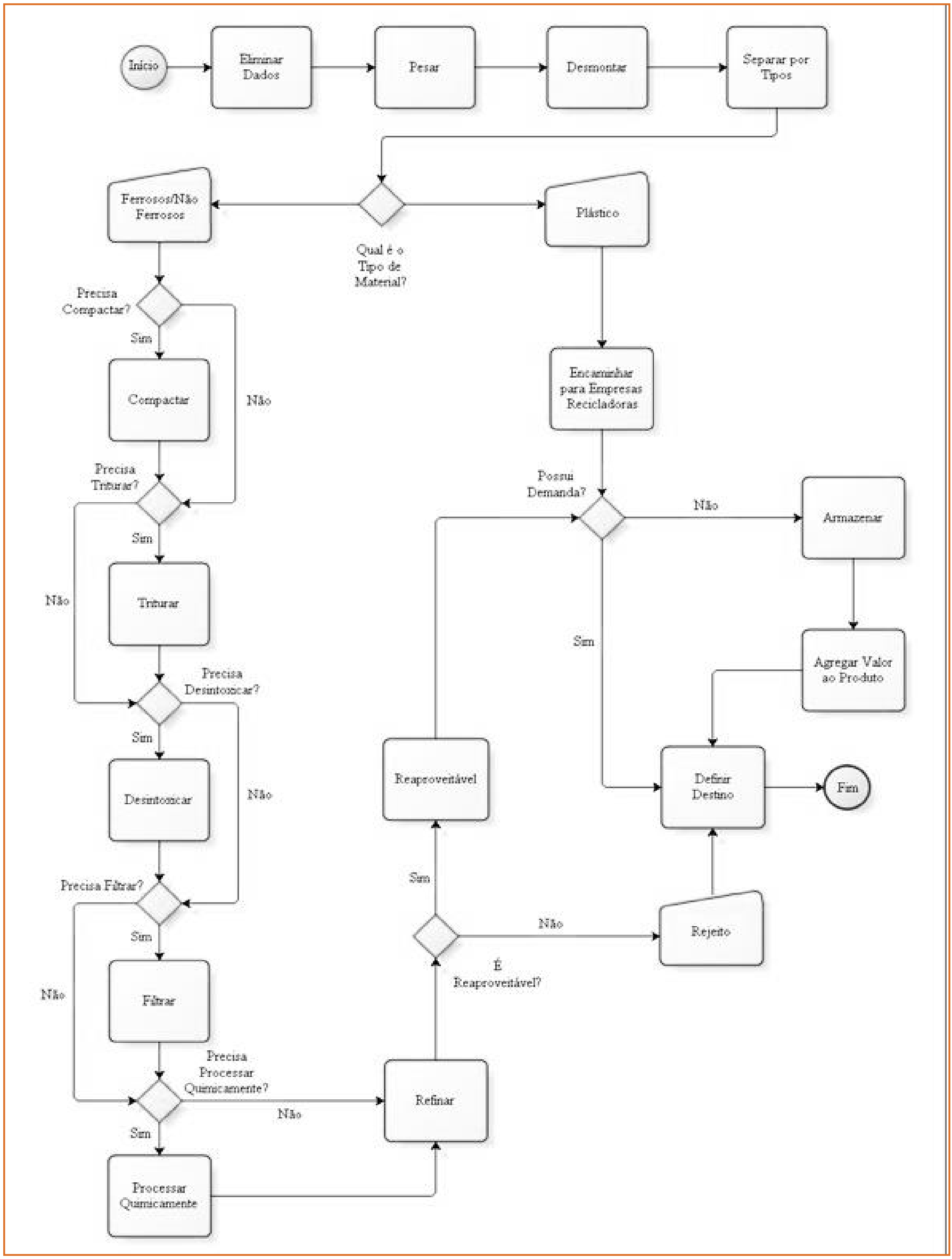


Caso o resíduo seja considerado como não reaproveitável, é classificado como rejeito e a este deve ser dado um destino ambientalmente adequado. Porém, se for considerado reaproveitável, sua demanda deve ser estudada para auxiliar decisões de estoques (procurando políticas de valorização do produto) ou de alocação de destinos que, nesse caso, será o mercado. Finalizando, assim, o ciclo reverso interno dos resíduos sólidos de produtos eletroeletrônicos.

\section{CONSIDERAÇÕES FINAIS}

O estudo se propôs a identificar qual seria o mapa de processos de pré-processamento de REE. Assim, o objetivo foi alcançado e permitindo, dessa forma, a visualização detalhada da atividade de reciclagem, uma vez que a mesma apresenta um alto grau de complexidade, consequência do diversos componentes existentes em cada EEE. O fluxograma proposto também pode auxiliar as cooperativas de catadores de lixo na organização e gestão de suas operações. Además, o resultado obtido nesta pesquisa contribui na divulgação desse tipo de informação, uma vez que existe a necessidade de destinar corretamente os REE.

No que diz respeito às dificuldades encontradas no decorrer do trabalho, dá-se ênfase à questão da escassez de fontes que tratam dos resíduos sólidos dentro do contexto da LR e da PNRS, muito provavelmente explicado pelo fato da Lei ter sido aprovada no ano de 2010. Nesse âmbito, como sugestão a novos trabalhos, recomenda-se que o mesmo assunto seja tratado, porém, com diferentes etapas de processamento de eletroeletrônicos, não deixando de retratar o cenário brasileiro, de como e quais empresas estão envolvidas nesta cadeia reversa.

\section{REFERÊNCIAS}

[1] ABDI. Agência Brasileira de Desenvolvimento Industrial. Logística Reversa de Equipamentos Eletroeletrônicos: Análise de Viabilidade Técnica e Econômica. Brasil: 2013. Disponível em:< http://www.mdic.gov.br/arquivos/dwnl_1367253180. pdf > . Acesso em: 12 out. 2014.
[2] ABINEE. Associação Brasileira da Indústria Elétrica e Eletrônica. Lixo: Muito celular e pouca reciclagem, dois males do Brasil. Brasil. Disponível e $\mathrm{m}:<$ http://www.noticia.abinee.org.br/publique/cgi/cgilua.exe/ sys/start.htm?tpl=home>. Acesso em: 14 out. 2014.

[3] ABRAMOVAY, R.; SPERANZA, J. S.; PETITGAND, Cécile. Lixo zero: gestão de resíduos sólidos para uma sociedade mais próspera. São Paulo: Planeta Sustentável. Instituto Ethos, 2013, 77 p.

[4] ALMÉRI, T. M.; SILVA, A. C. R.; PEREIRA, L. G. Logística Reversa como Diferencial Competitivo: uma visão sobre conceitos básicos e práticas imprescindíveis a gestão empresarial. Revista de Administração da Fatea, v. 7, n. 7, p. 83-97, 2014.

[5] ARAÚJO, M. G. Modelo de avaliação do ciclo de vida para a gestão de resíduos de equipamentos eletroeletrônicos no brasil. 2013. 1 v. Tese (Doutorado) - Curso de Planejamento Energético, Departamento de Programa de Planejamento Energético, Universidade Federal do Rio de Janeiro, Rio de Janeiro, 2013. Disponível em: <http://www.ppe.ufrj.br/ppe/ production/tesis/marcelo_guimaraes.pdf>. Acesso em: 13 out. 2014.

[6] BeRGAMO, K. M. L.; SteFAnELLO, P. R.. Logística Reversa nos ambientes empresariais. Revista Meio Ambiente e Sustentabilidade, v. 5, n. 3, p. 38-54, 2014.

[7] BRASIL. Política Nacional de Resíduos Sólidos (Lei no 12.305/2010). Brasília: Diário Oficial da União, 2010. Disponível em: <https://www.planalto.gov.br/ccivil_03/_ ato2007-2010/2010/lei/l12305.htm>. Acesso em: 02 de abril de 2014.

[8] CANTO, R. Lei de resíduos sólidos não foi cumprida. E agora? Carta Capital. 15 de agosto de 2014. Disponível em: <http://www.cartacapital.com.br/sustentabilidade/leide-residuos-solidos-nao-foi-cumprida-e-agora- 2697.html>. Acesso em: 22 de setembro de 2014.

[9] CEMPRE - Compromisso Empresarial para Reciclagem. Reciclagem e Reinserção. Disponível em: <http://www.cempre.org.br/descarte.php>. Acesso em: 14 out. 2014

[10] CSCMP - Council of Supply Chain Management Professionals. Disponível em <http://cscmp.org/aboutcscmp/Definitions.asp>, acesso em 27. Fev. 2015.

[11] DORNIER, P. P.; ERNST, Ricardo; FENDER, Michel; KOUVELIS, Panos. Logística e Operações Globais. São Paulo: Atlas, 2000.

[12] DUAN, H.; MILLER, T. R.; GREGORY, J.; KIRCHAIN, R. Quantitative characterization of domestic and transboundary flows of used electronics: analysis of generation, colletion, and export in the United States. Official Document of Environmental Protection Agency (EPA), under the umbrella of Solviong the e-waste problem (STEP), Dec, 2013, 121 p. 
[13] ECOD. REDAÇÃO. Política Nacional de resíduos sólidos é sancionada em Brasília. Eco desenvolvimento. 02 de agosto de 2010. Disponível em: <http://www.ecodesenvolvimento. org/noticias/politica-nacional-de-residuossolidos-esancionada >. Acesso em: 22 de setembro de 2014 .

[14] ECO DEBATE. Resíduos tecnológicos, artigo de Antonio Silvio Hendges. 06 de dezembro de 2012. Disponível em: < http://www.ecodebate.com.br/2012/12/06/residuostecnologicos-artigo-de-antonio-silvio- hendges/>. Acesso em: 08 de abril de 2015.

[15] ECOSUCATAS. Reciclar. 2015. Disponível em: <http:// www.ecosucatas.com.br/reciclar.asp>. Acesso em> 08 de abril de 2015 .

[16] ECYCLE. Entendendo os processos por trás da reciclagem de equipamentos eletrônicos. Disponível em:< http://www.ecycle.com.br/component/content/ article/44-guia-da-reciclagem/1823-o-que-e-lixoeletronico-elixo- ewaste-saiba-como-reciclar-reciclagemequipamentos-aparelhos-televisao-tubo-monitor-crtcomputador-celular- bateria-placas-memoria-hd-discorigido-entenda-riscos-saude-contaminacao-meio-ambientemetais-toxicos- descartar-corret.html>. Acesso em: 02 de abril de 2015.

[17] FONSECA, E. C. C.; BARREIROS, E. C. M.; GONÇALVES, P. V. S.; MELO, A. C. S.; NUNES, D. R. L.

Proposta de Mapa de processos de logística reversa de pós-consumo sob a ótica da política nacional de resíduos sólidos. 2015.

[18] FONSECA, F. O ciclo do lixo eletrônico - Reciclagem. Lixoeletronico.org (website). 2011. Disponível em:

<http://www.lixoeletronico.org/blog/o-ciclo-do-lixoeletr\%C3\%B4nico-3-reciclagem>. Acesso em: 12 Mar. 2015

[19] GERBASE, A. E.; OLIVEIRA, C. R. Reciclagem do lixo de informática: uma oportunidade para a química. Quím. Nova. vol.35, n.7, pp. 1486-1492. ISSN 0100-4042. 2012.

[20] GRUNDEMANN, H. R.; RAMOS, K. C. S. Logística reversa de descartes digitais: o destino do lixo eletrônico na cidade de Jaraguá do Sul - SC. Anuário da Produção de Iniciação Científica Discente, v. 14, n. 22, p. 103-112, 2014.

[21] JUCHNESKI, N. C. F.; VEIT, Dr. Hugo Marcelo. Monitores de LCD: caracterização dos materiais e processamento mecânico das placas de circuito impresso. Programa de Pós-Graduação em Engenharia de Minas, Metalúrgica e de Materiais, Universidade Federal Do Rio Grande Do Sul, 2013.

[22] LEITE, P. R. Desafios da Logística Reversa de pósconsumo no Brasil. Revista Tecnologística, São Paulo, p. 6467, maio 2014. Disponível em: <http://www.clrb.com.br/site/ publicacoes.asp?id=217>. Acesso em: 02 Out. 2014.
[23] LEVY, J. Sistemas Integrados de Resíduos Sólidos [Em linha]. [S.I.: s.n.]. 2006. Disponível em:<http://www. ecoservicos.com/content/documents/PD_9_JL.pdf>. Acesso em: 01 abr. 2015.

[24] MIGUEZ, E. C. Logística reversa como solução para o problema do lixo eletrônico: benefícios ambientais e financeiros. Rio de Janeiro: Qualitymark, 2010.

[25] NO OLHAR. Lixo eletrônico pode ser uma grande ameaça ao meio ambiente e à saúde. Disponível em:< http:// www.noolhar.org.br/noticias/lixo-eletronico.htm>. Acesso em: Fev de 2015.

[26] PESSOA, M. A. S.; SOUZA, S. J. O.; CASTRO, M. N.; CASTRO, R. M.; MESQUITA, G. M; SOUZA, P. C. Destinação final de resíduos de equipamentos eletricos e eletrônicos e uso da análise SWOT na logística reversa - um estudo teórico. Renefara, v. 5, n. 5, p. 130-149, 2014.

[27] PORTAL DO PURUS. Amazonas é o quinto Estado em geração de diária de lixo urbano por habitante. 06 de agosto de 2014. Disponível em: < http://www. portaldopurus.com.br/index.php?option=com_ content\&view =article\&id=14335: amazonas-e-oquinto-estado-em-geracao-diaria-de-lixo-urbano-porhabitante\&catid=68\&Itemid=322 >. Acesso em: Fev de 2013.

[28] PREFEITURA SÃO MIGUEL PAULISTA. E-lixo. O que é lixo eletrônico. 21 de março de 2013. Disponível em: <http:// www.prefeitura.sp.gov.br/cidade/secretarias/subprefeituras/ sao_miguel_paulista/noticias/?p=37007>. Acesso em: Fev de 2015

[29] PRODANOV, C. C.; FREITAS, E. C. Metodologia do trabalho científico: Métodos e técnicas da pesquisa e do trabalho acadêmico. 2 ed. Novo Hamburgo: Feevale, 2013.

[30] SILVA, E. L.; MENEZES, E. M. Metodologia da Pesquisa e Elaboração de Dissertação. 4aㅡ ed. Revisada e Atualizada. Florianópolis: UFSC, 2005.

[31] SPOLAVORI, A.; WELZEL, A.; SANTANA, D. V. M. Logística reversa aplicada a resíduos eletroeletrônicos: estudo de caso. VIII Convibra Administração - Congresso Virtual Brasileiro de Administração, 2012.

[32] VEIT, H. M. Emprego do Processamento Mecânico na Reciclagem de Sucatas de Placas de Circuito Impresso. Programa de Pós-Graduação em Engenharia de Minas, Metalúrgica e de Materiais, Universidade Federal do Rio Grande do Sul, 2001.

[33] YIN, R. K. Estudo de caso: planejamento e métodos. 2 ed. Porto Alegre: Bookman, 2001. 


\section{CAPÍTULO 7}

\section{INVESTIMENTOS EM P\&D (PESQUISA \& DESENVOLVIMENTO) E POTENCIAIS REFLEXOS NOS CUSTOS DE PRODUÇÃ̃o}

\section{Andreia Maria Berto}

\section{Claudelino Martins Dias Junior}

Resumo: No mundo globalizado delimitado por alta competitividade, qualidade dos produtos e concorrência acirrada, o êxito das empresas está vinculado à capacidade de inovação, colocando novos produtos no mercado, com melhor relação custo-benefício ao cliente, qualidade e velocidade superiores aos concorrentes. Entende-se que, neste contexto, os custos de produção não podem ser esquecidos e devem estar diretamente ligados à qualidade e produtividade. Neste estudo duas amostras de variáveis vinculadas a um ambiente de simulação foram utilizadas, uma com 132 (centro e trinta e dois) caracteres, realizada com alunos de graduação e outra com 84 caracteres com alunos de pós-graduação stricto sensu (mestrado e doutorado), ambos cursos de Administração. Os dados foram analisados por meio de técnicas de regressão linear simples e múltipla, com objetivo de verificar as hipóteses propostas de que as variáveis manutenção e pesquisa e desenvolvimento interferem diretamente na redução dos custos com mão de obra, e consequentemente, nos custos de produção. Os resultados demonstraram não haver relação significativa entre os investimentos em pesquisa e desenvolvimento e os custos com mão de obra/produção. Por outro lado, foi encontrada relação positiva e estatisticamente significativa entre os custos com manutenção e a redução dos custos de pessoal.

Palavras Chave: P\&D, Manutenção e Custos de Produção 


\section{INTRODUÇÃO}

$\mathrm{Na}$ economia global a sobrevivência das empresas depende da habilidade que demonstram em inovar e apresentar melhoria contínua, através da gestão eficaz de seus recursos, usando ferramentas que as direcionam a um caminho de qualidade e produtividade, como diferencial competitivo.

No entanto, percebe-se ainda, uma busca incessante das empresas pelo lucro embasadas em uma análise simplista de redução de custos e aumento de produção, desvinculando-as do caminho para sua sobrevivência no mercado. Obter qualidade e produtividade dos produtos, processos e serviços passa por diferentes pontos, como políticas de gestão da qualidade, alicerçamento em sistema de produção, investimento em pesquisa e desenvolvimento (P\&D), manutenção da produção, marketing e outros fatores estratégicos.

Neste contexto, os investimentos em manutenção e P\&D se mostram essenciais na garantia tanto da qualidade quanto da produtividade empresarial. Desta forma, colocam-se as hipóteses da pesquisa deste estudo:

a. H1: Quanto maior o investimento em P\&D, menor o custo de produção com mão de obra;

b. H2: Quanto maior o investimento em manutenção, menor o custo de produção com mão de obra.

Entende-se que, as duas variáveis estão diretamente relacionadas aos custos de produção e que, sua relação é estreita com os custos relacionados à mão de obra, costumeiramente uma parcela significativa dentro do valor total e onde os custos intangíveis são os mais representativos.

Este artigo está estruturado em seções, sendo que na próxima se desenvolve o problema e objetivos da pesquisa focados nos custos de produção e suas relações com as variáveis dependentes. $\mathrm{Na}$ seção seguinte se discutem os construtos custos de produção, manutenção, P\&D e a relação entre estes. As seções que seguem o referencial teórico apresentam os procedimentos metodológicos e os resultados do estudo. A última parte do artigo contém as conclusões e propostas para estudos futuros.

\section{PROBLEMA DE PESQUISA E OBJETIVO}

Os custos de produção são um fator crucial a todas as empresas, sendo um ponto de estudo constante por todos os interessados no assunto empresas, governos, fornecedores, órgãos públicos, universidades - que sempre buscam por melhores resultados. Neste caminho, o objetivo deste estudo é demonstrar a relação de investimentos em pesquisa e desenvolvimento e manutenção com os custos de produção, particularmente, os custos com mão de obra direta, partindo-se do uso de um simulador empresarial.

Para respaldar este estudo, tem-se como pressupostos: o investimento em pesquisa e desenvolvimento pode proporcionar resultados que são gerados no processo de trabalho (produção); e, as manutenções em equipamentos, maquinários e instalações proporcionam condições eficazes para a busca dos melhores resultados da operação e proporcionam a continuidade das atividades em igual ou superior patamar de produção.

Acredita-se que estes fatores proporcionem menores custos da produção e melhor desempenho operacional, a partir de processos mais acertados, funcionários com melhor conhecimento de suas atividades, bem como, a não necessidade de paradas na produção por problemas ocasionados por falhas em equipamentos, maquinário e consequentes erros de encaminhamento.

Neste sentido, espera-se responder a seguinte pergunta de pesquisa: existe relação entre os investimentos em P\&D e Manutenção na racionalização dos Custos de Produção na atividade de manufatura de produto de base tecnológica?

\section{REVISÃO BIBLIOGRÁFICA 3.1. CUSTOS DE PRODUÇÃO}

No final do século XIX surgiu um tipo novo de empresas para aquela época, caracterizado pela disponibilidade de capital financeiro, baseado em inovações tecnológicas e de produção. No século XX estas empresas se consolidaram e continuaram acelerando seu crescimento, atingindo maior visibilidade com os 
sistemas de transporte e a modernização dos meios de comunicação. Esperando exercer controle sobre os insumos, bem como, sobre a distribuição em nível de varejo, as empresas adotaram a estratégia de verticalização, movendo-se para trás e para frente dentro da cadeia. E, este movimento possibilitou a intensificação da exploração da economia de escala e escopo de produção, acumulando ainda mais recursos para as corporações (CHANDLER, 1992).

As empresas convivendo com a realidade do século XXI, de acordo com Brito e Pereira (2003), vivenciam atualmente a globalização da economia mundial, que encaminha a um constante aumento na competitividade organizacional. Isto coloca em contraste ideias e concepções que aumentam a produtividade, garantindo a qualidade e redução dos custos às empresas. Neste sentido, a utilização de sistemas de gestão eficientes que possam potencializar a utilização dos recursos nos processos produtivos é condição sine quan non à atuação empresarial.

Assim, entende-se necessário um planejamento prévio dos investimentos em bens de capital, sua tipificação e caracterização, em termos de utilização efetiva (em horas máquina) e sua alocação em projetos de pesquisa, os quais devem apresentar as estimativas de retorno econômico esperado (BORNIA, 2002). Para Martins (2006) deverá contemplar, ainda, a previsão de horas homem a serem utilizadas, segmentadas e categorizadas por tipo de profissional a ser alocado em cada um dos projetos e avaliação de horas a serem consumidas no processo de pesquisa ou de manutenção.

Agindo desta forma, é possível gerar novos conhecimentos e recriar a empresa e todos seus colaboradores em um processo contínuo. Como uma responsabilidade de todos na organização. Pois, como aponta Drucker (1992), a empresa precisa estar disposta a abandonar o conhecimento que a torne obsoleta e aprender a criar o novo através da melhoria contínua de todas as atividades; desenvolvimento de novas aplicações a partir de seus próprios sucessos; e inovação contínua como um processo organizado. Como foco, tem-se duas variáveis que se relacionam com estes pressupostos, em especial, no referencial teórico existente, premissa de base deste estudo.

\subsection{PESQUISA E DESENVOLVIMENTO}

No atual quadro econômico em que as empresas se instalam, delimitado por alta competitividade, qualidade dos produtos e concorrência pesada, o êxito empresarial está cada dia mais atrelado à capacidade de inovação tecnológica, colocando novos produtos no mercado, com custo-benefício maior para o cliente, melhor qualidade e em velocidade maior do que dos concorrentes. Neste cenário, observa-se que P\&D, a mais clássica das atividades inovativas, assume papel de destaque, influenciando diretamente o processo de inovação das empresas e dominando o estado da arte das novas tecnologias (ANDREASSI; SBRAGIA, 2002).

Assim, fazer ou não fazer P\&D deixou de ser uma opção para a totalidade das empresas, pois, a cultura de inovar já estava institucionalizada e sem chance de reversão do processo. Cabe as empresas inovar da forma certa, em produtos certos, em momentos oportunos e a custo reduzido, ou seja, uma questão de organização (CHRISTENSEN, 2002).

Como consequência deste contexto, verifica-se aporte representativo de investimento em P\&D na medida em que possibilita dar aporte a transformação do conhecimento incorporado pela empresa na sua linha de produtos para satisfazer as necessidades dos clientes atuais ou geram novas necessidades (MORT, 2001), criando assim, novos mercados. Para Langlois (2003), a área de P\&D, uma das fontes mais avultadas de geração do conhecimento, representa o repositório do recurso competitivo de valor agregado mais relevante e oferece a condição ímpar de diferenciação.

Esta ampliação da função de P\&D dentro do ambiente da empresa reafirma sua importância para a inovação, não apenas de produtos, mas, de processos operacionais e gestão. Esta relevância se reflete, também, em empresas pelos acréscimos significativos de recursos e pela autonomia na sua alocação (GOEL, 1999). Na antiga questão do fazer ou compras que passou a incorporar ao processo de decisão novas formas de administração, com destaque para as alternativas de realização das atividades técnicas de 
P\&D internamente, externamente ou combinando as duas opções.

O impacto destas alternativas se reflete diretamente na gestão de custos, notadamente na possibilidade de flexibilização e vinculação do montante total de custos fixos à receita gerada.

Os custos fixos são constituídos essencialmente por salários mensais, definidos com base no vínculo trabalhista, das equipes de técnicose de pesquisadores, quando da adoção do modelo de realização interna das atividades de P\&D. Ao optar pela externalização das atividades de pesquisa a empresa poderá se beneficiar, da redução de valores de despesas financeiras em virtude da não obrigatoriedade de acompanhar a evolução tecnológica, em termos de bens de capital destinados à pesquisa, deixando de imobilizar seu capital para esta finalidade (MORRISON, 2002), porém, poderá representar um risco ao negócio, quando da disponibilização do conhecimento que a empresa necessitará dispor a terceiros (WILLIAMSON, 1996).

Oqueéreforçado por diversas correntes do pensamento econômico que apontam o investimento em P\&D, como crucial para o desenvolvimento industrial, uma vez que proporciona maior eficiência no processo produtivo e maior competitividade para as empresas (JACOB et al, 2013). Campos e Valadares (1999) ressaltam que a inovação tecnológica é a grande ferramenta para o crescimento econômico, para os ganhos de eficiência e de competitividade. Calmanovici (2011) e Queiroz (2011) afirmam que empresas inovadoras que trabalham com investimentos constantes em P\&D e que mantém ferramentas de prospecção e avaliação de novas oportunidades conseguem ganhos mais eficazes com a inovação, são mais competitivas e contribuem para a economia, fortalecendo o esforço nacional no campo da ciência e tecnologia.

Complementarmente, Hulten (2000) reafirma a importância do investimento em P\&D, apontando que a análise do crescimento econômico é dada pela divisão em duas partes, a formação de capital e a tecnologia. Indo de encontro com o que os teóricos da nova teoria do crescimento e para um ramo da economia neoclássica, que o aumento da produtividade é dado por investimentos em capital humano, conhecimento e capital fixo.

Por outro lado, comenta que o mecanismo por meio do qual a inovação atua não é de fácil compreensão, pois, há heterogeneidade entre as empresas, além de dificuldade em garantir o retorno financeiro do processo de inovação.

Chaney et al (1991), defendendo a importância da inovação para as empresas, lembram que muitas análises empíricas têm demonstrado a relação entre indicadores relacionados à inovação, tais como gastos com P\&D, e o desempenho das empresas.

Hall (1987) em sua pesquisa com empresas americanas públicas do setor de manufatura relacionou os indicadores de gastos com P\&D e investimentos de capital com a taxa de crescimento. Os resultados mostraram que as empresas que não possuem programas de P\&D cresceram, em média, 1 a $2 \%$ menos do que as empresas que possuem esses programas, bem como, identificou que o investimento em P\&D é duas vezes mais eficiente do que o investimento de capital ao seu efeito na taxa de crescimento.

Mansfield (1962) demonstrou que empresas do setor de petróleo e de aço inovadoras apresentaram taxas de crescimento correspondentes a duas vezes as taxas de crescimento das empresas não inovadoras, sendo P\&D a principal representante.

A relação elação positiva vislumbrada entre Manutenção e Custos de Produção encontra respaldo em estudos como em Nogueira, Guimarães e Silva (2012) que afirmam que ao tratar de qualidade e produtividade, a Manutenção exerce um papel vital, evitando paradas sem programação ou produção fora de padrão. A manutenção o ativo é essencial ao aumento da confiabilidade e disponibilidade dos equipamentos para a produção. Belmonte e Scandelari (2006), colaboram para reforçar os resultados obtidos, quando afirmam que o planejamento e utilização do bom senso podem otimizar manutenções futuras, reduzindo-as ao máximo e diminuindo os custos de 
produção.

Andreassi (1999) em estudo sobre vários setores da economia brasileira rejeitou a hipótese de existência de uma relação significativa entre despesas de P\&D em período precedente e lucratividade em períodos subsequentes. A hipótese de relação entre a despesa em P\&D em período precedente e o crescimento do faturamento em período posterior, com um intervalo de dois anos, pode ser aceita para alguns segmentos com restrições, pois, não obteve resultados significativos quando realizou a análise nos setores industriais contidos na amostra.

\subsection{MANUFATURA E MANUTENÇÃO}

Segundo a Associação Brasileira de Normas Técnicas (ABNT, 1994), manutenção é a "combinação de todas as ações técnicas e administrativas, incluindo as de supervisão, destinadas a manter ou recolocar um item em um estado no qual possa desempenhar uma função requerida".

De cordo com Xavier (2005) a manutenção pode ser classificada em:

a. Manutenção corretiva: é a atuação para correção de falha ou do desempenho menor que o esperado. Pode ser dividida em: (1) Manutenção corretiva não planejada - é a correção da falha ou desempenho menor que o esperado após a ocorrência do fato; implica em altos custos, pois, causa perdas de produção e os danos aos equipamentos são maiores; (2) Manutenção corretiva planejada - é a correção que se faz em função de um acompanhamento preditivo, detectivo ou até mesmo pela decisão gerencial de se operar até ocorrer à falha, tende a ficar mais barato, mais seguro e mais rápido, pois segue um planejamento;

b. Manutenção preventiva: é a atuação realizada para reduzirem falhas ou queda no desempenho, obedecendo a um planejamento baseado em períodos estabelecidos de tempo. Para um melhor resultado é necessário uma correta determinação dos intervalos de tempo, porém, as empresas têm tendência conservadora, com intervalos normalmente menores que o necessário, o que implicam paradas e troca de peças desnecessárias;

c. Manutenção preditiva: são atividades de acompanhamento das variáveis ou parâmetros que indicam o desempenho dos equipamentos, de modo sistemático, visando observar a necessidade ou não de intervenção. Quando a intervenção resulta do acompanhamento preditivo é denominada Condition Based Maintenance (CBM) ou manutenção baseada na condição. Essa manutenção permite que os equipamentos operem por mais tempo e a intervenção não ocorre por suposições;

d. Manutenção detectiva: é a atuação efetuada em sistemas de proteção ou comando, buscando detectarem falhas ocultas ou não perceptíveis ao pessoal de operação e manutenção.

Importante observar que, ações de manutenções corretivas, usualmente, não podem ser planejadas. As falhas devem ser reparadas quando ocorrem, embora alguns reparos possam ser protelados. Conforme a ABNT (1994), esse tipo de manutenção está relacionado à ocorrência de falhas aleatórias, que não podem ser detectadas ou planejadas.

Entre os diferentes modelos desenvolvidos para a gestão da manutenção, tem-se:

a.Manutenção produtiva total (TPM): envolve toda a organização na otimização do processo produtivo, desde a alta gerência até os operários que trabalham no chão de fábrica, em busca de melhoria contínua da capacidade produtiva, da motivação das pessoas, do funcionamento dos equipamentos e da qualidade (REIS; COSTA; ALMEIDA, 2013);

b. Manutenção centrada em confiabilidade (RCM): desenvolvida por Stanley Nowlan e Howard Heap, da United Airlines, em 1978, a partir da necessidade de aumento da confiabilidade das aeronaves civis americanas (SIQUEIRA, 2005). Busca avaliar as consequências das falhas visando elevar a disponibilidade associada à redução dos custos e dos tempos de reparo das máquinas e equipamentos;

c. Manutenção baseada no risco (RBM): objetiva 
otimizar as tarefas de manutenção, mantendo um elevado nível de disponibilidade dos equipamentos, por meio de um estudo de todos os possíveis modos de falha, o que determina uma estimativa realista do nível de risco associado a cada modo de falha e o desenho de uma estratégia de manutenção que mitigue a ocorrência dos modos de falha de alto risco (KHAN; HADDARA, 2004).

O mais relevante de acordo com Otani e Machado (2008) é perceber que, entre todos os tipos de manutenção nenhuma modalidade substitui outra, porém associadas uma da outra, trarão resultados positivos em termos de performances gerais nas gestões das empresas.

Mirshawka (1991) corrobora com esta ideia, e aponta como maiores benefícios a previsão de falhas com antecedência suficiente para que os equipamentos sejam desativados em segurança, reduzindo os riscos de acidentes e interrupções do sistema produtivo; redução de prazos e custos de manutenção pelo conhecimento antecipado das falhas a serem reparadas; melhoria nas condições de operação dos equipamentos devido a menor desgaste, maior rendimento e produtividade.

Assim, ao se tratar de qualidade e produtividade, a manutenção exerce um papel vital, evitando que o equipamento pare sem programação ou produza fora de padrão. A manutenção do ativo é essencial no estabelecimento de uma estrutura, que proporcione o aumento da confiabilidade e disponibilidade dos equipamentos para a produção (NOGUEIRA: GUIMARÃES e SILVA, 2012).

Porém, há uma discussão recorrente, a decisão de realizar, ou não, atividades de manutenção, mesmo quando sabido de sua importância. Neste sentido a questão principal a discutir é a forma como os custos são analisados. Somente quando os custos de um programa de manutenção, demonstrando que o dinheiro aplicado em manutenção é um investimento, que proporciona redução não somente nos custos de reparo de máquinas, mas também nos de parada de máquinas.
Segundo Mirshawa e Olmedo (1993), os custos gerados pela função manutenção são apenas a ponta de um iceberg, onde a ponta visível corresponde aos custos com mão de obra, ferramentas e instrumentos, material aplicado nos reparos, custo com subcontratação e instalação ocupada pela equipe de manutenção. Sob a parte visível do iceberg, estão os maiores custos, invisíveis, da indisponibilidade do equipamento/ maquinário.

A relação entre custo de manutenção, custo da indisponibilidade e produtividade foi estudada por Chiu e Huang (1996), apontando que para uma relação custo-benefício mais adequada, a manutenção deve ser realizada de forma preventiva, em vez de situações de descontrole do processo produtivo pela falta de manutenção.

Outro estudo realizado por Murty e Naikan (1995) demonstrou que, a partir do ponto ótimo em investimento com manutenção preventiva, mais investimentos trazem poucos benefícios para a redução dos custos da falha e acabam elevando o custo total. Neste caso, a busca por falha zero, ou seja, 100\% de disponibilidade requer gastos cada vez maiores com manutenção, o que leva à redução do lucro da operação. Encontrar o ponto ótimo de disponibilidade, em que o custo da manutenção proporciona um nível de disponibilidade capaz de gerar máximo lucro à operação, é o grande desafio na gestão da manutenção. A manutenção deve garantir a produtividade e o lucro dos negócios da empresa com o menor custo possível.

Belmonte e Scandelari (2006) lembram que, o simples planejamento e utilização do bom senso podem otimizar manutenções futuras, reduzindo-as ao máximo e diminuindo os gastos com tais operações. Muitas das manutenções corretivas não planejadas ocorrem devido ao fato da não preocupação dos funcionários quanto ao controle de equipamentos, sendo que a operação advinda da rotatividade de funcionários nos diferentes postos de trabalho e variados horários são as características principais para tal manutenção.

Assim, a manutenção deve estar atrelada aos objetivos da empresa e ser conduzida de forma a proporcionar à empresa um grau de funcionalidade com um custo 
minimizado. A busca pela qualidade do processo e do produto passa pela qualidade da manutenção, sem a qual o montante investido em sistemas de gestão da qualidade pode ser inteiramente perdido. Apenas uma manutenção adequada pode garantir que o processo não perderá sua capacidade por desvios provocados por problemas no equipamento (SOURIS, 1992).

Neste contexto, observa-se que a gestão da manutenção tem sido objeto de alguns estudos como, pode-se citar, a pesquisa realizada por Jonsson (1997) que buscou analisar o status da gestão da manutenção em empresas de manufatura da Suécia, onde observou que um terço das firmas considera de pouca importância o setor de manutenção, e que isso é um grande obstáculo para proporcionar aprendizagem e trabalhar por melhorias contínuas. Outro estudo relevante foi a pesquisa sobre o status da gestão da manutenção em empresas de manufatura do Reino Unido realizado por Cholasuke, Bhardwa e Antony (2004), que demonstra o papel crítico que a manutenção assume como suporte das atividades de manufatura e que um aceitável nível de desempenho das indústrias é inalcançável sem o efetivo suporte da gestão da manutenção.

Murty e Naikan (1995), por sua vez, demonstraram matematicamente que, há retornos positivos na relação custo benefício entre custos de manutenção e diminuição de custos de produção voltados a mão de obra, porém alertam que, a partir do ponto ótimo em investimento com manutenção preventiva, mais investimentos trazem poucos benefícios para a redução dos custos da falha e acabam elevando o custo total. A busca por falha zero requer gastos cada vez maiores com manutenção, o que leva à redução do lucro da operação. Encontrar o ponto ótimo de disponibilidade, em que o custo da manutenção proporciona um nível de disponibilidade capaz de garantir a produtividade e o lucro dos negócios da empresa com o menor custo possível é a grande sacada das empresas.

Outro exemplo são os dados da Associação Brasileira de Manutenção (2007) que mostram que é incipiente e escassa a utilização de técnicas mais adequadas à gestão da manutenção e também, de procedimentos que possibilitem melhoras na produção, pois, $41 \%$ das empresas no Brasil não desenvolvem qualquer atividade voltada à manutenção.

\section{METODOLOGIA}

Esta pesquisa em sua abordagem do problema se caracteriza por ser quantitativa também denominada de pesquisa de levantamento (CRESWELL, 2007) e tem por característica principal a descrição quantitativa ou numérica de tendências, atitudes ou opiniões de uma população. Assim, o objetivo deste estudo busca observar resultados específicos em um cenário determinado.

Quanto aos objetivos, é caracterizada como uma pesquisa exploratória. De acordo com Malhotra (2006), a pesquisa exploratória tem como objetivo explorar ou realizar uma busca em um problema ou em uma situação para prover critérios e maior compreensão. Ainda, para Lakatos e Marconi (1996) a pesquisa exploratória apresenta como finalidade: (a) desenvolver hipóteses; (b) aumentar a familiaridade do pesquisador com um ambiente, fato ou fenômeno para a realização de uma pesquisa futura mais precisa; (c) modificar e clarificar conceitos. Ou seja, este tipo de pesquisa busca a interrelação com o problema de pesquisa, tendo como foco, estimar a proporção de elementos que tenham determinadas características dentro de uma população específica, com observação de relação entre variáveis.

Para tanto, visando identificar o quanto o investimento em pesquisa e desenvolvimento e em manutenção afeta nos custos de produção, em especial, nos custos de mão de obra, algumas etapas foram delimitadas:

a. Utilizado um simulador organizacional que tem por base um instrumento didático formado por regras econômicas a serem praticada para exercitar teorias, conceitos e técnicas, que proporciona a tomada de decisão seguida do exame dos resultados obtidos, partindo de condições iniciais das variantes do simulador e das relações de causa e efeito em teste (SAUAIA, 2013);

b. A simulação refere-se à prática pedagógica em Administração em turmas de graduação nos dois semestres de 2013 e em turma de pós- 
graduação stricto sensu (com alunos do mestrado e doutorado) no primeiro semestre de 2015, ambas da Universidade Federal de Santa Catarina (UFSC), sendo as disciplinas ministradas pelo mesmo professor;

c. Os resultados foram obtidos considerando oito trimestres para cada simulação (e turma) na graduação. Com oito grupos participantes das simulações nas duas turmas, sendo obtidos ao todo - 132 (cento e trinta e dois) caracteres para análise em cada variável;

d. Os resultados da turma de pós-graduação foram considerados para doze trimestres para cada simulação com sete grupos participantes, resultando 84 (oitenta e quatro) caracteres para análise;

e. Os dados foram relacionados utilizando a ferramenta estatística de regressão linear simples, seguida de regressão linear múltipla para indicar se os pressupostos iniciais se comprovam na amostra escolhida;

f. As análises de regressão foram realizadas, cada uma delas relacionando as variáveis independentes de custo de mão de obra aos investimentos de P\&D e manutenção;

g. Os dados foram apresentados e analisados em comparação aos levantamentos bibliográficos que oferecem base para a pesquisa e indica suas relações.

\section{ANÁLISE DOS RESULTADOS}

Adiante se apresentam os resultados das regressões, tendo como variáveis dependentes as medidas de desempenho P\&D e manutenção. Para cada uma dessas variáveis, foram testados modelos de regressões em isolado. A Tabela 1 apresenta um resumo das regressões lineares simples para as turmas de graduação e a Tabela 2 demonstra o resultado da turma de pós-graduação. Os resultados mostram que sozinhos os custos com mão de obra não possuíram poder de explicação nem significância estatísticas para a variável dependente P\&D, mas foram capazes de explicar um significativo percentual da variabilidade com o investimento em manutenção (57,87\% - turmas de graduação; 29,91\% turmas de pós-graduação). Esta última regressão também foi estatisticamente significante $(p<0,001)$, em ambos os casos, como pode ser visto em Tabela 1 e Tabela 2.

Tabela 1 - Significância das regressões - turmas graduação 2013

\begin{tabular}{|l|l|l|l|} 
Variável dependente & \multicolumn{2}{c}{ R2 } & \multicolumn{2}{c|}{ R2 Ajustado } & \multicolumn{1}{c|}{ p-valor } \\
\hline Manutenção & 0,5787 & 0,5753 & 0,0000 \\
\hline P\&D & 0,0759 & 0,0686 & 0,0016 \\
\hline
\end{tabular}

Fonte: Elaborada pelos autores.

Tabela 2 - Significância das regressões - turmas pósgraduação 2015

\begin{tabular}{|c|c|c|c|}
\hline Variável dependente & R2 & R2 Ajustado & p-valor \\
\hline Manutenção & 0,2991 & 0,2905 & 0,0000 \\
\hline$P \& D$ & 0,0623 & 0,0508 & 0,0022 \\
\hline
\end{tabular}

Fonte: Elaborada pelos autores.

Observa-se que há diferença nos percentuais referentes às turmas de graduação e pós- graduação, isto se deve ao fato de cada regressão representar significância para aquela vivência, porém, o mais relevante é perceber que nos dois casos a Manutenção e a P\&D apresentaram resultados com dados que levam a observar que, analisadas isoladamente a Manutenção tem relação direta com os custos de mão de obra, ao passo que P\&D não obteve esta conjugação, nem apresentou uma regressão com aceite estatístico.

Utilizando a regressão múltipla com as duas variáveis dependentes, observa-se que os parâmetros obtidos para a correlação com investimentos em mão de obra como variável independente está representada na Tabela 3 e 4, em acordo com as turmas aplicadas. Somente a variável manutenção apresentou significância estatística para o modelo $(p<0,001)$. Os dados relativos à variável $\mathrm{P} \& D$ não podem ser considerados, pois, não há significância estatística. 
Tabela 3 - Coeficientes da regressão do custo de mão de obra - turmas graduação 2013

\begin{tabular}{|l|l|l|}
\hline Variável dependente & \multicolumn{1}{l}{ Coeficiente } & \multicolumn{1}{l|}{ p-valor } \\
\hline (constante) & 151,5002 & 0,0000 \\
\hline Manutenção & $-12,7874$ & 0,0000 \\
\hline P\&D & $-2,5566$ & 0,0118 \\
\hline
\end{tabular}

Fonte: Elaborada pelos autores

Tabela 4 - Coeficientes da regressão do custo de mão de obra - turmas pós-graduação 2015

\begin{tabular}{|l|l|l|}
\hline Variável dependente & \multicolumn{1}{l}{ Coeficiente } & p-valor \\
\hline (constante) & 86,3937 & 0,0000 \\
\hline Manutenção & $-5,2911$ & 0,0000 \\
\hline P\&D & $-0,6810$ & 0,4978 \\
\hline
\end{tabular}

Fonte: Elaborada pelos autores

A variável manutenção apresentou coeficientes negativos, indicando uma relação direta entre a variável e a diminuição nos custos de mão de obra. Para o caso das turmas de graduação, pode-se afirmar que, a manutenção apresentou um coeficiente de -12,78, indicando uma variação positiva nos gastos com mão de obra de 1 ponto percentual associado a uma diminuição de 12,78 pontos percentuais na necessidade de investimento em mão de obra da empresa entre o período antecedente e o período subsequente à ocorrência desses gastos, tudo o mais mantido constante. O coeficiente de $-5,29$ para manutenção no caso das turmas de pós-graduação indica que, para cada ponto percentual dos custos em manutenção da empresa, a taxa de investimento em mão de obra é reduzida 5,29 pontos percentuais.

Estes resultados demonstram que a hipótese "H1Quanto maior o investimento em P\&D, menor o custo de produção com mão de obra", não foi explicada no estudo. Enquanto que, a hipótese "H2 - Quanto maior o investimento em manutenção, menor o custo de produção com mão de obra", foi comprovado estatisticamente.

\section{CONCLUSÕES}

Ressalta-se que os esforços em P\&D e Manutenção são fundamentais para as empresas se tornem mais competitivas, independente se as rubricas estão ou não ligados a custos de produção, pois, o retorno pode vir vinculado em outras contas, como aumento de vendas, consolidação no mercado, aumento do faturamento e do patrimônio da empresa, e em especial, no que está alicerçado à qualidade e produtividade indispensáveis ao contexto econômico global atual.

A realização deste estudo demonstra que em um ambiente simulado as empresas não conseguem os resultados apontados pela maioria dos estudos que o precedem, posto que estes evidenciem a importância do investimento em P\&D como redutor dos custos de produção.

Os resultados mostraram que a variável $P \& D$ não explicou a variabilidade dos custos de mão de obra das empresas, mas explicaram parte relevante da variabilidade quando ligada à variável Manutenção. Assim, a primeira hipótese proposta, de que o investimento em P\&D estaria positivamente associado aos custos de produção relacionados à mão de obra, foi rejeitada pela análise, enquanto a segunda hipótese, de que o investimento em manutenção estaria associado a diminuição dos custos de produção vinculados aos custos de mão-de-obra, foi evidenciada pelo estudo.

A não detecção de uma relação positiva entre $P \& D$ e a diminuição dos custos de produção, em especial aqueles relacionados aos custos de mão-de-obra, são contrários a alguns estudos empíricos anteriores. Por exemplo, tem-se Hall (1987) descobriu que as empresa americanas públicas do setor de manufatura que não possuíam programas de P\&D cresceram em média 1 a $2 \%$ menos do que as empresas que não possuíam programas no mesmo período.

Neste sentido, fazer ou não fazer P\&D e atuar preventivamente com manutenção deixou de ser uma opção para as empresas, pois, a cultura de inovar já está institucionalizada e sem chance de reversão, independente da relação existente com os custos de produção envolvidos. Compete às empresas inovar da forma certa, em produtos certos, em momentos oportunos e a custo reduzido, e este poderá ser produto para futuras correlações entre diferentes variáveis, que poderão verificar possibilidades mais 
lucrativas às empresas.

Para finalizar, observa-se necessidade de vincular ao simulador utilizado uma maior relação dos custos de produção com a variável P\&D, visto que, em ambientes reais e não virtuais esta associação é significativa.

\section{REFERÊNCIAS}

[1] ANDREASSI, T. Estudo das relações entre indicadores de P\&D e indicadores de resultado empresarial em empresas brasileiras. 1999. 213 p. Tese de Doutorado em Administração de Empresas, Universidade de São Paulo USP, São Paulo, 1999.

[2] ANDREASSI, T.; SBRAGIA, R. Relações entre indicadores de P\&D e de resultado empresarial. Revista de Administração, São Paulo v.37, n.1, p.72-84, janeiro/março 2002.

[3] ASSOCIAÇÃO BRASILEIRA DE NORMAS TÉCNICAS ABNT. NBR 5462: Confiabilidade e mantenabilidade. Rio de Janeiro: ABNT, 1994.

[4] ASSOCIAÇÃO BRASILEIRA DE MANUTENÇÃO ABRAMAN. Disponível em: <http://www.abraman.org.br/>. Acesso em: 15 jun. 2015.

[5] BELMONTE, D. L.; SCANDELARI, L. Gestão do Conhecimento: aplicabilidade prática na gestão da Manutenção. In: ENEGEP: XXVI Encontro Nacional de Engenharia da Produção, Fortaleza - CE, 2006.

[6] BRITTO, R.; PEREIRA, M. A. Manutenção autônoma: estudo de caso em empresa de porte médio do setor de bebidas. In: VII SEMEAD, Seminário de Estudos de Administração da USP - Universidade de São Paulo, 2003.

[7] BORNIA, A. C. Análise gerencial de custos: aplicação em empresas modernas. Porto Alegre: BOOKMAN, 2002.

[8] CALMANOVICI, C. E. A inovação, a competitividade e a projeção mundial das empresas brasileiras. Revista USP, v.89, p. 190-203, 2011.

[9] CAMPOS, I. M.; VALADARES, E. C. Inovação Tecnologia e Desenvolvimento Econômico. Unpublished paper, v. 6, n. 4, p. 573-610, 1991.

[10] CHANEY, P. K. et al. The impact of new product introductions on the Market value of firms. The Journal of Business, v. 64, 1991.

[11] CHANDLER, A. D. Organizational Capabilities and the Economic History of the Industrial Enterprise. The Journal of Economic Perspectives (1986-1998); Summer v. 6, n. 3; p. 79, 1992.
[12] CHIU, H. N.; HUANG, B. S. The economic design of $x$ control charts under a preventive maintenance policy. International Journal of Quality \& Reliability Management, Cambridge, v. 13, n. 1, p. 61-71, 1996.

[13] CHRISTENSEN, J. F. Corporate strategy and the management of innovation and technology. Industrial and Corporate Change, v. 11, n. 2, p. 263-288, 2002.

[14] CHOLASUKE, C.; BHARDWA, R.; ANTONY, J. The status of maintenance management in UK manufacturing organizations: results from a pilot survey. Journal of Quality in Maintenance Engineering, v. 10, n. 1, p. 5-15, 2004.

[15] DRUCKER, P. Administrando para o futuro. São Paulo: Enio Matheus Guazzelli \& Cia Ltda, 1992. GOEL, R. K. On contracting for uncertain R\&D. Managerial and Decision Economics, v. 20, n. 2, p. 99, mar 1999.

[16] GRESSLER, L. Introdução à Pesquisa: projetos e relatórios. São Paulo: Loyola, 2004.

[17] HALL, B. H. The relationship between firm size and firm grouwth in the US manufacturing sector. The Journal of Industrial Economics, v. 35, n. 4, p. 583-606, 1987.

[18] HULTEN, C. R. Total factor productivity: a short biography. New developments in productivity analysis, University of Chicago Press, p.1-54, 2001.

[19] JONSSON, P. The status of maintenance management in Swedish manufacturing firms. Journal of Quality in Maintenance Engineering, v. 3, n. 4, p. 233-58, 1997.

[20] LAKATOS, E. M.; MARONI, M. D. A. Técnicas de pesquisa: planejamento e execução de pesquisa, amostragens e técnicas de pesquisa, elaboração, análise e interpretação de dados. 2 3ed. São Paulo: Atlas, 1996.

[21] LANGLOIS, R. N. The vanishing hand: the changing dynamics of industrial capitalism. Industrial and Corporate Change, v.12, n.2, p.351-885, 2003.

[22] KHAN, F. I.; HADDARA, M. Risk-Based Maintenance (RBM): a New Approach for Process Plant Inspection and Maintenance, Wiley InterScience, v. 23, n. 4, p. 252-265, 2004.

[23] MANSFIELD, E. Entry, Gibrat's law, innovation in organizational learning. Organization Science, v. 2, n. 1, p. 1023-1051, 1962.

[24] MALHOTRA, N. Pesquisa de Marketing: uma orientação aplicada. Porto Alegre: Boockman, 2006. MARTINS, E. Contabilidade de custos. 9. ed. São Paulo: Atlas, 2006.

[25] MIRSHAWKA, V.; OLMEDO, N. C. Manutenção: combate aos custos na não-eficácia - a vez do Brasil. São Paulo: McGraw-Hill Ltda, 1993. 
[26] MIRSHAWKA, V. Manutenção Preditiva: Caminho para Zero Defeitos, São Paulo: Makron Books, McGraw- Hill, 1991. MORT, J. Nature, value and pursuit of reliable corporate knowledge. Journal of Knowledge Managemen; v.5, n.3, p. 222-230, 2001.

[27] MORRISON, S. Outsourcing growth keeps prognosis upbeat. Chemical Week, New York, v. 164, n. 8; p. 74, fev. 2002

[28] MURTY, A.S.R.; NAIKAN, V.N.A. Availability and maintenance cost optimization of a production plant. International Journal of Quality \& Reliability Management, Cambridge, v. 12, n. 2, p. 28-35, 1995.

[28] OTANI, M.; MACHADO, W.V. A proposta de desenvolvimento de gestão da manutenção industrial na busca da excelência ou classe mundial. Revista Gestão Industrial, v. 04, n. 02, p. 01-16, 2008.

[29] QUEIROZ, S. Obstáculos ao investimento em P\&D de empresas estrangeiras no Brasil. Revista USP, v. 89, p. 244255, 2011.
[30] REIS, A.C. B; COSTA, A. P. C e ALMEIDA, A.T. Diagnóstico da gestão da manutenção em indústrias de médio e grande porte da região metropolitana de Recife. Produção, v. 23, n. 2, p. 226-240, abr./jun. 2013.

[31] SAUAIA, A.C.A. Laboratório de Gestão: Simulador organizacional, jogo de empresa e pesquisa aplicada. 3 ed. São Paulo: Manole, 2013.

[32] SIQUEIRA, I. P. Manutenção centrada na confiabilidade. Rio de Janeiro: Qualitymark, 2005. SOURIS, J. P. Manutenção Industrial: custo ou benefício. Lisboa: Lidel, 1992.

[33] XAVIER, J. N. Manutenção: tipos e tendências. Disponível em: <http://www.engeman.com.br/site/ptb/artigostecnicos. asp/manutencaotiposetendencias.zip>, 2005. Acesso em 01 jul. 2015.

[34] WILLIAMSON, O. E. Economics and organization: a primer. California Management Review, v.38, n.2, p.131-146, 1996 


\section{CAPÍTULO8}

\section{MINÉRIO DE FERRO E VALE S.A.: UMA HISTÓRIA DE SUCESSO}

\section{Suheir Kamal Genena}

\section{Aguinaldo Eduardo de Souza}

\section{Francielly Galdino}

\section{Marília Patrão Viveiros}

Resumo: O objetivo deste artigo é analisar a relevância, para o Brasil, do minério de ferro no comércio internacional, bem como, constatar a importância dos investimentos da Vale S.A. no sistema logístico envolvido na mineração, transporte e exportação do minério de ferro. Para isso, realizamos pesquisa descritiva e bibliográfica, análise de dados governamentais, e de dados disponíveis no site da Vale S.A. Verificamos, que apesar da baixa nos preços do minério de ferro nos mercados internacionais, e da queda nas exportações desta commodity para a China, o maior importador mundial, a Vale S.A. mantém--se como a maior indústria de exploração mineral em âmbito nacional, e a maior empresa brasileira exportadora de minérios no âmbito internacional.

Palavras Chave: Exportação, Minério de Ferro, Produção, Transporte, Vale S.A. 


\section{INTRODUÇÃO}

O foco de estudo deste artigo científico será a Vale S.A., o sistema Norte de exploração de minério de ferro, em Carajás, no Pará, o Terminal Marítimo Ponta da Madeira, em São Luis, no Maranhão, os navios Valemax, de propriedade da Vale, a exportação do minério e sua importância para comércio exterior brasileiro.

O Brasil é o segundo maior exportador de minério de ferro do mundo, ficando atrás da Austrália. A Vale S.A., a maior empresa brasileira de mineração, conta com o apoio de quatro grandes sistemas de produção: Norte, Sul, Sudeste e Centro Oeste. O minério produzido é transportado por via férrea, pela Estrada de Ferro Carajás (EFC), concessão da Vale. O Terminal Portuário de Ponta da Madeira (TPPM), pertencente à Vale S.A., é um dos maiores terminais especializados no embarque de minério de ferro do mundo. Atualmente sua média anual de movimentação é de 112 milhões de toneladas. O terminal realizou o maior embarque mensal da história com 11,4 milhões de toneladas e o recorde diário de embarque, com 626 mil toneladas (esse último já foi superado em fevereiro de 2015, com 642 mil toneladas).

Os parâmetros de pesquisa utilizados no desenvolvimento deste artigo são: -classificação da mercadoria - NCM 2601.11.00 - Minérios de ferro e seus concentrados, exceto as piritas de ferro ustuladas (cinzas de piritas), não aglomerados, a ser explicado no capítulo 4; -país-alvo de exportação - China; -porto de saída - TPPM; -período: de janeiro de 2012 a julho de 2015 .

Tabela 1: Exportação de Minério de Ferro - 2012-2015

\begin{tabular}{|l|l|}
\hline Período & US\$ FOB \\
\hline Janeiro a dezembro 2012 & 4.561 .478 .072 \\
\hline Janeiro a dezembro 2013 & 5.062 .635 .189 \\
\hline Janeiro a dezembro 2014 & 4.238 .140 .982 \\
\hline Janeiro a julho 2015 & 1.056 .118 .634 \\
\hline Total & 14.918 .372 .877 \\
\hline
\end{tabular}

Fonte: Site Alice Web - MDIC, 2015 Elaboração própria

De acordo com pesquisas realizadas no Alice Web, site do governo federal que disponibiliza informações sobre a balança comercial brasileira, apurou-se que - Brasil exportou para a China, o maior importador mundial de minério de ferro, entre janeiro de 2012 e julho de 2015, um montante de US\$ 14.918.372.877, comercialização acordada sob o Incoterm Free on Board (FOB), ou seja, o exportador estará se comprometendo a entregar a carga dentro do navio, que fará o transporte internacional da mesma, sendo que o custos do transporte e seguro da carga ficará por conta do importador.

A exportação de minério de ferro é realizada através do Sistema Integrado de Comércio Exterior (Siscomex), utilizado para o controle de operações do comércio exterior, tanto na exportação, como na importação, por meio de um fluxo único, o Siscomex registra as atividades e controla as operações. Disponibilizado pelo Governo Federal, por meio dos órgãos gestores, Secretária de Comércio Exterior (Secex), órgão ligado ao Ministério do Desenvolvimento, Indústria e Comércio Exterior (MDIC), Banco Central do Brasil (Bacen) e a Receita Federal do Brasil (RFB).

\section{METODOLOGIA}

Este trabalho é uma pesquisa descritiva, elaborada através de referencial teórico bibliográfico, análise de dados em sites governamentais e institucionais. Para a elaboração da tabela e do gráfico, com dados referentes à exportação de minério de ferro, utilizouse as ferramentas eletrônicas Alice Web e Balança Comercial, e dados do relatório anual de 2014 da Vale S.A. (MDIC, 2015; PIRES, 2015)

Tendo como base o objetivo de explicitar a relevância do minério de ferro no comércio internacional e os investimentos da Vale em mineração, este trabalho foi formulado através de pesquisa descritiva, ou seja, através do estabelecimento de relações entre variáveis. (GIL, 2002, p. 42). Quanto ao delineamento da pesquisa para este trabalho, ele é classificado como pesquisa bibliográfica, por ter sido desenvolvida exclusivamente a partir de fontes bibliográficas. (GIL, 2002, p. 44) 


\section{REFERENCIAL TEÓRICO}

Segundo Keedi (2011), comércio exterior pode ser definido como a troca de mercadorias e serviços entre dois ou mais países e uma compensação financeira por essa troca. É composto por importação, que é a entrada de bens produzidos no exterior, e por exportação, ou seja, a saída de mercadorias para o exterior.

As motivações em torno do comércio são diversas. Entre os vários interesses podemos citar: recursos naturais, disponibilidade de terras para agricultura e pecuária, clima, desenvolvimento tecnológico, além dos motivos comerciais, políticos e financeiros. (KEEDI, 2011)

De acordo com Rodrigues (2012, p. 167-170) uma empresa, para se tornar exportadora, necessita internacionalizar sua marca e adotar postura de exportadora ativa. "O quarto tipo é o das empresas dispostas a fazer de tudo para atender a seu cliente, mesmo no que se refere a mudanças e adaptações de seus produtos para melhor atendimento. (RODRIGUES, 1996)

Deste modo, desde sua criação, e sobretudo após a privatização da Companhia Vale do Rio Doce - hoje Vale S.A. - esta sempre apresentou uma "cultura exportadora", uma vez que o produto escolhido para exportação, o minério de ferro, atende as exigências, necessidades e os mercados internacionais. (RODRIGUES, 2012)

Ainda Rodrigues (2012), no caso do minério de ferro, a exportação é direta. Ou seja, a mercadoria é faturada pelo fabricante do produto ao importador, e exige-se da empresa o conhecimento do processo de exportação em sua totalidade.

Keedi (2011), afirma, a exportação também pode ser definitiva, quando a mercadoria é incorporada ao ativo do país importador, e passa a ser nacional para todos os efeitos legais, deixando de pertencer ao ativo do país exportador.

No que se refere ao pagamento da mercadoria, ela pode ser exportada com, ou sem pagamento. Com pagamento, entende-se que o importador pagará ao exportador, ou seja, a entrada e saída de divisas nos dois países. Divisas são reservas em moeda estrangeria forte (dólar americano e euro), aceitas por todos os países para pagamento e recebimento. (KEEDI, 2011)

\section{EXPORTAÇÃO DE MINÉRIO DE FERRO}

Segundo Ferreira (2001), o minério de ferro é uma commodity que o Brasil exporta, por ser um dos maiores mineradores mundiais deste produto. $\mathrm{O}$ minério brasileiro é um dos melhores do mundo, por apresentar o maior teor de ferro contido, em geral superior a $60 \%$, o que confere ao Brasil vantagens competitivas na comercialização internacional.

A Vale, é a maior indústria de exploração mineral (IEM) do Brasil, após a aquisição de outras mineradoras nacionais e internacionais, e a coparticipação na exploração em mineradoras estrangeiras. Este fato faz com que ela seja a maior IEM exportadora brasileira. (PIRES, 2015)

A formação de preço desta commodity é dada da seguinte forma:

"O preço do minério de ferro é fixado para um determinado teor de ferro mínimo e também em função do tratamento sofrido pelo minério. Os principais elementos de custo dos minérios de ferro são: de mineração, de tratamento e de transporte. A composição de cada custo no produto final varia de caso a caso. Os custos de transporte internos até o porto de embarque e o frete transoceânico são os que mais oneram o preço final do produto. Baseados nos estudos realizados por QUARESMA (1987) e SOUZA (1991) os preços do minério de ferro dependem: da competição comercial, dos custos operacionais, da especificação do minério, do teor de ferro, dos impostos e taxas governamentais e da infraestrutura. O minério de ferro é comercializado 
entre os produtores e consumidores normalmente de três modos:

- Comércio através de contratos de médio e longo prazo entre vendedores e compradores;

- Comércio através do mercado "Spot", mediante contratos de curto prazo.

- Transferência através de minas cativas. (FERREIRA, 2001)

De acordo com o Dicionário Financeiro UOL (2015), mercado spot, ou preço spot é o mercado de commodities em que os negócios são realizados com pagamento a vista e entrega imediata de mercadorias.

Conforme o Departamento de Pesquisas e Estudos Econômicos Bradesco (Depec, 2015), até o ano de 2009, os preços do minério de ferro eram negociados anualmente entre exportadores brasileiros (Vale) e australianos (Rio Tinto e BHP Billiton) e os importadores japoneses (Nippon Steel), chineses (Baosteel) e europeus (Arcelor - maior produtora de aço do mundo) entre os meses de novembro e dezembro de cada ano, podendo se estender até o $1^{\circ}$ trimestre do ano seguinte; os preços acordados vigoravam a partir de 1 o de abril do ano seguinte.

Os contratos de fornecimento de minério de ferro eram de longo prazo (de 5 a 10 anos), em função das necessidades muito particulares quanto às especificações do minério fornecido pela fonte supridora. Nesses contratos eram fixadas as quantidades dentro de bandas podendo ser ajustadas de acordo com a maior ou menor necessidade de fornecimento.

Dado que o minério de ferro é uma commodity internacional, os preços praticados no mercado doméstico são balizados pelo mercado externo, descontadas as despesas portuárias. No mesmo sentido, os preços domésticos eram negociados anualmente.

A partir da negociação de 2010, as três grandes mineradoras acabaram com o modelo de "benchmark", passando a adotar acordos trimestrais. A Vale negocia trimestralmente, tomando como referência para o reajuste o lodex (Iron Ore Index). A BHP Billiton e Rio Tinto também passaram a adotar o sistema de acordo trimestral. As revisões trimestrais são definidas de acordo com a média dos preços nos três meses anteriores no mercado à vista. (DEPEC, 2015)

Segundo o MDIC (2015), afirma que as exportações brasileiras são reguladas pela Secretaria do Comércio Exterior, e realizadas através do Sistema Integrado do Comércio Exterior. Este sistema agiliza as exportações e visa integrar todos os órgãos governamentais envolvidos nestas transações (Órgãos Anuentes, Receita Federal, Banco Central, Polícia Federal, Autoridade Portuária, entre outros).

O produto minério de ferro, é classificado pelo Sistema Harmonizado de Designação e Codificação de Mercadorias $(\mathrm{SH})$, que é um código numérico internacional que objetiva identificar as mercadorias, para controles alfandegários e cobrança de impostos em sua entrada ou saída. (KEEDI, 2011)

Segundo Werneck (2008, p. 29), o sistema SH é composto por códigos de seis algarismos, iniciados por posições de quatro algarismos agrupadas em capítulos; os capítulos são agrupados em seções. Os agrupamentos do $\mathrm{SH}$ não são aleatórios e organizam as mercadorias por afinidades. A estrutura do $\mathrm{SH}$ visa facilitar, ao importador/exportador, a classificação de mercadorias e permite, também, a obtenção de dados estatísticos em níveis diversos.

A Nomenclatura Comum do Mercosul (NCM), a qual o Brasil adota, utiliza a estrutura do código $\mathrm{SH}$ em sua totalidade e acrescenta mais dois algarismos, que representam o item e o subitem da NCM. "O código NCM, portanto, é composto por oito algarismos, os seis primeiros oriundos do $\mathrm{SH}$ (parte internacional) e os dois últimos, regionais. " (WERNECK, 2008, p. 35)

A NCM é uma nomenclatura adotada em janeiro de 1995, pelo Bloco Econômico Mercado Comum do Sul (Mercosul), utilizada pelos Estados Partes - Argentina, Brasil, Paraguai, Uruguai e Venezuela e pelos Estados Associados - a Bolívia (em processo de adesão ao Mercosul), o Chile (desde 1996), o Peru (desde 2003), a Colômbia e o Equador (desde 2004). Guiana e 
Suriname tornaram-se Estados Associados em 2013. (MERCOSUL, 2015)

\section{CADEIA PRODUTIVA E SISTEMA DE TRANSPORTE DO MINÉRIO DE FERRO}

A Vale, maior indústria de exploração mineral e exportadora brasileira de minério de ferro, conta com uma ampla rede logística envolvida na produção, transporte e escoamento do minério de ferro. Esta rede é formada pelos sistemas de mineração - Norte, Sudeste, Sul e Centro-Oeste, por malhas ferroviárias e por terminais portuários especializados. A rede logística da Vale S.A. é composta por concessões governamentais. Assim ressalta-se que as concessões do governo federal, para exploração e comércio de minério de ferro no Brasil, são por período indeterminado. (PIRES, 2015)

O sistema Norte de mineração, ponto central deste capítulo, é composto pelo Terminal Ferroviário de Carajás (TFCJ), pela Estrada de Ferro Carajás - EFC e pelo Terminal Portuário de Ponta da Madeira (TPPM), O sistema é operado pela Vale S.A. (CARNEIRO, 2008)

Figura 1 - Operação no TPPM

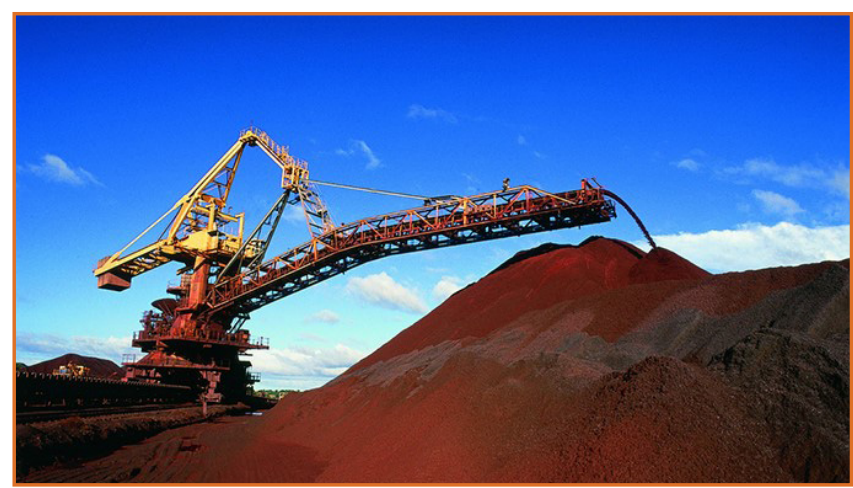

Fonte: VALE, 2015

Em 2014, a Estrada de Ferro de Carajás transportou um total de 105,9 bilhões de tku (tonelada por quilômetro útil transportado - o peso das mercadorias a serem transportadas excluindo o peso do vagão) de minério de ferro. As principais cargas transportadas pela Estrada de Ferro de Carajás são: minério de ferro, pelotas, minério de manganês, ferro gusa e granéis minerais (cobre e manganês). (PIRES, 2015)

\subsection{CADEIA PRODUTIVA DO MINÉRIO DE FERRO NO SISTEMA NORTE}

Localizado em Carajás, no estado do Pará, com minas a céu aberto e usinas de processamento de minério. São divididas entre Serra Norte, Serra Sul e Serra Leste. As atividades na Serra Norte são subdivididas em três áreas (N4W, N4E e N5) e duas instalações principais de beneficiamento. Todos esses elementos são partes integrantes do Sistema Norte da Vale.

O minério de hematita extraído nesse sistema é de alto teor de ferro (em média maior que 66\%). O processo de beneficiamento consiste em medição, peneiramento, hidroclonagem, britagem e filtragem. O resultado desse processo gera o sínter feed, o pellet feed e o minério granulado.

A fonte de energia para esse sistema provém de empresas regionais de energia elétrica, ou pela Aliança Geração, ou ainda, diretamente pela Vale.

Gráfico 1 - Média de produção do último triênio - Elaborado pelos autores

Média de produção $(2012,2013,2014)$ em milhões de ton métricas de minério

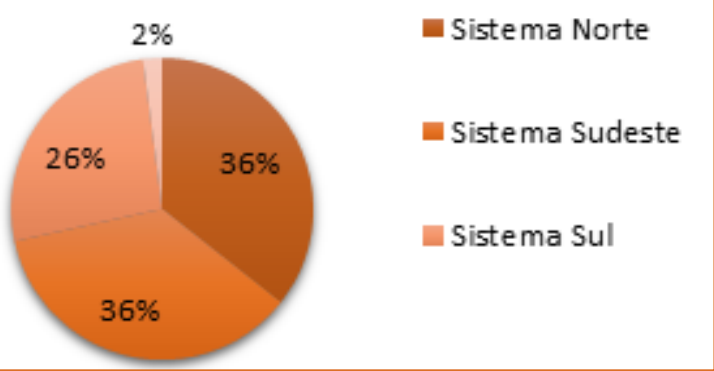

Fonte: PIRES,2015

No último triênio (2012, 2013 e 2014) o Sistema Norte produziu o equivalente a uma média de 110.467 milhões de toneladas métricas de minério, representando cerca de $34,40 \%$ da média total do mesmo período de todo o Sistema Vale (321.033 milhões de toneladas métricas de minério), praticamente empatando com a média de 110.867 milhões de toneladas métricas de minério do Sistema Sudeste (representando cerca de $34,53 \%$ da média total) e ficando acima da média de 81.867 milhões de toneladas métricas de minério do 
Sistema Sul (representando cerca de 25,50\% da média total) seguida também pela média de 6.233 milhões de toneladas métricas de minério do Sistema CentroOeste (representando cerca de 1,94\% da média total), conforme demonstrado no gráfico 1. (PIRES, 2015)

\subsubsection{DA EXTRAÇÃO À ESTOCAGEM}

Segundo a Vale (2015), o minério de ferro é transportado até o britador primário, localizado no interior da mina, onde serão reduzidos em partículas menores do que $20 \mathrm{~mm}$ (pode ser necessário passar até 03 vezes por esse processo para se chegar ao resultado esperado). Então, através de correias transportadoras, o minério de ferro é levado até a usina de beneficiamento (a usina tem $85 \mathrm{~km}$ de correias transportadoras).

Figura 2 - Caminhão "Fora de Estrada"

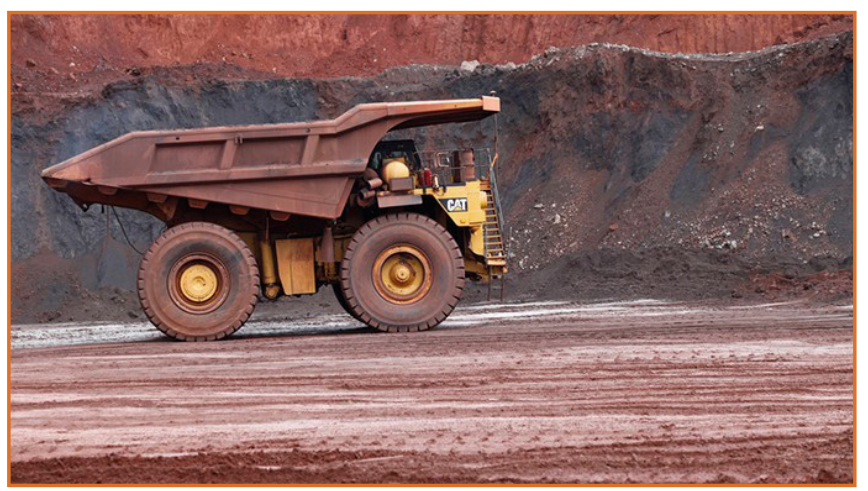

Fonte: Vale, 2015

Escavadeiras e pás carregadeiras retiram as toneladas de minério de ferro de bancadas de $15 \mathrm{~m}$ de altura e carregam os caminhões chamados "fora de estrada" (figura 2). Esses caminhões têm $8 \mathrm{~m}$ de altura, $15 \mathrm{~m}$ de comprimento e capacidade para transportar até 400ton, são específicos para trabalhos em minas, construções e pedreiras e são os maiores em operação no Brasil. Do material extraído, $50 \%$ é minério, o restante é chamado estéril (teor muito baixo de minério para ser aproveitado economicamente, sendo depositado em pilhas específicas para posterior descarte). (POLONI, 2015; VALE, 2015)
Figura 3 - Pátio de estocagem Sistema Norte, Carajás

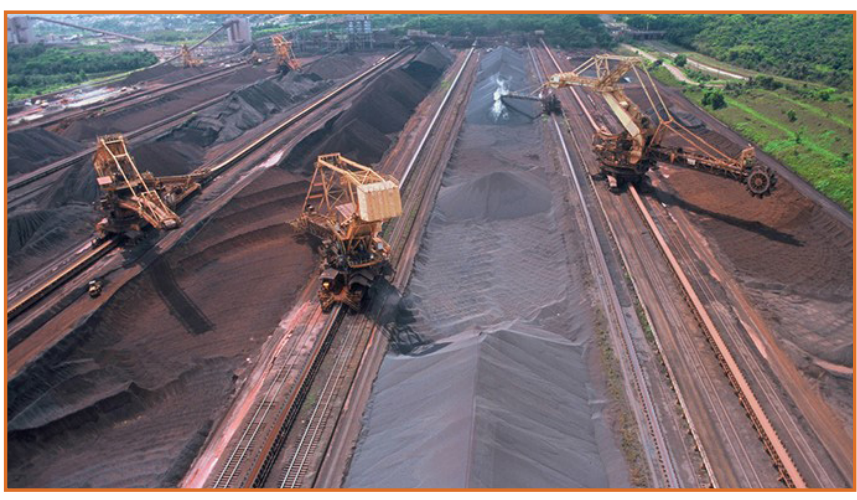

Fonte: Vale, 2015

$\mathrm{Na}$ usina de beneficiamento ocorre o processo de peneiramento através de 17 linhas de produção. O minério é separado em 03 tamanhos diferentes (granulado, sínter feed e pellet feed). Após a separação, o minério de ferro segue por correias transportadoras, 04 empilhadeiras e 01 recuperadoras até os 05 pátios de estocagem (figura 3). Aqui termina o processo de beneficiamento e inicia-se o transporte do minério beneficiado. (VALE, 2015)

\subsection{SISTEMA DE TRANSPORTE DO MINÉRIO DE FERRO BENEFICIADO}

Após a estocagem, em pilhas de até 18 metros de altura, o minério é movimentado por máquinas carregadoras até os silos de estocagem que se encontram no Terminal Ferroviário de Carajás (TFCJ). Estes reservatórios cilíndricos abastecem os 330 vagões do trem de carga da Vale. O trem passa por baixo dos silos e recebe a carga, num processo que dura aproximadamente 2 horas e meia. (VALE, 2015)

Segundo a Vale (2015), o trem de carga tem capacidade para transportar 40 mil toneladas de minério de ferro. Cada vagão pode carregar até 160 toneladas. De acordo com Carneiro (2008), depois de carregado, o trem segue pelos $892 \mathrm{~km}$ de extensão da Estrada de Ferro Carajás (EFC), chegando ao Terminal Ferroviário Ponta da Madeira (TFPM) que fica dentro dos limites do Terminal Portuário de Ponta Madeira (TPPM).

O trajeto entre Carajás/PA e São Luis/MA tem duração de 30 horas, do TFCJ até o TFPM. No TFPM os vagões são descarregados por 4 viradores de vagão, que 
tombam os vagões em um ângulo de $180^{\circ}$, sem a necessidade de desengatar cada vagão, tornando o processo mais rápido e eficiente. O minério é descarregado em silos e levado por um sistema de correias transportadoras até os pátios de estocagem no TPPM. (VALE, 2015)

De acordo com a Vale (2014), estando o minério nos pátios de estocagem do TPPM, máquinas recuperadoras e correias transportadoras levam 0 minério direto aos porões dos navios mineraleiros. O TPPM é um terminal especializado em minérios e tem capacidade de receber os navios Valemax, pertencentes à Vale.

O Terminal Portuário de Ponta da Madeira (TPPM) é um porto privado pertencente à Vale, inaugurado no ano de 1986, que está localizado no Complexo Portuário de Itaqui, à margem leste da Bahia de São Marcos, na Ilha de São Luis (MA). Possui profundidade natural de 26 metros, na maré baixa. Este fato permite menos gasto com dragagem, o que diminui o valor do frete, além de favorecer a atracação dos maiores mineraleiros Berge Stahl e os Valemax. A média anual de movimentação do TPPM era de 99,1 milhões de toneladas de minério de ferro e carga geral, mas em 2014 atingiu uma média de pouco mais 112 milhões de toneladas métricas de minério de ferro. (PIRES, 2015; VALE, 2015)

No TPPM, a Vale desenvolveu um sistema de inteligência artificial que permite operar, de forma remota, as máquinas empilhadeiras e recuperadoras usadas para transferir o minério do pátio até o navio. O sistema possibilita o comando à distância das máquinas a partir do Centro de Controle e Operações do Porto. O Maranhão é o primeiro Estado do Brasil a ter um terminal portuário com todas as máquinas de pátio operando em modo remoto. (REVISTA MINÉRIOS E MINERALES, 2013)

Além disso, o porto da Vale já trabalha com modelos matemáticos avançados que simulam 0 comportamento de atracação dos navios nos píeres, prevendo por exemplo a velocidade dos ventos e as correntes. A empresa mantém um modelo reduzido do terminal portuário na sede da Universidade de São Paulo (USP), onde acontecem as simulações de correntes marítimas e marés e seus efeitos sobre os navios em manobras e atracados nos píeres, além de permitir simular as manobras de atracação e desatracação dos navios. No modelo reduzido são realizados também treinamentos da equipe técnica do porto, além de permitir aos práticos e à Marinha avaliar a viabilidade das manobras dos navios. O modelo físico foi construído em 1979, em um enorme galpão e ocupa uma área de $1.600 \mathrm{~m} 2$ e é resultado da parceria técnico-científica da Vale e da Universidade de São Paulo (USP). (REVISTA MINÉRIOS E MINERALES, 2013)

Os navios Valemax, de propriedade da Vale, são os maiores navios mineraleiros do mundo, com as seguintes características:

- Comprimento: 365 metros;

- Boca (largura): 66 metros;

- Calado: 23 metros

- Capacidade: até 400.000 toneladas de carga. (VALE, 2015)

\section{CONCLUSÃO}

Tendo em vista os aspectos observados, o Brasil figura dentre os maiores exportadores de minério de ferro do mundo, ocupando a segunda posição no ranking mundial. Sua atuação como uns dos players principais, é de extrema relevância no comércio global de commodities. Isto deve-se ao papel fundamental das operações da Vale, sendo a maior indústria exploradora de minério no Brasil, bem como, a maior exportadora brasileira.

Verificou-se por meio deste artigo, alguns principais aspectos que permitem a Vale S.A manter-se em posição de destaque no comércio internacional, acerca das exportações de minério:

- O minério brasileiro é um dos melhores do mundo, pois apresenta o maior teor de ferro contido; em geral superior a $60 \%$, o que confere ao Brasil vantagens competitivas na comercialização internacional;

- Sistemas de produção: Norte, Sul, Sudeste e Centro Oeste, sendo de maior importância a cadeia 
produtiva do sistema norte e sistema sudeste, que juntas no período de 2012 a 2014, representaram quase $70 \%$ de toda produção da Vale no Brasil;

- O sistema logístico, com destaque, 2 terminais ferroviários: Ponta de Madeira e Carajás, 1 linha férrea: a Estrada de Ferro Carajás, com 892 km de extensão, bem como, o Terminal Portuário Ponta da Madeira, equipado com sistema de inteligência artificial. Um dos maiores terminais especializados no embarque de minério de ferro do mundo, capaz de receber os navios Valemax, pertencentes à Vale, navios estes, com capacidade de transportar 400 toneladas de minério de ferro.

Sendo assim, é indiscutível o papel da Vale como protagonista nas operações no comércio internacional, evidenciando o Brasil como grande exportador de commodities no cenário global. Contudo, é mister ratificar a importância das exportações de minério ferro na economia nacional, haja vista os impactos relevantes na balança comercial brasileira, tendo a Vale como divisor de águas nas exportações de commodities brasileira.

\section{REFERÊNCIAS}

[1] ALICEWEB2. Alice Web 2. Site do Ministério do Desenvolvimento, Indústria e Comércio Exterior, 2015. Disponível em: <http://aliceweb.mdic.gov.br//consulta-ncm/ index/type/exportacaoNcm>. Acesso em: 04 Setembro 2015.

[2] CARNEIRO, F. D. M. Simulação do Circuito de Minério do Terminal Ferroviário de Ponta da Madeira. Instituto Militar de Engenharia. Rio de Janeiro. 2008. Monografia apresentada ao curso de Especialização em Transporte Ferroviário do Instituto Militar de Engenharia.

[3] CHETWYND, G. Valemax. Vale S.A. Rio de Janeiro, p. 80. 2013

[4] DEPEC. Departamento de Pesquisas e Estudos Econômicos - Informativo Minério de Ferro. Bradesco Economia em Dia, 04 Setembro 2015. Disponível em: <http:// www.economiaemdia.com.br/EconomiaEmDia/pdf/infset_ minerio_de_ferro.pdf>. Acesso em: 03 Setembro 2015.

[5] FERREIRA, G. E. A Competitividade da Mineração de Ferro no Brasil. Rio de Janeiro: CETEM/MCT, 2001. Série Estudos e Documentos, 50.
[6] GIL, A. C. Como Elaborar Projetos de Pesquisa. 4ª . ed. São Paulo: Atlas, 2002. 42-44 p.

[7] KEEDI, S. ABC do Comércio Exterior. 4ª ed. São Paulo: Aduaneiras, 2011. ISBN 978-85-7129-585-8.

[8] MDIC. Ministério do Desenvolvimento, Indústria e Comércio Exterior. Site do Ministério do Desenvolvimento, Indústria e Comércio Exterior, 2015. Disponível em: <http:// www.mdic.gov.br/sitio/>. Acesso em: 15 Maio 2015.

[9] MERCOSUL. Página brasileira do MERCOSUL Governo Federal. Página brasileira do MERCOSUL, 04 Setembro 2015. Disponível em: <http://www.mercosul.gov. br/index.php/saiba-mais-sobre-o-mercosul>. Acesso em: 04 Setembro 2015.

[10] PIRES, L. S. Relatório Anual de 2014. Vale S.A. Rio de Janeiro, p. 280. 2015.

[11] POLONI, G. iG - Brasil Econômico. Site da iG, 2015. Disponível em: <http://economia.ig.com.br/empresas/ industria/saiba-mais-detalhes-sobre-os-caminhoesgigantes-da-vale/n1237726813639.html>. Acesso em: 06 Setembro 2015.

[12] REVISTA MINÉRIOS E MINERALES. Inteligência artificial em Ponta da Madeira. Revista Minérios e Minerales, São Paulo, n. 211, 2013. Disponível em: <http://www.minerios. com.br/EdicoesInt/211/Porto_de_Ponta_da_Madeira_MA_ tera_capacidade_ampliada.aspx $>$. Acesso em: 07 Setembro 2015.

[13] RODRIGUES, W. Sistemática de exportação: conceitos, operacionalização e práticas. In: ARTUR CÉSAR BORTOTO, M. R. M. C. R. J. S. R. Comércio Exterior: Teoria e Gestão. 3ạ. ed. São Paulo: Atlas S.A., 2012. Cap. 5, p. 165-206. ISBN 978-85-224-67549.

[14] UOL. Dicionário Financeiro UOL. Site da Universo On Line - UOL, 2015. Disponível em: <http://economia.uol. com.br/financas-pessoais/dicionario-financeiro/?letra=M>. Acesso em: 05 Setembro 2015.

[15] VALE. Regulamento do Terminal Ponta da Madeira. Site da Vale S.A., 2015. Disponível em: <http://www.vale. com/PT/business/logistics/ports-terminals/Documents/pdf/ regulamento_terminal_ponta_madeira-PT.pdf>. Acesso em: 07 Setembro 2015.

[16] VALE. Vale S.A. Site global da Vale, 2015. Disponível em: <http://www.vale.com/PT/business/mining/iron-ore-pellets/ Documents/carajas/index.html>. Acesso em: 10 Junho 2015.

[17] WERNECK, P. Como Classificar Mercadorias: Uma Abordagem Prática. 1a․ ed. São Paulo: Aduaneiras, v. Único, 2008. ISBN 978-85-7129-0. 


\section{CAPÍTULO 9}

\section{PREVISÃO DO CONSUMO ITALIANO DE GÁS NATURAL UTILIZANDO MODELOS ARIMA}

\section{Jair Paulino de Sales}

\section{Francisco de Assis Vilar Sobreira Júnior}

João Marcos Pereira Silva

\section{Andersson Alves da Silva}

Resumo: $O$ uso do gás natural (GN) como fonte de suprimento energético foi motivado principalmente pelo choque do petróleo na década de 70. Este insumo energético é composto por misturas de hidrocarbonetos que permanecem no estado gasoso em condições atmosféricas. O GN importado para a Itália é inserido na rede de gasodutos através de pontos de entrada distribuídos por todo território nacional. O presente estudo objetivou a utilização da metodologia Box-Jenkins (método ARIMA) na previsão do consumo de GN na Itália entre os anos de 2015 e 2020 com a utilização de séries temporais. Os dados do consumo italiano de GN entre os anos de 1980 e 2014 (obtidos através do EIA) foram analisados descritivamente para estimativa de componentes sazonais e cíclicos. Realizouse um estudo utilizando o método ARIMA para análise, modelagem e previsão da série temporal. Utilizaram-se os softwares gretl 1.10.2 e Microsoft Excel 2010 para a modelagem dos dados. O modelo ideal foi selecionado a partir dos critérios $\mathrm{AIC}, \mathrm{BIC}, \mathrm{HQC}$ e do erro padrão, levando em consideração a variância estatística dos modelos $(p<0,05)$. O modelo ARIMA $(0,2,1)$ mostrou-se adequado para a série em estudo. Como resultado, a perceptível queda do consumo de GN indicada pela previsão, objetivo deste trabalho, foi consonante com as previsões de agências internacionais especializadas, comprovando a eficiência do modelo proposto.

Palavras Chave: Box-Jenkins, ARIMA, Modelos de previsão, Gás natural. 


\section{INTRODUÇÃO}

A utilização do Gás Natural (GN) como insumo energético tornou-se uma alternativa sustentável nas últimas décadas, passando a ser adotado em larga escala nos países que apresentam baixa capacidade de geração de energia elétrica por outros meios, como no caso da Alemanha, Espanha e Itália. Em um referendo realizado na Itália em 2011 94\% da população mostrou-se contra a volta da produção de energia nuclear, desde 1987 extinta no país. Sobre a produção de energia hidroelétrica, a Itália encontrase em posição geográfica desfavorável e como não possui períodos de sol durante todo o ano a produção de energia solar é insipiente para a demanda local. A união desses fatores contribui, ainda mais, para a utilização do GN como fonte energética primaria no país.

Paro (2005) define gás natural como a parcela do petróleo que se encontra em fase gasosa ou mesmo em solução nas condições de reservatório e que permanece no estado gasoso nas condições atmosféricas, sendo composto por mistura de hidrocarbonetos, podendo ser encontrado em poços petrolíferos ou reservatórios de gás. Maranhão (2004) faz uma analogia afirmando que assim como o GN é a fase gasosa do petróleo, o asfalto é a parte sólida e a gasolina e o diesel são suas frações líquidas.

A importância do GN atribui-se a várias causas, a principal delas é a sua versatilidade. O GN é capaz de substituir praticamente todos os derivados do petróleo, podendo ser utilizado desde para a substituição do óleo combustível até para a produção de solventes e fertilizantes, servindo, também, de matéria prima fundamental na indústria petroquímica.

Outra de suas grandes vantagens é a sua capacidade de ser um combustível de queima total, sem deixar resíduos e não emitindo particulados (cinzas, nitretos, anidridos, etc.), contribuindo significativa e positivamente para preservação ambiental. Possui baixos índices de enxofre, assim contribui para evitar problemas decorrentes da corrosão (MARANHÃO, 2004).

Em um contexto histórico, o GN é utilizado desde a antiguidade, com pesquisas apontando que sua descoberta ocorreu no Irã entre os anos de 6000 e 2000 a.C., e que o mesmo já era conhecido na China desde 900 a.C., sendo, em meados de 211 a.C., que sua extração começou a ser efetuada com o intuito de sua utilização para o processo de secagem das pedras de sal (FERREIRA, 2006 apud FIOREZE, 2013).

O uso do GN como fonte de suprimento energético foi motivado principalmente pelo choque do petróleo nos anos de 1973 e 1979, duas décadas após o ocorrido o número de reservas mundiais de GN passaram de 63,2 para 139,7 trilhões de metros cúbicos (1975 a 1995) (FIOREZE, 2013). Hoje, na Itália, compreende $40,4 \%$ das fontes de energia primaria.

O GN importado para Itália é inserido na rede nacional através de pontos de entrada distribuídos no território nacional. Os principais fornecedores são Argélia, Rússia, Países Baixos e Noruega. A rede de distribuição atinge as cidades desde planícies aos vales, assim praticamente todos as casa italianas recebem o gás diretamente. O seu sistema de transporte é articulado em dois níveis: a distribuição primária que resguarda o transporte sobre escala nacional através de grandes tubulações; e a distribuição secundária que leva o produto a disposição do cliente final.

Diante do exposto, e considerando a significativa importância do GN para o desenvolvimento italiano, o presente estudo objetiva a utilização da metodologia Box-Jenkins (método ARIMA) na previsão do consumo de GN na Itália nos próximos anos, de forma a auxiliar na gestão energética do país.

\section{MATERIAL E MÉTODOS}

Os dados (obtidos através da Autorità per l'energia elettrica il gas ed il sistema idrico e da Energy Information Administration - EIA, ambas responsáveis pela divulgação de dados como consumo, produção e dependência energética) referentes ao consumo italiano de GN entre os anos de 1980 e 2014 foram analisados descritivamente para estimativa de componentes sazonais e cíclicos. Realizou-se um estudo utilizando o método ARIMA para análise, modelagem e previsão da série temporal. Utilizaramse os softwares gretl 1.10.2 e Microsoft Excel 2010 
para a modelagem dos dados estatísticos, seguindo metodologia descrita por Murteira, Muller e Turkman (1993).

Para a escolha do modelo ideal analisou-se um conjunto de observações na tentativa de explicar as interações existentes entre a variável e seus valores passados. Nesta análise verificou-se a variância estatística dos modelos $(p<0,05)$, os critérios de informação de Akaike (AIC), Bayesiano (BIC) e de Hannan-Quinn $(\mathrm{HQC})$. Após escolha do modelo realizou-se a previsão do consumo energético de GN na Itália para o período 2015-2020.

\section{METODOLOGIA BOX - JENKINS}

A metodologia Box-Jenkins, modelo ARIMA ( $p, d, q)$, toma por base o ajuste nos valores em observação, possuindo como objetivo a redução da diferença entre os valores observados e os propostos para próximo de zero, sendo capaz de descrever séries estacionárias e não estacionárias.

Considera-se uma série temporal como um conjunto de observações quantitativas registradas em um intervalo de instantes sucessivos, sendo descrita por Zt, no qual $t=\{1,2, \ldots, n\}$.

Para realizar uma previsão com a utilização de modelos ARIMA ( $p, d, q)$ faz-se necessária a identificação da ordem de $A R(p), I(d)$ e $M A(q)$, respectivamente grau auto regressivo, grau de diferenciação, grau das médias móveis. Como procedimento metodológico básico, o primeiro parâmetro a ser observado é o grau de diferenciação $\mathrm{I}(\mathrm{d})$, necessário para que os dados de Zt sejam estabilizados.

Zt será considerada estacionária quando seu teste de correlograma apresentar corte abrupto para um valor de autocorrelação. Para que isso seja possível faz-se necessário diferenciar a série I(d) vezes. As ordens dos parâmetros $A R(p)$ e $M A(q)$ são identificadas a partir da verificação das funções de autocorrelação (FAC) e autocorrelação parcial (FACP) da série Zt (RIBEIRO; PAULA, 2000; PINTO et al., 2008). De acordo com Gomes (1989), p, d, $\mathrm{q} \leq 2$, visto que a maioria das séries se torna estacionária após segunda diferenciação.

Desta forma um modelo ARIMA $(1,0,0)$ indicaria a ausência dos componentes I(d) e MA(q), logo poderia ser denominado simplesmente de AR (1). Caso o modelo fosse ARIMA $(2,0,1)$, o mesmo não possuiria o componente I(d) e poderia ser apresentado como ARMA $(2,1)$. Os modelos ARMA diferenciam-se do ARIMA apenas pela ausência de diferenciações, ou seja, as séries estudadas já precisam ser estacionárias. Já o modelo SARIMA acresce ao ARIMA o fator de sazonalidade. Em estudos com dados reais utilizam-se os modelos e ARIMA e SARIMA com maior frequência, já que as séries utilizadas normalmente são não estacionárias (MILESKI JUNIOR, 2007).

Segundo Murteira, Muller e Turkman (1993), a metodologia de Box-Jenkins pode ser descrita em 04 etapas: Identificação; Estimação; Avaliação do diagnóstico; Previsão. A figura 01 apresenta os estágios desta metodologia.

Visto que não existem modelos perfeitos, os critérios de informação de Akaike (AIC, 1974), Bayesiano de Schwarz (BIC, 1978) e Hannan e Quinn (HQC, 1979) objetivam selecionar os melhores modelos entre aqueles que foram selecionados, funcionam como medidores qualitativos de modelos estatísticos (FIGUEREDO, 2008; TEODORO, 2015).

Figura 01 - Metodologia de Box-Jenkins

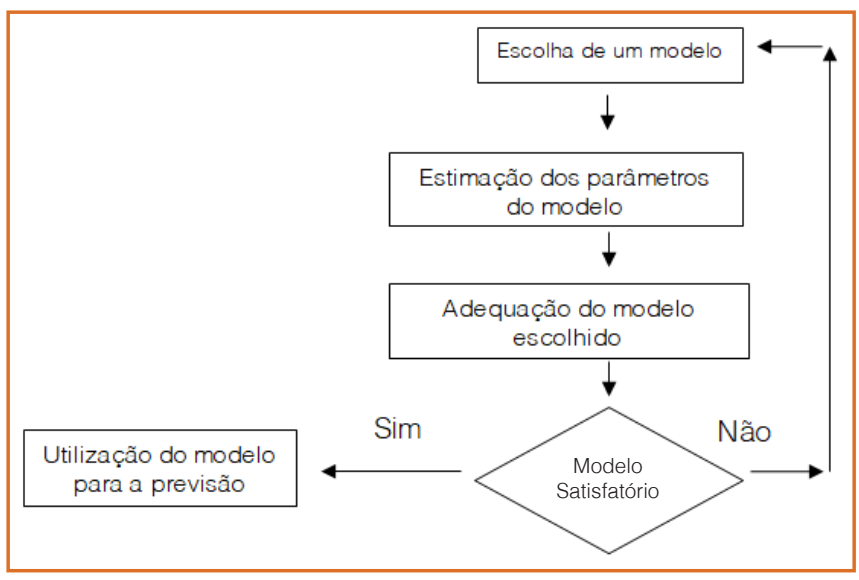

Fonte: Murteira, Muller e Turkman (1993), adaptado 


\section{RESULTADOS E DISCUSSÃO}

A série temporal foi construída a partir dos valores do consumo de GN na Itália entre os anos de 1980 e 2014 (figura 02). Todas as análises estáticas foram realizadas pelos softwares gretl 1.10 .2 e Microsoft Excel 2010.

Figura 02 - Gráfico do consumo (GN em bilhões de pés cúbicos)

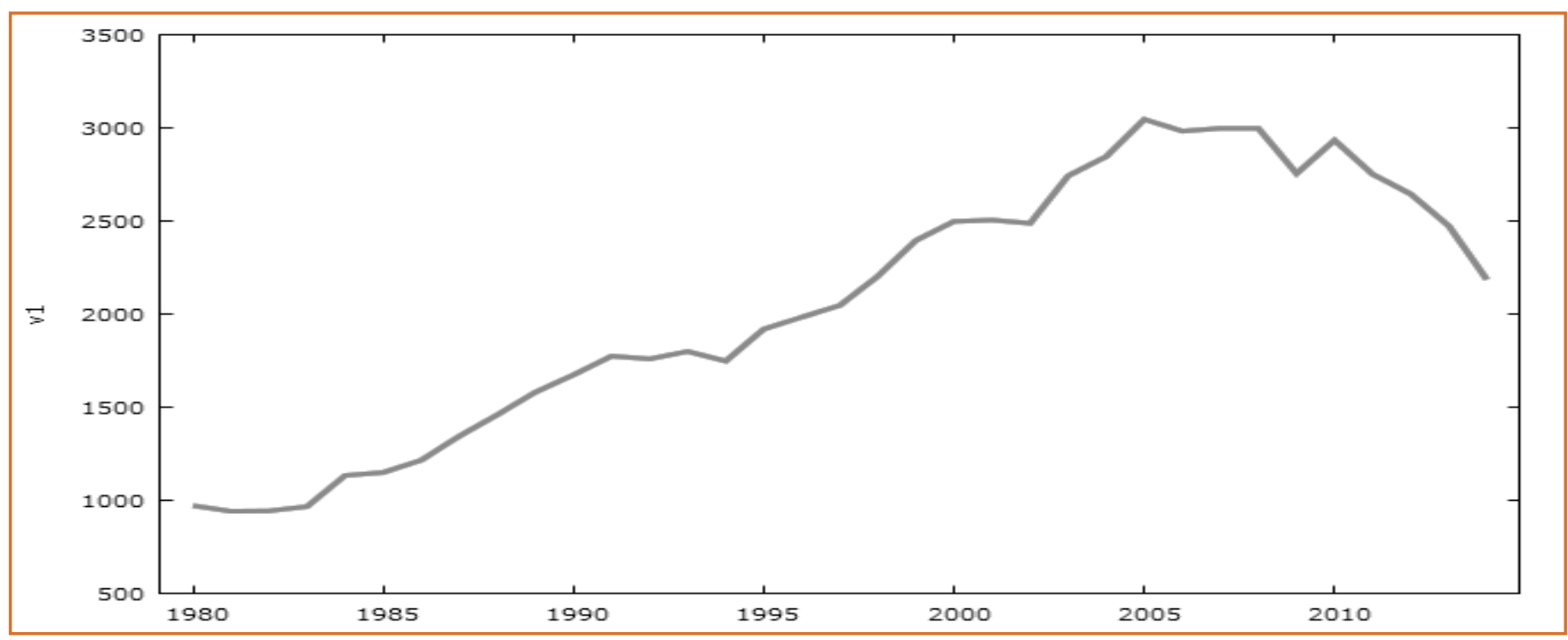

\subsection{IDENTIFICAÇÃO E ESTIMAÇÃO DO MODELO}

A partir de análises da função de autocorrelação (FAC) da série original constatou-se que a mesma era não estacionária, sendo necessárias duas diferenciações para que se apresentasse como estacionária (figura 03 e 04).

Figura 03 - Gráfico da função de autocorrelação (FAC) da série original

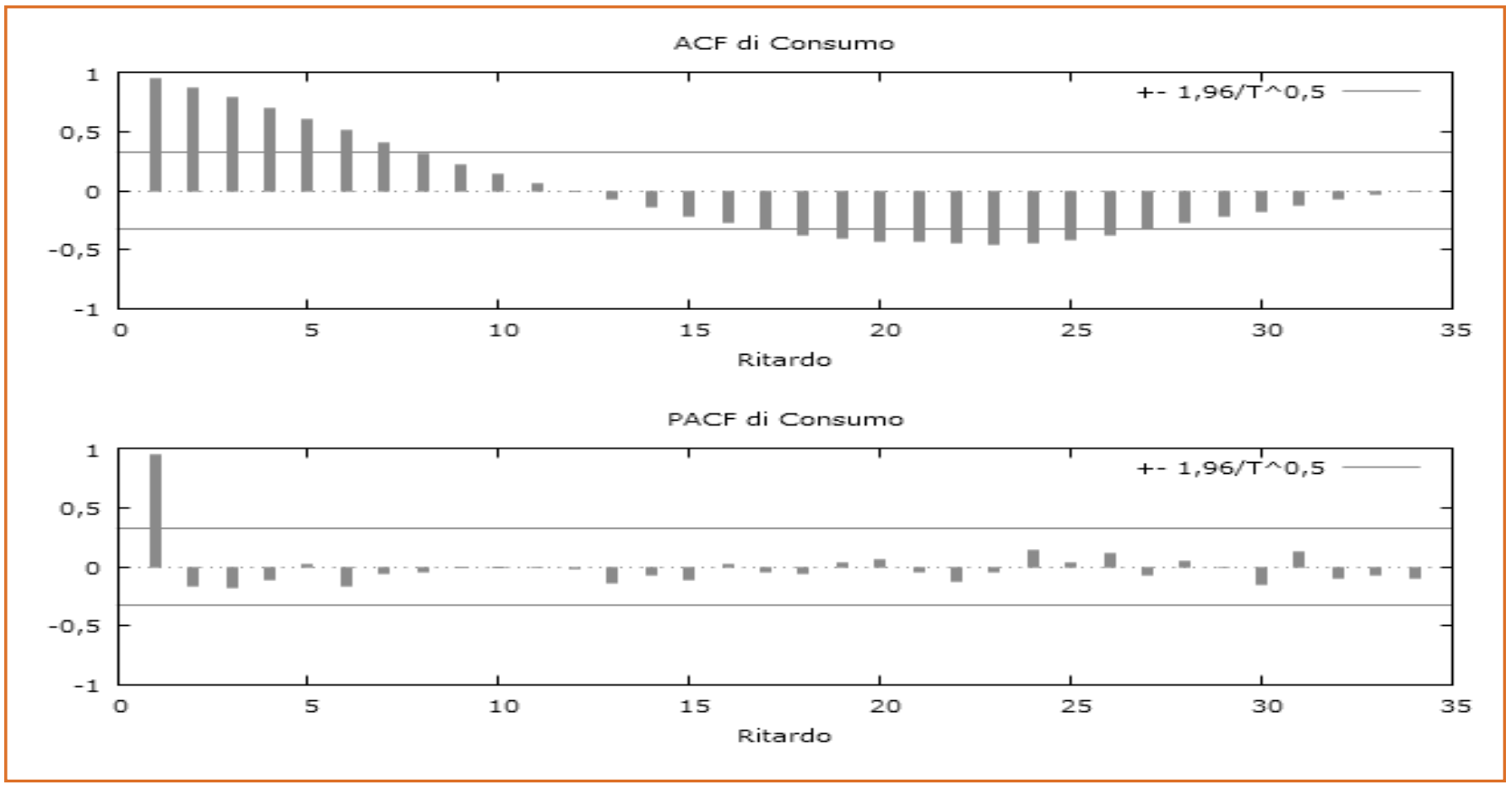


Figura 04 - Gráfico da função de autocorrelação (FAC) da segunda diferenciação

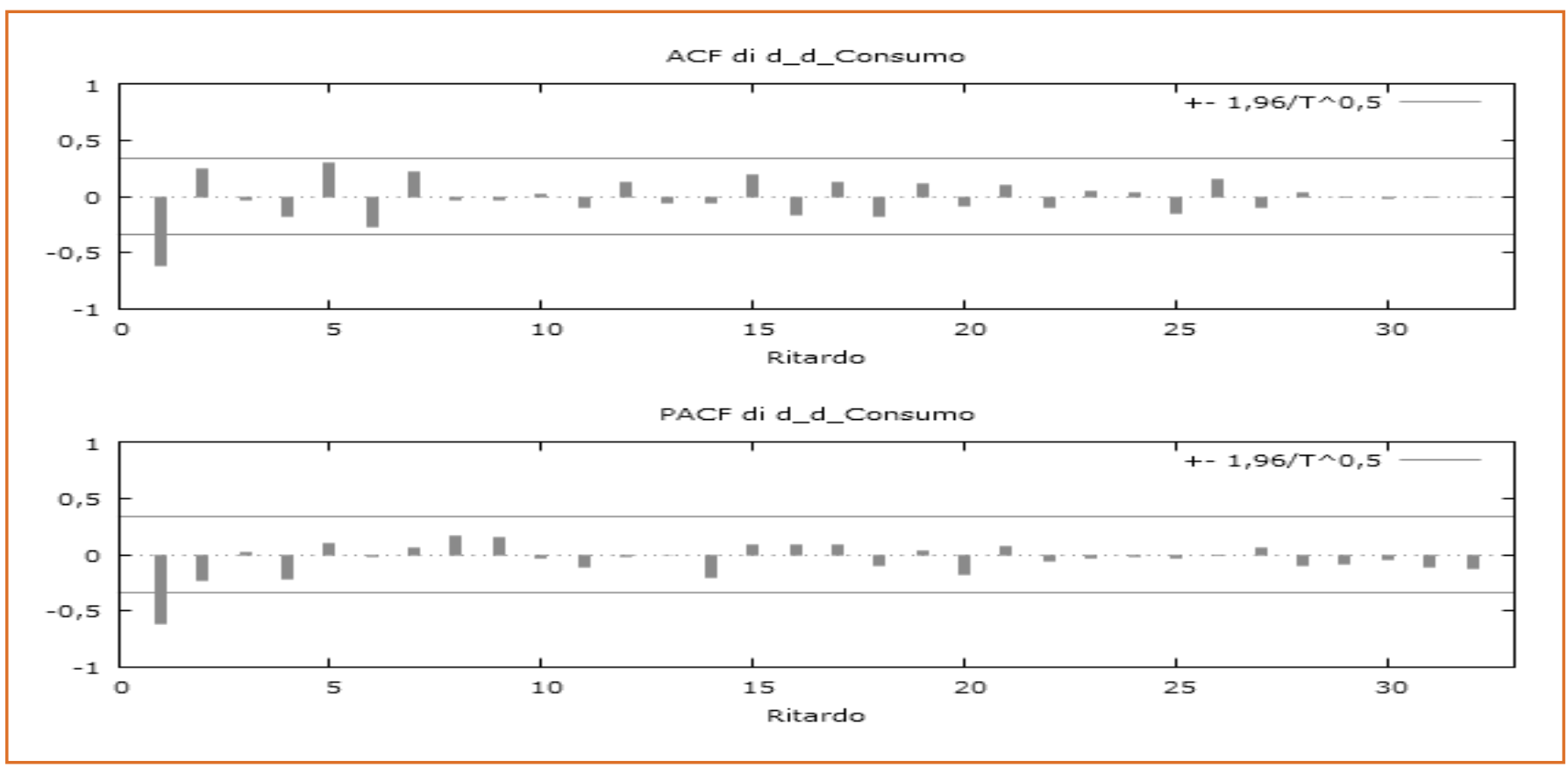

A partir da análise nas funções de autocorrelação e autocorrelação parcial da segunda diferenciação identificaram-se os possíveis valores para $A R(p)$ e $M A(q)$. Logo, foram testados cinco modelos com valores próximos aos selecionados. A figura 05 demonstra a comparação dos modelos entre os critérios adotados neste estudo.

Tabela 01 - Modelos ARIMA propostos

\begin{tabular}{|l|l|l|l|l|}
\hline \multicolumn{2}{|c}{ Modelo } & AIC & HQC & $\begin{array}{l}\text { Erro } \\
\text { Padrão }\end{array}$ \\
\hline ARIMA $(1,2,1)$ & 412,31 & 416,80 & 413,81 & 112,99 \\
\hline ARIMA $(1,2,0)$ & 415,55 & 412,56 & 413,56 & 117,25 \\
\hline ARIMA (1,2,2) & 414,30 & 420,28 & 416,32 & 112,98 \\
\hline ARIMA $(0,2,2)$ & 412,66 & 417,15 & 414,16 & 113,58 \\
\hline ARIMA $(0,2,1)$ & 412,40 & 415,39 & 413,40 & 116,75 \\
\hline
\end{tabular}

A tabela 01 relaciona os valores dos critérios de comparação e o erro padrão dos modelos propostos, especificados como segue: em vermelho, o menor valor de cada critério; em verde, o segundo menor valor de cada critério. O melhor modelo frente aos critérios adotados é o ARIMA $(0,2,1)$, pois este apresenta p-valor < 0,05 para todos os seus coeficientes, e menor número de critérios.

\subsection{AVALIAÇÃO DO DIAGNÓSTICO}

O modelo proposto ARIMA $(0,2,1)$ para a série em estudo mostrou-se adequado, pois seus resíduos apresentaram-se como normalmente distribuídos (figura 06) e não correlacionados (TEODORO, 2015). Pela análise gráfica da FAC e FACP (figura 05) constatase que nenhum lag apresentou valores significativos, indicando independência dos erros, o que comprova a adequação do modelo à série. 
Figura 05 - Função de autocorrelação (FAC) e autocorrelação parcial (FACP) dos resíduos do modelo ARIMA $(0,2,1)$ para as séries de dados em estudo

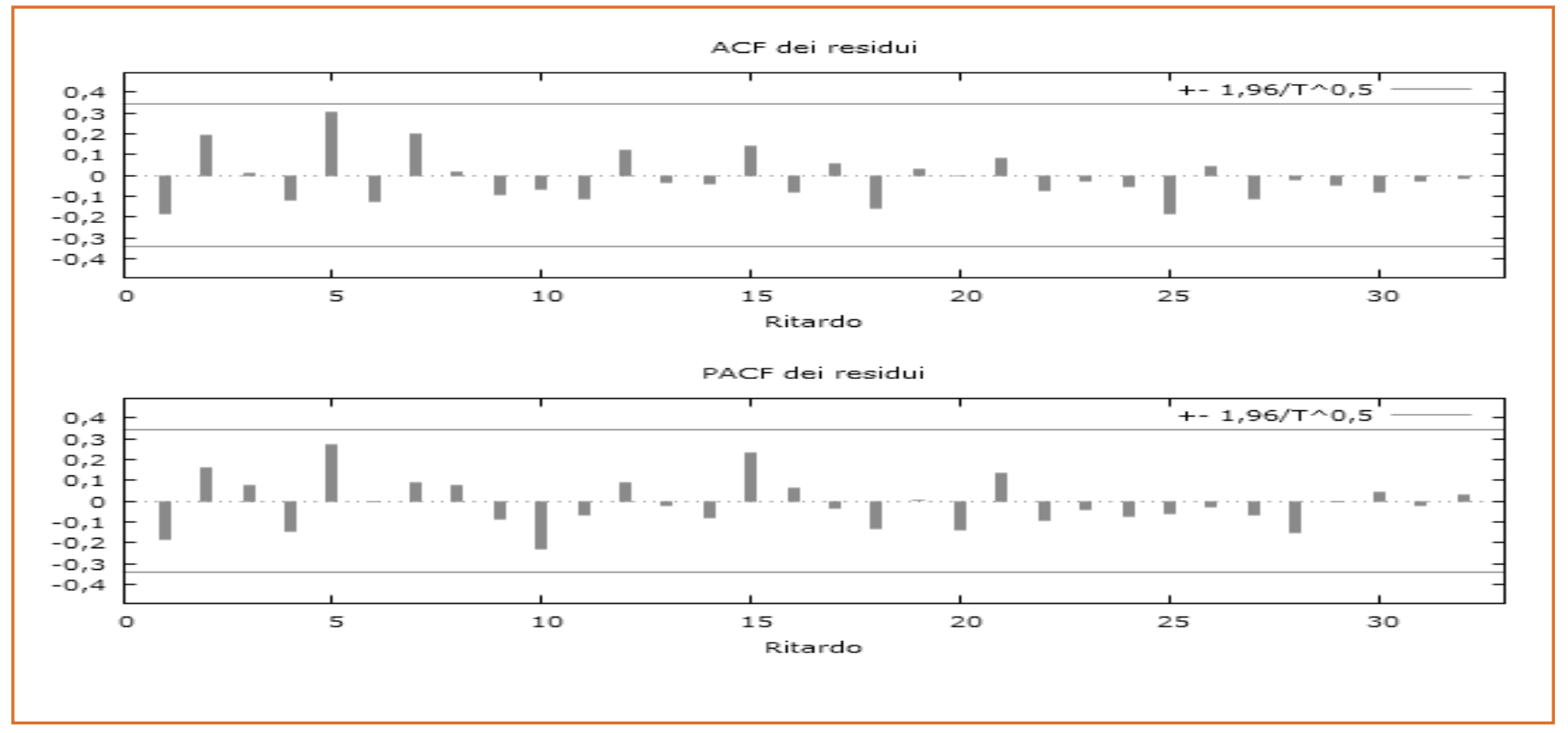

Figura 06 - Gráfico da distribuição normal dos resíduos do modelo ARIMA $(0,2,1)$ para as séries de dados em estudo

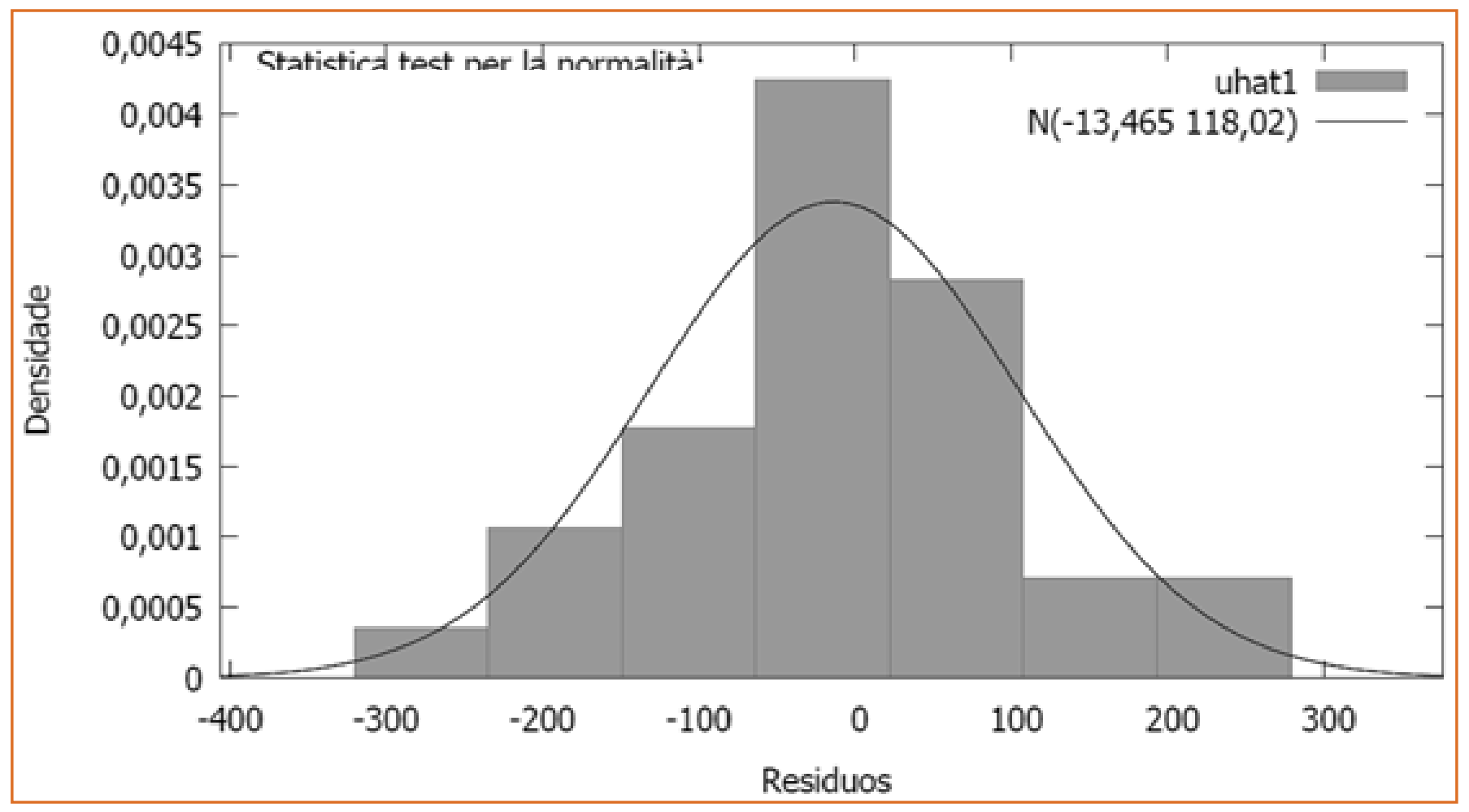

\subsection{PREVISÃO}

A tabela 02 contém os valores previstos para o período 2015-2020 e a figura 07 o respectivo gráfico para o modelo escolhido. 
Tabela 02 - Valores previstos para o período 2015-2020

\begin{tabular}{|l|l|l|l|l|} 
Periodo & \multicolumn{3}{l}{$\begin{array}{l}\text { Consumo } \\
\text { (bilhões de }\end{array}$} & \multicolumn{3}{l}{$\begin{array}{l}\text { Erro } \\
\text { pés cúbicos) }\end{array}$} & \multicolumn{3}{c|}{ Intervalo (95\%) } \\
\hline 2015 & 2022,34 & 116,75 & 1793,53 & 2251,16 \\
\hline 2016 & 1858,69 & 194,62 & 1477,23 & 2240,15 \\
\hline 2017 & 1695,03 & 257,29 & 1155,47 & 2234,60 \\
\hline 2018 & 1531,72 & 361,09 & 823,65 & 2239,11 \\
\hline 2019 & 1367,72 & 452,46 & 480,91 & 2254,53 \\
\hline 2020 & 1204,07 & 549,39 & 127,28 & 2280,85 \\
\hline
\end{tabular}

Figura 07 - Valores previstos para o período 2015-2020 em bilhões de pés cúbicos

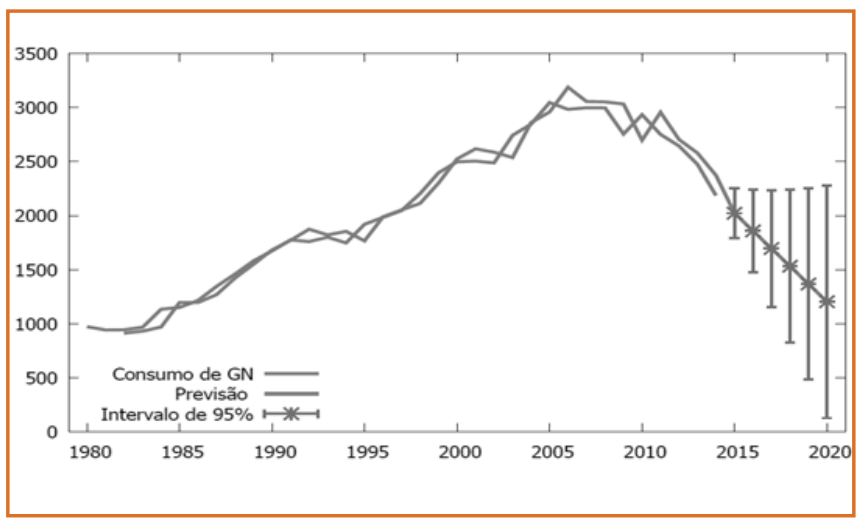

De acordo com dados da EIA (2013), a produção de GN na Europa apresentará queda entre os anos de 2015 e 2030, dados que convergem com os resultados aqui apresentados. A crise entre a Rússia e a Ucrânia prejudicou a distribuição do GN em, praticamente, toda a Europa, sendo os países com alto índice de dependência energética os mais prejudicados.

A Itália apresenta $86 \%$ de dependência energética internacional e 40,4\% da sua matriz energética é composta pelo GN (ENERDATA, 2011), logo se configura como um país altamente vulnerável a escassez de tal fonte de energia. A crise na Líbia também se apresenta como risco potencial no fornecimento de GN para a Itália.

\section{CONCLUSÃO}

O presente trabalho teve como objetivo a previsão do consumo italiano de GN entre os anos de 2015 e 2020 a partir da utilização da metodologia Box-Jenkins (ARIMA). O modelo proposto, ARIMA $(0,2,1)$, mostrou- se eficiente para o problema referido.

A perceptível queda do consumo de GN indicada pela previsão é consonante com previsões de agências internacionais especializadas (EIA, ENERDATA), comprovando a eficiência do modelo proposto.

A utilização de modelos de previsão a partir de séries temporais vem sendo amplamente divulgada por inúmeras áreas de estudo, seja para a gestão epidemiológica, com a predição de casos de doenças, seja para a gestão empresarial, com a previsão de vendas de um produto.

Esta característica interdisciplinar torna a utilização de modelos de previsão uma ótima ferramenta de auxílio em processos de tomadas de decisões. A complexidade matemática dos modelos torna-se insignificante devido ao avanço tecnológico, sobretudo da informática, já que modelos podem ser resolvidos muito mais rapidamente.

Como sugestão para pesquisas futuras, propõe-se a utilização de outras metodologias de previsão para séries temporais, como os modelos de Holt-Winters aditivo e/ou multiplicativo, e modelos de suavização exponencial.

\section{REFERÊNCIAS}

[1] EIA - U.S. Energy Information Administration. International Energy Outlook 2013: with Projections to 2040., 2013.

[2] ENERDATA. Ministero dello Sviluppo Economico. Disponível em: <http://www.sviluppoecono mico.gov.it/>. Acesso em: 14 mar 2014.

[3] FERREIRA, R.S. Desenvolvimento de materiais poliméricos uretânicos para purificação de gás natural: remoção de mercúrio e compostos à base de enxofre. Dissertação (Mestrado em Química) UFPR, Curitiba, 2006.

[4] FIGUEREDO, C. J. Previsões de séries temporais utilizando a metodologia Box-Jenkins e Redes Neurais para inicialização de Planejamento e Controle da Produção. 176 f. 2008. Dissertação (Mestrado em Ciências), Universidade Federal do Paraná, Curitiba, 2008.

[5] FIOREZE, M. et al. Gás natural: potencialidades de utilização no Brasil. Revista Eletrônica em Gestão, Educação e Tecnologia Ambiental, v. 10., n.10., p. 2251-2265, 2013. 
[6] GOMES, F.C. Os modelos Arima e a abordagem de Box-Jenkins uma aplicação na previsão do IBOVESPA a curtíssimo prazo. Rev. adm. empres., v. 29, n. 2, p. 6370, June 1989.

[7] MARANHÃO, R. A importância do gás natural. Rio de Janeiro. IE-UFRJ, IFES no 1.367, 2004.

[8] MILESKI JUNIOR, A. Análise de métodos de previsão de demanda baseados em séries temporais em uma empresa do setor de perfumes e cosméticos. 100 f. 2007. Dissertação (Mestrado em Engenharia de Produção e Sistemas), Pontifícia Universidade Católica do Paraná, 2007.

[9] MURTEIRA, B.J.F.; MULLER, D.A.; TURKMAN, K.F. Análise de Sucessões Cronológicas: McGraw-Hill, 1993.

[10] PARO, A.C. Estudo da contribuição do gás natural no setor elétrico - uma análise de cenários de sua expansão nos setores de geração termelétrica, cogeração e residencial. Dissertação (Mestrado em Engenharia Elétrica), Universidade de São Paulo, 2005.
[11] PINTO, P.A.L.A. et al. Aplicação do modelo ARIMA à previsão do preço das commodities agrícolas brasileiras. Anais do XLVI Congresso da Sociedade Brasileira de Economia, Administraçao e Sociologia Rural, Rio Branco AC, 2008.

[12] RIBEIRO, L. C.; PAULA, A.V. Previsão de população através dos modelos arima de Box e Jenkins: um exercício para Brasil. Anais do Encontro Nacional de Estudos Populacionais, 2000.

[13] SATO, R. C. Gerenciamento de doenças utilizando séries temporais com o modelo ARIMA. Einstein, v. 11, n. 1, p. 128-131, 2013.

[14] TEODORO, V.A. Modelos de séries temporais para temperatura em painéis de cimento-madeira. 96 f. 2015. Dissertação (Mestrado em Ciências), Universidade de São Paulo, Piracicaba, 2015. 


\section{CAPÍTULO 10}

\section{MÉTODOS DE DEGISÃO MULTICRITÉRIO APLICADOS NO}

DESENVOLVIMENTO DE NOVOS PRODUTOS: UMA ABORDAGEM TEÓRICA

\section{Ana Caroline Dzulinski}

\section{Aldo Braghini Junior}

Resumo: Este artigo tem como objetivo expor um quadro teórico sobre os principais assuntos publicados nos últimos anos que relacionam o Desenvolvimento de Novos Produtos (DNP) com Métodos Multicritério Aplicados a Decisão (MMAD) e desta forma identificar novas oportunidades de pesquisas na área. A metodologia aplicada para atender o objetivo foi a pesquisa através de uma Revisão Bibliográfica Sistemática (RBS) proposta por Kitchenham. Como resultado foram identificados 18 artigos, e sugeridas como conclusão as seguintes propostas de pesquisas futuras: utilização de ferramentas multicritério para priorização de atividades na criação de modelos de PDP, métodos multicritério aplicados na decisão de critérios a serem priorizados no PDP e aplicação de ferramentas multicritério objetivando a criação ou melhoria de modelos de PDP.

Palavras Chave: Desenvolvimento de novos produtos, Métodos de decisão multicritério, Revisão bibliográfica sistemática 


\section{INTRODUÇÃO}

Um projeto, segundo o guia PMBOK® (2014), é o conjunto de ações empregadas durante um determinado tempo para a criação de um produto, serviço ou resultado único, sendo o seu gerenciamento composto por cinco grupos de fases principais: iniciação, planejamento, execução, monitoramento e encerramento. O desenvolvimento de um produto trata-se, portanto, de um projeto sendo composto por fases distintas de execução, e consequentemente, por fases e atividades próprias de gerenciamento para cada fase.

Rozenfeld et al. (2010) define que o desenvolvimento de produtos é composto por atividades, onde são consideradas as necessidades do mercado, restrições tecnológicas, estratégias competitivas de produto e da empresa, buscando atender às especificações do projeto do produto e de seu respectivo processo produtivo. Em adição, Ulrich e Eppinger (2012) definem o desenvolvimento de produtos como um conjunto de atividades que iniciam no reconhecimento da oportunidade de mercado, e encerram após a produção com a venda e entrega do produto.

Visto que o desenvolvimento de produtos envolve atividades de execução em diferentes níveis, é evidente que ações de decisão estão inclusas neste processo. Cooper (2008) deixa claro em seu modelo de NPD (New Product Develompent - Desenvolvimento de Novos Produtos) que ao final de cada fase de desenvolvimento há uma etapa de decisão sobre a continuidade do projeto, denominada stage-gate, onde são analisados fatores críticos para a continuidade do projeto. Ações de decisão entre fases são encontradas também em outros modelos de Desenvolvimento de Novos Produtos (DNP), como o de Clark e Fujimoto (1991), e Ulrich e Eppinger (2012).

Desta forma pode-se afirmar que atividades de decisão não somente estão inclusas no processo de DNP, como são intrínsecas, entretanto, questiona-se como são solucionados os problemas envoltos nesta relação. Atividades de decisão podem ser estudadas em diversos aspectos, e de maneira a restringir a pesquisa exposta no presente artigo, optou-se em buscar de maneira mais detalhada a relação entre os dois assuntos em função dos Métodos de Multicritério de Apoio a Decisão (MMAD). Os métodos de decisão multicritério são ferramentas que auxiliam na tomada de decisão, e geralmente são utilizados quando o nível de complexidade envolvido é alto, ou seja, está relacionado a inúmeras variáveis que interferem na decisão, que não permitem uma escolha rápida e que garanta atender as expectativas do decisor.

O objetivo do presente artigo é, portanto, expor um quadro teórico sobre os principais assuntos publicados nos últimos anos que relacionam o DNP com MMAD e desta forma identificar novas oportunidades de pesquisas na área. No próximo tópico é apresentada a metodologia utilizada para alcançar o objetivo proposto, no tópico 3 e 4 encontra-se o referencial teórico sobre os principais assuntos abordados no artigo, no tópico 5 estão expostos os resultados obtidos através da metodologia e no tópico 6 as conclusões obtidas com o estudo.

\section{METODOLOGIA}

Para atender o objetivo do estudo foi utilizada a metodologia de pesquisa bibliográfica denominada de Referencial Bibliográfico Sistemático (RBS) proposto por Kitchenham (2004). Esse método, segundo a autora, é viável para avaliação e interpretação de todas as pesquisas disponíveis relevantes para uma questão de pesquisa específica, área temática ou fenômeno de interesse.

A RBS é estruturada em três fases fundamentais: planejamento, realização e relato dos resultados. As fases realizadas para o presente estudo são apresentadas nos próximos tópicos.

\subsection{PLANEJAMENTO DA RBS}

No Quadro 1 a seguir estão descritos os dados necessários para a referida fase do levantamento. 
Quadro 1 - Dados para planejamento do referêncial bibliográfico sistemático

\begin{tabular}{|c|c|}
\hline Objetivo da revisão & $\begin{array}{l}\text { Levantar estudos que abordem os temas de desenvolvimento de produtos e métodos } \\
\text { multicritério de apoio a decisão }\end{array}$ \\
\hline \multirow{4}{*}{$\begin{array}{l}\text { Fontes para identificação de estudos } \\
\text { primários }\end{array}$} & Materiais consultados: Periódicos \\
\hline & Bases de dados consultadas: Science Direct, Web of Science e Scopus \\
\hline & Palavras-chave: New Product Development; Multricriteria Decision Analysis \\
\hline & Período: 2005 - 2015 \\
\hline $\begin{array}{l}\text { Avaliação da qualidade dos dados } \\
\text { filtrados }\end{array}$ & Artigos de periódicos com avaliação Qualis A1, A2 e B1 \\
\hline Critérios de inclusão/exclusão & $\begin{array}{l}\text { Filtro 1: Artigos com a palavra-chave "product" no título; } \\
\text { Filtro 2:Artigos com a palavra-chave "Multricriteria Decision Analysis" no resumo; } \\
\text { Filtro 3: Leitura do resumo para seleção apenas de artigos que apontam a relação entre os } \\
\text { dois assuntos do objetivo da revisão }\end{array}$ \\
\hline
\end{tabular}

\subsection{REALIZAÇÃO DA RBS}

No levantamento realizado diretamente nas bases de dados, foram considerados para filtro o período de publicação e as palavras-chave. Nesse primeiro levantamento foram registados 5094 artigos, sendo que todos foram listados em planilhas eletrônicas com todas as informações disponíveis através das bases de dados.

Através da listagem foram removidos artigos duplicados, o que resultou em 5046 artigos. O próximo filtro foi aplicado, onde foram selecionados apenas os que são qualificados como A2, A1 e B1 pela última atualização da Qualis, resultando em 3291 artigos. Com os artigos resultantes foram buscados os que apresentavam a palavra product (produto) no título, obtendo-se 262 artigos. Nestes, foi realizado o último filtro direto onde foram buscados artigos que contivessem a palavra Multicriteria Decision Anlysis no resumo, e que fosse clara a relação dessa palavrachave com o desenvolvimento de produtos, finalizando a busca em 18 artigos relevantes ao objetivo da RBS.

\subsection{RESULTADO DA RBS}

No Quadro 2 estão listados os artigos resultantes da RBS. A descrição detalhada dos artigos e o quadro teórico estão expostos no tópico 5.

Quadro 22 - Artigos resultantes da RBS

\begin{tabular}{|c|c|c|c|c|}
\hline Ano & Autores & Título & Periódico & Qualis \\
\hline 2015 & Wang, Xiaojun & $\begin{array}{l}\text { A case study of an integrated fuzzy methodology for green } \\
\text { product development }\end{array}$ & $\begin{array}{l}\text { European Journal of } \\
\text { Operational Research }\end{array}$ & $\mathrm{A} 1$ \\
\hline 2014 & $\begin{array}{l}\text { Selim Zaim, Mehmet } \\
\text { Sevkli, Hatice } \\
\text { Camgöz-Akda, Omer } \\
\text { F. Demirel, A. Yesim } \\
\text { Yayla, Dursun Delen }\end{array}$ & $\begin{array}{l}\text { Use of }\{A N P\} \text { weighted crisp and fuzzy }\{Q F D\} \text { for product } \\
\text { development }\end{array}$ & $\begin{array}{l}\text { Expert Systems with } \\
\text { Applications' }\end{array}$ & A2 \\
\hline 2014 & $\begin{array}{l}\text { S. Vinodh, V. } \\
\text { Kamala, K. } \\
\text { Jayakrishna }\end{array}$ & $\begin{array}{l}\text { Integration of ECQFD, TRIZ, and }\{A H P\} \text { for innovative and } \\
\text { sustainable product development }\end{array}$ & $\begin{array}{l}\text { Applied Mathematical } \\
\text { Modelling }\end{array}$ & A2 \\
\hline 2013 & $\begin{array}{l}\text { H. Shidpour, M. } \\
\text { Shahrokhi, A. } \\
\text { Bernard }\end{array}$ & $\begin{array}{l}\text { A multi-objective programming approach, integrated into the } \\
\text { \{TOPSIS\} method, in order to optimize product design; in } \\
\text { three-dimensional concurrent engineering }\end{array}$ & $\begin{array}{l}\text { Computers \& Industrial } \\
\text { Engineering }\end{array}$ & $\mathrm{A} 2$ \\
\hline
\end{tabular}




\begin{tabular}{|c|c|c|c|c|}
\hline Ano & Autores & Título & Periódico & Qualis \\
\hline 2012 & Yan, H.-B. & $\begin{array}{l}\text { A fuzzy linguistic go/no-go decision model in new } \\
\text { product development }\end{array}$ & $\begin{array}{l}\text { Advanced Materials } \\
\text { Research }\end{array}$ & A1 \\
\hline 2011 & $\begin{array}{l}\text { Huynh, } \quad \text { VN; } \\
\text { Nakamori, Y }\end{array}$ & $\begin{array}{l}\text { A Linguistic Screening Evaluation Model in New } \\
\text { Product Development }\end{array}$ & $\begin{array}{lr}\text { leee } & \text { Transactions } \\
\text { on } & \text { Engineering } \\
\text { Management }\end{array}$ & B1 \\
\hline 2011 & $\begin{array}{l}\text { Lu, J; Ma, J; } \\
\text { Zhang, GQ; Zhu, } \\
\text { YJ; Zeng, XY; } \\
\text { Koehl, L }\end{array}$ & $\begin{array}{l}\text { Theme-Based Comprehensive Evaluation in New } \\
\text { Product Development Using Fuzzy Hierarchical } \\
\text { Criteria Group Decision-Making Method }\end{array}$ & $\begin{array}{lr}\text { leee } & \text { Transactions } \\
\text { on } & \text { Engineering } \\
\text { Management }\end{array}$ & A1 \\
\hline 2011 & $\begin{array}{l}\text { Chiu-Chi Wei, } \\
\mathrm{H} \text { o u n - W e n } \\
\text { Chang }\end{array}$ & $\begin{array}{l}\text { A new approach for selecting portfolio of new } \\
\text { product development projects }\end{array}$ & $\begin{array}{l}\text { Expert Systems with } \\
\text { Applications }\end{array}$ & A2 \\
\hline 2011 & Chin-Nung Liao & $\begin{array}{l}\text { Fuzzy analytical hierarchy process and multi- } \\
\text { segment goal programming applied to new } \\
\text { product segmented under price strategy }\end{array}$ & $\begin{array}{l}\text { Computers \& Industrial } \\
\text { Engineering }\end{array}$ & A2 \\
\hline 2011 & Hao-Tien Liu & $\begin{array}{l}\text { Product design and selection using fuzzy }\{Q F D\} \\
\text { and fuzzy }\{M C D M\} \text { approaches }\end{array}$ & $\begin{array}{l}\text { Applied Mathematical } \\
\text { Modelling }\end{array}$ & A2 \\
\hline 2009 & $\begin{array}{l}\text { H.S. Wang, Z.H. } \\
\text { Che, M.J. Wang }\end{array}$ & $\begin{array}{l}\text { A three-phase integrated model for product } \\
\text { configuration change problems }\end{array}$ & $\begin{array}{l}\text { Expert Systems with } \\
\text { Applications }\end{array}$ & $\mathrm{A} 2$ \\
\hline 2008 & $\begin{array}{l}\text { Ying-Ming Wang, } \\
\text { Kwai-Sang Chin }\end{array}$ & $\begin{array}{l}\text { A linear goal programming priority method for fuzzy } \\
\text { analytic hierarchy process and its applications in } \\
\text { new product screening }\end{array}$ & $\begin{array}{l}\text { International Journal } \\
\text { of Approximate } \\
\text { Reasoning }\end{array}$ & A2 \\
\hline 2008 & $\begin{array}{l}\text { Kwai-Sang Chin, } \\
\text { Dong-ling Xu, } \\
\text { Jian-Bo Yang, } \\
\text { James } \quad \text { Ping-Kit } \\
\text { Lam }\end{array}$ & $\begin{array}{l}\text { Group-based ER-AHP system for product project } \\
\text { screening }\end{array}$ & $\begin{array}{l}\text { Expert Systems with } \\
\text { Applications }\end{array}$ & $\mathrm{A} 2$ \\
\hline 2007 & $\begin{array}{l}\text { Gheorghe, R; } \\
\text { Xirouchakis, P }\end{array}$ & $\begin{array}{l}\text { Decision-based methods for early phase } \\
\text { sustainable product design }\end{array}$ & $\begin{array}{l}\text { International Journal of } \\
\text { Engineering Education }\end{array}$ & B1 \\
\hline 2006 & $\begin{array}{l}\text { Yi-Chia Chiu, } \\
\text { Benson Chen, } \\
\text { Joseph Z. Shyu, } \\
\text { Gwo-Hshiung } \\
\text { Tzeng }\end{array}$ & $\begin{array}{l}\text { An evaluation model of new product launch } \\
\text { strategy }\end{array}$ & Technovation & A1 \\
\hline 2004 & $\begin{array}{l}\text { Lin, CT; Chen, } \\
\text { CT }\end{array}$ & $\begin{array}{l}\text { New product Go/No-Go evaluation at the front } \\
\text { end: A fuzzy linguistic approach }\end{array}$ & $\begin{array}{lr}\text { leee } & \text { Transactions } \\
\text { on } & \text { Engineering } \\
\text { Management }\end{array}$ & B1 \\
\hline 2004 & $\begin{array}{l}\text { G ü I ç i n } \\
\text { Büyük özkan, } \\
\text { Orhan Feyzıglu }\end{array}$ & $\begin{array}{l}\text { A fuzzy-logic-based decision-making approach } \\
\text { for new product development }\end{array}$ & $\begin{array}{l}\text { International Journal of } \\
\text { Production Economics }\end{array}$ & A1 \\
\hline
\end{tabular}




\section{DESENVOLVIMENTO DE NOVOS PRODUTOS}

Em países em desenvolvimento como o Brasil, o PDP caracteriza-se na maioria dos casos como a consolidação de competências locais para adaptação de projetos mundiais participando de atividades especificas destes projetos. No caso de empresas multinacionais, pode haver a responsabilidade por etapas do desenvolvimento e fornecimento global do produto em função da capacidade de manufatura. Há ainda uma terceira característica do PDP, que é realizado por empresas globais onde cada filial é responsável pelo desenvolvimento de produto em função de suas capacidades tecnológicas e de manufatura (ROZENFELD et al. 2010).

Os estudos e modelos desenvolvidos sobre DNP ou PDP tem seguido basicamente três linhas de pensamento: a linear, a recursiva e a caótica. Os modelos lineares são os métodos mais tradicionais e lógicos da gestão do projeto focando nas saídas de cada atividade em relação ao tempo e custo, um exemplo desse modelo é o Stage-gatel $\circledast$ de Cooper. As linhas de pensamento recursiva e caótica referem-se aos processos de desenvolvimento onde há grandes inovações. Os modelos recursivos apresentam eventos em que uma atividade pode ser múltipla, concorrente e divergente e o processo inclui fead-back e loop de realimentação de informações. A linha de pensamento caótica referese ao modelo de processo que inicia com atividades não definidas vinculadas a inovação e finaliza-se com atividades semelhantes ao modelo linear (MCCARTHY et al., 2006).

Os modelos lineares são os mais difundidos e são o foco da pesquisa aqui exposta. Neste contexto, o desenvolvimento de produtos é um processo de negócio que está se tornando cada vez mais crítico em relação a competitividade, e essa característica está relacionada com a internacionalização de mercados, consequente aumento de diversidade $e$ variedade de produtos, e a redução do ciclo de vida. O Processo de Desenvolvimento de Produtos (PDP) possui, neste aspecto, papel estratégico relevante buscando identificar as necessidades do mercado e dos clientes, as possibilidades tecnológicas, busca o desenvolvimento em tempo adequado e um custo competitivo (ROZENFELD et al.2010).

Segundo Ulrich e Eppinger (2012), o PDP é uma sequência de etapas ou atividades que uma organização utiliza para conceber, projetar e comercializar um produto, sendo a maioria dessas atividades de cunho intelectual e organizacional. Segundo os autores, um PDP bem definido é viável por garantir a qualidade, pela coordenação que exige, pelo planejamento necessário, pela gestão e melhorias que podem ser alcançadas.

Os modelos de PDP seguem, portanto, fases sequenciais de atividades. OStage-gate $₫$ por exemplo, considera quatro fases principais de desenvolvimento: Desenvolvimento do conceito do produto, projeto do produto, teste e validação e lançamento do produto. Já o modelo de Ulrich e Eppinger (2012) considera seis fases: planejamento, desenvolvimento do conceito, projeto sistêmico, projeto detalhado, testes e melhorias, e produção inicial.

Independentemente do modelo de PDP a ser considerado, é notável que em todos as ações de decisão são necessárias, sejam elas para definição de atividades, ou para decidir sobre planos de continuidade do projeto. Para que possa ser feita a análise da relação do PDP com MMAD, no tópico seguinte serão sintetizados os principais conceitos sobre decisão multicritério.

\section{MÉTODOS DE DECISÃO MULTICRITÉRIO}

Os métodos de decisão multicritério são voltados à avaliação de um conjunto de possíveis ações ou alternativas potenciais, sendo que a avaliação pode estar direcionada a diferentes formas: seleção de uma alternativa preferida, ordenação das alternativas da melhor para a pior, classificação das alternativas em grupos distintos, entre outros (ROY e VINCKE, 1981). Todos os métodos, entretanto, possuem como semelhança a ideia de que a maioria das decisões pode apresentar um melhor resultado se houver a decomposição da avaliação global das alternativas através de critérios relevantes ao problema em análise (EHRGOTT, FIGUEIRA e GRECO, 2010). 
Roy e Vincke (1981) enfatizam que os métodos de decisão multicritério são embasados em modelos constituídos, em parte, de hipóteses matemáticas necessariamente restritivas, mas também são consideradas as informações subjetivas advindas do decisor. Quando se analisa qual método multicritério pode ser utilizado, além de ser necessário identificar se trata-se de ordenação, classificação ou seleção, deve ser observado se os critérios envolvidos são compensatórios ou não. Critérios compensatórios são aqueles que aumentam a medida que outro diminui, em contrapartida, os não compensatórios não admitem nenhuma forma de compensação (GUITOUNI e MARTEL, 1998)

Os principais métodos multicritério utilizados, segundo Guitouni e Martel (1998) são:

- MAUT (Multiattribute Utility Theory) ou MAVT (Multiattribute Value Theory): método utilizado em problemas de seleção, denominados problemas de critério único de síntese;

- AHP (Aalytic Hierachy Process): também é um método que busca a seleção da melhor alternativa, entretanto, utiliza-se de comparações aos pares para avaliar a decisão e cria níveis hierárquicos entre as alternativas;

- ELECTRE (Elimination Et Choix Traduisant la Réalité): Família de métodos multicritério os quais podem ser tanto de escolha, quando de ordenação e classificação.

- PROMETHEE (Preference Ranking Organization Method for Enrichment Evaluations): Possui os mesmos princípios do ELECTRE e introduz seis funções para descrever a preferência do decisor de acordo com cada critério;

Com base nos conceitos básicos ilustrados, no tópico a seguir serão expostos os resultados encontrados através da RBS.

\section{RESULTADOS}

Foi possível identificar que um dos pontos abordados na relação entre DNP e métodos multicritério é direcionado às decisões com aspecto sustentável ou ambiental. No artigo de Xiaojun (2015), o método multicritério é direcionado para avaliação de desempenho ambiental de diferentes produtos, levando em consideração a análise de ciclo de vida de cada um. A pesquisa de Vinodh, Kamala e Jayakrishna (2014) é voltada a proposta de um modelo que integra ferramentas utilizadas no DNP com o método AHP objetivando um desenvolvimento inovador $\mathrm{e}$ sustentável de componentes automotivos. Gheorghe e Xirouchakis (2007) propõem um método de avaliação dos projetos de produtos no estágio inicial, e através de um estudo de caso selecionam a melhor opção de projeto considerando os aspectos de sustentabilidade.

A ferramenta de QFD (Quality Function DeploymentDesdobramento Função Qualidade) foi um aspecto em comum de alguns artigos. Zaim et al. (2014) utilizam o método multicritério para obter as melhores características técnicas de classificação de um produto e serviço durante a implementação do QFD. A ferramenta de DNP utilizada na pesquisa de Vinodh, Kamala e Jayakrishna (2014), já citada no contexto de sustentabilidade, é o QFD. Liu (2011) em seu estudo integra o uso do QFD e o modelo de seleção (multicritério) de produtos para desenvolver uma abordagem de seleção e projeto de produto.

Métodos multicritério são utilizados no DNP na escolha de fornecedores para compor a cadeia de suprimentos, o que foi constatado no estudo de Shidpour, Shahrokhi e Bernard (2013). Nesse contexto, Wang, Che e Wang (2009) desenvolveram um modelo que objetiva encontrar as melhores estratégias para mudança de configuração dos produtos, de modo a selecionar a combinação adequada para fornecedores de peças.

Os demais estudos utilizam os métodos multicritério em fases ou atividades especificas do processo de desenvolvimento, ou para auxílio na decisão entre projetos de produto. Nota-se que os métodos estão relacionados com a preocupação em tomadas de decisão nos momentos críticos onde incorrem riscos e incertezas de projeto. Os riscos podem ocorrer tanto em fases iniciais de desenvolvimento, quanto em fases de lançamento do produto. 
Liao (2011) utiliza MMAD para selecionar a melhor estratégia de preço no desenvolvimento de um novo produto. O custo pode ser tratado como um critério para tomada de decisão, assim como tempo, número de envolvidos e treinamento necessário, portanto, os demais critérios podem ser utilizados para novos modelos de decisão entre melhores projetos.

Com base nos resultados encontrados, no próximo tópico serão levantadas as conclusões obtidas com a pesquisa.

\section{CONCLUSÕES}

Após a análise dos artigos resultantes da RBS observou-se que as pesquisas estão direcionadas para pontos específicos, ou ainda, em atividades e critérios específicos no PDP. Logo, tendo em vista as etapas dos processos e os modelos de PDP, foram levantadas as seguintes oportunidades de pesquisa:

- Utilização de ferramentas multicritério para priorização de atividades na criação de modelos de PDP;

- Métodos multicritério aplicados na decisão de critérios a serem priorizados no PDP;

- Aplicação de ferramentas multicritério objetivando a criação ou melhoria de modelos de PDP.

\section{AGRADECIMENTOS}

Os autores agradecem pelo auxílio concedido pela CAPES e pela Fundação Araucária através da bolsa e complementos.

\section{REFERÊNCIAS}

[1] BÜYÜKÖZKAN, G.; FEYZIOG $\square L U, \quad$ O. A fuzzylogic-based decision-making approach for new product development, International Journal of Production Economics, v. 90 (1), p. 27-45, 2004.

[2] CHIN, K.; XU, D.; YANG, J.; LAM, J. P. Group-based ERAHP system for product project screening, Expert Systems with Applications, v. 35 (4), p. 1909-1929, 2008.
[3] CHIU, Y.; CHEN, B.; SHYU, J. Z.; TZENG, G. An evaluation model of new product launch strategy. Technovation, v. 26, p. 1244-1252, 2006.

[4] CLARK, K.; FUJIMOTO, T. Product development performance: strategy organization and management in the world auto industry. Boston: Harvard Business School Press, 1991.

[5] COOPER, R. G. The Stage-Gate Idea-to-Launch Process-Update, What's New and NexGen Systems. Jounal Product Innovation Management, v. 25, n. 3, p. 213-232, Maio 2008.

[6] GUITOUNI, A.; MARTEL, J. M. Tentative guidelines to help choosing an appropriate MCDA method, European Journal of Operational Research, 109 (2), 501-521, 1998. HUYNH, V. N.; YOSHITERU, N. A Linguistic Screening Evaluation Model in New Product Development, Engineering Management, IEEE Transactions, v. 58 (1), p.165-175, 2011.

[7] KITCHENHAM, B. Procedures for performing systematic reviews. Joint Technical Report, Keele University Technical Report and Empirical Software Engineering National ICT Australia Ltd., p. 33, 2004.

[8] LIAO, C. Fuzzy analytical hierarchy process and multi-segment goal programming applied to new product segmented under price strategy, Computers \& Industrial Engineering, v. 61 (3), p. 831-841, 2011.

[9] LIN, C.; CHEN, C. New product go/no-go evaluation at the front end: a fuzzy linguistic approach, Engineering Management, IEEE Transactions, v.51 (2), p.197-207, 2004.

[10] LIU,H. Product design and selection using fuzzy QFD and fuzzy MCDM approaches, Applied Mathematical Modelling, v. 35 (1), p. 482-496, 2011.

[11] LU, J.; MA, J.; ZHANG, G.; ZHU, Y.; ZENG, X.; KOEHL, $\mathrm{L}$. Theme-Based Comprehensive Evaluation in New Product Development Using Fuzzy Hierarchical Criteria Group Decision-Making Method. Industrial Electronics, IEEE Transactions, v. 58 (6), p. 2236-2246, 2011.

[12] MCCARTHY, I. P.; TSINOPOULOS, C.; ALLEN, P.; ROSEANDERSSEN, C. New product development as a complex adaptive system of decisions. Journal of Product Innovation Management, 23(5), 437-456, 2006.

[13] RAZVAN, G.; PAUL, X. Decision-based methods for early phase sustainable product design. International Journal Of Engineering Education, v. 23, p. 1065-1080, 2007.

[14] ROY, B.; VINCKE, P. Multicriteria Analysis: Survey and news directions. European Journal of Operational Research, 8 (3), $207-218,1981$.

[15] ROZENFELD, H.; FORCELLINI, F. A.; AMARAL, D. C.; TOLEDO, J. C.; SILVA, S. L.; ALLIPRANDINI, D. H.; SCALICE, R. K. Gestão de Desenvolvimento de Produtos: uma referência para a melhoria do processo. 1.ed. São Paulo: Saraiva, 2010. 542 p. 
[16] SALVATORE, G.; EHRGOTT, M.; FIGUEIRA, J. R. Trends in Multiple Criteria Decision Analysis. Springer US, v. 1, 2010.

[17] SHIDPOUR, H.; SHAHROKHI, M.; BERNARD, A. A multiobjective programming approach, integrated into the TOPSIS method, in order to optimize product design; in threedimensional concurrent engineering, Computers \& Industrial Engineering, v. 64 (4), p. 875-885, 2013.

[18] ULRICH, K. T.; EPPINGER, S. D. Product design and development. 5th ed. Boston: McGraw Hill, c2012. xv, 415 p.

[19] Um guia do conhecimento em gerenciamento de projetos (guia PMBOK $®$ ) / [texto e tradução] Project Management Institute. - 5a. ed. - São Paulo: Saraiva, 2014.

[20] VINODH, S.; KAMALA, V.; JAYAKRISHNA, K. Integration of ECQFD, TRIZ, and AHP for innovative and sustainable product development, Applied Mathematical Modelling, v. 38 (11-12), p. 2758-2770, 2014.

[21] YAN, H. B.; MA, H. B. A Fuzzy Linguistic Go/No-Go Decision Model in New Product Development, Advanced Materials Research, v. 544, p. 121-129, 2012.
[22] ZAIM, S.; SEVKLI, M.; AKDA $\square$, H. C.; DEMIREL, O. F.; YAYLA, A. Y.; DELEN, D.; Use of ANP weighted crisp and fuzzy QFD for product development, Expert Systems with Applications, v. 41 (9), p. 4464-4474, 2014.

[23] WANG, X. A case study of an integrated fuzzy methodology for green product development. European Journal of Operational Research, p. 212 - 223, v. 241 (1), 2015.

[24] WANG, H.S.; CHE, Z.H.; WANG, M.J. A three-phase integrated model for product configuration change problems, Expert Systems with Applications, v. 36 (3), p. 5491-5509, 2009.

[25] WANG, Y.; CHIN, K. A linear goal programming priority method for fuzzy analytic hierarchy process and its applications in new product screening, International Journal of Approximate Reasoning, v. 49 (2), p 451-465; 2008.

[26] WEI, C.; CHANG, H. A new approach for selecting portfolio of new product development projects, Expert Systems with Applications, v. 38 (1), p. 429-434, 2011. 


\section{CAPÍTULO 11}

\section{DESCRIÇÃO DA UTILIZAÇÃO DO SISTEMA DE INFORMAÇÃ̃o}

GERENCIAL PARA RESOLUÇÃO DE PROBLEMAS

\section{EM EMPRESAS DO PIM}

\section{Bruno Mello de Freitas \\ Wesley Gomes Feitosa}

\section{Raimundo Nonato Alves da Silva}

Lidiane de Souza Assante

\section{João Evangelista Neto}

Resumo: Tendo em vista o problema da relevância da informação para a gestão e fomentação do conhecimento nas empresas, o presente artigo tem como objetivo avaliar a importância do Sistema de Informação Gerencial (SIG) na gestão empresarial para resolução de problemas. Em função do processo de constantes mudanças, principalmente no que diz respeito aos avanços da tecnologia atrelada a era da informação, um bom sistema de informações gerenciais será um fator preponderante na tomada de decisão. Aplicação de Inteligência nos negócios através de sistemas de comércio eletrônico, gestão de relacionamento com o cliente, gerenciamento da cadeia de suprimentos, planejamento de recursos da empresa e e-business são os principais termos relacionados à aplicação de tecnologia de informação na gestão de empresas. A metodologia da pesquisa foi caracterizada qualitativa com abordagem descritiva e como resultado um desenvolvimento gerencial eficaz e eficiente pressuposto, em qualquer organização, a existência de infraestrutura sistêmica para resolução de problemas, de forma ágil, sistemática e segura.

Palavras Chave: Sistema de Informação Gerencial, Tecnologia de Informação, Resolução de problemas. 


\section{INTRODUÇÃO}

O mundo vive na era da informação, exigindo das organizações uma gestão estratégica eficiente, a qual pode ser facilitada pela utilização de recursos inteligentes oferecidos pela tecnologia de informação e sistemas de informação.

Não se admite hoje uma empresa que queira competir com vantagem, sem a utilização dessas ferramentas. Estes fatos abrem lacunas para que os novos gestores, com novas visões busquem o aperfeiçoamento contínuo para suas empresas.

Devido a crescente demanda de informações pelos gestores, existe quase uma obrigação de se utilizar sistemas de informações para gerenciar e filtrar os dados recebidos e transformá-los em informações úteis para a organização. A competitividade global torna os mercados acirrados e as empresas necessitam das informações para sobreviver e crescer.

A Tecnologia da Informação segundo Rezende (2003) é o conjunto de recursos tecnológicos e computacionais para manipulação de informações e conhecimento, baseando-se em hardware, software, telecomunicações e gestão de informações. Lucas (apud ALBERTIN, 2002) informa que Sistema de Informação (SI) é o conjunto de procedimentos organizados que, quando executados, provêem informação para suportar a tomada de decisão e o controle numa organização. Podemos dizer com isso que os sistemas de informações são uma parte da Tecnologia da Informação.

Estes são alguns dos conceitos e sistemas que podem auxiliar uma organização a ser mais eficiente, eficaz e ágil na gestão de suas informações. Nesse sentido, o presente artigo tem objetivo de avaliar a importância do sistema de informação gerencial na resolução de problemas.

\section{TECNOLOGIA DE INFORMAÇÃO (TI):}

As empresas estão mudando continuamente, tornandose mais complexo e menos previsível, e gradativamente dependente de informações e de toda a infraestrutura tecnológica que permite o gerenciamento de enormes quantidades de dados.

Para Pereira \& Fonseca (1997), "a tecnologia da informação surgiu da necessidade de se estabelecer estratégias e instrumentos de captação, organização, interpretação e uso das informações".

As informações com qualidade e apresentadas em tempo hábil à tomada de decisão são de vital importância para as empresas modernas. O uso adequado dos recursos da Tecnologia de Informação garante a qualidade e pontualidade das informações. Foina (2001), conceitua Tecnologia da Informação como: "... um conjunto de métodos e ferramentas, mecanizadas ou não, que se propõe a garantir a qualidade e pontualidade das informações dentro da malha empresarial".

Batista (2004), define: "Tecnologia de Informação é todo e qualquer dispositivo que tenha a capacidade para tratar dados e/ou informações, tanto de forma sistêmica como esporádica, independentemente da maneira como é aplicada".

A gestão estratégica das informações, resultante da Tecnologia da Informação é parte integrante de qualquer estrutura gerencial de sucesso.

\subsection{SISTEMA}

A busca pela solução dos problemas conduz os gestores a unir as partes que compõem a organização para formar um sistema que dará condições para administrar o todo.

De acordo com Oliveira (2002), "sistema é um conjunto de partes interagentes e interdependentes que, conjuntamente, formam um todo unitário com determinado objetivo e efetuam determinada função". A formação de um sistema se dá pela união de diversas partes interdependentes que conjuntamente visam atingir um objetivo comum.

Batista (2004), define sistema como a "... disposição das partes de um todo que, de maneira coordenada, formam a estrutura organizada, com a finalidade 
de executar uma ou mais atividades ou, ainda, um conjunto de eventos que repetem ciclicamente na realização de tarefas predefinidas.

Segundo Resende e Abreu (2000), em geral os sistemas procuram atuar como:

a. Ferramentas para exercer o funcionamento das empresas e de sua intrincada abrangência e complexidade;

b. Instrumentos que possibilitam uma avaliação analítica e, quando necessária, sintética das empresas;

c. Facilitadores dos processos internos e externos com suas respectivas intensidades e relações;

d. Meios para suportar a qualidade, produtividade e inovação tecnológica organizacional;

e. Geradores de modelos de informações para auxiliar os processos decisórios empresariais;

f. Produtores de informações oportunas e geradores de conhecimento;

g. Valores agregados e complementares à modernidade, perenidade, lucratividade e competitividade empresarial.

As diversas formas de atuação dos sistemas permitem que as empresas conheçam a si, ou seja, conheçam o seu potencial interno, e estejam reparadas para atuar no meio externo e sobreviver aos incessantes ataques do mercado competitivo.

\subsection{SISTEMAS DE INFORMAÇÃO (SI)}

Os sistemas de informações têm papel fundamental nas organizações, são através deles que um administrador consegue ter um acesso com facilidade as informações de todos os aspectos de sua organização. A correta administração dessas informações é fundamental para seu sucesso, pois, com base nelas os executivos podem decidir o rumo da empresa.

Laudon \& Laudon (2004) definem que um sistema de informação é tecnicamente como um conjunto de componentes interrelacionados que coleta (ou recupera), processa, armazena e distribui informações destinadas a apoiar a tomada de decisões, a coordenação e o controle de uma organização. As características dos sistemas de informação já denotam sua principal vocação que é a de fornecer informações para o controle e para agilidade na tomada de decisão. Gil (1999), define que "... os sistemas de informação compreendem um conjunto de recursos humanos, materiais, tecnológicos e financeiros agregados segundo uma seqüência lógica para o processamento dos dados e a correspondente tradução em informações".

Na visão de Pereira e Fonseca (1997), "...os sistemas de informação (management information systms) são mecanismos de apoio à gestão, desenvolvidos com base na tecnologia de informação e com suporte da informática para atuar como condutores das informações que visam facilitar, agilizar e otimizar o processo decisório nas organizações.

Os sistemas de informação têm por objetivo gerar informações para a tomada de decisões, os dados são coletados, processados e transformados em informação e para isso, a gestão empresarial precisa cada dia mais do apoio de sistemas, pois estes dão segurança, agilidade e versatilidade para a empresa no momento em que se processam as decisões.

\subsection{SISTEMA DE INFORMAÇÃO GERENCIAL (SIG)}

O sistema de informação gerencial dá suporte às funções de planejamento, controle e organização de uma empresa, fornecendo informações seguras e em tempo hábil para tomada de decisão.

Para Oliveira (1998), os sistemas de informações gerenciais devem levar em consideração a quantidade e qualidade de informações geradas, pois segundo mesmo autor, alguns devem ser tomados em relação a esses fatores:

- As informações ficam dispersas dentro da empresa o que exige grande esforço para localizá-las;

- As informações importantes são retidas com exclusividade;

- As informações importantes geralmente chegam tarde; 
- As informações muitas vezes não são confiáveis.

Oliveira (2002), define que, "o sistema de informação gerencial é representado pelo conjunto de subsistemas, visualizados de forma integrada e capaz de gerar informações necessárias ao processo decisório".

Garcia \& Garcia (2003), definem que sistema de informação gerencial: "é qualquer sistema que produza posições atualizadas no âmbito corporativo, resultado da integração de vários grupos de sistemas de informação que utilizam recursos de consolidação e interligação de entidades dentro de uma organização".

Stair (1998), assim define, "o propósito básico de um SIG é ajudar a empresa a alcançar suas metas, fornecendo a seus gerentes detalhes sobre as operações regulares da organização, de forma que possam controlar, organizar e planejar com mais efetividade e com maior eficiência".

Os executivos devem buscar projetar os sistemas de informação gerencial inserindo dados de origem interna e externa, existindo portando, uma interação entre os meios, resultando na concretização dos objetivos preestabelecidos pela empresa.

As fontes externas advêm do relacionamento com fornecedores, acionistas, clientes e concorrentes, facilitadas nas atuais circunstâncias pela evolução tecnológica.

As fontes internas estão relacionadas aos bancos de dados mantidos pela organização. Os bancos de dados são atualizados pela captura e armazenamento dos dados resultantes da integração dos diversos sistemas que compõem a organização, entre eles, sistemas de finanças, sistemas de contabilidade, sistemas de recursos humanos, sistemas de venda e marketing.

A estrutura decisória da empresa, no contexto de processos gerenciais, classifica os sistemas de acordo com o problema organizacional que ajuda a resolver. Batista (2004), escreve que os sistemas são classificados em: sistema de nível estratégico, de conhecimento, tático e operacional. As informações geradas pelos sistemas de nível estratégico são utilizadas na definição do planejamento estratégico da organização, ou seja, tomada de decisão. Os sistemas de nível tático são usados no controle dos planejamentos operacionais, define as táticas ou metas a serem cumpridas. Os sistemas de conhecimento envolvem a transmissão de conhecimento e informação entre os departamentos. Os sistemas de nível operacional são utilizados para o desenvolvimento das tarefas diárias da empresa, como exemplo: sistema de compra/ venda.

Os sistemas de informação gerencial mudam constantemente para atender o dinamismo dos negócios, o que vai de encontro à necessidade de qualquer organização para sobreviver no mercado.

\subsection{FINALIDADES DOSSISTEMAS DE INFORMAÇÃO}

As empresas precisam estar preparadas para lidar com os problemas internos e externos do ambiente em que estão inseridas, para tanto buscam no desenvolvimento de sistemas de informações suporte para a resolução desses problemas. Laudon \& Laudon (1999), afirmam que "a razão mais forte pelas quais as empresas constroem os sistemas, então, é para resolver problemas organizacionais e para reagir a uma mudança no ambiente".

Os sistemas de informação objetivam a resolução de problemas organizacionais internos, e a conseqüente preparação para enfrentar as tendências da crescente competitividade de mercado.

Para Pereira \& Fonseca (1997), os sistemas de informação têm por finalidade "... a captura e/ou a recuperação de dados e sua análise em função de um processo de decisão. Envolvem, de modo geral, o decisor, o contexto, o objetivo da decisão e a estrutura de apresentação das informações".

De forma estruturada, os sistemas de informação dão condições para que as empresas reajam às mutações do mercado e se sinta alicerçadas por um processo decisório forte o suficiente para garantir a resolução dos problemas. 
Os benefícios são:

a. Aumento da capacidade de tratamento das informações;

b. Agrupamento da corporação mesmo através das distâncias geográficas;

c. Rapidez na obtenção dos dados;

d. Dados padronizados;

e. Integração de processos internos;

f. Confiabilidade nos relatórios;

g. Maior controle sobre a organização;

As desvantagens ou desafios são:

a. Alto custo;

b. Alteração no modo de operação das empresas;

c. Tempo de implantação demorado;

d. Funcionários terão de assumir novas funções ou responsabilidades;

e. Insegurança dos funcionários

f. Perda da flexibilidade;

g. Falha de comunicação;

h. Inexistência de procedimentos ou insuficiência de informações neles contidas;

i. Mau funcionamento de equipamentos ou falta de manutenção;

j. Falta de treinamento

\section{ANÁLISE DA APLICAÇÃO DA RESOLUÇÃO DE PROBLEMAS}

A necessidade de obter informações faz com que as organizações preocupem-se em absorver dados das mais diversas maneiras e fontes. O grande problema é que, muitas vezes, isto acontece sem a preocupação com a coerência dos dados, o que pode ocasionar significativos problemas para as futuras análises.

O motivo pelo qual as empresas são induzidas a construir sistemas de informação é para resolver problemas organizacionais e para reagir a mudanças no ambiente. Os desafios colocados por novos produtos e clientes, a concorrência acirrada, os avanços tecnológicos, as relações políticas, as circunstâncias econômicas e as regulamentações governamentais requerem mudanças, tais como técnicas mais aperfeiçoadas de produção, novos produtos e serviços, novos sistemas administrativos e novas habilidades dos empregados.

Afinal, a qualidade da decisão depende das informações que estão disponíveis no momento em que ela é tomada. Para Chiavenato (2000) tomada de decisão é o "processo de análise e escolha, entre várias alternativas disponíveis, no curso de ação que a pessoa deverá seguir". Assim, informações desencontradas e desatualizadas irão afetar neste processo. Portanto, a organização deve ter extremo cuidado ao coletar dados, certificando-se de que não existam ruídos ou incoerências.

Optar pela alternativa errada pode ser catastrófico para uma organização, devido a isso é necessário que a empresa planeje suas ações antecipadamente. Rezende (2003) afirma que "o planejamento estratégico é fundamental para a sobrevivência das organizações que estão preocupadas com sua inteligência empresarial ou organizacional".

O uso de ferramentas computacionais e métodos para gerenciar informações são de extrema importância, a integração entre os sistemas faz com que numa mesma tela ou relatório possa se obtiver o conhecimento de todas as áreas da empresa. E essas informações podem reduzir o custo de produção, diminuir o tempo de resposta ao mercado ou agilizar e incrementar as vendas.

Neste contexto veremos agora como cada sistema ou método se encaixa dentro das necessidades e desafios de uma organização.

Para iniciarmos a análise os critérios para a resolução de problemas são:

a. Admitir a ocorrência do problema ou anomalia ou fato;

b. Analisar a ocorrência;

c. Analisar as suas prováveis causas;

d. Definir a(s) tomada(s) de ação(ões) para solucioná-lo;

e. Definir método de monitoramento da(s) ação(ões). 
Seguindo os critérios, é de responsabilidade de o emitente admitir e analisar a ocorrência do problema, definir através da tabela $1(\mathrm{~F}+\mathrm{O}+\mathrm{C})$ o método de tomada de ação usando o sistema de informação que descreverá:

1. Ocorrência do problema:

Nome (exemplo: não liga, não monta, quebra, visual, não há registro)

\section{Análise da Ocorrência:}

Ajuda na correta compreensão do problema. Estima a correta dimensão do problema suas dependências e dependentes. Pergunta chave: "Que tipo de problema é este?".

\subsection{Origem da anomalia}
a. Ambiental
b. Processo ou produto ou setor
c. Gestão
d. Fornecedor
e. Cliente
f. Usuário

2.2 Identificação da anomalia
a. Código

Observação:

- Através do código do produto o sistema de informação já gerará dados como: nome do item, modelo, marca, fornecedor, valor, matéria prima, etc.

- Caso o problema ocorra em um item que seja montado em um conjunto completo, é importante criar um subcódigo para informar onde a anomalia ocorre especificamente. (exemplo: o problema ocorre em um cd player, então é necessário armazenar informações para o cd player (conjunto completo) e para o display(item com anomalia).

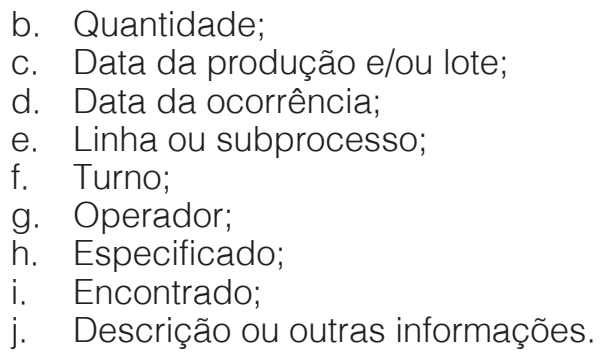

3. Análise das causas:

É a pesquisa ou investigação do problema com pessoas, documentos e questionários que deve resultar numa informação concisa do problema. Perguntas chave: "O que causa o problema?", "Por que ele ainda existe?", "Por que ele ainda não foi solucionado?".

Analisar a tabela 1 (pontuação FOC) para definição do método de análise para resolução de problemas. 
Tabela 1 - Pontuação FOC

\begin{tabular}{|c|c|c|c|}
\hline $\begin{array}{l}\text { Pont. } \\
\text { FOC }\end{array}$ & Freq. & Origem & Consequência \\
\hline 1 & $\begin{array}{l}\text { Até } \\
5 \%\end{array}$ & $\begin{array}{c}\text { Em um processo ou; em uma atividade ou; } \\
\text { Apresenta a parte estética inferior ao padrão } \\
\text { visual do cliente. }\end{array}$ & $\begin{array}{l}\text { Não diminuirá o nível de qualidade ou; } \\
\text { Não aumentará o custo por desperdícios ou; } \\
\text { Não afeta o prazo de entrega interno ou nos clientes ou; } \\
\text { Não ocasiona insatisfação nos colaboradores ou; } \\
\text { Não ocasiona impacto ao meio ambiente. }\end{array}$ \\
\hline 2 & $\begin{array}{l}\text { Acima } \\
\text { de } 5 \% \\
\text { Até } \\
30 \%\end{array}$ & $\begin{array}{c}\text { Em mais de um processo ou; } \\
\text { Em mais de uma atividade ou; } \\
\text { Quando há defeito no funcionamento que } \\
\text { pode prejudicar as funções do produto ou da } \\
\text { contra peça. }\end{array}$ & $\begin{array}{c}\text { Pequena diminuição no nível de qualidade ou; } \\
\text { Aumento no custo por desperdícios ou; } \\
\text { Pequena insatisfação nos colaboradores ou; } \\
\text { Pequeno impacto ao meio ambiente ou; } \\
\text { Afeta o prazo de entrega interno ou; } \\
\text { Afeta o cumprimento das metas estabelecidas para a organização. }\end{array}$ \\
\hline 4 & $\begin{array}{c}\text { Acima } \\
\text { de } 30 \%\end{array}$ & $\begin{array}{l}\text { Em quase ou todos os processos ou; } \\
\text { anomalia poderá ser percebida somente } \\
\text { pelo fornecedor, cliente ou usuário ou; } \\
\text { Quando o defeito ocasiona a perda do } \\
\text { Funcionamento ou na estrutura podendo } \\
\text { ocasionar danos físicos às pessoas. }\end{array}$ & $\begin{array}{l}\text { Diminuição considerável no nível de qualidade ou; } \\
\text { Custo por desperdícios maior que o lucro ou; } \\
\text { Insatisfação nos colaboradores ou; } \\
\text { Impacto ambiental incontrolável ou; } \\
\text { Afeta o prazo de entrega ou parada de linha de montagem nos } \\
\text { clientes ou; } \\
\text { Afeta o cumprimento das metas estabelecidas no cliente. }\end{array}$ \\
\hline
\end{tabular}

Fonte: Próprio autor (2015)

\section{Observação:}

Ao final do preenchimento das informações 1, 2 e 3 acima é gerado um número para controle e emitido um e-mail informativo ao gestor do setor responsável pela anomalia e às demais partes interessadas.

\section{Definição da(s) tomada(s) de ação(ões):}

É necessário o planejamento da implantação da solução e estratégia de desenvolvimento da resolução prevendo os impactos gerados, definindo nível geral de recursos, processo operacional geral, definição de mecanismos de medição da eficiência da resolução descrevendo detalhadamente os equipamentos, construções, pessoal e estoques da organização.

Após a definição da tabela 1 - Pontuação FOC, o método de análise e tomada de ação para resolução de problemas será de responsabilidade do setor onde ocorreu a anomalia, que deverá preencher no sistema as informações seguindo os critérios estabelecidos na tabela 2 - pontuação de risco $\mathrm{F}+\mathrm{O}+\mathrm{C}$ e após a conclusão dos métodos, o gestor da área analisará a(s) ação(ões) proposta(s), se OK, aprovará no sistema validando a ação para que de fato as implementações sejam realizadas, se NC, devolverá ao responsável para reavaliar as ações a serem tomadas e responder novamente no sistema; 
Tabela 2 - Pontuação de risco $\mathrm{F}+\mathrm{O}+\mathrm{C}$

\begin{tabular}{|c|c|}
\hline $\begin{array}{l}\text { Pontuação de } \\
\text { risco } \\
(\mathrm{F}+\mathrm{O}+\mathrm{C})\end{array}$ & Métodos de Análises para Resoluções de Problemas \\
\hline 3 & $\begin{array}{l}\text { Ação de Contenção (a primeira ação a ser tomada para não passar a anomalia para o cliente interno ou externo) - É } \\
\text { necessário por amostragem; } \\
\text { Análise da Causa - Não é necessário; } \\
\text { Plano de Ação - 3W (o quê, quando e quem); } \\
\text { Método de Monitoramento - Imediato. }\end{array}$ \\
\hline 4 & $\begin{array}{l}\text { Ação de Contenção - É necessário em uma porcentagem do lote; } \\
\text { Análise da Causa - 4M (material ou mão de obra ou máquina ou medida ou método ou meio ambiente); } \\
\text { Plano de Ação - 5W (o quê, quando, quem, onde e por que); } \\
\text { Método de Monitoramento - Imediato e após } 5 \text { dias. }\end{array}$ \\
\hline 5 & $\begin{array}{l}\text { Ação de Contenção - É necessário em todo lote; } \\
\text { Análise da Causa - Rastreabilidade do lote; Simulação do problema; } 6 \mathrm{M} \text { (material, mão de obra, máquina, medida, } \\
\text { método e meio ambiente); } \\
\text { Plano de Ação - 5W } 1 \mathrm{H} \text { (o quê, quando, quem, onde, por que e como); } \\
\text { Método de Monitoramento - Imediato e após } 5 \text { e } 30 \text { dias. }\end{array}$ \\
\hline 6 até 12 & $\begin{array}{c}\text { Ação de Contenção - É necessário em todo lote; } \\
\text { Análise da Causa - Rastreabilidade do lote; Simulação do problema; Mecanismo da ocorrência; 6M (material, mão de } \\
\text { obra, máquina, medida, método e meio ambiente); } \\
\text { Plano de Ação - 5W 2H (o quê, quando, quem, onde, por que, como e quanto); } \\
\text { Método de Monitoramento - Imediato e após 5, 30, } 60 \text { e } 90 \text { dias. }\end{array}$ \\
\hline
\end{tabular}

Fonte: Próprio autor (2015)

Observação:

a.O tempo para resposta será estipulado pela alta direção com base na pontuação de $\mathrm{F}+\mathrm{O}+\mathrm{C}$ da tabela 2 e os prazos estabelecidos pelo cliente;

b.Caso o prazo esteja próximo a extrapolar será comunicado para os responsáveis e gestor da área através do sistema solicitando providências;

c.As ações devem ser implementadas em curto prazo, salvo aquelas ações que dependem de compras no exterior ou outros que realmente precisarem de um tempo maior;

d.É de responsabilidade do gestor da área responsável pela anomalia acompanhar a implementação e eficácia da ação junto com os responsáveis das áreas.

5. Método de monitoramento da(s) ação(ões):

Após a provação da resposta pelo gestor da área responsável da anomalia, a mesma voltará para aprovação do emitente, onde deve verificar as ações e após o último prazo das ações registradas no sistema, deve fazer a verificação da implementação, se OK, deverá registrar as evidências que constate a execução do plano de ação, se NC, o emitente não aprovará a resposta (descrevendo a necessidade) e o setor responsável deverá corrigir o plano de ação e/ou o prazo estipulado. Posterior a aprovação do emitente do problema o sistema solicita aprovação do gestor do emitente e posteriormente às alçadas competentes. Por seguinte a aprovação da resposta é estipulado conforme a tabela 2 - pontuação de risco $\mathrm{F}+\mathrm{O}+\mathrm{C}$ ) a definição do tempo para realização da checagem das providências, que é de responsabilidade do emitente onde também deverá registrar novamente as evidências que constate a execução, assim, o registro na anomalia é finalizado de fato.

\section{CONCLUSÃO}

$\mathrm{Na}$ corrida para atender às demandas do mercado, as empresas buscam soluções que as diferenciem aumentando a sua competitividade. Decisões rápidas e corretas são fundamentais para a empresa alcançar bons resultados. Faz-se necessário aperfeiçoar o planejamento e execução das atividades, sincronizar a cadeia de suprimentos e reduzir os custos operacionais para aumentar a satisfação dos seus clientes e a 
lucratividade do negócio.

$\mathrm{Na}$ dependência das informações torna o uso dos sistemas de informação algo essencial para a sobrevivência das organizações, seu correto uso deve trazer benefícios a curto, médio e longo prazo para os empresários. Porém a aplicação da Tecnologia de Informação precisa ser moldada de acordo com as necessidades de cada organização. Empresas que pretendem investir em $\mathrm{Tl}$ precisam estar cientes de que tempo é dinheiro e para as organizações o lucro é a finalidade principal de sua existência. Tendo isso como base, é essencial que as empresas adotem sistemas de informação ajustados com as metas e objetivos do seu cliente.

A forma de uso e os benefícios dos sistemas de informação estiveram presentes neste artigo. Vimos que a utilização de sistemas de gestão de clientes visa adquirir maior conhecimento sobre o cliente, podendo com isso alterar a forma de resolução de problemas e efetuar mudanças e melhorias nos processos produtivos voltadas às necessidades de cada cliente.

Os sistemas de informação gerenciais fortalecem o plano de atuação das empresas. A geração de informações rápidas, precisas e principalmente úteis para o processo de tomada de decisão garante uma estruturação de gestão diferenciada, resultando em vantagem competitiva sobre as demais empresas.

Diante de tais características, o sistema de informações além de fornecer acesso e confiabilidade para a informação, deve dispor de um sistema de comunicação que leve em consideração os seguintes aspectos: os participantes no processo, as fontes e destinos da comunicação, a localização dos remetentes e destinatários, tempo entre o envio e recebimento da informação e o meio que viabilizará a comunicação.

Por outro lado, é necessário o desenvolvimento da cultura de planejamento, gestão e avaliação do conhecimento nessas empresas, pois apesar de serem inúmeras as vias de entrada de conhecimento, caso não ocorra de forma organizada, a disseminação, acessibilidade e possibilidade de transformação do conhecimento em vantagem competitiva torna-se inviável.

As empresas de projeto devem manter uma memória organizacional, na qual deve estar contida de forma organizada todo conhecimento adquirido da empresa. Esta memória deve estar permanentemente em operação na aquisição fornecimento de conhecimento.

O desafio para gerentes de tecnologia é identificar as melhores práticas no contexto de negócios em cada empresa, diferenciando modismos de realidade. $\mathrm{Na}$ maioria das vezes, infelizmente, o orçamento é reduzido, enquanto a alta gerência exige resultados concretos. Optar por ficar fora da revolução nos negócios pode ter conseqüências ainda piores. A empresa ideal será aquela que entre todas as variáveis conseguir integrar o melhor dos negócios real e eletronicamente.

\section{REFERÊNCIAS}

[1] ALBERTIN, ALBERTO L. Comércio Eletrônico: modelo, aspectos e contribuições de sua aplicação. 5. ed. São Paulo: Atlas, 2002.

[2] BATISTA, EMERSON DE OLIVEIRA. Sistema de Informação: o uso consciente da tecnologia para o gerenciamento. São Paulo: Saraiva, 2004.

[3] FOINA, PAULO SÉRGIO. Tecnologia de Informação: planejamento e gestão. São Paulo: Atlas, 2001.

[4] GARCIA, ELIAS; GARCIA, OSMARINA PEDRO GARCIA. A importância do sistema de informação gerencial para a gestão empresarial. Revista Ciências Sociais em Perspectiva, do Centro de Ciências Sociais Aplicadas de Cascavel, Cascavel, v.2 , n.1, p. 21-32, 1 sem. 2003.

[5] LAUDON, KENNETH C.; LAUDON, JANE P. Sistemas de Informação Gerencial: administrando a empresa digital. 5 ed. São Paulo: Prentice Hall, 2004.

[6] O’BRIEN, JAMES A. Sistemas de informação e as decisões gerenciais na era da Internet. Tradução Célio Knipel Moreira e Cid Knipel Moreira. 2. ed. São Paulo: Saraiva, 2003.

[7] OLIVEIRA, DJALMA DE PINHO REBOUÇAS DE. Sistemas de informação gerenciais: estratégias, táticas, operacionais. 8. ed., São Paulo: Atlas,1992.

[8] PEREIRA, MARIA JOSÉ LARA DE BRETÃS; FONSECA, JOÃO GABRIEL MARQUES. Faces da Decisão: as mudanças de paradigmas e o poder da decisão. São Paulo: Makron Books, 1997. 
[9] REZENDE, DENIS ALCIDES. Planejamento de Sistemas de Informação e Informática. São Paulo: Atlas, 2003.

[10] REZENDE, DENIS ALCIDES; ABREU, ALINE FRANÇA DE. Tecnologia da informação aplicada a sistemas de informação empresariais: o papel estratégico da informação e dos sistemas de informação nas empresas. São Paulo: Atlas, 2000.

[11] REZENDE, DENIS ALCIDES. Tecnologia da Informação Integrada à Inteligência Empresarial. São Paulo: Atlas, 2002.
[12] STAIR, RALPH M. Princípios de sistemas de informação: uma abordagem gerencial. Rio de Janeiro: LTC, 1998.

[13] TURBAN,E., MCLEAN,E.,WETHERBE,J. Tecnologia da informação para gestão. Transformado os negócios da economia digital.3 Edição.Porto Alegre. Editora Bookman,2004. 


\section{CAPÍTULO 12}

GESTÃO DO CONHECIMENTO E INOVAÇÃO: ESTUDO DE CASO EM UMA EMPRESA DE DISPOSITIVOS ELETROELETRÔNICOS

Rony Peterson da Rocha

\section{Andressa Carina Waideman Pedrezini}

Thays J. Perassoli Boiko

Márcia de Fátima Morais

Fabrício Wesley da Rocha

Resumo: Em razão da constante busca pelo aperfeiçoamento das atividades desenvolvidas na indústria, a gestão do conhecimento e inovação é apresentada com ênfase nos programas de melhoria contínua industrial. O presente estudo objetiva analisar os fatores críticos para a melhoria da gestão da inovação em um sistema de produção de dispositivos eletroeletrônicos. Este artigo mostrará o processo inicial para implantação de um sistema de geração de ideias e gestão da inovação em uma empresa de pequeno porte do setor metal-mecânico. A pesquisa fez parte de um projeto para apoio à gestão da inovação em empresas de pequeno, médio e grande porte no Paraná. O objetivo desta pesquisa foi de estudar a inicialização do processo para a gestão do conhecimento e inovação, bem como, analisar o processo de geração de ideias e a utilização de um processo sistematizado para qualidade das atividades executadas. Assim, o trabalho resultou em 91 ideias de melhoria organizacional e 106 ideias de melhoria de produtos e novos produtos, o que possibilitou aos empresários selecionar ideias para captação de recursos para futura implantação na empresa.

Palavras Chave: Gestão da Inovação, geração de ideias, brainstorming. 


\section{INTRODUÇÃO}

O gerenciamento do conhecimento organizacional passou aos poucos para uma conotação mais abrangente nas organizações, abrangendo desde qual seria o conhecimento almejado, como é criado, e como se usufrui dele. Assim, toda informação e conhecimento são fundamentais em todas as etapas do processo inovativo na empresa (STRAUHS, 2012).

Segundo Oliveira in Schroder (2012), é importante saber que o conhecimento nas empresas pode estar restrito a indivíduos, grupos, em áreas funcionais e que as empresas procuram simplificar esses conhecimentos para acesso de todos.

Entre os insumos de uma empresa (materiais, equipamentos, energia, etc), dois adquirem especial importância para o aumento da capacidade de gerar inovações e consequentemente aumento de competitividade: informação e conhecimento. O uso adequado desses insumos resultará na identificação de necessidade e mudanças em relação à necessidade dos clientes, tendências do mercado, potenciais lançamentos da concorrência. Para isso o conhecimento sobre a relação direta entre informação, conhecimento e inovação, devem seguir os estágios: obtenção de informação; tratamento de informação; transformação de informação em conhecimento; transformação do conhecimento em inovação (STRUHS,2012).

Para a melhora na geração das informações e maior êxito no processo de gestão do conhecimento visando à inovação, a utilização de técnicas para a geração de ideias podem estimular a proposição das ideias, auxiliar seu registro, bem como ajudar na discussão em grupo, assim algumas técnicas podem ser utilizadas de acordo com o perfil de cada uma das empresas tais como: o brainstorming; scamper; mapas mentais; associações de ideias; levantamentos de perguntas; seis chapéus (DAVID, 2011).

Assim, o presente artigo apresenta os resultados de um estudo sobre a análise dos fatores críticos para a melhoria da gestão da inovação em uma empresa de dispositivos eletroeletrônicos, desta forma, realizou-se um diagnóstico para levantamento de informações e uma análise do ambiente da empresa, assim como, exposições das ideias geradas em um workshop de inovação, e proposição de um plano de ação para melhoria da gestão da informação, conhecimento e consequentemente da inovação na empresa.

O artigo divide-se em seções onde serão descritos conceitos, técnicas e resultados da pesquisa. Nesta primeira seção é abordado uma introdução ao assunto. $\mathrm{Na}$ segunda seção será apresentado os conceitos sobre gestão da informação e do conhecimento, gestão da inovação, técnicas para efetivação do processo inovador e o plano para implementar a gestão da inovação na empresa. A terceira seção contempla a revisão de literatura com casos que podem ser comparados e/ou utilizados para melhoria do processo na empresa em que o estudo de caso foi realizado. $\mathrm{Na}$ quarta seção é apresentada a metodologia. Na quinta seção são apresentados e discutidos os resultados, isto é, como realizou-se a geração de ideias, as ideias geradas e os modelos dos documentos elaborados para a empresa. Na última seção são apresentadas as considerações finais e por fim, as referências bibliográficas.

\section{FUNDAMENTAÇÃO TEÓRICA}

\subsection{GESTÃO DA INFORMAÇÃO E DO CONHECIMENTO}

A gestão de uma empresa pode ocorrer de maneira profissional ou mesmo pelo sentimento do empresário ou pelos gestores que a conduzem, o fato é que ela existe e varia em sua organização e sistematização (FURTADO, 2011).

Segundo Straushs (2012), a gestão da informação e conhecimento são fundamentais para que a gestão de empresa e a gestão para o processo da inovação obtenham efetividade. A Gestão da Informação possibilitará o reconhecimento da informação, sua necessidade, como coletar, como selecionar e identificar sua qualidade, além de ajudar a organizar, armazenar e distribuir essa informação de maneira eficaz e eficiente proporcionando facilidade a informação e a criação do conhecimento organizacional. Associado a Gestão do Conhecimento, chega-se a conversão contínua do conhecimento 
em informação, e informação em conhecimento. A gestão abrange a produção do conhecimento através das pessoas que integram novas informações à sua experiência e produzem outras informações, que por sua vez facilitam a prática de inovação na empresa.

As características dos ambientes organizacionais para a geração do conhecimento influenciam em todas as variáveis para êxito da geração, o ambiente ideal é aquele que os indivíduos possam expressar, fazer tentativas e errar sem medo de punições. Um ambiente em que a ideia de que "conhecimento é poder" tenha sido desmitificada pelo entendimento do que essa expressão realmente significa (STRAUHS, 2012).

A Gestão do Conhecimento, segundo Strauhs (2012), reúne as condições que criam a infraestrutura, física e digital, necessária ao gerenciamento de diversos conhecimentos técnicos e pessoais espelhados no interior da empresa.

\subsection{GESTÃO DA INOVAÇÃO}

A área de inovação, assim como as outras áreas de competência da empresa, necessita de gestão, pois a inovação é um processo contínuo. Todas as atividades envolvidas no processo de inovação podem sofrer influência internas e externas ao processo, interferindo no resultado final da inovação (MANUAL DE OSLO, 1997).

No processo de Gestão da Inovação, a etapa de aprendizagem é fundamental para garantir a capacidade futura de criação de inovações. A aprendizagem associada às práticas desse gerenciamento, garante a retenção de conhecimentos na empresa e permite, ao longo do tempo, inovar cada vez mais, melhor e rápido (STRAUHS, 2012).

Para a efetivação da gestão da inovação em uma empresa, um processo sistêmico deve ser criado, e seu início está na gestão de ideias. Pois a gestão de ideias não é um modismo, é um processo essencial para a administração e consequentemente para a gestão da inovação. As inovações surgem de ideias, e as ideias se originam do conhecimento adquirido das pessoas.
No ambiente organizacional é preciso transformar os conhecimentos em propostas de projetos inovadores (DAVID, 2011).

De acordo com o Manual de Oslo (1997), o processo sistêmico envolvido na gestão da inovação, pode melhorar o desempenho da empresa, pois faz aumentar sua capacidade de inovar. Por exemplo, melhoramentos nos processos de produção podem permitir o desenvolvimento de um novo leque de produtos, e novas práticas organizacionais podem melhorar a capacidade empresarial de adquirir e criar novos conhecimentos que poderão ser usados para o desenvolvimento de outras inovações.

As inovações, normalmente são obtidas através das propostas de melhorias realizadas pelos próprios operadores, pois seu contato direto e diário com os equipamentos e com o processo permita a eles uma percepção apurada da situação, assim a utilização de técnicas para facilitar esse processo de geração e filtração das ideias, torna-se necessário para uma inovação efetiva (CARVALHO, 2011).

\subsection{TÉCNICAS PARA EFETIVAÇÃO DO PROCESSO INOVADOR}

Para efetivação do processo inovador, as técnicas de geração de ideias podem ser utilizadas com intuito de melhorar o processo para a gestão de ideias, e consequentemente melhora na qualidade das ideias geradas, proporcionando uma utilização máxima no cotidiano da empresa. Essas técnicas visam também sensibilizar e estimular o colaborador a se sentir mais à vontade, para espontaneamente, poder observar e refletir sobre as atividades do cotidiano da empresa.

As técnicas para a geração de ideias são enquadradas como divergentes e convergentes. As técnicas divergentes são: Brainstorming; Scamper; Mapas Mentais. Já as técnicas convergentes são: associação de ideias; levantamento de perguntas (5W2H); Seis Chapéus. Para um resultado melhor, a técnica convergente deve ser utilizada como complemento da técnica divergente utilizada (DAVID, 2011). 
O trabalho priorizou a utilização da técnica brainstorming, que segundo David (2011) é uma técnica a ser utilizada em grupo, pensando em respostas rápidas. O Grupo destina um tempo em um ambiente agradável para a geração de ideias, o condutor da técnica pode direcionar as ideias ou deixar livre, os participantes poderão utilizar flip chart e sulfite, quadro, mural, canetas, cartazes, post-it, projetor multimídia, entre outros meios para anotar as ideias geradas. O condutor irá controlar o tempo e critérios para geração. O tema deverá ser bem explicado, para que as ideias geradas tenham qualidade de acordo com a necessidade da empresa. O brainstorming é composto pelas seguintes etapas: preparação; geração de ideias; avaliação das ideias geradas; seleção; e implementação das ideias priorizadas.

A forma de participação dos integrantes se divide em três tipos principais: PARTICIPAÇÃO LIVRE OU DE PLENA LIBERDADE: Os integrantes da atividade apresentam espontaneamente suas ideias, sem uma ordem definida, sob a coordenação do facilitador; PARTICIPAÇÃO ORDENADA: Os membros do grupo declaram sequenciamente suas ideias, um de cada vez, sob orientação do facilitador. Um componente sugere uma ideia, e a sessão continua assim até que todos tenham contribuído; PARTICIPAÇÃO ESCRITA: As ideias são registradas, em vez de serem expostas em voz alta, e devem estar visíveis a todos os participantes (DAVID, 2011).

O facilitador poderá orientar para o grupo encubar as ideias, realizando diferentes sessões de brainstorming com intervalos de vários dias. Isso irá ajudar ao amadurecimento e tempo de análise, o que normalmente pode gerar novas proposições ao longo das outras sessões. A estratégia e a forma de como conduzir o brainstorming deve ser definido e combinado no inicio da atividade, para que tudo esteja claro para os participantes e a atividade seja mais produtiva (DAVID, 2011).

\subsection{PLANO PARA IMPLEMENTAÇÃO DA GESTÃO DA INOVAÇÃO}

Após a realização do diagnóstico, análise e brainstorming, é necessário que determine para a organização uma meta para dois a cinco anos, ou seja, que seja especificado em que estágio pretende estar para se tornar uma empresa inovadora. Para que seja mais prático o plano de inovação, são utilizados itens orientadores e perguntas para priorizar quais ideia serão implantadas, considerando "quando", "quem", "como" e "quanto" (CARVALHO, 2012).

\section{REVISÃO DE LITERATURA}

Schroder (2012) trabalhou em seu artigo como acontece o compartilhamento do conhecimento em indústrias do setor metal mecânico. Os resultados parciais mostraram que o processo de gestão de conhecimento é o ponto de partida para disseminação de ferramentas, práticas e tecnologias para a transferência de informações e conhecimento na indústria. Sendo assim, a incorporação dessas práticas no cotidiano da indústria possibilitará a melhor gestão de todos os setores.

Bastiani (2012) continua em uma linha semelhante ao artigo anterior, apresenta a importância da gestão do conhecimento nas organizações, e que através de um plano de ação resulta nos conhecimentos específicos para uma boa gestão e condução de estratégias e criação de novas ideias, fazendo com que o colaborador interaja no processo de geração do conhecimento e desenvolvimento da empresa. Conclui afirmando que as empresas devem utilizar os planos de ação para atingir os objetivos almejados através de estratégias competitivas.

O artigo de Macedo (2012) expõe as características que potencializam ou inibem a inovação no ambiente de uma empresa de informações para decisão de negócios. O artigo contempla os principais fatos históricos da empresa e aplicação de um questionário, o questionário analisou 29 dimensões, divididas nos fatores de influências: ideias, contexto, pessoas, transações e resultados. O estudo chegou à conclusão que os fatores de influência contribuem para um ambiente inovador, e de todas as dimensões analisadas foi identificado somente duas como fatores inibidores do processo de inovação: a padronização 
de procedimentos e frequência de comunicação.

Observando o processo de inovação para a pequena e média empresa, Panzarini (2012), através de um referencial teórico, ressalta a importância do processo de inovação e da transferência tecnológica para que a pequena e média empresa sobrevivam no ambiente competitivo. Sendo fundamental que a pequena e média empresa busque atualizações como estratégias competitivas, no entanto relata a necessidade de uma boa base de apoio para que essas empresas possam ter sucesso nesse processo.

Rezende (2012) apresenta em seu artigo um exemplo de um APL de metais sanitários em Loanda - PR, através de um estudo com os empresários do APL, constatou a importância do fluxo de informações (conhecimentos) em um APL, e toda a relação entre fornecedores, clientes e entidades de ensino. Demonstra também a dificuldade que as empresas do APL de Metais Sanitários em Loanda tem para o acesso as informações que maximizem o processo de aprendizagem e inovação.

Ainda no setor metal mecânico Lara (2012), relata que estratégias de produção e inovação devem estar associadas com o processo de entrega, com o processo de qualidade, com o custo e flexibilidade, verificando assim como ocorre a inovação no cotidiano e através de quais decisões. Em seu estudo observa que a inovação em produto ocorre em relação aos principais clientes, já as inovações organizacionais ocorrem por demanda do mercado, mas também como forma de reduzir custos. Percebe-se barreiras para inovação, primeiro pelo medo do empresário não ter o retorno almejado e o segundo ponto é por não apresentar um planejamento formal. Conclui dizendo que um estudo maior vem acontecendo com o objetivo de mostrar a relação entre prioridades competitivas e inovação em pequenas empresas, mas que no futuro outros trabalhos podem ocorrer em empresas de grande porte ou em um número maior de empresas.

O planejamento para a prática da gestão da inovação é citado por Lara (2012) em um estudo de caso, onde foram analisados os departamentos de Engenharia de Processo, Engenharia de Produto,
Qualidade e Fabricação, a pesquisa abordava nesses departamentos análise sobre estratégia e liderança, cultura e clima organizacional, planejamento e seleção, estrutura e desempenho, comunicação e colaboração, assim cada quesito foi analisado por departamento e verificado que a empresa possui consciência e preocupação em produtos, no entanto necessita da implantação de um programa de inovação estruturado.

Para que as decisões durante o planejamento do processo de inovação seja efetivo critérios de informação e decisão devem ser adotados. O artigo de Oliveira (2012) descreve uma proposta de categorias de informações de projeto e critérios de decisão que foi criada a partir da revisão da bibliografia, teve como resultado 15 categorias de informação e 8 categorias de critério de decisão. Assim, o conhecimento de cada item a ser levado em consideração é essencial para melhorar o planejamento da gestão do processo inovador

Falani (2012) em seu artigo mostra como um dos fatores principais para a influência da inovação no meio empresarial é a existência da cultura de inovação no ambiente organizacional, para que essa cultura de inovação seja desenvolvida, investimentos em capital intelectual tornam-se necessário para a implantação efetiva da cultura organizacional voltada para inovação. Conclui afirmando que a observação dos fatores que influenciam na cultura organizacional é essencial para um programa saudável e adequado para a realidade do ambiente organizacional e o processo de inovação torne-se rotina.

Araujo et al. (2013) desenvolveram um trabalho sobre o processo de inovação em laticínios do estado do Paraná. Os resultados mostraram que a gestão de tecnologias e inovações nesse tipo de indústrias é uma área que deve estar diretamente relacionada à alta direção e, muitas vezes sob a responsabilidade do departamento de P\&D ou Desenvolvimento de Novos Produtos. Durante o processo de geração de ideias, criação, desenvolvimento, aperfeiçoamento, equipes multidisciplinares trabalham desenvolvendo papéis relevantes para a qualidade e sucesso do produto final. 
Zeni et al. (2013 a) apresentaram um estudo teórico de análise de metodologias que avaliam a capacidade de inovação nas empresa. Neste trabalho identificou-se a existência de diferentes metodologias nos diferentes segmentos de mercado, portanto, na escolha da metodologia deve ser levado em consideração o tipo de setor da economia. Sobre a mensuração da inovação nas empresas, o estudo mostrou que grande parte das métricas resultam do Manual de Oslo e, tratam da inovação em empresas de manufatura, envolvendo pesquisa, desenvolvimento e comercialização. Os resultados da investigação em literaturas internacionais mostraram que a mensuração de uma atividade inovativa envolve: mensuração de input do processo de inovação, uma produção intermediária e uma mensuração direta de produção inovadora.

Zeni et al. (2013 b) elaboraram e aplicaram um questionário em quatro empresas do segmento de tecnologia da informação (TI) e engenharia, com objetivo de avaliar a capacidade de inovação em KIBS (Knowledge Intensive Business Services), com base nos seguintes indicadores: acesso ao conhecimento; construção da inovação; resultados obtidos com a inovação. Os resultados indicaram que as empresas investigadas apresentam facilidade no acesso ao conhecimento, contudo, essas demonstraram dificuldades no processo de construção de inovação, portando não são consideradas inovadoras.

Cavalcante e Matos (2013) aplicaram um questionário autoavaliativo em uma empresa prestadora de serviços do ramo de energia elétrica. O objetivo do trabalho foi de analisar o perfil de gestão da inovação em empresas prestadoras de serviços e avaliar critérioschave para aumentar resultados e buscar a melhoria contínua. Os resultados indicaram um estágio inicial de gestão da inovação, focado na melhoria de processos e estrutura, com práticas de melhoria em andamento. O questionário servirá de orientação para a definição de objetivos e metas.

Martins e Guimarães (2014) buscaram identificar em uma indústria de embalagens de vidro de porte médio, os fatores que influenciam na tomada de decisão para implementar inovação e as consequências desse processo na competitividade da mesma. No trabalho foi analisado um processo de reorganização produtiva e o emprego de novos métodos de fabricação e gerenciamento de negócios. Os resultados descrevem que a empresa desenvolveu uma posição concorrencial diferenciada, suficientemente rentável para a geração dos investimentos necessários à sua atualização tecnológica. Também foi percebido que a redução e a padronização do portfólio, bem como, a atuação em nichos específicos de mercado, tornaram a empresa mais flexível diante das variações nos demais segmentos de mercado de grandes volumes.

Rodrigues et al. (2014) avaliaram por meio da aplicação de um questionário estruturado baseado nas teorias desenvolvidas pela Innoscience, a percepção dos funcionários de todos os setores de uma indústria metalúrgica de pequeno porte, em relação a inovação. Verificou-se que apesar de não ter grandes investimentos para geração e implementação das inovações dentro da empresa, a inovação é vista por todos os funcionários, como parte importante para o processo produtivo.

Zattar et al. (2014) avaliaram o posicionamento de uma empresa brasileira de desenvolvimento de softwares com relação à inovação e o alcance de sua cultura inovadora. Os resultados mostraram que apesar da empresa já incentivar em sua cultura algumas iniciativas inovadoras, a mesma apresenta-se em um posicionamento inovativo moderado. A partir desses resultados, sugeriram-se medidas para aumentar o nível de inovação na empresa, a fim de fazer da inovação um processo contínuo.

\section{METODOLOGIA}

A base do trabalho foi através da aplicação de um questionário desenvolvido pelo Núcleo de apoio à Gestão da Inovação (NAGI), Senai-PR. O questionário teve como objetivo compreender como ocorre os processos de gestão gerenciais e operacionais para o desenvolvimento da inovação na empresa. O questionário foi aplicado através de uma entrevista aos empresários, onde os próprios consultores orientadores preencheram cada item do questionário. A entrevista foi conduzida abordando os temas: estratégia e 
mercado; produtos e serviços; clientes; concorrentes; fornecedores e parceiros; tendências atuais e futuras; estrutura e competência organizacional. A pesquisa foi qualitativa, baseada nas reapostas dos empresários e a percepção dos consultores orientadores. Sua fundamentação possibilitou a percepção sistêmica para preparação de um workshop de geração de ideias. Visto que a incorporação do processo de geração de ideias é a ação inicial para um ambiente inovativo.

O workshop foi realizado em duas etapas, o primeiro dia contou com a presença somente dos funcionários, foi iniciado com uma breve apresentação sobre o tema inovação, como funciona o processo para inovar, a diferença entre inovação e invenção, inovação radical e incremental, inovação em produto, processo, marketing e organizacional, obstáculos para inovar, dicas para aumentar a criatividade. Após a apresentação o workshop seguiu com o agrupamento dos participantes em equipes, cada equipe gerou ideias para melhoria organizacional. O segundo dia do workshop começou com uma apresentação aos empresários da análise feita dos cenários e tendências, análise do ambiente, síntese do cenário, tendências de setor, análise SWOT da empresa. A geração de ideias do segundo dia, contou com os funcionários estratégicos da empresa e convidados, o foco do segundo dia foi para geração de ideias para melhorias significativas de produtos $e$ novos produtos.

Com base na busca por fomentar a geração de ideias nas empresas participantes do projeto NAGI, foi escolhida de maneira intencional uma empresa de dispositivos eletrônicos, pois apresenta a visão voltada à inovação. A empresa estudada implantou um departamento de Pesquisa \& Desenvolvimento, para inovação continua em produtos. Está em fase de formação de equipe qualificada para que resoluções cotidianas sejam contínuas e assertivas. pequeno porte, com aproximadamente 80 funcionários, se localiza na região de Campo Mourão/PR e atua na fabricação de dispositivos eletroeletrônicos. Possui departamento de Pesquisa \& Desenvolvimento e está em fase de implantação de sistema para Planejamento de Controle da Produção (PCP). Neste estudo não será divulgado o nome da empresa, portanto, denominarse-á empresa ALFA.

A empresa foi analisada através de um diagnóstico desenvolvido pelo SENAI/PR, o diagnóstico serviu de base para a realização de um workshop personalizado para a empresa focado na área da inovação e para a realização de um brainstorming para geração de ideias.

\subsection{BRAINSTORMING}

O processo de geração de ideias na empresa ALFA, possibilitou a geração de 197 ideias, tanto de processos, como de produtos. A geração de ideias aconteceu em dois eventos, o primeiro evento contou com a participação de aproximadamente 25 funcionários e abordou o tema melhoria organizacional, o segundo evento contou a participação de aproximadamente 15 funcionários estratégicos e 10 convidados, abordou melhorias em produtos ou novos produtos.

O primeiro evento resultou em: 14 ideias para estrutura física da empresa; 13 para processo; 11 para capacitação; 7 para equipamentos; 7 para materiais de apoio; 3 para reuniões; 8 para organização; 3 para tecnologia de informação; 4 para comunicação; 5 para atendimento ao cliente; 15 para gestão de pessoas; 3 para recreação/lazer e bem estar; 13 para gestão de operações, um total de 106 ideias no primeiro evento. O segundo evento resultou em 91 ideias para melhoria nos produtos e novos produtos. Como pode ser visualizado na Figura 1.a e 1.b.

\section{RESULTADOS}

A empresa estudada atua no mercado nacional de 
Figura1.a - Ideias Geradas no Workshop

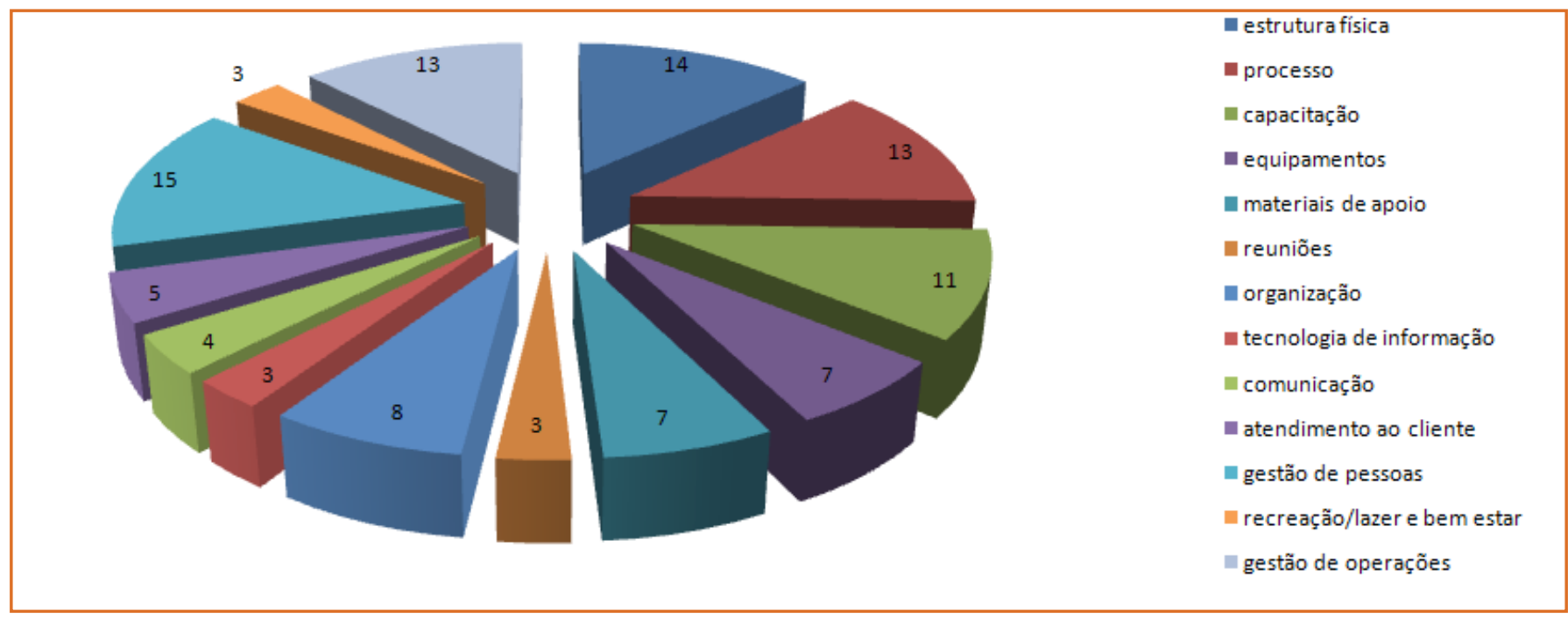

Figura 1.b - Ideias Geradas no Workshop

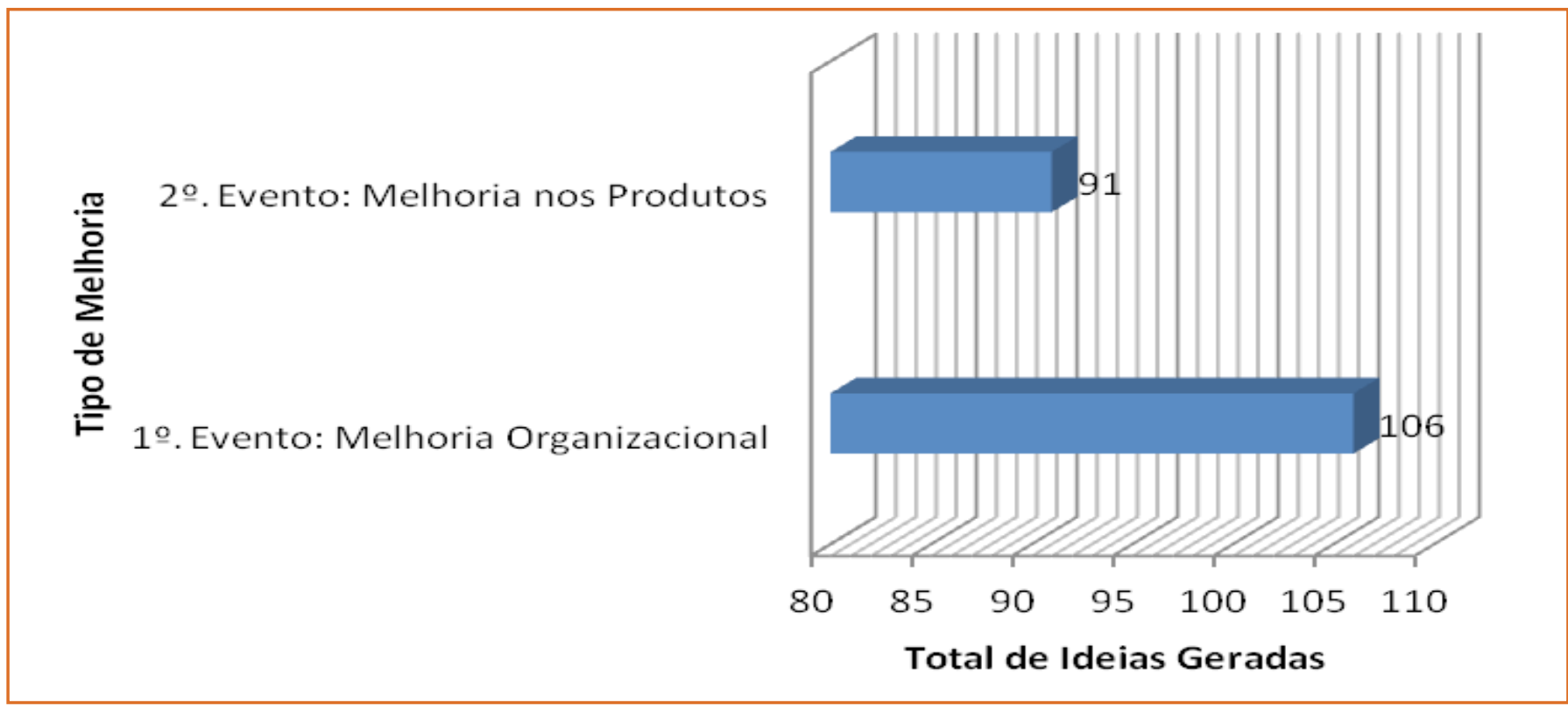

O workshop resultou em 197 ideias, as quais foram avaliadas em uma reunião. A reunião contou com a presença dos empresários e dos consultores orientadores do projeto. As ideias foram separadas para análise em melhoria organizacional e produtos, as ideias de melhoria organizacional foram guardadas para análise e avaliação interna na empresa.

A análise das ideias de produtos foi iniciada por uma identificação com cores, em amarelo as ideias de interesse para o futuro, em azul as ideias que no momento já estavam em projeto, em vermelho as ideias que não pertenciam à área de atuação e que os empresários não demonstravam interesse, e em verde as ideias que apresentavam características para captação de recursos governamentais, particulares para execução no momento. A avaliação e seleção seguiram alguns critérios de pontuação: ligação com a estratégia do negócio; vantagem competitiva do produto; atratividade de mercado; competências necessárias; viabilidade técnica; retorno financeiro.

Ao final da reunião, os empresários com auxílio dos consultores orientadores do projeto, selecionaram três 
ideias. Com base nessas ideias serão elaborados os documentos de captação de recursos e um plano de Gestão da Inovação. O plano de Gestão da Inovação auxiliará na prática dessas e de outras ideias não priorizadas no momento.

Foram elaborados três documentos denominados Termos de Abertura para Projeto (TAP), tais documentos serviram como orientação de embasamento teórico a captação de recursos. Os documentos apresentaram descrição do título do projeto, a descrição da oportunidade, natureza do projeto, objetivo, qual a estrutura física necessária, potencial mercado, competidores/concorrências, canal de distribuição, fornecedores, modelo de negócio e precificação, cronograma de macro etapas e orçamento, experiências anteriores de lançamentos de produtos, registros de marca e patentes.

Como etapa seguinte foi elaborado um Plano de Gestão de Inovação (PGI) e um Plano de Oportunidade de Inovação (POI). O PGI apresentou uma análise da cultura da empresa em relação à prática da inovação, identificação de oportunidades, alinhamento estratégico, estudo de viabilidade técnica e econômica, definição de recursos, implantação da gestão da inovação, e análise da aprendizagem da inovação. Após as análises de cada item, práticas foram sugeridas e apresentadas através de uma ferramenta chamada $5 \mathrm{~W} 2 \mathrm{H}$ como exemplificado no quadro 1.

Quadro 1- Levantamento de ações.

\section{LEVANTAMENTO}

Cultura para Inovação

\begin{tabular}{|c|c|c|c|c|c|c|c|}
\hline \multirow{2}{*}{$\begin{array}{c}\text { PRÁtICAS } \\
\text { SUGERIDAS }\end{array}$} & \multicolumn{7}{|c|}{ PLANO DE AÇÃO } \\
\cline { 2 - 8 } & Como & Quem & Quanto & Quando & Onde & Unidades & Porquê \\
\hline & - & - & - & - & - & - \\
\hline
\end{tabular}

O documento POI foi elaborado para cada uma das três ideias selecionadas para execução. O documento abrangia as tendências de mercado e inovação, estratégias competitivas (diversificação/liderança em custo/ customização), definição do que será desenvolvido e/ou implementado, responsável, quais ações, justificativa, e período operacional como visto no quadro 2.

Quadro 2- Plano de Oportunidade de Inovação

\begin{tabular}{|c|c|c|c|c|}
\hline $\begin{array}{c}\text { Definição } \\
\text { O que será desenvolvido e/ou implementado? } \\
\text { (descrição) }\end{array}$ & $\begin{array}{c}\text { Responsável } \\
\text { Por quem serão } \\
\text { desenvolvidas? }\end{array}$ & $\begin{array}{c}\text { Quais ações? } \\
\text { Quais serão as ações } \\
\text { desenvolvidas? } \\
\text { (ações) }\end{array}$ & $\begin{array}{c}\text { Justificativa } \\
\text { Porque serão } \\
\text { desenvolvidas? }\end{array}$ & $\begin{array}{c}1 \text { fase } \\
\text { operacional } \\
\text { Em qual } \\
\text { prazo serão }\end{array}$ \\
\hline- & - & - & - \\
\hline
\end{tabular}

\subsection{DISCUSSÃO DOS RESULTADOS}

O trabalho realizado na empresa ALFA serviu para identificar como é o cotidiano de uma empresa focada na área de inovação. Durante a aplicação do questionário, foi observado que a empresa possui características de inovação, no entanto não possuía planejamento formal para a inovação. Mesmo sem preparo formal, a empresa apresentou toda abertura para inicio da prática de incentivo a geração de ideias e consequentemente a um futuro programa de gestão da inovação.

A coleta dos dados se iniciou com a entrevista aos empresários, seguiu com uma visita a cada departamento da empresa, onde foi anotado pelos 
consultores orientadores as percepções visuais respectivas ao questionário aplicado. Os empresários deixaram a coleta de dados interessante, pois apresentaram com transparência todos os dados solicitados, com isso foi proporcionada uma base rica em conteúdo para ser utilizada na próxima etapa do trabalho.

A segunda etapa do trabalho consistiu na compilação dos dados, o que foi de suma importância para elaboração do material a ser utilizado no workshop. Para formatação do workshop os slides foram estruturados da seguinte forma: apresentação sobre o tema inovação; criatividade; geração de ideias para melhoria organizacional; cenários e tendências (análise do ambiente, síntese do cenário, tendências do setor, análise SWOT, apresentação da empresa, geração de ideias para produtos). A estruturação dos slides facilitou a condução do workshop, chegando a melhores resultados, visto que os empresários sentiram-se impressionados com as informações expostas nos slides de cenários e tendências, que em sua maioria não tinham realizado nenhuma avaliação.

O workshop foi realizado em duas etapas. A primeira etapa foi iniciada com uma breve apresentação sobre o tema inovação para os funcionários da empresa ALFA, os integrantes do workshop ficaram ambientalizados com o tema. Ainda na primeira etapa se seguiu com a geração de ideias para melhoria organizacional, as ideias geradas abrangiam desde o setor que trabalhavam como os outros setores, superando as expectativas. A segunda etapa foi iniciada com uma breve apresentação dos cenários e tendências aos empresários, onde os mesmos apontaram suas considerações, seguiu com a chegada dos funcionários estratégicos e convidados, onde em equipes geram ideias para melhorias dos produtos e ideias para novos produtos, superando as expectativas novamente.

Após o workshop, os consultores orientadores compilaram as ideias geradas em planilhas, e em reunião com os empresários selecionaram as ideias de acordo com as prioridades. Descartando ideias que não condiziam com o ramo de atuação e de interesse, identificando ideias em andamento, selecionando ideias de interesse para o futuro, e selecionando três ideias para a escritura dos termos de abertura para projetos.

Com base nos dados coletados na entrevista com a aplicação do questionário, do estudo feito da empresa e dos dados gerados no workshop, os consultores orientadores elaboram os documentos para que a empresa desse início ao processo de geração de ideias e consequentemente um programa de gestão da inovação. Os documentos foram constituídos de três Termos de Abertura para Projeto de captação de recursos, um Plano de Gestão da Inovação, um Plano de Oportunidade de Inovação. Foram apresentados e explicados aos empresários cada documento, sendo que os mesmo demonstraram total interesse na continuação do trabalho e uma futura implantação de um programa de geração de ideias e Gestão da Inovação na empresa.

A empresa ALFA possui e investe constantemente em tecnologias para facilitar as atividades executadas, mas não utiliza grande parte da tecnologia em seu cotidiano. A dificuldade da utilização da tecnologia deve-se a falta da formalização de uma gestão do conhecimento adequada, o que resulta em outras questões como a implantação do programa de inovação em toda a empresa. A empresa apresentou o interesse de aplicação de ferramentas para o aperfeiçoamento contínuo, no entanto necessita de planejamento e formalização de atividades estratégicas para a efetivação das atividades.

\section{CONSIDERAÇÕES FINAIS}

O conhecimento das atividades envolvidas à gestão da inovação no cotidiano de uma empresa é importante, pois pode ajudar a melhorar a tomada de decisão para as ações a serem realizadas. Assim a geração de ideias de maneira sistematizada, focada ou descentralizada, resulta na atividade inicial para implantação de um programa de gestão da inovação na empresa em questão. O estudo realizado trabalhou justamente esse ponto inicial, que aconteceu com o inicio de geração formalizada de ideias, assim também a compilação dessas ideias para uma tomada de decisão no momento do planejamento anual e priorização de ações a serem realizadas. 
Os dados foram coletados no brainstorming e serviram para a análise de que muitas vezes as atividades podem ser melhoradas, chegando à conclusão que atividades simples na maioria das vezes permanecem dias, meses e até mesmo anos presas no subconsciente do funcionário, por falta de incentivo a liberação dessas informações. Como visto no desenvolver do trabalho em apenas dois dias de brainstorming, foram geradas 197 ideias, das quais 14 ideias foram para melhoria da estrutura física da empresa, 13 para melhoria de processo, 11 para capacitação, 7 para aquisição e melhoria dos equipamentos, 7 para materiais de apoio, 3 para incentivo a reuniões estratégicas e operacionais, 8 ideias para melhoria da organização física da empresa, 3 para utilização de tecnologia de informação, 4 para melhoria na comunicação, 5 para melhoria no atendimento ao cliente, 15 para a gestão de pessoas, 3 para ações em recreação/lazer d bem estar, 13 para gestão de operações e 91 ideias para novos produtos.

Ainda que as empresas busquem auxílio de instituições com embasamento técnico para auxílio na implantação de programas para melhoria continua, fazendo com que os resultados dos trabalhos desenvolvidos obtenham resultados com maior qualidade, utilização máxima e com a efetividade pretendida, esperase que as empresas de pequeno porte comecem a visualizar a importância de incorporar os funcionários no processo de melhorias e novas ideias.

\section{REFERÊNCIAS}

[1] ARAÚJO, Alcione L. de; MONTEIRO, Francielli C.; CANTARELI, Maria H. G.; BITTENCOURT, Juliana V. M.; KOVALESKIS, João L. Inovação: evidência nos laticínios do estado do Paraná. CONGRESSO BRASILEIRO DE ENGENHARIA DE PRODUÇÃO, 3. Ponta Grossa, PR, Brasil, 04 a 06 de dezembro de 2013. Anais... III CONBREPRO, 2013.

[2] BASTIANI, J. A. de, ROBERTO, R. A. M., KOVALESKI, J. L., FRANCISCO, A. C. de. Identificação da gestão do conhecimento nas ferramentas de planos de ação. CONGRESSO BRASILEIRO DE ENGENHARIA DE PRODUÇÃO, 2. Ponta Grossa, PR, Brasil, 28 a 30 de dezembro de 2012. Anais... II CONBREPRO, 2012.

[3] CARVAlHO, H. G. de. Gestão da Inovação. Curitiba: Aymará, Série UTFinova, 2011.
[4] CAVAlCANTE, Carla T.; MATOS, Eloíza Apa . S. Á. de. Análise do Perfil de Gestão da inovação: um Estudo de Caso em uma Empresa Prestadora de Serviços do Sul do Brasil. CONGRESSO BRASILEIRO DE ENGENHARIA DE PRODUÇÃO, 3. Ponta Grossa, PR, Brasil, 04 a 06 de dezembro de 2013. Anais... III CONBREPRO, 2013.

[5] DAVID, D. E. H. Gestão de Ideias. Curitiba: Aymará, Série UTFinova, 2011.

[6] FALANI, S. Y. A., CAMPOS, M. C., SANTOS, K. G. B. dos, SILVA, M. L. S. da. Cultura da Inovação no ambiente organizacional: fatores influenciadores e métodos de avaliação. ENCONTRO NACIONAL DE ENGENHARIA DE PRODUÇÃO, 32, Bento Gonçalves, RS, 2012. Anais... XXXII ENEGEP, 2012.

[7] FURTADO, I. M. T. Processo de Gestão da Inovação. 2011. Disponível em: http://blogs.pr.sebrae.com.br/portal/ site/BlogsProd/template.PAGE/inovacao/.

[8] LARA, F. F., BONFIM, E. D., SERPA, J. F. Melhores práticas para a gestão eficaz da inovação de produtos: estudo de caso em um fabricante de equipamentos. XXXII ENCONTRO NACIONAL DE ENGENHARIA DE PRODUÇÃO, ENEGEP- Bento Gonçalves, RS, 2012.

[9] LARA, F. F., GUIMARAES, M. R. N. Estratégias de Produção e Inovação em empresas do setor Metal Mecânico. ENCONTRO NACIONAL DE ENGENHARIA DE PRODUÇÃO, 32, Bento Gonçalves, RS, 2012. Anais... XXXII ENEGEP, 2012.

[10] MACEDO, M., MULLER, L., DUARTE, M. A. T.. Caracterização do ambiente de inovação de uma empresa de informações para decisão de negócios. CONGRESSO BRASILEIRO DE ENGENHARIA DE PRODUÇÃO, 2. Ponta Grossa, PR, Brasil, 28 a 30 de dezembro de 2012. Anais... II CONBREPRO, 2012.

[11] MANUAL DE OSLO. Diretrizes para coleta e interpretação de dados sobre a inovação. OECD, OCDE, FINEP, 3ed. 1997

[12] MARTINS, Edson M.; GUIMARÃES, Márcia R. N. Estratégias e Inovação na Indústria de Embalagens de Vidro: Um Estudo de Caso em Empresa Vidreira de Médio Porte. CONGRESSO BRASILEIRO DE ENGENHARIA DE PRODUÇÃO, 4. Ponta Grossa, PR, Brasil, 03 a 05 de dezembro de 2014. Anais... IV CONBREPRO, 2014.

[13] OlIVEIRA, M. G., ROZENFELD, H. Proposta de categorias de informações de projeto de critérios de decisão usados no planejamento da inovação. ENCONTRO NACIONAL DE ENGENHARIA DE PRODUÇÃO, 32, Bento Gonçalves, RS, 2012. Anais... XXXII ENEGEP, 2012.

[14] PANZARINI, N. H., RODRIGUES, R. L., MATOS, E. A. S. A., KOVALESKI, J. L. O Processo de Inovação Tecnológica e Transferência de Tecnologia em Pequenas e Médias Empresas. CONGRESSO BRASILEIRO DE ENGENHARIA DE PRODUÇÃO, 2. Ponta Grossa, PR, Brasil, 28 a 30 de dezembro de 2012. Anais... II CONBREPRO, 2012. 
[15] REZENDE, J. L. de, SCHMIDT, A. S., SOUZA, A. D., RINAUDO, R. Aprendizagem e Inovação em APLs: um estudo no APL de Metais Sanitários de Loanda-PR. ENCONTRO NACIONAL DE ENGENHARIA DE PRODUÇÃO, 32, Bento Gonçalves, RS, 2012. Anais... XXXII ENEGEP, 2012.

[16] RODRIGUES, Reinaldo L.; PANZARINI, Nathalie $H_{\text {.; }}$ FRANCISCO, Antonio C. de; MATOS, Eloíza Apā. S. Á. de. Cenário da Inovação: Estudo de Caso em uma Metalúrgica de Pequeno Porte na Cidade de Ponta Grossa Pr. CONGRESSO BRASILEIRO DE ENGENHARIA DE PRODUÇÃO, 4. Ponta Grossa, PR, Brasil, 03 a 05 de dezembro de 2014. Anais... IV CONBREPRO, 2014.

[17] SCHRODER, C. C., MACEDO, M., MELIM, J. M. Tecnologias e o compartilhamento do conhecimento: um estudo de caso do setor metal-mecânico de Joinville/ SC. CONGRESSO BRASILEIRO DE ENGENHARIA DE PRODUÇÃO, 2. Ponta Grossa, PR, Brasil, 28 a 30 de dezembro de 2012. Anais... II CONBREPRO, 2012.

[18] STRAUHS, F. R. Gestão do Conhecimento nas Organizações. Curitiba: Aymará, Série UTFinova, 2012.
[19] ZATTAR, Izabel C.; GARCIA, C. G. S.; OLIVEIRA, Guilherme A. S.; CLETO, Marcelo G. Avaliação da Cultura Inovadora Empresarial: Um Estudo de Caso. CONGRESSO BRASILEIRO DE ENGENHARIA DE PRODUÇÃO, 4. Ponta Grossa, PR, Brasil, 03 a 05 de dezembro de 2014. Anais... IV CONBREPRO, 2014.

[20] ZENI, Adriana M.; MACEDO, Marcelo; FREITAS FILHO, Fernando; KLEINA, Jaqueline S. Análise das metodologias para mensurar a Capacidade de Inovação. CONGRESSO BRASILEIRO DE ENGENHARIA DE PRODUÇÃO, 3. Ponta Grossa, PR, Brasil, 04 a 06 de dezembro de 2013. Anais... III CONBREPRO, 2013 a.

[21] ZENI, Adriana M.; MACEDO, Marcelo; FREITAS FILHO, Fernando; KLEINA, Jaqueline S. A Capacidade de Inovação das Organizações com Serviços Intensivos em Conhecimento: Um estudo em empresas de $\mathrm{Tl}$ e Engenharia de Ponta Grossa. CONGRESSO BRASILEIRO DE ENGENHARIA DE PRODUÇÃO, 3. Ponta Grossa, PR, Brasil, 04 a 06 de dezembro de 2013. Anais... III CONBREPRO, 2013 b. 


\section{CAPITULO 13}

\section{LEAN SERVICE: APLICADO A UM PROCESSO DE ABASTECIMENTO}

\section{Tassiara de Almeida da Silva}

Jeancarlos Araldi

\section{Edson Pacheco Paladini}

Resumo: A busca pela excelência na prestação de serviços tem feito com que os Postos de Combustíveis procurem cada vez mais por técnicas que os diferencie no mercado. Através disto, esta pesquisa busca sugerir uma melhoria no processo de abastecimento de uma bomba de combustível, através das técnicas de lean service, que visa à eliminação do desperdício e a criação de valor para o cliente, ou seja, eliminar os passos desnecessários, alinhar os processos de atividade em um fluxo continuo, aumentar o foco no cliente e buscar sempre a melhoria continua. Para alcançar o objetivo desta pesquisa, utilizaramse os métodos de observação e cronometragem, mapeamento de processos e entrevista não estruturada no Posto de Combustivel X, onde buscaram-se dados e informações para a proposição da melhoria no processo de abastecimento. Os resultados obtidos com essa pesquisa mostraram que com a implantação e utilização do lean service no Posto de Combustivel X, não só o processo de abastecimento se tornará melhor, mas o Posto como um todo, pois as técnicas do lean service sugerem melhorias para todas as áreas do Posto de Combustivel $X$.

Palavras Chave: Processo de Abastecimento, Lean Service, Melhoria Continua, Posto de Combustível. 


\section{INTRODUÇÃO}

Nos últimos tempos os postos de combustíveis passaram por grandes transformações, os diversos planos econômicos do Brasil bem como os inúmeros conflitos entre países produtores e exploradores de petróleo, fizeram com que o mercado brasileiro de combustível sofresse várias oscilações. Antes os postos de gasolina faziam parte de um setor listado como segurança nacional, onde o governo militar definia tudo, o preço de venda, a quantidade que podia ser fornecida a distribuidora e até mesmo o horário de funcionamento.

Contudo, não havia concorrência, pois não se podia abrir um posto onde se bem entendesse. Mas de repente as coisas mudaram, houve a desregulamentação e o número de postos de gasolina, nos últimos cincos anos triplicou, aumentando assim a concorrência. Por isso os proprietários dos postos de gasolina viram as margens de seus negócios baixarem rapidamente, a concorrência aumentar cada vez mais e agora os mesmos estão tendo que disputar sua clientela.

Com esse cenário de competitividade em evidência, a busca pela excelência no âmbito empresarial tem feito com que as empresas busquem cada vez mais em desenvolver estratégias que as diferenciem no mercado. Por isso este trabalho tem a finalidade de estudar como melhorar o processo de abastecimento de uma bomba de combustível através das técnicas de lean service, buscando a otimização do tempo ocioso de seus colaboradores juntamente com o melhor escalonamento de trabalho. Para que assim seja possível aumentar a produtividade e a agilidade nos serviços prestados pelo posto de combustível visando sempre à melhora no processo de abastecimento e com isso a redução do tempo ocioso e o desperdício com investimentos desnecessários.

Segundo Scartezini (2009), melhorar os processos da organização é fator crítico para o sucesso institucional de qualquer empresa, seja ela pública ou privada, desde que realizada de forma sistematizada e que seja entendida por todos na organização. Assim, a melhoria nos processos de um posto de combustível deve passar por todos, para que assim seja possível desenvolver estratégias para que o mesmo consiga se destacar no mercado.
Desta forma, um processo é um grupo de atividades realizadas numa sequência lógica com o objetivo de produzir um bem ou serviço que tem valor para um grupo específico de clientes. Assim, através desses processos é criado um diferencial competitivo que é responsável pela criação de valor junto ao seu cliente (HAMMER; CHAMPY, 1994). De acordo com Hunt (1996), a análise dos processos mapeados permite a redução de custos no desenvolvimento de produtos e serviços, a redução nas falhas de integração entre sistemas e melhora no desempenho da organização, além de ser uma excelente ferramenta para possibilitar o melhor entendimento dos processos atuais e eliminar ou simplificar aqueles que necessitam de mudanças.

A escolha do mapeamento como ferramenta de melhoria baseia-se em seus conceitos e técnicas que quando empregadas de forma correta, permitem documentar todos os elementos que compõem um processo e corrigir qualquer um desses elementos que estejam com problemas sendo uma ferramenta que auxilia na detecção das atividades não agregadoras de valor (DE MELLO, 2008).

Através disso, Melton (2005), destaca que o mapeamento de processos utilizado em conjunto com as técnicas de lean service traz benefícios para a organização, pois através deles a organização consegue alcançar uma maior produtividade nas operações diárias. Assim, a utilização do lean service dentro da organização pode ser vista como uma forma de agregar valor, pois com a sua utilização é possível alinhar na melhor sequência possível as ações dos processos, bem como, realizar as atividades de maneira mais eficaz e sem interrupções, ou seja, oferecer aos clientes cada vez mais com cada vez menos, menos esforço humano, menos equipamentos, menos tempo, menos espaço e serviços customizados (VASCONCELOS et al. 2013).

Diante disto, o mapeamento de processos juntamente com o lean service visa eliminar o tempo ocioso bem como o desperdício com investimentos desnecessários, para que seja possível alcançar uma melhoria contínua, possibilitando assim aperfeiçoar a qualidade e eficácia no processo de abastecimento de uma bomba de combustível. 


\section{FUNDAMENTAÇÃO TEÓRICA}

\subsection{PROCESSOS}

Os alicerces de uma organização são os processos que nela estão envolvidos, por isso é muito importante que estes processos sejam conhecidos e documentados por completo, para que assim sejam geridos com eficiência.

Conforme Madiolo et al. (2006) enfatiza os processos nem sempre apresentam início e fim claros, não apresentando um fluxo bem definido e não sendo formados de atividades claramente delineadas, sendo assim, não precisam ser consistentes ou realizados numa sequência particular. Portanto os processos podem ser definidos como a forma pela qual as coisas são feitas.

Segundo Gonçalves (2000), os processos nas empresas são essencialmente dinâmicos e mudam com o decorrer do tempo, assim o seu funcionamento precisa estar sempre se adaptando, de modo que seja possível se adequar as novas situações. O mesmo autor cita ainda, que a idéia de processos está ligada a cadeia de valor, onde os processos são uma coleção de atividades que envolvem a empresa de ponta a ponta tendo como propósito entregar um resultado a um cliente final.

Desta forma, entender o funcionamento e quais são os tipos existentes de processos dentro de uma organização se tornou essencial para determinar como esses processos devem ser gerenciados para que assim seja possível obter o melhor resultado. Afinal, cada tipo de processo tem sua característica especifica e deve ser gerenciado de maneira específica (GONÇALVES, 2000).

Assim, a compreensão de como são gerenciados os processos dentro da organização se torna importante, pois, esses processos são a chave para o sucesso de qualquer negócio e com eles é possível atingir a vantagem competitiva desejada.

\subsubsection{MAPEAMENTO DE PROCESSOS}

Segundo Villela (2000), a ferramenta mapeamento de processos pode ser a melhor forma de entender as atividades que constituem os processos essenciais de uma organização e os processos que os apóiam em termos de finalidade, pontos de inicio, entradas e saídas.

Assim, essa ferramenta é essencial para que seja possivel definir melhor os processos, otimizar o tempo ocioso, reduzir os custos e as falhas de processos e melhorar o desempenho da organização.

Conforme Pinho et al. (2007), afirma que com um prévio mapeamento da organização é possível propor um novo gerenciamento no sentido de oferecer melhorias, mas para que essas melhorias sejam alcançadas existem quatro enfoques que devem ser considerados para as soluções propostas.

Assim, mapear os processos de uma organização ajuda a identificar as fontes do desperdício, fornecendo uma linguagem comum para tratar dos processos $e$ serviços, tornando as decisões mais visíveis, de modo com que todos da organização possam discuti-las (PINHO et al. 2007).

\subsection{LEAN SERVICE}

Apesar de o lean manufacturing ser visto como um conceito utilizado apenas em empresas de manufatura, muitas de suas técnicas são utilizadas em empresas de serviço, essas técnicas são denominadas como lean services.

Segundo Giannini (2007), o lean service começou a ser utilizado em empresas de operações e serviços a partir do ano de 2000, visando à redução das perdas tanto para a empresa como para os clientes, já que os serviços são inseparáveis, sendo produzidos e consumidos simultaneamente e, como consequência, não existe oportunidade de inspeção final antes da entrega.

De acordo com Oliveira (2011), o lean service pode 
ser definido como um sistema de operações e serviços padronizáveis, constituído apenas por processos/ atividades que agregam valor para o cliente, visando atender suas expectativas de qualidade e preço. $\mathrm{O}$ mesmo autor cita ainda que a execução do lean service é baseada nos princípios do lean manufacturing, com adaptações para as organizações prestadoras de serviços.

Portanto, no lean service o valor é criado se os desperdícios são reduzidos, através da redução das atividades que geram desperdícios e dos custos decorrentes, o valor também pode ser aumentado quando facilidades adicionais são oferecidas ao cliente. Assim, o equilíbrio custo-valor indica a situação onde o produto fornece exatamente o valor que 0 cliente está disposto a pagar e o seu custo (FORTES, 2010).

\subsection{KAIZEN}

O termo Kaizen tem origem japonesa e significa "mudar para melhor". Nas empresas representa que nenhum dia deve passar sem que sejam feitas melhorias. $O$ Kaizen assim como o lean service buscam a melhoria continua dentro da organização, tendo como objetivo a promoção de melhoramentos sucessivos e constantes, ou seja, mais e menores passos de melhoramento incremental (SLACK et al., 2002).

Para Sharma (2003), a filosofia Kaizen está baseada na eliminação de desperdícios, através do uso de soluções baratas que se apoiem na motivação e criatividade dos colaboradores para melhoras a prática dos seus processos de trabalho, com foco na busca pela melhoria continua.

Já Pimentel (2008), diz que o Kaizen não visa somente os ganhos de produtividade, redução de custos e eliminação de desperdícios. Mas também a melhoria continua das condições de trabalho de seus colaboradores, buscando desse modo a sua total interação com os processos, para através disso aumentar sua satisfação.

Assim, uma implementação bem sucedida do Kaizen trás benefícios em escala. Os maiores casos de sucesso são no Japão, onde a cultura do país e a sistemática do Kaizen são altamente compatíveis. Desta forma pode-se citar algumas empresas que implementaram com sucesso essa abordagem, sendo elas, Toyota Motor, Tokai Rika, Aisin, Aichi, Daí Nippon Toryo, JVC, Tetra-Park (LEITE, 2007).

\section{PROCEDIMENTOS METODOLÓGICOS}

Essa pesquisa realizou-se em um Posto de Combustivel da rede Ipiranga, na cidade de Passo fundo, caracterizando-se como uma pesquisa aplicada, pois buscou aperfeiçoar o processo de abastecimento de uma bomba de combustível através de técnicas de cronometragem e mapeamento de processos. Através disso, Silva e Menezes (2001), afirmam que a pesquisa aplicada objetiva gerar conhecimentos para a aplicação prática e solucionar problemas específicos. Classificou-se também como uma pesquisa qualitativa, pois nela foram utilizadas métricas para a mensuração do número de processos que são utilizados atualmente por um frentista no processo de abastecimento de uma bomba de combustível, bem como seria o modelo ideal de abastecimento através das técnicas de lean service, para assim construir tabelas e modelo A3 para a análise e melhora deste processo.

Para a coleta de dados desta pesquisa utilizouse às técnicas de observação e cronometragem, entrevistas não estruturadas com a gestora do posto e levantamento fotográfico. Já para a mensuração e análise dos dados coletados desta pesquisa utilizouse o processo A3 ou modelo A3, que é uma ferramenta do sistema Toyota de produção que gerencia os esforços de melhoria ou correlação da situação atual para uma situação futura desejável. Essa ferramenta baseia-se em resolver as causas/raízes dos problemas encontrados na organização bem como, melhorar o seu processo.

O modelo A3 é um processo de gerenciamento onde o problema, análise, ações corretivas e plano de ação são expressos em apenas uma das faces de uma única folha de papel de tamanho internacional $297 \times 420$ $\mathrm{mm}$. No modelo $A 3$, cada desafio que a organização 
precisa enfrentar (projeto ou problema) deve ser registrado em uma única folha de papel A3. Portanto o modelo A3 é uma ferramenta que se utiliza o autor (da solução) para apresentar de forma sintetizada e organizada a solução encontrada para o problema. Desta forma, o modelo A3 é dividido em dois lados onde o esquerdo contém a definição do problema e o direito que possui uma ou mais soluções junto às contramedidas necessárias, conforme será mostrado em anexo A (AQUINO, 2013).

\section{RESULTADOS E DISCUSSÕES 4.1 A EMPRESA EM ESTUDO}

O Posto de Combustivel $\mathrm{X}$, tem mais de 30 anos de atividades na cidade de Passo Fundo, em 2010 foi vendido e a direção que assumiu constituída por dois sócios traçou novas estratégias de gerenciamento, a fim de alavancar as vendas para assim conquistar novos clientes. Em 2011, um dos sócios deixou a empresa, vendendo suas ações para o atual proprietário. Hoje o posto conta com uma estrutura que oferece para seus clientes diversos serviços, sendo eles, posto de combustível, loja de conveniência, lavagem, empresa de lubrificantes, com troca de óleo para veículos e departamento especializado em motos.

\subsection{MAPEAMENTO ATUAL DO PROCESSO DE ABASTECIMENTO DE UMA BOMBA DE COMBUSTÍVEL}

O Posto possui 18 bombas de abastecimento, divididas em, gasolina comum, gasolina aditivada, óleo diesel S10 (para veículos produzidos a partir de 2012), óleo diesel aditivado e etanol (álcool) em media passam pelo Posto de Combustível em torno de 530 carros por dia, o ticket médio de abastecimento do Posto gira em torno de $R \$ 100,00$, dados coletados em entrevista com a gestora do Posto de Combustível X. Hoje o posto possui 14 funcionários na pista de abastecimento, que estão divididos em 3 turnos de 6 horas cada, onde os turnos da manhã e da tarde possuem 4 funcionários, e 1 chefe de pista para cada turno (manhã e tarde), no turno da noite após as 21 horas ficam somente 3 funcionários para atender até as 24 horas, pois conforme a gestora é um horário que tem menor movimento.

O processo de abastecimento de uma bomba de combustível acontece da seguinte forma, o cliente chega com o seu veiculo e estaciona no local indicado para o abastecimento, onde quando não se é em dias e horários de maior movimento é atendido logo em seguida pelo frentista, onde o mesmo pega a chave e verifica com o cliente quanto gostaria de abastecer e qual o tipo de combustível.

Logo em seguida o frentista se dirige até a parte lateral do carro no qual está localizado o tanque de abastecimento e abre o mesmo, após o tanque aberto o frentista desloca-se até a bomba de combustível coloca na mesma a quantia que o cliente pediu para abastecimento, pega a bomba e com ela descolase até o tanque onde o mesmo encaixa a bomba e começa o abastecimento.

Após ter abastecido com a quantia pedida pelo cliente o frentista retira a bomba de combustível do tanque do veiculo, e desloca-se para guardar a mesma, após isso o frentista retorna para o veiculo e fecha o tanque do mesmo. Seguindo em direção aonde esta o cliente, onde o frentista entrega a chave do veiculo e comunica-se com o cliente para que o mesmo efetue o pagamento.

No decorrer do processo de abastecimento, os que ocorrem em horários de menor movimento, muitas vezes acontece o auxilio de outro frentista oferecendo os serviços de complementação do processo de abastecimento que são os serviços de verificação de água e óleo, calibragem de pneus e limpeza de parabrisa. Em dias e horários que se tem mais movimento como foi mostrado no quadro 4, o mesmo frentista que abastece o veiculo, faz esses serviços, fazendo com que o abastecimento se torne mais demorado.

Para o pagamento do abastecimento do veiculo os que acontecem em dinheiro o frentista recebe, mas quando precisa de troco tem que se dirigir até o chefe de pista para conseguir. Já os que ocorrem em cartão, o cliente consegue efetuar o pagamento na pista de abastecimento somente com os cartões Visa e Master, 
os demais que o Posto aceita (Ipiranga, Sicredi, Banrisul, Refeisul, Elo, Sodexo, Goodcar, Ticket, Maxi, Senff, Pix, Cresol) o cliente tem que se deslocar até a loja AM/PM para conseguir efetuar o pagamento, fazendo com que assim aconteça maior demora para a finalização do abastecimento. A seguir na figura 1 é mostrado um fluxograma de como funciona o processo de abastecimento no Posto de Combustível X.

Assim, na figura 1 é mostrado o mapa atual do Posto de Combustível $\mathrm{X}$, com todas as etapas do processo abastecimento, bem como o tempo que é levado para efetuar cada um delas (em segundos).

Figura 1 - Mapa Atual Posto de Combustivel X

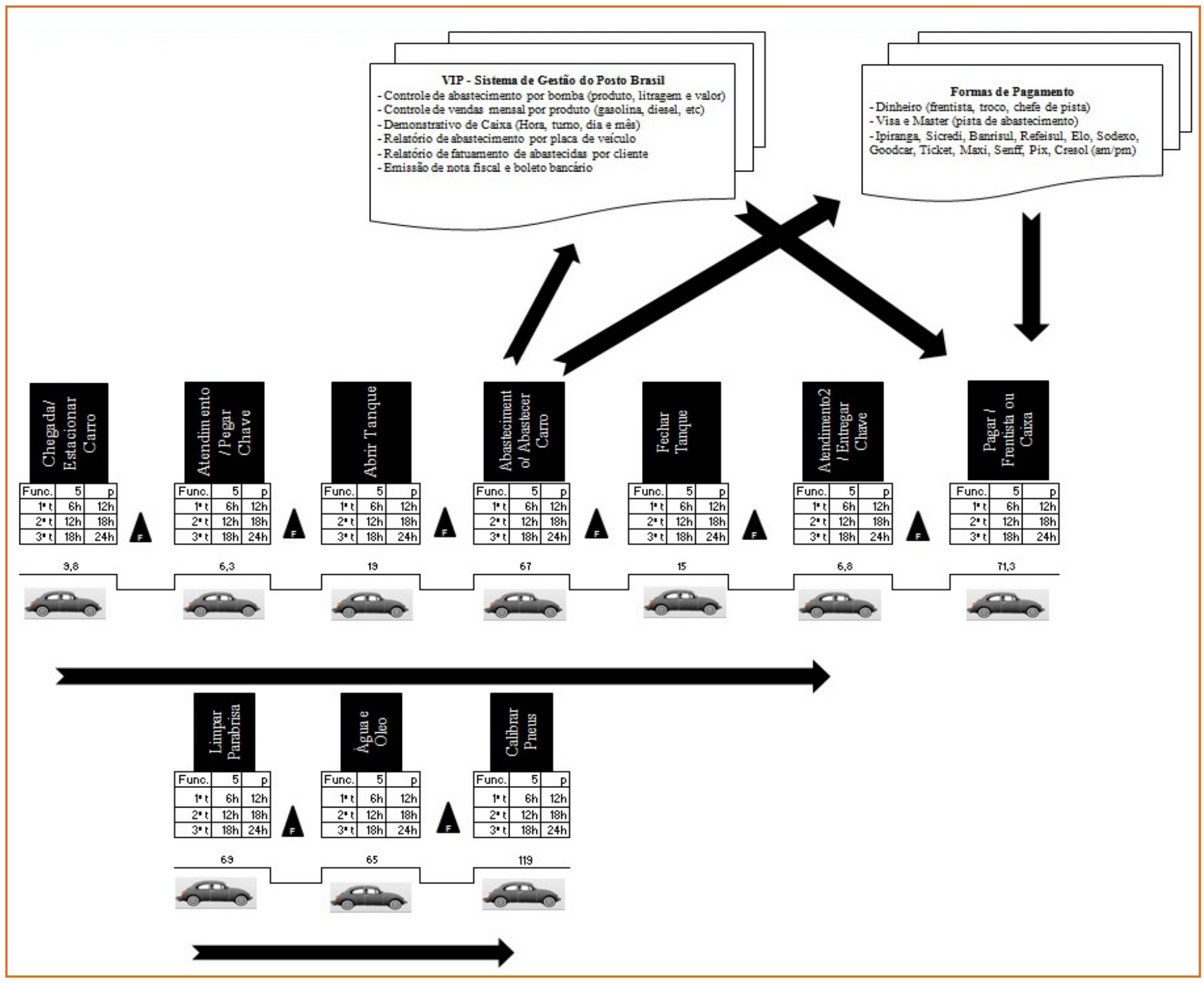

Desta forma, o mapa atual do Posto de Combustível X ilustrado na figura anterior mostra como funciona todo o processo de abastecimento do Posto, com todas as suas etapas e tempos levados para a efetivação de cada uma delas, juntamente com os serviços adicionais oferecidos pelo Posto. Com isso pode-se ter uma melhor percepção de como ocorre o abastecimento do Posto Brasil Ipiranga e todos os processos envolvidos desde quando o cliente estaciona seu veiculo para abastecer até a finalização desse abastecimento. 


\subsection{PROPOSIÇÃO DO NOVO MAPEAMENTO DOS PROCESSOS DE ABASTECIMENTO USANDO KAIZEN}

Através do mapeamento de processos do Posto de Combustível X, pode-se notar que o mesmo sofre com alguns problemas referentes à rotatividade de pessoal, bem como, problemas no sistema de pagamento e desperdício de tempo tanto de seus clientes quanto de seus funcionários. Visando tanto a melhora no processo de abastecimento como no escalonamento de seus funcionários buscou-se a elaboração de alguns kaizens, ou seja, algumas sugestões de melhoria continua para que o Posto de Combustível $X$ consiga deste modo, melhorar o seu processo de abastecimento e assim oferecer melhores serviços para seus cliente. Assim, os kaizens que serão propostos estarão ilustrados juntamente com o Mapa Atual do Processo de Abastecimento do Posto de Combustível $\mathrm{X}$, em forma de nuvens de melhoria continua.

Deste modo, estão listado alguns kaizens que o Posto de Combustível $X$ pode implementar não só no seu processo de abastecimento, mas também na forma de gestão do Posto de Combustível.

1. Investimento em um novo Sistema de Gestão: Apesar do posto já possuir um, seria necessário o investimento em um sistema mais moderno. Para que assim fosse possível integralizar a maneira de gestão, onde o sistema além de relatórios de abastecimento, controle e faturamento do Posto, o sistema pudesse ter o controle total das operações realizadas no Posto. Tais como:

- Identificação do perfil de consumo de clientes permitindo organizar ações de fidelização personalizadas;

- Gerenciamento do crédito do cliente para um ou mais postos de uma rede minimizando o risco de perdas;

- Monitoramento de todo o serviço remotamente via Web permitindo que o proprietário tenha total controle do negócio independente do local onde ele esteja;

- Demonstrativo de necessidade de pessoal por hora e dia de semana;
- Descontos pré-definidos no cadastro do cliente e/ou do produto;

- Controle de Frota e cadastro de veículos;

- Transferência Eletrônica de Fundos (TEF);

- Emissão e gestão de boletos bancário;

- Fidelização de seus clientes;

2. Aquisição de Máquina que aceite todos os tipos de Cartão: Conhecido como Sistema TEF (transferência eletrônica de fundos), com a aquisição dessa máquina o Posto conseguiria otimizar os pagamentos feitos no cartão de crédito, pois hoje o Posto conta apenas com uma máquina que aceita Visa e Master na pista de abastecimento, fazendo com que os clientes que possuem outros cartões tenham que se deslocar até a loja AM/PM para fazer o pagamento, e dessa forma aumentando o tempo de abastecimento e a demora para a conclusão do pagamento.

3. Treinamento para os funcionários: Investir em treinamento para os funcionários, pois com isso o Posto Brasil Ipiranga consegue ser mais eficiente, podendo oferecer desenvolvimento, organização e qualificação para o quadro de funcionários e assim, fazer com que a empresa destaque-se dentre os concorrentes pela qualidade dos serviços prestados e por possuir profissionais capacitados para resolver qualquer problema.

4. Novo Escalonamento: Fazer um novo escalonamento de funcionários, para que assim seja possível balancear e organizar os horários que possuem maior movimento, e com isso maior demanda de funcionários, para que todos os clientes sejam atendidos de maneira eficiente. Com esse novo escalonamento será possível dividir de forma certa o número de funcionários por turnos e diminuir a ociosidade dos mesmos.

5. Sistema de Controle de Abastecimento por Frentista: Programa Identifique, é um software que depois de instalado, cada frentista terá uma senha e para o abastecimento dos veículos as bombas somente serão liberadas com esta senha. Este 
programa contribuirá para controlar a produtividade de cada frentista, além de servir para segurança no controle de recebimentos, principalmente nos horários de maiores movimentos, onde nem sempre se identifica qual frentista abasteceu em cada bomba.

6. Reformulação do Layout: Reorganizar o layout do Posto principalmente nas áreas de estacionamento. Pois o fluxo de veículos é muito intenso e por varias vezes pode-se notar que isso influenciava na pista de abastecimento, ocorrendo de ter veículos maus estacionados dificultando a entrada e saída da pista de abastecimento.

7. Retenção de Novos Clientes: Elaborar uma estratégia para conseguir reter e fidelizar novos clientes, pois por se tratar de um ramo de mercado onde se tem muitos concorrentes é fundamental ter estratégias para que se consiga conquistar novos clientes e também manter os antigos satisfeitos com os serviços prestados pelo Posto.

8. Recrutamento e Seleção: Implementar a técnica de recrutamento e seleção para a contratação de novos funcionários. Onde o recrutamento e seleção possibilitará a diminuição de erros na escolha de perfis esperados pela empresa, e assim cosegue incorporar ao Posto colaboradores mais comprometidos. Pois quando se tem um perfil definido se consegue reduzir o tempo, os custos e os problemas relacionados a contratações indevidas.
9. Retenção de Colaboradores: Os funcionários são fundamentais para que a empresa se desenvolva e conquiste novos clientes, por isso, é um fatorchave investir na retenção de colaboradores. Através de um ambiente que possibilite ao colaborador desenvolver projetos com maior autonomia e novas competências, envolver os funcionários nos processos de decisão ou engajalos em projetos, escutar suas sugestões de forma apreciativa, criar ações parar melhorar o clima no ambiente de trabalho, estimular a troca de ideias. Todas essas ações fazem com que o funcionário se sinta valorizado e parte da equipe.

10. Controlar o estacionamento do Posto: Elaborar uma estratégia para controlar e organizar o estacionamento do Posto, para que o mesmo não influencie negativamente na pista de abastecimento.

11. Melhorar a comunição entre a pista de abastecimento e a AM/PM: Investir em Walk Talks para facilitar a comunicação entre a pista e a loja AM/PM, para que o frentista não tenha que se deslocar desnecessariamente para informar sobre os pagamentos referentes aos abastecimentos que ocorrem na pista de abastecimento.

Deste modo, na figura 2 é mostrado o mapa atual do Posto de Combustivel $\mathrm{X}$ juntamente com os Kaizens propostos. 
Figura 2 - Mapa Kaizens Posto de Combustivel X

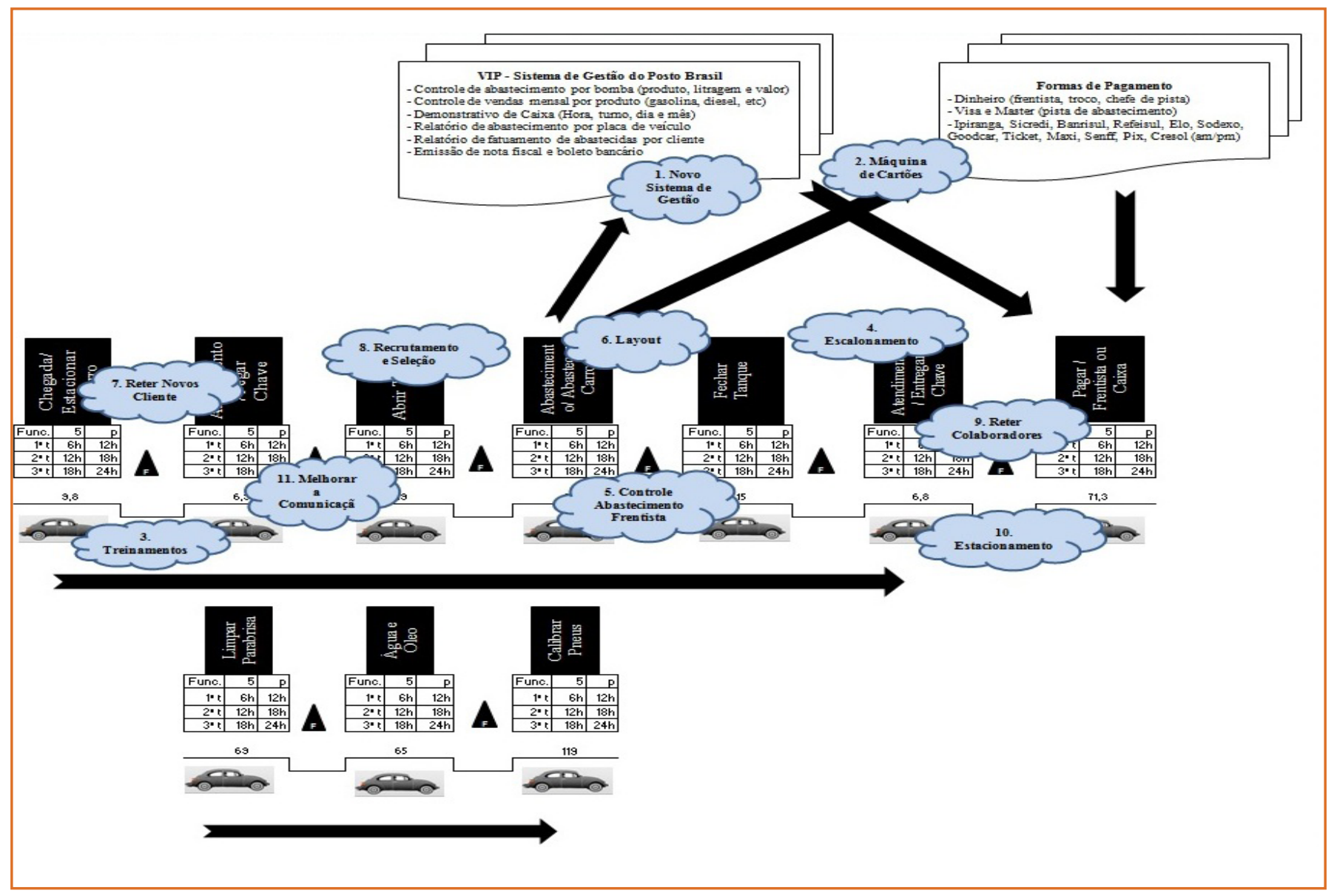

Deste modo, com a figura 2 pode-se ter um melhor entendimento de onde os kaizens propostos no Mapa atual do Posto podem ser alocados para que futuramente sejam implementados e consigam de fato ser a melhoria que o Posto de Combustível X precisa no seu gerenciamento como um todo.

\subsection{PROPOSIÇÃO DO NOVO MAPEAMENTO DO POSTO DE COMBUSTÍVEL - MAPA FUTURO}

Como foi observado anteriormente o processo de abastecimento do Posto de Combustível X vem sofrendo com alguns problemas referente à alta rotatividade de pessoal, bem como o tempo levado para o abastecimento e pagamento de cada veiculo em horários de maior demanda de serviço. Por isso buscou-se propor um novo mapeamento no processo de abastecimento do Posto de Combustível X, sendo esse mais otimizado e com algumas melhorias.
Para esse novo mapeamento será utilizado alguns kaizens já propostos anteriormente, pois com eles será possível à melhoria continua no processo de abastecimento, bem como novos processos e atividades que agregam valor para o cliente, visando sempre atender suas expectativas de qualidade de serviço prestado e preço.

Essas melhorias são proposta visando alguns princípios do lean service que são: reduzir os trade-offs de desempenho; fazer os processos de valor agregado fluírem e implementar sistema puxado pelo cliente; eliminar perdas na cadeia de valor das atividades, do desenvolvimento à entrega; aumentar o foco no cliente e seu envolvimento nos processos de desenvolvimento e entrega; dar poder aos funcionários e times.

Através desse novo mapeamento os tempos de cada processo serão otimizados e balanceados bem como o escalonamento de seus funcionários. A base de cada 
processo continuará a mesma só sofrendo algumas alterações no decorrer da sua efetivação.

Para que isso seja possível o Posto de Combustível $X$ terá que investir em um novo sistema de gerenciamento, onde possa identificar o perfil de consumo do cliente para assim organizar ações de fidelização personalizada, bem como o monitoramento de todo o serviço remotamente via WEB, que assim permitirá que o proprietário tenha total controle do Posto independente do local onde esteja.

Além desse novo sistema de gerenciamento o Posto de Combustível $X$ deverá investir também em uma nova máquina de cartão, onde a mesma aceite todos os tipos de cartão não apenas Visa e Master, essa maquina é conhecida como Sistema TEF (transferência eletrônica de fundos). Com a aquisição desta maquina - Posto de Combustível X conseguirá diminuir e otimizar o tempo que seus clientes levam para efetuar pagamentos nos cartões (Ipiranga, Sicredi, Banrisul, Refeisul, Elo, Sodexo, Goodcar, Ticket, Maxi, Senff, Pix, Cresol) que hoje não são aceitos diretamente na pista de abastecimento.

Outra melhoria que o Posto de Combustível X poderia implementar nesse novo processo de abastecimento, seria um sistema de controle de abastecimento por frentista, conhecido como Programa Identifique, esse programa é um software que após instalado no Posto cada frentista terá uma senha e para que seja possível efetuar o abastecimento dos veículos as bombas somente serão liberadas com esta senha. Com a instalação desse software o Posto de Combustível $X$ conseguirá ter maior controle da produtividade de cada frentista, além de obter maior segurança no controle de recebimentos, principalmente nos horários de maior movimento, onde nem sempre se identifica qual frentista abasteceu em cada bomba.

Já para os problemas ligados a rotatividade de colaboradores algumas atitudes e técnicas podem ser implementadas para a melhoria no processo de gestão do Posto de Combustível X. Essas melhorias devem começar desde quando o Posto Brasil Ipiranga decide pela contratação de um novo funcionário, através das técnicas de recrutamento e seleção, pois com a utilização dessa técnica o Posto de Combustível $X$ conseguirá minimixar os erros na escolha de perfis esperados pela empresa, e assim conseguirá incorporar ao Posto colaboradores mais comprometidos. Pois quando se tem um perfil definido se consegue reduzir o tempo, os custos e os problemas relacionados a contratações indevidas.

Outra estratégia que o Posto de Combustível X precisa criar e desenvolver é a retenção de novos clientes e fidelização dos já existentes, pois por se tratar de um ramo de mercado onde se tem muitos concorrentes é fundamental ter estratégias para que se consiga conquistar novos clientes e também manter os antigos satisfeitos com os serviços prestados pelo Posto.

Portanto, através dessa nova sugestão de mapeamento para o Posto de Combustível X os processos ligados ao abastecimento de veículos e rotatividade de pessoal podem se tornar mais otimizados e se implementadas todas as sugestões podem fazer com que o Posto de Combustível $X$ consiga oferecer um serviço com maior padrão de qualidade e também um pessoal mais comprometido e bem treinado no atendimento de seus clientes.

\section{CONCLUSÃO}

Desta forma, nota-se que por se tratar de um nicho de mercado onde se tem muita oferta e a competitividade é muito grande, o que foi proposto para o Posto de Combustível $X$ no decorrer da pesquisa faz com que o mesmo se diferencie nesse mercado e também consiga atingir a excelência na prestação dos seus serviços, através de um atendimento bem treinado e também de um processo de abastecimento otimizado e bem escalonado.

Pois, com a utilização das técnicas propostas de mapeamento de processos, lean service e um novo escalonamento de trabalho será possível que o Posto de Combustível $\mathrm{X}$ consiga solucionar os seus problemas referente à rotatividade de pessoal e demora no atendimento e pagamento na pista de abastecimento. 
Com essas melhorias proposta durante a pesquisa o Posto de Combustível $X$ contará não só com um processo de abastecimento mais otimizado, mas também com um gerenciamento de pessoal mais organizado e bem estruturado, dividido em etapas, assim facilitando a contratação de perfis certos para os cargos disponíveis no Posto.

Portanto, com a aplicação das praticas observadas referente ao lean service e kaizen todas as áreas do Posto podem ser beneficiadas, com custos mais baixos, serviços prestados de alta qualidade e entrega de melhores serviços no tempo e no padrão desejado pelo cliente.

Desta forma, pode-se dizer que os objetivos gerais e específicos desta pesquisa foram atingidos. A partir do mapeamento do processo de abastecimento do Posto de Combustível $\mathrm{X}$, no qual foi possível verificar onde se encontravam os problemas do Posto.

Bem como com as sugestões de kaizen para a melhoria continua do processo de abastecimento, facilitando assim a proposição de um novo processo de abastecimento com todas as melhorias continuas necessárias, para que o Posto de Combustível X possa desta forma, oferecer os melhores serviços para seus clientes.

Assim, a seguir será mostrado o modelo A3 feito para o Posto de Combustível X para que deste modo seja possível verificar desde a situação atual do Posto e como ficará após a efetivação de todas as melhorias continuas propostas.

Figura 3 - A3 Posto de Combustivel X

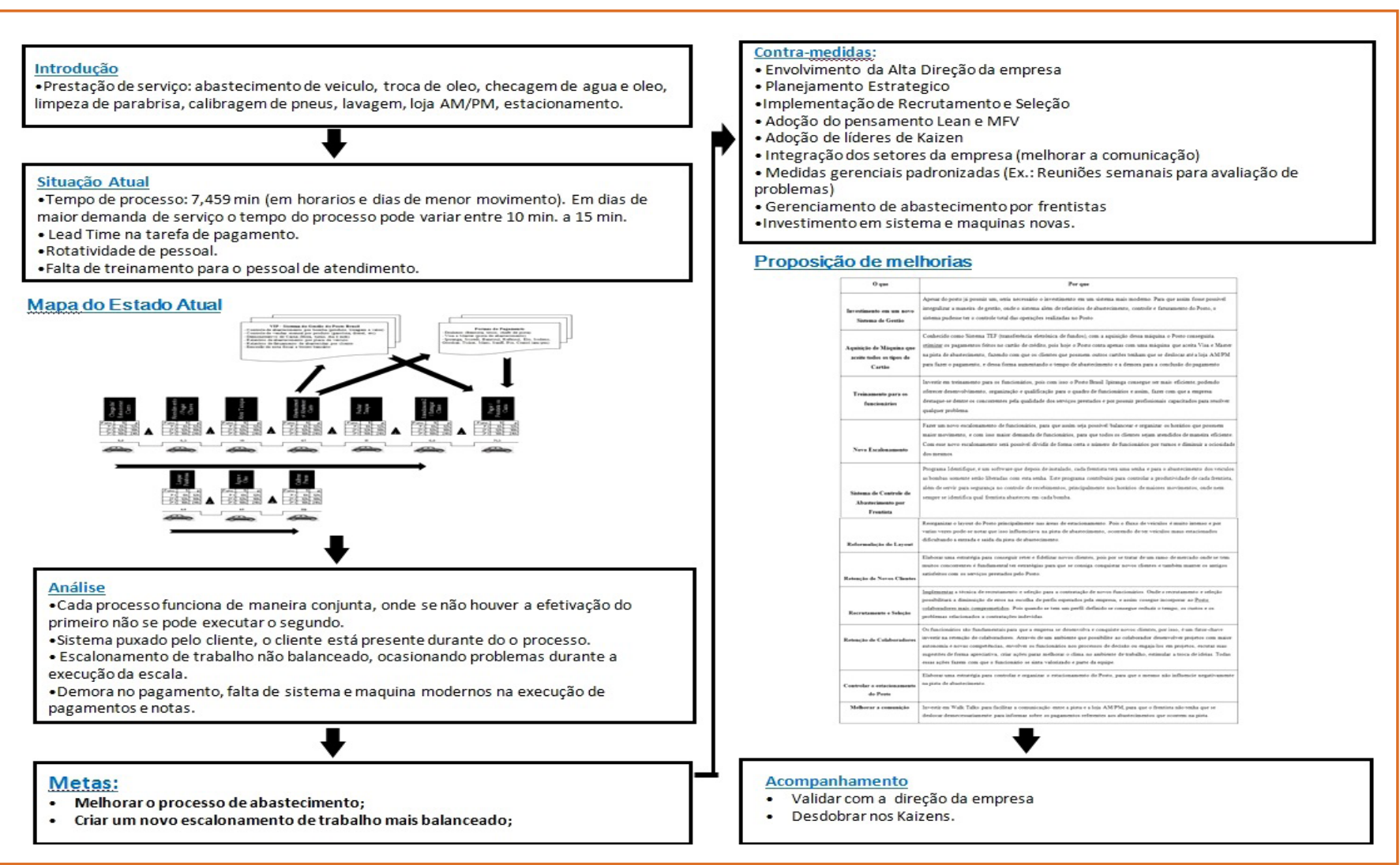

Portanto, com o modelo A3 é possível analisar a situação do Posto de Combustível X desde o começo da pesquisa e como o mesmo pode ficar após a inserção das melhorias sugeridas. Deste modo, podese concluir que as melhorias sugeridas com essa pesquisa só farão com que o Posto de Combustível $X$ se diferencie cada vez mais de seus concorrentes, através de um processo de abastecimento otimizado, atendimento diferenciado e prestação de serviço de alta qualidade. 


\section{REFERÊNCIAS}

[1] AQUINO, R. S. P. Lean TI e o A3 - Método de Solução de Problemas. Lean Institute Brasil, 2013. Disponível em: $<$ http://www.leanti.com.br/artigos/8/lean-ti-e-o-a3---metodode-solucao-de-problemas.aspx\#.VGDuUPnF_-4>. Acesso em: 10/11/2014.

[2] DE MELLO, A. E. N. S. Aplicação do Mapeamento de Processos e da simulação no desenvolvimento de projetos de processos produtivos. Itajubá, 2008. 116 p. Trabalho de Conclusão de Curso (Pós-Graduação); Universidade Federal de Itajubá; Engenharia de Produção; Itajubá, 2008.

[3] FORTES, C. S. Aplicabilidade de Lean Service na Melhoria de Serviços de Tecnologia da Informação (TI). Porto Alegre, 2010. 168 p. Dissertação (Mestrado); Universidade Federal do Rio Grande do Sul, PPGEP; Porto Alegre, 2010.

[4] GIANNINI, R. Aplicação de ferramentas do pensamento enxuto na redução de perdas em operações de serviços. São Paulo, 2007. 122 p. Dissertação (Mestrado); Escola Politécnica da Universidade de São Paulo; Engenharia de Produção; São Paulo, 2007

[5] GONÇALVES, J. E. L. As empresas são grandes coleções de processos. RAE - Revista de Administração de Empresas, Rio de Janeiro, v. 40, n.1, p. 6-19, Jan./Mar. 2000

[6] HAMMER, M.; CHAMPY, J. Reengineering the corporation. New York: HaperBusiness, 1994

[7] HUNT, V. D. Process Mapping: How to Reengineer your Business Process. John Wiley \& Sons, New York, 1996.

[8] LEITE, G. Administração da produção: A evolução com a ferramenta de melhoria contínua no Japão. Revista Técnica IPEP, São Paulo, SP, v. 7, n.1,p. 25-31, jan./jun. 2007.

[9] MADIOLO, A. D. S. et al. Gestão de processos em uma empresa do setor elétrico. GEPROS. Gestão da Produção, Operações e Sistemas, v. 1, n.2, p. 31-39, Abril. 2006.

[10] MELTON, T. The benefits of lean manufacturing: what lean thinking has to offer the process industries. Chemical Engineering Research and Design, v. 83, p. 662-673, 2005.
[11] OLIVEIRA, G. S. Proposta de Melhoria nos Processos Através das Ferramentas do Pensamento Enxuto e World Wide Web. Joinville, 2011. 41 p. Trabalho de Conclusão de Curso; Universidade do Estado de Santa Catarina; Engenharia de Produção e Sistemas; Joinville, 2011.

[12] PIMENTEL, F. F. Aplicação da Filosofia Kaizen na Escola de Administração do Exército. Salvador, 2008, 62 p. Trabalho de Conclusão de Curso; Escola de Administração do Exército e Colégio Militar de Salvador, Salvador, 2008.

[13] PINHO, A. et al. Combinação entre as técnicas de fluxograma e mapa de processo no mapeamento de um processo produtivo. In: Encontro Nacional de Engenharia de Produção, XXVII - ENEGEP, Foz do Iguaçu. Anais, ABEPRO, outubro, 2007.

[14] SCARTEZINI, L. M. B.; Análise e Melhoria de Processos. Disponível em: <http://www.aprendersempre.org.br/arqs/ GE\%20B\%20-\%20An\%E1lise-e-Melhoria-de-Processos.pdf. $>$. Acesso em 02/10/2014.

[15] SHARMA, A.; MOODY, P. E. A Máquina Perfeita; Como vencer na nova economia produzindo com menos recursos. Trad. Maria Lúcia G. Leite Rosa. 1.ed. São Paulo: Prentice Hall, 2003. 255 p.

[16] SILVA, E. L.; MENEZES, E. M. Metodologia da pesquisa e elaboração de dissertação. 3. ed. rev. atual. Florianópolis: Laboratório de Ensino a Distância da UFSC, 2001.

[17] SLACK, N. et al. Administração da produção. 2. ed. São Paulo: Atlas, 2002

[18] VASCONCELOS, D. C. et al. Lean e Green: A Contribuição da Produção Enxuta e da Gestão Ambiental para a Redução de Desperdícios. In: XXXVII Encontro da ANPAD. Rio de Janeiro, 2013.

[19] VILLELA, C. S. S. Mapeamento de Processos como Ferramenta de Reestruturação e Aprendizado Organizacional. Dissertação de Mestrado. PPEP/UFSC, Florianopolis, SC. 2000. 


\section{CAPÍTULO 14}

\section{OS PAPÉIS DE AGENTES EM REDE PARA A PROMOÇÃo DA INOVAÇÃO EM PEQUENAS EMPRESAS TRADICIONAIS}

\section{Geralda Cristina de Freitas Ramalheiro}

Ricardo Augusto Bonotto Barboza

\section{Sergio Azevedo Fonseca}

Resumo: $O$ universo das micro e pequenas empresas (MPEs) que operam em setores tradicionais da economia são compostos por barreiras à inovação, sendo necessárias políticas e intervenções públicas para minimizar as dificuldades. O objetivo deste estudo é relatar as virtudes, as limitações e as dificuldades de operacionalização de dois instrumentos indutores de inovações em MPEs de base tradicional. Para tanto foi verificada a periodicidade em que as MPEs, assistidas por ambos os instrumentos, inovaram. A estratégia metodológica compreendeu uma pesquisa qualitativa, de caráter exploratório, delineada como estudo de casos simples, com dados coletados por meio de entrevistas e observação participante. Apurou-se que as micro e pequenas empresas, mesmo aquelas que são alvos de programas e políticas públicas, apresentam muitas dificuldades para operacionalizar inovações. Notouse também que a junção dos dois instrumentos potencializou as atividades inovativas. Esses resultados corroboraram a virtuosidade do trabalho em rede para o desenvolvimento do perfil inovativo das MPEs.

Palavras Chave: Inovação. Agentes em rede. Pequenas empresas de base tradicional. 


\section{INTRODUÇÃO}

Na década de 1990 o Brasil foi palco de grandes transformações estruturais econômicas e políticas e dois fenômenos de grande interesse emergiram: primeiro, houve a expansão e o ganho de relevância das pequenas empresas; segundo, houve a disseminação das políticas públicas voltadas para apoiar as micro e pequenas empresas. A principal expressão do primeiro fenômeno foi o intenso movimento de criação de novos negócios, em grande parte feito por trabalhadores expulsos do mercado de trabalho formal. Desse modo, o universo das Micro e Pequenas Empresas (MPEs) formais e informais - adquiriu relevante papel social com o tempo (FONSECA, 2010). Outro fato a ser posto em destaque é que, se por um lado esses aumentos quantitativos são certos e firmes, por outro, a sua estabilidade é duvidosa: dados do SEBRAE (2015) vêm revelando, desde os anos 90, a grande fragilidade dos novos pequenos negócios (formais ou não), expressa em taxas de mortalidade superiores a $25 \%$ ao longo dos dois primeiros anos de existência. Já o segundo fenômeno é diretamente decorrente do primeiro, e corresponde às crescentes pressões a que foram submetidos os poderes públicos locais para a criação de políticas públicas capazes de oferecer suporte aos pequenos negócios, fazendo com que fosse gerado um contexto de expansão firme e vigoroso de políticas públicas que assegurassem maiores probabilidades de sucesso aos empreendimentos de pequeno porte. Dentre as políticas incorporadas nas agendas governamentais destacam-se as que objetivam estimular a inovação (CASSIOLATO; LASTRES, 2005; DIAS, 2011; FURTADO, 2005; VELHO, 2011; BALBACHEVSKY, 2010). Nesse contexto merecem particular destaque os programas de incubação de empresas e o Serviço Brasileiro de Respostas Técnicas (SBRT), ambos objetos de estudo neste trabalho.

As incubadoras de empresas apresentam relevantes contribuições na disseminação da cultura empreendedora e no fortalecimento gerencial das empresas assistidas, além de atuarem como agentes de estímulo à geração de inovações (AHMAD; 2014; BERGEK; NORRMAN, 2008; BØLLINGTOFT, 2012; BRUNEEL et al., 2012; LESÁKOVÁ, 2012; SOETANTO; JACK, 2013; SILVA et al., 2010). Nos casos em que as incubadoras não investem em ações indutoras de inovações (realidade presente em muitas incubadoras mistas e tradicionais) a gestão da inovação acaba relegada a um segundo plano (RAMALHEIRO, FONSECA; TERENCE, 2010). Sugere-se, neste trabalho, que os principais problemas enfrentados pelas incubadoras não tecnológicas para estimular inovações sejam a inexistência ou precariedade da oferta de infraestrutura laboratorial e de corpo técnico e a dificuldade em operacionalizar redes de inovação.

O SBRT, por sua vez, tem como missão principal elaborar notas técnicas que assegurem a transferência de conhecimentos técnicos de baixa complexidade e informações oriundas de universidades e centros de pesquisa para empreendedores e empreendimentos de pequeno porte, com a expectativa de que essas notas técnicas possam gerar inovações. A rede do SBRT, isoladamente, encontra limitações para operacionalizar seus objetivos, haja vista a distância imposta pelo atendimento remoto (on line) aos usuários do sistema (FONSECA et al., 2013). A fim de minimizar esse tipo de limitação, a unidade do SBRT localizada na Universidade Estadual Paulista (UNESP/ Araraquara), denominada Sistema Integrado de Respostas Técnicas (SIRT) estabeleceu uma parceria com a incubadora de empresas do município de Araraquara, de modo que a rede passasse a induzir demandas por notas técnicas por meio de prospecção direta junto aos usuários, neste caso empreendedores participantes do programa de incubação do município de Araraquara.

O objetivo deste trabalho é relatar as vantagens, as limitações e as dificuldades à operacionalização da parceria estabelecida entre o SIRT e a Incubadora de Empresas de Araraquara. Para tanto buscouse verificar a periodicidade com que as empresas assistidas inovaram, analisando os tipos, fontes e mecanismos usados para a promoção das inovações. O texto está estruturado em sete seções: esta primeira, introdutória; a segunda, em que são tratadas algumas das especificidades da inovação em empreendimentos de pequeno porte; na terceira são feitas considerações em torno do conceito de redes de inovação; a quarta aborda as características dos dois objetos da pesquisa; a quinta contempla a estratégia metodológica utilizada na pesquisa; a sexta compreende os resultados da pesquisa; na última são 
apresentadas as considerações finais.

\section{INOVAÇÃO EM EMPREENDIMENTOS TRADICIONAIS DE PEQUENO PORTE}

Como mostrava Schumpeter (1977), já na primeira metade do século 20, a inovação é fator crítico de sobrevivência empresarial, condição essa acentuada a partir do início do século XXI, caracterizado por mudanças e volatilidades aceleradas, novas tecnologias e novas formas organizacionais. Nessas condições torna-se crucial que as empresas possuam capacidade de gerar e absorver inovações (AMATO NETO; OLAVE, 2005; BARGE-GIL, 2010; DOH; KIM, 2014; FREEL, 2000; MCGUIRK; LENIHAN; HART, 2015; MCKELVEY; ZARING; LJUNGBERG, 2014; RADAS; BOŽlĆ, 2009; SOLOMON et al., 2013; SPITHOVEN; CLARYSSE; KNOCKAERT, 2011).

Nota-se que os tipos de inovação mais frequentes, adotados por empreendimentos de pequeno porte, são qualificados como inovações não tecnológicas ou inovações de baixa complexidade - low-tech innovations (GRIMPE; SOFKA, 2009; HEIDENREICH, 2009; KIRNER; KINKEL; JAEGER, 2009; NUNES; SERRASQUEIRO; LEITÃO, 2012; BARGE-GIL, 2010) e que o percurso pelo qual a extensa maioria incorpora inovações pode ser enquadrado no conceito de inovações abertas (GRIMPE; SOFKA, 2009; HEIDENREICH, 2009; VRGOVIC et al., 2014; TÖDTLING; LEHNER; KAUFMANN, 2009), tal como definido por Chesbrough (2003).

Radas e Božić (2009) defendem que os fatores que influenciam a inovação nas micro e pequenas empresas podem ser divididos em internos e externos, os primeiros referidos a características e políticas das MPE, os últimos às oportunidades que as MPE podem aproveitar do ambiente. Doh e Kim (2014) notaram que, no contexto das pequenas empresas, a inovação em produtos é vista como o resultado do investimento em competitividade por diferenciação e como estratégia de expansão do mercado e que as inovações em processos surgem como uma estratégia de competitividade por preços e como um caminho para a eficiência.
Em relação aos setores tradicionais, que são predominantemente caracterizados pela forte presença de micro e pequenas empresas, a literatura aponta a presença de limitações para realizar atividades de P\&D e para gerar inovações (SPITHOVEN; CLARYSSE; KNOCKAERT, 2011). Como evidenciou Barge-Gil (2010) as empresas fora dos setores de alta tecnologia, as empresas menores e, em certa medida, as empresas com baixa intensidade P\&D, inovam, frequentemente, por meio da cooperação, isso porque o número e a qualificação dos funcionários de muitas dessas empresas caem abaixo de uma massa crítica necessária (SPITHOVEN; CLARYSSE; KNOCKAERT, 2011). Os apontamentos de Mcguirk, Lenihan e Hart (2015) revelam que os funcionários de pequenas empresas que participam de treinamento têm maiores probabilidades de participarem de atividades inovativas. Outro fator propulsor da inovação em pequenas empresas são as participações em redes (DOH; KIM, 2014).

No que tange às dificuldades das MPE para inovar, a literatura (AMATO NETO; OLAVE, 2005; BARGEGIL, 2010; DOH; KIM, 2014; FREEL, 2000; MCGUIRK; LENIHAN; HART, 2015; MCKELVEY; ZARING; LJUNGBERG, 2014; RADAS; BOŽI $\square$, 2009; SOLOMON et al., 2013; SPITHOVEN; CLARYSSE; KNOCKAERT, 2011) revela a existência de um conjunto de fatores restritivos, sendo os principais: o fato das MPE operarem em segmentos de mercado estáveis; ofertarem produtos de baixa complexidade técnica; adotarem processos de trabalho rígidos; possuírem administração tradicional (familiar); contratarem mão de obra com baixa qualificação profissional; adotarem processos inovativos apenas pontuais e de caráter corretivo; utilizarem tecnologia agregada por fornecedores; buscarem resultados a curto prazo (falta de visão e planejamento de longo prazo); manterem distanciamento com universidades e centros de pesquisa e pouco controle sobre o ambiente externo.

Esse conjunto de fatores, inibidores de processos e atividades passíveis de criarem ambientes favoráveis à inovação, no contexto das micro e pequenas empresas, dos empreendimentos informais e dos empreendedores de baixa cultura e formação tecnológica, oferecem o desafio, à universidade, 
ao governo e aos próprios empreendimentos, para conceberem, implementarem e operacionalizarem instrumentos e mecanismos indutores de inovações. Neste contexto destacam-se as estruturas em redes para facilitar a operacionalização da cooperação e dos estímulos à inovação.

\section{ESTRUTURAS EM REDES E A PROMOÇÃO DA INOVAÇÃO}

A condição das empresas para inovarem é percebida, crescentemente, como sendo dependente não apenas das suas próprias competências e recursos internos, mas também da capacidade de integrar e mobilizar (ou seja, obter acesso a recursos que estão além dos limites organizacionais e até mesmo dos relacionamentos diretos) condições externas favoráveis. Para enfrentar as diversidades as empresas estão buscando se integrar em redes de inovação, buscando a colaboração externa (CORSARO et al., 2012; DOH; KIM, 2014; VAAN, 2014; VITORELI; GOBBO JUNIOR, 2013; ZHENG; LI; WU, 2013). Como consequência, as redes tornaram-se um foco central na literatura que trata das estratégias de inovação. Tem sido sugerido, recentemente, que além de recursos internos, as redes são uma importante fonte de vantagem competitiva para as empresas (CORSARO et al., 2012; ZHENG; LI; WU, 2013).

As relações de rede permitem que as empresas internalizem competências e recursos detidos por parceiros externos, passíveis de gerarem conhecimentos valiosos, ideias complementares e insights (VAAN, 2014). Por meio da estruturação de redes, as tecnologias ou os conhecimentos não são apenas trocados, mas coletivamente desenvolvidos, contribuindo para a superação das dificuldades e desafios existentes (TÖDTLING; LEHNER; KAUFMANN, 2009; VAAN, 2014; ZHENG; LI; WU, 2013). Trata-se, assim, de um processo dinâmico de aprendizagem coletiva.

Neste cenário, as inovações passaram a ser vistas, de forma crescente, como o resultado de um processo integrado e articulado de geração, difusão e aplicação de conhecimentos (TÖDTLING; LEHNER; KAUFMANN, 2009). Algumas trocas são baseadas em acordos formais ou contratos (P\&D para a cooperação, P\&D por meio de alianças, consórcios de investigação e outros), incluindo declarações formais sobre a partilha de tarefas, custos, benefícios e receitas; outras podem ser informais, baseadas na confiança (ZHENG; LI; WU, 2013; TÖDTLING; LEHNER; KAUFMANN, 2009; VITORELI; GOBBO JUNIOR, 2013). As redes formais, com frequência, porém não exclusivamente, são estabelecidas com grandes empresas, empresas de tecnologias especializadas ou grandes organizações de pesquisa. Já as redes informais, tais como aquelas dos distritos industriais italianos, são particularmente baseadas na confiança, na compreensão compartilhada dos problemas e objetivos, bem como na aceitação de regras comuns e normas de comportamento (ZHENG; LI; WU, 2013; TÖDTLING; LEHNER; KAUFMANN, 2009; VITORELI; GOBBO JUNIOR, 2013).

Vários fatores podem ser citados como motivadores para a inserção de uma empresa em uma rede, com destaque para:

- É por meio de atividades estratégicas, ou seja, do networking, que as empresas têm acesso às informações complementares, aos mercados e às tecnologias que são necessárias à inovação;

- Por meio da cooperação e do intercâmbio de informações as empresas constroem uma base de conhecimento substancial e são capazes de se envolver em relações de troca futuras;

- O networking também aumenta as oportunidades de aprendizagem e a obtenção de acesso ao conhecimento externo;

- Por meio das redes há um partilhamento dos riscos (CORSARO et al., 2012).

Vitoreli e Gobbo Junior (2013) destacam que a formação de redes é uma solução alternativa viável, principalmente para as pequenas e médias empresas (PMEs), que geralmente se encontram em desvantagem nas atividades de inovação frente às grandes corporações. Doh e Kin (2014) observaram que os governos têm tentado promover alianças e construir redes entre setores transversais para apoiar as micro e pequenas empresas, citando como exemplos 
as políticas que procuram melhorar o acesso das MPE à informação sobre oportunidades de networking, aumentar a participação das MPE nas redes de investigação e inovação e apoiar o surgimento e manutenção de clusters (Doh \& Kim, 2014). No cenário brasileiro, diversos instrumentos de políticas públicas foram criados para facilitar a inserção e a permanência das micro e pequenas empresas em redes de inovação, tais como: os Arranjos Produtivos Locais (APLs), os Parques Tecnológicos, as Incubadoras de Empresas, as aceleradoras, as Redes Temáticas de Centros de Inovação, o Serviço Brasileiro de Respostas Técnicas (SBRT) entre outras. Este estudo teve como objetivo relatar as vantagens, as limitações e as dificuldades à operacionalização de dois destes instrumentos: Incubadora de Empresas e SBRT.

\section{O SBRT E AS INCUBADORAS DE EMPRESAS}

O Serviço Brasileiro de Respostas Técnicas (SBRT) teve em sua concepção o objetivo de orientar empreendedores e empreendimentos de pequeno porte na solução de problemas técnicos de baixa complexidade. Para o alcance desse objetivo foi criada uma rede de instituições nacionalmente reconhecidas que fornecem de forma gratuita diversos tipos de informações, com o propósito de contribuir para a melhoria e a qualidade de produtos e processos (SBRT, 2015).

A partir de 2010 o SBRT passou a ser constituído por nove instituições presentes em todo o território nacional: o Serviço Nacional de Aprendizagem Industrial do Rio Grande do Sul - SENAI/RS; o Instituto Tecnológico do Paraná - TECPAR; a Universidade de São Paulo - USP; a Universidade Estadual Paulista - UNESP; a Rede de Tecnologia do Rio de Janeiro - REDETEC; o Serviço Nacional de Aprendizagem Industrial de Minas Gerais - SENAI-MG; a Universidade de Brasília - UNB; o Serviço Nacional de Aprendizagem Industrial do Amazonas - SENAI/AM; e o Instituto Euvaldo Lodi da Bahia - IEL/BA.

Duas características principais são definidoras da estratégia nuclear do SBRT: o atendimento a demandas espontâneas, implicando que os agentes de respostas vinculados à rede são acionados apenas quando uma demanda é postada no sistema; e o foco na gestão do conhecimento, denotando que, embora o sistema tenha sido concebido como instrumento de apoio a inovações, suas atividades são essencialmente orientadas para as operações de busca, elaboração, sistematização, armazenagem e disponibilização de informações. A materialização desta estratégia é viabilizada pela oferta de serviços de apoio à informação.

O fluxo de atendimento do SBRT é composto pelas seguintes etapas: primeiro o usuário acessa o site do SBRT, se cadastra e lê atentamente o termo de uso; como passo seguinte, consulta o Banco de Dossiês e Respostas Técnicas do SBRT, onde poderá encontrar respostas para sua demanda; caso não encontre a solução esperada, submete nova demanda. A demanda é encaminhada ao agente regional da rede que será responsável por elaborar a resposta. Na sequência, a resposta é publicada no site e o usuário recebe um e-mail informando que ela está pronta e que pode ser consultada a qualquer momento (FONSECA; BARBOZA, 2014). O banco de dados do SBRT continha, em 2014, mais de 21 mil notas técnicas classificadas por palavras-chave, elaboradas pelos nove agentes da rede e é de livre acesso a todos os cadastrados no site (FONSECA et al., 2013).

Salienta-se que o objetivo do SBRT é fornecer informações capazes de sanar dúvidas e elevar o patamar tecnológico dos empreendimentos atendidos. Ao contribuir para a gestão da informação municia o empreendedor de insumos necessários à gestão da inovação (FONSECA et al., 2013).

Incubadoras de empresas, por sua vez, são organizações que constituem ou criam um ambiente de apoio propício para a criação e o desenvolvimento de novas empresas (AHMAD, 2014; BERGEK; NORRMAN, 2008; BØLLINGTOFT, 2012; BRUNEEL et al., 2012; LESÁKOVÁ, 2012; SOETANTO; JACK, 2013). Os formuladores de políticas em níveis nacional, regionais e locais consideram as incubadoras como agentes institucionais de promoção da dinamização econômica, da inovação e da sustentabilidade (BARBERO et al., 2012; FONSECA, 2010; GRIMALDI; GRANDI, 2005; RATINHO; HENRIQUES, 2010; 
SCHWARTZ; HORNYCH, 2010; SCHWARTZ, 2013).

São vistas também como agentes de apoio ao fortalecimento de empresas recém-nascidas, e como ambientes de estímulo para spin-offs universitários (Bergek \& Norrman, 2008). Para cumprir com efetividade seus papéis, as incubadoras de empresas ofertam serviços capazes de fortalecer os empreendimentos assistidos, minimizando as taxas de mortalidade e ampliando as taxas de sucesso. Uma das facilidades ofertadas são os espaços físicos, tanto individuais quanto compartilhados, que proporcionam economias de escala e redução de custos. Esses espaços geralmente são constituídos por recepção, serviços de escritório, salas de reuniões, salas de conferências, estacionamento, laboratórios, equipamentos de pesquisa e instalações para produção das empresas (BØLLINGTOFT, 2012; BRUNEEL et al., 2012; LESÁKOVÁ, 2012; RATINHO; HENRIQUES, 2010; SOETANTO; JACK, 2013). Outro serviço disponibilizado são atividades que aceleram a curva de aprendizado e proporcionam capacitação gerencial, geralmente em formatos de consultoria individual e treinamentos (BØLLINGTOFT, 2012; BRUNEEL et al., 2012; LESÁKOVÁ, 2012; RATINHO;
HENRIQUES, 2010; SOETANTO; JACK, 2013). Ofertam também acesso às redes tecnológicas, profissionais e de financiamento que são capazes de facilitar o acesso a recursos externos, ao conhecimento e à legitimação das atividades executadas pelos empreendedores incubados (BØLLINGTOFT, 2012; BRUNEEL et al., 2012; COOPER; HAMEL; CONNAUGHTON, 2012; LESÁKOVÁ, 2012; RATINHO; HENRIQUES, 2010; SOETANTO; JACK, 2013).

A expansão dos programas de incubação data dos anos 90 , tendo como países pioneiros, ainda na década de 70, os Estados Unidos e a França. Na sua origem, a ideia de incubadora esteve associada ao propósito de estimular o surgimento de negócios resultantes de projetos tecnológicos desenvolvidos no interior de centros de pesquisa, universitários ou não. O êxito inicial alcançado pelas incubadoras tecnológicas fez com que a ideia de incubação passasse a ser vista como uma possibilidade capaz de proteger, estimular e fortalecer os pequenos negócios em quaisquer ramos da atividade econômica. Resultado disso é que o conceito original passou a ganhar derivações e adjetivações, tal como exposto no quadro 1.

Quadro 1 - Descrição da tipologia de incubadoras

\begin{tabular}{|c|c|c|c|}
\hline $\begin{array}{l}\text { Classificação por tipo de negócio } \\
\text { abrigado }\end{array}$ & Classificação & bjetivo institucional & Classificação por natureza jurídica \\
\hline & Modelo & Objetivo & \multirow{5}{*}{$\begin{array}{l}\text { - Privadas, sem fins lucrativos; } \\
\text { - Públicas; } \\
\text { - Privadas, com fins lucrativos. }\end{array}$} \\
\hline \multirow{4}{*}{$\begin{array}{l}\text { - Mistas } \\
\text { - Tradicionais } \\
\text { - Agroindustriais } \\
\text { - Culturais - Solidárias } \\
\text { - De serviços }\end{array}$} & Universidade & Desenvolvimento tecnológico & \\
\hline & Participativo & Desenvolvimento local & \\
\hline & Corporativo & Fortalecimento institucional & \\
\hline & Empresarial & Retorno de investimentos & \\
\hline
\end{tabular}

Fontes: FONSECA 2000; ANPROTEC, 2012

M'Chirgui (2012) enfatiza que o sucesso dos programas de incubação está estritamente ligado à efetividade da integração dos programas junto aos sistemas locais de inovação. Esta integração possibilita o maior envolvimento com redes capazes de gerar inovações e desenvolvimento econômico. Nessa mesma direção, Ratinho e Henriques (2010) e Alsos, Hytti e Ljunggren (2011) sustentam que as ligações universitárias são fundamentais para o sucesso dos programas. Segundo os autores, essa ligação pode ser alcançada por meio da proximidade física, do estabelecimento de relações que possibilitem a transferência de tecnologias e conhecimentos e do estabelecimento e consolidação de compromissos institucionais. É importante salientar que cada tipo de incubadora apresenta especificidades, um modelo de gestão próprio e, por 
consequência, um posicionamento diferente em relação aos fatores de sucesso. Grande parte da literatura foca as contribuições das incubadoras tecnológicas para a promoção da inovação (MIAN, 1997; BARBERO et al., 2012; ENRÍQUEZ; COSTA, 2001) legando ao segundo plano as incubadoras mistas e tradicionais.

Isoladamente, tanto incubadoras quanto o SBRT vêm enfrentando limitações para operacionalizarem plenamente seus objetivos no Brasil. O SBRT porque se encontra distante das micro e pequenas empresas (FONSECA et al., 2013) e as incubadoras, principalmente as tradicionais e mistas, porque se ressentem de proximidades para o estabelecimento de parcerias com universidades e centros de pesquisa, vistas com essenciais para a promoção da inovação (RAMALHEIRO; FONSECA; TERENCE, 2010). A percepção dessas limitações norteou um dos agentes vinculados à rede SBRT, no caso o Sistema Integrado de Respostas Técnicas (SIRT) da UNESP, a buscar a diferenciação das suas atividades, passando a atuar em conjunto com incubadoras mistas e tradicionais no interior do Estado de São Paulo, com destaque para a Incubadora de Empresas de Araraquara.

\section{METODOLOGIA}

\subsection{OBJETOS DE ESTUDO}

O objeto de estudo desta pesquisa concentrou-se em dois instrumentos de políticas públicas utilizados para apoiar micro e pequenos empreendimentos, sendo o primeiro deles: o projeto SIRT e o segundo o programa Incubadora de Empresas de Araraquara.

O Sistema Integrado de Respostas Técnicas (SIRT) é o segundo agente do SBRT que atua no Estado de São Paulo (o outro é o Disque Tecnologia da USP). O vínculo institucional é com a Universidade Estadual Paulista Júlio de Mesquita Filho - UNESP, por meio da Agência Unesp de Inovação, sendo coordenado pelo Departamento de Administração Pública da Faculdade de Ciências e Letras de Araraquara e administrado financeiramente pela Fundação para o Desenvolvimento da UNESP - Fundunesp (UNESP, 2015).

O SIRT possui, em sua concepção, alguns aspectos inovadores, idealizados de modo a contribuir para o permanente aprimoramento das atividades do SBRT como um todo. O primeiro diferencial está na proposta de atuação na perspectiva da indução de demandas. Consta explicitamente no projeto do SIRT o entendimento de que, mais do que o atendimento a demandas espontâneas, emanadas de pontos geográficos dispersos no Estado, a Universidade deva atuar, por meio da oferta de respostas técnicas, como agente de política pública visando a promoção do desenvolvimento local sustentável. Para alcançar esse intento, a equipe técnica do SIRT identifica e seleciona, prioritariamente na região geográfica em que atua (centro paulista), segmentos de atividades que revelem fragilidades técnicas e tecnológicas e que, portanto, possam vir a expressar sensibilidade para a elaboração de demandas por respostas técnicas. O segundo aspecto inovador está na composição da equipe de mediadores. Para essa composição, a seleção foi direcionada a estudantes, de graduação e pós-graduação, das quatro unidades da UNESP que compõem o campus de Araraquara - Faculdade de Ciências e Letras, Faculdade de Ciências Farmacêuticas, Instituto de Química e Faculdade de Odontologia. O objetivo visado foi a montagem de uma equipe multidisciplinar, que viesse a atuar de forma integrada e cooperativa, potencializando os conhecimentos específicos e propiciando resultados sinérgicos. O terceiro componente inovador, passível de implantação apenas a médio prazo, é o correspondente à proposta de uma estrutura composta por núcleos descentralizados de captação de demandas por respostas técnicas. O caráter multi-campi da UNESP favorece essa concepção, propiciando elementos para uma ainda maior cooperação da universidade com os meios sociais externos nos quais está inserida. Outro elemento inovador do projeto do SIRT é o correspondente à atuação em rede. Além de integrar internamente diferentes campi, unidades e departamentos da UNESP, - SIRT já nasce articulado a uma rede de agentes externos, compostos, inicialmente, pelas prefeituras de seis municípios da região central paulista (por meio do Projeto Centro Paulista, vinculado ao programa de cooperação internacional Brasil Próximo, firmado entre o Governo Federal Brasileiro e cinco regiões italianas), pelo escritório regional do SEBRAE-SP e pelo DT/USP, 
com o qual irá partilhar as demandas por respostas técnicas emanadas do Estado de São Paulo (UNESP, 2015).

Já o programa de Incubação de Araraquara foi criado em 1997 por meio de uma parceria estabelecida entre a Prefeitura Municipal, a Federação das Indústrias do Estado de São Paulo - FIESP e o Serviço Brasileiro de Apoio às Micro e Pequenas Empresas - SEBRAE. A Prefeitura se responsabilizou por oferecer o espaço físico e serviços de segurança, manutenção e limpeza; a FIESP pelo gerenciamento e o SEBRAE pela gestão e financiamento das atividades de consultoria e de apoio técnico. Institucionalmente a incubadora foi subordinada à pasta da Secretaria de Desenvolvimento Econômico da Prefeitura e vinculada à Coordenadoria de Ciência e Tecnologia. Ao todo a sua gestão passou por quatro momentos; de 1997 a 2007 pela já citada FIESP; de 2008 a 2010 pelo Instituto AEQUITAS; pelo Instituto INOVA em 2011; e a partir de 2012 a responsabilidade pela gestão ficou a cargo da UNESP/Araraquara. Atualmente os principais objetivos do programa são a criação de novos negócios, a geração de emprego e renda, a promoção da inovação e a articulação com as demais políticas públicas já mantidas pela Prefeitura Municipal e outros agentes locais, de modo transversal e muitas vezes intersetorial.

5.2 Estratégia metodológica e procedimentos de coleta de dados

A estratégia metodológica utilizada compreendeu uma pesquisa qualitativa, de caráter exploratório, delineada como estudo de dois casos únicos, cada qual com enfoque holístico - embora não totalizante. Justifica essa abordagem metodológica o foco da pesquisa em dois objetos institucionais distintos, com destaque para aspectos particulares e peculiaridades das suas respectivas operações. Essa opção metodológica encontra respaldo em Yin (2001), quando o autor defende a utilização do estudo de caso como método de investigação científica para a avaliação de experiências bem sucedidas. Os dados foram coletados por meio de entrevistas e observação participante. A pesquisa foi realizada entre os meses de março e abril de 2015, tendo como principais fontes de dados dois grupos de informantes: o primeiro composto pelos coordenadores do SIRT e da incubadora; o segundo com representantes dos empreendimentos incubados em Araraquara que foram atendidos pelo SIRT.

A primeira etapa da pesquisa compreendeu um mapeamento das empresas que foram atendidas pelo SIRT e pelo programa de incubação em um período de dois anos (março de 2013 a fevereiro de 2015). Nesse mapeamento buscou-se classificar as empresas em quatro grupos: o primeiro composto pelas empresas não atendidas pelo SIRT; o segundo pelas empresas atendidas, mas que não inovaram; o terceiro pelas empresas atendidas e que inovaram; e o último pelas empresas que estavam iniciando o atendimento e que não apresentavam resultados mensuráveis. O quadro 2 sintetiza o resultado deste mapeamento.

Quadro 2 - Classificação tipológica das empresas incubadas

\begin{tabular}{|c|c|c|c|}
\hline $\begin{array}{l}\text { Empresa não } \\
\text { atendidas } \\
\text { pelo SIRT }\end{array}$ & $\begin{array}{l}\text { Empresas } \\
\text { atendidas } \\
\text { mas, que não } \\
\text { inovaram }\end{array}$ & $\begin{array}{l}\text { Empresas } \\
\text { atendidas e que } \\
\text { inovaram }\end{array}$ & $\begin{array}{l}\text { Empresas } \\
\text { que } \\
\text { iniciaram o } \\
\text { atendimento }\end{array}$ \\
\hline $\begin{array}{l}10 \text { empresas } \\
(29,41 \% \\
\text { do total de } \\
\text { empresas } \\
\text { incubadas) }\end{array}$ & $\begin{array}{l}8 \text { empresas } \\
\text { (23,52\% } \\
\text { do total de } \\
\text { empresas } \\
\text { incubadas) }\end{array}$ & $\begin{array}{l}11 \text { empresas } \\
\text { (32,35\% do total } \\
\text { de empresas } \\
\text { incubadas) }\end{array}$ & $\begin{array}{l}5 \text { empresas } \\
\text { (14,7\% do } \\
\text { total de } \\
\text { empresas } \\
\text { incubadas) }\end{array}$ \\
\hline
\end{tabular}

Fonte: Elaboração própria com base nos resultados da pesquisa

Como pode ser observado, o programa SIRT/UNESP atendeu, nos 24 meses analisados (março de 2013 até fevereiro de 2015), aproximadamente 56\% das empresas incubadas em Araraquara, das quais 57,9\% aplicaram as informações e obtiveram algum grau de inovação.

A etapa seguinte foi a investigação das inovações geradas, com base em entrevistas com os empresários atendidos, buscando apurar:

- A intensidade e a profundidade dos impactos das inovações. A referência utilizada foi a classificação de Schumpeter de inovações incrementais introdução de mudanças relativamente marginais ou de menor escala na concepção de um produto ou de um processo existente - e inovações radicais - aquelas baseadas em desvios significativos em 
relação ao design existente e à concepção do produto (RADAS; BOŽIĆ, 2009; VELU, 2014);

- Os processos por meio dos quais as inovações foram geradas e difundidas. Para tanto se analisou o grau de interatividade das empresas inovadoras com os agentes do SIRT e com os analistas da incubadora. A fim de avaliar estas interatividades procedeu-se à aplicação da tipologia de grau de intensidade desenvolvido por Fonseca (2010) e adaptado para este trabalho. Segundo estatipologia as relações podem ser classificadas em 5 graus: Dependência total onde os estímulos e os apoios da incubadora e do SIRT foram absolutamente essenciais para que o empreendimento inovasse ou, em outras palavras, o empreendimento não inovaria caso não estivesse na incubadora e caso não estivesse recebido o atendimento do SIRT; Grande dependência - os programas estimularam as inovações e ofereceram apoios cruciais para a inovação, tais como infraestrutura, respaldo técnico e outros, porém o empreendimento teria condições de inovar de forma independente, embora com dificuldade; Média dependência - os programas buscaram oferecer os apoios necessários às inovações, sempre que demandados, realizando ações periódicas de estímulo; Baixa dependência - o empreendimento inovou independente dos programas, porém buscou apoio sempre que necessário, sendo parcialmente atendido; ou Nenhuma dependência - o empreendimento inovou com independência total dos programas;

- As competências para a inovação. Buscou-se analisar a existência e a característica do corpo técnico que estava à disposição e que foi utilizado pelas empresas incubadas. Neste quesito apurouse a quantificação dos números técnicos que cada empreendimento teve acesso durante o processo inovador. Na sequencia investigou-se se estes eram técnicos internos, pertencentes ao quadro de colaboradores fixos da empresa, se eram corpo técnico dos programas investigados ou se eram consultores independentes;

- As iniciativas dos programas para as inovações. Segundo Fonseca (2010), na gestão da inovação as incubadoras podem adotar cinco posturas: podem ser proativas; podem atuar na gestão; podem ser reativas; podem realizar o monitoramento; ou podem se manter distantes do processo inovador. Partindo-se desta classificação, buscou-se analisar a postura da Incubadora e por adaptação a postura do SIRT/UNESP junto a cada empresa por meio desta tipologia. Como proativos foram enquadrados os casos em que os programas tomaram as iniciativas de alertar as empresas para a necessidade de inovar, realizaram atividades indutivas permanentes, identificaram e buscaram fontes de recursos, técnicos, materiais e financeiros; Gestão - aproximaram as empresas com outros agentes técnicos externos, ofereceram apoio à elaboração de projetos e responsabilizaramse pela gestão da infraestrutura de suporte à inovação; Reatividade - ofereceram apoio sempre que demandados; Monitoramento - apenas acompanharam os processos; ou Distanciamento - não interferiram.

A terceira etapa correspondeu à análise estrutural da parceria estabelecida entre a incubadora de empresas de Araraquara e o SIRT/UNESP. Para viabilizar esta investigação, utilizou-se um questionário semiestruturado que abarcou os seguintes pontos: os objetivos da parceria; os pontos positivos e negativos da parceria; os pontos que poderiam ser aperfeiçoados na parceria; a avaliação que os coordenadores faziam do nível de satisfação das empresas atendidas e do nível de aplicação das informações contidas nas notas técnicas; a frequência com que os incubados recorriam ao serviço do SBRT; e uma síntese da avaliação que os coordenadores faziam da contribuição do SBRT para a promoção da inovação nas empresas atendidas.

Como se buscou evidenciar nos parágrafos precedentes desta seção a pesquisa envolveu múltiplos pesquisadores, abrangeu múltiplas fontes de dados, empregou múltiplas técnicas para a coleta e se desenrolou em etapas sucessivas. A combinação dessas características do perfil da pesquisa justifica, por si só, a necessidade da triangulação dos dados (múltiplos olhares e múltiplas abordagens), com vistas à identificação dos seus efetivos significados. 
As técnicas utilizadas para a análise dos dados compreenderam, essencialmente, a análise de conteúdo e a estatística descritiva simples.

\section{RESULTADOS E DISCUSSÕES}

Os resultados da pesquisa mostram duas dimensões, a primeira refere-se à investigação das características das inovações geradas pela parceria entre o SIRT e a Incubadora de Empresas de Araraquara e a segunda evidencia a análise estrutural da parceria SIRT/Incubadora. O quadro 3 apresenta os resultados sintetizados da primeira dimensão.

Quadro 3 - Resultado da análise das inovações geradas

\begin{tabular}{|c|c|c|c|c|}
\hline Empresa estudada & Intensidade & $\begin{array}{l}\text { Grau de } \\
\text { dependência }\end{array}$ & Competências Técnicas & $\begin{array}{l}\text { Iniciativas dos } \\
\text { programas }\end{array}$ \\
\hline Empresa 1 & Alta complexidade & $\begin{array}{l}\text { Baixa } \\
\text { dependência }\end{array}$ & $\begin{array}{l}\text { Consultores dos programas: } 3 \\
\text { Consultores independentes: } 1 \\
\text { Colaboradores próprios: } 1\end{array}$ & Monitoramento \\
\hline Empresas 2 e 9 & $\begin{array}{l}\text { Baixa } \\
\text { complexidade }\end{array}$ & $\begin{array}{l}\text { Média } \\
\text { dependência }\end{array}$ & $\begin{array}{l}\text { Consultores dos programas: } 6 \\
\text { Consultores independentes: } 2 \\
\text { Colaboradores próprios: } 2\end{array}$ & Gestão e Proatividade \\
\hline Empresas 3 e 7 & $\begin{array}{l}\text { Baixa } \\
\text { complexidade }\end{array}$ & $\begin{array}{l}\text { Grande } \\
\text { dependência }\end{array}$ & $\begin{array}{l}\text { Consultores dos programas: } 6 \\
\text { Consultores independentes: } 2 \\
\text { Colaboradores próprios: } 3\end{array}$ & Proatividade \\
\hline Empresas 4 e 5 & $\begin{array}{l}\text { Baixa } \\
\text { complexidade }\end{array}$ & $\begin{array}{l}\text { Baixa } \\
\text { dependência }\end{array}$ & $\begin{array}{l}\text { Consultores dos programas: } 3 \\
\text { Consultores independentes: } 2 \\
\text { Colaboradores próprios: } 3\end{array}$ & Reatividade \\
\hline Empresas 6 e 8 & Alta complexidade & Dependência total & $\begin{array}{l}\text { Consultores dos programas: } 8 \\
\text { Consultores independentes: } 2 \\
\text { Colaboradores próprios: } 6\end{array}$ & Gestão e Proatividade \\
\hline Empresas 10 e 11 & $\begin{array}{l}\text { Baixa } \\
\text { complexidade }\end{array}$ & Dependência total & $\begin{array}{l}\text { Consultores dos programas: } 8 \\
\text { Consultores independentes: } 1 \\
\text { Colaboradores próprios: } 2\end{array}$ & Gestão e Proatividade \\
\hline
\end{tabular}

Fonte: Elaboração própria com base nos resultados da pesquisa

Como pode ser observado, a pesquisa revelou que $27 \%$ das empresas que foram atendidas pela parceria Incubadora-Sirt e que obtiveram inovações, desenvolveram inovações passíveis de serem enquadradas como de alta tecnologia: duas dessas empresas estão desenvolvendo produtos inéditos na área da saúde e uma desenvolveu um novo processo de produção de bebida destilada. As demais inovações geradas foram de baixa complexidade: em sua maioria, realizaram-se mudanças no formato do modelo de negócio (em alguns casos os empreendedores passaram a executar novas atividades econômicas e em outros focaram o seu modelo). Notou-se também que algumas empresas apresentaram mudanças nos processos de fabricação (ora por aquisição de equipamentos/automação, ora por adaptação de processo e por substituição de matéria-prima). Diversos autores chegaram a constatações equivalentes em suas pesquisas, a exemplo citam-se os estudos de Grimpe e Sofka (2009), Heidenreich (2009), Kirner, Kinkel \& Jaeger (2009), Nunes, Serrasqueiro e Leitão (2012) e Barge-Gil (2010) abordando inovações não tecnológicas ou inovações de baixa complexidade (low-tech innovations).

$\mathrm{Na}$ avaliação a respeito dos processos pelos quais as inovaçõesforam geradas e difundidas, constatou-seque o grau de interatividade das empresas inovadoras com os agentes do SIRT e com os analistas da incubadora foi considerado de dependência total em quatro casos. Em virtude disso sugere-se que os estímulos e os apoios da incubadora e do SIRT foram absolutamente essenciais para que os empreendimentos inovassem. Esta avaliação foi justificada pelo fato de que, nesses casos, os empreendedores foram estimulados pela incubadora para a necessidade de inovarem 
e tiveram seus processos e produtos analisados cuidadosamente pela equipe do SIRT, que indicou o potencial de cada empresa e as possíveis fontes viabilizadoras de recursos adicionais para a inovação. Na seqüência a equipe do SIRT passou a elaborar projetos, posteriormente submetidos a programas de apoio à inovação, como o PIPE (Programa Inovativo da Pequena Empresa) da FAPESP (Fundação de Amparo à Pesquisa do Estado de São Paulo) e o edital SEBRATEC do SEBRAE (Serviço Brasileiro de Apoio às Micro e Pequenas Empresas).

Em dois casos o SIRT e a incubadora estimularam e ofereceram importantes apoios para as inovações, embora tenha se constatado que as duas empresas teriam condições de inovar de forma independente. Em ambos os casos as inovações geradas foram de baixa complexidade, sem que fossem elaborados projetos. Nos demais casos a dependência das empresas foi considerada média ou baixa $(54,5 \%$ dos casos) uma vez que os apoios (do SIRT e incubadora) foram oferecidos apenas quando demandados.

A literatura aponta que algumas competências são necessárias para a inovação, entre as quais se destacam: a presença de um corpo de profissionais especializados e qualificados; a forte liderança dos responsáveis pela organização; a existência de estratégias e planejamento para o futuro; as atividades de pesquisa e desenvolvimento (D'ESTE et al., 2012; RADAS; BOŽlĆ, 2009). São competências necessárias para o diálogo e a colaboração com outras empresas, para a manutenção de relações de cooperação para a pesquisa, para a transferência de tecnologia com as universidades e os centros de pesquisa e para a captação de recursos financeiros ou demais tipos de apoios governamentais (D'ESTE et al., 2012; RADAS; BOŽIĆ, 2009). Os resultados desta pesquisa evidenciam que a parceria entre o SIRT e a Incubadora teve, como uma de suas consequências, o estímulo ao desenvolvimento dessas competências nas empresas assistidas - com maior intensidade nas empresas com maior grau de dependência. Este resultado confirma as conclusões de Love,
Roper, \& Vahter (2014) e D'Este et al. (2012) de que a inovação depende crucialmente da capacidade das empresas de absorverem conhecimentos externos, combinando-os com seus próprios conhecimentos, tácitos ou explícitos. Além do mais, é um resultado que corrobora também com os postulados da literatura de inovação estratégica que reconhece, cada vez mais, que a combinação de fontes de conhecimento interno e externo é um elemento-chave de uma estratégia de inovação bem-sucedida (LOVE; ROPER; VAHTER, 2014). Assim, confirma-se, neste trabalho, que um elemento importante no processo inovador (seja ele de alta ou baixa complexidade) é a identificação e o aproveitamento de conhecimentos complementares entre diferentes atividades situadas dentro e fora dos limites da empresa.

Tomando-se como variável analítica o grau de proatividade do SIRT e da incubadora, constatou-se que das 11 empresas que apresentaram inovações, em oito casos ( $72 \%$ ) os programas tomaram a iniciativa de alertar as empresas para a necessidade de inovar, realizando atividades indutivas permanentes, identificando e buscando fontes de recursos, técnicos, materiais e financeiros. Por outro lado, em uma empresa (9\%) constatou-se que apenas o monitoramento das ações inovativas foi realizado; e nos dois outros casos (19\%) os programas foram reativos.

Em relação à segunda dimensão analítica desta pesquisa, qual seja, a análise estrutural da parceria estabelecida entre o SIRT e a Incubadora de Empresas de Araraquara, constatou-se que os gestores de cada programa apresentam visões distintas da parceria, como pode ser observado no quadro 4. Para o SIRT a parceria é uma forma de ampliar o alcance da rede enquanto que para a incubadora é uma oportunidade para ampliar o leque de serviços passíveis de serem oferecidos. Este é um indicativo de que o serviço em rede, ou seja, de que a parceria é uma forma de alavancar a capacidade operacional de cada programa, por consequência, é um mecanismo complementar de atuação de cada programa. 
Quadro 4 - Resultado da análise dos vínculos da parceria

\section{Atividades oferecidas pelos programas}

\begin{tabular}{|l|l|l|}
\hline $\begin{array}{l}\text { Incubadora } \\
\text { Consultorias gerenciais e } \\
\text { espaço físico }\end{array}$ & \begin{tabular}{l}
\multicolumn{1}{c|}{ Sirt } \\
Apoio Tecnológico de \\
baixa complexidade
\end{tabular} \\
$\begin{array}{l}\text { Incubadora + Sirt } \\
\text { Fortalecimento técnico e } \\
\text { gerencial por meio de } \\
\text { estímulos e incentivos }\end{array}$ \\
\hline
\end{tabular}

\begin{tabular}{|c|c|c|}
\hline jetivos da parceria & & \\
\hline $\begin{array}{l}\text { Na visão da Incubadora } \\
\text { Oferecer um respaldo } \\
\text { técnico para as empresas } \\
\text { incubadas }\end{array}$ & $\begin{array}{l}\quad \text { Na visão do Sirt } \\
\text { Potencializar os resultados } \\
\text { proporcionados pela rede } \\
\text { do SBRT }\end{array}$ & $\begin{array}{l}\text { Na visão integrada } \\
\text { Proporcionar uma rede } \\
\text { pró-inovação efetiva }\end{array}$ \\
\hline
\end{tabular}

\section{Resultados práticos da parceria}

Frequência de uso da parceria

Poucas empresas buscam de forma independente o sistema, elas esperam os agentes do SBRT diagnosticarem fragilidades.

Em média, cada empresa recebe um diagnóstico no inicio de cada ano, no qual é elaborado um plano de ação.

\section{Contribuição do SIRT para a inovação nas empresas Incubadas}

As dúvidas iniciais do empreendedor são, em sua maioria, sanadas pelo SIRT.

Os diagnósticos funcionam como um sensibilizador, ou seja, um alerta para a necessidade de inovar.

As ações do SIRT possibilitam a identificação da potencialidade de inovação de cada empresa.

Análise das laços que movem a parceria
\begin{tabular}{|l|}
\multicolumn{1}{|c|}{ Pontos positivos } \\
Ampliação da rede de parcerias; \\
A possibilidade de oferecer consultoria \\
técnica de baixa complexidade para as \\
empresas incubadas; \\
Aumento no número de demandas geradas \\
por usuário; \\
Oportunidade para validar a metodologia de \\
prospecção e indução de demandas.
\end{tabular}

\begin{tabular}{|l|}
\multicolumn{1}{|c|}{ Pontos negativos } \\
O prazo de respostas, em alguns casos, \\
desestimula o acesso a soluções por parte \\
dos empresários; \\
Dificuldade dos pesquisadores em \\
conseguir levantar demandas em empresas \\
muito tradicionais.
\end{tabular}

Pontos que podem ser melhorados Um monitoramento mais frequente por parte dos pesquisadores do SIRT

Fonte: Elaboração própria com base nos resultados da pesquisa

O quadro confirma alguns dos indicativos da literatura e as proposições constantes da seção três deste texto. Sobretudo no que diz respeito aos efeitos da articulação entre agentes com vistas ao alcance de objetivos comuns, no caso a alavancagem de inovações em empresas de baixa propensão para inovar. Merecem destaque, entre as ideias-síntese constantes do quadro, as que dizem respeito a: o alcance dos objetivos da parceria - constatou-se que tanto para a incubadora quanto para o Sirt suas atividades foram potencializadas a partir da atuação em conjunto, logrando o alcance de efeitos sinérgicos; os resultados práticos da parceria - notadamente no que se refere ao papel exercido por ambos os agentes como indutores de inovações para as empresas assistidas, quebrando a inércia e as resistências das empresas (tal como apontado por grande parte da literatura revista na seção dois deste texto) para investirem em iniciativas de inovação; os pontos negativos identificados - tanto o relativo aos prazos dilatados para o atendimento às demandas, tecnicamente justificáveis em virtude do processo de pesquisa envolvido, porém passíveis de ajuste por meio de métodos de gestão mais rigorosos e orientados, quanto o referente à necessidade de aprimoramento e estreitamento do diálogo entre os agentes de respostas técnicas e os empreendedores 
(quebra de barreiras entre dois campos culturais distanciados).

\section{CONSIDERAÇÕES FINAIS}

Duas principais conclusões emergem a partir da leitura dos resultados da pesquisa. A primeira, extraída do quadro 3 é consistente com grande parte dos indicativos da literatura, confirma a baixa propensão autônoma das micro e pequenas empresas para inovarem, evidenciada pela pequena proporção das empresas pesquisadas classificadas no extrato considerado de "baixa dependência" para com os aportes e contribuições dos dois agentes de apoio à inovação. A segunda também converge com grande parte dos apontamentos da literatura, relativos à importância dos instrumentos e dos agentes de políticas públicas como indutores de condições passíveis de facilitarem a inovação no segmento das micro e pequenas empresas. Essa conclusão resulta da constatação da pesquisa quanto à efetividade, em termos dos resultados alcançados, das iniciativas e medidas tomadas pelos dois agentes pesquisados. Em síntese, e remetendo ao título deste trabalho, os resultados da pesquisa permitem apontar, em caráter conclusivo, que a atuação em rede de agentes de políticas públicas pode contribuir fortemente para a quebra de barreiras e resistências para a geração ou a incorporação de inovações pelas micro e pequenas empresas - tanto tradicionais quanto tecnológicas.

Essas conclusões remetem à confrontação entre os resultados alcançados pela pesquisa e os objetivos propostos, que visavam identificar, em outras palavras, virtudes e restrições da parceria entre os dois agentes investigados. Uma das constatações da pesquisa foi que ambos os agentes acabaram se beneficiando, em termos da potencialização das suas atividades nucleares, com o estabelecimento da parceria. Esse ganho propiciou, por sua vez, o efeito positivo em cadeia da indução de inovações nas empresas assistidas simultaneamente pelos dois agentes. Já no plano das restrições os dois casos estudados não foram capazes de identificar fatores que dificultassem o diálogo entre as equipes de ambos os agentes, possivelmente em razão da origem comum de ambos - o Departamento e o curso de Administração Pública da Unesp de Araraquara - e da direção unificada.

Esse conjunto de conclusões e constatações, embora convergentes com parcela não desprezível da literatura especializada, devem ser tratadas em caráter estrito, dadas as limitações, metodológicas e de abrangência da pesquisa. Isso implica o reconhecimento de que resultados e conclusões constantes deste texto não devem ser extrapolados a outros contextos. Outra consideração a ser feita, a título de finalização deste texto, diz respeito ao reconhecimento de uma das fragilidades da pesquisa, qual seja, a relativa à omissão do uso de grupos de controle que viessem a possibilitar o estabelecimento de parâmetros comparativos. Fica aqui indicada, pois, uma das possibilidades de pesquisas futuras, que venha a utilizar dois grupos de controle, um correspondente a empresas assistidas por incubadoras sem parceria com o SBRT, outro contemplando empresas assistidas pelo SBRT sem estarem vinculadas a incubadoras.

\section{REFERÊNCIAS}

[1] AHMAD, A. J. A mechanisms-driven theory of business incubation. International Journal of Entrepreneurial Behaviour \& Research, v.20, n.4, p.375-405, 2014.

[2] ALSOS, G. A.; HYTTI, U.; LJUNGGREN, E. Stakeholder theory approach to technology incubators. International Journal of Entrepreneurial Behaviour \& Research, v.17, n.6, p.607 - 625, 2011

[3] AMATO NETO, J.; OLAVE, M. E. L. A formação de redes de cooperação e clusters em países emergentes: uma alternativa para PMEs no Brasil. In J. AMATO NETO (Ed.), Redes entre organizações: domínio do conhecimento e da eficácia operacional. 1 ed., p. 68 - 93. São Paulo: Atlas, 2005

[4] ANPROTEC. Estudo, análise e proposições sobre as Incubadoras de Empresas no Brasil - Relatório Técnico. Brasília, 2012.

[5] BALBACHEVSKY, E. Processos decisórios em política científica, tecnológica e de inovação no Brasil análise crítica. In: Nova Geração de Política Científica e Tecnológica. Campinas: CGEE, 35 p, 2010.

[6] BARBERO, J. L.; et al. Revisiting incubation performance. Technological Forecasting and Social Change, v.79, n.5, p.888-902, 2012. 
[7] BARGE-GIL, A. Cooperation-based innovators and peripheral cooperators: An empirical analysis of their characteristics and behavior. Technovation, v.30, n.3, p.195206, 2010.

[8] BERGEK, A.; NORRMAN, C. Incubator best practice: A framework. Technovation, v.28, n.1-2, p.20-28, 2008.

[9] BØLLINGTOFT, A. The bottom-up business incubator: Leverage to networking and cooperation practices in a self-generated, entrepreneurial-enabled environment. Technovation, v.32, n.5, p.304-315, 2012.

[10] BRUNEEL, J.; et al. The Evolution of Business Incubators: Comparing demand and supply of business incubation services across different incubator generations. Technovation, v.32, n.2, p.110-121, 2012.

[11] CASSIOLATO, J. E.; LASTRES, H. M. M. Sistemas de Inovação e Desenvolvimento: as implicações da política. São Paulo em Perspectiva, v.19, n.1, p.34-45, jan./mar. 2005

[12] COOPER, C. E.; HAMEL, T. A.; CONNAUGHTON, S. L. Motivations and obstacles to networking in a university business incubator. The Journal of Technology Transfer, v.37, n.4, p.433-453, 2012.

[13] CORSARO, D.; et al. The impact of network configurations on value constellations in business markets - The case of an innovation network. Industrial Marketing Management, v.41, n. 1, p.54-67, 2012

[14] DIAS, R. B. O que é a política científica e tecnológica? Sociologias, Porto Alegre, v.13, n.28, p.316-344, set./dez. 2011.

[15] DOH, S.; KIM, B. Government support for SME innovations in the regional industries: The case of government financial support program in South Korea. Research Policy, v.43, n.9, p.1557-1569, 2014.

[16] D'ESTE, P.; et al. What hampers innovation? Revealed barriers versus deterring barriers. Research Policy, v.41, n.2, p.482-488, 2012

[17] ENRIQUEZ, G.; COSTA, J. G. C. Sistemas locais de inovação tecnológica, incubadoras de empresas e desenvolvimento da indústria no Pará. Saber, n.3, p.103120, 2001.

[18] FONSECA, S. A. Avaliação do processo de implantação e do desempenho de incubadoras empresariais mistas: um estudo de caso no estado de São Paulo. Universidade De São Paulo, São Paulo, 2000.

[19] _. Modelo para a avaliação do desempenho e o apoio à gestão de incubadoras. Universidade Estadual Paulista (UNESP), Araraquara, 2010.
[20] FONSECA, S. A. et al. A Resposta Técnica como fator indutor de inovações de baixa complexidade para empreendimentos de pequeno porte. Congresso da Associação Latino-Iberoamericana de Gestão de Tecnologia (ALTEC), 15. Anais... Porto - Portugal, 2013.

[21] FONSECA, S. A.; BARBOZA, R. A. B. Relatório de atividades sistema integrado de respostas técnicas universidade estadual paulista (UNESP). Araraquara, 2014.

[22] FREEL, M. S. Barriers to Product Innovation in Small Manufacturing Firms. International Small Business Journal, v.18, n.2, p.60-80, 2000.

[23] GRIMALDI, R.; GRANDI, A. Business incubators and new venture creation: an assessment of incubating models. Technovation, v.25, n.2, p.111-121, 2005.

[24] GRIMPE, C.; SOFKA, W. Search patterns and absorptive capacity: Low- and high-technology sectors in European countries. Research Policy, v.38, n.3, p.495-506, 2009.

[25] HEIDENREICH, M. Innovation patterns and location of European low- and medium-technology industries. Research Policy, v.38, n.3, p.483-494, 2009.

[26] KIRNER, E.; KINKEL, S.; JAEGER, A. Innovation paths and the innovation performance of low-technology firms-An empirical analysis of German industry. Research Policy, v.38, n.3, p.447-458, 2009

[27] LESÁKOVÁ, $\square$. The Role of Business Incubators in Supporting the SME Start-up. Acta Polytechnica Hungarica, v.9, n.3, p.85-95, 2012

[28] LOVE, J. H.; ROPER, S.; VAHTER, P. Dynamic complementarities in innovation strategies. Research Policy, v.43, n.10, p.1774-1784, 2014.

[29] M'CHIRGUI, Z. Assessing the Performance of Business Incubators: Recent France Evidence. Business and Management Research, v.1, n.1, p.62-76, 2012

[30] MCGUIRK, H.; LENIHAN, H., \& HART, M. (2015). Measuring the impact of innovative human capital on small firms' propensity to innovate. Research Policy, 44(4), 965976.

[31] McKelvey, M., Zaring, O.; Ljungberg, D. Creating innovative opportunities through research collaboration: An evolutionary framework and empirical illustration in engineering. Technovation, v.39, p.26-36, 2014.

[32] MIAN, S. A. Assessing and managing the university technology business incubator: An integrative framework. Journal of Business Venturing, v.12, n.4, p.251-285, 1997.

[33] NUNES, P. M. M.; SERRASQUEIRO, Z.; LEITÃO, J. IS there a linear relationship between R\&D intensity and growth? Empirical evidence of non-high-tech vs. high-tech SMEs. Research Policy, v.41, n.1, p.36-53, 2012. 
[34] RADAS, S.; BOŽI $\square$, L. The antecedents of SME innovativeness in an emerging transition economy. Technovation, v.29, n.6-7, p.438-450, 2009.

[35] RAMALHEIRO, G. C. F.; FONSECA, S. A; TERENCE, A. C. Um estudo sobre o desempenho de incubadoras em municípios do interior paulista. In: Encontro Nacional de Engenharia de Produção - ENEGEP, 30. Bauru. Anais... São Carlos, ABEPRO, 2010. p.1-14, 2010.

[36] RATINHO, T., \& HENRIQUES, E. The role of science parks and business incubators in converging countries: Evidence from Portugal. Technovation, v.30, n.4, p.278-290, 2010.

[37] SCHWARTZ, M. A control group study of incubators' impact to promote firm survival. The Journal of Technology Transfer, v.38, n.3, p.302-331, 2010.

[38] SCHWARTZ, M.; HORNYCH, C. Cooperation patterns of incubator firms and the impact of incubator specialization: Empirical evidence from Germany. Technovation, v.30, n.910, p.485-495, 2010.

[39] SOETANTO, D. P.; JACK, S. L. Business incubators and the networks of technology-based firms. The Journal of Technology Transfer, v.38, n.4, p.432-453, 2013.

SOLOMON, G. T.; et al. Survival of the fittest: Technical assistance, survival and growth of small businesses and implications for public policy. Technovation, v.33, n.8-9, p.292-301, 2013.
[40] SPITHOVEN, A.; CLARYSSE, B.; KNOCKAERT, M. Building absorptive capacity to organise inbound open innovation in traditional industries. Technovation, v.31, n.1, p.10-21, 2011.

[41] TÖDTLING, F.; LEHNER, P.; KAUFMANN, A. Do different types of innovation rely on specific kinds of knowledge interactions? Technovation, v.29, n.1, p.59-71, 2009.

[42] UNESP. Sistema Integrado De Resposta Técnica (SIRT). Araraquara, 2015.

[43] VAAN, M. Interfirm networks in periods of technological turbulence and stability. Research Policy, v.43, n.10, p.16661680, 2014

[44] VELU, C. Business model innovation and third-party alliance on the survival of new firms. Technovation, v.35, p.1$11,2014$.

[45] VITORELI, M. C.; GOBBO JUNIOR, J. A. O papel das redes de transformação no processo de inovação: estudos de caso sobre a descoberta e a comercialização da inovação. Produção, v.23, n.3, p.723-734, 2013.

[46] YIN, R. Estudo de caso, planejamento e métodos. São Paulo: Bookman, 2001.

[47] ZHENG, S.; LI, H.; WU, X. Network resources and the innovation performance: evidence from Chinese manufacturing firms. Management Decision, v.51, n.6, p.1207-1224, 2013. 


\section{CAPÍTULO 15}

\section{PROPOSTA DE MELHORIA DE PROCESSO DE PLANEJAMENTO DA CONTRATAÇÃo DE TI NA GESTÃo PÚBLICA}

Dyego Alves da Silva

Edgard Costa Oliveira

Edna Dias Canedo

Simone Borges Simão Monteiro

Resumo: No setor governamental, o processo de contratação de TI é altamente complexo e envolve muitos recursos públicos. Na busca da melhoria contínua, a análise dos processos gerenciais é um fator crítico de sucesso para garantir que as contratações atendam ao interesse público. A proposta deste artigo consiste na aplicação do Modelo de Gestão Balanced Scorecard no processo do Planejamento da Contratação de Solução de Tecnologia da Informação (PCSTI) na esfera governamental. Para tanto foram realizadas pesquisas bibliográficas em documentos e normas, dando ênfase ao Guia de Boas Práticas de Contratação para Soluções de TI e a Estratégia Geral de TI (EGTI) sendo proposto um mapa dos objetivos estratégico e indicadores do processo. Os resultados obtidos com este estudo mostram que é pertinente a aplicação do modelo, podendo auxiliar os órgãos a aprimorarem os processos. A estrutura proposta do Balanced Scorecard foi adaptada às particularidades da gestão pública, conforme proposto na EGTI. Os resultados da pesquisa indicam que a implantação do Balanced Scorecard como instrumento de tradução da visão, planos e estratégia de governo podem proporcionar inúmeros benefícios, ao contemplar medidas de efetividade, eficiência, eficácia e economicidade dos serviços públicos.

Palavras Chave: Balanced Scorecard, Gestão Pública, Planejamento da Contratação de Solução de TI. 


\section{INTRODUÇÃO}

É incontestável a importância da aplicação de Tecnologias da Informação (TI) nos mais diversos ramos do conhecimento humano. A crescente evolução dos equipamentos e aplicações voltadas para a comunicação, bem como o crescente acesso aos computadores, estão colocando a humanidade frente a grandes mudanças.

No âmbito da administração pública os órgãos promovem TI de forma direta, desenvolvida pelo próprio órgão, ou indireta por meio da compras de ativos de TI e da terceirização de serviços e bens. Na Administração Pública Federal (APF) a terceirização tem suas diretrizes fundamentadas no Decreto-Lei 200/1967 (BRASIL, 1967), que estabelece em seu art. 10, § $7^{\circ}$ que tarefas executivas, sempre que possível, poderão ser executadas indiretamente mediante contrato. Além deste decreto, tem o 2.271/1997 (BRASIL, 1997) que definiu que as atividades de informática como serviços e que devem ser preferencialmente executados por meio de execução indireta. Destaca-se que o governo é o maior comprador de TI do mercado.

Barbosa (2006) e Cardoso (2009, 2000) reportaram problemas de desempenho das contratações de TI no setor público em decorrência da falta de formalização do processo da contratação, ausência de gestão, falta de conhecimento sobre o processo e de deficiências na sua execução.

O processo de contratação de TI, para ser eficiente, precisa de planejamento, monitoramento e controle que sejam capazes de nortear os investimentos e assegurar o benefício pretendido para os processos de negócio. Deve permear toda a organização, fornecendo à área de TI a clareza necessária acerca da direção e dos objetivos organizacionais. Toda contratação de bens e serviços de $\mathrm{Tl}$ deve possuir como objetivo primordial o atendimento de um ou mais objetivos estratégicos, detalhando o benefício pretendido e os indicadores e metas para alcançá-los (CRUZ, 2008).

Somente no ano de 2014, o orçamento governamental para TI em âmbito da APF foi de R\$7.298.664.964 de reais, segundo o acórdão 916/2015 do Tribunal de Contas da União (TCU, 2015). Tal montante demonstra que é necessário observar as contratações de TI com atenção

Existe a necessidade de gerenciamento constante dos processos e atividades de Planejamento das Contratações de Soluções de TI (PCSTI), pois são complexos e envolvem muitos artefatos, pessoas, unidades administrativas, atividades e acarreta diretamente nos gastos públicos. A carência de aportes teóricos e práticos tem por consequência gerar contratações ineficientes e equivocadas que podem gerar falhas durante a vigência dos contratos, as quais poderiam ser evitadas, é latente a necessidade de se ter foco na agregação de valor dos recursos gastos.

Ademais, as falhas se refletem em novas contratações, corretivas ou adicionais, utilizando mais recursos públicos simplesmente porque o processo adequado não foi implementado nem gerenciado, por falta de metodologia. Sem a devida gestão, podem ocorrer aquisições indevidas e desnecessárias, perda de prazos e tempo, indisponibilidade de serviços entre outros problemas como o superfaturamento e a corrupção.

Assim, tendo em vista a necessidade de gestão estratégica o Modelo de Gestão Balanced Scorecard (BSC) pode ser aplicado, como um sistema de gestão que conectaobjetivos estratégicos à operacionalização. Ou seja, o BSC torna a visão estratégica em objetivos e medidas capazes de serem avaliadas e comparadas, ao apresentar informações sobre os fatores críticos de sucesso, bem como fornece uma estrutura de comunicação da visão estratégica para os funcionários (CAMPBELL, 1997; KAPLAN; NORTON, 1992; TSENG, 2010).

Em pesquisa a diversos órgãos da Administração Pública, como a Receita Federal do Brasil unidade de Brasília, Ministério do Planejamento e Orçamento, Tribunal de Contas da União, Tribunal de Contas do Distrito Federal, a Secretaria de Planejamento e Orçamento do Distrito Federal, Instituto Brasileiro de Museus e em guias, normas, planos estratégicos e boas práticas aplicadas ao processo PCSTI, identificou-se que nenhum desses órgãos estão aplicando algum modelo de gestão por indicadores. Sendo este um problema de Planejamento Estratégico, contribui 
negativamente para a falta de controle da execução do processo, assim a realidade brasileira atual demonstra carência de mecanismos que permitam mensurar 0 real cumprimento dos objetivos que a Administração Pública se propõe a realizar, para fins de controle e de responsabilização.

No PCSTI, os gestores devem conhecer em detalhes, para a tomada de decisões, os departamentos, unidades, gerências, processos e/ou funções para os quais desejam propor melhorias e modificações. Nesse contexto faz-se pertinente a aplicação do modelo de gestão BSC. O objetivo deste artigo é apresentar a aplicação do modelo BSC adaptado para organizações públicas e ao processo PCSTI, visando o aprimoramento dos órgãos públicos no Brasil.

Este artigo está estruturado da seguinte forma: a segunda seção apresenta o referencial teórico. Na terceira seção são apresentados os procedimentos metodológicos. Na quarta seção é realizada a contextualização e análise e discussão dos resultados e na quinta seção são expostas as considerações finais.

\section{REFERENCIAL TEÓRICO}

Nesta seção são apresentados conceitos referentes à gestão de processos, aspectos normativos aplicados ao PCTI e acerca do Modelo de Gestão o qual será proposto os indicadores.

\subsection{GERENCIAMENTO POR PROCESSOS}

Processo é definido como uma ordenação específica das atividades de trabalho no tempo e no espaço, com um começo, um fim, inputs e outputs claramente identificados, enfim, uma estrutura para a ação (DAVENPORT, 1994).

A Gestão por Processos de Negócio ou Business Process Management (BPM) é um conjunto de diversos elementos, conceitos e metodologias que tem o objetivo de tratar processos de negócio de forma holística (CRUZ, 2010). O BPM é uma metodologia que visa proporcionar um melhor controle organizacional por meio de suas ferramentas. Trata- se de uma abordagem estruturada, com base na visão por processos, de análise e melhoria contínua dos elementos de processo de uma organização que agrega métodos, técnicas e ferramentas para suporte ao planejamento, à implantação, ao gerenciamento e à análise (BALDAM et al., 2009). Neste contexto, é pertinente o estudo do processo de Planejamento da Contratação de Soluções de TI, que é apresentado na próxima seção.

\subsection{CONTEXTO DO PLANEJAMENTO DAS CONTRATAÇÕES DE SOLUÇÕES DE TI NO BRASIL}

O processo de Contratação de Soluções de TI tem por objetivo obter produtos e serviços de TI que satisfaçam as necessidades de negócio da organização contratante, alinhados à estratégia da organização e a legislação brasileira, cumprindo com os princípios de eficácia, efetividade, economicidade, legalidade e legitimidade dos projetos de TI (CRUZ; ANDRADE; FIGUEIREDO, 2011).

Segundo o Guia de Boas Práticas em Contratação de Solução de Tecnologia da Informação (BRASIL, 2012), o processo de planejamento de contratação de solução de $\mathrm{TI}$, participa de uma conjuntura de vários processos de trabalhos, tais como: o processo de planejamento do órgão governante superior que o órgão é submetido; o processo de planejamento do órgão; o planejamento de TI do órgão; o processo de planejamento conjunto das contratações de soluções de TI e do orçamento de TI; o processo de seleção do fornecedor; o processo de gestão do contrato; o processo de governança de TI; o processo de controle; as legislações, normas e jurisprudência pertinentes; e os processos relacionados a recursos humanos.

Os planos de órgãos hierarquicamente superiores ou especializados podem influenciar as contratações de unidades administrativas hierarquicamente inferiores. Assim, os respectivos planos das unidades administrativas são limitados tanto pelos planos dos órgãos superiores quanto dos normativos e diretrizes do contexto em que o órgão está inserido.

A Instrução Normativa 04 de 2014 (IN 04/2014) (BRASIL, 2014) institui em seu artigo 4ำ que as contratações de 
TI deverão ser precedidas de planejamento, elaborado em consonância com o Plano Diretos de Tecnologia da Informação (PDTI) e o planejamento estratégico ou o instrumento equivalente do órgão. Este dispositivo busca garantir que todos os recursos gastos com as contratações de TI estejam em consonância para a concretização da estratégia do órgão, evitando assim desperdícios. Dessa forma, o órgão irá adquirir TI para a evolução do órgão e não adquirir TI para a TI. A IN 08/2014 estabelece em seu artigo 8 que o processo de contratação deve possuir três fases, que são o Planejamento da Contratação, a Seleção de Fornecedores e o Gerenciamento do Contrato.

A Estratégia Geral de Tecnologia da Informação (EGTI) é um mecanismo de gestão do Sistema de Administração dos Recursos de Tecnologia da Informação (SISP) que norteia a TI dos órgãos federais, definindo o plano estratégico que visa promover a melhoria contínua da gestão e governança de TI, bem como a manutenção da infraestrutura e auxilia os órgãos do SISP na elaboração dos Planejamentos de Tecnologia da Informação, a necessidade da EGTI está regulamentada no artigo 3으 da IN 04 de 2014 (BRASIL, 2014).

O processo de elaboração da EGTI baseou-se, com adaptações, na metodologia BSC, a EGTI 2013-2015 define nove objetivos estratégicos dispostos em cinco perspectivas: Sociedade; Governo Federal; Processos Internos; Pessoas, Aprendizado e Crescimento; e Financeiro. Após a definição desses objetivos e da orientação estratégica para alcançá-los, foram estabelecidos indicadores e suas respectivas metas, de forma a mensurar objetivamente os resultados alcançados pelos órgãos. Na EGTI 20132015 evidenciam-se os objetivos relacionados a gestão orçamentária e as pessoas de $\mathrm{TI}$, dimensões fundamentais para solucionar as atuais dificuldades do SISP (BRASIL, 2012).

A EGTI possui a função de interligar a estratégia entre os Órgãos Setoriais, Seccionais, Correlatos e o Órgão Central do SISP e possibilita o acompanhamento das ações realizadas, a retroalimentação e, em caso de necessidade, o realinhamento da estratégia. Os propósitos do plano são que os objetivos estratégicos sejam alcançados e que a TI seja estabelecida como um ativo com capacidade de proporcionar melhorias na oferta de serviços e efetividade das políticas públicas, consolidando, assim, a TI como elemento estratégico para a gestão pública (BRASIL, 2012).

No âmbito da APF o Decreto 3.591/2000 em seu artigo 17 e a Instrução Normativa número 63 do TCU, estabelecem que o primeiro ponto de controle das contratações de TI é de responsabilidade dos administradores participantes dos processos de trabalho de contratação de TI, tendo responsabilidade por assegurar que as atividades sob sua supervisão ocorram de forma organizada, com eficiência, eficácia, de acordo com a legislação e a respectiva jurisprudência, a partir de controles internos pertencentes nos processos de trabalho.

As atividades e trabalhos relacionados ao planejamento da contratação de TI são altamente dependentes de recursos humanos, servidores públicos, para tanto o setor de TI deve mensurar a carga de trabalho de cada atividade para assim propor a quantidade e a qualificação ideal dos membros da equipe, para que se execute uma atividade específica. Pois este aspecto está diretamente relacionado com o alcance do resultado almejado com a contratação. A Figura 1 apresenta o esquema do contexto do planejamento das contratações de soluções de TI. 
Figura 1 - Contexto do planejamento das contratações de soluções de TI.

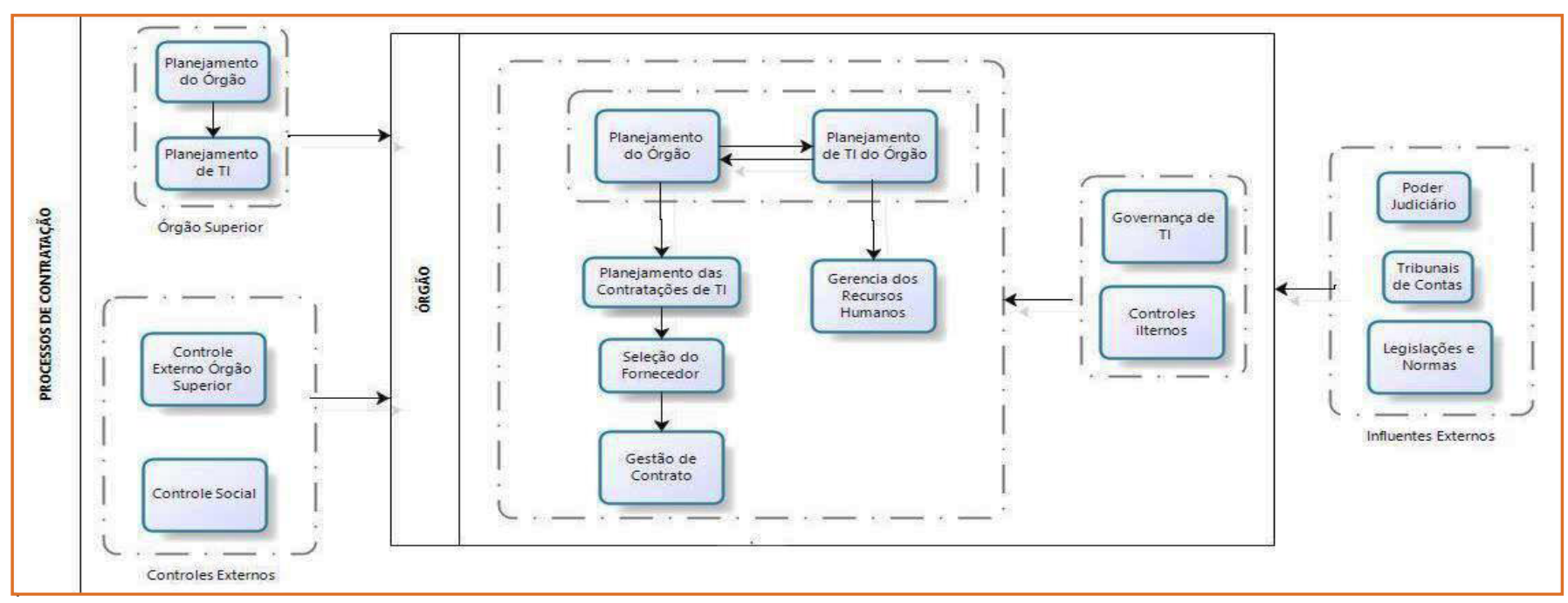

Fonte: Adaptado de Brasil (2012)

Dentro dessa perspectiva torna-se pertinente a aplicação do modelo de gestão BSC, que é apresentada na próxima seção.

\subsection{BALANCED SCORECARD}

Balanced Scorecard é um modelo de gestão que permite mapear a estratégia de uma organização e transformá-la em objetivos estratégicos. Esses objetivos, quando desdobrados em indicadores de desempenho, são distribuídos nas perspectivas financeiras, cliente, processos internos, e aprendizado e crescimento (KAPLAN e NORTON, 2006).

Kaplan e Norton (1997) promovem o BSC como um sistema gerencial que fornece a estrutura necessária para traduzir a estratégia em termos operacionais, visando a melhoria dos processos internos, a valorização do cliente e o aumento de capacidade de aprendizagem e crescimento, acrescentando-se também a medição do desempenho organizacional de indicadores que não fossem apenas os financeiros.

O modelo de gestão BSC pressupõe a escolha dos indicadores para administrar uma organização, não apenas os financeiros e os econômicos, sendo necessário monitorar também as perspectivas relacionadas ao mercado, aos processos internos e às pessoas (MAGALHAES; BRITO, 2007), proporcionando que o planejamento dos objetivos estratégicos, metas e ações sejam alinhados as suas perspectivas. Para um eficiente controle de execução do planejamento é necessário que sejam estabelecidos indicadores que sinalizem como tais objetivos serão alcançados.

O maior diferencial do BSC consiste na estruturação dos objetivos estratégicos, seus indicadores em perspectivas e a construção do relacionamento entre estes objetivos por meio de uma relação de causa e efeito (REDI, 2003). Esta lógica é explicitada por uma ferramenta denominada de mapa estratégico, no qual cada objetivo é conectado a uma cadeia de causa e efeito, e associado a indicadores que relacionam os resultados planejados na estratégia aos vetores que devem levar a este resultado (KAPLAN; NORTON, 2000).

Dentro dessa perspectiva, faz-se pertinente o estudo da metodologia do BSC aplicado ao contexto das organizações públicas, que será apresentado na próxima seção.

\subsubsection{BALANCED SCORECARD APLICADO A ORGANIZAÇÕES PÚBLICAS}

A administração pública, para ser eficiente, deve focar em resultados, qualidade e na gestão inteligente dos recursos públicos. Para tanto, são necessárias atividades de planejamento das metas almejadas com a celebração de ajustes e um método para mensurar 
os resultados. Para tal, propõe-se o uso do BSC, ferramenta originalmente desenvolvida para medição de desempenho na iniciativa privada e que atualmente vem sendo utilizada amplamente na Administração Pública, proporcionando meios para facilitar a gestão e as mudanças das organizações públicas do século XXI (NIVEN, 2008).

Para a aplicação do BSC na administração pública, há aspectos nas organizações do setor público que divergem do setor privado impedindo a transferência direta e linear do BSC (PFEIFFER, 2010). Algumas premissas são essenciais à aplicação do modelo clássico em instituições públicas. Como o foco deve estar nos conceitos de planejamento, controle e de estratégia, devem-se observar as diretrizes institucionais já existentes e a interação entre as ações, as dimensões gerenciais propostas no BSC tradicional devem ser tomadas com orientação básica, cada organização pública deve transformar o modelo e traduzí-lo em sistemas corporativos aderentes a sua realidade e necessidades gerenciais (BERGUE, 2011).

Assim, a adequação da metodologia é imprescindível ao propósito de utilizar o modelo do BSC para orientar a ação administrativa na consecução dos fins estratégicos das organizações públicas (PFEIFFER, 2010). Nesse contexto destacam-se os trabalhos de Felix et. al. (2011), Santos (2003), Niven (2008) e Bergue (2005) que formularam propostas de adaptações do modelo clássico voltadas ao emprego na administração pública.

A escolha do BSC neste artigo deve-se ao fato de o modelo ter sido adotado por um grande número de órgãos públicos e apresentarem bons resultados, tais como no Supremo Tribunal Federal, Tribunal Regional Federal da $1^{\circ}$ Região, Câmera dos Deputados, Gabinete de Segurança Institucional da Presidência da República, Ministério da Agricultura, Pecuária e Abastecimento, Ministério Público do Estado de Goiás, Banco Nacional de Desenvolvimento Econômico e Social, Governo do Estado de Minas Gerais e do Rio de Janeiro, Tribunal de Contas da União, na Estratégia Geral de Tecnologia da Informação e outros (ROZELITO et al al.,2011;LUZ, 2010; SOUSA, 2010). Entretanto, após ampla pesquisa, não identificamos, até o momento, nenhum órgão que aplicou a metodologia BSC sob o processo do Planejamento da Contratação de Soluções de TI.

Seguindo o estado da arte e dos padrões apresentados nos modelos de referência, será realizado um estudo de caso. A próxima seção apresenta a metodologia aplicada neste trabalho.

\section{METODOLOGIA}

Nesta seção é realizada a descrição do método de aplicação do Modelo de Gestão Balanced Scorecard para organizações públicas com desdobramento no processo de Planejamento da Contratação de Solução de TI. A pesquisa foi dividida em duas etapas: a primeira etapa serviu de apoio à concepção e ao desenvolvimento do modelo de pesquisa, partindo de modelos teóricos de gerenciamento de TI que teve como base a pesquisa bibliográfica e a análise de dados secundários.

Após a realização da pesquisa bibliográfica e o levantamento de todo o referencial teórico relevante, algumas das informações contidas naquele mesmo referencial foram analisadas, discutidas e trazidas para essa pesquisa, sendo a base das informações que serviram de subsídio para o desenvolvimento deste trabalho.

$\mathrm{Na}$ segunda etapa foram feitas entrevistas semiestruturadas, apoiadas por um roteiro constituído por questões relacionadas ao referencial teórico e uma sessão de brainstorming com servidores públicos gestores atuantes no processo de PCSTI do Governo do Distrito Federal, da Receita Federal do Brasil unidade de Brasília, do Ministério do Planejamento, Orçamento e Gestão e do Instituto Brasileiro de Museus. A escolha desses órgãos deve-se ao fato de os mesmos apresentarem crescente e relevante utilização da TI e pela informatização de processos.

O brainstorming foi direcionado para propor e compilar em um mapa os objetivos estratégicos genéricos e indicadores de gestão organizacional e governamental na perspectiva do PCSTI, de forma gráfica, tendo como propósito simplificar o entendimento das estratégias 
a todos envolvidos, assegurar a coesão e funcionar como ferramenta de divulgação. Os objetivos são associados entre si e se dispõem numa vinculação de causa e efeito, expondo o que deve ser executado para atingir a visão de futuro e para o cumprimento da missão. A próxima seção apresenta dos dados e a devida análise realizada neste estudo de caso.

\section{ANÁLISE E DISCUSSÃO DOS RESULTADOS}

O BSC estrutura-se em perspectivas que possibilitam cumprir a estratégia projetada de forma harmônica. Os objetivos estratégicos propostos foram agrupados horizontalmente nas perspectivas do BSC propostas pela adaptação da EGTI do triênio 2013-2015, que são:

- pessoas, Aprendizado e Crescimento: dispõe os objetivos pertinentes ao desenvolvimento de pessoas e de estruturação da organização;

- financeiro: associados aos objetivos direcionados os recursos orçamentária;

- processos Internos: possui os objetivos relacionados às ações internas e auxilio direto a obtenção da visão;

- governo: perspectiva que permeia entre os processos internos e os resultados vinculados a sociedade, que busca acurar a habilidade de gestão governamental; e

- sociedade: reúne os resultados tangíveis da estratégia que possuem visibilidade social.

A Figura 2 dispõe o mapa estratégico proposto.
Figura 2 - Proposta de Mapa Estratégico para o PCSTI.

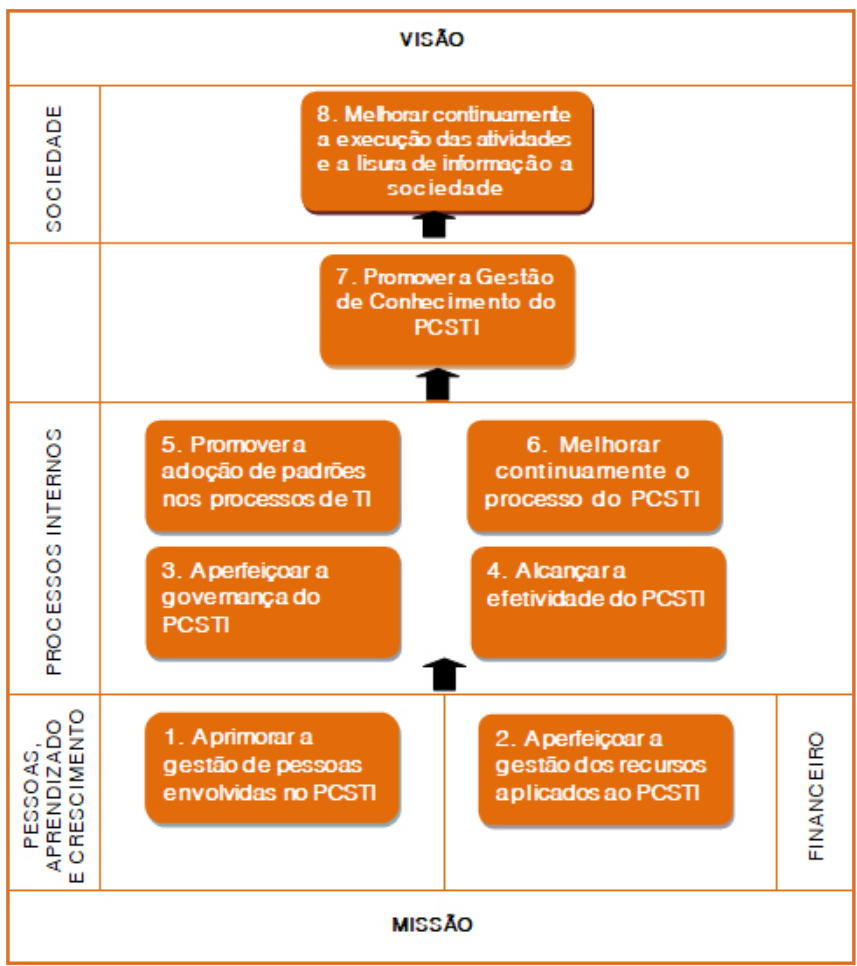

Fonte: Autor

Os objetivos propostos possuem a seguinte descrição:

a) Aprimorar a gestão de pessoas envolvidas no PCSTI: proporcionar que a gestão de pessoas seja executada de forma macro e integrada, ressaltando aos participantes a sua importância;

b) Aperfeiçoar a governança do PCSTI: alinhar o PCSTI as estratégias e objetivos da organização, definindo papéis e responsabilidades e envolvendo a alta administração nas decisões, além de adotar práticas de governança que permitam a entrega de valor ao órgão;

c) Alcançar a efetividade na gestão do PCSTI: adotar processos de trabalho e boas práticas de gestão relevantes e sensíveis à gestão do PCSTI visando à melhoria contínua dos resultados;

d) Promover a adoção de padrões no processo PCSTI: prover condições para uso de padrões tecnológicos, padrões de processo, infraestrutura e métodos, os quais permitam o melhor desempenho nas atividades relacionadas ao PCSTI e executem com qualidade as atividades e com racionalização dos recursos disponíveis;

e) Promover a Gestão de Conhecimento do PCSTI: 
apoiar o uso das práticas relacionadas à gestão do conhecimento, de forma a incentivar a cultura do compartilhamento e simplificação do acesso à informação no órgão, ampliando a geração e a troca de informações entre os diversos setores;

f) Melhorar continuamente o processo do PCSTI: promover a melhoria do processo, por meio de ações que contribuam para a atualização, automação e disseminação das informações pertinentes aos servidores envolvidos;

g) Aperfeiçoar a gestão dos recursos aplicados ao PCSTI: adotar boas práticas de gestão recursos para garantir o uso efetivo dos recursos financeiros necessários ao cumprimento das metas relacionadas ao PCSTI; h) Melhorar continuidade a execução das atividades e a lisura de informações a sociedade: promover a melhoria dos serviços prestados aos cidadãos, por meio de ações que contribuam para a democratização e a transparência no acesso as informações públicas.

A partir dos objetivos estratégicos, foram propostos indicadores para o processo do PCSTI, os indicadores são ferramentas de gestão para o monitoramento, aplicadas na mensuração de resultados ou características desejáveis do processo. Possibilitam compreender melhor os avanços em termos de resultados ou de impactos quando analisa a evolução. A Tabela 1 apresenta os indicadores propostos.

Tabela 1 - Indicadores propostos para o processo PCSTI.

\begin{tabular}{|c|c|}
\hline OBJETIVO & INDICADOR \\
\hline \multirow[t]{2}{*}{$\begin{array}{l}\text { 1. Aprimorar a gestão de pessoas } \\
\text { envolvidas no PCSTI }\end{array}$} & $\begin{array}{l}\text { 1.1 Proporcionar que a gestão de pessoas seja executada de forma macro e integrada, ressaltando } \\
\text { aos participantes a sua importância. }\end{array}$ \\
\hline & $\begin{array}{l}1.2 \text { Número de capacitações realizadas por servidores em competências alinhadas com o PCSTI } \\
\text { por semestre }\end{array}$ \\
\hline $\begin{array}{l}\text { 2. Aperfeiçoar a governança do } \\
\text { PCSTI }\end{array}$ & 2.1 Número de reuniões do Comitê Gestor de TI que abordam temas relacionados ao PCSTI . \\
\hline \multirow[t]{3}{*}{$\begin{array}{l}\text { 3. Alcançar a efetividade na gestão } \\
\text { do PCSTI }\end{array}$} & $\begin{array}{l}\text { 3.1 Acompanhamento e controle do prazo de execução das fases do planejamento das } \\
\text { contratações. }\end{array}$ \\
\hline & $\begin{array}{l}\text { 3.2 Percentual de Processos de PCSTI concluidos com sucesso (geraram Termo de Referencia ou } \\
\text { Projeto Básico), que tiveram o DOD aceito. }\end{array}$ \\
\hline & 3.3 Percentual de DODs aceitos. \\
\hline \multirow{2}{*}{$\begin{array}{l}\text { 4. Promover a adoção de padrões no } \\
\text { processo PCSTI }\end{array}$} & 4.1 Percentual de erros relacionados ao preenchimento dos artefatos do PCSTI. \\
\hline & 4.2 Conformidade dos artefatos aos check lists. \\
\hline $\begin{array}{l}\text { 5. Promover a Gestão de } \\
\text { Conhecimento do PCSTI }\end{array}$ & 5.1 Número de eventos de gestão que abordam o PCSTI \\
\hline \multirow{2}{*}{$\begin{array}{l}\text { 6. Melhorar continuamente o } \\
\text { processo do PCSTI }\end{array}$} & 6.1 Índice de processos do PCSTI otimizados. \\
\hline & 6.2 Índice de satisfação do cliente interno. \\
\hline $\begin{array}{l}\text { 7. Aperfeiçoar a gestão dos recursos } \\
\text { aplicados ao PCSTI }\end{array}$ & 7.1 Índice de investimento do PCSTI. \\
\hline $\begin{array}{l}\text { 8. Melhorar continuamente a } \\
\text { execução das atividades e a lisura } \\
\text { de informação a sociedade }\end{array}$ & 8.1 Número de artefatos disponibilizados à consulta pública. \\
\hline
\end{tabular}

Fonte: Autor

Esse estudo propôs um mapa dos objetivos estratégicos e indicadores para o processo do PCSTI de organizações públicas, sendo essas as atividades iniciais para a aplicação do modelo BSC. Assim para uma instituição implementar o BSC nesse contexto pode remodelar esse mapa estratégico e os indicadores propostos e deve desenvolver metas, forma de cálculo e iniciativas estratégicas, determinando o público alvo e as necessidades de informação sobre o desempenho específicos para a realidade da instituição.

No delineamento da aplicação do BSC, deve-se 
considerar que tipo de análise de desempenho os usuários gostariam de ter; o horizonte de tempo para a obtenção das informações; o foco da mensuração (processo, produto, atividades, etc); e suas características de interesse.

\section{CONSIDERAÇÕES FINAIS}

A velocidade e dinâmica em que as ações ocorrem nos ambientes de TI, faz com que as organizações possuam uma forte dependência da TI para prover e receber serviços que sustentam as atividades operacionais. Dessa forma, gerenciar o Planejamento de soluções de TI é indispensável para a execução das atividades de TI dos órgãos, as quais envolvem grandes volumes de recursos públicos.

Deixar de gerenciar o planejamento das contratações de forma padronizada, controlada e a mensurar pode causar desordem administrativa, não atendimento as demandas, gastos públicos desnecessários e aquisição do objeto diferente do almejado. Nesse contexto, o modelo de gestão BSC possui grande aplicabilidade.

As organizações públicas exercem papel essencial e insubstituível no Estado democrático, sendo conhecidas muitas vezes por ingerências e tomada de decisões não fundamentadas, necessitando de ferramentas que possibilitem uma gestão planejada e comprometida com os objetivos estratégicos e, essencialmente, com os anseios sociais.

É necessária a constante busca pela excelência estratégica da organização dos seus processos, das atividades, dos colaboradores e da otimização das aplicações dos recursos. Destaca-se que o Planejamento da Contratação de Soluções de TI afeta diretamente nos gastos de recursos públicos.

Para tanto, não apenas o Plano Diretor da TI pode alcançar com eficiência os objetivos, mas, também, a aplicação da metodologia do BSC que surge como ferramenta complementar para a implementação estratégica e gestão do processo. O BSC agrupa os objetivos estratégicos em perspectivas, o alinhamento destes objetivos com indicadores facilitam a gestão e o planejamento.

A aplicação do modelo possibilita a comparação da evolução histórica interna na própria organização, permitindo planejamento estratégico mais preciso e um acompanhamento ou monitoramento constante, evitando-se que as demandas despontem como emergências problemáticas apenas quando algum indicador atinja o seu nível crítico. Assim, após ser aplicado e analisado o modelo de gestão colaborará com a melhoria dos processos que os compõem.

A proposta desse trabalho se alinha com a Estratégia Geral de TI 2013-2015, contribuindo para o alcance dos seguintes objetivos estratégicos dispostos neste instituto que são aperfeiçoar a governança de $\mathrm{Tl}$, alcançar a efetividade na gestão de TI e fomentar a adoção de padrões tecnológicos e soluções de TI.

O emprego do BSC no PCSTI integrados a uma ferramenta de automação e a gestão de qualidade ou a governança corporativa poderá proporciona aos gestores melhores informações, essenciais a uma boa gestão e consequentemente auxiliará tomada a de decisões. Este método constitui-se um fator de mudança ao melhoramento dos serviços públicos e ao alcance dos anseios sociais, sem precisar onerar os cofres públicos. Contribuindo expressivamente para uma reformulação da cultura organizacional, gestão dos processos e o alcance dos objetivos estratégicos do órgão.

\section{REFERÊNCIAS}

[1] BALDAM, R.; VALLE, R.; PEREIRA, H.; HILST, S.; ABREU, M.; SOBRAL, V. Gerenciamento de processo de negócios: BPM - Business Process Management. 2ª Ed. São Paulo: Érica, 2009.

[2] BARBOSA, A. F.; JUNQUEIRA, A. R. B.; LAIA, M. M.; FARIA, F. I. Governança de TIC e contratos no setor público. In: CATI - Congresso Anual de Tecnologia da Informação, 2006, Escola de administração de Empresas de São Paulo da Fundação Getulio Vargas (FGV-EAESP), São Paulo, 2006. Disponível em: <http://www.fgvsp.br/cati/artigos/pdf/T00241. pdf>. Acesso em: 31 jul. 2015.

[3] BERGUE, S. T. Gestão estratégica de pessoas e Balanced Scorecard em organizações públicas. Análise, v. 16, n. 2, 2005. 
[4] BRASIL. Decreto o 200 de 25 de fevereiro de 1967 Disponível em: <http://www.planalto.gov.br/ccivil_03/ decreto-lei/del0200.htm>. Acesso em jun. de 2015.

[5] Tribunal de Contas da União. Acórdão 1952/2007-TCU-Plenário. Projeto de decisão normativa anual que define, para 2008, as unidades jurisdicionadas cuj os responsáveis devem apresentar contas ao tribunal relativas ao exercício de 2007, com a composição das suas peças e forma de organização, consoante dispõe o art. $4^{\circ}$ da in tcu n $47 / 2004$. projeto de instrução normativa para alteração de alguns dipositivos d a in tcu no 47/2004 transcurso do prazo fixado pelo plenário sem apresentação de emendas ou sugestões. parecer pela aprovação dos projetos. Disponível em: < http://www.tcu.gov.br/Consultas/ Juri s/Docs/judoc\%5CA cord\%5C20070920\%5CTC-018-2 47-2007-5.doc>. Acessado em: jan. 2015

[6] Modelos de gestão em organizações públicas. teorias e tecnologias para análise e transformação organizacional. Caxias do Sul: EDUCS, 2011.

[7] Decreto no 2.271 de 07 de julho de 1997. Disponível em: <http://www.planalto.gov.br/ccivil_03/ decreto/d2271.htm>. Acesso em jun. de 2015.

[8] _ Instrução Normativa - SLTI 4, de 11 de setembro de 2014. Dispõe sobre o processo de contratação de Soluções de Tecnologia da Informação pelos órgãos integrantes do Sistema de Administração dos Recursos de Informação e Informática (SISP) do Poder Executivo Federal. 2010. Disponível em: < http://www.governoeletronico.gov. br/biblioteca/arquivos/instrucao-normativa-nb0-4-de-11-desetembro-de-2014-compilada/download>. Acesso em jun. de 2015 .

[9] CAMPBELL, A. Keeping the engine humming. Business Quarterly Summer, p. 40-46. 1997.

[10] CARDOSO, G. S. Processo de aquisição de produtos e serviços de software para administração pública do Estado de Minas Gerais. 2006. 166f. Dissertação (Mestrado em Ciência da Computação). Belo Horizonte, Universidade Federal de Minas Gerais, 26 de junho de 2006. Disponível em: $\quad$ <http://dspace.lcc.ufmg.br/dspace/bitstream/1843/ RVMR- 6TJQEU/1/giselesilvacardoso.pdf>. Acesso em: 31 jul. 2015.

[11] CARDOSO, H. M. Diagnóstico da Terceirização da Engenharia de software na Gerência de Unidade de Aplicações em Administração, Controle e Finanças da Prodabel - UFS-PB. 2000. 41 f. Monografia (Especialização em Informática Pública). Belo Horizonte - Minas Gerais, Pontifícia Universidade Católica de Minas Gerais, 2000. Disponível em: <http://www.pbh.gov.br/prodabel/cde/ publicacoes/2000/cardoso2_2000.pdf>. Acesso em: 31 jul. 2015.

[12] COLLIS, J.; HUSSEY, R. Pesquisa em administração: um guia prático para alunos de graduação e pós-graduação, 2. ed.Porto Alegre: Bookman, 2005.
[13] CRUZ, C. S. Governança de TI e conformidade legal no setor público: um quadro referencial normativo para a contratação de serviços de TI. 2008. 252f. Dissertação (Mestrado em Gestão do Conhecimento e da Tecnologia da Informação). Universidade Católica de Brasília, Brasília, 2008. Disponível em: <http://www.bdtd.ucb.br/tede/tde_ arquivos/3/TDE-2008-11- 25T123713Z-687/Publico/Texto CompletoCruz - 2008.pdf>. Acesso em: 25 jul. 2015.

[14] CRUZ, T. BPM \& BPMS: Business Process Management \& Business Process Management Systems. São Paulo, $2^{\underline{a}}$ edição, 2010

[15] DAVENPORT, T. H. Reeengenharia de processos: como inovar na empresa através da tecnologia da informação. Rio de Janeiro: Campus, 1994.

[16] DENCKER, A. F. M. Métodos e técnicas de pesquisa em turismo. 4. ed. São Paulo: Futura, 2000.

[17] GIL, A. C. Como elaborar projetos de pesquisa. $4^{\circ}$ ed., São Paulo, Atlas, 2002. http://www.tcu.gov.br/Consultas/ Juris/Docs/judo c\%5CAcord\%5C2007 0920\%5CTC-018 -247-2007-5.doc 1. Acesso em: 10 fev. 2015.

[18] KAPLAN, R. S.; NORTON, D. Alinhamento: usando o Balanced Scorecard para criar sinergias corporativas. Rio de Janeiro: Elsevier, 2006.

[19] _. A estratégia em ação: Balanced Scorecard. (L. E. Filho, Trad.). Rio de Janeiro: Elsevier, 1997.

[20] _. The balanced scorecard: measures that drive performance. Harvard Business Review, p. 71-79, jan./fev. 1992.

[21] _. Organização orientada para a estratégia. Rio de Janeiro: Campus, 2000.

[22] Luz, S. M. Implantação e Benefícios da Utilização do Balanced Scorecard na Administração Pública: o Caso do Superior Tribunal de Justiça. Brasília, 2010.

[23] MAGALHÃES, I. L.; Brito, W. Gerenciamento de serviços de TI na prática: uma abordagem com base na ITIL: inclui ISO/IEC 20.000 e IT Flex. São Paulo: Novatec Editora, 2007.

[24] NIVEN, P. R. Balanced scorecard: step by step for government and nonprofit agencies. 2. ed. Hoboken: John Wiley \& Sons Inc., 2008.

[25] PFEIFFER, P. "PEM revisitado: Como Balanced Scorecard e gerenciamento de projetos podem aperfeiçoar o planejamento estratégico municipal", in: BROSE, Markus (org.). Metodologia participativa: uma introdução a 29 instrumentos. $2^{\underline{a}}$ ed. Porto Alegre: Tomo Editorial, 2010.

[26] REDI, R. Modelo de Gestão da Implementação da Estratégia através do Uso Integrado do Balanced Scorecard e do Gerenciamento pelas Diretrizes. Dissertação de Mestrado em Engenharia de Produção - Universidade Federal do Rio Grande do Sul, Rio Grande do Sul, 2003. 
[27] ROZELITO F.; FELIX P.P.;TIMÓTEO, R. Balanced Scorecard: adequação para a gestão estratégica nas organizações públicas. Revista do Serviço Público Brasília . 2011.

[28] Souza, A. S. Avaliação do planejamento estratégico da Câmara dos Deputados com ênfase no Balanced Scorecard. Alessandro Shirlei de Souza. 2010.
[29] TSENG, M. L. Implementation and performance evaluation using the fuzzy network balanced scorecard. Computers \& Education, v. 55, 2010. 


\section{CAPITULO 16}

\section{ANÁLISE DA ACURACIDADE DE ESTOQUES: UM ESTUDO DA APLICAÇÃO DO MÉTODO DO INVENTÁRIO ROTATIVO NA EMPRESA ALFA}

\section{Izadora Pereira}

\section{André Luís Almeida Bastos}

Resumo: O presente trabalho trata de um estudo sobre a aplicação do método do inventário rotativo para o controle da acuracidade no estoque de componentes acabados em uma empresa metal mecânica localizada na cidade de Brusque/SC. Tem-se como propósito expor uma síntese sobre o conceito de inventário e acuracidade, além da aplicação da ferramenta. A presente pesquisa é caracterizada como exploratória e estudo de caso. Esta ferramenta é de extrema eficácia pois, pode haver um melhor monitoramento e análise dos ajustes físicos e sistêmicos. O presente trabalho levou a empresa a investir um maior tempo em um período de análise para o levantamento das possíveis causas que contribuem para a baixa acuracidade.

Palavras Chave: Inverntário rotativo, Acuracidade, Estoque. 


\section{INTRODUÇÃO}

A acirrada competitividade entre as empresas no mercado, implica na necessidade de produzir cada vez mais, com melhor resposta ao cliente, além do mínimo de desperdício e estoque de materiais. Neste sentido, as empresas estão buscando técnicas e métodos que propiciem o alcance dessas metas e maximizem seus resultados operacionais.

Um dos grandes problemas atualmente nas empresas é o elevado estoque de materiais (matérias-primas, componentes e produtos acabados). Os estoques implicam em capital parado da empresa, além de requerer um espaço físico adequado para a manutenção das características do material estocado, sem deteriorá-lo. Adicionalmente, este estoque irá requerer mão de obra para controlá-lo, além de sistemas e controles para isto.

O fato é que os estoques surgem nas empresas principalmente devido ao desbalanceamento entre a oferta e procura dos materiais, ou seja, por conta das variações no fluxo logístico desde o fornecedor até o cliente. E, geralmente, os estoques formados ajudam as empresas a atender as necessidades do cliente e não interromper a produção, mas por outro lado pode onerar a empresa se não for administrado corretamente. Dessa forma, a gestão de estoque torna-se vital em qualquer organização (CORREA E CORREA, 2005).

Assim, um gerenciamento eficiente e eficaz dos estoques torna-se fundamental para a sobrevivência dos negócios por envolver aspectos financeiros, devido aos custos de oportunidade de estocagem e outros fatores relevantes na organização, como a previsão da demanda e acurácia dos estoques. Por outro lado, a acuracidade dos estoques implica nos resultados do faturamento da empresa e nos planos de produção emitidos pelo PPCP.

\section{FUNDAMENTAÇÃO TEÓRICA}

\subsection{INVENTÁRIO FÍSICO}

O inventário físico consiste, na prática, na operaçao de contagem dos itens de estoque. Martins e Campos (2003) o define como a contagem física dos itens em estoque. Compreende, na verdade, em uma contagem periódica dos materiais existentes (físico) com o objetivo de com comparar de comparação com os estoques registrados e contabilizados em controle da empresa, a fim de se comprovar sua existência e exatidão (VIANA, 2010).

No caso de detectar uma diferença entre o inventário físico e os registros do controle de estoques, devem ser feitos os ajustes conforme recomendações contábeis e tributárias" (MARTINS; ALT, 2009, p. 199)". De acordo com Viana (2010), o inventário tem como propósito confrontar a situação física dos estoques, em um determinado périodo, em relação aos registros contábeis correspondentes ao mesmo período. Dessa forma, através deste método de controle de estoque, é possível levantar erros que podem ocorrer na rotina de trabalho e de sistema.

De acordo com Martins e Alt (2009) e Dias (2012), os inventários podem ser classificados em inventário periódico e inventário rotativo. É denominado inventário periódico quando o mesmo é realizado em um determinado período. Este tipo de inventário abrange todos os materiais em estoque e geralmente é efetuado ao final de um exercício fiscal ou duas vezes ao ano. Neste tipo de operação, em geral torna-se necessário haver uma força tarefa para a realização da contagem física, a qual costuma demandar um bom tempo das pessoas envolvidas nesta operação.

Já o inventário rotativo é realizado com maior frequência durante o ano. Este tipo de operação abrange uma quantidade menor de itens de todas as classes $A, B$ e C. A vantagem do inventário rotativo é que o mesmo dá maior estabilidade para a análise e aplicação dos ajustes. Bertaglia (2009, p. 358), demonstra a seguir as vantagens que este tipo de inventário proporciona:
a. identificação das causas dos problemas;
b. correção de erros;
c. eliminação dos inventários físicos;
d. concentração dos esforços em áreas críticas;
e. redução dos erros de contagem;
f. pessoal mais especializado;
g. planejamento mais confiável;
h. estoque em níveis mais adequados. 


\subsection{ACURACIDADE DE ESTOQUES}

O termo acuracidade, derivado do inglês "accuracy", tem como significado a precisão que há entre as informações levantadas nos inventários, com base na quantidade de peças no físico versus as quantidades que constam no sistema (DROHOMERETSKI, 2009).

Segundo Nunes et al. (2014), a acuracidade de estoque é considerada um indicador de qualidade e confiabilidade. Quando as informações levantadas no estoque não são as mesmas que constam nos sistemas, pode-se dizer que o item não possui acuracidade ou não está acurado. Ainda de acordo com Nunes et al. (2014), esta falta de acurácia dos estoques afetam todos os setores da empresa, causando problemas para a gerência, aos operadores e para a área de planejamento da produção.

Arnold (2014, p. 342), cita que registros imprecisos de estoque resultam em:

a. vendas perdidas;

b. falta de material e programas perturbados;

c. excesso de estoques (dos itens errados);

d. baixa produtividade;

e. baixo desempenho nas entregas;

f. expedição excessiva, já que as pessoas estarão sempre reagindo a uma situação má, em vez de estarem planejando para o futuro.

A acurácia tem como propósito medir a porcentagem de itens corretos existentes no estoque. De acordo com Martins e Alt (2009), pode-se calcular a acurácia dos controles, tanto em quantidade quanto em valor, na qual podem ser expressas pelas seguintes equações:

Acurácia $=\frac{\text { Número de itens com registros corretos }}{\text { Número total de itens }} \times 100$
Acurácia $=\frac{\text { Valor de itens com registros corretos }}{\text { Valor total de itens }} \times 100$

O objetivo das empresas é que $100 \%$ dos itens em seus almoxarifados estejam corretos. Porém dificilmente as empresas conseguem atingir este percentual. Tornase mais fácil melhorar o percentual de acurácia de
$10 \%$ até $90 \%$, do que aumentar seu percentual de $90 \%$ a 100\%. Por este motivo, tolerâncias nos controles são aplicadas (BERTAGLIA, 2009).

\section{PROCEDIMENTOS METODOLÓGICOS}

Nesta pesquisa utilizou-se o estudo de caso, devido à necessidade de entender in loco a situação do setor a ser estudado e do problema a ser solucionado. A escolha da empresa e do setor estudado devese pela facilidade de obtenção dos dados pelos pesquisadores.

Para alcance do objetivo proposto foram utilizados os seguintes procedimentos de coleta de dados: observação participativa das ações propostas pela equipe de trabalho e a coleta de informações e de registros em arquivos.

Os indicadores utilizados para comparação de desempenho foram aqueles que estavam disponíveis na empresa ou que os pesquisadores puderam investigar nos dados histórico.

\section{RESULTADOS E DISCUSSÕES \\ 4.1. A EMPRESA E O PROCESSO}

A empresa estudada é do ramo automotivo e se localiza na cidade de Brusque. Com aproximadamente mil funcionários, seu principal objetivo é atender o mercado automotivo, disponibilizando produtos uma diversidade de produtos para este mercado.

No presente estudo, o método do inventário rotativo foi aplicado para o setor de supermercado de componentes acabados, onde são armazenados componentes que ainda não passaram pelo processo de montagem. No diagnóstico preliminar realizado no setor, constatou-se uma grande dificuldade em manter a acuracidade acima da meta exigida pela empresa, definida em $95 \%$.

O setor de supermercado de componentes acabados possui atividades como armazenamento de componentes, separação de kits que serão encaminhados para a linha de montagem, além do próprio abastecimento da linha. Entretanto, espera-se 
que as movimentações devam ocorrer de forma que o físico e o sistema sejam movimentados ao mesmo tempo, buscando, assim, a manutenção da exatidão das informações.

\subsection{RESULTADOS}

De acordo com o propósito do estudo aplicado na empresa, para avaliar a acuracidade no setor de supermercado de componentes acabados, são feitos inventários rotativos. Nesta operação, devem ser geradas listas com uma quantidade de endereços a serem auditados semanalmente, cada um com seu respectivo item. Mensalmente devem ser contados em média de 4 listas, porém como a demanda de contagens paralelas encontra-se elevada, os recursos disponíveis da empresa não são suficiente para o setor manter o ritmo considerado ideal para a realização dos inventários rotativos. Por este motivo, são contados em torno de 3 listas mensalmente.

Estas listas de contagem são formadas por endereços com respectivos itens da Curva ABC. Na Tabela 1, a seguir, são apresentadas informações referentes às contagens realizadas no ano de 2014 e 2015.

Tabela 1: Relação de listas contadas para o inventário rotativo no ano de 2014

\begin{tabular}{|c|c|c|c|c|c|} 
Tipo & Lista & $\begin{array}{c}\text { Data de } \\
\text { emissão }\end{array}$ & $\begin{array}{c}\text { Qtd de } \\
\text { itens }\end{array}$ & $\begin{array}{c}\text { Qtd de } \\
\text { itens }\end{array}$ & Acuracidade \\
\hline 5 & 1 & $17 / 02 / 2014$ & 51 & 35 & $68,63 \%$ \\
5 & 2 & $01 / 04 / 2014$ & 51 & 50 & $98,04 \%$ \\
5 & 3 & $07 / 05 / 2014$ & 51 & 50 & $98,04 \%$ \\
5 & 4 & $19 / 05 / 2014$ & 51 & 47 & $92,16 \%$ \\
5 & 5 & $06 / 06 / 2014$ & 51 & 49 & $96,08 \%$ \\
5 & 6 & $14 / 07 / 2014$ & 51 & 47 & $92,16 \%$ \\
5 & 7 & $15 / 08 / 2014$ & 51 & 47 & $92,16 \%$ \\
5 & 8 & $01 / 09 / 2014$ & 51 & 42 & $82,35 \%$ \\
5 & 9 & $23 / 09 / 2014$ & 51 & 43 & $84,31 \%$ \\
5 & 10 & $22 / 10 / 2014$ & 51 & 51 & $100,00 \%$ \\
5 & 11 & $27 / 10 / 2014$ & 51 & 45 & $88,24 \%$ \\
5 & 12 & $02 / 12 / 2014$ & 53 & 50 & $94,34 \%$ \\
\hline
\end{tabular}

A Tabela 1, apresentada anteriormente, demonstra a quantidade de listas emitidas para a execução do inventário rotativo no ano de 2014, no almoxarifado tipo 5, o qual corresponde ao estoque de componentes acabados da empresa. Percebe-se que a quantidade de listas emitidas é inferior à quantidade de listas mensais solicitadas pela empresa. Observa-se que entre fevereiro e dezembro de 2014, foram emitidas apenas 12 listas, ou seja, em número bem inferior à média de 4 listas mensais, solicitadas pela empresa.

No ano de 2014 obteve-se uma média anual de 90,55\% do índice de acuracidade, sendo assim um percentual abaixo das exigências da empresa, conforme descrito anteriormente. Para melhor compreensão de como obter os percentuais de acuracidade de cada lista, a seguir é apresentado a equação para aplicação, utilizando como exemplo o valor da primeira lista de contagem, apresentado na Tabela 1.

Acurácia $=\frac{\text { Quantidade de itens com registros corretos }}{\text { Quantidade total de itens }} \times 100$
Acurácia $=\frac{35}{51} \times 100$
Acurácia $=68,63 \%$

Já no ano de 2015, tem-se observado que os inventários rotativos estão sendo realizados com maior frequência, ocasionando maior estabilidade para a análise e aplicação dos ajustes e levantamento de erros que proporcionam o baixo índice deste indicador.

Conforme apresentado na Tabela 2, até o mês de agosto foram geradas vinte e quatro listas de contagem para o inventário rotativo, com freqüência média mensal de três listas. 
Tabela 2: Relação de listas contadas para o inventário rotativo no ano de 2015

\begin{tabular}{|c|c|c|c|c|c|}
\hline Tipo & Lista & $\begin{array}{l}\text { Data de } \\
\text { emissão }\end{array}$ & $\begin{array}{l}\text { Qtd } \\
\text { de } \\
\text { itens }\end{array}$ & $\begin{array}{c}\text { Qtd de } \\
\text { itens } \\
\text { acurados }\end{array}$ & Acuracidade \\
\hline 5 & 1 & $14 / 01 / 2015$ & 51 & 51 & $96,23 \%$ \\
\hline 5 & 2 & 21/01/2015 & 53 & 51 & $96,23 \%$ \\
\hline 5 & 3 & 02/02/2015 & 53 & 48 & $90,57 \%$ \\
\hline 5 & 4 & $11 / 02 / 2015$ & 53 & 49 & $92,45 \%$ \\
\hline 5 & 5 & 23/02/2015 & 53 & 50 & $94,34 \%$ \\
\hline 5 & 6 & 03/03/2015 & 53 & 48 & $90,57 \%$ \\
\hline 5 & 7 & $12 / 03 / 2015$ & 53 & 50 & $94,34 \%$ \\
\hline 5 & 8 & 23/03/2015 & 53 & 41 & $77,36 \%$ \\
\hline 5 & 9 & 06/04/2015 & 53 & 30 & $76,92 \%$ \\
\hline 5 & 10 & $15 / 04 / 2015$ & 53 & 36 & $92,31 \%$ \\
\hline 5 & 11 & 20/04/2015 & 53 & 38 & $97,44 \%$ \\
\hline 5 & 12 & 02/05/2015 & 53 & 38 & $95,00 \%$ \\
\hline 5 & 13 & $11 / 05 / 2015$ & 53 & 33 & $82,50 \%$ \\
\hline 5 & 14 & 20/05/2015 & 53 & 32 & $80,00 \%$ \\
\hline 5 & 15 & 01/06/2015 & 53 & 38 & $95,00 \%$ \\
\hline 5 & 16 & 15/06/2015 & 53 & 37 & $92,50 \%$ \\
\hline 5 & 17 & 22/06/2015 & 53 & 38 & $95,00 \%$ \\
\hline 5 & 18 & 24/06/2015 & 53 & 34 & $85,00 \%$ \\
\hline 5 & 19 & 01/07/2015 & 53 & 32 & $80,00 \%$ \\
\hline 5 & 20 & 08/07/2015 & 53 & 35 & $87,50 \%$ \\
\hline 5 & 21 & 22/07/2015 & 53 & 37 & $92,50 \%$ \\
\hline 5 & 22 & 05/08/2015 & 53 & 35 & $89,74 \%$ \\
\hline 5 & 23 & $13 / 08 / 2015$ & 53 & 28 & $71,79 \%$ \\
\hline 5 & 24 & 25/08/2015 & 53 & 29 & $74,36 \%$ \\
\hline \multicolumn{5}{|c|}{ Média } & $88,66 \%$ \\
\hline
\end{tabular}

No ano de 2015 o formato das listas de contagem para o inventário rotativo sofreram algumas alterações, a fim de obter um melhor controle e padronização na realização das análises e ajustes.

Anteriormente mantinha-se uma quantidade constante de 51 a 53 endereços, entretanto, alguns destes endereços eram inativos, ou seja, endereços que não existiam. Estes endereços inativos correspondiam em torno de $15 \%$ a $20 \%$ de endereços acurados, mascarando, dessa forma, o real percentual da acuracidade. Para melhorar a precisão desta operação, foi solicitada a alteração da lista, onde os endereços inativos foram retirados, assim mantendo um padrão constante de 39 ou 40 endereços a serem auditados em cada lista de contagem gerada.

Adicionalmente, o inventário rotativo não possuía um percentual de tolerância aplicado. Para melhorar a análise das divergências, tolerâncias de $2 \%$, em relação à variação existente entre as quantidades do físico e do sistema foram aplicadas.

No momento em que se realiza a contagem dos endereços a serem auditados percebe-se grandes dificuldades em encontrar itens acurados. Para a obtenção dos resultados apresentados nas tabelas 1 e 2 apresentadas anteriormente, são feitos ajustes manualmente, onde outros endereços correspondentes ao item também são contados a fim de verificar a possibilidade da existência da divergência sem passar por ajustes no sistema.

Entre os meses de março e agosto de 2015, houve a necessidade da criação de duas planilhas para a realização do inventário, uma na qual o que realmente era encontrado no momento da contagem e outra que apresentava o resultado das tabelas apresentadas anteriormente. Por exemplo, nesta planilha, com os resultados encontrados no momento de uma contagem constam 661 endereços, porém destes 661 endereços auditados, 265 estavam não acurados. Ao aplicar a equação para o cálculo do índice de acuracidade, obtem-se um percentual de 59,91\% de acurácia do estoque. A seguir a equação é apresentada evidenciando o resultado da análise efetuada.

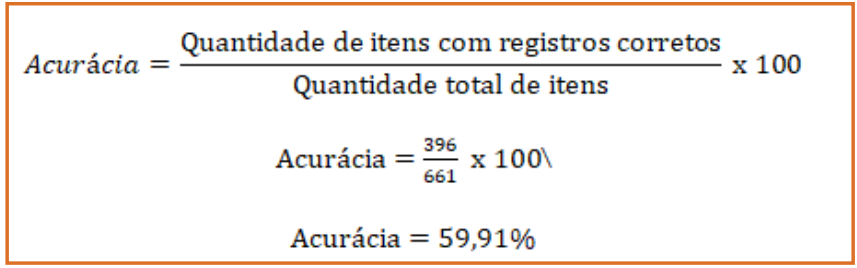

Por meio destes 661 endereços auditados, com 265 não acurados, foi possível fazer um levantamento de quais são os principais erros que estão impactando na realização da contagem. A Tabela 3 apresenta um levantamento quantitativo destes erros. 
Tabela 3: Erros encontrados no momento da contagem

\begin{tabular}{|c|c|c|c|}
\hline $\begin{array}{l}\text { Erros encontrados no } \\
\text { momento da contagem }\end{array}$ & Qtd & Por erro & Acumulado \\
\hline $\begin{array}{l}\text { Erro de movimentação física } \\
\text { e sistêmica entre endereços }\end{array}$ & 123 & $46,42 \%$ & $46,42 \%$ \\
\hline $\begin{array}{l}\text { Falta de transferência de } \\
\text { almoxarifado }\end{array}$ & 52 & $19,62 \%$ & $66,04 \%$ \\
\hline $\begin{array}{l}\text { Peças armazenadas sem } \\
\text { lançamento via sistema }\end{array}$ & 37 & $13,96 \%$ & $80,00 \%$ \\
\hline $\begin{array}{l}\text { Peças separadas a mais para } \\
\text { o kit da linha de montagem }\end{array}$ & 21 & $7,92 \%$ & $87,92 \%$ \\
\hline Erro de inventário & 18 & $6,79 \%$ & $94,72 \%$ \\
\hline Peça misturada & 4 & $1,51 \%$ & $96,23 \%$ \\
\hline Peças produzidas a mais & 3 & $1,13 \%$ & $97,36 \%$ \\
\hline Erro de balança & 2 & $0,75 \%$ & $98,11 \%$ \\
\hline Peças não encontradas & 2 & $0,75 \%$ & $98,87 \%$ \\
\hline Acerto indevido & 1 & $0,38 \%$ & $99,25 \%$ \\
\hline $\begin{array}{l}\text { Alocação indevida do } \\
\text { material }\end{array}$ & 1 & $0,38 \%$ & $99,62 \%$ \\
\hline $\begin{array}{l}\text { Fora do padrão de } \\
\text { embalagem }\end{array}$ & 1 & $0,38 \%$ & $100,00 \%$ \\
\hline $\begin{array}{l}\text { TOTAL DE ENDEREÇOS } \\
\text { COM PROBLEMAS }\end{array}$ & \multicolumn{3}{|c|}{265} \\
\hline
\end{tabular}

A Tabela 3 apresentou 12 problemas encontrados com os 265 endereços não acurados. Na Figura 1, a seguir, é apresentado um gráfico de Pareto, possibilitando evidenciar os maiores problemas encontrados.

Por meio da Figura 1, percebe-se que o erro com maior significância foi o "Erro de movimentação física e sistêmica entre endereços. Este erro corresponde a $46,42 \%$ de todos os problemas abordados.

Figura 1: Pareto de erros encontrados no momento da contagem

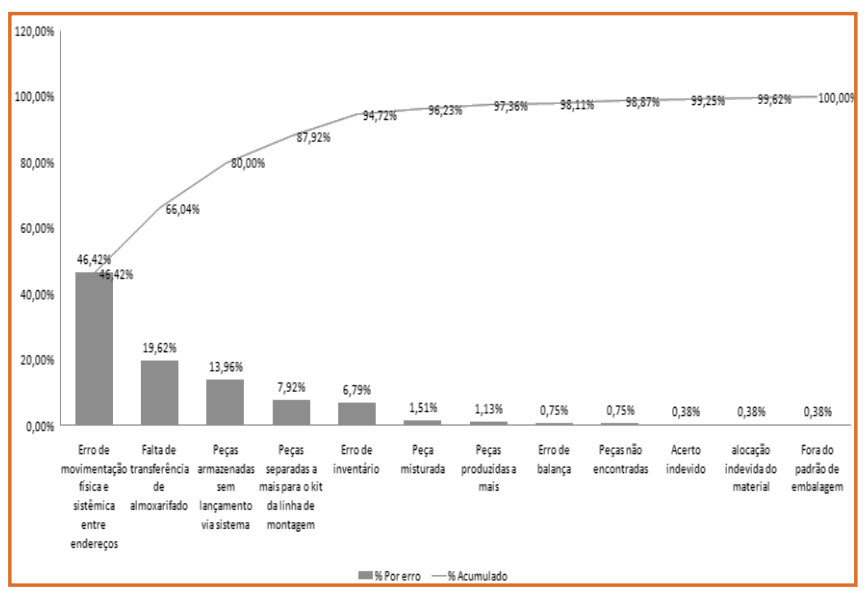

Após o levantamento dos erros que estavam ocasionando a baixa acuracidade nos endereços auditados no momento da contagem, foi possível fazer uma classificação de quais ruas (corredores dos endereços), apresentavam um maior índice com estes problemas, conforme ilustrado na Tabela 4.

Tabela 4: Ruas que apresentam maior índice dos erros encontrados no momento da contagem

\begin{tabular}{|l|l|l|l|}
\multicolumn{5}{c}{$\begin{array}{c}\text { Quantidade de } \\
\text { endereços não } \\
\text { acurados }\end{array}$} & Por erro & Acumulado \\
\hline $5 E$ & 43 & $16,23 \%$ & $16,23 \%$ \\
\hline $5 F$ & 43 & $16,23 \%$ & $32,45 \%$ \\
\hline $5 D$ & 41 & $15,47 \%$ & $47,92 \%$ \\
\hline $5 G$ & 38 & $14,34 \%$ & $62,26 \%$ \\
\hline $5 B$ & 36 & $13,58 \%$ & $75,85 \%$ \\
\hline $5 C$ & 30 & $11,32 \%$ & $87,17 \%$ \\
\hline 5 I & 12 & $4,53 \%$ & $91,70 \%$ \\
\hline 5 a & 11 & $4,15 \%$ & $95,85 \%$ \\
\hline $5 L$ & 10 & $3,77 \%$ & $99,62 \%$ \\
\hline $5 H$ & 1 & $0,38 \%$ & $100,00 \%$ \\
\hline Total & 265 & & \\
\hline & & &
\end{tabular}

O setor de supermercado de componentes acabados possuem ruas classificadas pelas letras de $\mathrm{A}$ a $\mathrm{H}$. O número 5 que se encontra antes das letras representa a identificação do almoxarifado. A Figura 2 ilustra quais ruas apresentaram maiores problemas com os erros apresentados anteriormente.

Figura 2: Ruas que apresentam maior índice dos erros encontrados no momento da contagem

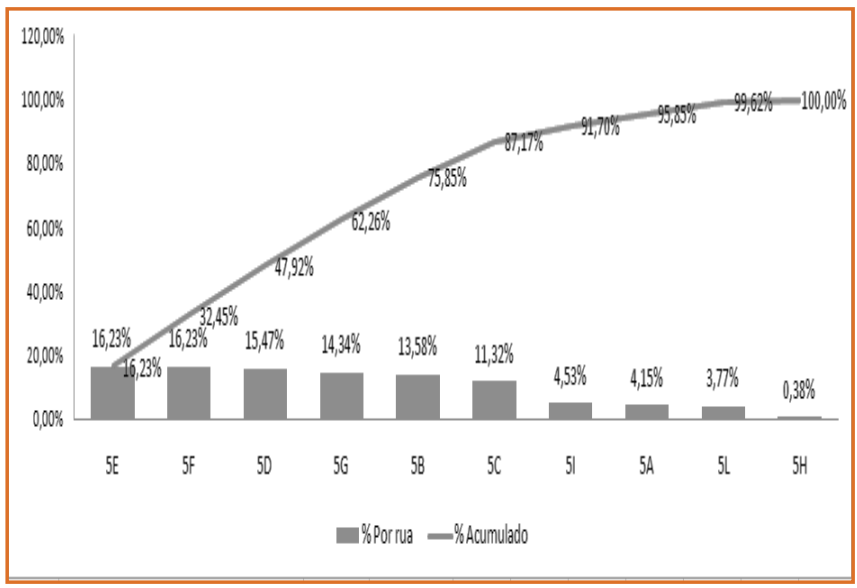

O método de controle de estoque através do inventário 
rotativo, mostrou-se ser uma ferramenta extremamente adequada às necessidades da empresa em estudo, pois é possível ter um melhor monitoramento e controle da exatidão das informações.

No momento, a empresa está em busca de mais evidências para a promoção de melhorias na acuracidade do estoque de componentes acabados. Além destes erros encontrados através dos inventários rotativos, se faz necessário o mapeamento de toda a logística interna, a fim de identificar quais pontos críticos que podem afetar a baixa acuracidade. Os colaboradores do setor em estudo estão cientes que após o levantamento dos pontos críticos, é possível atuar nas reais causas destes problemas, utilizandose de ferramentas da qualidade para tanto.

\section{REFERÊNCIAS}

[1] ARNOLD, J. R.T.. Administração de materiais: uma introdução. 1a. ed. São Paulo: Atlas, 1999.

[2] BERTAGLIA, P. R. Logística e gerenciamento da cadeia de abastecimento. 2. ed. São Paulo: Saraiva, 2009.
[3] CORRÊA, H. L.; GIANESI, I. G. N.; CAORI, M.; Planejamento, Programação e Controle da Produção, Atlas, 2005

[4] DIAS, M. A. P. Administração de materiais: princípios, conceitos e gestão. 6. ed. São Paulo: Atlas, v. 7, 2012.

[5] DROHOMERETSKI, E. Um estudo do impacto das formas de controle de inventário na acuracidade de estoques. 2009. 157f.. Dissertação (Mestrado em Engenharia de produção e sistemas) - Pontifícia Universidade Católica do Paraná, Curitiba, 2009.

[6] MARTINS, P. G.; ALT, P. R. C. Administração de materiais e recursos patrimoniais. 3. ed. São Paulo: Saraiva, 2009.

[7] MARTINS, P. G.; CAMPOS, P. R. C. Administração de materiais e recursos patrimoniais. 1. ed. São Paulo: Saraiva, 2003.

[8] NUNES, R. V; DOS SANTOS, S. H. X; DE ASSIS, C. W. C; FONSECA, R. DE C; CIRIACO, F. S. P. A relevância do estudo da acuracidade de estoques em um comércio atacadista. In: Congresso Nacional de Excelência em Gestão, 10, 2014, Rio de Janeiro e Niterói. Anais... Rio de Janeiro e Niterói, 2014, p. 1-22.

[9] VIANA, J. J. Administração de materiais: um enfoque prático. 1. ed. São Paulo: Atlas, v. 10, 2010. 


\section{CAPÍTULO 17}

CADEIA DO FRIO: REVISÃO DA LITERATURA E ESTUDO DE CASO EM UMA SORVETERIA

\section{Flavia Haweroth}

\section{Vanina Macowski Durski Silva}

\section{Sílvia Lopes de Sena Taglialenha}

Resumo: A busca por redução de custos e melhoria na qualidade dos produtos é cada vez maior nas cadeias de suprimentos. Na cadeia do frio os produtos necessitam de controle de temperatura, umidade e outras variáveis ambientais, tornando o desafio na busca pela eficiência ainda maior. São vários exemplos de produtos que precisam ser mantidos em ambiente adequado para garantir integridade e qualidade, ou para assegurar uma maior durabilidade. Este trabalho faz, através de um estudo de caso, uma análise do comportamento da temperatura usando dados reais fornecidos por uma fabricante e distribuidora de sorvetes. O objetivo é identificar pontos críticos durante o roteiro executado, apontando possíveis causas e consequências à qualidade do produto.

Palavras Chave: Cadeia do Frio, Análise de Temperatura, Sorvetes. 


\section{INTRODUÇÃO}

A crescente exigência por qualidade, flexibilidade e rapidez de entrega de produtos imposta pelos clientes em conjunto com o desenvolvimento do mercado global, exige das empresas um melhor planejamento de seus processos logísticos para que consigam manter-se no mercado, atendendo seus clientes da melhor forma com um menor custo possível.

A busca por redução de custos das operações logísticas como: transporte, armazenagem e distribuição, faz com que as empresas revejam seus processos logísticos, para estudarem possíveis melhorias tanto em qualidade de produtos e serviços oferecidos ao cliente como um valor que este queira e se motive a pagar (CAVALCANTI, MACHADO e SANTANA, 2010).

Neste contexto surge o conceito de Cadeia de Suprimentos que para Ballou (2006), trata do conjunto de atividades logísticas, como transporte, controle de estoques, que se repetem inúmeras vezes ao longo do canal pelo qual matérias-primas vão sendo convertidas em produtos acabados, aos quais se agrega valor ao consumidor. A Cadeia de Suprimentos está presente em praticamente todos os setores industriais, porém ela pode ter suas peculiaridades de acordo com o tipo de produto que esteja sendo manuseado, como o caso de produtos perecíveis (PRADO e BARROS, 2014).

Denomina-se Cadeia do Frio as cadeias logísticas que manipulam produtos que necessitam de controle de temperatura e umidade, pois sem isto a qualidade do produto seria comprometida. Pereira et al. (2010) definem Cadeia do Frio como o conjunto dos processos de armazenamento, conservação, distribuição, transporte e manipulação dos produtos, de uma forma que se mantenha uma baixa temperatura.

Sendo assim, analisando a literatura científica, percebese que há escasso estudo a respeito do tema. Tal fato levou à decisão pela realização desta pesquisa, que pretende estudar a cadeia logística de produtos resfriados e congelados e, realizar um estudo de caso, em uma empresa do ramo de sorvetes, analisando dados fornecidos da temperatura dos caminhões em um roteiro real de distribuição realizado pela empresa. A partir destes dados serão gerados gráficos a fim de identificar causas de possíveis situações críticas, para propor-se soluções, bem como apontar os pontos positivos da operação. Esta pesquisa se caracteriza então, quanto aos seus objetivos, como descritiva, pois visa observar e analisar dados operacionais e técnicos obtidos sem interferência.

\section{REFERENCIAL TEÓRICO \\ 2.1 DEFINIÇÃO DE CADEIA DO FRIO}

A utilização de baixas temperaturas para a conservação de alimentos é prática antiga. Já na pré-história o homem percebeu que o frio de uma caverna ou o uso da neve poderia manter a qualidade da caça por mais tempo, permitindo que ela pudesse ser armazenada para períodos de escassez, e com o passar dos anos e a industrialização, as técnicas de resfriamento foram sendo aprimoradas (USDA, 2015).

A aplicação de temperaturas, durante o transporte tem como objetivo além de manter a integridade microbiológica manter a integridade física, química e organoléptica do produto (BAPTISTA, 2006). O frio conserva o alimento pela inibição total ou parcial dos principais agentes causadores de alterações: atividade microbiológica, enzimática e metabólica dos tecidos animais e vegetais após sacrifício e colheita. A aplicação do frio pode ocorrer pelo resfriamento ou congelamento do produto fresco ou processado (ORDÓÑEZ, 2005).

De modo geral a "Cadeia do Frio é uma vertente da Cadeia de Suprimentos e da refrigeração, pois agrega, de um lado, a gestão logística e suas funções de controle e monitoramento, e de outro, os recursos técnicos da engenharia de refrigeração" (SILVA, 2010, p. 7). Sendo assim a gestão eficiente da CF depende dos avanços destas duas áreas.

Para Carvalho (2013) o surgimento do operador logístico foi um dos principais avanços no transporte no Brasil, e para Coyle, Hall e Ballenger (2001) também houveram avanços no processo de transporte com desenvolvimento de embalagens, que possibilitaram o aumento da vida útil do produto e o alcance de mercados mais distantes. O aumento da consciência do consumidor e a exigência de padrões de qualidade 
constituem papel relevante para o desenvolvimento de tecnologias.

Carvalho (2013) destaca também que o transporte, entre todas as atividades logísticas, é o maior responsável pela perda da qualidade dos alimentos devido à falta de controle do ambiente. Kierstan e Ford (1998) mostram em seu trabalho que a perda da qualidade ao longo da Cadeia do Frio é cumulativa e irreversível, conforme pode ser observado na Figura 1. $\mathrm{Na}$ curva de qualidade é possível notar que durante o transporte, devido à não manutenção da temperatura adequada, existe uma inclinação negativa acentuada.

Sobre a perda de qualidade durante o transporte Baptista (2006) defende que os danos ao produto também podem acontecer pelo uso incorreto do frio. No caso da refrigeração vários produtos alimentícios terão sua qualidade reduzida se forem expostos a temperaturas inferiores à crítica (temperatura de congelação) que varia de um produto para outro. Já os alimentos que necessitam ser congelados, principalmente carnes e pescados, sofrem pouco com variações de temperatura. A desidratação, queimadura pelo gelo e o desenvolvimento de microrganismos são outros causadores de perdas durante o transporte.

Figura 1 - Curva de qualidade do produto durante os processos na CF.

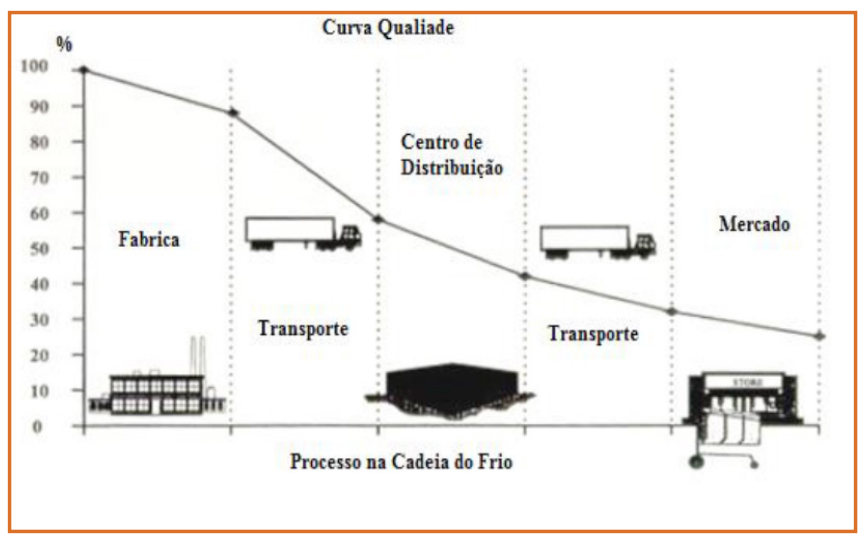

Fonte: Kierstan e Ford (1998)

O transporte é umas das atividades de maior impacto dentro do alto custo logístico brasileiro. A Fundação Dom Cabral (2014) divulgou uma pesquisa feita com 111 empresas brasileiras, que juntas são responsáveis por $17 \%$ do PIB brasileiro, sobre os custos logísticos. O resultado é que estes consomem $11,2 \%$ da receita das empresas e $48,6 \%$ delas consideram muito alta a influência dos transportes na formação do preço final de seus produtos. Tendo isso em vista, as perdas de carga durante esta atividade da cadeia são de grande impacto.

\subsection{EXEMPLOS DE ATUAÇÃO}

A Cadeia do Frio é um termo aplicável a diversos tipos de produtos chamados perecíveis e que necessitam de controle de temperatura para manter suas propriedades naturais. São os casos de alimentos (carnes, frutas e hortaliças, lacticínios) e também de flores, medicamentos, órgãos para transplante e vacinas (PRADO; BARROS, 2014). Além destes, os cosméticos, as obras de arte, películas fotográficas e produtos químicos também se encaixam na descrição (SILVA, 2010).

A conservação pode acontecer por resfriamento ou congelamento. As faixas de temperatura abrangidas por estas duas condições são um pouco tênues, pois podem depender da constituição do produto, mas fisicamente um produto está congelado quando a água em seu interior congela. Segundo Silva (2010) e Heap (2006), a temperatura ideal para produtos congelados é de $-18^{\circ} \mathrm{C}$ ou abaixo. Quanto ao resfriamento pode variar de $-1,5^{\circ} \mathrm{C}$ até $15^{\circ} \mathrm{C}$, respeitando a faixa apropriada para cada produto. O mais importante no que diz respeito aos produtos refrigerados, segundo Heap (2006), são as flutuações de temperatura; estas devem ser evitadas ao máximo. Alguns destes produtos serão abordados de forma mais detalhada a seguir.

Carnes e frutos do mar: Nestes produtos o objetivo da refrigeração é diminuir a temperatura da carcaça, reduzindo a taxa de crescimento dos microrganismos patogênicos e deteriorantes, retardando atividades enzimáticas que contribuem para alterações físicas e organolépticas da carne. O resfriamento também prepara a carcaça para a desossa, pois, as baixas temperaturas tornam firme a gordura (BRIDI e CONSTANTINO, 2009). Os microrganismos são os principais agentes deteriorantes e estes de desenvolvem bem a temperatura de $\mathrm{O}^{\circ} \mathrm{C}$ e $5^{\circ} \mathrm{C}$. Devido a isso os pescados de água fria possuem 
menor tempo de armazenamento do que os de água quente. Quando congelados a qualidade final é fortemente influenciada pela condição no momento do congelamento. Recomenda-se que os pescados sejam mantidos a uma temperatura próxima de $\mathrm{O}^{\circ} \mathrm{C}$ antes de serem congelados (ABIAF, 2008).

Vegetais (frutas, verduras e legumes): Nos vegetais como frutas, verduras, legumes e também nas flores, a refrigeração permite reduzir a velocidade de certos processos fisiológicos (como a respiração, a transpiração e o amadurecimento), aumentando assim o período de armazenamento destes produtos, com uma intensidade e amplitude característica para cada um deles (TOLEDO, 1991). Quando congeladas, a temperatura recomendada é $-18^{\circ} \mathrm{C}$, e temperaturas mais quentes reduzem, e muito, a vida de estocagem. As frutas podem ser congeladas inteiras ou em pedaços com ou sem outros ingredientes, ou ainda com açúcar ou calda, em sucos, concentrados e pasta. Os métodos utilizados para o congelamento são muito variados e dependem do produto e do objetivo, podendo inclusive ser feito com o uso de nitrogênio líquido (ABIAF, 2008).

Laticínios: Atualmente a coleta do leite é feita a granel, e o resfriamento do leite acontece imediatamente após sua ordenha. O leite é acondicionado em tanques de expansão, onde sua temperatura situa-se na faixa dos $4^{\circ} \mathrm{C}$, temperatura ideal para garantir a manutenção da qualidade do leite na propriedade leiteira, visto que ao sair do úbere pode se contaminar com microrganismos provenientes da teta, mãos do ordenhador, utensílios de ordenha, fragmentos de alimentos, da poeira do ambiente, e de insetos. Com a chegada do caminhão isotérmico, o leite é transferido para o caminhão sem contato manual (RIBEIRO et al., 2003; TEIXEIRA e RIBEIRO, 2000). Segundo Teixeira e Ribeiro (2000) a temperatura máxima de chegada do leite na recepção das unidades de processamento (cooperativas, industrias e mini usinas) é de $10^{\circ} \mathrm{C}$ e é importante que a refrigeração do leite ocorra no máximo em duas horas após a ordenha.

Flores: Em 2013 as vendas de flores no Brasil cresceram $8 \%$ em relação ao ano anterior, fato devido à tendência de construir com áreas verdes e a popularização destes produtos em supermercados e lojas de bairro que permitiram a ascensão rápida deste setor (DONATO, 2014). Após a colheita as flores devem passar por um processo de resfriamento que deve acontecer antes da paletização para o envio para transporte. O processo chamado de pré-cooling consiste em posicionar as flores inicialmente numa área de resfriamento, na água, com temperaturas de 12 a $15^{\circ} \mathrm{C}$ e, em seguida em uma câmara fria de $2^{\circ} \mathrm{C}$, para depois fazer a paletização (ANEFALOS, 2004). Este processo evita que este tipo de produto se deteriore durante o transporte.

Medicamentos: Os medicamentos representam uma parte bastante sensível na CF, pois a perda da qualidade nestes produtos pode causar sérios danos à saúde do paciente. Os medicamentos também possuem alta importância econômica devido ao seu valor e problemas durante o transporte ou armazenamento podem causar grandes perdas aos fabricantes. Fatores como embalagem, acondicionamento, quantidade a ser transportada e o meio de transporte, além do cumprimento das normas da ANVISA (Agência Nacional de Vigilância Sanitária) devem ser observados para garantir a segurança e a integridade dos medicamentos (DI MAIO e SILVA, 2014).

Órgãos e tecidos: Segundo dados do Sistema Nacional de Transplantes, o Brasil ficou em segundo lugar no ano de 2013 em números absolutos de transplantes renais e hepáticos. Já em números por milhão de população (pmp) as posições giraram em torno da 30aㅡ dependendo do órgão transplantado. Em 2014 as taxas foram de 29,6 pmp no transplante de rim e 9,2 pmp no transplante de fígado. A menor taxa foi a de transplantes de pulmão, apenas 0,4 pmp (ABTO, 2014). A logística envolvida no transplante abrange o acondicionamento, armazenagem e transporte de órgãos dentro de tempos curtos e em distâncias que podem ser enormes devido à extensão territorial do país. Sendo assim a preservação correta do órgão durante os processos da cadeia de suprimentos é de suma importância para evitar a isquemia e garantir o sucesso final. Essa preservação acontece pela hipotermia (baixas temperaturas) e uso de substâncias químicas. 


\section{CENÁRIO NACIONAL}

A Cadeia do Frio está sendo afetada de forma positiva pelas mudanças que vem ocorrendo com a sociedade: (a) os hábitos do dia a dia causando a falta de tempo no preparo de refeições e, (b) a globalização fazendo com que produtos de todos os tipos de culturas sejam consumidos por todos os mercados ao redor do mundo.

O estilo de vida mudou ao longo das últimas décadas, levando ao aumento de consumo de produtos resfriados e congelados, pois são mais fáceis e rápidos de serem preparados. Para que se garanta a qualidade do produto o controle de temperatura ao longo de toda a Cadeia do Frio deve ser rigorosamente monitorado (CARVALHO, 2013).

Alguns avanços foram conquistados pela Cadeia do Frio nos últimos anos e merecem destaque, entre eles o monitoramento online e a modernização de equipamentos e caminhões e, o momento é de conscientização e mudança. De acordo com a Associação Nacional dos Fabricantes de Implementos Rodoviários (Anfir, 2013 apud Hira 2014), em 2013, o mercado de veículos pesados com sistemas de refrigeração cresceu 54\%, quando comparado a 2012, e o de veículos leves frigoríficos cresceu $22 \%$, em relação ao mesmo ano.

Ainda segundo Hira (2014) os erros mais comuns observados no transporte frigorificado são a configuração errada da temperatura e o posicionamento errado da carga, impedindo a circulação correta de ar; sendo o maior desafio a vencer: os valores de investimentos em equipamentos, que pode ser considerado um investimento de alto risco devido ao péssimo estado das rodovias em termos de infraestrutura e segurança.

\section{ESTUDO DE CASO}

A referida empresa atua na fabricação e distribuição de sorvetes há 24 anos em Joinville-SC. As informações sobre a empresa foram obtidas em visitas técnicas e conversas com o responsável pelo setor de logística e também diretamente no site da mesma.
No início, os sorvetes eram fabricados de forma artesanal, mas a marca cresceu e passou a ser produzida em escala industrial. Hoje os produtos estão presentes em parte dos estados de Santa Catarina e Paraná. O serviço de distribuição é próprio e é usado o espaço da própria planta fabril como armazém e centro de distribuição. Além disso o serviço é auxiliado por outros três centros de distribuição localizados em Curitiba, Mafra e Florianópolis.

Os produtos oferecidos são variados. Em 1998 a produção se resumia a potes de 1 ou 2 litros quando foi iniciada a produção de picolés diferenciados. Hoje são produzidos potes de 1, 2, 6 e 10 litros, picolés e outros. Os sabores variam desde tradicionais até edições limitadas e especiais e, a empresa também trabalha com linhas de produtos sem açúcar e com leite de soja.

Bragante (2010) explica que a última etapa da produção de sorvetes é o endurecimento que acontece após o sorvete já estar embalado e deve acontecer a -25ํㅡ para evitar formação de cristais de gelo. Na empresa em estudo o produto permanece nesse processo por aproximadamente 24 horas. Este autor argumenta que a aparência do sorvete é essencial para o consumidor, e esta é prejudicada pelo derretimento. Algumas características do produto derretido são: Produto espumoso; Produto escamoso, com flocos; Produto coalhado devido à presença de proteínas desestabilizadas que intensificam a atividade microbiana e tornam o sorvete impróprio para consumo; Separação do soro: usualmente associado ao caráter coalhado.

Nas visitas realizadas à empresa buscou-se observar os processos de armazenagem, carregamento dos caminhões e transporte, características dos equipamentos e também os processos decisórios usados pela gerência na distribuição de seus produtos.

A empresa possui uma frota de 33 veículos equipados com baús frigorificados de três tamanhos diferentes para atender necessidades específicas (abastecer centros de distribuição, entregas na região e para locais com restrições de tráfego ou entregas pequenas). $O$ isolamento é feito com painéis do 
tipo sandwich, isolado com poliuretano de alta densidade e revestidos de fibra de vidro. O sistema de refrigeração utilizado é o eutético, com alimentação elétrica independente do motor. De acordo com Silva (2010) o sistema eutético usa uma estrutura de tubos ou placas com cavidade internas, construídas com material de boa condutividade. Com o veículo vazio é injetado um gás refrigerante impulsionado pelo motor elétrico para um circuito de serpentinas das placas. $O$ gás é propagado por convecção e a solução eutética congela, podendo chegar a $40^{\circ} \mathrm{C}$, mas devido à troca de calor com a carroceria a estabilização acontece em torno de $25^{\circ} \mathrm{C}$.

A frota é equipada também com um equipamento de rastreamento da temperatura administrado por uma empresa terceirizada. O monitoramento é um importante instrumento na CF uma vez que manter a temperatura é a garantia da integridade da mesma, e sendo assim, garante transparências nos processos da empresa. Na parte interna das carrocerias do tipo sorveteira além das divisões internas, que tem um objetivo de organizar, existem cortinas de PVC nas portas para diminuir a troca de calor com o ambiente externo. Observou-se que as cortinas são geralmente presas para os lados ou para cima para facilitar o carregamento da carga. A justificativa dada é que em razão da baixa temperatura as cortinas acabam se tornando perigosas causando ferimentos nos braços dos funcionários.

Quanto à distribuição, na cidade de Joinville e região, é feita a partir da fábrica que também tem a função de abastecer os outros três centros de distribuição. Durante o verão, é feita com base em uma divisão geográfica, ou seja, um caminhão que deixa a fábrica se destina sempre a atender determinada região. Os dados que a empresa forneceu são originados do rastreamento de um roteiro de entrega feita em junho de 2014, um mês com baixa demanda. Os pontos de entrega, que podem ser vistos na Figura 2, são na sua maioria na cidade de Jaraguá do Sul, que situa-se a 50 $\mathrm{km}$ de Joinville.

Pode-se observar também algumas entregas em Joinville, próximas à fábrica (em azul) indicando que o roteiro foi aproveitado para atender regiões diferentes.
Essa identificação da localização é possível pois além das temperaturas, o rastreador identifica a localização do caminhão e a referência daquela localização, um cliente cadastrado por exemplo. É possível então, saber o momento em que o caminhão esteve em determinado ponto de entrega e a temperatura nas aberturas de porta.

Figura 2 - Distribuição dos pontos de entrega.

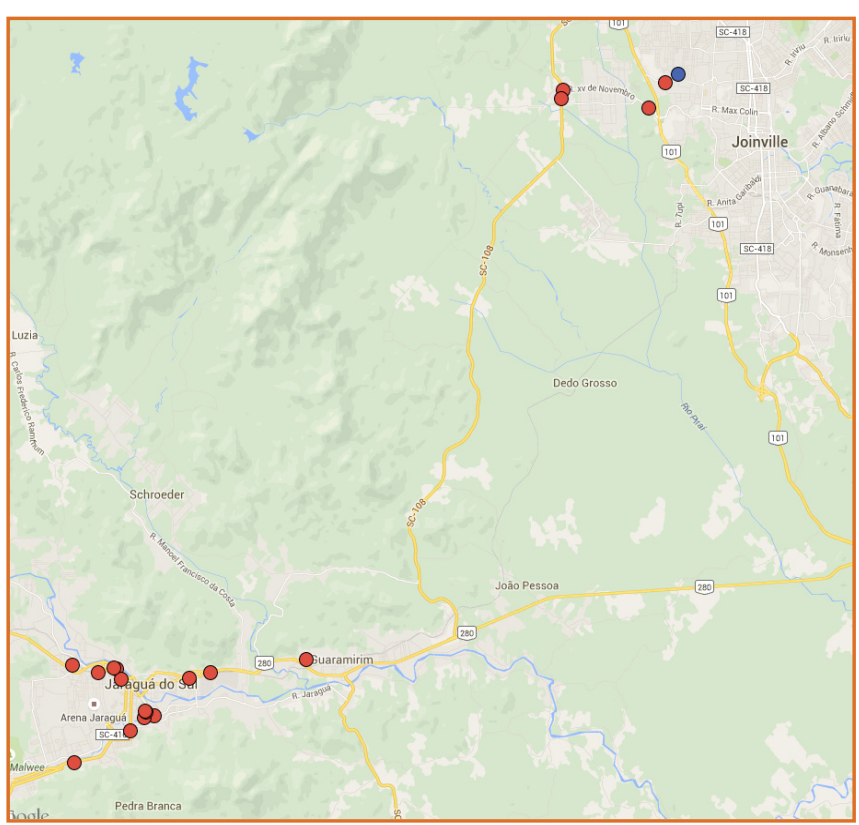

Fonte: Google Earth

Conforme a planilha de rastreamento, o percurso do caminhão inicia às 5h40min e encerra às 16h15min e a distância total percorrida é de $149 \mathrm{~km}$. O carregamento do caminhão foi feito na noite do dia anterior, prática comum da empresa de acordo com o responsável. Os dados de rastreamento fornecidos iniciam às 0h00min e não existe uma periodicidade constante nas medições, estas geralmente acontecem quando uma alteração na temperatura é detectada, numa abertura de portas, por exemplo.

A partir dos dados foram gerados gráficos da temperatura em relação ao tempo. O primeiro, ilustrado na Figura 3, refere-se ao período da madrugada onde o caminhão se encontra estacionado no pátio da empresa. Nesse período, quando o caminhão está carregado e com as portas fechadas, existe uma tendência linear de diminuição da temperatura. Num período de quase 5 horas a queda foi de $3^{\circ} \mathrm{C}$ e permanecendo abaixo da temperatura de estabilização 
do sistema eutético.

Figura 3 - Variação da temperatura dentro do caminhão enquanto parado no pátio da fábrica

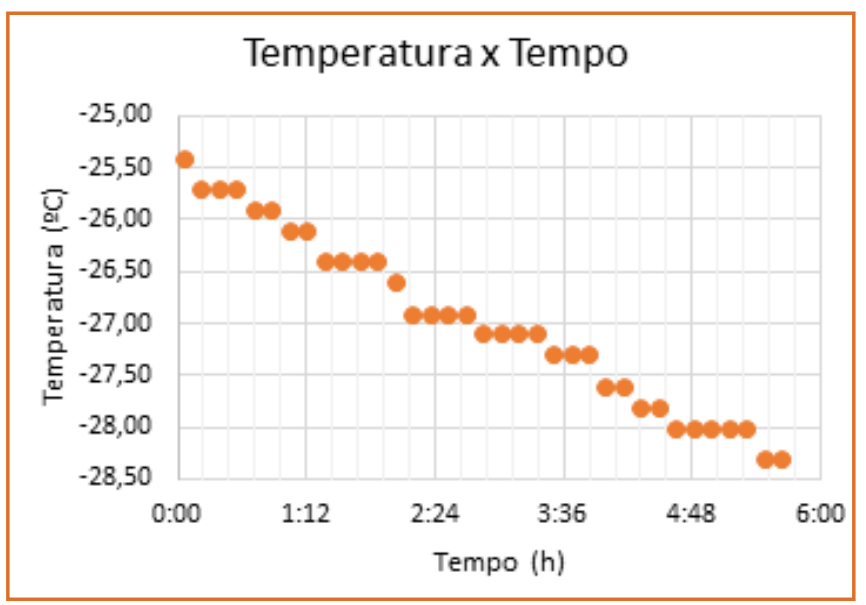

Figura 4 - Variação da temperatura dentro do caminhão ao longo do percurso

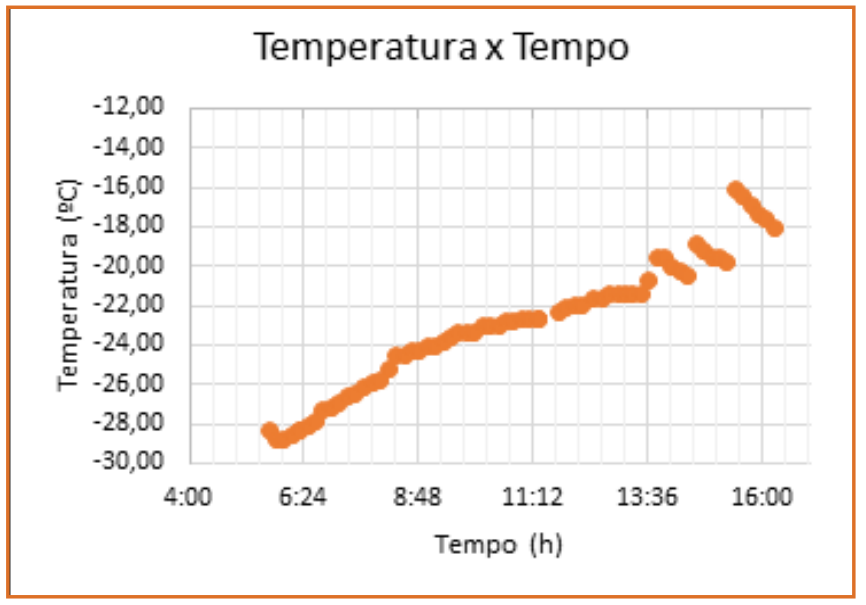

Diferente do anterior, o gráfico da Figura 4 mostra uma tendência linear crescente da temperatura no interior do caminhão enquanto as visitas aos clientes são realizadas. Na primeira parte até o início da tarde não existe nenhum comportamento anômalo da temperatura, a queda é linear e pode estar sendo causada influenciada por fontes de calor que o sistema de refrigeração não consegue remover. Uma dessas fontes é o calor externo conduzido através do isolamento. O próprio isolamento de poliuretano sofre uma queda de desempenho, que segundo Silva (2010) pode ser de 3 a $5 \%$ ao ano, acarretando na perda de capacidade de isolamento.

Num segundo estágio existe um comportamento mais anômalo, com aumentos bruscos de temperatura acompanhados de uma queda em seguida. Para entender o que poderia ter levado a estes acontecimentos foi realizada uma análise mais pontual da planilha.

A Tabela 1 apresenta 0 primeiro período de anormalidade, onde a temperatura subiu $2^{\circ} \mathrm{C}$ em 20 minutos. Devido ao fato de o caminhão estar parado no mesmo cliente, é provável que estivesse acontecendo uma descarga de produto, e, portanto, as portas estavam abertas. Chama-se atenção para a demora nesse processo que pode ser explicado pelo porte do cliente e com certeza pela quantidade de produtos a serem retirados.

Tabela 1 - Dados do rastreamento

\begin{tabular}{|c|c|c|}
\hline \multicolumn{1}{|c|}{ Hora $(\mathbf{h})$} & Localização & Temperatura $\left({ }^{\circ} \mathbf{C}\right)$ \\
\hline $13: 25$ & Cliente A & $-21,4$ \\
\hline $13: 35$ & Cliente A & $-20,7$ \\
\hline $13: 45$ & Cliente A & $-19,5$ \\
\hline $13: 55$ & Em Curso & $-19,5$ \\
\hline $14: 05$ & Cliente B & $-20,0$ \\
\hline $14: 15$ & Cliente B & $-20,2$ \\
\hline $14: 25$ & Cliente B & $-20,4$ \\
\hline
\end{tabular}

Fonte: Autoria própria

Logo após esse aumento existe uma queda de $1^{\circ} \mathrm{C}$ em 30 minutos, ou seja, o sistema de refrigeração conseguiu se recuperar apesar de muito mais lentamente do que o aumento em si. Nesse período o caminhão esteve parado com as portas fechadas, provavelmente aguardando espaço para descarregar em outro cliente, também de grande porte. Na sequência, o processo de aumento e queda se repete. Cabe destacar que o sistema possui a capacidade de se recuperar, apesar de precisar de um tempo para isso. No início do roteiro as entregas são mais frequentes e o tempo para recuperação não é suficiente.

O terceiro aumento brusco acontece ainda na visita ao Cliente $\mathrm{B}$ e é de $3^{\circ} \mathrm{C}$ em 10 minutos. Esse tipo de aumento é demasiado alto se o sistema não tiver o tempo para se recuperar, ou se a carga for mais sensível e perder qualidade rapidamente. No final do trajeto, 
ao chegar à fábrica, a temperatura do caminhão é de $18^{\circ} \mathrm{C}$, que significa $10^{\circ} \mathrm{C}$ mais alta do que na partida, mas no trajeto chegou a subir até $-16^{\circ} \mathrm{C}$.

Para uma melhor compreensão da variação da temperatura é preciso expandir este estudo, buscando junto à empresa estudada um acompanhamento detalhado da atividade de entrega de produtos, monitorando o tempo de abertura das portas dos veículos bem como outras variações ocorrentes no processo. Além disso, sugere-se o acompanhamento da temperatura versus qualidade do produto. A Tabela 1 apresenta o formato indicado para as tabelas. É importante lembrar que as tabelas devem estar separadas do corpo do texto por uma linha em branco (12 pontos). Para tanto, pode-se usar uma linha do estilo "Tabela Espaçamento" entre o corpo de texto anterior à tabela e a mesma, conforme exemplificado a seguir.

\section{CONSIDERAÇÕES FINAIS}

Transportar um produto perecível de um lado a outro do mundo, exigência comum do mundo globalizado, é um desafio maior do que fazer o mesmo com qualquer outro produto. As cadeias de suprimentos de um modo geral surgiram para suprir essa complexidade criada pelas novas exigências de mercado. Os consumidores estão cada vez mais cientes de seu poder de exigir produtos de qualidade, os órgãos reguladores mais atentos e o mercado impulsionando o próprio mercado através da competitividade entre empresas.

$\mathrm{Na}$ CF os processos de estocagem e transporte exigem cuidados extras e, para um produto extremamente sensível cada incremento de temperatura precisa ser estudado. As tecnologias de refrigeração, controle e monitoramento de temperatura evoluíram junto com a expansão da CF para facilitar a gestão e melhorar a infraestrutura desse tipo de cadeia. No Brasil e em outros países em desenvolvimento os desafios são grandes em termos de políticas públicas que permitam a expansão das empresas desse setor.

Os sorvetes são produtos que necessitam de pouco cuidado na oscilação de temperatura, mas quando expostos a temperaturas inapropriadas se deterioram rapidamente, se tornando, talvez não inconsumíveis, mas incomerciáveis. Os custos de perdas durante o transporte só tornam o custo do próprio transporte ainda mais insustentável para as empresas.

As alterações de temperatura nas aberturas de portas são inevitáveis, mas podem ser compensadas através da gestão eficiente da cadeia. A temperatura do caminhão é capaz de se recuperar, e na medida que o comportamento dela puder ser previsto, soluções de roteirização combinada com análise de temperatura poderão ser aplicados com mais facilidade e praticidade pelas empresas. Essas soluções irão permitir que as decisões de roteiro na Cadeia do Frio sejam decididas, não apenas baseadas em custos operacionais do transporte, mas também do ponto de visto da qualidade de carga transportada e da eficiência energética.

\section{REFERÊNCIAS}

[1] ABIAF, Associação Brasileira da Indústria de Armazenagem Frigorificada. Manual Técnico Operacional Volume I - A mercadoria no armazém frigorificado. 2008.

[2] ABTO, Associação Brasileira de Transplantes de Órgãos. Registro Brasileiro de Transplantes. Disponível em: http://www.abto.org.br/abtov03/Upload/file/RBT/2014/ rbt2014-lib.pdf Acesso em: 22 mai. 2015.

[3] ANEFALOS, L. C. Modelo insumo-produto como instrumento de avaliação econômica da cadeia de suprimentos : o caso da exportação de flores de corte. São Paulo, 2004.

[4] BALLOU, R. H. Gerenciamento da Cadeia de Suprimentos: Logística Empresarial. Bookman, 2006.

[5] BAPTISTA, P. Higiene e Segurança Alimentar no Transporte de Produtos Alimentares. 2006.

[6] BRAGANTE, A G. Tecnologia de Fabricação de Sorvetes. 2010. Disponível em: <http://abgtecalim.yolasite. com/resources/Tecnologia da Fabricação de Sorvetes.pdf>. Acesso em: 27 jun. 2015.

[7] BRASIL, Agência Nacional de Vigilância Sanitária. Resolução n. 266 de 22 de setembro de 2005. Regulamento técnico para fixação de identidade e qualidade de gelados comestíveis e, preparados para gelados comestíveis, pós para o preparo e bases para gelados comestíveis. Diário Oficial da União, Brasília, DF, 23 set. 2005. 
[8] BRIDI, A. M.; CONSTANTINO, C. Qualidade e Avaliação de Carcaças e Carnes Bovinas. In: Congresso Paranaense dos Estudantes de Zootecnia. Maringá. 2009.

[9] CARVAlHO, C. C. Otimização Dinâmica da Logística de Distribuição de Produtos Alimenticios Refrigerados e Congelados. Universidade Estadual de Campinas. Campinas, 2013.

[10] CAVALCANTI, M.; MACHADO, S. T.; SANTANA, W. G. Cadeia logística do frio : um estudo da qualidade em portos secos brasileiros. XXX Encontro Nacional de Engenharia de Produção. São Carlos, 2010.

[11] COYLE, W.; HALL, W.; BALLENGER, N. Transportation technology and the rising share of US perishable food trade. Changing Structure of Global Food Consumption and Trade, p. 31-40, 2001.

[12] DI MAIO, C. A.; SILVA, J. L. G. DA. Armazenagem e distribuição de medicamentos na cadeia fria. Latin American Journal of Business Management, v. 5, n. 2, p. 115-133, 2014.

[13] DONATO, V. Mercado de plantas ornamentais e flores cresce mais de $8 \%$ no Brasil. Disponível em: <http:// g1.globo.com/jornal-hoje/noticia/2014/02/mercado-deplantas-ornamentais-e-flores-cresce-mais-de-8-no-brasil. html>. Acesso em: 22 jan. 2015.

[14] FUNDAÇÃO DOM CABRAL. Custo logístico consome $11,2 \%$ da receita das empresas e transporte é o maior vilão. 2014. Disponível em: <http://www.fdc.org.br/Paginas/default. aspx>. Acesso em: 06 jun. 2015.

[15] HEAP, R. D. Cold chain performance issues now and in the future. Bulletin of the IIR, v. 4, 2006.

[16] HUBER, E. Resfriamento a vácuo de cortes de carnes após cozimento. Florianópolis, 2004.
[17] HIRA, R. Cadeia do frio: mantendo a qualidade e a integridade do produto. 2014. Disponível em: www. mundologistica.com. br/portal/noticia.jsp?id=2007. Acesso em: 22 mai. 2015.

[18] KIERSTAN, M.; FORD, G. Food transportation. Blackie Academic \& Professional, 1998.

[19] ORDÓÑEZ, J. A. Tecnologia de Alimentos: Componentes dos Alimentos e Processos. Porto Alegre, 2005.

[20] PEREIRA, V. D. F. et al. Avaliação de temperaturas em câmaras frigoríficas de transporte urbano de alimentos resfriados e congelados. Ciência e Tecnologia de Alimentos, v. 30, n. 1, p. 158-165, 2010.

[21] PRADO, J. R.; BARROS, T. D. Cold chain management : análise da roteirização na distribuição de sorvetes. Universidade Tecnológica Federal do Paraná. Ponta Grossa, 2014

[22] RIBEIRO, P.C.C. et al. Transporte na indústria brasileira de laticínios: um estudo de caso. XXIII ENEGEP - Ouro Preto, MG, Brasil, v. 21, 2003.

[23] SILVA, G. B. A gestão da cadeia do frio: uma análise de fatores logísticos. CEFET/RJ, 2010.

[24] TEIXEIRA, S. R.; RIBEIRO, M. T. Transporte do leite a granel. Embrapa Gado de Leite, 2000.

[25] TOLEDO, R. T. Fundamentals of Food Process Engineering. New York, USA: Chapman \& Hall, 1991.

[26] USDA - United States Department Of Agriculture. Refrigeration and food safety. Disponível em: <http://www. fsis.usda.gov/ Fact_Sheets/Refrigeration_\%26_Food_Safety/ index.asp\#1>. Acesso em: 22/01/ 2015. 


\section{CAPÍTULO 18}

ESTUDO DE ALTERNATIVAS PARA EXPORTAÇÃO DA SOJA BRASILEIRA ATRAVÉS DO PORTO DE ITAQUI

\section{Priscila Santos Clemente da Silva}

\section{Marcos Vinicius H. da Silveira}

Tathiana Apollo dos S. da C. Camargo

Resumo: A produção de soja no país é vista com bons olhos pelo mundo todo, pois os grãos aqui produzidos são considerados como os de melhor qualidade. Mas problemas logísticos fazem com que alguns compradores optem por outros países produtores dos grãos. Enquanto alguns países sabem explorar a intermodalidade para ganhar tempo no escoamento do grão, o Brasil fica pra trás devido a obras ferroviárias em atraso, estradas em péssimas condições e hidrovias não exploradas, fatores que determinariam e poderiam agilizar o processo de exportação do grão.

Palavras Chave: Soja, exportação, intermodalidade. 


\section{INTRODUÇÃO}

Neste projeto serão apresentadas alternativas para o melhor escoamento da produção da soja no Brasil. No desenvolvimento veremos a importância do grão para a economia, os problemas logísticos enfrentados pela falta de interação entre os modais, a possibilidade de melhor explorar o Porto de Itaqui e, por fim, trazendo assim algumas possíveis soluções para ajudar no crescimento da economia do país.

\section{FUNDAMENTAÇÃO}

Essa pesquisa irá abordar o transporte da soja até o Porto de Itaqui, Iocalizado em São Luiz, Estado do Maranhão pelo modal ferroviário, o qual é pouco explorado e tem grande potencial.

Para Simchi Levi (2010), reduzir custos e melhorar os níveis de serviço, as estratégias eficazes de gestão da cadeia de suprimentos precisam contemplar as interações entre seus diferentes níveis. A cadeia de suprimentos, também chamada de rede logística, consiste em fornecedores, centros de produção, depósito, centros de distribuição, varejistas, além das matérias prima, estoques de produtos em processo e produtos acabados que se deslocam entre as instalações.

Segundo Christopher (2007), a cadeia de suprimentos ganhou muito mais espaço em organizações de todas as atividades e setores. Na verdade a cadeia é uma rede que forma teias de organização independentes, porém, ao mesmo tempo interdependentes. Como resultado da crescente terceirização de tarefas que antes eram desempenhadas pela própria empresa, a complexidade desse rede foi crescendo e por razão aumentou e muito a importância do gerenciamento da cadeia de suprimentos.

Atualmente o Porto de Santos retém o maior número de exportação do grão, no período de Janeiro/2014 o porto citado exportou a marca de 12,65 milhões de toneladas enquanto o Porto de Itaqui exportou no mesmo período 1,85 milhões de toneladas. (MDIC, 2015).

No período da safra, de fevereiro a maio a chegada ao Porto de Santos conta com congestionamentos intermináveis nas suas rodovias, se dividida a exportação deste grão para uma região pouca explorada para este fim, caso do Porto de Itaqui, melhoraria a malha da região Sudeste, diminuiria tempo de viagem marítima do grão, visto que Itaqui se encontra mais próximo aos países compradores do grão, que são: China, Países Baixos, Estados Unidos e Tailândia.

O modal ferroviário tem o menor gasto de combustível que no rodoviário, levando em consideração o transporte de cargas a longas distâncias; se explorada de forma eficiente, minimizaria gastos de custos de transporte.

Não podemos esquecer a taxa de acidentes entre os dois modais: rodoviário $x$ ferroviário; a falta de investimento nas rodovias, muitas em estado de conservação precárias, falta de acostamento e afins faz com que incidentes e acidentes se tornem inevitáveis, fazendo assim com que tempo seja perdido, afetando assim na credibilidade entre comprador $\mathrm{x}$ fornecedor.

A finalidade do transporte é de facilitar o acesso aos bens de consumo, fazendo com que seja possível a troca deste bem, Fornecedor x comprador x fornecedor, por valores viáveis. Por este e outros motivos que serão explorados nessa pesquisa notamos a grande importância que o transporte possui no elo da cadeia de logística de suprimentos.

\section{METODOLOGIA}

Segundo Andrade (2010), metodologia são o conjunto de métodos ou caminhos que são percorridos na busca do conhecimento.

Pesquisa exploratória tem a finalidade de proporcionar maiores informações sobre o assunto aqui estudado, definir os objetivos, formular as hipóteses de uma pesquisa ou descobrir novo tipo de enfoque.

Para o trabalho utilizamos o método comparativo com a finalidade de verificar semelhanças e explicar divergências. Segundo Andrade (2010), o método comparativo é utilizado tanto para comparações de 
grupos no presente, no passado ou entre os existentes e os do passado quanto em sociedades iguais ou em diferentes estágios de desenvolvimento e o método dedutivo que partindo-se de teorias e leis gerais podese chegar à determinação ou previsão de fenômenos particulares.

\section{A PRODUÇÃO DA SOJA}

A soja é uma planta da família das leguminosas. Seu nome científico é Glycine Híspid. A oleaginosa fornece alimento para o homem, para os animais domésticos e serve também como matéria-prima para a indústria. $O$ complexo da soja compreende uma cadeia produtiva que envolve desde a produção interna voltada para a exportação do produto bruto, até a transformação do produto voltada para a indústria esmagadora que processa a soja em farelo ou óleo para a exportação ou para consumo interno. A soja em grão, além de dar origem a vários produtos alimentícios, também está presente na composição de óleos, tintas, graxas, entre outros.

A soja desempenha o papel de principal oleaginosa produzida e consumida no mundo. Contudo, levou-se muito tempo para o homem conseguir explorar o grão devidamente. A soja inicialmente teve sua origem na China há 5.000 anos, onde sofreu domesticação no século XI a.C. A sua comercialização se deu somente no século XX pelos Estados Unidos como forrageira e posteriormente como grão. Em 1940 iniciou-se o uso da cultura como grão, que ao longo de 20 anos tomou todo o lugar da soja usada como forrageira.

Seu primeiro registro no Brasil se deu 1882 na Bahia. O grão passou a ter uma grande importância nacional na década de 70 principalmente no Sul e Centro-Oeste do Brasil. Atualmente somos o segundo maior produtor de Soja do mundo e também segundo maior exportador.

\subsection{A CADEIA DE SUPRIMENTOS E O CAMINHO DA SOJA}

A gestão da cadeia de suprimentos tem como principal objetivo reduzir custo, que constitui na soma dos insumos (mão de obra, energia, materiais diversos, equipamentos, instalações fixas, etc.) necessários para realizar um determinado serviço ou operação, consequentemente terá a redução de tempo. Para ser eficiente tem que se trabalhar de maneira interligada $e$ sempre ter o acompanhamento do processo desde a origem do produto até a chegada as mãos do cliente. O gerenciamento da cadeia de suprimentos baseiase nessa estrutura e algumas características devem ser levadas em consideração ao elaborar a rede. A origem, tipo de fornecedor (no caso aqui estudado o produtor), o meio de transporte (portos marítimos, ou fluviais, ferroviários, rodoviários, terminais intermodais), a geografia (Estados, municípios e países no caso de importação) e o destino que em geral são para unidades de produção de empresas e os armazéns ou depósitos.

O escoamento da produção de grãos de soja no Brasil acontece de duas maneiras: o transporte da lavoura para o armazém da fazenda que na maioria das vezes é de responsabilidade do produtor (realizado através de carretas, tem seu custo elevado devido más condições nas estradas rurais sem pavimentação que pode acarretar em incidentes e/ou acidentes) e o transporte dos armazéns dos produtores para exportação ou para a indústria de processamento, a soja em grãos segue por ferrovias, rodovias ou hidrovias.

A soja em grão geralmente é transportada em granel, em raras ocasiões são ensacadas para sua movimentação.

\subsection{ARMAZENAGEM}

A armazenagem é a atividade que auxilia na conservação dos produtos, mantendo assim a quantidade e a qualidade natural dos grãos de soja, evitando perdas se feita do modo correto.

As funções da armazenagem estão classificadas em intrínsecas e extrínsecas. As funções intrínsecas da armazenagem são: conservação da produção; redução de perdas e estocagem dos excedentes agrícolas. As funções extrínsecas estão relacionadas com o transporte e a comercialização da produção agrícola, são elas: racionalizar o transporte; coleta de safra; suporte de comercialização; formação de estoques 
reguladores; e auxilio às políticas governamentais.

Os armazéns estão presentes nos mais diversos elos de escoamento da soja para exportação.

\subsection{TRANSPORTE}

O transporte é na cadeia de suprimentos um dos mais importantes elos, é fundamental entender todos os tipos de modais que podem ser utilizados para ser realizado o transporte adequado da carga, principalmente no caso da soja de ser um produto perecível.

Segundo Alvarenga (2000), uma forma de quantificar o esforço de transporte ou o seu nível de produção é necessário determinar o momento de transporte, ou seja, o total de toneladas-quilômetro executado pelos diversos modos. Os cincos modais de transporte básicos são: ferroviário, rodoviário, aquaviário (fluvial e marítimo), dutoviário e aéreo, esses dois últimos não será mostrado neste estudo, pois, dos cinco modais de transporte existentes apenas três são utilizados no escoamento da soja (rodoviário, ferroviário e aquaviário/ hidroviário). O modal dutoviário não é utilizado devido às características físicas do produto, enquanto que o modal aéreo é extremamente caro para o transporte de commodities.

Os meios mais eficientes para o transporte da soja para exportação, levando em consideração grandes volumes, longas distâncias e valor agregado relativamente baixo são as ferrovias e hidrovias. Tais modais, embora demandem um maior tempo de transporte, têm capacidade bem mais elevada e, quando disponíveis, podem trazer economia de custos e redução de perdas.

Um dos problemas relacionados ao escoamento da produção da soja é que ela é realizada logo após a colheita acarretando grandes, congestionamentos nas estradas e nos terminais exportadores, se tem pressa em escoar o produto devido a falta de armazenamento nas propriedades ou próximo aos locais de produção.

Segundo Vieira (2002), modal de transporte mais utilizado no Brasil é o rodoviário (67\%), muito mais caro que o ferroviário e, mais ainda, que o hidroviário. O papel do modal rodoviário deveria ser o de atuar nas "pontas", levando os produtos aos terminais ferroviários e/ou hidroviários, que respondem por apenas 28\% e $5 \%$, respectivamente, do total da soja transportada no país. Paralelamente, os EUA transportam $61 \%$ da sua produção por hidrovias e apenas 23\% é transportada por rodovias. Quanto à Argentina, embora o transporte rodoviário seja responsável por cerca de $80 \%$ do escoamento da soja, as distâncias percorridas são relativamente pequenas (250 a $300 \mathrm{~km}$ ) quando comparadas às do Brasil (900 a 1.000 km). Diante dos problemas estruturais do Brasil, o custo de escoamento da produção interna é, em média, 83\% e $94 \%$ superior, respectivamente, ao dos Estados Unidos e da Argentina. (EMPRAPA- Empresa Brasileira de Pesquisa Agropecuária).

Conforme Figura 1 é possível notar as características de cada modal e vantagens diferentes por exemplos precisamos de 3,57 caminhão graneleiro para 1 vagão graneleiro. 


\section{Vantagens - Intermodalidade}

Cada modal apresenta características e vantagens diferentes.

Vantagens comparativas por meio de transporte

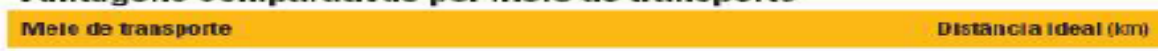

Rodovia

Ferrovia

Hidrovia
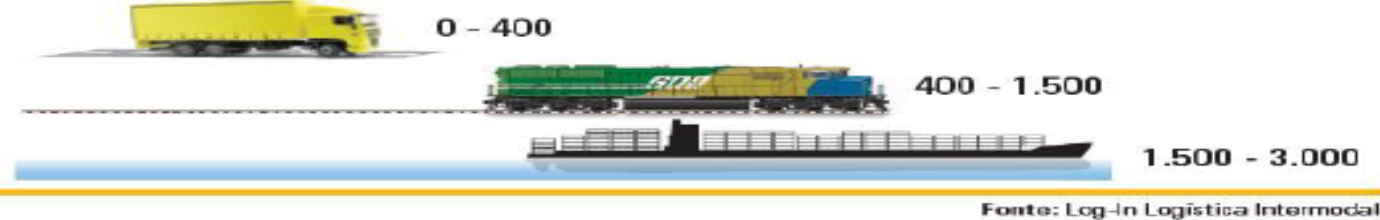

Fonte: Log-1n Logistica Intermodal

Para transportar os $\mathbf{4 6 4}$ milhões de toneladas de carga movimentados por ferrovia em 2014 , seriam necessários 16,5 milhões de caminhões ou 45,3 mil caminhões/dia por ano.

Competitividade comparada

Vagão graneleiro (100 toneladas de carga)

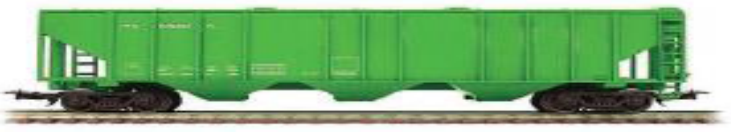

Um trem composto de 100 vagōes,

com as medidas acima,

substitui 357 caminhoes.

Fonte: Log-In Logistica Intermodal
Gaminhão graneleiro (28 toneladas de carga)
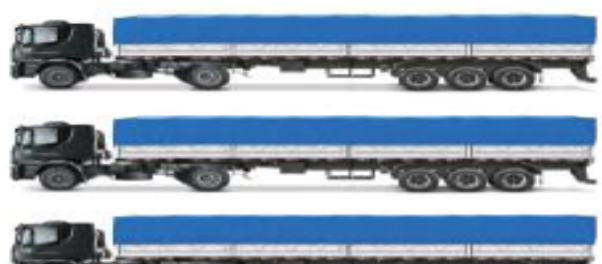

3,57 caminhø̄es (aprox. 100 toneladas de carga)

Fonte: ANTF(2015)

\subsubsection{FERROVIÁRIO}

As ferrovias foram introduzidas no final do século XIX durante a Regência e o Segundo Reinado, de uma forma inicialmente lenta através de empresas privadas.

Este modal se utilizado é o sistema mais eficaz para transportar cargas de baixo valor agregado a grandes distâncias como a soja em grão, mas no Brasil, o transporte por trens é utilizado principalmente em distâncias médias de 400 a 500 quilômetros. A ferrovia acaba não sendo explorada para o seu mais característico fim, devido também a malha viária não ser muito extensa para o atendimento da demanda e a integração operacional entre concessionárias ser deficiente, pelas diferenças de bitolas entre malhas.

Quando transportamos uma grande quantidade de um produto a granel, podemos uniformizar os vagões e as operações, permitindo também a utilização de trens de maior tonelagem e trens unitários, com isto se teria facilidade nas operações nos terminais, os custos seriam bem diluídos no custo médio global para distâncias relativamente longas.

\subsubsection{RODOVIÁRIO}

Modal mais utilizado para o transporte da soja, mas que infelizmente devido a precariedade de alguns trajetos das rodovias neste país, acaba não sendo o meio que melhor se encaixa para o escoamento deste commodities. As principais rodovias utilizadas são a BR 163 que interliga o estado do Mato Grosso aos estados do Pará e Mato Grosso do Sul, que permite a saída sentido Porto de Paranaguá e a BR 364 que liga as áreas produtoras do Mato Grosso ao estado de Rondônia e permite a saída sentido Porto de Santos/ SP.

Segundo CNT (2014), a BR 163 de seus 1.120 $\mathrm{km}$ estudados, no geral foram classificadas como regular seu estado de conservação. A BR 364 teve a 
mesma classificação em seus 1.150 km estudados. A precariedade das estradas resulta em mais paradas para manutenção do meio de transporte, acidentes, acarretando assim em atraso ou perda do produto.

A maioria dos acidentes registrados em estradas federais de Mato Grosso no ano de 2014 ocorreu na BR-364, conforme dados estatísticos da Polícia Rodoviária Federal (PRF). Segundo a instituição, 1.793 acidentes ocorreram nessa rodovia, o que corresponde a 40,59\% do total de ocorrências. Nas cinco rodovias federais que passam pelo estado foram registrados 4.428 acidentes deste resultaram em 280 mortes.

A segunda rodovia com mais acidentes é a BR-163, com $1.087(24,54)$ A BR-364 é conectada à BR-163. A BR-364 lidera o ranking de acidentes fatais: 82 pessoas morreram nos acidentes, o que corresponde a $29 \%$ do total.

\subsubsection{AQUAVIÁRIO E HIDROVIÁRIO}

O transporte aquático, aquaviário ou hidroviário consiste no transporte de mercadorias e de passageiros por barcos, navios ou balsas, via um corpo de água, tais como oceanos, mares, lagos, rios ou canais. O transporte aquático engloba tanto o transporte marítimo, utilizando como via de comunicação os mares abertos, como transporte fluvial, usando os lagos e rios. Como o transporte marítimo representa a grande maioria do transporte aquático, muitas vezes esta denominação é usada como sinônimo. Este modo de transporte cobre o essencial das matérias primas (petróleo e derivados, carvão, minério de ferro, cereais, bauxita, alumínio e fosfatos, entre outros). Paralelamente a estes transportes a granel, o transporte aquático também cobre o transporte de produtos previamente acondicionados em sacas, caixotes ou outro tipo de embalagens, conhecidos como carga geral.

OBrasil possuiatualmente porvolta de 13 mil quilômetros de vias navegáveis utilizadas economicamente para o transporte de cargas e passageiros, podendo atingir aproximadamente 44 mil quilômetros navegáveis, caso sejam realizadas obras em cerca de 29 mil km de vias que tem sua disponibilidade natural já constatada. A ausência de investimentos adequados no setor contribui de forma crucial para o desbalanceamento da matriz de transportes brasileira e para os problemas na intermodalidade do país. Obras como dragagem, transposição de trechos não navegáveis por meio de eclusas e canais artificiais, derrocagem de obstáculos naturais, balizamento e sinalização são necessárias para o desenvolvimento da malha hidroviária, que também necessita de investimentos na modernização, ampliação e obras de melhorias em portos, alguns em completa defasagem, e em terminais fluviais intermodais. $O$ incentivo massivo à cabotagem também é de suma importância. A Cabotagem é a navegação entre portos do mesmo país, e se contrapõe à navegação de longo curso, que é realizada entre portos de diferentes países.

A soja saindo do Porto de Santos ao Porto de Shangai leva em média 30 dias para seu destino final, levando em consideração a velocidade de 20 nós. Saindo-se do Porto de Itaqui a média da navegação cai para 26 dias, usando-se a média da mesma velocidade.

\subsection{PRODUTOR}

A soja é a cultura agrícola brasileira que mais cresceu nas últimas três décadas e corresponde a 49\% da área plantada em grãos do país. O aumento da produtividade está associado aos avanços tecnológicos, ao manejo e eficiência dos produtores. No contexto mundial, - Brasil apresenta vantagens territoriais, climáticas e tecnológicas no processo produtivo da soja. No entanto, essa vantagem diminui quando se considera o complexo soja como um todo. Dentre os principais fatores associados a essa perda, está a logística de transporte (rodovias, ferrovias, hidrovias e portos).

Os principais produtores mundiais atualmente são: Estados Unidos, Brasil, Argentina e China.

No Brasil, as principais regiões produtoras são o Sul, Sudeste e Centro Oeste. No entanto, atualmente a cultura está crescendo no Norte e Nordeste.

A soja é o produto agrícola que mais gera volume (em toneladas) de exportação para o Brasil, exigindo muito da estrutura logística do país. E se caracteriza como 
um dos produtos mais destacados da agricultura nacional e na balança comercial.

Segundo a Embrapa (Empresa Brasileira de Pesquisa Agropecuária) a safra 2013/2014 da soja no Brasil foi 85,656 milhões de toneladas, sendo o segundo maior produtor do grão no mundo. O destino da soja brasileira é principalmente China, os Países Baixos, Espanha e Estados Unidos.

Mais produtivo plantar soja no Brasil e mais lucrativo plantar nos Estados Unidos. No Brasil planta-se soja o ano inteiro, e produz $11 \%$ mais que uma fazenda nos Estados Unidos. Muitas vezes excedendo sua capacidade de armazenamento e com risco de perder parte da carga. A distância entre os produtores e os porto demora quase 1 semana.

\subsubsection{DO PRODUTOR AO PORTO}

O maior gargalo logístico está em como o Brasil faz sua soja chegar até o porto. Problemas com a capacidade de armazenagem (especialmente nas fazendas) e a escolha do modal rodoviário para percorrer grandes distâncias determinam o grau de dificuldade no escoamento e corroboram as preocupações dos compradores sobre o momento da entrega do produto.

Um dos principais pontos a ser considerado é a capacidade de armazenagem, especialmente aquelas instaladas nas próprias fazendas, raramente nas propriedades brasileiras ocorre a utilização de silos metálicos. Com isso, os produtores ficam dependentes de armazenagem de terceiros ( que ainda é insuficiente no Brasil ), causando um custo adicional, ou são forçados a escoar a maior parte da produção logo após a colheita, causando pressões sobre as rodovias, o frete e também nos portos. Parte desses caminhões servem, portanto, como silos no momento da safra. Além disso, os agricultores deixam de ter a possibilidade de escolha do melhor momento para vender a soja.

Outro fator primordial para o funcionamento eficiente da logística é a existência de uma infraestrutura adequada de transporte para o escoamento da produção até o porto.

\section{PRINCIPAL MODAL UTILIZADO}

As deficiências de logística no transporte afeta significativamente a competitividade internacional das exportações brasileiras, principalmente para produtos com baixo valor agregado. Os problemas de escoamento, juntamente com as deficiências na capacidade de armazenagem, representam um dos principais pontos que dificultam o desenvolvimento do agronegócio brasileiro.

O modal de transporte mais utilizado no Brasil é o rodoviário (67\%), muito mais caro que o ferroviário e, mais ainda, que o hidroviário. O papel do modal rodoviário deveria ser o de atuar nas "pontas", levando os produtos aos terminais ferroviários e/ou hidroviários, que respondem por apenas 28\% e 5\%, respectivamente, do total da soja transportada no país. Paralelamente, os EUA transportam $61 \%$ da sua produção por hidrovias e apenas 23\% é transportada por rodovias. Quanto à Argentina, embora o transporte rodoviário seja responsável por cerca de $80 \%$ do escoamento da soja, as distâncias percorridas são relativamente pequenas (250 a $300 \mathrm{~km}$ ) quando comparadas às do Brasil (900 a 1.000 km). Diante dos problemas estruturais do Brasil, o custo de escoamento da produção interna é, em média, 83\% e $94 \%$ superior, respectivamente, ao dos Estados Unidos e da Argentina.

Os altos custos de transporte acabam tendo grandes reflexos negativos sobre os preços recebidos pelos produtores, especialmente àqueles localizados em regiões mais distantes dos portos. Os sojicultores de Sorriso e Campo Novo do Parecis (MT), distantes cerca de $2.000 \mathrm{~km}$ dos principais portos de exportação.

Outro problema relacionado ao escoamento interno da produção de soja é a concentração do seu escoamento logo após a colheita, acarretando problemas de congestionando nas estradas e nos terminais exportadores. Essa pressa em escoar o produto devese à falta de armazenamento nas propriedades ou próximo aos locais de produção. 
A maioria dos portos apresenta problemas de acesso rodoviário. Por causa dessas deficiências na estrutura portuária brasileira, os custos de transporte da safra brasileira são elevados. Cálculos realizados pela multinacional Bunge e apresentados ao governo brasileiro em 2004, indicaram que as empresas que escoavam grãos para o mercado internacional naquele ano pagariam US\$1,2 bilhão em multas decorrentes da espera dos navios nos portos nacionais. Esse custo de sobre-estadia é pago pelas empresas quando há atrasos portuários no embarque ou desembarque das mercadorias. O estudo indicou que essa espera nos portos nacionais é, em média, de 22 dias e que o custo por dia parado é de US\$50.000,00. Quem paga, em última instância, é o produtor, que, por causa disso, recebe menos pela saca de soja vendida ao exterior.

\subsection{ACESSO FERROVIÁRIO AO PORTO}

A participação do modal ferroviário no Porto de Santos, apesar de crescente, ainda é reduzido ante a abrangência da malha com acesso ao Porto.

A plena utilização do transporte ferroviário em Santos depende de regras que permitam que todas as concessionárias utilizem o corredor de acesso ao Porto, desde Campinas até o arco ferroviário que alcança as duas margens do porto. A fim de que os investimentos na infraestrutura ferroviária sejam viabilizados, é necessária a remuneração adequada às concessionárias titulares dos trechos de uso compartilhado. O aumento do transporte ferroviário nos trechos compartilhados é do interesse mútuo das concessionárias, desde que elas possam estabelecer arranjos entre elas, distribuindo de forma justa os correspondentes ganhos de receitas. Soluções eficientes, porém, dependem da limitação de eventual poder de mercado por parte de algumas concessionárias, daí a importância de iniciativas do poder regulatório.

Apenas os portos de Itaqui, Santos, Paranaguá, Rio Grande, São Francisco do Sul e Vitória têm acesso ferroviário.

\section{IMPLANTAÇÕES DE SILOS MÓVEIS}

Buscando alternativas logísticas para o escoamento da soja brasileira a implantação de Silos móveis na cidade de Uruaçu/Góias é um importante investimento que facilitaria e economizaria tempo no transporte da soja.

Uruaçu está situada no coração de Goiás, a 280 km da capital Goiânia e a 300 km da capital Federal, Brasília. Com a chegada da ferrovia Norte Sul, Uruaçu tem chamado atenção de diversos investidores nacionais e internacionais, acenados pelo porto seco no município.

Portos secos são uma espécie de área de transbordo (depósito) para posterior embarque e/ ou desembarque de cargas que serão exportadas ou que foram importadas através dos portos fluviais litorâneos (Santos/SP; Vitória/ES; e Itaqui/MA, dentre outros). Os portos secos exercem importante função complementar à Ferrovia Norte-Sul que foi idealizada para baratear os custos de escoamento da produção nacional, hoje bastante onerosos e demorados por serem feitos ainda primordialmente pela malha rodoviária das estradas federais que cortam o País.

\subsection{CAMINHO ALTERNATIVO}

A cidade de Sorriso localizada no Estado do Mato Grosso é a maior produtora da soja brasileira. Grande parte de sua produção é destinada ao Porto de Santos litoral de São Paulo, que fica 2.004 km de distância. Que transportado pelo modal rodoviário sem nenhum imprevisto leva aproximadamente 25 horas para chegar.

A cidade de Sorriso fica a $1175 \mathrm{~km}$ de Uruaçu localizado no estado de Goiás onde sugerimos o silo móvel que a partir dele seguiria viagem ao porto de Itaqui através do modal ferroviário que levaria em torno de 23 horas, a diferença entre o sistema de logística está na quantidade transportada e o custo. Essa diferença entre custo $\mathrm{x}$ benefício é notória, pois 80 vagões equivalem a 240 caminhões com uma diferença de $8 \mathrm{~h}$ contra $60 \mathrm{~h}$ respectivamente para o seu desembarque. 


\section{PORTO DE ITAQUI}

Porto de águas profundas e localização geográfica estratégica. Essas são características que conferem ao Porto de Itaqui a porta de entrada e escoamento de produtos, isso dá uma vantagem competitiva em relação a outros portos do Brasil. O Complexo é formado pelo Porto da Alumar e pelo Terminal Marítimo Ponta da Madeira (TMPM), sob a gestão da mineradora Vale, e administrado pela Empresa Maranhense de Administração Portuária (Emap).

O Porto do Itaqui está localizado no interior da Baía de São Marcos e seu acesso hidroviário não conta com a formação de barra. O canal acesso possui profundidade natural mínima de 27 metros e largura aproximada de $1,8 \mathrm{Km}$, isto torna as condições de navegabilidade boas.

Hoje uma das maiores dificuldades para o embarque de soja no porto é a disputa da esteira juntamente com o embarque de ferro, isso acarreta em um atraso na produção junto com pouca área de armazenamento para a safra.

Sua movimentação geral ficou em 2013 em torno de aproximadamente 11,8 milhões de toneladas, sendo que 19,5 \% corresponde a movimentação de soja.

O acesso ferroviário do Maranhão é composto pela Estrada de Ferro Carajás - EFC com 892 km (em duplicação), Ferrovia Norte-Sul - FNS 215 km (em expansão) e Companhia Ferroviária do Nordeste CFN.

\section{EXPORTAÇÃO DA SOJA}

Os produtos do complexo da soja brasileira destinados ao mercado externo (China e Europa, principalmente), são escoados através de dez corredores principais: Itacoatiara (AM), Santarém (PA), Itaqui (MA), Ilhéus (BA), Corumbá (MS), Vitória (ES), Santos (SP), Paranaguá (PR), São Francisco do Sul (SC) e Rio Grande (RS). Paranaguá, Santos e Rio Grande são responsáveis por quase $80 \%$ de toda a exportação.

\section{SOJA VISÃO FUTURO}

O Brasil é autossuficiente na produção de soja, abastecendo o mercado interno e enviando o excedente ao mercado externo. O consumo interno está em constante ascensão e a previsão é de que $45 \%$ do aumento da produção seja destinado ao mercado interno em 2019.

Estudos indicam que para não ter maiores problemas futuros para o escoamento das suas safras, o Brasil precisa ampliar a capacidade de escoamento dos seus portos.

O complexo de soja (grão, farelo e óleo) é o principal gerador de divisas cambiais do Brasil, com negociações anuais que ultrapassam US $\$ 20$ bilhões. Em 2019, a produção nacional deve representar 40\% do comércio mundial do grão.

\section{CONSIDERAÇÕES}

Neste estudo identificamos alguns dos grandes problemas para o escoamento da soja no país e a sobrecarga ao Porto de Santos, onde acarreta em vários problemas logísticos, fazendo com que se perca o valor do produto em gastos com fretes, manutenção, salário de motorista, combustível, já que o modal rodoviário é o mais utilizado para este fim.

Sugerimos uma mudança de rota ao porto de Itaqui, devido seu crescimento e investimento em um novo berço que será utilizado para escoar a soja e de um silos móvel, servindo assim de transbordo, em Uruaçu. Uma maior exploração nos modais como o ferroviário e/ou hidroviário, poderia diminuir os custos retornando assim um melhor valor ao produtor desta oleaginosa do nosso país.

\section{REFERÊNCIAS}

[1] ALVARENGA, A. C. Logística Aplicada-Suprimento E Distribuição Física. N. Logística Aplicada-Suprimento E Distribuição Física; 3르 Ed., São Paulo: Blucher, 2000. ed. São Paulo: Blucher, 2000.

[2] ANDRADE, M. M. D. Introdução A Metodologia Do Trabalho Científico. 10aㅡ Ed.; São Paulo, Atlas 2010. ed. São Paulo: Atlas, 2010. 
[3] ANTF. ANTF. ANTF, 2015. Disponivel em: <http://www. antf.org.br/images/2015/informacoes-do-setor/numeros/ balanco-do-transporte-ferroviario-de-2014-v130815.pdf>. Acesso em: 25 ago. 2015.

[4] BONATO, G. A soja mais competitiva do Brasil. Brasil 247, 2014. Disponivel em: <http://www. brasil247.com/pt/247/ agro/>. Acesso em: 02 set. 2015.

[5] CHRISTOPHER, M. Logística E Gerenciamento Da Cadeia De Suprimentos. São Paulo: Thomson Learning, 2007.

[6] COMEX, R. B. Brasil Comex. Revista Brasil Comex, 2015. Disponivel em: <http://www.brasilcomex.net/integra asp?cd=2064\&_sm_au_=i6VF0bnffZVMTFNM>. Acesso em: 12 set. 2015.

[7] DALL'AGNOL, A. Embrapa. Agência Embrapa, 2015. Disponivel em: <http://www.agencia.cnptia.embrapa.br/ gestor/soja/arvore/CONTAG01_15_271020069131.html?_ sm_au_=i6VFObnffZVMTFNM>. Acesso em: 12 ago. 2015.
[8] GUIMARÃES, A. CNT.org. CNT, 2012. Disponivel em: $\quad$ <http://www.cnt.org.br/Paginas/Agencia_Noticia. aspx?noticia=estudo-cnt-sistema-ferroviario-26032013\&_ sm_au_=i6VFObnffZVMTFNM>. Acesso em: 02 set. 2015.

[9] MAPA. www.agricultura.gov.br. MAPA, 2000. Disponivel

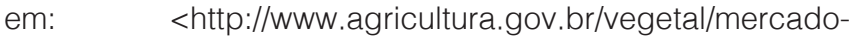
interno>. Acesso em: 02 ago. 2015.

[10] PONTES, H. L. J. Sistemas e Gestão, Ceará, v. IV, p. 155, ago. 2009. Disponivel em: <http://www.revistasg.uff. br/index.php/sg/article/viewFile/V4N2A5/V4N2A5?_sm_ au_=i6VFObnffZVMTFNM>.

[11] RURAL Centro. Rural Centro, 2012. Disponivel em: <http://ruralcentro.uol.com.br/analises/transporte-earmazenagem-de-soja-sao-gargalos-maiores-que-portos> Acesso em: 25 ago. 2015.

[12] SIMCHI-LEVI, D. Cadeia De Suprimentos: Projeto E Gestão. Porto Alegre: Bookman.

[13] VIEIRA, G. B. Transporte Internacional De Cargas. São Paulo: Aduaneiras, 2002 


\section{CAPÍTULO 19}

\section{FLUXO LOGÍSTICO A PARTIR DO DIAGRAMA DE CAUSA-EFEITO DE ISHIKAWA: UM ESTUDO EM UM COMÉRCIO DE MATERIAIS DE CONSTRUÇÃO}

\section{Christian Monteiro Schutts}

\section{Michele Schneider}

Julio César Zilli

\section{Adriana Carvalho Pinto Vieira}

\section{Ricardo Pieri}

Resumo: Em um ambiente competitivo, as organizações necessitam estudar seus processos e reduzir custos para se tornarem competitivas, de forma que a administração de materiais se torna um tema recorrente na gestão das organizações. Neste contexto, o estudo tem por objetivo analisar o fluxo logístico a partir do Diagrama de Causa-Efeito de Ishikawa em um comércio de materiais de construção localizado na cidade de Criciúma - SC. Metodologicamente trata-se de uma pesquisa, quanto aos fins de investigação, descritiva e aplicada, e quanto aos meios, se caracteriza como bibliográfica, documental e um estudo de caso. Os assuntos discutidos na literatura, como administração de recursos e materiais, foram apresentados com intuito de confrontar com os dados da pesquisa documental realizada na empresa, verificando a presença de desvios por meio da aplicação do Diagrama de Causa-Efeito de Ishikawa. Com uma abordagem qualitativa, foram obtidas informações por meio dos relatórios documentais e uma visita in loco na empresa, envolvendo as etapas de compras, controle de estoque, recebimento, armazenagem, conferência, cadastro, expedição e entrega. Os resultados concluem e encaminham sugestões para as correções no processo logístico, dentre os quais se destacam a organização de layout, controle de estoque e documentação de processos, a fim de melhorar as ações da organização. Novos estudos podem ser realizados e encaminhar futuras melhorias para aplicar e alcançar evoluções no fluxo logístico nas empresas envolvidas.

Palavras Chave: Administração, Recursos, Diagrama, Causa-Efeito. 


\section{INTRODUÇÃO}

O fluxo dos materiais na organização se inicia com o contato inicial com o fornecedor até a efetivação da entrega dos produtos ao cliente final. Esta movimentação engloba todas as funções de compras, planejamento e controle da produção, distribuição, exigindo um fluxo funcional de informações e conformação com as necessidades dos clientes (CHRISTOPHER, 1999).

Nas últimas décadas houve um aumento no estudo do fluxo logístico nas organizações nas mais diversas áreas, como na relação com a competitividade (ESCORSIM; KOVALESKI; SANCHES, 2007), varejo nacional (MACHLINE; AMARAL, 1998), e a relação entre fornecedores e varejistas (ARKADER et al, 2007).

A incessante procura por ações inovadoras por meio da busca por novos produtos ou por maneiras diferentes de se oferecer serviços são atitudes que buscam satisfazer as necessidades e expectativas os clientes a todo o momento, para assim conquistá-los, maximizar os lucros e estabelecer relações duradouras com os clientes e consumidores. Isto é o que caracteriza uma empresa que está com uma orientação correta para o mercado (SAMARA; BARROS, 2002).

É notória a importância deste estudo para o meio acadêmico e para o meio empresarial contemporâneo, agregando informações para estudos relacionados ao tema. Neste sentido, o estudo contribui para uma melhor aplicação do fluxo logístico nas empresas, tendo o objetivo de apontar possíveis desvios na aplicação das funções cotidianas. Assim, o estudo tem por objetivo analisar o fluxo logístico a partir do Diagrama de Causa-Efeito de Ishikawa em um comércio de materiais de construção localizado na cidade de Criciúma - SC.

O trabalho apresenta inicialmente uma caracterização sobre a Administração de Recursos e Materiais, bem como o Diagrama de Causa-efeito proposto por Ishiwava. Em seguida são apresentados os procedimentos metodológicos que ampararam o desenvolvimento da pesquisa e a apresentação e discussão dos resultados. Por fim, se destacam as considerações finais e as referências.

\section{ADMINISTRAÇÃO DE RECURSOS}

De acordo com Martins e Alt (2000) a administração de recursos está se desenvolvendo com ferramentas de gerência, que atuem com recursos a níveis menores. Está é uma prática empenhada nas situações, pois os recursos se encontram cada vez mais escassos, desde o gerenciamento de itens tangíveis à prestação de serviços.

Para Viana (2002) as empresas dispõem de diversos recursos e aponta como principais os recursos materiais, financeiros, humanos, mercadológicos e administrativos. Este conjunto de mecanismos é o meio em que as organizações desenvolvem suas operações.

De acordo com Costa e Faria (2005) o método de administração dos recursos materiais é o agrupamento de todas as funções que estão inseridas e envolvidas no processo logístico de uma empresa. Para Dias (2009) a administração de materiais tem o objetivo de amortizar os demais processos, uma atividade que procura a otimização de resultados, com aumento de eficiência dos meios financeiros.

Conforme Viana (2002) gerir os recursos materiais é a função que tem como responsabilidades a busca dos melhores resultados, lucratividade e produtividade. Deste modo, o administrador deve controlar os processos da organização, orientando a seguir as rotinas de trabalho, gerindo de forma eficaz mãode-obra, equipamentos, material, serviços e capital, desenvolvendo de forma correta os processos. De acordo com o autor, as empresas dispõem de diversos tipos de recursos para a realização das suas operações, dentre os recursos há o recurso financeiro, que constitui em todos os aspectos as execuções da empresa que estejam envolvidas com dinheiro.

Os recursos financeiros numa organização possuem função de extrema importância. É por meio deste recurso que as dívidas são quitadas e assim posiciona a empresa uma situação digna para a sequência de suas atividades e busca dos lucros. O responsável pelo setor financeiro tem que dispor de saldo de caixa, 
para pagar suas contas e manter o crédito perante seus fornecedores, o pagamento de suas obrigações nas datas corretas acarreta no aumento do crédito da organização no mercado, caso contrário, nas situações de não conseguir honrar suas dívidas o credito será diminuído e a principal função de um gestor financeiro não estará sendo executada (JOHNSON, 1976).

Seguindo com as afirmações de Viana (2002) os recursos financeiros são definidos como todos os recursos disponíveis que estejam em alguma maneira relacionada com o dinheiro. As empresas necessitam de diversos recursos para realização das suas operações, e dentre estes recursos, estão os fatores humanos, que são constituídos por toda operação dentro da organização que esteja envolvida de qualquer forma com a atividade humana no âmbito empresarial.

Toda ferramenta empenhada para o atendimento ao público, uma atividade com intuito de vender, é uma pratica dos recursos mercadológicos que compõem o escopo da empresa, tanto que Viana (2002, p. 39) afirma "[...] recursos mercadológicos: constituem toda a atividade voltada para o atendimento do mercado de cliente e consumidores da empresa". O esquema que constituir a estrutura administrativa de alguma empresa como as funções de diretores, gerentes e demais cargos afim pode-se determinar como o recurso administrativo disponível da organização.

\subsection{ADMINISTRAÇÃO DE MATERIAIS}

A administração de materiais, de acordo com Dias (2009), tem como principal função abastecer os demais setores da organização para que seja dada sequência nos processos da organização, e assim atingir o máximo possível de lucro. As empresas usam de seu capital para a aquisição de materiais e dessa forma espera-se que esse valor injetado seja o lubrificante para a entrada de recursos financeiros.

De acordo com Francichini e Gurgel (2002) a base da administração de materiais está ligada ao controle do abastecimento de materiais, sendo que a gerencia deste setor está diretamente ligada aos resultados de todos os demais setores da empresa. Ainda seguindo as afirmações dos autores, as aquisições equivocadas de materiais geram uma saída desnecessária de recursos financeiros e acaba não contribuindo com o processo produtivo, e assim desencadeando em uma série de problemas subsequente ao fluxo de trabalho da empresa.

Para Figueiredo, Fleury e Wanke (2003) a boa administração de materiais é o funcionamento correto dos processos, ou seja, com disponibilidade de mercadorias no momento em que os clientes desejam, com tempos de ciclos e prazos de entrega satisfatórios, havendo sistemas de informação para o apoio na administração de materiais. Deste modo, o processo será bem aplicado dando o resultado esperado, satisfazendo as necessidades do cliente. Conforme Dias (2009) as empresas devem ter ciência de que é elemento básico possuir um eficiente sistema de controle para a gestão de materiais sem distinção se a organização é do setor industrial ou varejista.

Controlar os procedimentos de uma organização e administrar os materiais de modo a analisar o que o precisa ser feito e quais serão as devidas iniciativas de correção necessárias a serem tomadas é uma estratégia importante para elevar o nível de progresso em relação aos objetivos traçados (DIAS, 2009). O Quadro 1 destaca os procedimentos e os respectivos esclarecimentos. 
Quadro 1 - Procedimentos fundamentais na administração de materiais

\begin{tabular}{|l|l|}
\hline PROCEDIMENTO & \begin{tabular}{l} 
ESCLARECIMENTO \\
\hline O que deve ser comprado.
\end{tabular} \\
\hline Como deve ser comprado. & Revela o procedimento mais recomendável. \\
\hline Quando deve ser comprado. & Identifica a melhor época. \\
\hline Onde deve ser comprado. & Implica o conhecimento dos melhores segmentos de mercado. \\
\hline De quem deve ser comprado. & Implica o conhecimento dos fornecedores da empresa. \\
\hline Por que preço deve ser comprado. & Evidencia o conhecimento da evolução dos preços no mercado. \\
\hline Em que quantidade deve ser comprada. & Estabelece a quantidade ideal, por meio da qual haja economia na compra. \\
\hline
\end{tabular}

Fonte: Viana (2002, p. 40)

De acordo com Viana (2002) a execução do processo de administrar os materiais com estratégia de um processo sem erros, eleva a função de executar tarefas complexas que envolvem diversas variáveis. O quadro anterior apresenta algumas tarefas que o responsável pelo setor de entradas e saídas de materiais da empresa deve estar atento.

\subsection{DIAGRAMA DE CAUSA EFEITO}

O Diagrama de Causa-Efeito é uma técnica de análise desenvolvida por Kaoru Ishikawa no Japão em 1950. Esta ferramenta é estruturada em um modelo semelhante a uma espinha de peixe, ilustrado na Figura 1 e caracterizado no Quadro 2, onde as linhas verticais são as causas das deficiências no fluxo logístico, podendo ser seis origens geralmente caracterizadas por: medição, materiais, mão de obra, maquinas, métodos e meio ambiente e a linha horizontal é o efeito (FERROLI; LIBRELOTTO; FERROLI, 2010).

Figura 1- Espinha de peixe

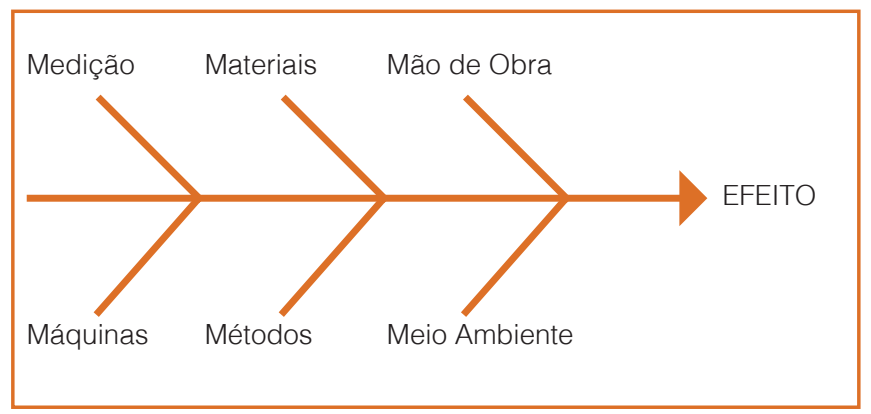

Fonte: Baseado em Ishikawa (1993).
Esta ferramenta se caracteriza como um instrumento para se aplicar no controle da qualidade, aplicável em atividades diversas, de modo que contribui na identificação de desvios no fluxo logístico, observando uma possível existência e localização dos gargalos na organização em que se aplicar a ferramenta da análise da espinha de peixe (ISHIKAWA, 1993).

Quadro 2 - Caracterização do Diagrama de Causa-Efeito

\begin{tabular}{|c|c|}
\hline ORIGEM & CARACTERISTICA \\
\hline Método & $\begin{array}{l}\text { As causas dos desvios estão relacionadas ao } \\
\text { método pelo qual o trabalho é executado. }\end{array}$ \\
\hline $\begin{array}{l}\text { Matéria- } \\
\text { prima }\end{array}$ & $\begin{array}{c}\text { A causa está relacionada com os materiais } \\
\text { utilizados no processo. }\end{array}$ \\
\hline $\begin{array}{l}\text { Mão de } \\
\text { Obra }\end{array}$ & Os desvios são ocasionados pelo colaborador. \\
\hline Máquinas & O maquinário é o causador do desvio. \\
\hline Medida & $\begin{array}{l}\text { A falta, ou utilização de indicadores de medição } \\
\text { inadequados, é o causador do desvio. }\end{array}$ \\
\hline $\begin{array}{l}\text { Meio } \\
\text { Ambiente }\end{array}$ & O ambiente contribui na geração dos desvios. \\
\hline
\end{tabular}

Fonte: Ishikawa (1993).

\section{PROCEDIMENTOS METODOLÓGICOS}

Quanto aos fins de investigação, trata-se de uma pesquisa descritiva e aplicada (OLIVEIRA, 1999), uma vez que descreve o fluxo logístico na entrada e saída de mercadorias em uma empresa de materiais de construção, bem como sugere ações para a resolução dos desvios encontrados. 
Quanto aos meios de investigação, se caracteriza como bibliográfica, documental e um estudo de caso. De acordo com Martins e Theóphilo (2009) a pesquisa bibliográfica é um excelente meio de formação para qualquer tipo de pesquisa científica. Este método de pesquisa tem como fundamento explicar e discutir o assunto tema, dando contribuições para a construção da plataforma teórica do estudo. Os autores ainda afirmam que a pesquisa documental possui semelhanças com a pesquisa bibliográfica, porém são dados que tem como origem documentos que não são de acesso ao público em geral, normalmente são relatórios e dados de levantamentos periódicos das empresas.

Neste sentido, foi realizada uma visita in loco e uma análise dos relatórios documentais da empresa em estudo, caracterizando-se um estudo de caso único, envolvendo as etapas de compras, controle de estoque, recebimento, armazenagem, conferência, cadastro, expedição e entrega. Os dados apontados tiveram uma análise essencialmente qualitativa (OLIVEIRA, 1999).

\section{APRESENTAÇÃO DOS RESULTADOS}

As atividades logísticas apresentadas na empresa, local da aplicação da pesquisa, dispõem dos seguintes processos: compras, recebimento, conferência, cadastramento, armazenagem, controle de estoque, reposição de estoque, abastecimento de gondolas, expedição e por fim, a entrega dos produtos aos clientes.

De acordo com Messias (1979) nas estruturas empresarias que se dispõem da necessidade de administração de materiais, funções como de compras, transporte, armazenagem, conservação, manipulação e controle de estoques são essenciais, afirmando que tais funções tem o dever de assegurar a decorrência dos processos dentro das empresas.

\subsection{COMPRAS}

As compras são realizadas diariamente, de acordo com os materiais que são prioridades de aquisição e para a aplicação de determinadas funções há um único responsável, que dispõem das responsabilidades de pesquisa de fornecedores e comparações de preços.

Para a compra de produtos, há diversas ferramentas, como: cotações via internet, telefone ou visitas de representantes. Muitas das compras da empresa são realizadas quando, vendedores ou representantes, dos mais diversos atacados e indústrias visitam o estabelecimento oferecendo seus produtos, no qual a maior parte destes representantes dispõe de um roteiro que estabelecem suas visitas na empresa uma vez a cada trinta dias.

\subsection{CONTROLE DE ESTOQUE}

Com a presença dos fornecedores, o estoque dos materiais é observado de forma visual, para constatar quantidades que se encontram no estabelecimento e a partir desta etapa o comprador decide a necessidade de concretizar o pedido.

A empresa possui seu sistema de atendimento que também faz o controle fiscal de entradas e saídas de mercadorias. Porém, esta ferramenta ainda não está implantada para auxiliar no controle de estoque. Assim, o controle visual é a principal ferramenta de auxílio na tarefa de controle de quantidades de materiais em estoque.

A empresa não se restringe em comprar apenas com a visita dos representantes. Quando há a constatação de que algum item está em falta ou em quantidades consideradas abaixo do mínimo, o comprador busca fornecimento, uma vez que possui 759 fornecedores cadastrados em seu sistema interno. O contato é realizado por telefone ou via e-mail.

Uma ressalva importante sobre a aplicação dos processos logísticos da empresa é que não há uma definição formal para níveis de estoques mínimos, tanto para definir quando há a necessidade de comprar e também não há dados registrados pelo estabelecimento para a definição da quantidade a ser colocado no pedido. Porém, as projeções de vendas 
são estabelecidas pelo comprador para a aquisição dos materiais. Outro ponto que merece ressalva é que grande parte dos produtos primeiramente faltam para depois serem comprados.

Como o mix de produtos é extenso, em torno de 12.000 itens e não há ferramentas informatizadas com dados de controles para as quantidades faltantes, não são possíveis de se apontar. Porém, é de conhecimento da gerência do estabelecimento que a incidência de produtos não se dá em materiais pesados e sim em mercadorias como ferramentas definidas como itens de balcão, tais como: discos de corte, serras, máquinas, parafusos e demais itens desta linha.

\subsection{RECEBIMENTO}

No momento do recebimento o conferente exerce sua função e observa quais materiais estão chegando ao estabelecimento, verificando as condições dos produtos, em busca de possíveis defeitos e avarias. Neste momento é indicado para qual local do depósito serão direcionados os produtos, que podem ser direcionados ao pavilhão nos fundos da empresa ou para o estoque dentro do estabelecimento.

\subsection{ARMAZENAGEM}

O layout do estabelecimento dispõem de um pavilhão coberto na parte de trás do terreno destinado à estocagem de materiais pesados e de maior volume, como cimento, argamassas, telhas, cal, madeiras, tubos, caixas d águas, pisos, forros pvc e etc. E um espaço de depósito no segundo piso da loja para materiais que ficam dispostos nas gondolas da empresa, materiais como conexões, tintas, solventes, ferramentas, lâmpadas e etc. são dispostos no estoque que fica na parte superior da loja.

Porém, não há documentação ou qualquer tipo de registro que possa indicar o local exato em que foi estocada. Desta forma, sua localização é conhecida pelo colaborador que guardou e a presença deste colaborador nas atividades da empresa torna-se essencial para o funcionamento ágil e satisfatório aos clientes.

Para a descarga dos materiais pesados, existe o auxílio de empilhadeira que descarrega os produtos e os armazena de forma mais rápida, pratica e segura, agilizando para o transportador e para a loja o processo de descarregamento.

$\mathrm{Na}$ armazenagem dos produtos há um cuidado especial por parte estabelecimento, uma vez que diversos materiais são perecíveis, como no caso dos cimentos, argamassas e similares, havendo dessa forma, a observação de restrições nas condições de armazenagem dos produtos. Neste sentido, o cimento, por exemplo, é estocado em local seco, havendo cobertura, com proteção contra intemperes que podem ocasionarumidade que são prejudiciais à qualidade do produto.

\subsection{CONFERÊNCIA}

O conferente realiza o acompanhamento do descarregamento dos materiais até a armazenagem no local correto dentro do depósito do estabelecimento. No momento do recebimento, é observadoo estado de conservação dos volumes que estão sendo descarregados e havendo problemas de violação da embalagem ou deteriorização do produto, todo o material passa a ser conferido item a item para a correta certificação da veracidade dos dados da nota e qualidade dos materiais recebidos. Somente após a conferência dos produtos, o conferentecarimba e assina o canhoto da nota fiscal e liberar os entregadores.

No momento da conferência dos itens da nota fiscal, - conferente tem a responsabilidade de separar uma unidade de cada produto que consta na nota fiscal, com a finalidade de auxiliar a responsável pelo cadastramento dos materiais no sistema do estabelecimento.

\subsection{CADASTRAMENTO}

O cadastramento é realizado logo após a conferência 
da nota fiscal. Neste processo os dados específicos dos produtos são lançados em seu cadastro e o código de barras do produto é incluído no sistema. Os impostos e valores de frete são calculados nesta etapa e lançados com o preço de custo de cada produto e suas margens são estabelecidas, formando o preço de venda. Após este processo, as mercadorias são distribuídas em gondolas e prateleiras para ficar a disposição dos clientes.

\subsection{EXPEDIÇÃO}

Grande parte dos materiais está disposta em paletes facilitando a movimentação no depósito. Con a finalidade de facilitar os processos de movimentação e armazenagem, muitos produtos ficam guardados separadamente, como os tubos que são distribuídos em gavetões que os deixam separados por bitolas, agilizando no momento de separar para entregar ao cliente.

Consta no sistema do estabelecimento, aproximadamente 12.000 itens cadastrados, ressultando em quantidade excessiva de mercadorias para controlar. Nesse sentido, uma alternativa que a empresa aplica para auxiliar no controle de estoque, é a estratégia de que os vendedores assumem a responsabilidade de auxílio na verificação dos níveis de estoque, ou seja, no momento em que constatam que algum item esta abaixo do nível mínimo, que é uma quantidade que não há números definidos e a experiência do profissional é que irá definir de modo visual a necessidade de comprar. Deste modo este produto será anotado em um caderno, que funciona como ferramenta de controle de estoque sendo um auxiliador para evitar faltas.

O espaço das gondolas e mostruários da empresa são reabastecidos de acordo com a necessidade. Os vendedores também são responsáveis em realizar esta tarefa. Neste sentido, há preocupação em manter estes ambientes sempre organizados, sem espaços vazios, mantendo-os com diversos itens a disposição dos clientes.

O consumidor final conta com duas formas de atendimentos. A forma mais tradicional para o setor de materiais de construção, conta com auxilio do vendedor para realizar o orçamento e consequentemente fechamento da negociação. Após o fechamento da negociação, o clientese direciona ao caixa e efetua o pagamento Caso haja a necessidade de entrega de algum produto por meio do sistema de entrega do estabelecimento, seus dados são anotados em seu pedido e a data da entrega é determinada de comum acordo entre cliente e empresa. Outro método de atendimento é o método self service, em que o próprio cliente busca seu produto desejado e vai ao caixa efetuar seu pagamento e não envolve atendimento de vendedor algum.

Para os métodos de atendimento apresentados anteriormente, ambos se aplicam de modo que as mercadorias passam pela verificação eletrônica, que contabiliza o valor unitário e as quantidades que estão sendo compradas. Caso o cliente opte por não levar o material, o estabelecimento se responsabilizará com a entrega até o domicilio do cliente, efetuando a cobrança de taxa de entrega no valor de $\mathrm{R} \$ 8,00$. Em caso de clientes que residem na cidade de Criciúma, havendo variações de valor para demais municípios.

\subsection{ENTREGA}

Nos casos em que o comércio de materiais de construção é o responsável pela entrega dos materiais, eles serão primeiramente separados e conferidos pelos responsáveis da expedição. Os materiais serão levados para o cliente de caminhão, sendo disponível as entregas de segunda à sexta das 8:00h às 17:30h e sábado das 8:00h às 12:00h. Como a empresa dispõe de três caminhões para realizar as entregas, os três são distribuídos de modo que possa atender um maior número de clientes numa mesma data.

Há um cuidado por parte do responsável da logística de distribuição da empresa em organizar rotas de entregas próximas para melhor rendimento do processo e diminuição do custo do serviço. As definições das rotas são estabelecidas diariamente de acordo com a necessidade logística da empresa de acordo com a data. 
A programação das datas de entregas fica em torno de 24 a 48 horas, a partir da data da compra. Diversas entregas não têm seus produtos entregues todos no mesmo momento, pois muitas vezes não há disposição dos itens na empresa, ficando pendente até o momento que a mercadoria constar novamente no estoque do estabelecimento e assim ser completado o processo de entrega aos clientes.

\section{ANÁLISE DOS RESULTADOS}

De acordo com Ishikawa (1993) o agrupamento dos fatores deve ser corretamente controlado a fim de que os processos sejam transformados em causas que resulte em bons produtos e efeitos. Da observação dos processos logísticos da empresa, diversos problemas foram diagnosticados nas atividades, desde situações de recebimento de mercadorias vindos do fornecedor, até as situações de compras e entrega aos clientes do estabelecimento, conforme pode ser observadono Quadro 3.

Quadro 3 - Classificação dos setores (causa-efeito)

\begin{tabular}{|c|c|c|c|}
\hline SETOR & DESVIO & MÉDODO & DESPERDÍCIO \\
\hline Distribuição & $\begin{array}{l}\text { A aplicação informal dos processos logísticos interno envolve em muitas } \\
\text { ocasiões o movimento desnecessário de materiais de forma desordenada. }\end{array}$ & Método & $\begin{array}{l}\text { Transporte/ } \\
\text { estoque }\end{array}$ \\
\hline Distribuição & $\begin{array}{l}\text { Não há cuidados em relação em posicionamento de mercadorias, com } \\
\text { ausência de zelo para organizar os lotes dos produtos nos pallets e locais } \\
\text { de armazenagem. }\end{array}$ & Método & Material \\
\hline Armazenagem & $\begin{array}{l}\text { Ausência de definição acerca do nível de estoque a ser aplicado pela } \\
\text { empresa. }\end{array}$ & Medição & Estoque \\
\hline Armazenagem & Não identificação e localização dos materiais no estoque. & Meio ambiente & $\begin{array}{l}\text { Estoque e tempo } \\
\text { de resposta }\end{array}$ \\
\hline Distribuição & $\begin{array}{l}\text { Inexistência de uma área para separação de mercadorias na fase de } \\
\text { expedição. }\end{array}$ & Meio ambiente & Estoque \\
\hline Recebimento & $\begin{array}{l}\text { Não há uma área adequada para cadastramento, pois são realizadas no } \\
\text { balcão de atendimento aos clientes. }\end{array}$ & Meio ambiente & Estoque \\
\hline Recebimento & Erros no momento de cadastramento de produto. & Mão de obra & Material e estoque \\
\hline Armazenagem & $\begin{array}{l}\text { Disposição dos materiais de modo incorreto, materiais diferentes } \\
\text { misturados. }\end{array}$ & $\begin{array}{l}\text { Mão de obra/ } \\
\text { Meio ambiente }\end{array}$ & Estoque \\
\hline Armazenagem & $\begin{array}{l}\text { Problemas com espaços, havendo situações de espaços vazios e outros } \\
\text { extremamente cheios, em consequência da falta de dimensionamento do } \\
\text { depósito. }\end{array}$ & Meio ambiente & Estoque \\
\hline Armazenagem & Aplicação exclusiva do método visual para controle de estoque. & Método & Estoque \\
\hline Armazenagem & $\begin{array}{l}\text { Ausência de ferramenta para controle de estoque para assim diminuir } \\
\text { faltas de mercadorias ou compras desnecessárias. }\end{array}$ & Método & Estoque \\
\hline Distribuição & Inexistência de sistema de senhas para atendimento aos clientes. & $\begin{array}{l}\text { Mão de obra/ } \\
\text { Método }\end{array}$ & Fluxo \\
\hline Distribuição & $\begin{array}{l}\text { Em dias de grande movimento formam-se filas e acúmulo de pessoas } \\
\text { frente ao balcão diminuindo o espaço de circulação e causando } \\
\text { desistência de alguns clientes que decidem ir embora. }\end{array}$ & Meio ambiente & $\begin{array}{l}\text { Ociosidade e } \\
\text { superprodução. }\end{array}$ \\
\hline Armazenagem & $\begin{array}{l}\text { Depósito localizado sobre a loja, dificultando a movimentação de produtos } \\
\text { pesados nas escadas. }\end{array}$ & Meio ambiente & Estoque \\
\hline Distribuição & $\begin{array}{l}\text { Problemas com prateleiras e gondolas que ficam momentos com espaços } \\
\text { vazios, deixando os clientes sem opções de mercadorias, situação devida } \\
\text { ao não planejamento de reposição adequada das gôndolas. }\end{array}$ & Mão de obra & $\begin{array}{l}\text { Estoque e } \\
\text { Ociosidade }\end{array}$ \\
\hline Distribuição & $\begin{array}{l}\text { Falta de um estudo para melhor organizar o layout dos produtos na loja, } \\
\text { um melhor planejamento da distribuição destes, aplicando-se melhor os } \\
\text { pontos de vendas, maximizando o fluxo e consequentemente o lucro. }\end{array}$ & Meio ambiente & Fluxo \\
\hline Distribuição & $\begin{array}{l}\text { Falta de treinamento para funcionários melhor aplicar as tarefas do } \\
\text { processo logístico. }\end{array}$ & Mão de obra & Treinamento \\
\hline Distribuição & $\begin{array}{l}\text { Ausência de um controle de segurança que dê garantias que pessoas não } \\
\text { peguem mercadorias e saiam do estabelecimento sem passar pelo caixa e } \\
\text { efetuar o devido pagamento. }\end{array}$ & Meio ambiente & Segurança \\
\hline Armazenagem & $\begin{array}{l}\text { Mercadorias ficam a nível zero no estoque, prejudicando as necessidades } \\
\text { dos clientes e a rentabilidade da empresa. }\end{array}$ & Método & Estoque \\
\hline
\end{tabular}


As observações realizadas no processo logístico da empresa e apresentado no Quadro 2, apontam que dos 19 problemas diagnosticados no fluxo logístico da organização 68\% estão relacionados aos procedimentos da gestão de estoques.

As informações processadas na análise do diagnóstico não são caracterizadas como desperdícios. Porém, a concretização do processo com a presença dos desvios tornam o processo defeituoso e geradores de desperdícios. Baseando-se na técnica de classificação do diagrama de Ishikawa (1993), a ocorrência das falhas se dá por falta de técnicas administrativas. Logo seu método de medida não é através da quantidade. Porém, caracterizada pela participação dos seguintes desvios, de acordo com o Quadro 4.

Quadro 4 - Desvio motivado pela ausência de informações

\begin{tabular}{|c|c|c|}
\hline SETOR & DESVIOS PELA AUSÊNCIA DE INFORMAÇÕES & CLASSIFICAÇÃO \\
\hline Armazenagem & Inexistência de documentos atualizados em relação ao estoque (inventário) & Medição \\
\hline Armazenagem & $\begin{array}{l}\text { Presença de desperdícios, motivados pelo manuseio incorreto da empilhadeira, } \\
\text { causando avarias em sacos de cal, cimentos, argamassas e quebra de pisos e } \\
\text { porcelanatos. }\end{array}$ & Mão de obra/ Máquina \\
\hline Distribuição & Organização e distribuição dos materiais na loja, sem setores definidos. & Meio ambiente \\
\hline Armazenagem & O cadastro do mix de itens é desatualizado & Medida \\
\hline Distribuição & $\begin{array}{l}\text { Há ausência de informações documentais quanto o volume de clientes, apenas } \\
\text { estimativas. }\end{array}$ & Medida \\
\hline Armazenagem & $\begin{array}{l}\text { O método de observação visual é o único para definir as quantidades de materiais no } \\
\text { estoque. }\end{array}$ & Método \\
\hline Armazenagem & $\begin{array}{l}\text { O pedido de compra é efetuado com base nos níveis de estoques observados } \\
\text { visualmente e com apreciação nas experiências anteriores de compra, não há } \\
\text { considerações em relação ao fluxo de clientes, pois não há informações neste sentido. }\end{array}$ & Método \\
\hline Distribuição & $\begin{array}{l}\text { Ausência de documentação para informar as movimentações logísticas dos produtos na } \\
\text { empresa, dificultando o fluxo com a ausência de informações de localização. }\end{array}$ & Método \\
\hline Distribuição & $\begin{array}{l}\text { Os produtos que os clientes compram, por vezes não são entregues todos de uma única } \\
\text { vez, por situações de estarem em falta. }\end{array}$ & Mão de obra \\
\hline Distribuição & $\begin{array}{l}\text { Não há relatório para apontar os erros cometidos pelos colaboradores, em relação ao } \\
\text { processo de expedição e entrega referente a itens ou quantidades erradas. }\end{array}$ & Medida \\
\hline Distribuição & $\begin{array}{l}\text { Falta de um mural de informações no depósito para informar os colaboradores, } \\
\text { comunicados e tarefas. }\end{array}$ & Material \\
\hline
\end{tabular}

Fonte: Elaboração própria

Os dados apresentados nos Quadros 3 e 4, quando aplicados no diagrama de Causa-Efeito, no modelo espinha de peixe de Ishikawa (1993) tem-se a seguinte estrutura, conforme ilustrado na Figura 2.

Figura 2 - Espinha de peixe com dados aplicados

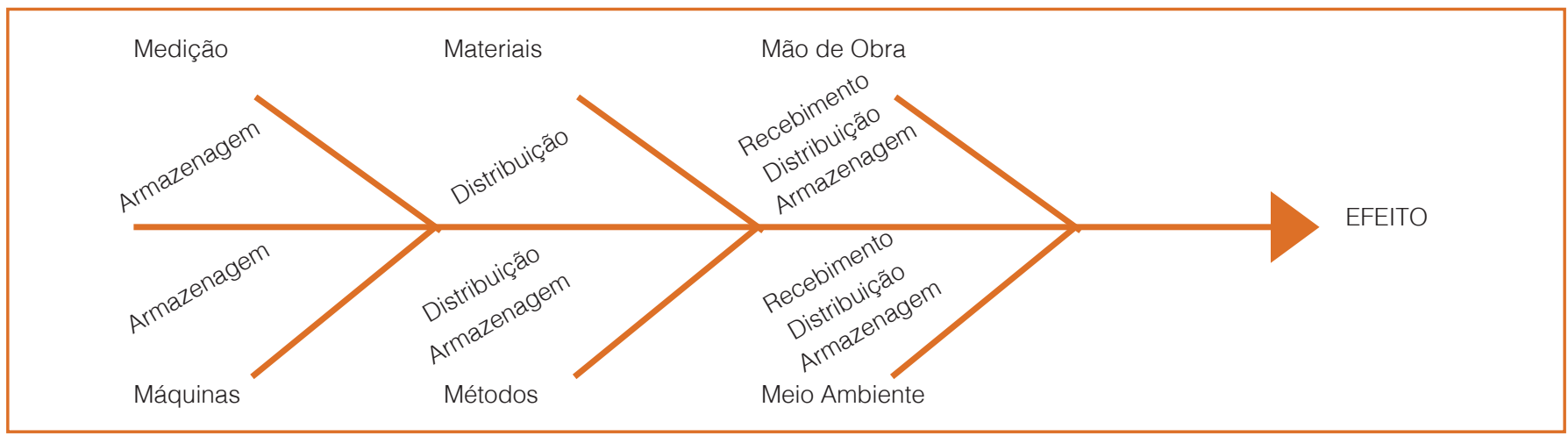

Fonte: Elaboração própria 
A relevância de efetuar uma análise de identificação das motivações dos desvios, levando em consideração as causas-efeitos nos departamentos da empresa, é com o intuito de assimilar os problemas para o desenvolvimento de um estudo que introduza na empresa métodos de correção dos problemas avaliados, com o objetivo de melhoria nos processos logísticos do comércio de materiais de construção.

\section{CONSIDERAÇÕES FINAIS}

O estudo teve por objetivo analisar o fluxo logístico em uma empresa vinculada ao comércio de materiais de construção localizada na cidadede Criciúma - Santa Catarina.

O Diagrama de Causa-Efeito de Kaoru Ishikawa (1993) foi a ferramenta de análise aplicada para entender as origens/causas dos desvios e problemas. Neste sentido, destacam-se as seguintes sugestões de melhoria para a empresa em estudo:

a. a) Realizar um inventário geral dos itens para ajustes dos estoques no sistema;

b. b) Informatização do controle de estoques e das entradas e saídas de mercadorias e atualização do cadastro dos produtos;

c. c) Revisão do mix de produtos com intuito de maximizar a gestão de estoque com o auxilio da classificação dos itens e definição de itens por grau de importância das vendas;

d. d) Definição de políticas de estoques, com determinação do nível de estoque considerando estoque minimo, máximo, estoque de segurança e ponto de pedido para cada item;

e. e) Estudo do layout atual da empresa, considerando a localização dos itens de acordo com a importancia, otimizando a movimentação e circulação de materiais no espaço de armazenagem;

f.f) Criação de novos espaços no layout do estabelecimento, com criação de um local especifico para gerenciar as atividades de expedição e outro local (balcão isolado dos balcões de atendimento). Este novo espaço seria destinado para as funções relativas a cadastramento de mercadorias e entradas e saídas de notas fiscais.

g. g) Elaborar um cronograma de inventário rotativo para os itens com maior movimentação, possbilitando a identificação rápida dos problemas de impressição dos estoques e estabelecer cronogramas semestrais de inventários gerais para a verificação dos estoques.

h. h) Treinamento dos funcionários para correta movimentação e manipulação dos produtos, para que se minimizem os problemas de manuseio de materiais;

i. i) Redefinição dos processos de separação dos pedidos e expedição, para que se minimize os problemas eventuais de entregas fracionadas aos clientes;

j. j) Estabelecer procedimentos para verificação e acompanhamento da expedição dos pedidos e medição dos problemas gerados na entrega;

k. h) Colocação de mural de informações e comunicados no setor de expedição.

Este estudo não atende a todas as necessidades para o fluxo logístico no setor de comércio de matérias de construção, porém se empenhou para identificar possiveis falhas e poder contribuir com melhorias que se transforme em situações geradoras de lucro para os estabelecimentos deste setor. Portanto, novos estudos devem ser aplicados para que novos dados sejam apresentados e assim auxiliar no bom gerenciamento das empresas.

\section{REFERÊNCIAS}

[1] ARKADER, R.; FIGUEIREDO, K.; HIJJAR, M. F.; GOLDSMID, I. K. Segmentação logística: um estudo na relação entre fornecedores e varejistas no Brasil. 2007 Disponível em:< http://www.scielo.br/scielo.php?script=sci_ arttext\&pid=S1415-65552007000400002 $>$. Acesso em: 01 out. 2014.

[2] CHRISTOPHER, M. Logística gerencial da cadeia de suprimentos: estratégias para a redução de custos e melhoria de serviços. São Paulo, Pioneira, 1999.

[3] COSTA, M. de F. G. da; FARIA, A. C. de. Gestão de custos logísticos: custeio baseado em atividades (ABC): balanced socrecard (BSC): valor econômico agregado (EVA). São Paulo: Atlas, 2005. 
[4] DIAS, M. A. P. Administração de materiais: uma abordagem logística. 4 ed. São Paulo: Atlas, 1993.

[5] _. Administração de materiais: princípios, conceitos e gestão. 5 ed. São Paulo: Atlas, 2009.

[6] ESCORSIM, S.; KOVALESKI, J. L.; SANCHES, A. M. O papel dos fluxos logísticos para a competitividade empresarial. 2007. Disponível em: <http://ri.uepg.br:8080/ riuepg/handle/123456789/776> . Acesso em: 01 out. 2014.

[7] FERROLI, P. C. M.; LIBRELOtTO, L. I.; FERROLI, R. H. Discussão Conceitual dos possíveis desdobramentos dos processos de fabricação de produtos. Disponível em: <http:// www.abepro.org.br/biblioteca/ENEGEP2002_TR52_0059. pdf>. Acesso em: 21 mar. 2014.

[8] FIGUEIREDO, K. F.; FLEURY, P. F.; WANKE, P. Logística e gerenciamento da cadeia de suprimentos: planejamento do fluxo de produtos e dos recursos. São Paulo: Atlas, 2003.

[9] FRANCISCHINI, P.; GURGEL, F. do A. Administração de materiais e do patrimônio. São Paulo: Pioneira Thomson, 2002.

[10] ISHIKAWA, K. Controle de qualidade total: à maneira japonesa. Rio de Janeiro: Campos, 1993.
[11] JOHNSON, R. W. Administração financeira. 4 ed. São Paulo: Pioneira, 1976.

[12] MACHLINE, C.; AMARAL JÚNIOR, J. B. C. Avanços logísticos no varejo nacional: o caso das Redes de farmácias. 1998. Disponível em: <http://www.scielo.br/pdf/rae/v38n4/ a08v38n4.pdf>. Acesso em: 01 out. 2014.

[13] MARTINS, G. D., THEÓPHILO, C. R. Metodologia da investigação científica para ciências sociais aplicadas. São Paulo : Atlas, 2009.

[14] MARTINS, P. G.; ALT, P. R. C. Administração de materiais e recursos patrimoniais. São Paulo: Saraiva, 2000.

[15] MESSIAS, S. B. Manual de administração de materiais: planejamento e controle estoques. 6 ed. São Paulo: Atlas. 1979

[16] OLIVEIRA, S. L. Tratado de metodologia científica. São Paulo: Pioneira Thomsom Learning. 1999.

[17] SAMARA, B. S.; BARROS, J. C. de. Pesquisa de marketing: conceitos e metodologia. 3. ed São Paulo: Prentice Hall, 2002.

[18] VIANA, J. J. Administração de Materiais: um enfoque prático. São Paulo: Atlas, 2002. 


\section{CAPÍTULO 20}

REDUÇÃO DE CUSTOS OPERACIONAIS E CONDIÇÕES INSEGURAS EM UM ALMOXARIFADO APÓS AUTOMATIZAÇÃO DE ROTAS INTERNAS

\section{Pedro Ferrelli}

\section{Raphael Ribeiro Machado}

\section{Wesley de Araujo Moreira}

\section{Ruy Gomes da Silva}

Resumo: A movimentação de cargas dentro de um armazém ou até mesmo na área fabril é um dos desperdícios mais relevantes em uma empresa, pois além de aumentar o fluxo de veículos e pessoas, não agrega valor ao produto acabado, em face desta problemática o presente artigo apresenta um estudo de caso que trata da viabilização e implementação de um AGV (Veículo Guiado Automaticamente) nas áreas logísticas de movimentação interna de materiais. Esse projeto foi implementado em uma indústria de fabricação de máquinas agrícolas, na cidade de Curitiba/Pr. O AGV é usado no transporte de carrinhos de movimentação interna de peças para pré- montagens de máquinas agrícolas. Com embasamento teórico, explicou-se as aplicações da administração de estoques, a movimentação interna de materiais, os ganhos da aplicação da automação industrial, os diferentes sistemas logísticos e as particularidades dos AGV's. Expõe-se também os ganhos financeiros, os ganhos na área de segurança e os ganhos nos processos da implementação do equipamento.

Palavras Chave: Segurança, Logística, AGV, Movimentação. 


\section{INTRODUÇÃO}

Em virtude da globalização, tivemos diversos reflexos em vários segmentos industriais, desde o aumento da competitividade e o acesso a diversas tecnologias. Uma das soluções encontradas, embora ainda pouco praticada pelas companhias, é a mudança do conceito logística, agora responsável desde o recebimento da matéria prima até a entrega do produto acabado na casa do cliente. A logística pode atuar em diversas áreas, entre as quais a área de suprimentos, produção e distribuição. (CHING, 2009)

Para que a matéria-prima possa transforma-se ou ser beneficiada, pelo menos um dos três elementos básicos de produção - homem, máquina ou material - deve movimentar-se; se não ocorrer essa movimentação, não se pode pensar em termos de processo produtivo. (DIAS, 2010)

Toda movimentação realizada no interior de uma empresa, não agrega valor ao produto, e essa movimentação teoricamente não é paga pelo cliente. O cliente paga pelo produto, na qualidade e no tempo esperado, o quanto esse produto vai ser movimentado no interior na empresa não interesa para o cliente. Porem, essa movimentação tem um custo, e esta na responsabilidade da empresa gerenciar essa movimentação, e buscar maneiras de reduzir os custos de movimentação, buscando tecnologias para diminuir ao maximo essa movimentação. Muitas empresas optam por mudar o layout da linha de produção e estoque, para conseguir reduções consideradas satisfatórias. (SHINGO, 1996)

A empresa que prima pela manutenção de sua competitividade no mercado globalizado precisa estar constantemente em busca de melhores profissionais e equipamentos, realizando mais com menos. Reduzir custos matendo a qualide e atendendo ao cliente com excelencia é um dos maiores desafios enfrentados pelas empresas. Para conseguir isso é necessário investimento em inovação tecnologica visando diminuir desperdicios, ociosidade, retarbalho e riscos. A automação de processos aparece como uma possivel solução para esses problemas, diminuindo a necessidade da mão humana no porcesso produtivo e proporcionando um controle maior sobre todas as suas etapas. (SILVA, 2013)

\section{FUNDAMENTAÇÃO TEÓRICA}

Este artigo apresenta um estudo sobre a viabilidade da aplicação de um AGV, a importância em termos financeiros, à utilização de novas tecnologias e alguma ferramenta utilizada na implementação dessa tecnologia. A demonstração desse material está dividido em alguns tópicos: (i) Administração de Estoques, (ii) Movimentação de materiais, (iii) Sistema Logístico, (iv) Automação Industrial, (v) Automatic Guided Vehicle (AGV), (vi) Ferramenta TWTTP e (vii) Gerenciamento da Cadeia de Suprimento.

\subsection{ADMINISTRAÇÃO DE ESTOQUES}

De muitas formas, a administração de materiais é o inverso da distribuição física. Trata do fluxo de produtos para a firma ao invés de a partir dela. Muitas atividades da administração de materiais são compartilhadas com a distribuição física. Entretanto existem algumas diferenças que são a chave da boa administração do fluxo de suprimentos. Essas diferenças enfocam principalmente o modo pelo qual os fluxos são iniciados e sincronizados e a seleção das fontes de fornecimento. (BALLOU, 2011)

O gerenciamento logístico, do ponto de vista sistêmico, é o meio pelo qual as necessidades dos clientes são satisfeitas mediante a coordenação dos fluxos de materiais e de informação que se estendem do mercado, passando pela empresa e suas operações, até os fornecedores. Para conseguir essa ampla integração da empresa, é preciso uma orientação bem diferente daquela que geralmente se encontra na organização convencional. (CHRISTOPHER, 2009)

De forma geral, estoque é o que compreende todos os produtos que estão armazenados em um determinado local, desde o momento em que é armazenado até quando é direcionado para uma próxima atividade. Tanto na entrada, quanto na saída desse material do estoque, é imprescindível o controle de rastreabilidade e identificação desse produto. Dependendo das particularidades de cada empresa, esses estoques podem apresentar diferentes formas de controle e características. (ARNOLD, 2009) 
O estoque tem participação efetiva nos processos produtivos das empresas, como estoques de matéria prima, estoques de produtos não acabados e estoque de produtos acabados. Segundo Arnold (2009) os estoques são materiais e suprimentos que uma empresa ou instituição mantém, seja para vender ou para fornecer insumos ou suprimentos para o processo de produção. Todas as empresas e instituições precisam manter estoques. Frequentemente, os estoques constituem uma parte substancial dos ativos totais.

Tais estoques tem grande importância, principalmente financeiro. Em um balanço patrimonial, podem representar de $20 \%$ a $60 \%$ dos ativos totais, dependendo do seu tamanho e do ramo empresarial. À medida que os estoques vão sendo utilizados, convertem-se em dinheiro, gerando o retorno sobre o investimento. Todo estoque é um investimento e corresponde a um capital empregado e assim, tem um custo. Para manter uma empresa em funcionamento custa dinheiro, e boa parte desse dinheiro é destinada a capital de giro para a aquisição, manutenção e movimentação de estoques. Além desses fatores, o armazenamento de material geram determinados custos como juros, depreciação, aluguel, equipamentos, mão de obra, obsolescência, seguro e conservação, que se somados geram grandes despesas as empresas. (ARNOLD, 2009)

Muitas empresas buscam implementar o conceito do sistema Toyota de produção. Pois os avanços alcançados utilizando ferramentas desse sistema, já ajudou muitas empresas a sair de situações de crise e alcançar posições importantes no mercado. A principal filosofia desse sistema é o Just-in-Time, o qual diz que se deve produzir a quantidade certa, na hora certa, ou seja, procurar eliminar ao máximo os estoques. Mas a completa aplicação desse sistema, dificilmente é implantada com sucesso por um problema de cultura. Então as empresas buscam a adaptar-se, a sua realidade a um modelo de sucesso, e essa adaptação geralmente compõe na implementação de um estoque de segurança, no qual admite a possibilidade de algumas falhas no sistema produtivo, sem que essas falhas gerem grandes impactos na produção. Com essa redução considerável de estoque, busca-se a diminuir a necessidade de um alto volume do capital de giro, deixando os gastos com estoques menores. (SHINGO, 1996)

A missão do gerenciamento logístico é planejar e coordenar todas as atividades necessárias para atingir os níveis desejados de qualidade e de serviços prestados ao menor custo possível. A logística, portanto, deve ser vista como o vinculo entre o mercado e a base de suprimentos. O alcance da logística perpassa toda a organização, do gerenciamento da matéria prima até a entrega do produto final. (CHRISTOPHER, 2009)

\subsection{MOVIMENTAÇÕES DE MATERIAIS}

O uso da tecnologia da informação na logística de armazenagem e distribuição pode reduzir tempo de resposta, aumentar a eficiência no uso do espaço físico e na movimentação de materiais resultando em aumento de competitividade. (MACHADO e SELLITTO, 2012)

Para que a matéria prima possa transformar-se ou ser beneficiada, pelo menos um dos três elementos básicos de produção (homem, máquina ou material), deve movimentar-se; se não ocorrer essa movimentação, não se pode pensar em termos de processo produtivo. (DIAS, 2010)

A movimentação de materiais pode ser classificada de acordo com a atividade funcional a que se destinam, tais como cargas unitárias, cargas a granel, embalagens, tipo de armazenamento, e também pela analise de dados como levantamento de rotas de transporte, layout, custos, e um sistema eficiente de otimização dos processos de movimentação de materiais. (DIAS, 2010)

Com a alta necessidade de se produzir mais com menos, há uma necessidade de redução dessas atividades de movimentação, pois não agregam valor ao custo final do produto, ou seja, se considerarmos a alta movimentação como um problema separado dos demais, a simples redução nos trajetos percorridos desde a entrada do material à empresa até sua transformação na linha de produção, constituiria em uma solução ideal, pois em termos macros, essa pode 
ser a causa de ociosidade de homens e equipamentos, que tem reflexos negativos nos custos do produto final. Pois a principal função do homem no processo produtivo é processar, controlar ou coordenar, com isso o excesso de movimentação do homem é um desperdício produtivo, no qual no período em que está realizando a movimentação poderia estar produzindo, e se considerar que se contratam pessoas apenas para realizar movimentações, essas pessoas são pessoas consideradas improdutivas. (DIAS, 2010)

Para o problema de alta movimentação de materiais, há diversas maneiras de se aperfeiçoar os processos. Pode-se iniciar com ajustes de layout, melhoria na circulação com corredores bem definidos, melhorando a localização estratégica do(s) almoxarifado(s), deixando as mercadorias mais próximas dos pontos de uso por exemplo. Outro ponto que pode ser melhorado são as rotas de movimentação, que definem por onde e quando os materiais devem ser movimentados, empregando mínimas distancias a ser percorrida, mínima manipulação dos mesmos, segurança nas movimentações, máxima saturação dos equipamentos e mão de obra, máxima utilização do espaço físico disponível, e o tipo de equipamento a ser utilizado. (DIAS, 2010)

\subsection{SISTEMA LOGÍSTICO INTERNO}

Com o passar dos anos, o sistema logístico dentro de um cenário global, vem se aperfeiçoando de maneira rápida. O seguimento tem sido alvo constante de investimento para solução de problemas e na redução dos custos do produto final. A embalagem e a movimentação de materiais são componentes do sistema de fluxo, onde os materiais se movimentam em uma instalação de produção até serem convertidos em produto acabado, que é distribuído para consumo. Como partes vitais desta corrente fornecimento-produção-distribuição, a embalagem e a movimentação de materiais poderão contribuir para o aperfeiçoamento da produtividade de todo sistema. (MOURA\&BANZATO, 2014)

Seguindo esse fluxo de informações, a logística tem papel vital na eficiência produtiva das empresas.
Desde quando o material sai do fornecedor até o seu armazenamento interno, do seu fluxo de movimentação interna para produção, agregando valor ao produto final, todas essas etapas contribuem na eficiência produtiva empresarial. O bom planejamento da logística, seja interna ou externa, garante um bom desempenho produtivo. A logística consiste em fazer chegar a quantidade certa das mercadorias certas ao ponto certo, no tempo certo, nas condições certas e ao mínimo custo. (MOURA\&BANZATO, 2014)

\subsection{AUTOMAÇÃO INDUSTRIAL}

Quando se fala em equipamento de movimentação de materiais, após a conclusão prévia das analises dos fluxos de materiais, uma ferramenta muito utilizada na solução de problemas é a automação. Automação industrial é o uso de qualquer dispositivo mecânico ou eletroeletrônico para controlar máquinas e processos. Entre os dispositivos eletroeletrônicos podem-se utilizar computadores ou outros dispositivos lógicos (como controladores lógicos programáveis ou CLP's), substituindo, muitas vezes, tarefas humanas ou realizando outras que o ser humano não consegue realizar. Em muitos casos onde é exigido um alto nível de qualidade, e o ser humano não consegue atingir os parâmetros de qualidade esperado, também é aplicado à automação. É um passo além da mecanização, onde operadores humanos são providos de maquinas para auxiliá-los em seus trabalhos, porem por lei no Brasil não são todas as atividades que podem ser automatizada, pois o governo entende-se que se deixar automatizar uma linha de produção inteira, em vários ramos de produção, geraria uma alta taxa de desemprego impactando na economia do país. (NOLL, 2010)

Uma vez compreendido o conceito de logística, a necessidade de automatizar os processos ganha peso nas decisões sobre os investimentos nas organizações, a automação na logística característica ser um conjunto de tecnologias que disponibiliza os meios necessários á operação do processo decisório em qualquer empresa, por meio do processamento dos dados disponíveis, aplicando técnicas computadorizadas ou mecânicas para diminuir o uso de mão de obra em 
qualquer processo. (NOLL, 2010)

Para Fialho (2008) caracteriza a automação em duas partes, que são: automatismos e automação. Automatismos são os recursos, maquinas e ferramentas de trabalho, com condições de minimizar ou anular o trabalho realizado pelo homem em um processo de produção. Automação não é apenas a troca de homem no processo de produção, mas sim um modo de assegurar produtividade, rendimento, garantia da qualidade do produto e, principalmente, a redução dos custos do processo.

A automação é tratada por Groover (2001) como uma grande área que busca integrar a mecânica, a eletrônica e as tecnologias computacionais no sentido de colaborar com o processo de fabricação. Ainda conforme Groover, o sistema produtivo, pode ser dividido em duas partes para facilitar o controle: automação do processo de manufatura e informatização de amparo ao sistema de manufatura.

\subsection{AUTOMATIC GUIDED VEHICLE (AGV)}

O AGV, veículo guiado automaticamente, é um veículo que se movimenta de forma autônoma dispensando o auxílio de operadores. Desenvolvidos para transporte, transferência e armazenagem de produtos conectam diversas áreas ou máquinas.

Considerado uma das tecnologias, mas interessantes para transportes de materiais nas indústrias, principalmente no que se diz respeito a pagamento de produção (logística), coletar o material do armazém e transportá-lo até a linha de montagem, seu transporte é seguro e eficaz, trazendo grandes benefícios à produção e aos usuários desse sistema. (ATLEE, 2001)

Estes veículos têm como função poupar tempo na execução das atividades, reduzir a mão de obra nas movimentações internas das empresas, redução de custos e otimização de área produtiva que podem comunicar uns com os outros para a otimização de suas rotas assim como passar ou solicitar informações para outras máquinas e equipamentos podendo ser integrados à qualquer ambiente.
Existem diversas maneiras de o AGV reconhecer o percurso que ele deverá realizar, a escolha desta deverá levar em condição a situação do ambiente, principalmente do piso onde será implementado o sistema. Abaixo está sendo citadas três formas utilizadas para aplicação desse sistema:

- Óptica: sensores detectam uma faixa branca entre duas pretas, podendo estas ser pintadas ou até mesmo fitas de demarcação de piso. Sendo a opção mais barata de implementação, esta opção é recomendada para áreas de pouco tráfego de empilhadeiras, ou até mesmo áreas exclusivas para rotas de AGVs. Nesta aplicação basta ter o percurso de faixas branca e preta que os AGVs já conseguem identificar o percurso, não são necessários equipamentos adjacentes.

- Indutiva por Frequência: a Orientação Indutiva por Frequência conta com uma antena que identifica o sinal emitido por um cabo (1,5mm flexível) que através de um corte no piso é colocado à cerca de $20 \mathrm{~mm}$ da superfície. Esta implementação é altamente recomendada para áreas de altíssimo tráfego de empilhadeiras e máquinas de arraste, onde possivelmente poderia ser danificada qualquer forma de identificação através de faixas. Para que seja possível a identificação do percurso através da antena nesta aplicação se faz necessária a utilização de um gerador de frequência que deve ser instalado em um painel próximo ao percurso do AGV.

- Laser: para esta aplicação é utilizado um sensor laser fixo no AGV que se orienta através de pontos reflexivos que são fixados em pontos estratégicos como colunas e paredes. Por se tratar de um sistema com custo mais elevado que os outros, a utilização desta tecnologia é recomendada apenas para áreas de tráfego intenso onde não é possível fazer corte no piso (AGVS, 2014).

No estudo de caso que será apresentado, o tipo de sensor escolhido foi o óptico. O sensor fotoelétrico é conhecido como sensor óptico, e baseia-se na transmissão e recepção de luz infravermelha, que pode 
ser refletida ou interrompida pelo objeto detectado. Esse sensor é composto por dois circuitos básicos: um transmissor, responsável pela emissão do feixe de luz e o receptor, responsável pela recepção do feixe de luz (BONACORSO \& NOLL, 2010).

Os principais benefícios na utilização de veículos guiados automaticamente estão na redução dos custos com mão-de-obra, maior flexibilidade no manuseio e transporte dos materiais, melhor organização da programação do processo, melhor utilização do espaço disponível, maior segurança dos sistemas, aumento da produção e controle de inventários mais eficaz (KIM \& TANCHOCO, 1999).

\subsection{FERRAMENTA TWTTP}

É uma ferramenta de qualidade que visa detectar a causa real do evento (excluindo a possibilidade de que ele seria uma condição insegura) e analisar mais profundamente em detalhe as causas ocultas de ato inseguro. Assim, são feitas cinco perguntas que tem como foco verificar competência e conhecimento do operador, verificar gerenciamento e procedimento, verificar atitude e comportamento, verificar fatores de distração, nível de atenção com problemas pessoais e o envolvimento de operadores, envolvendo-os na percepção do "perigo" (YAMASHINA, 2007).

\subsection{GERENCIAMENTO DA CADEIA DE SUPRIMENTOS}

Uma cadeia de suprimento engloba todos os estágios envolvidos, direta ou indiretamente, no atendimento do pedido de um cliente. A cadeia de suprimento não inclui apenas fabricantes e fornecedores, mas também transportadores, depósitos, varejistas e os próprios clientes. Dentro de cada organização, utilizando como exemplo uma fábrica, a cadeia de suprimento inclui todas as funções envolvidas no pedido do cliente, como desenvolvimento de novos produtos, marketing, operações, distribuição, finanças e o serviço de atendimento ao cliente, entre outras (Meindl, 2009).

O estoque existe na cadeia de suprimento devido a uma inadequação entre suprimento e demanda. Essa inadequação é intencional em uma siderúrgica, onde é mais econômico fabricar grandes lotes que serão armazenados para vendas futuras. A inadequação é intencional também para um varejista que prefere manter seu estoque como antecipação à futura demanda. O estoque é o principal fator gerador de custos em uma cadeia de suprimento e exerce um forte impacto na responsividade (MEINDL, 2009).

\section{PROBLEMÁTICA}

Este trabalho apresenta um estudo de caso de uma melhoria na área de logística de uma empresa de equipamentos agrícolas localizada na cidade de Curitiba/Pr. Tem como objetivo, apresentar os principais ganhos na utilização da automação no setor de movimentação interna de materiais do estoque para as linhas de produção da empresa.

No projeto de melhoria do sistema de movimentação logístico interno, primeiramente foram levantados os principais problemas que necessariamente precisavam ser reduzidos.

Foram coletados dados junto a segurança do trabalho que registrou em uma só área e em um curto espaço de tempo, dois acidentes relativos a movimentação interna feita com rebocadores. Para estudo das possíveis causas dos acidentes, utilizou-se a técnica de análise TWTTP.

Também se verificou que, devido à alta variação da produtividade, havia necessidade de duas pessoas e dois rebocadores para atender a linha de produção.

Coletados preliminarmente esses dados, constatouse uma oportunidade de resolução de problemas e ganhos financeiros com a implementação da tecnologia de automação na logística, no caso um AGV.

Estudou-se então uma rota que, se bem aplicada, resultaria em ganhos com a utilização do AGV. Utilizando um sistema de navegação óptico, com apenas uma rota de abastecimento o AGV conseguiu fazer o abastecimento de uma linha de montagem com quatro postos e mais uma linha de pré-montagens 
com três postos. A figura 1 apresenta o layout da rota planejada para implementação do AGV.

Figura 1 - Esboço de layout de rota proposta para AGV.

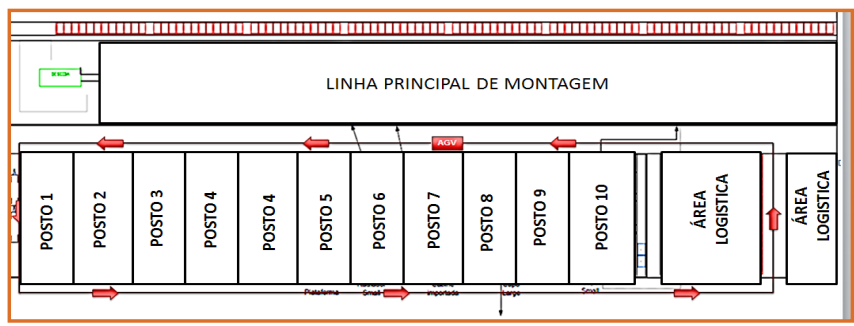

Fonte: Autores, 2015

Com a instalação do sistema e inicio das atividades do equipamento, verificou-se grandes ganhos, como em aspectos de segurança e produtividade. Os acidentes logísticos chegaram a zero na área de aplicação, pois ao contrário do uso de rebocadores e empilhadeiras que além do risco físico que traziam a área, que dependia da atenção e perícia dos operadores, a nova sistemática implementada com o uso do AGV, possibilitava o acidente zero, o que antes ocorria em uma media de dois por mês, pois o equipamento conta com sensores que detectam qualquer possível colisão, acionando automaticamente sua parada de emergência, que com essa redução também impactou em ganho de produtividade com a não parada de equipamentos e afastamento de pessoas.

\section{RESULTADOS}

Os resultados obtidos na implementação do novo sistema de movimentação logística interna podem ser verificados na Tabela 1 e no Gráfico 1, que trazem um comparativo do sistema antigo, baseado em um rebocador, uma empilhadeira e dois operadores, e o novo sistema que utiliza apenas o AGV.

O ganho financeiro anual foi muito expressivo, se levado em consideração os contratos de aluguel de equipamentos, contrato de trabalho com operadores, com todas as suas considerações legais, tem altos custos variáveis às companhias.

Também pode ser destacado que, quanto menos equipamentos estiverem deslocando-se no mesmo local de trabalho, os ricos de acidentes são eminentes.
Destacam-se também os possíveis problemas nos fluxos e rotas de abastecimento com a alta concentração de veículos em um determinado local de trabalho.

A tabela 1 e a Figura 1, mostram um resumo dos resultados financeiros da implementação do equipamento. A Figura 2 mostra o AGV cumprindo a rota proposta.

Tabela 1 - Ganho financeiro anual do projeto

\begin{tabular}{l|l|l|}
$\begin{array}{l}\text { Custos de } \\
\text { movimentação }\end{array}$ & $\begin{array}{l}\text { Sistema } \\
\text { Antigo }\end{array}$ \\
\hline $\begin{array}{l}\text { Mão de obra de 2 } \\
\text { pessoas }\end{array}$ & $\mathrm{R} \$ 261360,00$ & - \\
\hline Rebocador & $\mathrm{R} \$ 30000,00$ & - \\
\hline Empilhadeira & $\mathrm{R} \$ 60000,00$ & - \\
\hline Aluguel do AGV & - & $\mathrm{R} \$ 63700,00$ \\
\hline Total geral & 351360,00 & $\mathrm{R} \$ 63700,00$ \\
\hline $\begin{array}{l}\text { Ganho financeiro do } \\
\text { projeto }\end{array}$ & & $\mathrm{R} \$ 287660,00$ \\
\hline
\end{tabular}

Fonte: Autores, (2015)

Figura 1 - Comparativo financeiro do projeto

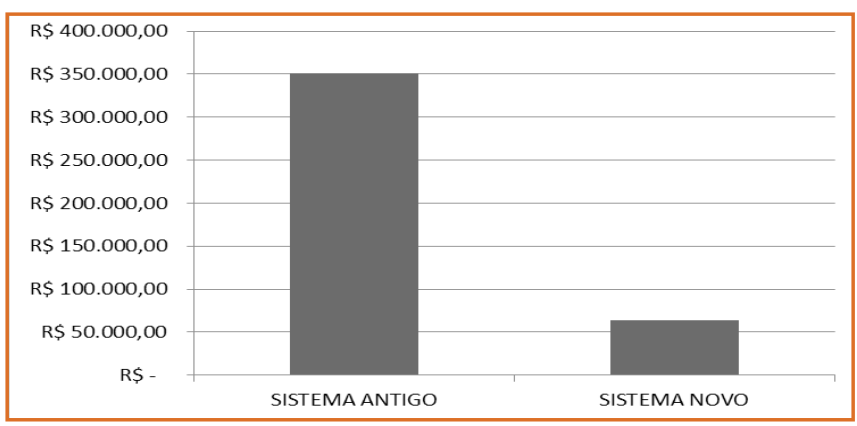

Fonte: Autores, 2015

Figura 2 - AGV cumprindo rota proposta

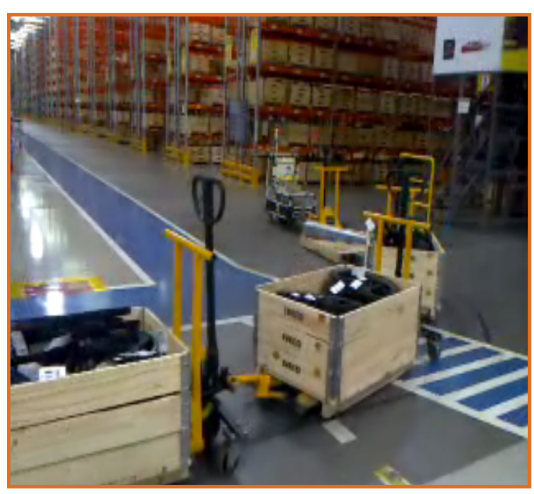

Fonte: Autores, 2015 


\section{CONCLUSÃO}

$\mathrm{Na}$ análise realizada no presente estudo de caso, concluiu-se que a automação industrial, bem como novas tecnologias apresentam ganhos mensuráveis como o rápido retorno do investimento. O payback do projeto é de menos de um ano, porém obtiveram-se ganhos imensuráveis como saúde e segurança nas áreas de trabalho. Em uma área onde ocorriam em media 2 acidentes mensais relativos a movimentação interna logística, após a implantação do AGV, esse numero caiu à zero, o AGV torna-se uma das soluções mais viáveis para resolução de problemas de circulação, movimentação e de segurança nas áreas de logística interna das empresas.

Com a necessidade constante de redução de custos e melhoria nas áreas de segurança, as empresas que não investirem em novas tecnologias para os processos e na resolução dos problemas, muito provavelmente estão fadadas a falência.

Pode-se então afirmar que, com certeza, a automação veio para melhorar os fluxos de trabalho e a forma que ele é realizado, trazendo aos processos produtivos mais agilidade, produtividade, viabilidade financeira e acima de tudo segurança.

\section{REFERÊNCIAS}

[1] AGVS, MOVING FORWARD. Proposta técnica, 2014.

[2] ARNOULD, J. R. Administração de Materiais. São Paulo: Editora Atlas S. A, 2011.

[3] ATLEE, J. Selecting safer building products in pratice. Journal of Cleaner Production, 459 - 463, 2001.

[4] BALLOU, R. H. Logística Empresarial. São Paulo: Atlas, 2011.
[5] BANZATO, R. D. Embalagem, Unitização \& Conteinerização. São Paulo: Iman, 2014.

[6] CHING, Y. H. Gestão de Estoques na Cadeia de Logística Integrada.São Paulo: Atlas, 2009.

[7] CHRISTOPHER, M. Logística e Gerenciamento da Cadeia de Suprimentos.São Paulo: CENGAGE learning, 2009.

[8] CROWSOX, R. Assembly Process - Finishing, Packaging, and Automation.New York: Taylor and Francis Group, 2006.

[9] DIAS, M. A. Administração de Materiais São Paulo: Editora Atlas S. A, 2010.

[10] FIALHO, A. B. Automação Pneumática: Projetos, Dimensionamento e Análise de Circuitos. 6aㅡ ed. São Paulo: Erica, 2008.

[11] GROVER, P. M. Automation, production Systems and Computer - Integrated Manufacturing. New jersey: Hall, 2001.

[12] KIM, C. W. \& TANCHOCO, J. M. AGV dispatching based on workload balancing. 1999.

[13] MEINDL, S. C. Gerenciamento da Cadeia de Suprimentos. São Paulo: Pearson, 2009.

[14] NOLL, N. G. Automação Eletropneumática. São Paulo: Editora Érica Ltda, 2010.

[15] SELLITTO, A. M. Beneficios da implementação e utilização de um sistema de gerenciamento de armazens em um centro de distribuição. Revista produção Online, 46-72, 2012.

[16] SILVA, D.S. Analise do Impacto da Automação da Movimentação Interna na Produtividade Industrial, 2013.

[17] SHINGO, S. O sistema toyota de produção do ponto de vista da engenharia de produção. Porto Alegre: bookman, 1996.

[18] YAMASHINA, H. Challenge to world class manufacturing. International Journal of Quality of Reliability Management, Kyoto, 12(34), 30-31, 2007. 


\title{
CAPÍTULO21
}

\section{USO DE FERRAMENTAS TEGNOLÓGICAS E PRÁTICAS LOGÍSTICAS NA GESTÃO DA GADEIA DE SUPRIMENTOS DA CONSTRUÇÃO CIVIL}

\author{
Christiane Wagner Mainardes Krainer \\ Jefferson Augusto Krainer \\ Cezar Augusto Romano \\ Bernardo Pasquini Cavassin \\ Ryan Ramos Scheidt
}

Resumo: O setor da construção civil é caracterizado como tradicional e conservador, apresentando um histórico de baixa velocidade na corrida por novos recursos tecnológicos, contrapondo-se aos demais setores, em que a tecnologia é rapidamente absorvida, implantada e aperfeiçoada. Com suporte nestas informações, o presente trabalho tem como objetivo caracterizar a gestão da cadeia de suprimentos de empresas de construção civil, além de identificar a utilização de ferramentas/práticas tecnológicas no gerenciamento dessa cadeia. Para alcançar esse objetivo foi realizada uma pesquisa descritiva e quantitativa em empresas construtoras, mais especificamente empresas de incorporação de empreendimentos imobiliários e de construção de edifícios. Os resultados obtidos foram analisados descritivamente, com a finalidade de sintetizar uma série de valores de mesma natureza, permitindo uma visão global da sua variação. Constatou-se que as empresas pesquisadas estão focadas em melhorar a produtividade e a qualidade de seus produtos, mas não concentram seus esforços na melhoria de sua cadeia de suprimentos. Afirmam confiar em seus fornecedores e reconhecem a importância de seus clientes, porém mantêm um frágil relacionamento com ambos e não tratam os primeiros como verdadeiros parceiros. O uso de novas tecnologias de gestão nas empresas pesquisadas ainda é precoce e imaturo, apesar das empresas terem conhecimento da sua necessidade e de seus benefícios. Algumas construtoras já implataram novas tecnologias de gestão e outras, a maioria, não, somente as conhecem e procuram utilizar seus princípios.

Palavras Chave: Construção Civil, Cadeia de Suprimento, Ferramentas Tecnológicas, Práticas de Gestão. 


\section{INTRODUÇÃO}

A Indústria da Construção Civil é uma atividade econômica que envolve tradicionais estruturas sociais, culturais e políticas. Segundo Nascimento e Santos (2003) no Brasil o segmento é caracterizado como tradicional e conservador, apresentando um histórico de baixa velocidade na corrida por novos recursos tecnológicos, contrapondo-se aos demais setores, em que a tecnologia é rapidamente absorvida, implantada e aperfeiçoada.

A atividade de transformação na indústria da construção civil leva em conta o produto final imóvel, em geral único, com longo ciclo de existência e inconstância de utilização de recursos (CASAROTTO, 1995). A indústria é composta por inúmeras organizações desde fornecedores de materiais, de projetos, de serviços e de mão de obra a empresas propriamente de engenharia. Cada organização detém estruturas distintas, mas busca um objetivo comum, entregar algum produto ou serviço que seja necessário para o processo produtivo da construção como um todo (ETCHALUS et al., 2006).

A baixa produtividade, associados a desperdícios, retrabalhosedescumprimento de prazosécaracterística do setor da construção, a qual é apontada pelo baixo desenvolvimento da gestão logística de suprimentos e serviços (VIEIRA, 2006). Outros fatores diretamente ligados a baixa produtividade são a carência da mão de obra especializada e a dificuldade de administração de obras simultâneas (SALLABERY, 2009). Segundo Vieira (2006), todos estes itens negligenciados pelo setor tem origem na administração da cadeia de suprimentos. Porter (2011) ressalta que a performance eficiente (alta produtividade) de uma organização está diretamente associada a uma gestão eficaz de sua cadeia de suprimentos. Logo, é importante destacar a atenção na gestão de materiais nas obras, primeiro devido ao alto valor financeiro do produto final, segundo pela grande quantidade de suprimentos envolvidos e terceiro pelo alto custo de alguns suprimentos (HAGA; SACOMANO, 2000).

Nesse particular, para o desenvolvimento organizacional das construtoras, os sistemas de gestão devem integrar os setores da empresa, os controles, os processos e os agentes externos, permitindo, por exemplo, que um colaborador interfira, em tempo real, diretamente no resultado do trabalho do outro (RODRIGUES, 2002). Vieira (2006) salienta que uma integração eficiente e eficaz entre os envolvidos faz-se a partir de um fluxo de informações ordenado e controlado por meio do uso de ferramentas tecnológicas que facilitem e operacionalizem esse sistema, tais como: Warehouse Management System - WMS; Electronic Data Interchange - EDI; Material Requirements Planning - MRP; Enterprise Resource Planning - ERP; dentre outras.

Ferreira e Zancul (2014) identificaram que os gestores da indústria da construção civil estão focando esforços na melhoria do planejamento de empreendimentos e na adoção de métodos de gestão, o que releva uma mudança de postura e mentalidade do setor. Para atender as duas principais demandas, continuam os autores, se faz fundamental a implantação de práticas como: planejamento da necessidade e uso de recursos e de materiais, utilização de software Building Information Modeling (BIM), conceitos de Lean Construction, melhoria no fluxo de materiais, práticas de parcerias e otimização de fornecedores e de compras.

Com suporte nestas informações, o presente trabalho tem como objetivo caracterizar a gestão da cadeia de suprimentos de empresas de construção civil, além de identificar a utilização de ferramentas/práticas tecnológicas no gerenciamento dessa cadeia.

\section{REVISÃO BIBLIOGRÁFICA}

A indústria da construção civil no Brasil não acompanhou a evolução que sofreu outros setores industriais e, assim, vem convivendo há muito tempo com desperdício e improvisos dentro de seus processos. Vieira (2006) sustenta que os desperdícios e perdas que podem representar de 25\% a 30\% do custo da obra estão relacionados com uma questão logística Simchi-Levi et al. (2010), pouco desenvolvida. A maioria das causas, acrescenta o autor, está ligada à cadeia de suprimentos, seja relacionada com a gestão de materiais propriamente ditos, seja envolvendo atividades de compra, de armazenamento, de transporte e de movimentação dentro do canteiro de 
obras. Segundo Simchi-Levi et al. (2010), o objetivo da gestão da cadeia de suprimentos é a eficiência em termos de produção e de custos para todo o sistema, desde a produção das matérias primas até a distribuição dos produtos acabados.

Para Isatto (2005, p. 64) "a cadeia de suprimentos de um empreendimento consiste em um sistema composto por múltiplas empresas conectadas através de ligações comerciais com o propósito de realizar - empreendimento". O setor de suprimentos de uma construtora representa a ligação entre o setor administrativo da empresa e o setor de execução (canteiro de obras), assumindo forte importância estratégica para obter melhor qualidade na construção e a redução de custos. Soma-se a isso o fato desse setor integrar outros departamentos da empresa e ter uma relação com o mercado, formando um grande potencial de melhoria da qualidade das construtoras (OLIVEIRA; LONGO, 2008).

Oliveira e Gavioli (2012) aduzem que o funcionamento em conjunto dos agentes envolvidos na cadeia de suprimentos garante a plena e correta execução das atividades dentro do canteiro de obras. Defendem, também, os autores a importância de realização de parcerias duradouras, pois assim não haverá interrupção de abastecimento de materiais, o que diminui o risco de atrasos e multas contratuais, além de tornar a empresa confiável e de qualidade. Segundo Santos (2006, p. 15) "Para que a formação de parcerias obtenha sucesso é necessário que exista alguns elementos chaves entre os envolvidos na cadeia como: confiança, relações de longo prazo e o compartilhamento das informações". O autor afirma que quanto à troca de informações, pode-se incluir desde especificações de produtos e projetos, planejamento e programação de compras até acesso total a uma base de dados dos clientes.

Edum-Fotweet et al. (2001), por seu turno, apontam que o modo como as informações são gerenciadas pelos atores (envolvidos) da cadeia de suprimentos da construção é fundamental para uma efetiva e eficiente gestão da cadeia. Ademais, continuam os autores, informações coerentes e devidamente mapeadas geram "entregas eficientes" e isso está associado diretamente a todo o processo de construção.

Para melhorias em toda a cadeia de suprimentos, é extremamente importante a redução dos problemas e falhas na comunicação entre o setor de suprimentos da empresa e as obras, muito presente na construção civil (OLIVEIRA; LONGO, 2008), há que se promover uma gestão integrada dos sitemas organizacionais (RODRIGUES, 2002). Xue et al. (2004) afirmam que outros fatores que geram problemas de eficiência nas cadeias de suprimentos é a separação entre o projeto e a construção do empreendimento, bem como a falta de coordenação e integração entre as variadas faces funcionais envolvidas.

Por outro lado, Vieira (2006) salienta que é necessária a implantação de tecnologias da informação para que se promova a ordenação e o controle do fluxo informacional, integrando-se todos os agentes da cadeia produtiva, fazendo com que trabalhem em sinergia e com um único objetivo.

A Tabela 1 apresenta as principais ferramentas/ práticas tecnológicas utilizadas na construção civil e as possíveis impactos destas no processo produtivo. 


\begin{tabular}{|c|c|c|}
\hline \multicolumn{3}{|c|}{ FERRAMENTAS/PRÁTICAS TECNOLÓGICAS (NA CONSTRUÇÃO CIVIL) } \\
\hline & Descrição & Possíveis impactos no processo produtivo \\
\hline $\begin{array}{c}\text { Eletronic Data Interchange } \\
- \text { EDI }\end{array}$ & $\begin{array}{l}\text { Conecta e viabiliza a troca de informações entre } \\
\text { duas ou mais organizações, com o propósito de } \\
\text { facilitar uma transação de negó-cios. }\end{array}$ & $\begin{array}{c}\text { Agilizam os processos logísticos de troca de informações e } \\
\text { promovem uma maior integração entre todos os agentes da cadeia } \\
\text { de suprimentos (BENTO et al., 2012; VIEIRA, 2006). } \\
\text { Possibilita uma transferência rápida e econômica de dados e } \\
\text { documentos, gerando, por consequência, melhora na eficiência } \\
\text { operacional da organização (SANTOS, 2006). } \\
\text { Diminuem os erros gerados pelo volume de papéis e erros de } \\
\text { digitação (BENTO et al., 2012). }\end{array}$ \\
\hline Intranet e extranet & $\begin{array}{l}\text { Rede fechada, exclusiva, com acesso somente } \\
\text { para os colaboradores (intranet) ou aberta } \\
\text { também a clientes e fornecedores (extranet). }\end{array}$ & $\begin{array}{l}\text { Instrumentalizam o compartilhamento de informa-ções, facilitando } \\
\text { pedidos e pagamentos e qualquer troca de dados necessários e } \\
\text { corriqueiros entre as organizações e, também, entre estas e seus } \\
\text { clientes. }\end{array}$ \\
\hline $\begin{array}{l}\text { Warehouse Management } \\
\text { System (WMS) }\end{array}$ & $\begin{array}{l}\text { Sistema de automação do processo de } \\
\text { armazenagem que auxilia no gerencia-mento } \\
\text { de almoxarifados, depósitos, arma-zéns e } \\
\text { centros de distribuição. Suas principais funções } \\
\text { são: recebimento, inspeção, endereçamento, } \\
\text { estocagem, emissão de documentos, } \\
\text { gerenciamento do inventário (a partir do } \\
\text { recebimento), prepara-ção e liberação da } \\
\text { expedição (BARTHOLDI; HACKMAN, 2011). }\end{array}$ & $\begin{array}{l}\text { Propicia ganhos logísticos, como: expressiva redução de custos } \\
\text { e tempo operacionais, ganho de eficiência, redução de erros, } \\
\text { acuracidade de inventários, maior controle sobre uso dos produtos } \\
\text { (VIEIRA, 2006). Não é raro, contudo, adverte o referido autor, o } \\
\text { WMS não gerar os ganhos logísticos esperados, mormente quando } \\
\text { não planejada e previamente avaliada a sua implantação e, ainda, } \\
\text { quando o sistema não seja operado por pessoas qualificadas. }\end{array}$ \\
\hline $\begin{array}{l}\text { Terceirização de serviços ou } \\
\text { subcontratação (em inglês, } \\
\text { outsourcing) }\end{array}$ & $\begin{array}{l}\text { Contratação de empresa especializada para } \\
\text { a realização de serviços específicos em cada } \\
\text { etapa de uma obra. }\end{array}$ & $\begin{array}{l}\text { a) vantagens: melhoria da qualidade do produto final; facilitação } \\
\text { do controle dos custos; redução de estoques; crescimento da } \\
\text { empresa sem grandes investimentos; uso de novas tecnologias } \\
\text { sem custos extras; b) desvantagens: dependência de terceiros; } \\
\text { fornecedores não qualificados e comprometidos com a qualidade } \\
\text { do produto final; e dificuldade na busca do parceiro ideal (VIEIRA, } \\
\text { 2006). } \\
\text { Fomenta a criação de parcerias que visam à melhoria do processo } \\
\text { produtivo, apesar de muitas construtoras ainda não enxergarem } \\
\text { o subempreiteiro como um parceiro que pode colaborar para o } \\
\text { mútuo crescimento organizacional (VIEIRA, 2006). }\end{array}$ \\
\hline $\begin{array}{l}\text { Building Information } \\
\text { Modeling (BIM) }\end{array}$ & $\begin{array}{l}\text { Cria digitalmente modelos virtuais precisos de } \\
\text { uma construção que suportam o projeto em } \\
\text { todas as suas fases. Os modelos digitais contêm } \\
\text { geometrias e informações reais necessárias } \\
\text { para o apoio à construção, à fabricação e às } \\
\text { atividades de aquisições (EASTMAN et al., } \\
\text { 2011). }\end{array}$ & $\begin{array}{l}\text { Fornece a base para novos projetos, as capacidades das } \\
\text { construções e as relações e papéis de todos os envolvidos no } \\
\text { projeto, facilitando a integração entre o projeto do empreendimento } \\
\text { e a construção, resultando um processo construtivo mais enxuto, } \\
\text { com custo mais baixo e reduções de prazos (EASTMAN et al., } \\
\text { 2011). } \\
\text { Proporciona uma visão detalhada de todo o processo de } \\
\text { aquisição, definindo quantidades de elementos e detalhes dos } \\
\text { materiais e componentes do produto (IRIZARRY et al., 2013). }\end{array}$ \\
\hline Lean Construction & $\begin{array}{l}\text { É a aplicação da filosofia Lean que deriva do } \\
\text { método Toyota de produção de automóveis } \\
\text { (Toyotismo) à construção civil. O principal } \\
\text { objetivo dessa filosofia de gestão é a eliminação } \\
\text { das atividades que não agregam valor ao } \\
\text { produto, reduzindo-se, por consequência, os } \\
\text { desperdícios e maximizando-se o aproveitamen- } \\
\text { to dos recursos (GRENHO, 2009). Por se } \\
\text { tratar de um meio de eliminação de atividades } \\
\text { causadoras de perdas, também é chamada de } \\
\text { Construção Enxuta (TONIN e SCHAEFER, 2013). }\end{array}$ & $\begin{array}{l}\text { É a aplicação da filosofia Lean que deriva do método Toyota } \\
\text { de produção de automóveis (Toyotismo) à construção civil. O } \\
\text { principal objetivo dessa filosofia de gestão é a eliminação das } \\
\text { atividades que não agregam valor ao produto, reduzindo-se, por } \\
\text { consequência, os desperdícios e maximizando-se o aproveitamen- } \\
\text { to dos recursos (GRENHO, 2009). Por se tratar de um meio de } \\
\text { eliminação de atividades causadoras de perdas, também é } \\
\text { chamada de Construção Enxuta (TONIN e SCHAEFER, 2013). }\end{array}$ \\
\hline $\begin{array}{l}\text { Material Requirements } \\
\text { Planning - MRP }\end{array}$ & $\begin{array}{l}\text { Sistemas que realizam o cálculo de quantos } \\
\text { materiais de determinado tipo são necessários } \\
\text { para confecção dos produtos e em que } \\
\text { momento eles devem chegar a empresa. }\end{array}$ & $\begin{array}{c}\text { Requer para obtenção de um bom desempenho, um planejamento } \\
\text { e controle estruturado da produ-ção, em níveis de longo, médio e } \\
\text { curto prazo. Na construção civil, no entanto, não há um elevado } \\
\text { grau de padronização, cada obra é diferente, com materiais } \\
\text { diversos, o que dificulta a implantação e o desempenho do MRP } \\
\text { (VIEIRA, 2006). }\end{array}$ \\
\hline
\end{tabular}

Fonte: Elaborado pelos autores (2014) com base na literatura 
De ressaltar que a introdução de novas práticas e tecnologias gerenciais deve atender às necessidades e interesses dos agentes da cadeia de suprimentos, sejam eles: escritório, obra, fornecedores e/ou clientes. Afinal, deve-se definir clara e objetivamente todas as ferramentas de gestão utilizadas para planejar e controlar as atividades realizadas, a fim de que todos desenvolvam e obtenham benefícios ao longo do processo (HAGA; SACAMANO, 2000).

\section{METODOLOGIA}

Para a concretização do objetivo deste artigo foi realizada uma pesquisa descritiva, com abordagem quantitativa em 25 construtoras brasileiras. A Tabela 2 resume as características das organizações pesquisadas e as respectivas ocorrências de destaque (em percentual).

Tabela 2 - Perfil das empresas pesquisadas

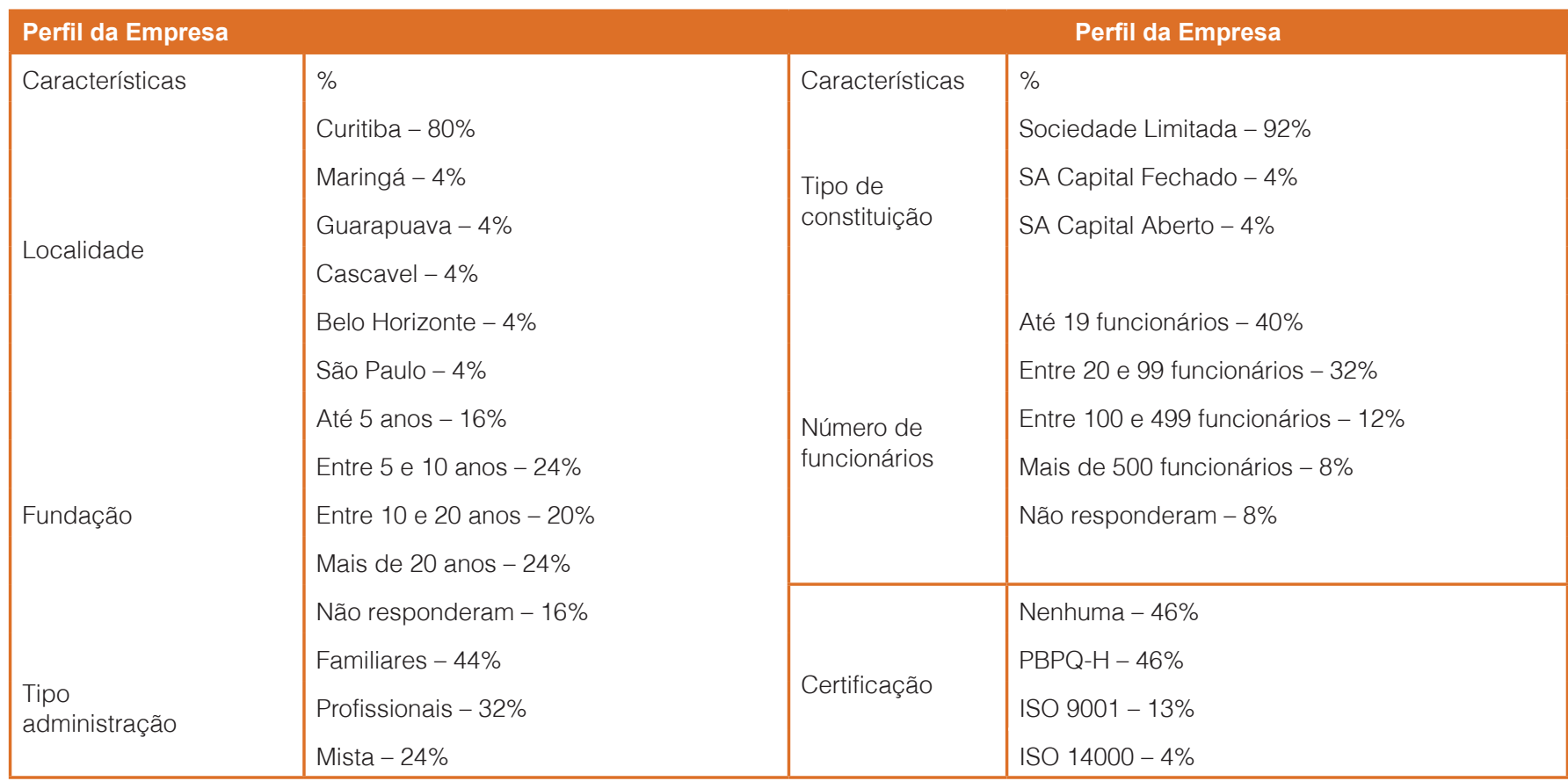

Fonte: Autores (2014)

O público alvo definido foi de empresas da construção civil, mais especificamente empresas de incorporação de empreendimentos imobiliários e de construção de edifícios. Optou-se por uma amostragem não probabilística por conveniência, empresas que retornaram ao apelo da pesquisa. Dessa forma, a amostra, na presente pesquisa, não pode ser considerada como representativa da população, as extrapolações e generalizações não são possíveis.

Para a coleta de dados foi utilizado o método survey com aplicação de um questionário, o qual foi desenvolvido a partir da adaptação dos instrumentos de pesquisa testados e utilizados no PRONUX, estabelecendo-se, também, relação com o referencial teórico pesquisado e com o objeto de pesquisa. Esclareça-se que o PRONUX trata-se de um projeto financiado pelo
Conselho Nacional de Desenvolvimento Científico e Tecnológico (CNPQ) que tem por objetivo desenvolver um sistema integrado de gestão da produção que seja adequado às necessidades específicas das micro e pequenas empresas brasileiras.

O questionário foi subdividido em três partes. A primeira parte refere-se ao perfil da organização (8 questões abertas), a segunda aborda as características da cadeia de suprimentos das organizações (34 questões fechadas) e a terceira apresenta as ferramentas de tecnologia da informação (TI) na cadeia de suprimentos (64 questões fechadas).

Para transformar as variáveis qualitativas em quantitativas utilizou-se da escala de diferencial semântica que compreende um par de adjetivos ou 
frases antônimas. Os entrevistados distribuíram as respostas em uma escala de 1 a 7 pontos. Segundo Hair Jr. et al. (2005), o número de categorias mais apropriado é de no máximo 7 níveis.

Com a finalidade de sintetizar uma série de valores de mesma natureza, permitindo uma visão global de sua variação, as respostas do questionário foram analisadas descritivamente. A análise descritiva tem por objetivo analisar e descrever as características ou relações entre os fenômenos analisados (HAIR JR. et al., 2005). Para facilitação da análise aplicou-se medidas que resumem ainda mais os dados obtidos, apresentando valores que sejam representativos da série toda. Empregou-se dois tipos de medidas: as de posição central (moda e média) que representam a tendência dos dados se agruparem em torno de valores centrais e as de dispersão (desvio padrão) que descrevem a tendência desses valores partirem de valores centrais.

\section{RESULTADOS E DISCUSSÕES}

Com vistas a atender o objetivo deste artigo as respostas do questionário foram analisadas descritivamente. A Tabela 3 traz os resultados obtidos no tocante à caracterização da cadeia de suprimentos, mais especificamente em relação aos fornecedores (variáveis P1 a P13), às características das empresas pesquisadas (variáveis P14 a P31) e ao nível de relacionamento com os clientes (variáveis P32 a P34).

Tabela 3 - Resultados - Caracterização da cadeia de suprimentos (fornecedores, empresas e clientes)

\section{Resultados - Fornecedores}

Item Pergunta

\begin{tabular}{|c|c|c|c|c|}
\hline P1 & A empresa tem processo de seleção de fornecedores de materiais/serviços? & 4,92 & 5 & 1,80 \\
\hline P2 & A empresa avalia desempenho dos fornecedores de materiais/serviços? & 5,00 & 6 & 1,73 \\
\hline P3 & Existe um relacionamento operacional com os fornecedores? & 3,96 & 6 & 1,97 \\
\hline P4 & É realizado uma pesquisa de satisfação dos fornecedores? & 3,00 & 1 & 1,85 \\
\hline P5 & A relação entre a empresa e os fornecedores é duradoura? & 5,64 & 6 & 1,11 \\
\hline P6 & Há monitoramento atividades dos fornecedores na execução dos serviços? & 5,28 & 7 & 1,74 \\
\hline P7 & Há reuniões frequentes entre os fornecedores e o setor de suprimentos e/ou o corpo técnico? & 4,32 & 5 & 1,57 \\
\hline P8 & Qual o nível de confiança da empresa em relação a seus fornecedores? & 5,52 & 6 & 1,33 \\
\hline P9 & Qual o custo da troca de fornecedor? & 3,80 & 5 & 1,41 \\
\hline P10 & O preço da matéria prima varia de um fornecedor para outro? & 3,88 & 3 & 1,65 \\
\hline P11 & A qualidade da matéria prima varia de um fornecedor para outro? & 4,42 & 5 & 1,59 \\
\hline P12 & A empresa possui alguma parceria com fornecedores de materiais? & 3,56 & 3 & 1,96 \\
\hline P13 & O fornecedor tem autonomia para a entrega de materiais sem pedidos? & 1,52 & 1 & 1,08 \\
\hline \multicolumn{5}{|c|}{ Resultados - Empresas } \\
\hline P14 & A tecnologia de execução de serviços é de difícil domínio? & 3,63 & 4 & 1,66 \\
\hline P15 & A empresa utiliza tecnologias construtivas diferenciadas? & 3,38 & 2 & 1,97 \\
\hline P16 & Qual o nível de integração entre os processos empresariais? & 4,50 & 4 & 1,44 \\
\hline P17 & Qual nível de interação entre departamentos/áreas dentro da empresa? & 5,54 & 5 & 1,06 \\
\hline P18 & A alta administração é dinâmica e aberta a novas ideias? & 5,29 & 5 & 1,43 \\
\hline P19 & A cultura organizacional é orientada à colaboração? & 5,39 & 6 & 1,16 \\
\hline P20 & A empresa investe em capital intelectual? & 3,70 & 3 & 1,94 \\
\hline P21 & Qual o nível de controle exercido sobre as atividades / funcionários? & 5,04 & 5 & 1,04 \\
\hline P22 & Há integração no planejamento de empreendimentos entre o setor comercial e a execução? & 5,13 & 6 & 1,49 \\
\hline P23 & Há controle dos prazos de execução e de entregas dos empreendimentos? & 5,75 & 6 & 1,33 \\
\hline
\end{tabular}




\begin{tabular}{|l|l|l|l|l|}
\hline P24 & Há planejamento formal das instalações dos canteiros de obras? & 5,17 & 6 & 1,40 \\
\hline P25 & A empresa tem sistema formal procedimentos de execução de serviços? & 4,54 & 6 & 2,13 \\
\hline P26 & Qual a posição da empresa em relação à redução custos nas atividades e empreendimentos? & 6,04 & 7 & 1,15 \\
\hline P27 & Qual o nível de preocupação da empresa em relação às melhorias dos processos de trabalho? & 5,63 & 7 & 1,28 \\
\hline P28 & A empresa realiza o planejamento estratégico? & 5,00 & 6 & 1,44 \\
\hline P29 & A empresa faz sistematicamente uma análise de desempenho interno com base em indicadores? & 4,38 & 6 & 2,00 \\
\hline P30 & Quando há obras simultâneas, o cronograma é realizado em conjunto? & 3,83 & 1 & 2,39 \\
\hline P31 & O gerenciamento de suprimentos de obras simultâneas é centralizado? & 4,00 & 1 & 2,49 \\
\hline Resultados - Clientes & & 4,63 & 7 & 2,46 \\
\hline P32 & A empresa tem procedimentos atender reclamações/sugestões clientes? & 4,25 & 7 & 2,47 \\
\hline P33 & É realizada uma pesquisa e análise de satisfação dos clientes? & 4,57 & 7 & 2,31 \\
\hline P34 & A empresa avalia qualidade dos seus serviços pós-vendas com clientes? & & 7 \\
\hline
\end{tabular}

Fonte: Autores (2014)

Extrai-se da análise da Tabela 3 que as empresas pesquisadas afirmam ter relações duradouras com seus fornecedores (média 5,64) e confiarem neles, entretanto indicam o predomínio da não existência de autonomia para a entrega de materiais sem pedido $(1,52)$. Em relação a longevidade das relações entre empresas e fornecedores apenas 24\% atestam ter relações que duram mais do que 5 anos, provavelmente isso ocorra porque, em geral o período de execução de um empreendimento é de menos de 5 anos.

As empresas caracterizam-se pela pouca intensidade de relacionamento operacional (média 3,96), pouca realização de pesquisa de satisfação dos fornecedores (média 3,00), e com parcerias abaixo da média com fornecedores (média 3,56). Destaque-se que 32\% das empresas não realizam nenhuma pesquisa de satisfação, apesar de avaliarem seu desempenho, - que denota um pensamento individualista das construtoras, posicionamento contrário ao processo de parcerias. As respostas reforçam um processo mediano de seleção (média 4,92), de avaliação do desempenho (média 5,00) e de monitoramento das atividades dos fornecedores (média 5,28), indicando que há espaço para melhorias nos processos citados.

Note-se que as construtoras pesquisadas estão focadas na redução de custos em suas atividades e empreendimentos (média 6,04) e na melhoria dos processos de trabalho (média 5,63). Entretanto, apesar de se mostrarem com uma preocupação elevada na redução de custos e na melhoria dos processos de trabalho, é moderado para baixo o uso de tecnologias construtivas diferenciadas (média 3,38 ). As organizações, na sua maioria, exercem um controle mais incisivo sobre suas atividades e sobre seus funcionários (média 5,04), controle quase intensivo dos prazos de execução e de entrega dos empreendimentos (média 5,75). Em contrapartida, $16 \%$ dos respondentes não fazem uso de indicadores para a análise de desempenho interno (média 4,58).

Revela-se alta a troca de informações entre os departamentos (média 5,54), uma integração significativa entre os setores comercial e de execução no momento do planejamento de seus empreendimentos (média 5,13) e nível mediano de integração entre os processos empresariais (média $4,5)$. Pouco menos da metade das empresas (44\%) assinalou que fazem o planejamento formal do canteiro de obras (P24) de maneira quase integral (média 5,17), o cronograma e o gerenciamento de suprimentos, no caso de obras simultâneas, são realizados de forma mais individualizada e descentralizada (44\%) do que em conjunto e centralizada (média 3,83, média 4,00, respectivamente).

Finalizando a investigação da cadeia de suprimentos das organizações, em relação ao nível de relacionamento com os clientes, ficou claro uma divisão de posicionamento quanto a esses processos, mostrando uma variedade na forma em que as empresas interagem com seus clientes e a importância dada a eles (média 4,00 e desvio padrão 2,5). 
Na parte 3 do questionário, para investigar o uso das ferramentas/práticas tecnológicas utilizadas na cadeia de suprimentos das organizações pesquisadas, sondou-se o gerenciamento de TI e do conhecimento, o EDI - internet e a extranet, o WMS, o outsourcing, o BIM, o Lean Construction e o MRP. Os resultados obtidos foram reproduzidos na Tabela 4.

Tabela 4 - Resultados - práticas e ferramentas tecnológicas utilizadas na cadeia de suprimentos

\begin{tabular}{|c|c|c|c|c|}
\hline \multicolumn{5}{|c|}{ Resultados - Gerenciamento do Tl e do Conhecimento } \\
\hline Item & Pergunta & Média & Moda & $\begin{array}{l}\text { Desvio } \\
\text { Padrão }\end{array}$ \\
\hline P35 & A empresa possui um departamento específico de Tecnologia da Informação? & 2,88 & 1 & 2,05 \\
\hline P36 & $\begin{array}{c}\text { É possível acessar informações da empresa por um sistema de TI, distinguindo hierarquicamente os } \\
\text { usuários? }\end{array}$ & 4,52 & 7 & 2,49 \\
\hline P37 & Há processos verificação necessidades, avaliação e melhoria sistemas TI? & 3,20 & 1 & 2,00 \\
\hline Item & $\begin{array}{c}\text { Resultados - Gerenciamento do Tl e do Conhecimento } \\
\text { Pergunta }\end{array}$ & Média & Moda & $\begin{array}{l}\text { Desvio } \\
\text { Padrão }\end{array}$ \\
\hline P38 & A empresa busca manter-se atualizada, traz melhores soluções em TI? & 4,00 & 5 & 2,02 \\
\hline P39 & $\begin{array}{c}\text { A empresa adota algum procedimento para que ocorra ou para intensificar o compartilhamento do } \\
\text { conhecimento individual/coletivo? }\end{array}$ & 3,20 & 2 & 1,55 \\
\hline P40 & $\begin{array}{c}\text { Os conhecimentos criados são transformados em algo concreto (produtos ou soluções reutilizáveis) e } \\
\text { são disseminados na organização? }\end{array}$ & 3,60 & 5 & 1,80 \\
\hline P41 & $\begin{array}{l}\text { Os colaboradores possuem grande variedade de competências e experiências, qualificando-os a lidar } \\
\text { com os desafios impostos pelo ambiente? }\end{array}$ & 4,08 & 6 & 1,85 \\
\hline P42 & $\begin{array}{l}\text { Existe um sistema de recompensa ou incentivo para aqueles que contribuem com suas ideias ou } \\
\text { apresentam sugestões? }\end{array}$ & 2,52 & 1 & 1,64 \\
\hline P43 & $\begin{array}{l}\text { A organização é tolerante aos erros cometidos pelos colaboradores e receptível aos pedidos de } \\
\text { ajuda? }\end{array}$ & 5,08 & 7 & 1,71 \\
\hline P44 & A organização costuma registrar as experiências que deram certo? & 3,84 & 5 & 2,13 \\
\hline P45 & Esses registros são consultados para resolução de problemas similares futuros e tomadas de decisão? & 3,84 & 1 & 2,23 \\
\hline P46 & Os processos são mapeados? & 3,88 & 6 & 2,19 \\
\hline P47 & Por meio do mapeamento de processos a empresa identifica as interferências entre as atividades? & 3,63 & 1 & 2,32 \\
\hline \multicolumn{5}{|c|}{ Resultados - EDI (Internet e Extranet) } \\
\hline P48 & $\begin{array}{l}\text { A empresa possui um processo de comunicação intra-organizacional por meio de sistema/software/ } \\
\text { rede? }\end{array}$ & 3,79 & 1 & 2,48 \\
\hline P49 & Como avalia a importância de trocas de informações claras e disponíveis dentro da empresa? & 5,58 & 7 & 1,79 \\
\hline P50 & $\begin{array}{c}\text { No caso de possuir um sistema/software/rede para comunicação intra-organizacional, o sistema traz } \\
\text { benefícios facilmente perceptíveis? }\end{array}$ & 4,95 & 7 & 2,38 \\
\hline P51 & $\begin{array}{c}\text { A empresa tem um processo de comunicação externa com fornecedores, clientes ou filiais através de } \\
\text { algum sistema/software/rede? }\end{array}$ & 2,83 & 1 & 2,15 \\
\hline P52 & Como avalia a comunicação com os fornecedores da empresa? & 4,92 & 5 & 1,47 \\
\hline P53 & Possuem algum padrão formal de comunicação com fornecedores externos? & 5,21 & 7 & 2,06 \\
\hline P54 & A empresa possui algum tipo de sistema/software/rede para emitir ordens ou pedidos de compra? & 4,71 & 7 & 2,66 \\
\hline P55 & Com que frequência ocorre erros nas ordens de compra? & 5,75 & 7 & 1,48 \\
\hline P56 & Na falta de suprimentos na obra, este é reposto com rapidez? & 4,83 & 5 & 1,31 \\
\hline
\end{tabular}


Resultados - WMS

\begin{tabular}{|c|c|c|c|c|}
\hline P57 & Qual a importância de se praticar uma boa gestão de armazém? & 6,38 & 7 & 0,88 \\
\hline P58 & A empresa tem a preocupação com o gerenciamento de armazéns? & 5,75 & 7 & 1,45 \\
\hline P59 & A empresa tem algum tipo de sistema de gerenciamento de armazém? (WMS) & 3,04 & 1 & 1,76 \\
\hline P60 & A empresa possui um armazém central para toda a construtora? & 2,61 & 1 & 2,13 \\
\hline P61 & É realizado o gerenciamento integrado do almoxarifado de distintas obras? & 2,57 & 1 & 1,75 \\
\hline P62 & $\begin{array}{l}\text { Qual o nível de integração entre o sistema de gerenciamento de armazém (ex. WMS) e as outras } \\
\text { ferramentas de gestão da empresa (ex. ERP)? }\end{array}$ & 2,43 & 1 & 1,75 \\
\hline
\end{tabular}

Resultados - Outsourcing

\begin{tabular}{|c|c|}
\hline P63 & É política da empresa terceirizar alguns serviços da fase de produção? \\
\hline P64 & Qual o nível de terceirização dos serviços? \\
\hline P65 & A empresa considera os subempreiteros/terceirizados como parceiros? \\
\hline P66 & Há processo de avaliação coerente sobre a conveniência da terceirização? \\
\hline P67 & Há critério/método para a avaliação da contratação dos subempreiteiros? \\
\hline P68 & Existe um processo de avaliação da qualidade dos subempreiteiros? \\
\hline
\end{tabular}

Resultados - BIM

\begin{tabular}{|c|c|c|c|c|}
\hline P69 & Qual o nível conhecimento gestores sobre a tecnologia BIM para utilização no processo construtivo? & 3,83 & 2 & 1,83 \\
\hline P70 & Qual grau de utilização do BIM no processo construtivo/gerencial empresa? & 2,63 & 1 & 2,06 \\
\hline P71 & A empresa realiza a compatibilização de projetos das obras? & 4,52 & 5 & 2,00 \\
\hline P72 & A empresa identifica o BIM como importante para a gestão de suprimentos? & 4,08 & 4 & 1,98 \\
\hline
\end{tabular}

\section{Resultados - Lean Construction}

\begin{tabular}{|c|c|c|c|c|}
\hline P73 & Qual o nível de mecanização no transporte de materiais? & 4,63 & 7 & 1,71 \\
\hline P74 & São planejados/realizados controles de qualidade durante a execução da obra? & 5,57 & 6 & 1,20 \\
\hline P75 & Qual nível de padronização nos insumos? & 5,13 & 6 & 1,22 \\
\hline P76 & Qual nível de padronização dos processos para execução dos serviços? & 5,17 & 5 & 1,24 \\
\hline P77 & Qual o tamanho dos lotes de serviços? & 4,27 & 4 & 1,24 \\
\hline P78 & Qual o tamanho das equipes responsáveis pelos lotes? & 3,32 & 3 & 1,52 \\
\hline P79 & A empresa se preocupa em reduzir os tempos de espera de funcionários "entre frentes" de trabalho? & 5,48 & 7 & 1,50 \\
\hline P80 & A empresa se preocupa em eliminar interdependências/alienação atividades? & 5,29 & 6 & 1,68 \\
\hline P81 & Qual o nível de beneficiamento dos produtos/suprimentos fora da obra? & 4,13 & 5 & 1,73 \\
\hline
\end{tabular}

\section{Resultados - Lean Construction}

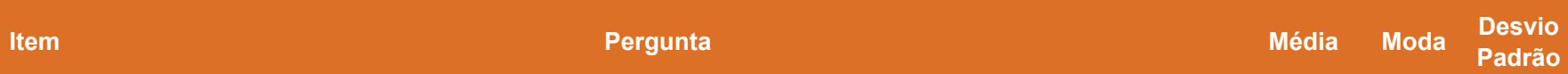

\begin{tabular}{|c|c|c|c|c|}
\hline P82 & Qual o nível de especialização da mão-de-obra? & 4,29 & 3 & 1,27 \\
\hline P83 & São oferecidas flexibilizações dos produtos aos clientes? & 4,04 & 5 & 1,90 \\
\hline P84 & É política da empresa divulgar p/ os clientes/funcionários/terceiros o andamento da obra e produção? & 4,88 & 6 & 1,57 \\
\hline P85 & A empresa se preocupa com a organização e limpeza da obra? & 5,83 & 7 & 1,34 \\
\hline P86 & A empresa realiza reuniões equipes de produção/gerência melhoria contínua? & 5,08 & 6 & 1,59 \\
\hline P87 & Há preocupação com racionalização processos e redução perdas/desperdícios? & 5,21 & 6 & 1,64 \\
\hline P88 & É politica empresa buscar inovações tecnológicas melhores processos, produção, fluxo informações? & 4,79 & 5 & 1,64 \\
\hline P89 & A construtora visita obras ou recolhe informações de outras empresas do setor de sucesso? & 4,09 & 3 & 1,78 \\
\hline
\end{tabular}


Resultados - MRP

\begin{tabular}{|c|c|c|c|c|}
\hline P90 & A empresa tem processo cálculo prévio quantidade de materiais p/ obras? & 5,38 & 5 & 1,35 \\
\hline P91 & $\begin{array}{r}\text { Há processo de armazenamento, por meio de banco de dados, dos históricos de pedidos de materiais } \\
\text { para possíveis previsões de pedidos? }\end{array}$ & 5,08 & 7 & 2,15 \\
\hline P92 & Os estoques são consultados antes do pedido de materiais? & 5,54 & 7 & 1,61 \\
\hline P93 & $\begin{array}{r}\text { Existe um planejamento de pedidos de materiais de maneira a garantir que os insumos estejam na } \\
\text { obra na quantidade correta e no tempo certo? }\end{array}$ & 4,91 & 6 & 1,59 \\
\hline P94 & $\begin{array}{r}\text { É calculado previamente a quantidade de mão de obra, equipamentos e ferramentas para cumprir o } \\
\text { programa em seus respectivos prazos? }\end{array}$ & 5,17 & 5 & 1,4 \\
\hline P95 & Existe padronização dos insumos dos empreendimentos da construtora? & 4,82 & 4 & 1,22 \\
\hline P96 & Existe planejamento, programação e controle da produção bem estruturado? & 4,42 & 5 & 1,74 \\
\hline P97 & A empresa possui ajuda de algum sistema para padronizar, automatizar e controlar esses processos? & 3,96 & 1 & 2,18 \\
\hline P98 & Qual a importância p/ empresa sistemas planejamento, controle e automação de processos internos? & 4,33 & 5 & 2,01 \\
\hline
\end{tabular}

Fonte: Autores (2014)

Das respostas obtidas na Tabela 4 é possível averiguar que, em geral, as empresas não têm um departamento de TI específico (média 2,88), e, quando o têm não o avaliam e, se os avaliam, não o fazem periodicamente (média 3,2). Em contrapartida, quanto à atualização dos sistemas de $\mathrm{TI}$, as organizações buscam, medianamente, atualizações (média 4). Outro ponto a destacar é o mapeamento dos processos que tem por finalidade a melhoria dos processos, identificando as interferências entre as atividades realizadas pela organização é realizado abaixo do nível médio nos respondentes (média 3,88).

Em relação ao gerenciamento do conhecimento, as organizações se mostram tolerantes aos erros e receptíveis aos pedidos de ajuda (média 5,08), contudo não registram as experiências proveitosas $(3,84)$. Ressalte-se que os respondentes não costumam adotar procedimentos para intensificar o compartilhamento do conhecimento (média 3,2), tampouco transformam e disseminam o conhecimento (média 3,60) e, em geral, não adotam sistemas de recompensas e incentivo para intensificar o compartilhamento do conhecimento (média 2,52).

É possível identificar, também, que as construtoras investigadas consideram a troca de informações de fundamental importância para organização (média 5,58), entretanto apenas 32\% dos respondentes possuem sistema de comunicação interna altamente desenvolvido (média 3,79). As construtoras descrevem frequências consideráveis de erros nas ordens de compra (média 5,75), o que é corroborado pela existência de sistema para emissão de pedidos de compra medianamente desenvolvido (média 4,71) e pela não existência de processo de comunicação externa por meio de um sistema (média 2,83).

As empresas estão cientes de que uma boa gestão de almoxarifados e estoques é muito importante, fundamental, entretanto, $50 \%$ delas relatam possuir um sistema pouco desenvolvido ou não possuir sistemas de gerenciamento de armazéns e 20\% possuem, no máximo, um sistema medianamente desenvolvido. Este fato evidencia que esses sistemas foram desenvolvidos dentro das próprias empresas e que, provavelmente, não são programas como o WMS, específicos para essas tarefas e completamente automatizados. Outro ponto a destacar é que poucos respondentes possuem um almoxarifado central e realizam um gerenciamento integrado do almoxarifado de diferentes obras.

As maiorias das construtoras pesquisadas terceirizam sua produção (média 5,38), considerando os subempreiteiros parceiros $(5,46)$ e buscando terceirizar seus serviços a mais de uma subempreiteira $(4,33)$. Apesar do alto índice de terceirização, as organizações apresentam um comportamento mediano quando questionadas sobre um processo de avaliação da coerência em terceirizar $(4,33)$. O mesmo posicionamento se repete em relação a método e existência de avaliação dos subempreiteiros (4,54, 
4,46, respectivamente).

O nível de conhecimento dos gestores acerca da tecnologia BIM é regular, apenas $12 \%$ dos respondentes afirmam ter conhecimento mais aprofundado desta tecnologia. Os respondentes, em média, não identificam a importância e a utilidade do BIM para a gestão de suprimentos, apesar de $52 \%$ dos entrevistados relatarem a realização de compatibilização de projetos.

De observar (Tabela 5) que as organizações pesquisadas preocupam-se com a organização e limpeza da obra (média 5,83), planejam e realizam controles de qualidade (média 5,57) e buscam reduzir o tempo de espera "entre frentes" de trabalho (média 5,48). Demonstram, também, preocupação em eliminar interdependências de atividades (média 5,29) e em racionalizar processos com o objetivo de reduzir perdas e desperdícios (média 5,21). Associados a estes resultados, um pouco acima da média estão os níveis de padronização dos insumos (média 5,13) e dos processos para a execução dos serviços (média $5,17)$ e a realização de reuniões com equipe técnica (média 5,08).

Com relação às políticas de divulgação do andamento da obra e de busca de inovações tecnológicas, as empresas se comportam um pouco acima da média (4,88 e 4,79, respectivamente). Os respondentes posicionaram-se medianamente em relação ao nível de mecanização $(4,63)$, de especialização da mão de obra $(4,29)$ e de beneficiamento dos suprimentos fora da obra $(4,13)$. As empresas, igualmente, oferecem aos clientes um nível médio de flexibilização de seus produtos $(4,04)$.

Quanto ao MRP, observa-se que nenhuma empresa possui um software específico e apenas 36\% dispõem de sistemas ERP, porém todas as empresas praticam alguns princípios do MRP em algum nível. Os respondentes consultam os estoques nas obras antes da realização dos pedidos de materiais $(5,52)$, calculam a quantidade de materiais necessários para as obras (média 5,38) e dimensionam a necessidade de mão de obra e de ferramentas para cumprir os prazos das obras $(5,17)$. As construtoras apresentam um comportamento bem acima da média em relação à existência de planejamento de pedidos de materiais (média 4,91), de processo de armazenamento (média 5,08 ) e de padronização dos insumos (média 4,88).

\section{CONSIDERAÇÕES FINAIS}

Mediante 0 presente estudo analisou-se as características das organizações selecionadas e a utilização de ferramentas tecnológicas e práticas de gestão na cadeia de suprimentos da construção civil. Os resultados indicam que as empresas de construção civil pesquisadas estão focadas em melhorar a produtividade e a qualidade de seus produtos, mas não concentram seus esforços na melhoria de sua cadeia de suprimentos.

As construtoras mantêm um frágil relacionamento com fornecedores e clientes, afirmam confiar em seus fornecedores, entretanto não os tratam como verdadeiros parceiros, e entendem a importância dos clientes, mas não se relaciona com os mesmos. Os resultados, também, demonstram que as organizações pesquisadas investem pouco em capacitação, pesquisa e desenvolvimento e que em obras simultâneas não realizam o cronograma em conjunto e também não centralizam o gerenciamento dos suprimentos. A maioria definiu como intensa a troca de informações entre os atores da cadeia de suprimentos, uma característica clara da construção civil, porém não há integração entre eles. Poucas empresas fazem o mapeamento de processos e avaliam as interferências entre suas atividades. Relatam, em geral, que seus departamentos são integrados, contudo, há indícios de que o fluxo de informação é desordenado e mal controlado pelas empresas.

No que diz respeito às questões relacionadas ao uso de ferramentas tecnológicas e adoção de práticas de gestão aplicáveis à cadeia de suprimentos da indústria da construção civil, verifica-se uma crescente preocupação por parte das empresas pesquisadas, mas que ainda não desencadeou mudanças perceptíveis. O uso de novas tecnologias de gestão nas empresas pesquisadas, portanto, ainda é precoce e imaturo, apesar das empresas terem conhecimento 
da sua necessidade e de seus benefícios. Ademais, a maioria das organizações busca manter-se atualizada quanto às melhores soluções empresariais e se mostram abertas a inovações, apesar de relutarem em sair de sua zona de conforto.

Algumas construtoras já implantaram novas tecnologias de gestão e outras, a maioria, não, somente as conhecem e procuram utilizar seus princípios. Viera (2006) afirma que a implementação de tecnologias faz com que as empresas gerenciem de forma mais eficiente e eficaz suas cadeias de suprimentos, e, por consequência, aumentem sua produtividade, gerem um aumento de lucros e por fim ganhem um maior reconhecimento no setor.

Quanto aos sistemas MRP, pôde-se constatar que nenhuma empresa tem o software específico, porém algumas adquiriram módulos de MRP dentro dos seus sistemas ERP. Entre as empresas que o adquiriram, nem todas utilizam seus módulos de maneira correta, porém pode-se notar que investem tempo e recursos para a melhoria na utilização desta ferramenta. Por outro lado, nas empresas que não adquiriram o módulo de MRP, nota-se que boa parte delas já pratica alguns dos princípios de MRP, como cálculo prévio das quantidades de materiais e mão-de-obra, além da realização de planejamento e controle sobre a produção.

Conclui-se que uma mudança no posicionamento das organizações pesquisadas em relação ao gerenciamento de sua cadeia de suprimentos se mostra necessária para que para que possam obter ganhos efetivos de produtividade.

\section{REFERÊNCIAS}

[1] BARTHOLDI, J. J. e HACKMAN, S. T. Warehouse \& Distribution Science. Atlanta, 2011.

[2] BENTO, A. R., TOMBOSI, S. L. e PRUS, E. M. A tecnologia EDI aplicada como ferramenta para controle logístico da produção da indústria automotiva. $68^{\circ}$ Congresso Anual da ABM. Belo Horizonte, 2012. Disponível em: <http://www. santacruz.br/v4/download/a-tecnologia-edi-aplicada.pdf. $>$. Acesso em: 30 set. 2014
[3] CASAROTTO FILHO, N. Ante-Projeto industrial: das estratégias empresariais à Engenharia. 1995. Tese (Doutorado de Engenharia de Produção). Programa de Pós-Graduação em Engenharia de Produção. Universidade Federal de Santa Catarina. Florianópolis, 1995.

[4] EASTMAN, C., TEICHOLZ, P., SACKS, R. e LISTON, K. BIM Handbook - A guide to building information modeling for owners, managers, designers, engineers, and contractors. 2 ed. Nova York: John Wiley \& Sons Inc, 2008.

[5] EDUM-FOTWE, F. T., THORPE, A. e McCAFFER, R. Information procurement practices of key actors in construction supply chains. European Journal of Purchasing \& Supply Management. vol. 7, setembro, p. 155-164, 2001. Disponível em:

<http://www.sciencedirect.com/science/article/pii/ S0969701200000241>. Acesso em: 14 out. 2014

[6] ETCHALUS, J. M. et al. Aspectos da tecnologia da informação em pequenas empresas da Construção Civil. Synergismus scyentifica UTFPR, Pato Branco, 2006. Disponível em: <http://pessoal.utfpr.edu.br/arildo/arquivos/ Artigo\%20Pato\% 20Branco.pdf>. Acesso em: 13 nov. 2010.

[7] FERREIRA, A. V. e ZANCUL, E. Estudos sobre produtividade na construção civil: desafios e tendências no Brasil. Ernst \& Young, 2014. Disponível em:

<http://www.ey.com/Publication/vwLUAssets/EY_Estudo_ Produtividade_na_Construcao_Civil/\$FILE/Estudo_Real_ Estate.pdf>. Acesso em: 20 set. 2014

[8] GRENHO, L. F. S. Last Planner System e Just-in-Time na Construção. 126 f. Dissertação (Mestrado em Engenharia Civil) - Faculdade de Engenharia da Universidade do Porto, Porto, 2009

[9] HAGA, H. C. R. e SACOMANO, J. B. Gestão da Rede de Suprimentos na Construção Civil: Integração de um Sistema de Administração da Produção. Universidade de São Paulo. São Carlos, 2000. Disponível em: <http://www.abepro.org.br/ biblioteca/ENEGEP1997_T3102.PDF>. Acesso em: 18 set. 2014

[10] HAIR JR., J. F. et al. Fundamentos de métodos de pesquisa em administração. Porto Alegre: Bookmann, 2005.

[11] IRIZARRY, J., KARAN, E. P. e JALAEI, F. Integrating BIM and GIS to improve the visual monitoring of construction supply chain management. Automation in Construction 31. p. 241-254, 2013. Disponível em: <http://www.researchgate. net/publication/257371573_Integrating_BIM_and_GIS_to_ improve_the_visual_monitoring_of_construction_supply_ chain_management>. Acesso em: 14 out. 2014

[12] ISATTO, E. L. Proposição de um modelo teóricadescritivo para a coordenação inter-organizacional de cadeias de suprimentos de empreendimentos de construção. 305 f. Tese (Doutor em Engenharia) - Universidade Federal do Rio Grande do Sul, Porto Alegre, 2005. 
[13] KOSKELA, L. Application of the new production philosophy to construction. Stanford University, 1992.

[14] NASCIMENTO, L. A.; SANTOS, E. T. A indústria da construção na era da informação. Revista Ambiente, v.3, n.1, p. 69-81, 2003. Disponível em:

<http://www.antac.org.br /ambienteconstruido/pdf/revista/ artigos/Doc11178.pdf > Acesso em: 06 nov. 2010.

[15] OLIVEIRA, J. L. d. e GAVIOLI, M. K. A importância da gestão da Cadeia de Suprimentos na Construção Civil. Faculdade de Tecnologia de Jundiaí. Jundiaí, 2012. Disponível em:

<http://www.centropaulasouza.sp.gov.br/pos-graduacao/ workshop-de-pos-graduacao-e-pesquisa/007workshop-2012/workshop/trabalhos/servenggest/aimportancia-da.pdf>. Acesso em: 04 out. 2014

[16] OLIVEIRA, M. B. d. e LONGO, O. C. Gestão da Cadeia de Suprimentos. IV Congresso Nacional de Excelência em Gestão. VI Congresso de Excelência em Gestão. Niterói, 2008. Disponível em:

<http://www.novomilenio.br/cursos/Artigos/ Gest $\%$ C $3 \%$ A $30 \% 20$ da $\% 20$ Cadeia $\% 20$ de $\% 20$ Suprimentos $\% 20$ na $\% 20$ Industria $\% 20$ da $\% 20$ Constru\%C3\%A7\%C3\%A30\%20Civil.pdf>. Acesso em: 19 set. 2014

[17] PORTER, M. E. Competitive advantage of nations: creating and sustaining superior performance. Simon and Schuster, 2011.

[18] RODRIGUES, M. P.P. Identificação de estratégias de ação para implantação de sistemas de gestão integrada um estudo exploratório na construção civil. 2002. Dissertação de Mestrado, Programa de Pós-Graduação em Engenharia de Produção, Universidade Federal de Santa Catarina, Florianópolis, 2002.
[19] SALLABERRY, C. R. Implementação de um sistema ERP em uma empresa construtora: impactos no processo de aquisição de materiais. 2009. 64f. Trabalho de Conclusão de Curso (Diplomação em Engenharia Civil) - Departamento de Engenharia Civil, Universidade Federal do Rio Grande do Sul, Porto Alegre, 2009.

[20] SANTOS, A. P. L. Modelo procompras: formulação, implantação e avaliação da compra pró-ativa na construção de edifícios. 2006. Tese de Doutorado, Programa de PósGraduação em Engenharia Civil [PPGEC], Universidade Federal de Santa Catarina, Florianópolis, 2006.

[21] SIMCHI-LEVI, D., KAMINSKY, P., \& SIMCHI-LEVI, E. Cadeia de suprimentos projeto e gestão: conceitos, estratégias e estudos de caso. 3 ed., São Paulo: Bookman / Artmed, 2012.

[22] TONIN, L. A. P. e SCHAEFER, C. O. Diagnóstico e aplicação da Lean Construction em construtora. XXXIII ENCONTRO NACIONAL DE ENGENHARIA DE PRODUCAO. Salvador, 2013. Disponível em: <http://www.abepro.org. br/biblioteca/enegep2013_TN_STP_177_013_21856.pdf>. Acesso em: 12 out. 2014.

[23] VIEIRA, H. F. Logística aplicada à Construção Civil: como melhor o fluxo de produção nas obras. 1 ed. São Paulo: Editora Pini, 2006.

[24] XUE, X., LI, X., SHEN, Q., \& WANG, Y. Anagent-based framework for supply chain coordination in construction. Automation in Construction, 14, 413-430, 2004. 


$$
\text { Alutary }
$$




\section{Marcelo Ruy (Organizador)}

Possui graduação em Engenharia de Produção Mecânica - USP - Escola de Engenharia de São Carlos (1997), mestrado em Engenharia de Produção pela Universidade Federal de São Carlos (2002) e doutorado em Engenharia de Produção pela Universidade Federal de São Carlos (2011). Tem experiência na área de Engenharia de Produção, com ênfase nos seguintes temas: Estatística, Qualidade e Desenvolvimento de Produtos.

\section{Adriana Carvallho Pinto Vieira}

Possui graduação em Direito pela Universidade Estadual de Ponta Grossa (1993), mestrado em Direito pela Universidade Metodista de Piracicaba (1999) e doutorado em Desenvolvimento Econômico pela Universidade Estadual de Campinas (2009). Professor disciplinas (Pesquisa, Desenvolvimento e Inovação - PDI e Informações e Conhecimento nas Organizações - ICO/PPGDS), Direito Comercial Comparado (Curso Administração/COMEX) da UNESC. Líder do Grupo de Pesquisa: Propriedade Intelectual, Desenvolvimento e Inovação (PIDI). Atualmente é pesquisador colaborador da Universidade Federal do Estado do Rio de Janeiro, colaborador da Universidade do Contestado e professor titular da Universidade do Extremo Sul Catarinense. Tem experiência na área de Direito e Administração, com ênfase em Sistema de Propriedade Intelectual, atuando principalmente nos seguintes temas: sistema de propriedade intelectual, indicação geográfica, estudos jurídicos (direito consumidor), gestão da inovação, agronegócio, cadeias alimentares e biotecnologia, comércio exterior e negócios internacionais.

\section{Aguinaldo Eduardo de Souza}

Possui graduação em Administração de empresas, MBA em Gestão Portuária Infraestrutura, logística e Negociação, MBA em Gestão Empresarial com ênfase em Gerenciamento de Projetos, Especialização em Docência do Ensino Superior e Mestrando em Engenharia da Produção pela Universidade Paulista (UNIP). Participa como membro do Grupo de Pesquisa em Redes de Suprimentos (RESUP), Estudo das Redes Produtivas do Agronegócio, abrangendo a linha de pesquisa em Logística e Redes de Suprimentos. Vivência profissional mais de 15 anos na área de Logística Portuária e Comércio Exterior. Atualmente atua como docente do ensino superior na CEETEPS.

\section{Alcione Lino de Araújo}

Doutora em Engenharia de Produção pela Universidade Tecnológica Federal do Paraná (UTFPR). Mestre em Engenharia de Produção pela Universidade Tecnológica Federal do Paraná (UTFPR). Especialista em Gestão de Pessoas e Administração Hospitalar. Possui graduação em Administração de Empresas pela Universidade Estadual da Paraíba. Atualmente é Professora do Ensino Básico, Técnico e Tecnológico do Instituto Federal do Maranhão. Tem experiência na área de Administração, atuando principalmente nos seguintes temas: qualidade, gestão de estoque, logística, administração de serviço. 


\section{Aldo Braghini Junior}

Possui graduação em Engenharia Mecânica pela Universidade Estadual Paulista Júlio de Mesquita Filho (1995), mestrado (1998) e doutorado (2002) em Engenharia Mecânica pela Universidade de São Paulo e pós-doutorado em Engenharia Mecânica (2005) pela Universidade Estadual de Campinas. É Professor da Universidade Tecnológica Federal do Paraná no Departamento de Engenharia Industrial onde trabalha com desenvolvimento de produto desde (2005). Na pesquisa atua em linhas de pesquisa tanto na Engenharia Mecânica (cutting tools wear; cutting fluids; milling; drilling; turning; stainless steel; hard materials machining) quanto na Engenharia Industrial (product development; fuzzy front end; development methodology; conceptual project;). Orienta dissertações desde 2007 e teses desse 2012.

\section{Ana Caroline Dzulinski}

Professora de Magistério Superior Substituto do departamento de Engenharia de Produção da Universidade Tecnológica Federal do Paraná (Ponta Grossa, Paraná); Doutoranda (2016) em Engenharia de Produção pela Universidade Tecnológica Federal do Paraná (Ponta Grossa, Paraná), do grupo de pesquisa de Desenvolvimento de Produtos e Processos de Manufatura; Formação obtida na Universidade Tecnológica Federal do Paraná (UTFPR), Campus Ponta Grossa (PR): Mestrado em Engenharia de Produção (2014 - 2016): Grupo de pesquisa de Desenvolvimento de Produtos e Processos de Manufatura; Pós- Graduada em Gestão Industrial - Produção e Manutenção (2012) Graduada em Engenharia de Produção em Controle e Automação (2007 - 2011) Graduada em Tecnologia em Fabricação Mecânica (2012 - 2017). Experiência Profissional: Trabalhou na Indústria de 2011 (Agosto) a 2013 (Outubro) na área de desenvolvimento de novos produtos e processos de manufatura do segmento metalmecânico e ferramentas.

\section{Ana Rita Schneider Dias}

Graduada em Administração pelo Centro Universitário Franciscano (2011). Pós-graduada em Gestão de Finanças e da Informação pela Faculdade Palotina - FAPAS (2013). Atualmente, está cursando MBA em Finanças e Controladoria pela UNOPAR (2017).

\section{Andersson Alves da Silva}

Graduado em Engenharia de Produção Mecânica pela Universidade Regional do Cariri (URCA) (2012-2017). Foi Coordenador Institucional na Voitto Treinamento e Desenvolvimento (2015); Bolsista de Extensão com o Projeto: Resíduos Sólidos e a Sustentabilidade do Planeta (2016); Monitor da disciplina de "Resistência dos Materiais" (2015).

\section{André Cristiano Silva Melo}

"Professor Titular da área de Suprimentos e Coordenador dos Programas de Pós-Graduação Stricto Sensu do CCNT/UEPA. Engenheiro Mecânico pela UFPA, Mestre e Doutor em Engenharia de Produção pela COPPE/UFRJ. Atualmente professor de disciplinas da área de logística em cursos de graduação e pós-graduação da UEPA." 


\section{André Luis Almeidla Bastos}

É Engenheiro Mecânico, com especialização em Engenharia do Produto e Processo (UFSC), mestre e doutor em Engenharia de Produção (UFSC). É professor universitário de cursos de graduação e pós-graduação nos cursos de Engenharia de Produção e Administração. É pesquisador líder do grupo vinculado ao CNPq denominado Núcleo de Estudos em Gestão e Desenvolvimento de Produtos e Processos. Atuou em diversos setores da organizações produtivas, tais como: PPCP, Engenharia de Produto, Qualidade, Marketing, Suprimentos e Produção. Autor de dezenas de artigos publicados em congressos nacionais e internacionais.

\section{Andrea Roseli Moreira Cruz Jankoski}

Possui graduação em Bacharel em Ciências Econômicas pela Universidade Federal do Paraná (1997). Especialista em Projetos Empresarias Públicos e Privados (1998), Especialista em Informática - Tecnologia da Informação (2002) e Especialista em Desenvolvimento Econômico (2013) pela Universidade Federal do Paraná, Mestre em Planejamento e Governança Pública pela Universidade Tecnológica Federal do Paraná. É servidora pública da Universidade Federal do Paraná desde 1992.

\section{Andreia Maria Berto}

Graduada em Administração Hospitalar pelo Centro Universitário São Camilo (2000), MBA em Marketing pela Fundação Getúlio Vargas, Mestre em Gestão de Negócios pela Universidade Católica de Santos (2009) e doutoranda em Administração pela UFSC - Universidade Federal de Santa Catarina. Atualmente é professora tutora da Fundação Getúlio Vargas, consultora hospitalar na Pró-Sáude Assoc. Beneficente da Ass. Social e Hospitalar e integrante do Núcleo Interdisciplinar de Estudos em Gestão da Produção e Custos da UFSC. Experiência na área de Administração, com ênfase em Administração Hospitalar, atuando principalmente com os seguintes temas: planejamento estratégico, administração hospitalar, acreditação hospitalar.

\section{Andressa Carina Waideman Pedrezini}

Engenheira de Produção Agroindustrial, pela Universidade Estadual do Paraná - Campus de Campo Mourão (2009). Especialista em MBA em Gestão Empresarial, pela Universidade Estadual do Paraná - Campus de Campo Mourão (2013). Agente Local de inovação para área Metal-Mecânica, SEBRAE/PR (2010-2012). Consultora em Inovação, projeto com foco em captação de recursos, SENAI/PR (2012-2013). Micro empreendedora na empresa Vitta Artefatos, produção de acessórios para indústria de torneiras

\section{Bernardo Pasquini Cavassin}

Graduado em Engenharia Civil (UFPR), Pós-graduado em Finanças (FAE Business School), MBA em Gestão do Mercado Imobiliário e da Construção Civil (ISAE-FGV). Atualmente é Gestor de Incorporação e Novos Negócios, atua na prospecção de terrenos para incorporação imobiliária, desenvolvimento e aprovação de empreendimentos imobiliários com foco no programa "Minha Casa Minha Vida". 


\section{Bethânia Ávila Rodrigues}

Possui graduação em Administração pela Universidade Federal do Rio Grande, especialização em Administração e Logística, com experiência na área logística do setor hospitalar público, atuando em processos de administração de estoques e compras. Mestre em Engenharia de Produção, pela Universidade Tecnológica Federal do Paraná, onde atuou na área de gestão de empreendimentos agrícolas familiares. Atualmente, é doutoranda em Engenharia de Produção, pela Universidade Tecnológica Federal do Paraná, atuando na linha de pesquisa de Gestão da Inovação Agroindustrial.

\section{Bruna Ferreira Lederes}

Graduada em Administração pelo Centro Universitário Franciscano.

\section{Bruno Mello de Freitas}

Mestrado em Engenharia Mecânica pela COPPE/UFRJ (2013) na área de processos de fabricação, especialização em Engenharia da Qualidade na UGF, formação acadêmica em Engenharia Mecatrônica pela UEA (2007). Atualmente é professor assistente do departamento de Engenharia de Materiais, na Universidade do Estado do Amazonas - UEA/EST.

\section{Cezar Augusto Romano}

Graduado em Engenharia Civil (UFPR), Doutor e Mestre em Engenharia de Produção (UFSC), professor titular da Universidade Tecnológica Federal do Paraná (UTFPR). Foi Diretor-Geral do Campus Medianeira da UTFPR (1992-1996) e Vice-Reitor da UTFPR (1996-2002). Atualmente é Diretor-Geral do Campus Curitiba, Conselheiro Eleito do Conselho Universitário (COUNI) e do Conselho de Planejamento e Administração (COPLAD). É professor permanente do Programa de Pós-Graduação em Engenharia Civil (PPGEC) e do Mestrado Profissional em Administração Pública (PROFIAP) atuando nas áreas de estratégia, planejamento, gestão com foco na produtividade organizacional.

\section{Christian Monteiro Schutts}

Graduação em andamento em Agronomia pelo Instituto Federal Catarinense. Possui graduação em Administração pela Universidade do Extremo Sul Catarinense (2014). Trabalho de conclusão de curso com ênfase na Avaliação do modelo de gerenciamento de estoques em um materiais de construção localizado em Criciúma-SC. Tem experiência na área de Administração, gestão de estoques, logística e vendas.

\section{Christiane Wagner Mainardes Krainer}

Graduada em Engenharia Civil (UFPR), Mestre em Engenharia Civil (UTFPR), MBA em Marketing pela Fundação Getúlio Vargas (FGV) e professor colaborador de Engenharia Civil da Universidade Federal do Paraná. Atua nos seguintes temas de pesquisa: supply chain, logística, gestão integrada da produção, gestão da construção com foco na produtividade organizacional e gestão do conhecimento. 


\section{Claudelino Martins Dias Junior}

Possui Graduação em Administração pela Universidade da Região da Campanha (1994), Especialização em Gestão Estratégica dos Recursos Empresariais pela Universidade Federal de Santa Maria/URCAMP (1996), Mestrado em Engenharia de Produção pela Universidade Federal de Santa Catarina (2003) e Doutorado pelo Programa de Pós-Graduação em Engenharia de Produção da Universidade Federal de Santa Catarina em Regime de Co-Tutela de Tese com a Faculdade de Ciências e Tecnologia da Universidade Nova de Lisboa. Atualmente é Professor Adjunto do Departamento de Administração da Universidade Federal de Santa Catarina em Florianópolis.

\section{Denilson Ricardo de Lucena Nunes}

Possui graduação em Engenharia Civil pela Universidade da Amazônia (1999). Mestrado em Engenharia Civil pela Pontifícia Universidade Católica do Rio de Janeiro (2002). Doutorado em Engenharia de Produção (2014) pela Pontifícia Universidade Católica do Rio de Janeiro. Professor assistente II da Universidade do Estado do Pará no curso de Engenharia de Produção.

\section{Dyego Alves da Silva}

Doutorando pela Faculdade de Economia, Administração e Contabilidade da Universidade de Brasília (UNB), área de concentração Administração. Mestre em Computação Aplicada pelo Departamento de Ciência da Computação (CIC) da Universidade de Brasília (UNB), área de concentração Gestão de Riscos, título concedido em 2016. Possui graduação em Sistemas de Informação pelo Centro Universitário Euro-Americano (2008), pós-graduações latu sensu em Gestão de Projetos de Software pelo Centro Universitário do Maranhão (2011) e em Docência do Ensino Superior pela Faculdade de Tecnologia Equipe Darwin (2011). Atualmente é servidor público no Governo do Distrito Federal.

\section{Edgard Costa Oliveira}

Professor Adjunto III do Curso de Engenharia de Software da Universidade de Brasília, UnB, Campus Gama. Pós-doutorado em andamento pelo Dept. de Ciência da Computação UnB e Brunel University de Londres. Doutor e Mestre em Ciência da Informação pela UnB/FCI (2006 e 2001). Professor do Mestrado em Computação Aplicada/ Governança e Gestão de Riscos do CIC/UnB. Professor dos Cursos de Especialização em Gestão de Tecnologia da Informação e Segurança da Informação ENE/FT/UnB. Pesquisador e professor em disciplinas: Computação Semântica, Web Semântica e Ontologias, Projeto Integrador de Engenharias, Introdução à Engenharia, Governança e Gestão de Riscos, Normas e Padrões de Segurança da Informação, Projeto de Sistemas de Informação, Humanidades e Cidadania para Engenharias, dentre outras. Pesquisa em Projetos de Web Semântica, Arquitetura da Informação e Interoperabilidade de Sistemas, Ontologias e Dados Abertos. 26 anos de experiência profissional e de pesquisa em $\mathrm{TI}$, com ênfase em web semântica, engenharia de software, gerenciamento de projetos, organização da informação, segurança da informação e gestão de riscos. 


\section{Edna Dias Canedo}

Doutora em Engenharia Elétrica pela Universidade de Brasília (UNB). Área de concentração: Telecomunicações - Modelo de Confiança para a Troca de Arquivos em uma Nuvem Privada. Título concedido em 15.08.2012. Mestre pela Universidade Federal da Paraíba UFPB. Área de concentração: Sistemas de Software. Área Especifica: Engenharia de Software, título concedido em 29.08.2002. Graduada em Análise de Sistemas pela Universidade Salgado de Oliveira; Goiás (1999). Professora do curso de Engenharia de Software da Faculdade FGA Gama, da Universidade de Brasília ? UNB. Atua na área de desenvolvimento de sistemas desde 1998, tendo trabalhado como Analista de Sistemas na Empresa de Processamento de Dados do Estado de Goiás Prodago, até o ano de 2000. Em Brasília atuou na Poliedro como Consultora de Desenvolvimento e Gerência de Projetos e como Analista de Sistemas Pleno em Desenvolvimento na ECT - Empresa de Correios e Telégrafos até abril de 2010, desenvolvendo atividades na área de Governança em Tecnologia da Informação na implantação do framework COBIT. Desde 2000 dedica-se a atividades de docência universitária nos cursos de graduação e pós-graduação, atuando na área de Segurança de Software, Sistemas de Software, Engenharia de Software, Orientação a Objetos, Gerência de Projetos, Teste de Software, Arquitetura Orientada a Serviços, Programação e Governança em Tecnologia da Informação.

\section{Edson Pacheco Paladini}

Doutorado em Engenharia de Produção pela Universidade Federal de Santa Catarina, Brasil(1992). Professor Titular da Universidade Federal de Santa Catarina, Brasil

\section{Elizabeth Liang}

Graduanda em Engenharia de Produção pela Universidade Federal do Paraná (UFPR) e possui Técnico em Gestão de Pequenas e Médias Empresas (nível médio integrado) pela Universidade Tecnológica Federal do Paraná (2012).

\section{Emmily Caroline Cabral da Fonseca}

Estudante de Engenharia de Produção na Universidade do Estado do Pará. Desenvolvedora de pesquisas na área de Logística. Experiência em chão de fábrica do setor alimentício e de embalagens. Ex-bolsista de iniciação científica - CNPq.

\section{Eriton Carlos Martins Barreiros}

Acadêmico de Engenharia de Produção pela Universidade do Estado do Pará - UEPA. Estagiário em indústria de argamassa, rejunte e aditivos. Voluntário no Núcleo Integrado de Logística e Operações - NILO. Ex-Voluntário de iniciação científica - CNPq. 


\section{Ernane Rosa Martins}

Doutorado em andamento em Ciência da Informação com ênfase em Sistemas, Tecnologias e Gestão da Informação, na Universidade Fernando Pessoa, em Porto/Portugal. Mestre em Engenharia de Produção e Sistemas. Possui Pós-Graduação em Tecnologia em Gestão da Informação, Graduação em Ciência da Computação e Graduação em Sistemas de Informação. Professor de informática no Instituto Federal de Educação, Ciência e Tecnologia de Goiás - IFG (Campus Luziânia) ministrando disciplinas nas áreas de Engenharia de Software, Desenvolvimento de Sistemas, Linguagens de Programação, Banco de Dados e Gestão em Tecnologia da Informação.

\section{Fabrício Wesley da Rocha}

Tecnólogo em Alimentos pela Universidade Tecnológica Federal do Paraná - UTFPR. Graduado em Turismo e Meio Ambiente pela Universidade Estadual do Paraná Campus de Campo Mourão. Licenciado em Geografia pela Faculdade Chafiq-São Paulo. Atuou como pesquisador bolsista pela FAPESP no Instituto Tecnológico de Alimentos ITAL- Campinas, na área de produção e processamento industriais, tendo como enfoque projetos ambientais.

\section{Flaubiane Figueredo Machado}

Graduada em Administração pelo Centro Universitário Franciscano.

\section{Flavia Haweroth}

Graduada em Engenharia de Transportes em Logística pela Universidade Federal de Santa Catarina. Desenvolve pesquisas nas áreas de Cadeia do Frio e Roteirização e Programação de Veículos em setores de saúde e transporte público.

\section{Flaviani Souto Bolzan Medeiros}

Graduada em Administração (2011) e Especialista em Finanças(2013) pelo Centro Universitário Franciscano. Mestre em Engenharia de Produção na área de Gerência de Produção (2015) pela Universidade Federal de Santa Maria (UFSM). Atualmente, é Doutoranda no Programa de Pós-Graduação em Administração da UFSM na linha de pesquisa Sistemas e Mercado.

\section{Francielly Christine Venâncio Galdino}

Graduada em Tecnologia e Gestão Portuária pela Faculdade de Tecnologia da Baixada Santista (Fatec Santos - 2016)

\section{Francisco de Assis Vilar Sobreira Júnior}

Graduado em Engenharia de Produção (URCA) e mestrando em Engenharia de Produção (PPGEP/UFPE). 


\section{Geralda Cristina de Freitas Ramalheiro}

Possui graduação em Administração Pública pela Universidade Estadual Paulista Júlio de Mesquita Filho (2012) e mestrado em Gestão de Organizações e Sistemas Públicos pela Universidade Federal de São Carlos (2016). Atualmente é analista na Incubadora de Empresas de Araraquara e pesquisadora - colaboradora na Universidade de Araraquara. Tem experiência na área de Administração pública, com ênfase em Políticas Públicas de estímulo ao empreendedorismo e o ensino de Administração.

\section{Izadora Pereira}

É graduada em Engenharia de Produção pelo Centro Universitário de Brusque -UNIFEBE. Possui experiência em empresas de pequeno e grande porte, na atuação em atividades relacionadas a atendimento aos clientes e Logística. Tem atuado especificamente no setor metalmecânico com o desenvolvimento de instruções operacionais de trabalho e padronização dos processos internos, bem como na implantação e acompanhamento da execução do Warehouse Management System -WMS (Sistema de gerenciamento de estoques) nos estoques de componentes e produtos acabados da empresa. Atua também na identificação e oportunidades de melhoria no setor, por meio de análise de indicadores e ferramentas de qualidade.

\section{Jair Paulino de Sales}

Graduado em Engenharia de Produção (URCA) e mestrando em Desenvolvimento Regional Sustentável (PRODER/UFCA). Realizou período de graduação sanduíche pelo Programa Ciência sem Fronteiras no curso de Ingegneria Gestionale (UNIMORE). Membro do Grupo de Pesquisa em Modelagem Estatística, Simulação e Otimização de Risco (MESOR).

\section{Jeancarlos Araldi}

Doutorando em Engenharia de Produção pela Universidade Federal de Santa Catarina, Brasil. Professor da Faculdade IMED, Brasil

\section{Jefferson Augusto Krainer}

Bacharel em Direito pela Faculdade de Direito de Curitiba, Mestre em Ciência, Gestão e Tecnologia da Informação (UFPR) e professor colaborador da Universidade Estadual do Paraná nos cursos de Ciências Sociais. Atua nos seguintes temas de pesquisa: supply chain, logística, gestão integrada da produção, gestão da construção com foco na produtividade organizacional e gestão do conhecimento. 


\section{João Evangelista Neto}

Pós-doutorado em Engenharia de Materiais e Metalurgia, POLI/USP, Possui graduação em Engenharia Mecânica pelo Instituto de Tecnologia da Amazônia (2002), graduação em Tecnologia Mecânica pelo Instituto de Tecnologia da Amazônia (1987), graduação em Engenharia Civil pelo Centro Universitário do Norte (2016), graduação em Engenharia Elétrica pelo Instituto de Tecnologia da Amazônia (2004) e doutorado em Engenharia Elétrica pela Universidade Federal do Pará (2012). Atualmente é professor efetivo da Universidade do Estado do Amazonas, professor/pesquisador do Centro Universitário do Norte, não existe vinculo funcional. - Universidad del Oriente Cuba e professor da pós-graduação - Instituto Dados da Amazônia, leciona na UFAM/PPGEE, Programa de Pós-graduação e Engenharia Elétrica. leciona na Pós-graduação em Engenharia de Segueança do Trabalho da UEA, Tem experiência na área de Engenharia Elétrica, com ênfase em Engenharia Elétrica, atuando principalmente nos seguintes temas: base de combustível, máquinas e sistemas eletroeletrônicos, edificações, sistemas de combate a incêndio e manutenção preditiva.

\section{João Marcos Pereira Silva}

Graduado em Engenharia de Produção (URCA) e mestrando em Engenharia de Produção (PPGEP/UFPB). Realizou período de graduação sanduíche pelo Programa Ciência sem Fronteiras no curso de Ingegneria Gestionale (UNIMORE).

\section{Juliana Andréia Rüdell Boligon}

Mestre em Engenharia de Produção pela Universidade Federal de Santa Maria (2009). Atualmente, é professora e coordenadora do Curso de Administração do Centro Universitário Franciscano.

\section{Juliana Vitória Messias Bittencourt}

Possui graduação em Engenharia Agronômica pela Universidade Estadual de Ponta Grossa (1997), mestrado em Agronomia (Produção Vegetal) pela Universidade Federal do Paraná (2000) e doutorado em Genética Molecular - University of Reading (2007). Atualmente é professor da Universidade Tecnológica Federal do Paraná, orientadora no PPGEP (Programa de Pós Graduação em Engenharia de Produção) na UTFPR, Campus Ponta Grossa. Realiza pesquisas voltadas à linha de pesquisa de Desenvolvimento Rural, com o objetivo de avaliar as demandas sociais e técnicas do meio rural, analisar os efeitos econômicos e sociais de políticas públicas sobre o desenvolvimento agrícola nacional, identificar as potencialidades e dificuldades da cadeia de produção agroalimentar. Possui experiência em coordenação de projetos bilaterais e organização de equipes com caráter multidisciplinar. 


\section{Julio Cesar Zilli}

Mestre em Desenvolvimento Socioeconômico (2015), MBA em Gestão Empresarial (2003), Especialização para o Magistério Superior (2007) pela Universidade do Extremo Sul Catarinense (UNESC) e Graduado em Ciências Contábeis (1997) pela Universidade do Vale do Itajaí (UNIVALI). Autor de capítulos de livro, artigos científicos publicados em revistas e anais de congressos/seminários/simpósios nacionais e internacionais. Como professor, experiência nos Cursos de Graduação em Administração e Comércio Exterior da UNESC e Escola Superior de Criciúma (ESUCRI) envolvendo as disciplinas de Legislação Aduaneira, Logística Internacional, Transportes e Seguros Internacionais, Práticas Gerenciais de Exportação e Importação, Negociações Internacionais, Administração Estratégica, Introdução ao Comércio Exterior, Projeto de Pesquisa e Trabalho de Curso (TCC).

\section{Lidiane de Souza Assante}

Possui graduação em Língua Portuguesa pelo Centro Universitário do Norte (2007). Atualmente é professor de ensino superior do Centro Universitário do Norte nos cursos de Administração e Gestão de Recursos Humanos. Mestrado em Engenharia da Produção pela UFAM. Possui Pós-graduação lato sensu em MBA em Gestão Organizacional: com ênfase em Operações e Serviços pela UFAM (2014); Gestão, Supervisão e Orientação Educacional pela Faculdade Metropolitana de Manaus (2011). Atua também nos seguintes temas: redação técnica, comunicação e lógica, homem, sociedade e meio ambiente, gestão de pessoas, gerência de projetos, gestão de negócios, metodologia da pesquisa científica, TCC, Ética e Legislação Profissional, Estágio Supervisionado, Fundamentos Acadêmicos, Avaliação de Desempenho e Planejamento de Carreira, Gestão de Cargos e Salários, Comportamento Organizacional, Comunicação Empresarial/Profissional, Introdução a Engenharia. Atualmente vem ministrando Cursos Livres de oratória, técnica de apresentação e Técnicas de Redação (e-mails e documentos formais). Tem experiência em reconhecimento de cursos de ensino superior pelo MEC, bem como em Comissão Própria de Avaliação (CPA), Apoio Pedagógico e Administrativo. Palestrante de oratória, storytelling, liderança de sucesso, técnicas de apresentação para seminários e palestras.

\section{Márcia de Fátima Morais}

Engenheira de Produção Agroindustrial pela Faculdade Estadual de Ciências e Letras de Campo Mourão (2002). Mestre em Engenharia (Engenharia de Produção) pela Universidade de São Paulo (2008). Doutoranda em Engenharia de Produção e Sistemas pela Universidade Pontifícia Católica do Paraná. Desenvolve pesquisas na linha Modelos de Apoio à Tomada de Decisão da área de concentração Gerência de Produção e Logística. Atualmente é professora assistente da Universidade Estadual do Paraná, Campus de Campo Mourão. Tem experiência na área de Engenharia de Produção, com ênfase em Pesquisa Operacional. 


\section{Marcos Vinicius Henrique da Silveira}

Atua a 15 anos no setor portuário, atualmente trabalha no Porto de Santos. Possui Formação de Líderes, Gestão de pessoas com Ênfase em Liderança Organizacional pela Escola Superior de Administração e Gestão Strongs , formado em Comércio Exterior , graduando em Gestão Portuária pela Fatec Baixada Santista . Visitou Portos Europeus onde se habilitou em Desenvolvimento Estratégico Portuário pela Antwerp/Flanders Port Training Center ( APEC ) Bélgica .

\section{Maria Helene Giovanetti Canteri}

Graduada em Farmácia e Bioquímica pela Universidade Estadual de Ponta Grossa-UEPG (1993) e com Mestrado (2003) e Doutorado (2010) em Tecnologia de Alimentos pela Universidade Federal do Paraná e em Sciences Agronomiques pela Université dAvignon et Pays de Vaucluse (2010). Cursou estágio Pós-Doutoral sobre o tema parede celular de frutos e análise multivariada no Institute National de la Recherche Agronomique (França- 2015). Docente desde 1996 no Ensino Básico, Técnico e Tecnológico da Universidade Tecnológica Federal do Paraná (UTFPR)- Campus de Ponta Grossa, nas áreas de Bioquímica, Nutrição, Métodos de Conservação de Produtos Vegetais, Análise Sensorial e Estatística. Atuou como colaboradora no Mestrado em Ciência e Tecnologia de Alimentos da UEPG entre 2011 e 2016. Atua como docente permanente no Programa de Pós Graduação em Engenharia de Produção (Qualidade de Vida e Inovação Agroindustrial). Desenvolve trabalhos, principalmente, nas seguintes temáticas: bioquímica de alimentos, pectina, fibra, parede celular, frutas e hortaliças, resíduos agroindustriais, planejamento de experimentos, qualidade de vida e inovação agroindustrial.

\section{Marilia Patrao Viveiros}

Graduada como tecnóloga em Gestão Portuária pela Faculdade de Tecnologia da Baixada Santista Rubens Lara (Fatec Santos) e em Logística com ênfase em Transportes pela Faculdade de Tecnologia da Baixada Santista Rubens Lara (Fatec Santos). Áreas de interesse como: Importação e exportação, logística e cadeia de suprimentos, modais de transporte, modelagem e simulação de processos, planejamento e controle de produção e pesquisa acadêmica. Atualmente trabalha como Assistente de Planejamento Operacional na Libra Terminais (Grupo Libra) no Porto de Santos/SP.

\section{Michele Domingos Schneider}

Possui graduação em Administração de empresas pela Universidade do Extremo Sul Catarinense (2003) e mestrado em DESENVOLVIMENTO SOCIOECONÔMICO pela Universidade do Extremo Sul Catarinense (2016). Atualmente é professor titular da Universidade do Extremo Sul Catarinense. Tem experiência na área de Administração, com ênfase em Logística empresarial, atuando principalmente nos seguintes temas: educação a distância, logística, educação, gestão e competitividade. 


\section{Nathália Almeida Castro Rodrigues}

Graduanda em Engenharia de Produção na Universidade do Estado do Pará (UEPA). Realizou intercâmbio na Alemanha, onde fez graduação sanduíche na Leibniz Universität Hannover (Member of TU9 - German Institutes of Technology), em Hannover, cursando Mechanical Engineering (Bachelors programme in Production and Logistics) em 2015/2016. Realizou estágio na área de Facility Management (2016)."

\section{Pedro Otavio Ferrelli}

Graduado em engenharia da produção na instituição FACEAR de Curitiba, que incentiva os alunos a escreverem artigos. Atuei por quatro anos em uma multinacional de bens de capital do ramo agricola. E em paralelo a dois anos abri uma empresa de serviço de estacionamento na região de Curitiba.

\section{Priscila Santos Clemente da Silva}

"Graduanda no curso superior: Tecnologia em Gestão Portuária, na Faculdade de Tecnologia Rubens Lara ( Fatec Baixada Santista - 6 o ciclo). Participação em Congressos: Estudo de alternativas para exportação da soja brasileira através do Porto de Itaqui - Publicado e Apresentado ao Congresso Brasileira de Engenharia de Produção - CONBREPRO (2015) ISSN 2237-6143 (Autora Principal). Utilização das Hidrovias na exportação de soja através do Arco Norte - Publicado e Apresentado 8ª Edição do Congresso de Logística das FATECS na Faculdade de Tecnologia Zona Leste (2017) (Autora Principal). Análise e simulação do fluxo de transporte em um terminal de contêineres - Publicado e Apresentado na $8^{\mathbf{a}}$ Edição do Congresso de Logística das Fatecs na Faculdade de Tecnologia Zona Leste (2017) ( Autora Principal). Formada em Técnico em Logística pelo Centro Paula Souza - ETEC Praia Grande. Interessa-se por pesquisas relacionadas as Hidrovias Brasileiras e a utilização da mesma para o escoamento da soja brasileira."

\section{Raimundo Nonato Alves da Silva}

Mestrado em gestão na UNIVALI (2012), Especialização em Engenharia de Produção UFAM (1993). Sanduiche com a UFSC, graduação em Engenharia de Produção pelo UNINORTE / LAUREATE (2013), graduação em Farmácia - Bioquímica pelo Centro Universitário Nilton Lins (2006), graduação em Ciências Economia pela UFAM (2001), graduação em Tecnologia Mecânica pelo Instituto de Tecnologia da Amazônia (1985). Atualmente é professor/pesquisador Universidade do Estado do Amazonas, UEA na área da Engenharia de Materiais, leciono no Centro Universitário do Norte. Tem experiência na área de Engenharia mecânica e produção atuando principalmente nos seguintes temas: Qualidade (auditorias externas), TPM, Desenvolvimento de novos fornecedores nas áreas de plásticos, metais, subconjuntos, Auditoria da Qualidade e Ambiental, além de novos materiais. Leciona no PPGQP - Programa de Pós-Graduação em Qualidade e Produtividade da FUCAPI (Fundação Centro de Análise e Pesquisa e Inovação Tecnológica). 


\section{Raphael Ribeiro Machado}

"Engenheiro de Logística da CNH Industrial. Responsável pela engenharia logística da BU Hearders - Análise e aprovação de PPAPs de embalagens diversas. Estudo e desenvolvimento da estrutura para operações logísticas em chão de fábrica (sistema de chamada, lay out, armazenagem, roteirização, fluxo, tempos, melhorias de dispositivos). Estudos e aplicações para redução de custos e desperdícios para departamento. Utilização da plataforma SAP para abertura de OC's e RM's, solicitações de PENF's, controle de gastos em PEPs, revisão de NF's."

\section{Ricardo Augusto Bonotto Barboza}

Possui Graduação em Ciências Econômicas pela UNESP/Araraquara (1998), Mestrado em Engenharia Urbana pela Universidade Federal de São Carlos (2003) e Doutorado em Alimentos e Nutrição pela UNESP/Araraquara (2011). Possuí pós-doutoramento em Alimentos e Nutrição pela Faculdade de Ciências Farmacêuticas da UNESP/Araraquara. Atualmente é Professor Doutor do Departamento de Administração da Universidade de Araraquara (UNIARA) e Pesquisador Sênior do Departamento de Administração Pública da Faculdade de Ciências e Letras da UNESP/Araraquara. Trabalha na linha de pesquisa sobre empreendedorismo e inovação para micro e pequenas empresas.

\section{Rony Peterson da Rocha}

Engenheiro de Produção Agroindustrial, pela Universidade Estadual do Paraná - Campus de Campo Mourão (2004). Doutor e Mestre em Engenharia Química - Modelagem e Otimização de Processos, pelo Programa de Pós Graduação em Engenharia de Química, Universidade Estadual de Maringá (UEM). Especialista em MBA em Gestão Empresarial e Especialista em Gestão Ambiental pela FECILCAM - Faculdade Estadual de Ciências e Letras de Campo Mourão . Professor Adjunto do Colegiado de Engenharia de Produção, Universidade Estadual do Paraná - Campus de Campo Mourão, Campo Mourão/PR. Pesquisador do Grupo de Estudos e Pesquisas em Processos e Gestão de Operações (GEPPGO). Coordenador do Curso de Engenharia de Produção Agroindustrial (2016-2017).

\section{Ruth Margareth Hofmann}

Possui graduação em Ciências Econômicas, mestrado e Doutorado em Educação pela Universidade Federal do Paraná. Atualmente é professora do curso de graduação em Engenharia de Produção da UFPR. 


\section{Ruy Gomes da Silva}

Mestre em Engenharia de Produção e Sistemas pela PUCPR; Graduado em Engenharia de Produção - CESUPA; Professor. Orientador e Coordenador de TCC do Curso de Engenharia de Produção - CESUPA; Coordenador do grupo de pesquisa de Tomada de decisão e Simulação de Processos - CESUPA; Coordenador do curso de Especialização em Engenharia da Qualidade - CESUPA; Experiência de 15 anos na indústria de beneficiamento de minério, na empresa HYDRO Alunorte, atuado nas funções de Coordenador de Produção, Gerente operacional e Especialista de Processo. Com experiência em SDCD (comando digital distribuído a distância) e extenso conhecimento nos processos e operações de "chão de fábrica").

\section{Ryan Ramos Scheidt}

Graduado em Engenharia Civil (UFPR), engenheiro de obra em empresa de urbanismo. Participa de pesquisas nas áreas de supply chain, logística, lean construction, modernização da construção e gestão de obras públicas. Atua em gerenciamento, acompanhamento e execução de obras de construção civil e de loteamentos e condomínios fechados no Brasil.

\section{Sergio Azevedo Fonseca}

Concluiu o doutorado em Administração pela Universidade de São Paulo em 2000, tendo se tornado livre-docente em Administração pela UNESP em junho de 2010. Atualmente é Professor Adjunto da Universidade Estadual Paulista Júlio de Mesquita Filho. Atua, também, como docente do Programa de Pós-Graduação em Gestão de Organizações e Sistemas Públicos, da Universidade Federal de São Carlos. Bolsista de Produtividade em Desenvolvimento Tecnológico e Extensão Inovadora do CNPq (PDT). Publicou 27 artigos em periódicos especializados e 59 trabalhos completos em anais de eventos. Possui 7 capítulos de livros publicados. Orientou estudantes de iniciação científica, mestrado e doutorado.é revisor de nove periódicos, nacionais e internacionais. Entre 1998 e 2016 coordenou 13 projetos de pesquisa. Atualmente participa de seis projetos, de pesquisa e extensão, coordenando quatro deles. Atua na área de Políticas Públicas para o Desenvolvimento Local. Em seu currículo Lattes os termos mais freqüentes, na contextualização da produção científica e tecnológica, são: Políticas Públicas Sócio-Ambientais; Incubadoras de Empresas, Desenvolvimento Local Sustentável, Inovação na Micro e Pequena Empresa, Cooperação Universidade-Empresa-Sociedade, Gestão da Inovação, Economia Solidária..

\section{Silvia Lopes de Sena Taglialenha}

Professora Associado I da Universidade Federal de Santa Catarina, Chefe do Departamento de Engenharias da Mobilidade, Centro Tecnológico de Joinville, Coordenadora do Grupo de Pesquisa GIT - Grupo de Infraestrutura e Transportes. Possui Licenciatura em Matemática, com habilitação em Física - UNESP - Faculdade de Ciências e Tecnologia - Júlio de Mesquita Filho, Mestrado em Matemática Pura (Análise) - ICMC-USP Universidade de São Paulo - São Carlos e Doutorado em Engenharia Elétrica (Automação) - UNESP - Faculdade de Engenharia de Ilha Solteira. Atua principalmente nos seguintes temas: Pesquisa Operacional, Otimização, Meta Heurísticas, Planejamento da Expansão de Sistemas de Transmissão de Energia Elétrica. 


\section{Simone Borges Simão Monteiro}

Possui Graduação em Engenharia Química pela Universidade Federal de Uberlândia (1995), Mestrado em Engenharia de Produção (Gestão de Sistemas Agroindustriais) pela Universidade Federal de São Carlos (1998), Especialização em Sistemas de Produção Enxuta pela USP (2004) e Doutorado em Engenharia de Produção (Gestão da Qualidade) pela Universidade Federal de São Carlos (2006). Foi professora da Universidade de Franca (UNIFRAN) de 2000 a 2010. Por dois anos consecutivos (2006 e 2007) coordenou o curso de Pós-Graduação Lato Sensu em Gestão de Operações e Logística na UNIFRAN. É Professora Adjunta III do Departamento de Engenharia de Produção da Universidade de Brasília (UnB) e Coordenadora de Projetos do CEFTRU - Centro Interdisciplinar de Estudos em Transportes. É Professora e Pesquisadora no Programa de pós-graduação em Computação Aplicada (PPCA) da UnB na Linha de pesquisa de Gestão de Risco. Tem experiência na área de Engenharia de Produção, com ênfase em Garantia de Controle de Qualidade, Gestão da Qualidade, Gestão de Projetos e Análise e Melhoria de Processos e atua nos seguintes temas: ISO 9000, Sistemas de Gestão da Qualidade, Gestão de Serviços, Ferramentas da Qualidade, Ferramentas Estatísticas para o Controle e Melhoria de Processos, Gestão de Riscos aplicados à Qualidade, Gestão de Projetos e Educação em Engenharia (Abordagem PBL e $\mathrm{PjBL})$.

\section{Suheir Kamal Genena}

Graduada em Tecnologia e Gestão Portuária pela Faculdade de Tecnologia da Baixada Santista (Fatec Santos - 2016). Áreas de interesse: Importação e exportação, logística internacional, supply chain, modais de transporte e pesquisa acadêmica.

\section{Tassiara de Almeida da Silva}

Possui Graduação em Administração de Empresas pela IMED Bussines School. Tathiana Apollo Dos Santos da Cruz Camargo. Graduanda no curso Gestão Portuária ministrado pela Fatec Rubens Lara - Baixada Santista

\section{Thays j. Perassoli Boiko}

Engenheira de Produção Agroindustrial, pela Universidade Estadual do Paraná - Campus de Campo Mourão (2002). Mestre em Engenharia de Produção - Pesquisa Operacional Aplicada aos Sistemas de Produção, pelo Departamento de Engenharia de Produção, Escola de Engenharia de São Carlos (EESC), Universidade de São Paulo (USP) (2008). Professora Assistente do Colegiado de Engenharia de Produção, Universidade Estadual do Paraná Campus de Campo Mourão, Campo Mourão/PR. Pesquisadora do Grupo de Estudos e Pesquisas em Processos e Gestão de Operações (GEPPGO). Membro do Comitê de Apoio ao Desenvolvimento do Empreendedorismo no Território Piquirívai-Pr. 


\section{Vanessa Ishikawa Rasoto}

Possui graduação em Administração pela Faculdade Católica de Administração e Economia (1993), mestrado em Administração pela Universidade Federal do Paraná (1999) e doutorado em Engenharia da produção - Gestão de Negócios pela Universidade Federal de Santa Catarina (2006). Atualmente é Vice-Reitora, professora permanente do mestrado do Programa de Pós-graduação em Planejamento e Governança Pública (mestrado profissional - disciplina: habitats de inovação), professora Titular da UTFPR, ex-Assessora para Assuntos Estudantis da Reitoriaex-diretora da Agência de Inovação, ex-coordenadora do Programa de Empreendedorismo e Inovação da UTFPR-Câmpus Curitiba. Tem experiência na área de Educação, Gestão de Habitats de Inovação Tecnológica, projetos de pesquisa e extensão, atuando principalmente nos seguintes temas: Finanças, Viabilidade de projetos, Empreendedorismo e Inovação.

\section{Vanina Macowski Durski Silva}

Engenharia de Produção Agroindustrial pela Faculdade Estadual de Ciências e Letras de Campo Mourão, especialista em Gestão de Agronegócios pela Fesurv . Mestre e doutora em Eng. de Produção na área de Logística e Transporte pela Universidade Federal de Santa Catarina. Atualmente é professora Adjunto III do Departamento de Engenharias da Mobilidade da Universidade Federal de Santa Catarina, sendo também Coordenadora do Grupo de Pesquisa em Logística Dinâmica e Autônoma voltado à logística autônoma e à dinamicidade dos sistemas logísticos. Atuou como engenheira de produção na área de Planejamento e Controle da Produção em empresas de grande porte como Perdigão Agroindustrial S.A., atual Brasilfoods e Macedo Agroindustrial S.A, atual Tyson Foods.

\section{Wesley de Araujo Moreira}

Formado em técnico mecânico no Colégio Técnico Industrial de Araucária (CTI) e recentemente graduado em Engenharia de Produção pela Faculdade Educacional Araucária FACEAR, onde tive a oportunidade e o incentivo para escrever artigos científicos. Atuo no área metal mecânica a mais de 15 anos. A 12 anos trabalho em uma empresa do ramo Óleo e Gás, onde atuei 9 anos na produção como Torneiro CNC, operando e programando tornos horizontais e verticais, leves e pesados. A cerca de 2 anos fui transferido para função de Planejador de Processos, onde desenvolvo roteiros para fabricação, desenho para auxiliar o entendimento na produção, cotação de $\mathrm{HH}$ para novos projetos (BID) e auxilio na implementação do Lean Manufacturing na companhia com projetos de melhoria contínua.

\section{Wesley Gomes Feitosa}

Possui Mestrado Profissionalizante em Engenharia da Produção (UFAM), Possui Graduação em Engenharia Civil (LAUREATE INTERNATIONAL UNIVERSITIES/UNINORTE), Possui Licenciatura Plena em Matemática (MINISTÉRIO DA DEFESA/CIESA). Atualmente é Doutorando em Educação pela Universidad Columbia del Paraguay (UCP) e Especialização em Engenharia de Segurança do Trabalho pela (LAUREATE INTERNATIONAL UNIVERSITIES/UNINORTE). Atua como Professor horista do (LAUREATE INTERNATIONAL UNIVERSITIES/UNINORTE), Professor efetivo da Secretaria de Educação e Cultura (SEDUC/AM) e Secretaria de Educação e Cultura Municipal (SEMED/AM). 

ISBN 978-85-93729-26-3

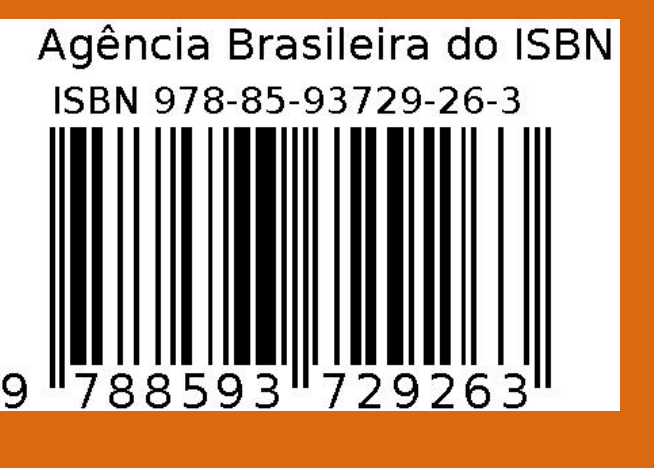

9788593729263

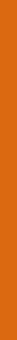

